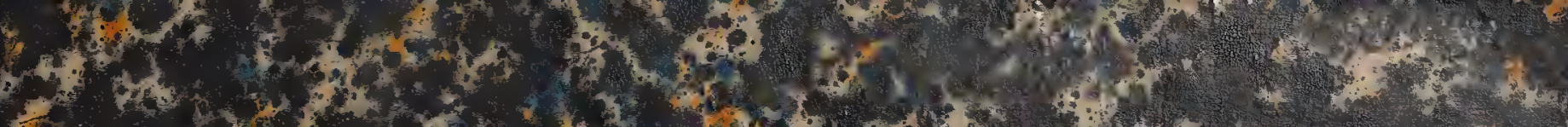

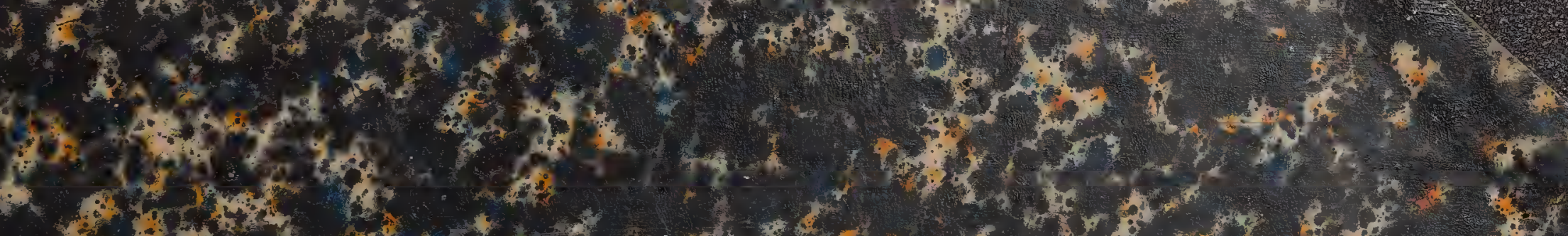

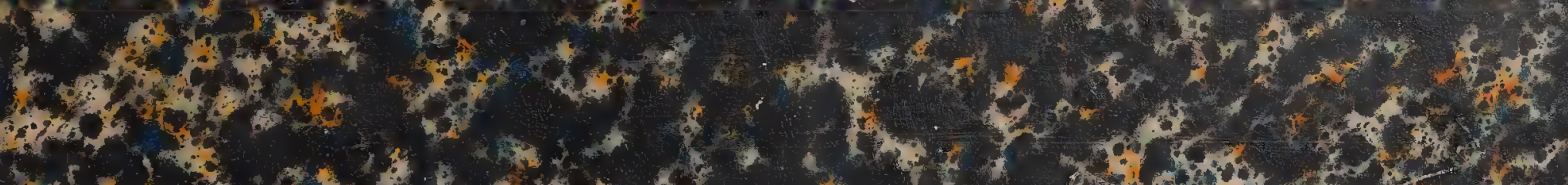

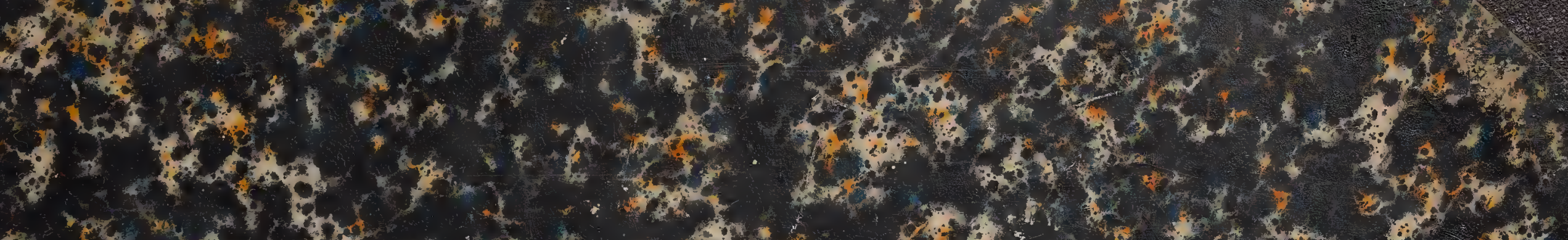

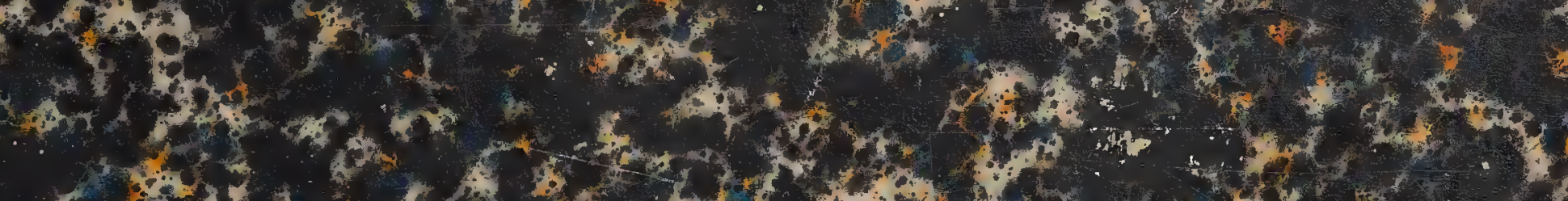

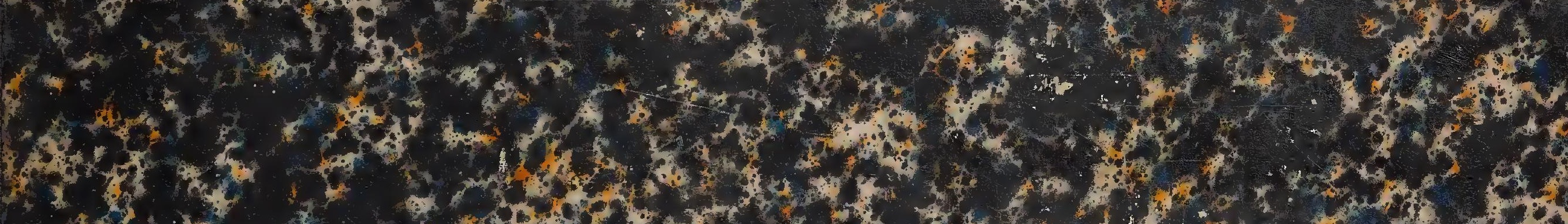

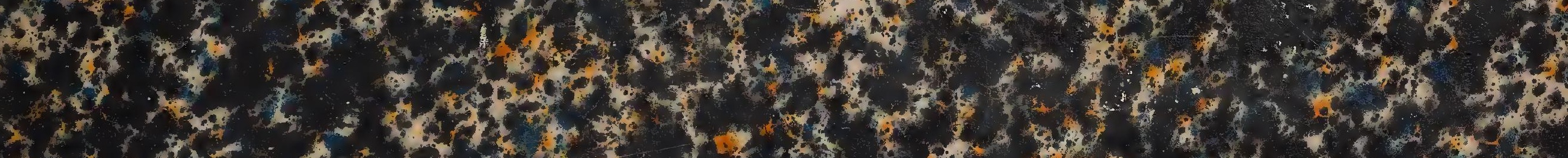

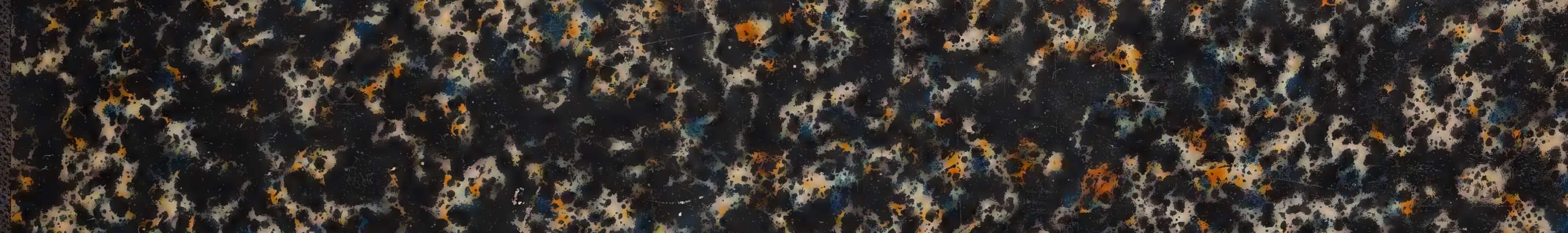

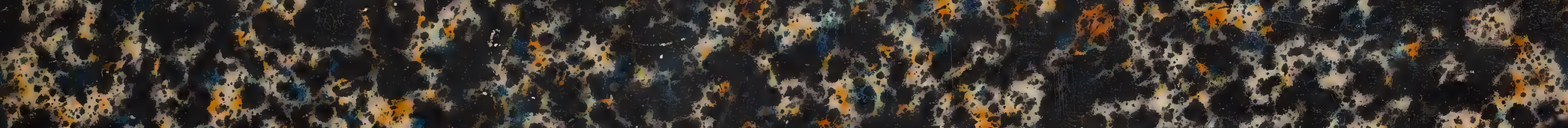

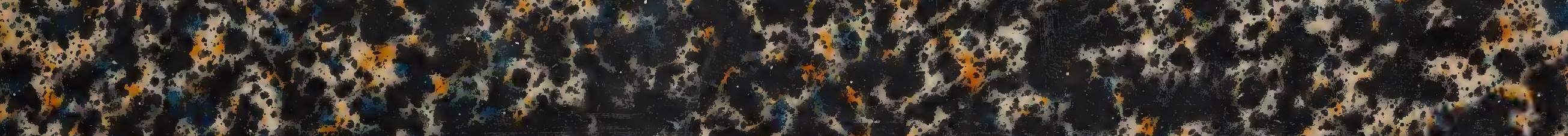

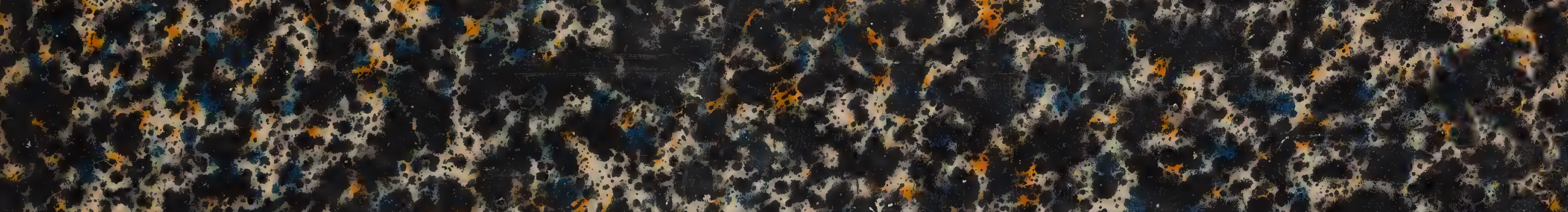

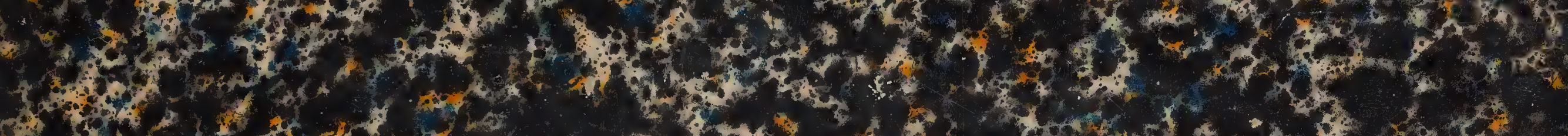

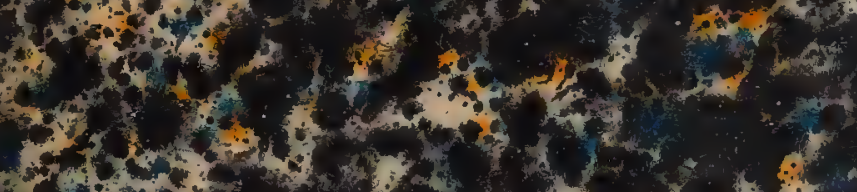

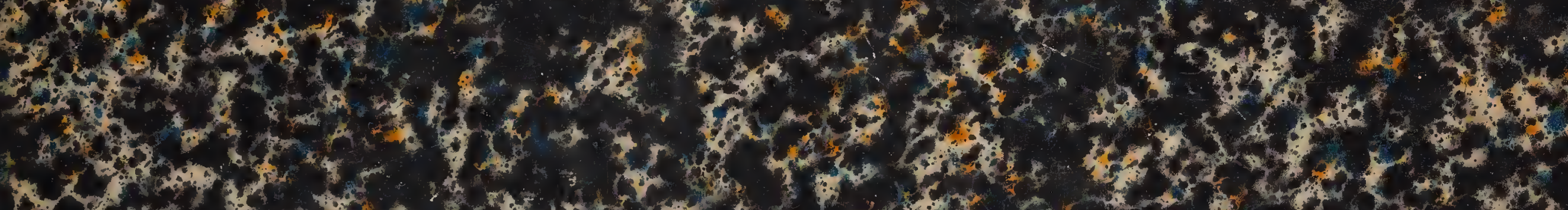

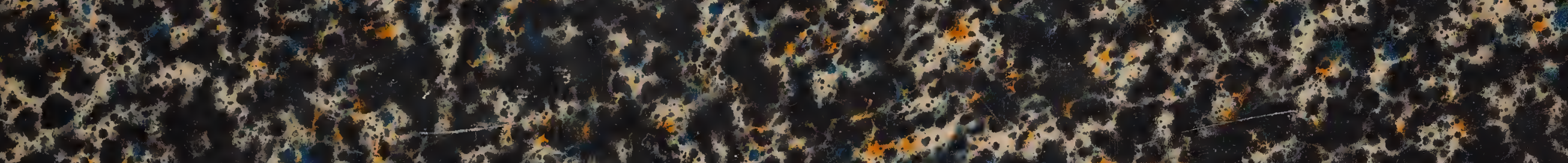

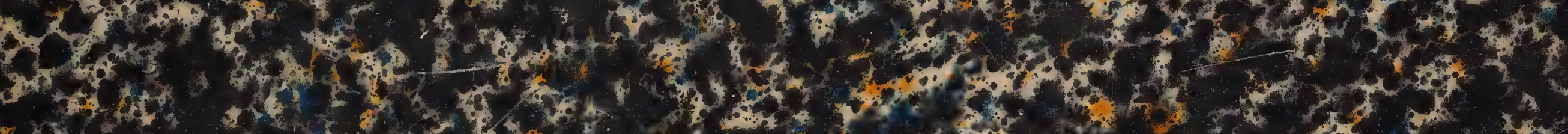

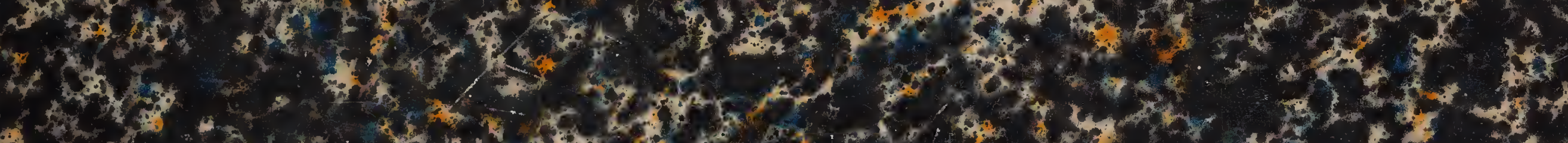

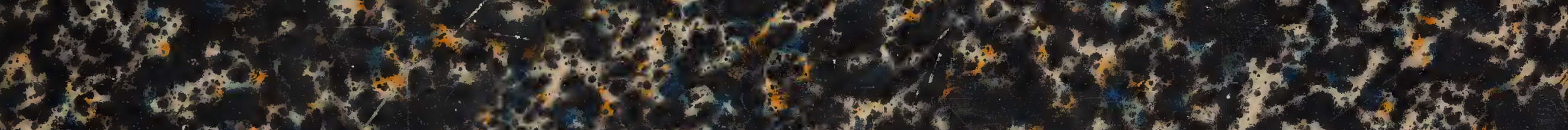

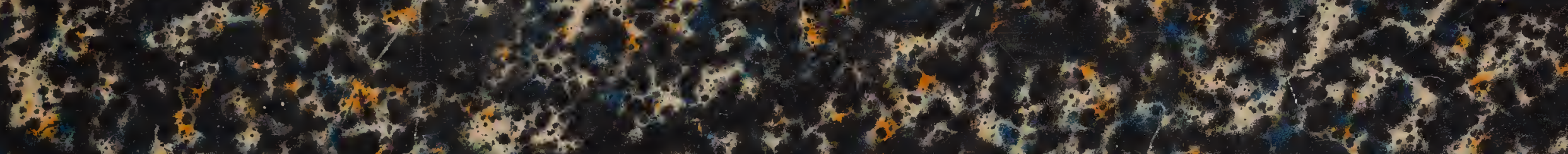

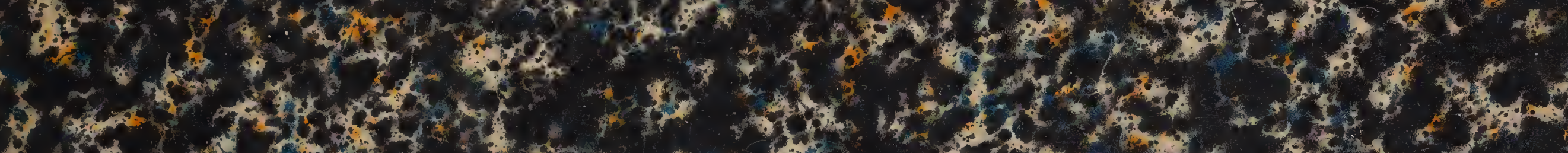

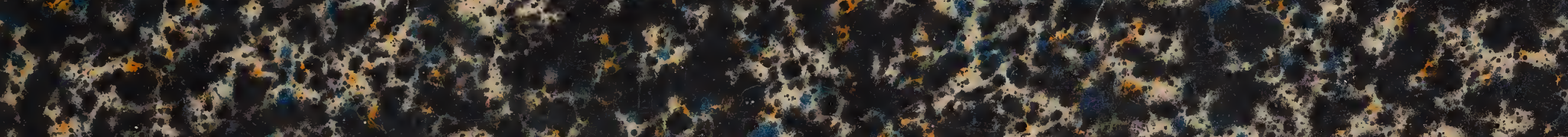

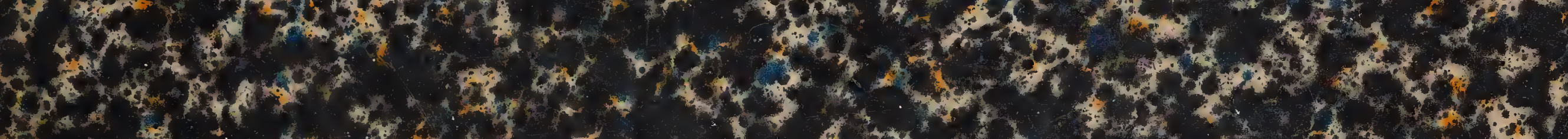

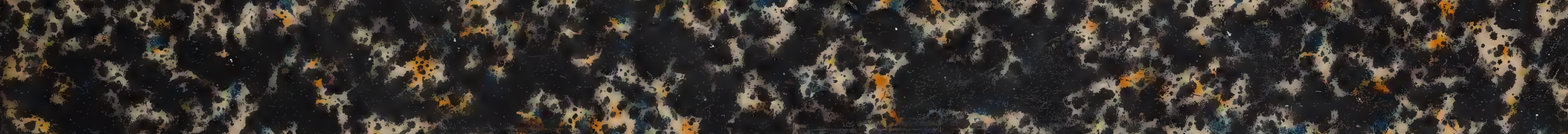

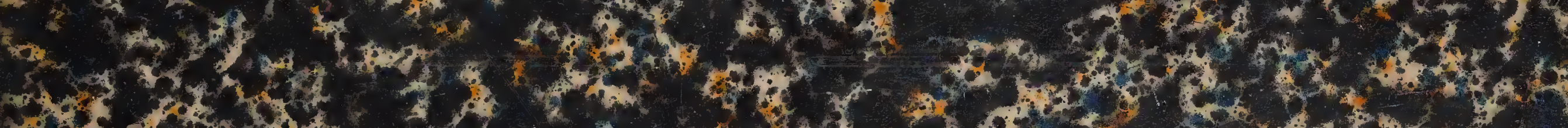

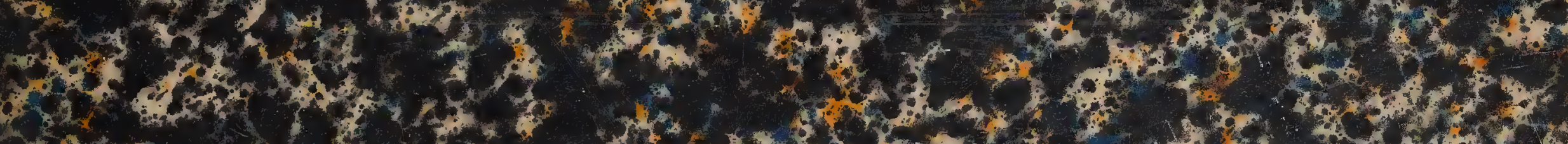

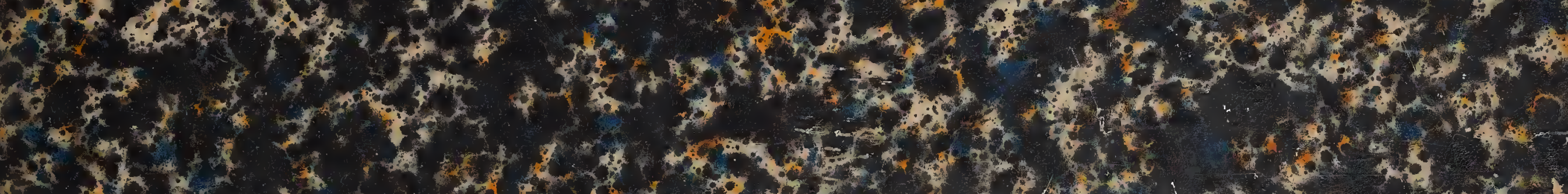

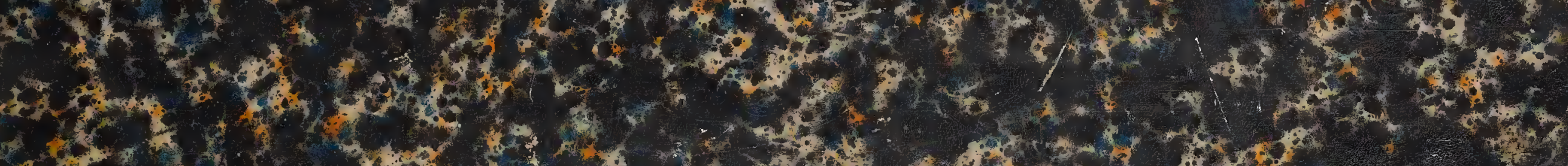

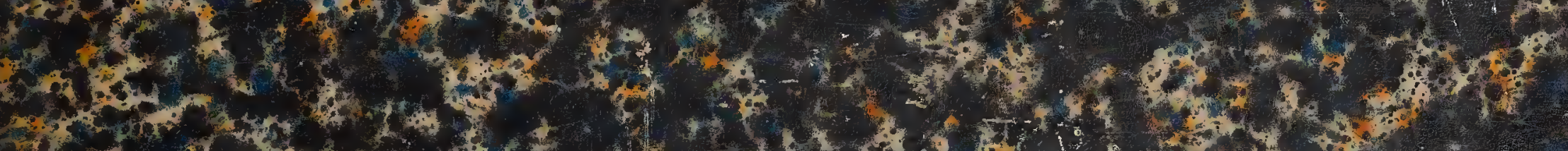

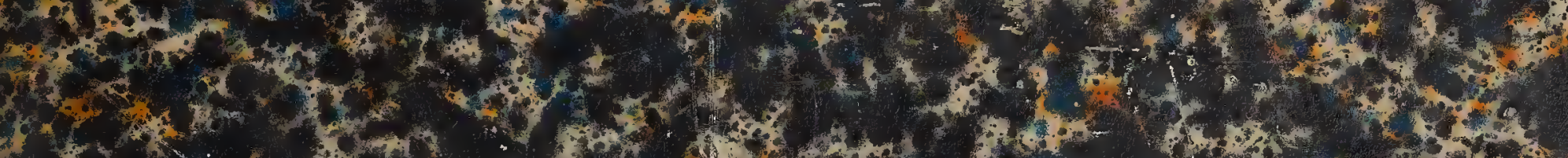

$7 x^{2}$.

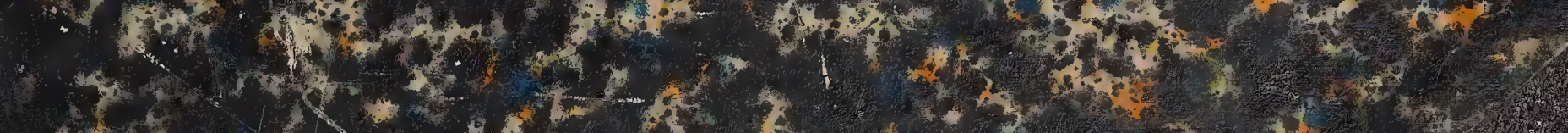

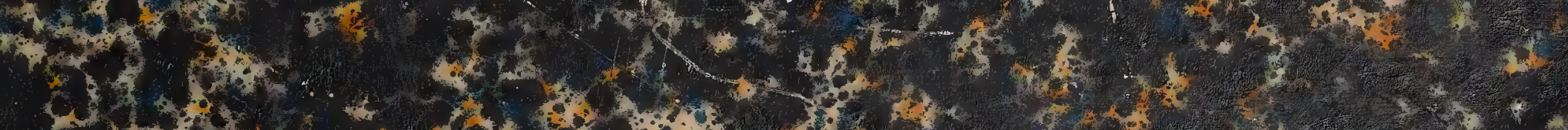

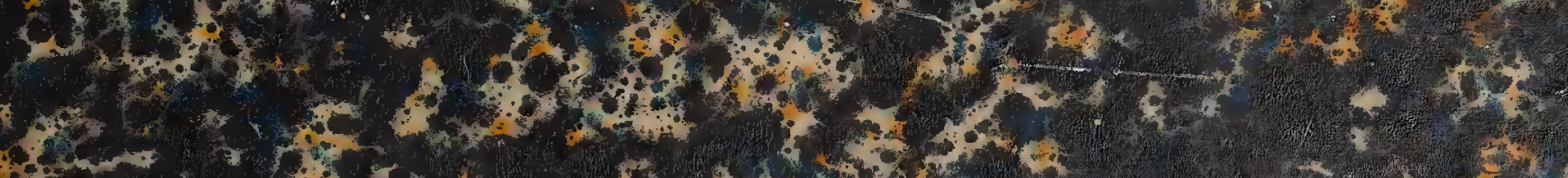



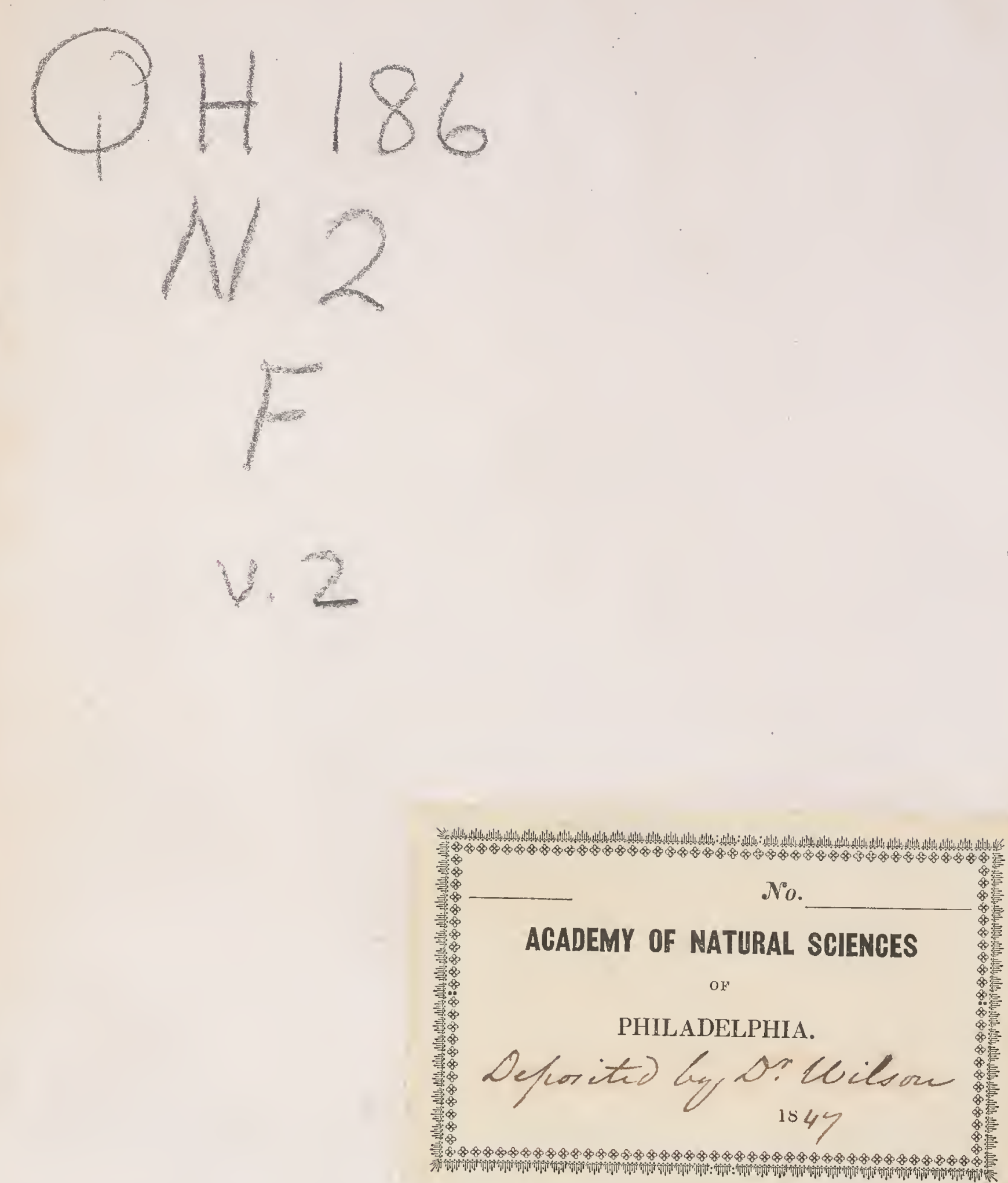


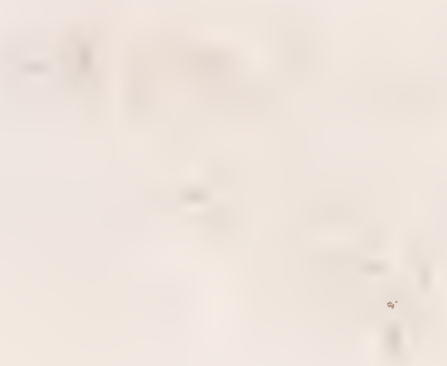





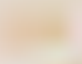
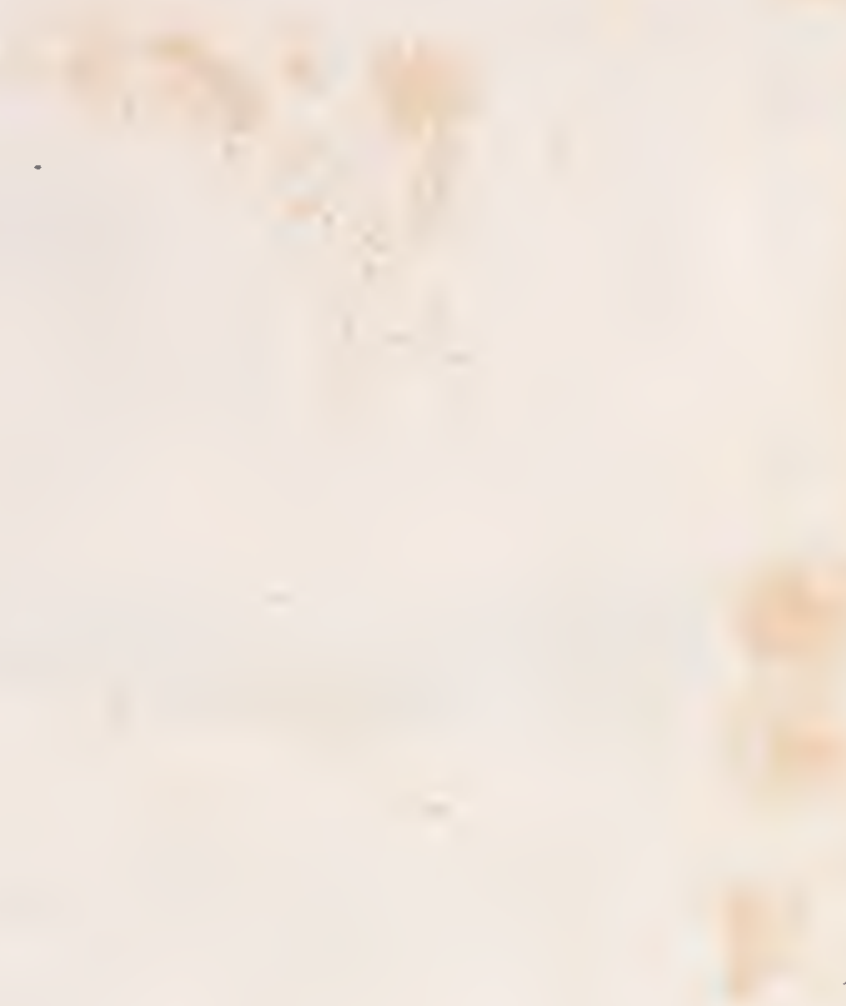

$\because$ 



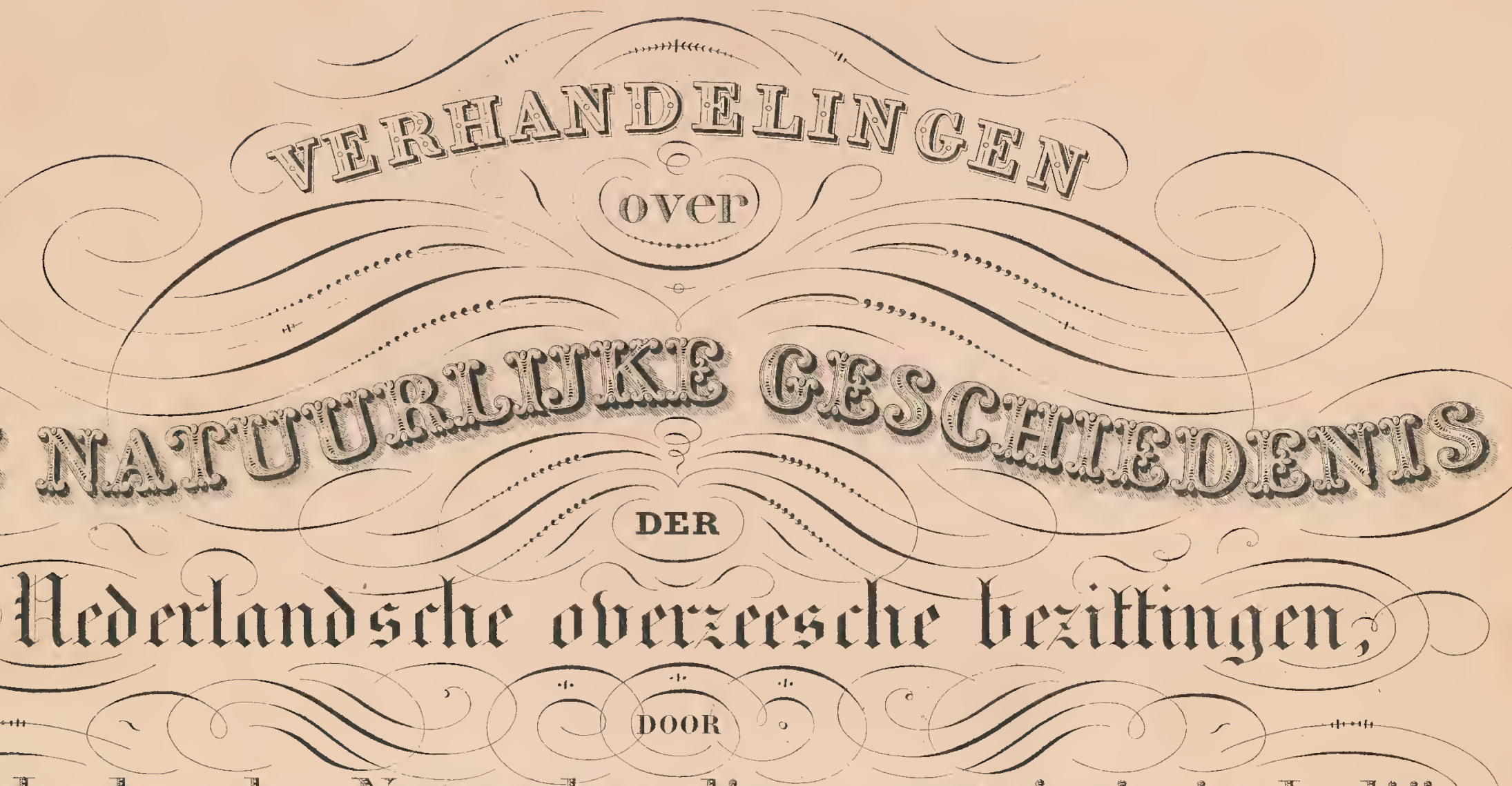

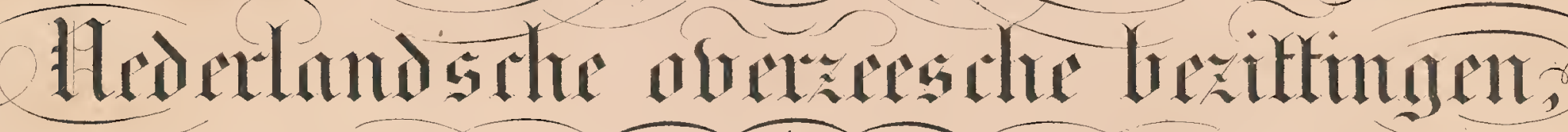

de Leden der Natuntkundige commissie in Thdie
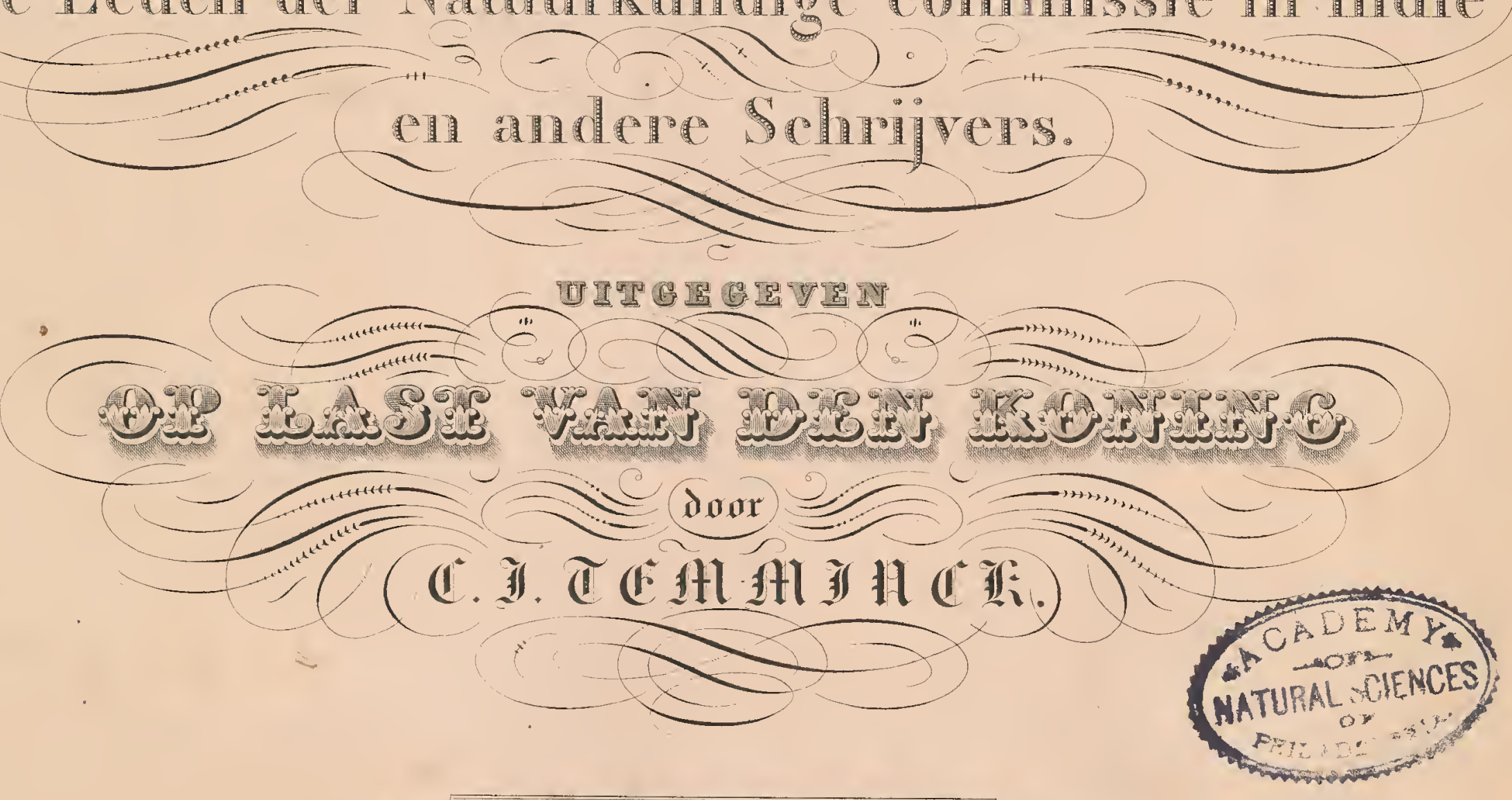

\section{Q B 1) IAIN D}

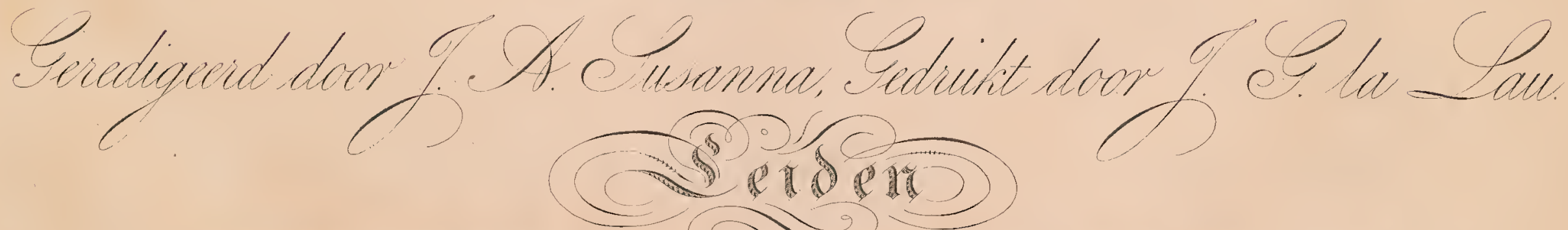

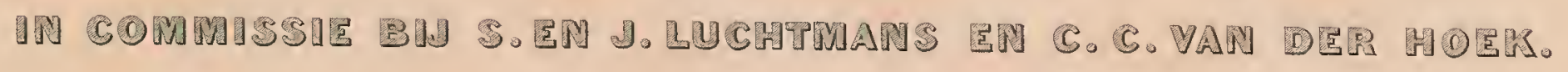

$$
1839-1842 .
$$




$$
\begin{gathered}
\text { QH } 186 \\
N 2 \\
F \\
V .2
\end{gathered}
$$




\section{K R U I I K K U N D E,}

P. W. II O B T II A L S. 


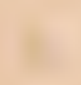

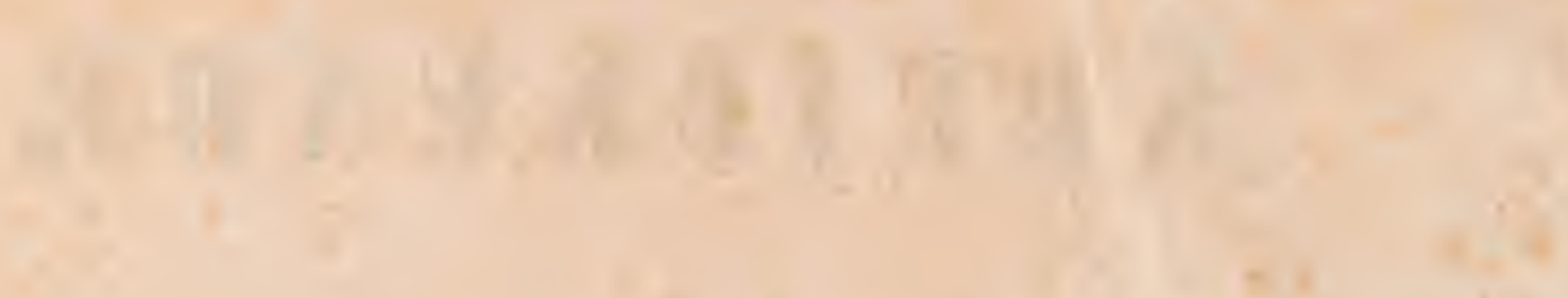

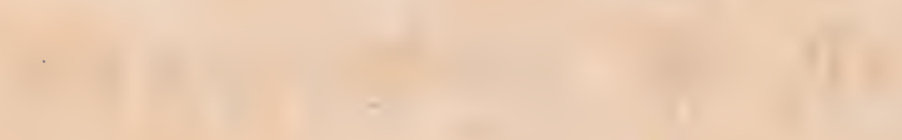




\section{R E G I S T E R.}
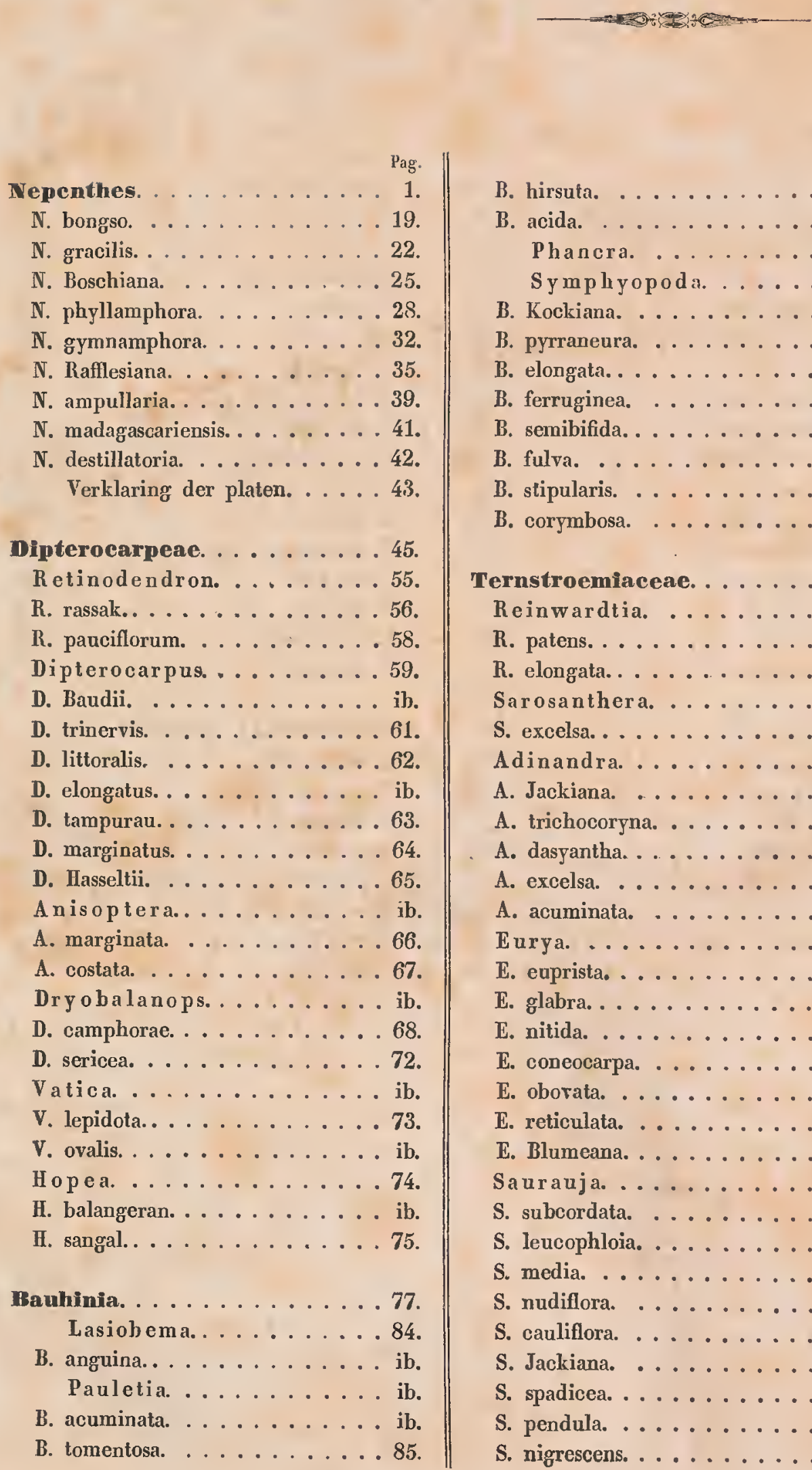

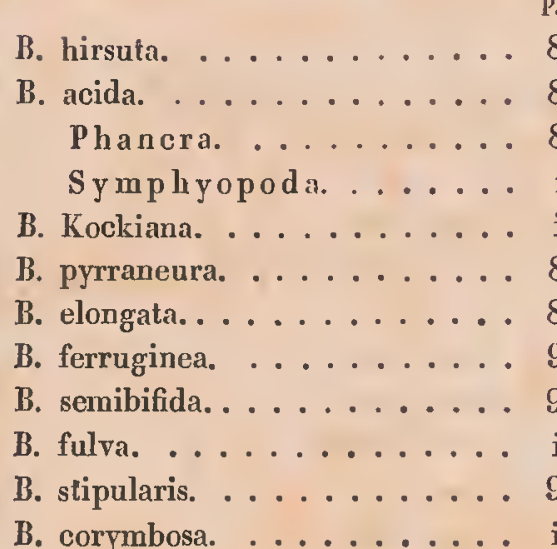

Ternstroemiaceac. . . . . . 93

Reinwardtia. . . . . . . 101

R. patens. . . . . . . . 102.

R. elongata. . . . . . . . . 103.

Sarosanthera. ........ ib

S. excelsa............ 104

Adinandra. . . . . . . 105

A. Jackiana. . . . . . . . 106

A. trichocoryna. . . . . . . . 107.

A. dasyantha. . . . . . . . . 108

A. excelsa. . . . . . . . . . 109

A. acuminata. . . . . . ib

Eurya. .......... 110

E. euprista. . . . . . . . 113

E. glabra. . . . . . . . . . 114

E. nitida. . . . . . . . 115

E. coneocarpa. . . . . . 117

E. oborata. . . . . . . . 118

E. reticulata. . . . . . . . . .

E. Blumeana. . . . . . . 119

Saurauja. . . . . . . . 120

S. subcordata. . . . . . . 124

S. leucophloia. . . . . . . 125

S. media. . . . . . . . . ib.

S. nudiflora. . . . . . . 126

S. cauliflora. .......... ib

S. Jackiana. … . . . . 127

S. spadicea. .......... ib

S. pendula. . . . . . . . ib

S. nigrescens. . . . . . . 128 .
S. vulcani. . . . . . . . 128.

S. excavata. . . . . . . . . 130 .

s. leprosa. . . . . . . . . . i ib

S. distasosa. . . . . . . . . 131

S. ferox. . . . . . . . . . . 132

S. setigera. . . . . . . . 133 .

S. tewensis. . . . . . . . ib

S. Reinwardtiana. . . . . . . 134

S. sakoembangensis. . . . . . . ib.

S. singalangensis........ ib

Ploiarium. . . . . . . . . 135

P. elegans. . . . . . . ib.

Laplacea. . . . . . . . 136

L. vulcanica. . . . . . . . ib

Antheëischima. . . . . . 137

A. excelsa. . . . . . . . 138

Closaschima. . . . . . . . 139

C. ovalis. ........... 140

C. marginata. . . . . . . . 141.

Schima. . . . . . . . 142

S. crenata. . . . . . . . . 143

S. Noronhae. . . . . . . . 144

S. antherisosa. . . . . . 145 .

pyrenaria. ......... îb.

P. serrata. . . . . . . . 146

P. oïdocarpa. . . . . . . . 147 .

P. masocarpa. . . . . . . . . ib

P. lasiocarpa. .......... ib

Calpandxia. . . . . . . 148

C. lanceolata. ......... ib.

C. quiscosaura. . . . . . . . 149

\section{Nauclea en cenige verwante}

geslachten. ........ 150

Platanocarpum. ...... 152

P. subditum. . . . . . 153.

Anthocephalus........ ib

A. morindaefolius. ........ 154

$\mathrm{N}$ a uclea. .................. 156 .

N. strigosa. . . . . . . . . 157

N. purpurascens. . . . . . . ib

N. synkorynes. . . . . . . . 158 .

N. obtusa. .......... ib 


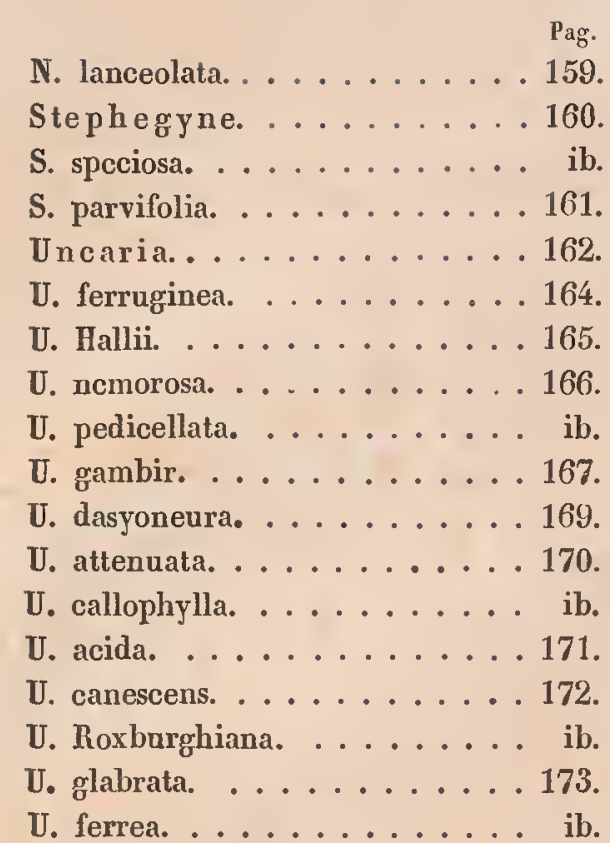

Cratoxylon en Tridesmis. . . 175

Cratoxylon.......... ib

C. polyanthum......... ib.

C. glaucum. . . . . . 176

C. Hornschuchii. . . . . . . . . 178

Tridesmis. . . . . . . . . 179

T. formosa. . . . . . . . . ib.

Salacia en Hippocratea. . . 181. Salacia. .......... ib

S. polyantha. . . . . . . . 182

S. ovalis. . . . . . . ib

S. kalahiensis. . . . . . . . 183 .

S. exsculpta. . . . . . . . ib

S. prinoïdes. . . . . . . . 184 .

S. macrocarpa. ........ ib.

Hippocratea. . . . . . . 185

H. indica . . ....... ib.

H. glaga. . . . . . . . . 186 .

H. macrantha. . . . . . . . . 187.

H. salacioìdes. . . . . . . . 188

Praravinia en Omphacarpus. 189.

Praravinia.......... ib

P. densiflora. . . . . . . 190 .

0 mphacarpus. . . . . . . 192

0. opacus. . . . . . . . 193

0. hirsutus. ......... ib
Eiken van den Indischen $\mathbf{A r}$ -

chipel. . . . . . . . . . . . 195

Quercus hystrix. . . . . . . 201

Q. mappacea. . . . . . . . 202

Q. oligoneura. ........... 203

Q. anceps........... 204

Q. racemosa. .......... 205

0. microcalyx. $\ldots \ldots$

Q. leptogyne. .......... ib.

Q. gracilis. . . . . . . . 207.

Q. Blumeana. . . . . . . . . . 208

Q. encleisacarpa. . . . . . 209

Q. Reinwardtii. . . . . . . 211

Q. costata. . . . . . . . . 212

Q. Ewyckii. . . . . . . . . ib.

Q. annulata. . . . . . . . . . 213

Q. omalokos. . . . . . . 214.

Q argentata. ......... 215

Q. oïdocarpa. . . . . . . . 216.

Indische Melastomaceae. . . 218 .

Osbeckia. . . . . . . . . 223

0. linearis. . . . . . . . . . 224

IIelastoma.......... ib.

II. polyanthum. . . . . . 225 .

M. erectum. . . . . . . . 226

II. lanuginosum. . . . . . . . 227 .

II. Jackianum. . . . . . . . ib.

II. punctatum. . . . . . . 229

II. asperum. . . . . . . . 230 .

II. setigerum. . . . . . . . ib.

II. pulcherrimum. . . . . . . 231 .

II. Boryanum. . . . . . . . 232.

M. nitidum. . . . . . . . 234.

0thanthera. ........ 235

0. bracteata. ......... ib

Dissochaeta. . . . . . . 236 .

D. fallax. ......... ib.

D. intermedia. . . . . . . ib

D. gracilis. . . . . . . . 237 .

D. bracteata. . . . . . . ib

D. cyanocarpa. . . . . . . . 238 .

D. bipulvinata. . . . . . . 239 .

D. rostrata. . . . . . . ib.

D. nodosa. . . . . . . ib.
D. biligulata. . . . . . . 240 .

Marumia. . . . . . . . ib.

II. affinis. . . . . . . . . 241

II. leprosa. . . . . . . . . ib.

II. pachygyna. . . . . . . 242 .

II. vulcanica. . . . . . . . 243

M. Jackii. . . . . . . . . . ib.

II. stellulata. ........ ib.

Dalenia.............. ib.

D. speciosa. . . . . . 244 .

Medinilla. . . . . . . 245 .

II. polyantha. . . . . . . ib

Pachycentria. . . . . . 246

P. tuberculata. ........ ib.

Pogonanthera. . . . . . 247

p. pulverulenta. ........ ib.

0chthocharis. ........ ib.

0. paniculata. ........ ib

Sonerila. ......... 248 .

S. begoniaefolia. . . . . . . ib.

S. picta... . . . . . . . 249 .

S. obliqua. . . . . . . 250 .

Anerincleistus. ........ ib.

A. hirsutus. . . . . . . ib.

Driessenia. . . . . . . . 251

D, axantha. ......... ib

Phyllagathis. . . . . . 252.

P. rotundifolia. . . . . . . ib.

P. gymnantha. ......... ib.

Kibessia. . . . . . . 253 .

K. cordata. . . . . . . ib.

K. simplex. . . . . . . . . ib.

Ewyckia. . . . . . . . . 254

E. galeata. ........ ib.

E tuberculata. . . . . . . 255

E cordata, .......... ib

\section{Cleisocratera, Boschia en}

Maranthes. . . . . . . . . 256

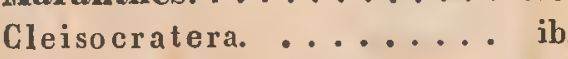

C. elegans. . . . . . . 257

Boschia.............. ib

B. excelsa. . . . . . . . 258

Maranthes. ......... ib

II. multiflora. . . . . . . . 259 


\title{
OVER HET GESLACHT
}

\section{N E P D N T II E S,}

\author{
DOOR
}

\author{
P. W. K 0 R T II A L S,
}

PHIL. DOCT., RIDDER DER ORDE VAN DEN NEDERLANDSGHEN LEEUW, LID VAN DE NATUURKUNDIGE COMMISSIE IN OOST-INDIË.

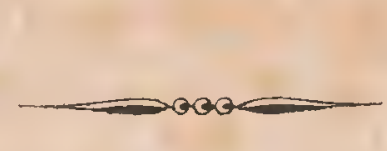

Onder de ons door Benzon $\left(^{*}\right)$ bekend gemaakte gewassen, vinden wij er cen vermeld, dat, volgens dezen sehrijver, door de afdruiping van vocht uit de bladen, den regen schijnt na te bootsen en dat door Sprengel voor Nepenthes gehouden wordt $(t)$. Met dit gevoelen kan ik mij niet vereenigen: veeleer zoude ik, na de meer uitvoerige beschrijving, welke Linschoten ecnige jaren later leverde (\$), van gevoelen zijn, dat Benzon en Linschoten eenen op de Caesalpinia pluviosa gelijkenden boom, of misschien wel dezen zelven, bedoeld hebben.

De bekendwording der Nepenthes bchoort dus tot een nieuwcr tijdvak, en de eerste bepaalde opgave derzelve moet den Gouverneur van Madagascar, Flacourt, worden toegeschreven. Mij vond haar in de omstreken van de door de Franschen op dit eiland genomene bezitting, leerde haar van de inlanders onder den naam van Poenga kennen, en deelde ecne beschrijving en afbeelding van haar mede, onder de benaming van Amramatico $(*)$.

$\left(^{*}\right)$ Benzonius, Nova novi orbis historia.

( $t$ ) Sprengel, Historia rei herbariae, I. p. 373.

(\$) Linschoten, Indiae Orientalis, Pars 3. Cap. 5.

$(\star)$ Flacourt, His toire de la grande Isle de Madagascar, p. $130 . N^{\text {o }}, 43$. Botanica. 
Het aanwezen van een gelijkvormig gewas op Ceylon, werd eenige jaren later door Paulus Hermann, die langen tijd (van 1669) op dit eiland Geneesheer was, bekend gemaakt, toen deze, door het vreemde van den vorm getroffen, eenige der verzamelde voorwerpen aan Commelyn, te Amsterdam, toezond. Door dezen beoefenaar der kruidkunde werd de van Ceylon ontvangen sehat aan den beroemden J. Breyne, bij gelegenheid, dat deze Holland bezoeht, getoond en medegedeeld, om de eigendom der wetenschap te worden. Het vond dan ook in den door Breyne uitgegeven Prodromus eene plaats, en werd vermeld onder bijvoeging, dat het zeer gelijk was aan de Madagaseaarsehe Amramatieo ( $\left.{ }^{\star}\right)$.

De bladen werden vervolgens door Amman onder den naam van Bandoera afgebeeld $(\dagger)$, en de geheele plant, in 1682, door II. N. Grimm, volgens door hem, niet ver van Colombo op Ceylon gevondene voorwerpen, onder den naam van Planta mirabilis destillatoria besehreven ( $($ ).

Het aanwezen van eenen gelijksoorligen vorm in den Arehipel, werd ons door Rumphius bekend, en zijne afbeelding en besehrijving komen, onder den naam van Cantharifera, in het door hem reeds in 1702 voltooide werk voor $\left(_{*}\right)$.

Deze drie vermelde, door hunne uitwendige gedaante zoo zeer overeenstemmende gewassen, waren dus ontdekt, toen Linnaeus als hersehepper der wetensehappelijke nomenelatuur optrad. Evenwel sehijnt hem de Ceylonsehe plant alleen door voorwerpen en de andere sleehts door besehrijvingen en afbeeldingen bekend te zijn geweest, en hare in het oog vallende overeenkomst met de afbeeldingen der Madagaseaarsehe en Moluksehe planten aanleiding te hebben gegeven, om allen onder den soortsnaam destillatoria met den geslaehtsnaam Nepenthes te vereenigen. De eerste naam was zeer goed gekozen om de eigensehap der plant uit te drukken; de tweede was meer diehterlijk, en herinnerde aan een gewas, dat in de oudheid den roem had vàn uitstekende smartverdrijvende eigensehappen te bezitten $(\downarrow)$.

Deze bekerdragende gewassen komen nu onder den geslachtsnaam Nepenthes bij de volgende sehrijvers voor. Door Poiret $\left.{ }^{\star \star}\right)$ werd het eerst het soortelijk versehil der onder den Linneaansehen naam vereenigde gewassen aan het lieht gebragt, en eene wetensehappelijke besehrijving van de door Commerson aan de Fransehe verzamelingen bezorgde Madagaseaarsehe plant, onder den naam van Nepenthes Madagaseariensis geleverd, en tevens eene naamsverandering van de planten der oostelijker streken voorgesteld. Deze laatste werden nu als Nepenthes Indica vermeld en bleven vereenigd, tot dat Willdenow aan de Ceylonsehe plant als de oorspronkelijke, door Linnaeus bedoelde soort, den naam van Nepenthes destillatoria gaf, en aan die van den Arehipel en de door Loureiro van Coehinehina beschrevene plant, dien van Nepenthes phyllamphora toekende $(t+)$.

(*) J. Breyne, Prodromus, I. p. 18.

( $†$ ) Ephemeridium Academiae Naturae curiosorum, Ann. 1. Observ. 23.

(§) Hetzelfde werk, Observatio 146.

(^) Rumphius, Herbarium Amboinense, T. 5. Tab. 59.

(t) Homerus, Odyssea IV. 221. Plinius, Historia naturalis, Lib. XXI. 21. Lib. XXV. 2.

${ }^{* *}$ Eneyclopedie Botanique, Nepenthes.

(十t) Willdenow, Species Plantarum, T.4. p. 874.

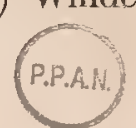


Later werden er aan dit drietal soorten door het onderzoek van den Hoogleeraar Reinwardt (van 1816 - 1822) nog twee toegevoegd, van welke de eene op het eiland Java en de andere soort op Celebes wordt aangetroffen. Beiden zijn het eerst door den Heer Nees von Esenbeck onder de haar door den Heer Reinwardt gegevene namen besehreven $\left(^{*}\right)$. Bijna gelijktijdig had de ontdekking der fraaije Nepenthes ampullaria en N. Rafflesiana (vermoedelijk de N. maxima Rwdt.), op de cilanden Singapoera, Bintang enzv., door W. Jaek, plaats ( $\mathrm{t}$ ). De Heer Brongniart, eene uitvoerige besehrijving van de in de Parijsche verzamelingen voorhandene Nepenthes destillatoria en N. Madagascariensis leverende, maakte bij die gelegenheid melding eener soort onder den naam van $\mathbf{N}$. cristata, die, hoewel door Nees von Esenbeck met de Javaansehe N. gymnamphora als identiesch beschouwd, vermoedelijk op wortelbladen van onderseheidene soorten berust. Deze reeds bekende zes soorten werden door onze latere reizen op Sumatra en Borneo, met nog een drietal onvermelde soorten vermeerderd.

Blijkens deze korte gesehiedenis behooren de soorten van Nepenthes in de, door den grooten oceaan bespoelde, tusschen de keerkringen gelegene oorden te huis. $\mathrm{Z}_{\mathrm{ij}}$ vertegenwoordigen hier, door hare vormen, de Noord-Amerikaansehe Sarraceniae en den aan Nieuw-Holland eigenen Cephalotus. De westelijkst gevondene soort is de Nepenthes Madagascariensis, welke op het eiland Madagascar, in de oorspronkelijke bosschen der lagere streken voorkomt, alwaar, volgens Bojer en Hilzenberg, de Tanghina veneniflua, de beruehte giftboom van dit eiland niet zeldzaam is. Op Ceylon groeit de Nepenthes destillatoria vooral in de vochtige opene plaatsen, waar cnkele struikbossen in de grasvlakten verspreid zijn, tussehen deze struiken als een verscheidene voeten lang klimgewas, of zij treedt minder welig van tusschen het gras te voorschijn. Oostelijker op de eilanden van den Archipel tot aan NieuwGuinea's zuid-westkust, in de Philippijnen en op het vasteland in Cochinehina merkt men meerdere soorten op. De Nepenthes ampullaria, N. Rafflesiana, N. phyllamphora wassen in de moerassige bossehen van Sumatra's westkust, en de N. Bongso, eene nieuwe soort, op de met uitgebrande steenblokken bedekte bergruggen van den aldaar gelegen’ Merapi. De beide eerste soorten zijn daarenboven op de kleine eilanden, tegen over Malakka's zuidpunt te huis, en de N. phyllamphora heeft Sumatra's oostkust (§), Banea, Coehinehina, de Molukken, Tidore en Nieuw-Guinea tot groeiplaatsen. Het laatstgenoemd gervas werd door ons waargenomen in de moerassige bosschen van het bezocht gedeelte van Borneo's zuid-oostkust. De Nepenthes gracilis versierde in deze landstreek daarentegen de drooge zanden steengronden, en een heerlijk ontwikkelde vorm van N.Boschiana, de bossehen van het hoogere gebergte. De Nepenthes gymnamphora is tot dusverre alleen bekend als bewoner der oorspronkclijke bosschen van Java's gebergte.

Hoewel de versehillende standplaatsen, waar deze planten groeijen, op de ontwikkeling derzelve eenen aanmerkelijken invloed uitoefenen, bieden eehter de bekende soorten eene zeer overeenstemmende groeiwijze aan.

$\left(^{*}\right)$ Nees von Esenbeck in Annales des Sciences naturelles, Tom. 3.

( + ) De eerste vermelding dezer soorten vindt men in eenen brief van W. Jack aan zijnen Vader, dato 20 Junij 1819.

(\$) Deze opgave bcrust op het door Rumphius medegedeelde, en op de mij door bewoners van Corinthie, die dc rivier naar Palembang waren afgezakt, gegevene inlichtingen. 
De worteltjes der pas ontkiemde planten zijn spilvormig en worden bij meerdere uitgroeijing door eene menigte vezeltjes takrijk. Vervolgens vormt de wortel eenen wortelstok, die zieh bijna horizontaal onder den grond ontwikkelt, of in den vorm van eene rank over denzelven heenkruipt. In het eerste geval is hij zwart en zeer houtig; in het laatste neemt hij het voorkomen van de steng aan. Deze wortelstok bezit dikwerf aan het begin, zoo als Rumphius dit reeds zeer juist afbeeldt, eene knolvormige verdikking, welke vooral op droogere plaatsen eene aanzienlijke ontwikkeling erlangt, en sehijnt mij toe, na de afsterving der bladdeelen voort te duren. Uit den wortelstok ontwikkelen zich op onbepaalde afstanden nieuwe spruiten, die grootendeels eene geringe uitgroeijing verkrijgen, omdat meestal de eene derzelve zieh ten koste der andere vergroot. Deze hoofdsteng neemt nu bij hare vergrooting bijzonder in lengte toe, terwijl zij sleehts eene geringe vermeerdering van dikte ondervindt.

De stengen zijn bij eene aanzienlijke verlenging in het benedenste gedeelte bladerloos, en bezitten daar enkele verspreidene bladgroepen. Hare oudere deelen hebben eenen rolronden vorm en den houtaehtigen aard van den wortelstok; hare jongere bezitten, naarmate de bladen meer of minder gesteeld zijn, eenen driehockigen vorm en eene meer kruidachtige geaardheid. Bij de Nepenthes graeilis is de jonge steng driezijdig en de afloopende bladstelen vormen langs de, aan de bladen tegenovergestelde zijden, bladaardige randen; bij de N. Bosehiana zijn deze randen op de ronde steng tegen over elkander geplaatst. De jongere stengen van al de mij bekende soorten hebben eene meer of minder ontwikkelde haarbedekking, welke aan de Nepenthes Rafflesiana enzv. een grijs, en aan de N. ampullaria enzv. een bruin aanzien geeft. Dit harig bekleedsel blijft bij de laatstgenoemde soort voorhanden, maar ontvalt aan de andere met de uitgroeijing der plant; hetgeen deze bijna geheel glad doet worden. Omtrent dit bedeksel heb ik opgemerkt, dat het uit langere eenvoudige en uit kleinere meer stervormige haartjes bestaat, en dat de eerste veelal het spoedigst verdwijnen.

Zoo als reeds door vroegere sehrijvers, de Heeren Valentini en Lindley $\left(^{\star}\right)$ is aangetoond, versehilt de steng van Nepenthes van de gewone zamenstelling, doordien de grenzen tussehen vaten en merg minder bepaald zijn, dan gewoonlijk. Zeer jonge toppen der steng bestaan uit een zeer fijn mergaardig eelweefsel, hetwelk rijk aan korrels en omgeven is door een uit eene eellenlaag bestaand vlies. Lager heeft dit eelweefsel eenige spiraalvaten, die gemeenlijk met eenen afgeronden top tussehen vier eellen besloten zijn; hetzelve is door eene vezellaag omringd. Wanneer men de ontwikkelde stengen in het gebladerd gedeelte onderzoekt, dan leveren zij de volgende zamenstellende deelen. - De opperhuid bestaat uit ééne of twee, zelden uit meerdere lagen van dikwandige, eene groene of bruine kleurslof bevattende, eellen. Onder haar liggen de dikwandige, van zeer aanzienlijke openingen voorziene bastvezels, met eene menigte tussehen dezelve verspreide spiraalvaten. De bastlagen omringen een zeer los eelweefsel, waarin eenige, vooral uit spiraalvaten bestaande, vaatbundels verstrooid liggen. Nu volgt een ring, die in het bovengedeelte uit ééne of twee en in het lager gedeelte van de steng uit meerdere rijen van kleine eellen bestaat. Deze omgeeft eene, zieh aan het bloote oog als een witte, vezelige eirkel voordoende laag, die met gewapende oogen waargenomen, spiraalvaten van ongeveer $\frac{\mathrm{r}}{20}$ streep middellijns doet zien.

$\left.{ }^{*}\right)$ Lindley, Introduction to Botany, p. 69 . 
Deze spiraalbundelring wordt door eene cellenlaag, waarin enkele bastvezelbundels verspreid zijn, van de houtlaag geseheiden. De houtlaag met het ongewapend oog gezien, doet zieh voor, als uit twee versehillende lagen bestaande, van welke de buitenste rijk is aan kleine gaaljes en de binnenste, het merg omringende, eene zeer digte zamenstelling aanbiedt. Bij eenige vergrooting nemen wij in deze houtlaag spiraal- en rozenkransvaten, gestipte langwerpige eellen en vezels, en ook mergeellen waar. De buitenste laag bevat alleen regelmatige mergstralen, die uit dikwandige tafelvormige eellen bestaan, en in de gemelde eellenlaag onder de spiraalvaten verloopen; vervolgens rozenkransvaten met tamelijk lange, door bijna horizontale dwarsbanden aangetoonde leden, en zeer kleine, digt gedrongene vezels. De binnenste laag, die als het mergkanaal kan aangemerkt worden, bestaat uit groolere, dikwandige vezels, langwerpige vezeleellen, met bruine kleurstof gevulde eellen, benevens eenige spiraalvaten, die door de dikkere wanden en den grooteren omvang gemakkelijk erkend kunnen worden. Tussehen deze laag is het merg besloten, hetwelk uit twee soorten van eellen en uit spiraalvaten bestaat. De eene en talrijkste soort van eellen is tevens de grootste en vormt een los weefsel; tussehen deze zijn de andere, meer dan de helft kleinere, zoodanig in rijen boven elkander geplaatst, dat zij bij een oppervlakkig onderzoek vezels sehijnen te zijn. De eerste hebben tussehen dikke wanden kleine holten, en in de laatste omgeven dunne wanden eene bruine kleurstof. Niet zelden zijn deze kleine eellen bij de spiraalvaten geplaatst, zoodat ik in het begin, bij geringe vergrooting, een’ vaatbundel meende te zien ( ${ }^{\star}$ ). De spiraalvaten hebben somwijlen eene aanzienlijke grootte, ongeveer $\frac{T}{I 3}$ streep middellijns, en zeer dikke draden, die mij voorkwamen bijna vierkantig te zijn.

De oudere stengen versehillen door het gemis van de buitenste epidermis, de bastvezellaag en het daaronder gelegen eelweefsel met deszelfs vaatbundels, die mij voorkomen, deelen te zijn van de afloopende bladstelen der jongeren. Haar buitenvlies bestaat uit eene menigte kleine eellen, met bruin gekleurde wanden; het bedekt de reeds vermelde laag van spiraalvaten; hieronder ligt het eelweefsel en verder naar binnen de reeds bij de jongere steng waargenomene deelen. Bij deze gelijke zamenstelling leveren eehter de bestanddeelen eenig versehil. De spiraalvaten zijn over het algemeen veel kleiner; hunne draden bezitten naauwelijks de helft der grootte van de in jongere stengen voorkomende. De buitenste ring van de houtlaag, aan zijne gaatjes te erkennen, is veel meer ontwikkeld, eehter zijn zijne vaten van gelijke geaardheid. De binnenste is meer te zamengedrongen en omgeeft een digt, dikwandig eelweefsel met verspreide spiraalvaten. Dit eelweefsel bestaat uit twee soorten van eellen, en niet zelden bevatten ook hier de grootere eellen kleine bruine bolletjes. Deze zamenstelling der steng met het tot dusver bekende van andere gewassen vergelijkende, is het voorkomen van de spiraalvaten in het merg eene eenigzins met de Monoeotyledonen in verband staande en met verseheidene Dieotyledonen overeenkomende versehijning $(\dagger)$, van welke de Heer Treviranus vele voorbeelden, en de Heer Sehultz ons eenige afbeeldingen gegeven hebben. Daarentegen staat het voorkomen van den spiraalring tussehen bast en hout nog geheel op zieh zelf.

$\left(^{*}\right)$ Het is belangrijk, deze zamenstelling te vergelijken met hetgeen de Heer Meyen, in Wiegmann's A rchiv für Naturgeschichte, 1838 , p. 297, over de vezelen van het vlas vermeldt, waardoor het niet onwaarschijnlijk wordt, dat deze langwerpige cellen, als nog niet tot een geheel zaamgegroeide vezels te beschouwen zijn.

(†) Treviranus, Physiologie, I. p. 209 
Na deze uitweiding omtrent de zamenstellende deelen der steng, zetten wij de besehouwing van het uiterlijke der plant verder voort. De knoppen zijn zelden geheel rolrond, maar veelal eenigzins zamengedrukt en omvatten de jongere deelen. Hunne meerdere of mindere lengte hangt af van de ontwikkeling van den steel, aan welks einde de beker in eenen zeer jongen staat slechts eene kleine teruggebogene verdikking vormt. Deze, even als het verlengde gedeelte van de middelnerf, en de middelnerf benevens de randen der knoppen, zijn veelal digt behaard.

De knoppen ontrollen zich bij de meerdere vergrooting, en gaan door de uitgroeijing, in geheel van het gewone afwijkende bladvormen over, welke uit een' steel, eene meer of minder groote bladschijf, met eene sterk ontwikkelde middelnerf, die zich boven de bladsehijf verlengt, en uit een' knods of bekervormig ligehaam bestaan. De bladen hebben; naar gelang van hunnen stand, eene veranderde evenredigheid in derzelver zamenstellende deelen.

De wortel en benedenste stengbladen bezitten dikwerf alleen aan den voet, waar zieh het blad met de steng vereenigt, eene geringe scheèvormige uitbreiding, wier middclnerf in eenen ongelijken driehoekigen steel uitloopt, welks bovenste gedeelte altijd vlak is. In den jeugdigen staat eindigt deze steel in een klein onregelmatig rolrond of vierkantig ligchaam. Deze verdikking neemt vervolgens eenen meer regelmatigen vorm aan, en wordt bijna kogelvormig bij Nepenthes ampullaria, meer eivormig bij $\mathbf{N}$. gymnamphora of langwerpig bij $\mathbf{N}$. gracilis. Al deze hoofdvormen zijn echter min of meer driekantig, waarbij liet van de spil afgewende of buitenste gedeelte rond, en het naar haar toegekeerde, vlak is. De gemelde vlakte wordt aan de beide zijden door twee bladaardige uitgesnedene kammen begrensd, welke somwijlen eene aanzienlijke uitgroeijing verkrijgen.

Bij eene meerdere vergrooting van deze veelvormige holle aanhangsels, openen zij zich aan de geknotte uiteinden door een deksel, dat aan de uitstekende hoogste punt vastgehecht, zieh naar de spil der plant ontsluit en, zieh vervolgens van deze verwijderende, terugbuigt. Dit deksel is vliezig, cirkelrond of meer ovaal, en verandert bij den voortgaanden groei van den beker weinig in grootte of vorm.

De stengbladen hebben eene andere evenredigheid. De vlakke bladsehijf wordt door eenen, dikwerf aanzienlijk langen steel, welke aan de beide zijden een smal bladaardig, bij de steng eindigend randje heeft, gedragen: zij is meest langwerpig ovaal, aan beide einden spits, zelden stomp uitloopende, en heeft in hare nervuur veel overeenkomst met die, welke bij eenige monocotyledonische gewassen wordt waargenomen. De hoofdnerven ontspringen aan den voet, zelden uit de middelnerf, loopen vervolgens bijna evenwijdig met den rand van de bladschijf, en vereenigen zich aan den top met de middelnerf: zij zijn door eene menigte kleine aderen verbonden, waardoor een uit vierkante mazen bestaand net wordt gevormd.

De steel, welke, zoo als ik boven reeds aanstipte, eene voortzetting der middelnerf van de gemelde bladschijf is, vertoont zich onder twee gedaanten: in de digt bij de bloemen geplaatste bladen eindigt hij dikwerf in eene eenigzins verdikte punt, en heeft dan schijnbaar alleen het doel, om als klawier de te 
zwakke steng te ondersteunen, waartoe zich het uiteinde in eenige krullen terugbuigt en de naastbij gelegene takken omwindt: bij anderen ontwikkelen zich aan het einde van den steel de reeds gemelde bekers. In dit geval gaat hij eerst regtstandig op, kronkelt zich vervolgens in twee of drie krullen om, en buigt zieh dan loodregt naar beneden, om in den omgebogenen voet van den beker over te gaan: zoodat hier de steel door de krullen als klawier dient en tevens den opgerigten stand van den beker bevordert. Bij eenige planten zijn deze bekers regelmatig buisvormig, bij andere buisvormig met eene verwijding boven den voet en bij sommige meer regelmatig treehtervormig. Op dezelve verdwijnen de bij de bekers der jongere planten dikwerf zeer ontwikkelde ingesnedene bladvormige kammen, naarmate zij hooger geplaatst zijn, en laten op die van zeer ontwikkelde planten dikwerf alleen in kleine randen hunne over-blijfsels terug. De mond of opening der bekers van de steng en wortelbladen is door eene vlakke geribde bladuitbreiding gekroond. In zeer jonge bekers is deze boord vlak, en bij meer ontwikkelde is, zoo wel het binnenwaartsche, als het naar buiten gelegen gedeelte van deze bladuitbreiding omgerold; het binnenwaartsche heeft den omtrek seherp getand. Over het algemeen zijn de deksels van de bekers der stengen meer uitgegroeid, dan die van de bekers der wortelbladen, en van eene minder langwerpige gedaante.

De stengbekers hebben, even als de wortelbekers, drie hoofdnerven, welke met de kanten van den steel in verband staan; twee derzelve zijn tegen over de spil gelegen, en eene is van de spil verwijderd. Tusschen de beide eersten, op welke zieh de gemelde kammen ontwikkelen, verdwijnen ééne of somwijlen meerdere nerven van den voet naar den rand. De andere nerven, welke grootendeels uit den steel of in kleiner aantal uit de gemelde twee kamnerven haren oorsprong nemen, loopen bijna allen uit, op het tegen over de spil gelegen punt der aanheehting van het deksel. Zij vereenigen zieh hier gedeeltelijk in een klein, somwijlen getand aanhangsel, en breiden zieh anderdeels in het deksel weder uit. Tussehen deze hoofdnerven zijn eene menigte kleinere aderen, welke eehter door de meerdere buigingen, een minder regelmatig net vormen, dan op den vlakken bladboord. De nervuur der deksels is, door hare rigting en door hare meer boogvormige takverdeeling, van de bovengemelde onderscheiden en komt meer met die der gewone bladen overeen.

De gemelde bekers zijn vóór het opengaan tot op de helft, zelden daar boven, met vocht gevuld, hetgeen een genoegzaam bewijs oplevert, dat dit voeht in den beker zelven afgescheiden wordt en niet ontstaat door den invallenden regen of dauw. Nadat de bekers zich geopend hebben, blijft deze afseheiding van vocht, vooral op vochtige plaatsen, voortduren, en in geledigde tocgedekte bekers heb ik telkens weêr nieuw voeht zien afscheiden. Rumphius, welke de Amboinsche Nepenthes gedurende eenigen tijd schijnt waargenomen te hebben, deelt ons mede, dat deze afscheiding voornamelijk des naehts zoude plaats vinden. De in de nabijheid van Padang door mij gedane waarnemingen, stemmen met dit door Rumphius medegedeelde gevoelen niet geheel overeen, maar pleiten er voor, dat de des naehts in de tropische gewesten zoo rijkelijk vallende dauw een groot aandeel heeft aan dit door Rumphius bekend gemaakt verschijnsel; terwijl de gedurende den dag plaats hebbende en niet in aanmerking genomene verdamping van het vocht, zeker het hare zal hebben bijgebragt om Rumphius tot: de meerdere afseheiding gedurende den nacht te doen besluiten. In den omtrek van Padang had ik in een' zeer vochtigen bodem eenige gewassen waargenomen, waarvan sommigen in de schaduw en anderen 
op eene meer aan de zon blootgestelde plaats grociden. De jongere, nog ongeopende bekers dezer, op onderscheidene plaatsen tierende gewassen, versehilden eenigzins ten opzigte van de in dezelve aanwezige hoeveelheid voeht. De in de sehaduw gegroeiden bevatteden geene zoo aanzienlijke hoeveelheid, als de anderen. Dit bragt mij op het denkbeeld, dat de zonnestralen welligt deze afseheiding bevorderden. Ten cinde hieromtrent eenige zekerheid te hebben, traehtte ik deze gewassen, zoo veel hunne standplaats zulks toeliet, vergelijkend na te gaan. Ik ledigde nu des avonds de reeds geopende bekers en sloot eenige met daartoe vervaardigde kleine papieren hoedjes. Mijne proefgewassen den volgenden morgen bezoekende, vond ik in de bekers van allen eenig voeht, maar het minste in de met gemelde hoedjes geslotene, hetgeen mij dus de meerdere hoeveelheid der anderen aan de voehtigheid van den dampkring deed toesehrijven. Mijne bekers op nieuw geledigd en eenige weder gesloten hebbende, vond ik des avonds in de in de sehaduw geplaatste gewassen zeker geene meerdere hoeveelheid voeht, dan des morgens; terwijl de geopende, aan de zon $\left(^{\star}\right)$ blootgestelde, even zoo gevuld waren, en de met hoedjes geslotene niet minder inhielden, dan des morgens. De planten nu eenige dagen aan ziehzelve overgelaten zijnde, bleek het mij, dat de in de zon geplaatste, door het lieht tot eene meerdere afseheiding geprikkeld werden, daar de hoeveelheid voeht van de besehaduwde voorwerpen, die der onbesehaduwde weinig overtrof, terwijl toeh de uitdamping ten nadeele van de laatste in aanmerking behoort genomen te worden. Ik heb getraeht, aan deze proef eenige meerdere zekerheid te geven door eenige bekers met fijn goudvlies, dat door zijden draden om de randen derzelve bevestigd was, af te sluiten: dan ook deze proef kon mij geene quantitative beslissing opleveren; eehter bewees zij genoegzaam, dat de hoeveelheid van het des daags afgeseheiden voeht, dàt van den naeht overtrof. Ik heb wijders gepoogd, deze proeven met afgesneden en in het water geplaatste bladen te herhalen; maar de ondervinding heeft mij ras bewezen, dat deze gewassen dan spoedig alle levenswerking verliezen, om sleehts korten tijd een kwijnend aanzijn te behouden.

Nog niet te vreden met deze reeds zoo merkwaardige afseheiding, heeft men aan het deksel der bekers een afwisselend sluiten en openen toegekend $(\dagger)$, hetwelk, volgens De Candolle, door eenigen aan den staat van den dampkring, door anderen aan de in den beker bevatte hoeveelheid voeht toegesehreven wordt. Dit versehijnsel, reeds door den Heer Treviranus omtrent de $\mathbf{N}$. destillatoria ontkend, is door mij bij geene der geziene soorten waargenomen, en men behoeft sleehts de verandering, welke de mond van den beker na de opening ondergaat, op te merken, om hieruit af te leiden, dat eene nieuve sluiting van denzelven onmogelijk is. Het in de bekers afgeseheiden voeht heeft een eenigzins troebel voorkomen, eenen flaauwen, zoetaehtigen smaak, en gaat, aan zieh zelf overgelaten, spoedig tot bederf over. Eenige met hetzelve genomen qualitative proeven, hebben mij bij de verdamping eenen eigenaardigen reuk doen opmerken en als vaste overblijfsels een zuringzuur zout, benevens plantaardige slijmstof doen vinden ( $(\S)$.

$\left(^{*}\right)$ In de zon teekende de Thermometer daar ter plaatse, des middags ten 2 ure, $94^{\circ}$ en somwijlen tot $104^{\circ} \mathrm{F}$.

(

( $($ ) Ik durf niet bepalen of dit vocht een voortbrengsel is, dat door uitwaseming in den beker wordt verzameld, dan wel of het door eene afscheiding wordt voortgebragt; voor het laatste schijnt de overeenkomst van hetzelve met het vocht uit de stammen van slingergewassen te pleiten. 
Deze zonderlinge vochtafseheiding heeft de Heer Treviranus het eerst getracht uit een meer physiologiseh oogpunt te doen kennen. Hij nam ten dien cinde de Nepenthes destillatoria waar en dcelde dienaangaande mede, dat de bovenste helft van de binnenvlakte gekleurd en met ecnen bruinen dauw, zoo als men gewoonlijk op de vlakte van vruchten en bladen, ter beseherming tegen voeht opmerkt, bedekt en dat de benedenste daarentegen blinkend is, vol kleine, klieraehtige en gcdeeltelijk van epidermis ontbloote heuveltjes. De Heer Treviranus houdt het voor waarschijnlijk, dat deze kliermassen het voeht afseheiden, en dat hetzelve zich in den beker niet boven de blinkende klierrijke oppervlakte verheft $\left(^{\star}\right)$.

De Heer Brongniart heeft ons in zijne beschrijving der Nepenthes mede reeds op deze klieren opmerkzaam gemaakt, zonder zich eehter bijzonder met derzelver zamenstel bezig te houden $(\dagger)$.

In eene bekroonde prijsverhandeling van den Heer Meyen over de afseheidings-organen der planten (\$), heeft gemelde schrijver aan de binnenste oppervlakte van de Nepenthes-bekers zijne bijzondere opmerkzaamheid toegewijd, zijne waarnemingen omtrent de klieren der $\mathbf{N}$. destillatoria medegedeeld en door afbeeldingen opgehelderd. In dit stuk treedt de Heer Meyen met het gevoelen op, dat het niet onwaarsehijnlijk is, dat gemelde klieren de blinkende stof afzonderen, welke de binnenvlakte der bekers gedeeltelijk bedekt, en dat het voeht uit de gekwetste plaats tusschen de opperhuid en de klier te voorschijn komt, even als zulks bij de bcleediging der epidermis van andere planten gesehiedt. Ter staving van dil gevoelcn voert hij aan, dat deze klcine klieren in de nog ongeopende bekers, van eene groene kleur en zeer saprijk zijnde, geen vocht afzonderen, en dat zulks eerst later, na de scheuring van de opperhuid, waarmede deze klieren geheel bedekt zijn, plaats vindt.

Deze waarnemingen van de Hceren Treviranus en Meyen medegedeeld hebbende, wil ik mijne waarnemingen, die van 1832 dagteekenen, hieromtrent opgeven. De wortelbladen hebben de binnenste oppervlakte der bekers somwijlen geheel met deze klieren bedekt; bij de stengbladen van Nepenthes Bongso en N. Rafflesiana en, volgens de opgave vau den Heer Brongniart, ook bij de N. Madagascariensis $\left({ }_{\star}\right)$, wordt dit mede waargenomen; bij de andere onderzoehte soorten beslaat deze blinkende oppervlakte de helft en soms zelfs een geringer gedeelte van de lengte der buis; terwijl het hoogere deel eencn blaauwen of purper-rooden dauw bezit: deze dauw is mij voorgekomen meer vlies- dan wasaardig te zijn, en dus door de afsehilfering van de epidermis gevormd te worden. De vorm der klieren van de onderzoehte soorten stemt met de door den Heer Meyen van de N. destillatoria opgegevene struetuur overeen.

Hare ontwikkeling, door den Heer Meyen op de Nepenthes destillatoria waargenomen, is door mij ook bij andere soorten nagegaan. De binnenvlakte van zeer jonge, pas te voorsehijn komende bekertjes, is op het uiterlijk aanzien nog geheel gelijk; fijne plaatjes van dezelve, bij sterke vergrooting nader

(*) Treviranus, Zeitschr. für Physiolog. III. p. 75.

( $)$ Annales des Sciences naturelles, I. p. 38.

(\$) Meyen, Ueber die Sekretions-Organen der Pllanzen, p. 11 u.s.w.

(屯) Brongniart, gen. werk, p. 38. Botantca. 
onderzoeht, bieden een tamelijk gelijk eelweefsel en, tussehen de doorsehijnende cellen, andere met donkere stippen aan. Dergelijke fijne plaatjes van grootere bekers waargenomen, bewijzen, dat deze gestipte cellen de aanstaande klieren zijn. Zij onderscheiden zich in deze bekers duidelijk als eirkelronde, uit eene menigte kleine eelletjes bestaande groepen van het uit grootere eellen bestaand weefsel, en zijn in het begin nog gehecl door de opperhuid bedekt. Vervolgens neemt, bij meerdere ontwikkeling, deze bedekkende huid in dikte af en vertoont zieh als een vliezig deksel. Dit deksel is naar beneden open en bezit daar eene bijna regt afgesnedene zijde, die digt op de ondergelegene vlakte sluit. Bij meerdere uitgroeijing wordt de onderzijde van dit deksel meer boogvormig. Het bedekt in de geopende bekers veelal de helft der klier en bestaat, even als de overige opperhuid, uit langwerpige, digt aan elkander sluitende cellen: allcen bij Nepenthes ampullaria bedekt gemeld deksel een kleincr gedeelte der klieren en heeft het meer vierkante cellen. De klieren bestaan uit eene menigtc van kleine, digt aan elkander sluitende cellen. In de jonge bekers hebben zij mij de waarneming van den Heer Meyen bevestigd, en hier waren deze kleine eellen zeer saprijk en met grocnc, bencvens enkele bruine korrel t.jes (bij N. ampullaria), opgevuld.

Eenen eenigzins anderen vorm en eene verschillende zamenstelling vertoonen de kliercn, welke op de binnenvlakte van de deksels der bekers verspreid zijn. Met het bloot oog of bij geringe vergrooting gezien, zijn zij kleine, eirkelronde en op de nerven meer ovale, door cenigzins verhevene ringen omgevene holten. Bij eene verticale snede nader onderzocht, worden deze holten of op de oppervlakte zigtbare diepten ons. als de ingangen tot grootere holen bekend, die, in het midden, eene verhevenheid tegenover de opening hebben. De doorsnede dezer organen, mei eenige vergrooting onderzoeht zijnde, toonde mij de volgende zamenstelling: de uit eene laag van vierkante cellen bestaande opperhuid buigt zieh bij de holten binnenwaarts en bekleedt nu den rand en het bovenste gedeelte derzelven, terwijl de verhevenheid in het midden der holten, door eene gelijke zamenstelling, eene vroegere gemeensehap met de opperhuid verraadt; het overige gedeeltc der holten bestaat daarentegen uit zeer kleine cellen, welke eenige overeenkomst met die der bekerklieren bezitten.

Na deze beschrijving van de zamenstelling tot den aard dezer organen overgaande, herinneren wij ons het gevoelen van den Heer Meyen, dat de binnenklieren eene bruine blinkende stof zouden afzonderen: dit denkbeeld komt mij minder waarsehijnlijk voor, omdat ik nimmer bij de onderzoehte soorten eene dergelijke afscheiding heb kunnen waarnemen. Na ecn vergelijkend onderzoek van de glanzige en doffe binnenvlakte der bekers is het mij waarschijnlijkcr, dat deze glans aan de meerder ontwikkelde dikte van de epidermislaag is toe te sehrijven.

Moeijelijker is het om te beslissen tusschen de opgegevenc denkbeelden van de Heeren Treviranus en Mcyen, nopens de afseheidingsplaats van het voeht, welke de eerstgemclde in de klieren zoekt, en de laatstgenoemde in een beleedigd eclweefsel om de klieren vooronderstelt plaats te vinden. Het laatste gevoelen, hoewel veel voor zich hebbende, zoo men de verwonding van dc opperhuid nagaat, heeft eehter dàt tegen, dat de afscheiding dan na de uitgroeijing zoude verminderen of geheel eindigen, omdat de natuur cene dergelijke verwonding spoedig zoude hebben hersteld: zoo als ons de opperhuid van de bladranden der Aroïdeën en anderen bewijst. Het eerste denkbeeld van den Heer Treviranus, dat het afgescheiden voeht 
uit de kleine klieren deszelfs oorsprong neemt, is mij dus meer waarsehijnlijk en kan door andere daadzaken vergelijkend worden ondersteund. Bij de Sarraeenia hecft de afseheiding van het voeht door de haren plaats; bij de Urtieeën wordt zij even zoo van deze waargenomen, en bij vele anderen zijn zij als afseheidingsorganen bekend. Daar nu deze haren meestal als verlengde eellen voorkomen, zoo geloof ik, dat wij hunne werking ter vergelijking en tot ondersteuning gevoegelijk kunnen aannemen.

Bij de grootere bekers heb ik deze klieroppervlakte dikwerf met kleine kraaltjes voeht bedekt gezien, en deze bevoehtiging bij de onderzoehte soorten, vooral in het benedenste van den beker, waar, tussehen het binnenste en buitenste bekleedsel, een aanzienlijk, zeer voehtrijk eelweefsel de vaatbundels omgeeft, waargenomen. Dit eelweefsel in de zamenstelling van het meer vliezige deksel geheel gemist wordende, zoo kan men hieraan welligt toesehrijven, dat deze voehtafseheiding op dit deel geèn plaats vindt.

Na de vermelding van de zamenstellende deelen der bladen, moeten wij de denkbeelden omtrent den aard derzelve kortelijk doorloopen. De Heer Willdenow $\left(^{*}\right)$ besehouwde de bekers als eigenaardige bladvormige uitgroeijingen. De Heer De Candolle laat zieh omtrent deze bladen op eene wijze uit, welke doet gelooven, dat hij de vlakke sehijf als een' bezoomden steel en den beker als de ware bladsehijf aanneemt $(\dagger)$, en op eene andere plaats doet hij ons gelooven, dat hij alleen het deksel der bekers als de bladsehijf, en het overige als een gedeelte van den bladsteel besehouwl (\$). In de bekervormige uitbreiding ziet de Heer Bisehoff veranderde vormen van geheele of gedeelten van bladorganen, en door de vergelijking van de Sarracenia met de Nepenthes sehijnt hij tot het gevoelen van den Heer De Candolle over te hellen, dat het deksel het blad is $\left(_{*}\right)$. De Heer van Hall het eerste gevoelen van den Geneefsehen Hoogleeraar aannemende, besehouwt de bekers als de bladsehijven en noemt hen bladbuizen ( $t$ ). Omtrent dezen bladvorm heeft de Heer Link het gevoelen uitgedrukt, dat de vlakke bladuitbreiding de wezentlijke bladsehijven, en dat de bekers bloemaardige aanhangsels zouden zijn $\left({ }^{\star *}\right)$. De Heer Turpin houdt de vlakke uitbreiding voor eenen bezoomden steel en den beker voor een omgeslagen, met de randen zamengegroeid blad, en noemt de opening van den beker Maeropile.

Wij zien uit deze opgave, dat de meeste sehrijvers de geheele bladvormige uitbreiding voor een, in deszelfs deelen veranderd blad houden. Ik zal hier eenige opmerkingen bijvoegen. Van de steng af beginnende, trekt de gesteelde of ongesteelde vlakke uitbreiding het eerst de aandaeht. Bij de kiemende of pas uit zaad opgekomene plantjes, is deze uitbreiding weinig ontwikkeld, en bij de eenigzins meer uitgegroeide, die van 4 of 5 bladen voorzien zijn, vertoont zij zieh seheedevormig: in beiden was de beker

(*) Grundriss der Kräuterkunde, 5 Ausg. p. 93.

(†) Physiologie végétale, p. 279.

(\$) 》 $)$ p. 320.

(*) Handbuch der botanischen Terminologic, p. 243.

(t) Tijdschrift voor Nat. Gesch. en Physiologie van J. v. d. Hoeven en W. H. de Vriese, III. bl. 9; en

an Hall, Eerste beginselen der Plantkunde, bl. 48.

$\left.{ }^{* *}\right)$ Philosophia Botanica, I. p. 475. 
reeds geheel aanwezig. De vlakke bladuitbreidingen hebben takverdeelingen van nerven, welke weinig van die der bekers afwijken : in beiden is de hoofdrigting naar één bepaald punt, en bij beiden zijn de grootere nerven door kleinere dwarsaderen verbonden. Wanneer deze vatenloop met dien van andere gewassen vergeleken wordt, dan vindt men eene gelijke bewerktuiging in de bladseheeden van de Unbelliferae, in de holle bladstelen van Trapa enzv., en hierdoor word ik in het denkbeeld versterkt, om met den Heer De Candolle èn de vlakke uitbreiding èn den beker als tot den bladsteel behoorende organen te beschouwen; terwijl ik hel deksel, waarin wij eene meer netvormig vertakte nervuur waarnemen, als den eigenlijken vertegenwoordiger der bladschijf aanmerk.

De steel, waaraan de beker bevestigd is, heeft de nerven van de vlakke bladuitbreiding, even boven het einde derzelve, in eenen geslotenen vatenring vereenigd en, in het midden van dezen, een mergaehtig celweefsel. Meer van de gemelde bladuitbreiding verwijderd, is de steel driekant, en heeft zich de gemelde vaatring in drie door celweefsel geseheidene vaatbundels verdeeld. Deze zijn aan den voct van de bekers duidelijk zigtbaar, en een derzelve is aan de beneden- en twee aan de bovenzijde van den steel gelegen. De beide laaisten vormen de grondnerven der kammen, en uit dezelve ontstaan zij-nerven, die naar hel eindpunt van de ondernerf verloopen. Hier vercenigen zieh de drie hoofdnerven en vormen zij eenen platgedrukten vaatbundel mel zeer weinig parenehymatisch weefsel. Vervolgens verdeelen zij zieh weder in het deksel, en geven zij aan hetzelve, door hare takverdeelingen, eene nervuur, welke met die der bladen van andere Dicotyledonen veel overeenkomst heeft.

De onderzochte soorten bezitten allen, zoowel voor de mannelijke als voor de vrouwelijke bloemen, eene in of door uitgroeijing boven den oksel geplaatste pluimvormige bloeiwijze, met cen- of tweebloemige steeltjes, bij $\mathbf{N}$. gracilis, phyllamphora, of met tot bijschermen vereenigde steeltjes bij $\mathbf{N}$. Madagascariensis, N. ampullaria enzv. Deze bloeiwijze, waarin de bloemen zieh van den voet naar den top openen, is vooral in hare eerste ontwikkeling bij $\mathbf{N}$. ampullaria met eene bruine donzige, bij $\mathbf{N}$. gracilis met eene bruine zijdeaardige, bij $\mathbf{N}$. Rafflesiana met eene digte grijze en bij $\mathbf{N}$. phyllamphora met eene lossere beharing bekleed, en verliest dil bekleedsel bij eene verdere ontwikkeling dikwerf grootendeels. De algemeene bloemsteel is min of meer vijfhoekig en heeft de bloemstelen met verbreede voeten op zijne kanten geplaatst. De benedenste bloemsteeltjes dragen veelal min of meer ontwikkelde sehutblaadjes; de hoogere bezitten slechts geringe sporen, en de naar den top der bloempluim geplaatste, geene overblijfsels derzelve. Bij de overeenstemmende bloeiwijze der mannelijke en vrouwelijke planten, doet de vorm der knoppen dezelve spoedig onderscheiden: de mannelijke bloemen zijn bij deze kogelrond, en de vrouwelijke meer eivormig. De vier deelen of aan den voet zaamgegroeide bladen van het bloembekleedsel zijn vóór de opening der bloem in diervoege gelegen, dat de twee buitenste groote, de beide bimnenste, tegen over de spil geplaatste kleinere deelen bedekken; zij zijn in de mannelijke bloemen bijna cirkelrond en in de vrouwelijke ovaal, tamelijk dik, van buiten, vooral om den rand behaard, van binnen met kleine groefjes en, na de opening der bloem, terug geslagen.

De mannelijke bloemen rieken onaangenaam. In haar midden staat de cilindervormige, min of meer vierkantige meeldraden-kolom, met eenigzins verdikte uiteinden. Zij is bij de opening der bloem 
zeer kort, neemt vervolgens in lengte toe, en draagt op den top cene kogelvormige verdikking, aan welke 8,12 tot 16 meelknopjes geheeht zijn. In den jeugdigen staat zijn deze meelknopjes in dezelfde rigting met de spil, en eerst later worden, door de ontwikkeling, de ongelijke grootte, benevens de onregelmatige buigingen te weeg gebragt. Zij zijn langwerpig, vóór hunne opening in het midden gevoord, en hebben, aan weèrszijden van den niet zeer ontwikkelden helmknoop, één hokje. Deze hokjes bestaan sleehts uit een klepje, dat zieh inbuigt en op den helmknoop sluit, zoodat de stuifknopjes van Nepenthes eigenlijk sleehts de helft of een hokje van een gervoon helmknopje aanbieden. In de zamenstelling onderseheidt men onder een vrij dik buitenvlies, een uit twee rijen spiraaleellen bestaand endotheeium. Thet uitgeworpen stuifmeel is kogelrond, of bestaat somwijlen uit drie of vier verbondene kogeltjes, die aan den stuifmeelvorm van de Godeniaecae, Erieeae enzv. herinneren $\left({ }^{\star}\right)$.

De vrouwelijke bloemen hebben in het midden, in plaats van de stuifdradenkolom, het vruehtbeginsel. Dit is bij eenigen gesteeld: N. Rafflesiana, enzv., bij anderen vastzittend of op den torus geheeht: N. graeilis. Het heeft eenen langwerpigen, vijfzijdigen, naar het aanheehtingspunt eenigzins verdikten en afgeronden vorm. De eene dezer zijden of de geknotte top wordı door den somwijlen vierlobbigen, platgedrukten, door vier voren ingesnedenen stempel gekroond: de anderen vormen den omvang. $Z_{\text {ij }}$ zijn door stompe, tegen over de bloemdeelen gelegene kanten verbonden, in het midden eenigzins gevoord en met dezelfde beharing als de jongere bloemstelen bedekt. Inwendig is het vruehtbeginsel verdeeld in vier volkomene hokjes met gladde wanden. Met deze zijn de naar den voet der hokjes verbreede en naar boven smaller wordende moederkoeken verbonden, die aan iedere zijde van den wand uit eenen hoofdvaalbundel bestaan, welke zieh even boven den voet van het hokje, over of door de oppervlakte van den wand verdeelt $(\dagger)$.

De eitjes vertoonen zieh, in zeer jonge vruehtbeginsels, als kleine, boven den moederkoek uitstekende, ronde, of aan den top eenigzins geknotte, uit eellen bestaande knopjes. $\mathrm{Zij}_{\mathrm{ij}}$ worden bij eene meerdere ontwikkeling langwerpiger en eindigen dan in eene versmalde buis: in het benedenste of buikvormig gedeelte van deze eitjes zijn de twee eellenlagen, door de mindere ontwikkeling van de binnenbuis, duidelijk erkenbaar; en somwijlen is het mij gelukt, deze beiden te seheiden: alsdan vertoont zieh het binnenvlies zeer fijn en het buitenste van eene meerdere dikte. De meer uitgegroeide eitjes zijn reeds langwerpiger, en door derzelver doorsehijnendheid laten zij duidelijk zien, dat het punt van aanheehting van het binnen- of kernvlies, boven den voet is verheven. De kernzak is in dien staat reeds boven zijn aanheehtingspunt een weinig buikvormig en naar boven versmald. In de meer ontwikkelde eitjes zag ik het aanheehtingspunt meer van den voet verwijderd en het boveneinde meer doorsehijnend. In dien staat had er reeds eene veranderde rigting van den kernzak plaats, waardoor het draadje, waarin deze eindigt, naar beneden gebogen werd. De ontwikkeling thans verder in hare versehillende tijdperken vol-

$\left.{ }^{*}\right)$ Vroeger in Indië gedane onderzoekingen doen mij vermoeden, dat hier de moedereellen van het stuifmeel drie deelen bevatten: daar dit eehter met het gewoonlijk voorkomende viertal in strijd is, zoo laat ik deze waarneming aan latere onderzoekingen ter bevestiging over.

( + ) Somwijlen gebeurt het, dat de eitjes aborteren, en zieh in ieder hokje een min of meer vleezig, langiverpig ligehaam bevindt, hetwelk van boven en beneden in den hoek van het hokje is vastgehecht; vermoedelijk is dit eene vrije placenta.

Botanica. 
gende, dan zien wij het aanheehtingspunt van den kernzak meer en meer van den voet van het zaad verwijderen, en de omdraaijing van den kernzak, en dus de benedenwaartsehe rigting van den wortel, als een gevolg van deze uitgroeijing, te voorsehijn treden. De binnenzaadmond wordt hierdoor naar beneden gekeerd en vertoont zieh in het zaad, aan het einde van een meer of minder ontwikkeld, uit eelweefsel bestaand buisje, met eene kleine verdikking. Voor zoover ik dit nagegaan heb, heeft dit buisje geenen zamenhang met de buitenzaadhuid $\left(^{\star}\right)$.

De rijpe vruehten zijn drooge, somwijlen op een klein steeltje gezetene langwerpige, stomp vierkantige, in het midden of meer naar den voet verdikte, bruine, gladde of behaarde kapsels. Zij springen in vier met de bloembekleedselen afwisselende, door een deel van den stempel gekroonde kleppen, open. Ieder dezer heeft op de binnenvlakte het tegen dezelve overstaande gedeelte van de middelsehotten. De seheiding van deze middelsehotten is van dien aard, dat er geen spil terug blijft, en dat alleen een verdikte zoom langs den vrijen binnenrand der tussehensehotten het vroegere vereenigingspunt aanduidt.

De zaadjes dezer gewassen hebben het voorkomen van kleine vliezige, in het midden eenigzins verdikte of verbreede, aan de beide einden spits uitloopende draadjes of plaaljes. Z Zij zijn, bij eenige vergrooting waargenomen, somwijlen geheel glad, somwijlen, vooral in het midden, met eene geribde of bultige oppervlakte. Het buitenste zaadomhulsel is door eene vliezige, uit lange, zelden korte, bijna vierkantige eellen bestaande huid gevormd. Onder dit bekleedsel ligt een los merenehymatiseh eelweefsel $(\dagger)$, hetwelk, vooral boven en onder de kern, eene meer aanzienlijke ontwikkeling erlangt, en tussehen de buitenhuid en kern somtijds bijna geheel verdwijnt. Tussehen dit eelweefsel en bij anderen meer tegen de buitenzaadhuid bevestigd, loopt de raphé. Dit voedingsvat buigt zieh vervolgens op meerdere of mindere hoogte boven de kern om, en daalt dan benedenwaarts, om zieh met de binnenzaadhuid te verbinden. Het bestaat uit langgestrekte eellen en gestipte vaten. De kern, van de buitenzaadhuid en het eelweefsel geseheiden, vertoont zieh als een rolronde zak, welke in een fijn draadje of buisje, tegen over de raphé geplaatst, eindigt. Dit draadje kan als een verlengde binnenzaadmond besehouwd worden, en bestaat uit een gestrekt eelweefsel. De binnenste zaadvlies is zeer fijn en wordt gevormd door langwerpige eellen, welke door hare breedte, van die der buitenhuid versehillen. Behalve naar de beide einden is deze binnenste zaadhuid geheel door de kern gevuld. Deze is rolrond, aan den wortel en het bladgedeelte stomp, somwijlen in een klein puntje eindigende, wit van kleur, en heeft de kiem geheel door kiemwit omgeven.

Dit kiemwit is van eenen olieaehtigen aard, en zet zieh bij zijne vorming het eerst langs de wanden van de omringende bekleedselen, terwijl het binnenste, de kiem omgevende gedeelte, dan nog eene olieachtige vloeibare stof vormt. De kiem heeft, in de nog onrijpe zaden, den vorm van een hart, van hetwelk de wortel het spitse en de zaadlobben het verdikte einde uitmaken. Bij meerdere ontwikkeling

${ }^{*}$ ) De Heer Brongniart, aan wien wij de ontdekking van dit buisje verschuldigd zijn, schijnt tol het gevoclen over te hellen, dat hetzelve een vaatbundel is, die tot de beviuehtende vaten behoort.

(†) Gaertner (de Fruct. II. p. 18. Tab. 83.) geeft cene vrij goede beschrijving van de zaadbekleedsels. 
wordt de wortel dikker en de beide zaadlobben zijn nog aanzienlijk van elkander verwijderd $\left({ }^{\star}\right)$. Door verdere uitgroeijing veranderende, verkrijgt de rijpe kiem eenen rolronden, aan beide zijden in stompe punten eindigenden vorm. De wortel derzelve is naar het aanhechtingspunt van het zaad gekeerd en vormt ongeveer de helft der kiem. De zaadlobben sluiten nu met de vlakke zijden tegen elkander, en tusschen dezelve vertoont zich de plumula als een klein puntje.

Omtrent den aard der zaadbekleedsels zijn de gevoelens verdeeld. De Heer Nees wilde het buitenste zaadbekleedsel als een' zaadrok (A rillus) beschouwd hebben. De Heer Brongniart en anderen hebben het daarentegen voor een wezentlijk gedeelte van het zaad, voor de buitenste zaadhuid (Testa) aangenomen. Met dit gevoelen van den Heer Brongniart vereenig ik mij, omdat het gemelde buitenbekleedsel reeds in de eitjes ontwikkeld is, en wel somwijlen met de raphé zamenhangt, maar ook niet zelden zieh geheel vïj van deze vertoont.

Hetgeen ons $\mathbf{D}^{\mathrm{r}}$. Graham ( $(\boldsymbol{f})$ omtrent de ontkieming der $\mathbf{N}$. destillatoria ( $($ ) vermeldt, heb ik ook bij N. phyllamphora waargenomen. Bij de zaden, op eenen moerassigen bodem gelegen, begon zich het midden of kerngedeelte uit te zetten, en vervolgens te splijten. Uit deze spleet traden nu de tegen elkander gelegene zaadlobben met eene lieht groene kleur te voorsehijn, en kort na hare ontwikkeling zich scheidende, deden zij het groene ronde pluimpje zigtbaar worden. In dit tijdvak of wel iets vroeger, groeit uit dit verdikte gedeelte het worteltje, hetwelk eerst enkelvoudio spilvormig, vervolgens, door de vorming van een aantal vezels, zeer getakt voorkomt. Inmiddels neemt het pluimpje aan grootte toe cn bestaat uit twee omgebogene, zeer ongelijke ligchaampjes. Deze buigen zich bij meerdere ontwikkeling terug, en vertoonen dan ongesteelde, kleine, buikvormig verwijde, met ingesnedene kammen voorziene bekertjes. Bij het nu volgende bladpaar zijn deze bekertjes reeds aan het einde van kleine, vlakke bladuitbreidingen geplaatst, welke bij de verder ontwikkelende, achtervolgens aanmerkelijk toenemen. De inwendige struetuur dezer jonge bekertjes is gelijk aan die der wortelbladen, en de uitwendige vorm biedt bijna geene afwijking aan.

Na de gesehiedenis van de plant en de beschrijving harer deelen te hebben opgegeven, blijft ons de beschouwing van hare plaats in het wetenschappelijke stelsel over. Nadat men de Nepenthes in hare groeiplaatsen waargenomen had, boden zij weinig moeijelijkheid voor de Linneaansehe rangsehikking aan, omdat zij hier, wegens het voorkomen der mannelijke en vrouwelijke bloemen op verschillende planten, in de klasse der tweehuizigen konden opgenomen worden. Minder gemakkelijk was het, haar eene plaats in een natuurlijk stelsel aan te wijzen. Versehillende schrijvers hebben ten dien opzigte andere gedachten gehad, die gedeeltelijk door gebrek aan voorwerpen, ten deele door hunne wijze van beschouwing moesten ontstaan. Wanneer wij het daaromtrent bekende nasporen, dan blijkt het, dat de verdienstelijke en ijverige Adanson de eerste proef nam, om onze Nepenthes in een natuurlijk stelsel te

${ }^{*}$ ) De Heer Richard heeft het eerst het denkbeeld van Gaertner wederlegd, dat de Nepenthes-kiem slechts ééne zaadlob had.

(†) Edinburgh Journ. 1830. p. 380.

(\$) Dit is vermoedelijk de Nepenthes phyllamphora. 
brengen en haar, naar de door hem geziene afbeeldingen oordeelende, met den naam Bandura, bij zijne Aristoloehiae plaatste, onder bijvoeging, dat het hem voorkwam, dat een nader en naauwkeuriger onderzoek der planten zelve, haar in eene andere familie, nabij de Sarracenia zoude overbrengen. In de door Linnaeus ontworpene rangschikking, welke Giseke heeft medegedeeld, is haar geene plaats aangewezen, en in de Genera van Jussieu staat Nepenthes onder de geslachten, wier verwantsehap onzeker was. Bij gelegenheid, dat de Heer R. Brown de verdeeling der door Jussieu hervormde vereeniging van de Aristoloehiae in twee familiën voorstelde, liet hij den wenk van Adanson niet verloren gaan, maar maakte toen tevens op de verwantschap van Nepenthes tot de Aristoloehiae opmerkzaam. Meer bepaaldelijk hield zich de Heer Brongniart met dit onderwerp bezig, toen hij dit geslaeht uitvocrig behandelde; en zijn onderzoek deed hem het gevoelen omhelzen, dat Nepenthes met Cytinus vereenigd, eene eigene familie konde vormen. In dit gevoelen deelde ook zijn ambtgenoot, de Heer A. Rirhard. Bij anderen eehter vond het minder bijval, omdat bij den afwijkenden habitus dezer beide geslachten, en bij de onvolledige kennis der zaden van Cytinus, alléén de mannelijke bloemen tot deze vereeniging: aanleiding konden geven.

Reeds in 1827 maakte de Hoogleeraar Blume zijn gevoelen bekend, dat de Nepenthes een aan de Aristoloehiae verwant geslaeht was, en dat zij als de grondvorm van eene kleine, aan de genoemde en aan de Dioscoreae verwante familie kon beschouwd worden $\left(^{\star}\right)$. Het denkbeeld van afscheiding vinden wij ook door den Ileer Bartling aangenomen. De Heer Link vermeldde, in 1829, de Nepenthes als eene afdeeling der Aristoloehiae, onder den naam Nepenthinae.

Het voorstel ter vorming eener nieuwe familie, werd in $1830(t)$ door den Heer Lindley verwezentlijkt, en de Nepenthes, onder den naam Nepentheae, tusschen de Droseraeeae en Lineae geplaatst. Deze plaatsing besehouwde de schrijver slechts als voorloopig en zij geschiedde met de verklaring, dat er eene menigte verbindende vormen noodig waren, om deze familie in hare nieuwe standplaats te vestigen. Getrouw aan zijne vroegere voorstelling, bevestigde de Heer Blume, in 1834, zijn reeds voor zeven jaren geuit beginsel, door de Nepenthes als eene familie aan te nemen. De Heer R. Brown in hetzelfde jaar, zijn gevoelen omtrent deze planten duidelijker opgevende en uitbreidende, volhardde bij zijn vroeger denkbeeld omtrent hare verwantschap, en bewees tevens het doeltreffende van de vorming eener nieuwe familie. In de tweede uitgave van het Natural System, p. 204, van 1836, neemt de Heer Lindley het gevoelen van zijnen beroemden landgenoot aan, en vormt hij van Nepentheae en Aristolochiae eene groep, onder den naam Columnosae. De Heer Endlieher, het gevoelen zijner voorgangers deelende, nam de Nepenthes als eene bijzondere familie en de vereeniging derzelve met de Aristolochiae, onder den naam Serpentariae aan (\$). Het algemeen aangenomen gevoelen, dat Nepenthes eene afzonderlijke familie kan vormen, deelende, wil ik de verwantschap derzelve nog kortelijk toeliehten. De meeste sehrijvers hebben het voetspoor van Adanson gevolgd, door de Nepenthes in de nabijheid der Aristoloehiae

${ }^{*}$ ) Enumeratio plantarum Javae etc. p. 84. (Anno 1827).

(†) Lindley, Natural System, p. 154 .

(\$) Genera plantarum, p. 345. 
te plaatsen, en de Heeren Lindley en Endlicher hebben haar beiden in ééne groep vereenigd. Het hoofdkenmerk, dat de een voor zijne Columnosae, en de ander voor zijne Serpentariae opgeeft, is het: gebrek aan houtringen $\left(^{\star}\right)$. Het onderzoek der Aristoloehia grandis Khs. $(\dagger)$ deed mij reeds het gemis dezer eoneentrisehe ringen betwijfelen, en dat der A. Sipho bewees mij, dat het hout der Aristoloehiae deze ringen niet geheel mist: want bij eene doorsnede van de steng ziet men duidelijk ringvormige, uit grootere en kleinere vaten en vezels bestaande lagen, en in ieder dezer zijn twee ringen, van welke de binnenste grootendeels uit wijder gestipte vaten bestaat, en de buitenste eenen meerderen rijkdom van vezels bezit. Zoo als uit de vroeger gegevene besehrijving blijkt, heeft Nepenthes in hare houtdeelen eene geheel andere zamenstelling, en ontbreken aan deze de regelmatige eoneentrisehe lagen, terwijl de grootere, met diepten voorziene vaten, onregelmatig tussehen de vezels verspreid liggen. De groeiwijze der beide familiën vergelijkend gade slaande, vinden wij het volgende, niet minder opmerkelijk onderseheid: bij de Aristoloehiae is zij overeenstemmend met die van andere tweezaadlobbige gewassen; bij de Nepentheae daarentegen, herinnert zij aan de bij de eenzaadlobbige gewassen plaats hebbende ontwikkeling. Zoowel de omhullende als de wezentlijke of geslachtsdeelen van de bloem, zijn bij beiden zeer versehillend. De eersten zijn bij de Nepentheae onder het vruehtbeginsel geplaatst, en bij de Aristoloehiae boven hetzelve gezeten, of indien men wil, gedeeltelijk er mede zamengegroeid. De omhullende bloemdeelen liggen vóor de opening van de bloem, bij de Aristoloehiae klepvormigo (bij Heterotropa van Morren en Deeaisne, met de randen naar binnen gebogen) en bij de Nepentheae paarsgewijze, als dakpannen over elkander. Om eenige overeenkomst in de geslaehtsdeelen te vinden, moeten wij aannemen, dat de vrouwelijke in de mannelijke bloemen der Nepentheae aborteren, en dat de knop, waar de helmknopjes tegen bevestigd zijn, met de epigynisehe sehijf van de Aristoloehiae kan vergeleken worden. De opening van de vruehten der Aristoloehiae wijkt zeer af van die der Nepentheae. Bij de eersten heeft eene dehiseentia septicida, bij de anderen daarentegen eene dehiscentia loeulieida plaats (\$). Bij de Aristoloehiae en Nepentheae hebben de zaden eene niet zeer digt om de kern sluitende buitenhuid, het voedingsvat tussehen deze doorloopende en aan de tegenovergestelde zijde van het aanheehtingspunt des zaads met de kernhuid verbonden. Bij de eersten is deze raphé verdikt en bij de laatsten draadvormig. De kiem van de Nepentheae overtreft door hare ontwikkeling het kiemwit, en die der Aristoloehiae wordt daarentegen door dit, aanzienlijk overtroffen. De Dioseoreae, in andere punten zeer versehillend, bieden in het lossc buitenzaadvlies en de hieronder doorloopende raphé eenige overeenkomst aan. Even zoo heeft onze familie, in de verbinding der helmdraden, eenige overeenkomst met de Menispermeae (Anamyrta, enzv.), Schizandrae (Kadsura), Sterculiaceae en Euphorbiaceae. Vervolgens komt voor de Nepentheae de verwantschap met de Drose-

$\left.{ }^{*}\right)$ De Heer Lindley zegt, bl. 214 van de tweede uitgave van zijn Natural System, dat de Menispermaeeae ook geene houtringen bezitten: hiertoe heeft gewis het onderzoek van zeer poreuse stengen den geëerden sehrijver aanleiding gegeven, daar de meer vaste niet alleen deze concentrische lagen duidelijk doen zien, maar deze ringen zich in drooge stengen somwijlen van elkander scheiden. Bij de stengen van slingerende Uncariae, Dissochaetae, Marumiae, Uvariae, Bauhiniae enzv., welke cene losse houtzelfstandigheid bezitten, verdwijnen deze houtringen dikwerf geheel.

( $t$ ) Deze soort komt op Sumatra, in het gebergte Singalang, voor.

(S) Vermoedelijk door eene drukfout wordt in het familiekenmerk der Aristoloehiae van de Genera van Endlieher', bl. 344, aan deze eene dehiseentia loenlicida toegesehreven. Botanica. 
raceae, in wier nabijheid de Heer Lindley dezelve reeds vroeger had geplaatst, in aanmerking. De bloembekleedselen zijn ook bij deze onder de vruchtdeelen geplaatst en hebben, vóór de opening der bloem, dezelfde ligging. In de zamenstelling der kapsels is dezelfde grondvorm aanwezig. Bij de Droseraceae, welke veelhokkig zijn, groeijen uit het middelgedeelte der kleppen de middelschotten uit, en vereenigen zich deze in het midden van het vruchtbeginsel: daarentegen scheiden zij zich weder in de vrucht, en laten dan geen spoor van eene middelkolom achter. Deze middelschotten zijn dikwerf bij de Droseraceae, even als bij de Nepentheae, naar den voet met de grootste hoeveelheid zaden bedekt. De zamenstelling der zaden levert verscheidene punten van overeenkomst op. Ook bij Droseraceae hebben zij dikwerf een los omhullend buitenvlies, langs hetwelk de raphé loopt, tot hij zich tegen over het punt van aanhechting van het zaad met het kern- of binnenvlies vereenigt. In het algemeen zijn de Nepentheae, door de zamenstelling der vrucht, zeer verwant aan de door Lindley als Cistales voorgestelde groep, en bieden zij punten aan van vergelijking in de aanhechting der eitjes, de wijze van openspringen der kapsels en in de zamenstelling der zaden.

De aan dezen, door hunnen vorm verwante gewassen vergelijkende, komen Dionaea, Sarracenia en Cephalotus in aanmerking. De Dionaea heeft cenige overeenkomst door de wijze van ontwikkeling en door den vorm der bladen, welke, zoo als bekend is, bestaan uit eenen bladvormig uitgebreiden steel, die de steng omvat, en uit eene tweelobbige bladschijf; de eerste is zeer goed te vergelijken met den bladvormigen steel en de laatste met het bekergedeelte van Nepenthes. Vóór de ontwikkeling is de prikkelbare bladschijf zamengevouwen en op den bladsteel teruggebogen: de geheele vorm verschilt dan zeer weinig van eene jonge Nepenthes-plant. In beiden bestaat dus eene knopvorming derbladen, die eenige gelijkheid. met en eenen overgang tot de Droseraceae aantoont $\left(^{*}\right)$. De verwantschap met Sarracenia berust op cenige gelijkheid van den bladvorm en misschien van de vruchtdeelen, terwijl die met Cephalotus $(\dagger)$ alleen in den vorm der bladen kan gezocht worden. De beide laatstgenoemden staan, als gelijkvormige gewassen, in eenige verbinding met de Nepentheae; de Droseraceae en Aristolochiae komen als verwantschapsvormen in aanmerking, en de eerstgenoemden moeten, naar het mij voorkomt, de Nepentheae in hare nabijheid hebben.

$\left(^{*}\right)$ Door de waarneming van de Dionaea muscipula, is het ook mij gebleken, dat de bladschijven, vooral in het middelste gedeelte, langs de nerf aangeraakt, de prikkelbaarheid doen blijken, en dat deze eigenschap misschien in verband staat met eene eigenaardige soort van haren en met de door uitvalling dezer, ontstaande diepten, die vooral in het middelgedeelte zijn geplaatst. In den tuin van Berlijn schijnt deze plant hare prikkelbaarheid gedeeltelijk te verliezen (Meyen, Phys iologie, 3. p. 545); hier te Leiden, heb ik zeer dikwerf vliegen, tusschen de beide lobben gevat, waargenomen, en de opene lobben, bij eene prikkeling en tusschenlegging van haar, zich tot elkander zien voegen.

$(\dagger)$ Lang nadat ik dit geschreven had, ontving ik door de goedheid van den Heer Donkeler, een blad van Cephalotus ter bezigtiging. Hierdoor heb ik de gelijkheid van de nervuur der bovenlip met die der deksels van Nepenthes kunnen waarnemen. Voor het overige verschilt de grondvorm des blads van Cephalotus en hetzelve schijnt mij toe, als een blad beschouwd te moeten worden, waarin het parenchym ontbreekt. Voor dit gevoelen pleit eene vergelijking van den loop der nerven in de bladen van Cephalotus, met dien der nerven van de vleezige bladen van eenige soorten van Mesembryanthemum, enzv. (Treviranus, Physiologie, I. bl. 439.) 


\section{NEPENTHES BONGSO. KHS.}

N. phyllodiis sessilibus basi biauriculatis, ascidiis infundibuliformibus, inflorescentiâ racemosâ subpubescente, pedicellis uni-vel bifloris, ovariis substipitatis.

De oudere stengen, naauwelijks de dikte eener ganzensehacht overtreffende, zijn van eene min of meer rolronde gedaante, bijna bladerloos, van eene donker grïzze kleur en geheel glad. De jongere stengen zijn stomp vierkant, aan de uiteinden meer scherpkantig met gevoorde zijden, bijna geheel glad en van eene grijze of grijs-groene kleur. De phyllodia, ongeveer 3 of 4 Ned. duimen van elkander verwijderd, zijn overhoeks geplaatst, zoodat het derde bijna boven het eerste staat. In den knop zijn zij omgerold en omvatten zij het volgende blad; vervolgens zich ontwikkelende, buigen zij terug en nemen op het laatst eenen horizontalen, en niet zelden eenen teruggebogenen stand aan. De jonge steng-phyllodia zijn licht-groen, van buiten glad, maar van binnen, naar den top en even beneden denzelven, min of meer behaard. Hunne gedaante is langwerpig, van boven eenigzins breeder, ingedeukt, stomp, zelden spits; even boven den voet nemen zij weder in breedte toe, omvatten hier de steng en bezitten aan de zijden twee ronde oortjes. De oudere phyllodia hebben den rand eenigzins kroes, zijn van boven glad, van onderen met eene bruine stofaehtige beharing bedekt, lederachtig, 9 Ned. duim lang, 2,5 duim breed; door dezelve loopen, behalve eene zeer ontwikkelde middelnerf, vier tot zes kleine, op verschillende hoogten uit de middelnerf ontstaande zij-nerven, in eene met den rand overeenstemmende rigting, die zich weder naar den top vereenigen. Tusschen deze overlangsche nerven zijn een aantal kleine, die op de ondervlakte netvormig uitsteken. De middelnerf steekt alleen aan de onderzijde van het vlak aanzienlijk uit, en heeft daar drie zijden: zij zet zieh boven de besehreven bladvlakte in eenen steel voort, welke in den jeugdigen staat geheel door eene grijze beharing is bedekt, en in een langwerpig, driehoekig, puntig, even zoo digt behaard knodsje eindigt. De oudere, veeltijds door het afvallen der beharing geheel gladde stelen, komen onder twee vormen voor: bij den een' ontwikkelt het beschreven knodsje tot een bekervormig aanhangsel; bij den anderen blijft dit onontwikkeld. In het laatste geval zijn de stelen, bij het verlaten der bladuitbreiding, vier- of soms driekantig, en worden, naar het einde, meer rolrond. Hier vinden wij altijd eene min of meer aanzienlijke, grijs behaarde, rolronde en puntig uitloopende verdikking, welke, naarmate van de meerdere ontwikkeling, eene meer aanzienlijke holte aanbiedt. In het eerste geval bereiken de stelen niet zelden eene lengte van 2 palmen, cn hebben in den geheelen loop eene driekante gedaante. De jongere bekers, waarin zij eindigen, zijn door eene digte, grijze beharing bedekt, knodsvormig, aan den top seheef afgesneden; de naar de spil gekeerde zijde is het kortste, en de andere met eene bogt oploopende en in een lijnvormig aanhangsel eindigende. In dezen onontwikkelden staat is de stelling der bekers onbestemd, doeh eene meerdere ontwikkeling maakt de rigting meer bepaald. Door de buiging en soms door de kronkeling der stelen, nemen de bekers eenen vertikalen stand aan, die de opening naar boven rigt. De ontwikkelde stengbekers zijn treehtervormig, met den voet in eene kleine bogt omgebogen, en hier met het regtstandig. nederdalende einde van den steel verbonden. Het tegen over de spil staande gedeelte van den beker is vlak; het afgewende deel is rond, verwijdt zieh naar boven en vernaauwt vervolgens weder even beneden de opening. Deze van de spil verwijderde zijde is het langste, en op het einde derzelve heeft de inhechting van het deksel plaats. De opening van den beker is seheef, bijna rond, en van eenen geribden 
rand omgeven. De reeds gemelde, tegen over de spil geplaatste, vlakke zijde, wordt door twee uitstekende randen bepaald: tussehen deze loopen drie nerven, welke vele zij-aren afgeven, naar den rand der opening. Een grooter aantal nerven, welke mede in den steel haren oorsprong nemen, geeft aan den voet een geribd voorkomen. Deze loopen door de geheele lengte van den beker, en vereenigen zieh vervolgens beneden of in het aanheehtingspunt van het deksel. Behalve deze hoofdnerven, welke het grootste getal uitmaken, vereenigen zieh hier nog eenige, uit de reeds vermelde uitstekende randen voortkomende nerven. Tussehen deze hoofdnerven vertoonen zieh eene menigte aderen, welke, de nerven bijna regthoekig snijdende, hierdoor een uit vierkante mazen gevormd weefsel doen ontstaan. Op de lieht-groene grondkleur der bekers zijn onregelmatig purperkleurige vlakken verspreid, en eene fijne bruine beharing geeft aan de geheele oppervlakte een gestipt voorkomen. De opening staat tot de lengte als 1 tot 3 , en de geheele lengte der bekers is zoo afwisselend, dat zij tussehen de 6 en 14 Ned. duimen versehilt. Hunne binnenvlakte is naar de opening dof purperkleurig, het lagere gedeelte meer glanzig en nog meer naar den voet blinkend geel. In het benedenste gedeelte zijn de ovale kliertjes het grootste, maar ook het minst talrijk; en naar boven nemen zij in grootte af en in getal toe. Het menigvuldigst zijn zij in het hoogste gedeelte der bekers; dáár eehter verandert hun vorm en nemen zij eene meer ronde gedaante aan. Even beneden den voet van het deksel is een klein, platgedrukt, min of meer behaard draadje, waarin een gedeelte der nerven eindigt; het ander vereenigt zieh daarentegen in den voet van het deksel, en breidt zieh daarin als aderen uit. Dit deksel is ten naastenbij eirkelrond, aan den top ingedeukt of afgesneden, aan den voet hartvormig ingesneden, van buiten met eene fijne beharing en van binnen, vooral naar het midden, van eene menigte kleine, ronde of langwerpige, door walletjes omringde kliertjes voorzien, vliezig, 2 Ned. duimen lang, 3 duimen breed, aan de binnenzijde niet zelden purperkleurig en zeer rijk aan aderen. Deze aderen zijn bij haar ontstaan aan den voet van het deksel, meest oneven van getal en splijten zieh hooger weder in kleinere; vervolgens vereenigen zieh deze talrijke verdeelingen weder en vormen hierdoor, in de vliezige uitbreiding, eene sehoone, zamenhangende ârenvleeht. De in de oksels geplaatste bloemtrossen hebben den algemeenen steel van den voet tot op ongeveer de helft of twee derden naakt; dit gedeelte is zamengedrukt, met ronde kanten, glad of met kleine verspreide grijze haren; het bloemdragend gedeelte is vier- of vijfzijdig, seherpkantig, grijs behaard, en heeft de bloemen spiraalsgewijze geplaatst. De bloemsteeltjes hebben eenen verbreeden, zaamgedrukten voet, en worden naar het einde meer rolrond; de benedenste dragen even boven den voet, min of meer uitgegroeide, laneet-lijnvormige, toegespitste, grijs behaarde sehutblaadjes, welke 1 Ned. duim tot 2 strepen lang zijn; de hooger geplaatste missen deze geheel of hebben dezelve op enkele der bloemsteeltjes als draadvormige aanhangsels. Ieder bloemsteeltje draagt één, zelden twee bloempjes en is ongeveer 4 à 6 strepen lang. De vier deelen van het bloembekleedsel zijn ovaal, van boven stomp, van buiten behaard, van binnen glad met eene menigte langiverpige groefjes, dik, 2 strepen lang en 1 streep breed, voortdurend en, kort na de opening der bloem, benedenwaarts omgeslagen. Het in het midden der bloem op een klein steeltje geplaatste vruehtbeginsel is stomp-vierkantig, de kanten tegen over de bloemdeelen, mel gevoorde zijden, naar den voet eenigzins afgerond, naar den top afgeknot, door den vastzittenden stempel gekroond en grijs behaard. De stempel is vierlobbig, van boven vlak, met twee elkander kruisende voren, die over de kanten uitkomen. De rïjpe kapsels hebben, even als het vruchtbeginsel, 
eenen langwerpigen vorm, doeh eene meer verspreide beharing, zelden meer dan één' duim lengte, èn springen in het midden der vermelde kanten in vier, met het bovenste gedeelte eenigzins omgebogene, kleppen open. Deze langwerpig ovale kleppen zijn van binnen glad, door een vierde gedeelte van den stempel gekroond, en dragen op het midden de dunne, naar boven en beneden eenigzins verdikte, plaatvormige wanden, welke de vrueht vierhokkig maken. Langs deze wanden zijn de kleine zaadjes, van den voet der kapsels tot op ongeveer het midden, geplaatst. De onrijpe, die door mij gezien zijn, waren in het midden rolrond, somtijds eenigzins zamengedrukt en eindigden aan weêrszijde draadvormig.

Deze soort werd door ons op den berg. Merapi, op Sumatra, waargenomen. Bij de bestijging van dezen, in het midden van het rijk van Menang-Karbau gelegen, 2912 N. Ellen hoogen berg $\left(^{\star}\right)$, troffen wij haar aan, nadat wij het digte boseh verlaten hadden en ons op de minder digt begroeide, ja soms bijna kale bergruggen bevonden. Eene bijgeloovige gewoonte onzer begeleiders gaf tot het vinden der eerste plant aanleiding. Op eene kleine, in het midden kale, maar door helder groen bebladerde Euryae retieulatae en witte, welriekende bloemen dragende Laplaeeae vuleanieae Khs. $(\dagger)$, omzoomde vlakte gekomen zijnde, verrigteden onze begeleiders hunne gebeden en bragten eene soort van offer aan de bewaakster van den berg, Poeti-Bongso, terwijl ik intussehen, de om ons heen verspreide struiken doorzoekende, eene bijna geheel verdorde plant vond. Den weg hooger op, langs den zieh versmallenden bergrug voortzettende, zagen wij deze Nepenthes-soort, op ongeveer $2500 \mathrm{~N}$. Ellen, minder zeldzaam. Hier slingerde zij zieh, met ongeveer $2 \mathrm{~N}$. Ellen lange stengen, tussehen de kleine groepen van Thibaudia elliptiea Bl., Gaultheria punetata BI., Eurya retieulata Khs., Ardisia laevigata Bl. en Photinia serrata Khs.; dan weder verried zij haar aanwezen door haar liehtgroen loof, tussehen de grijskleurige Gleiehenia vuleaniea BI., en deed zij, door eene mindere ontwikkeling en de broosheid harer deelen, het ongunstige harer groeiplaats kennen.

De Nepenthes Bongso is, door den weinig ontwikkelden, bladvormigen steel, verwant aan N. Gymnamphora en $\mathbf{N}$. graeilis, maar wijkt van beiden, door den treehtervorm der bekers af. Zij heeft dezen vorm der bekers gemeen met de N. Madagaseariensis, van welke zij overigens door de beharing en de bloeiwijze verselilt.

$\left.{ }^{*}\right)$ Behalve de hoogte van dezen berg, zijn nog de hoogten der boven de bergketen uitstekende, vulkanische toppen van den Ophir of Passaman en van den Singalang, door de waamemingen van den Heer Horner, bekend geworden. De eerste is 2924 N. Ellen (niet 4219 ellen, zoo als Nairne heeft opgegeven) en de tweede, de Singalang, 2936 ellen hoog. De bergtoppen van den Talang of Soloashie, en van den Merapi of Piek van Corinthie, welke zuidelijker boven de bergketen van Sumatra's westkust uitsteken, zijn nog niet bestegen. Deze echter, naar van zee genomene hoeken, met de bovengenoemden vergelijkende, kunnen niet aanmerkelijk van elkander verschillen.

$(†)$ Beiden zullen, in de tweede of derde aflevering van dit werk, beschreven worden. 


\section{NEPENTHES GRACILIS. KHs.}

N. phyllodiis decurrentibus, ascidiis radicalibus ventricoso-tubulosis, caulinis cylindrico-tubulosis, inflorescentiâ racemosâ fusco-sericeâ, pedunculis unifloris, ovariis sessilibus.

De wortel dezer soort zwelt somwijlen tot eenen onregelmatig ronden of meer langwerpigen, houtigen knol aan, uit welken een aantal kleine worteltjes ontstaan, benevens één, zelden meer, rolronde, soms gevoorde, knobbelige, houtige, bruin gekleurde, horizontaal onder of over den bodem kruipende wortelstok. Uit dezen wortelstok ontwikkelen zieh eene menigte zwarte, rijk met vezeltjes bedekte worteltjes, ter plaatse, waar jonge blad- of stengseheuten te voorsehijn komen. Van deze groeit meestal sleehts één, zelden meerdere, tot hoofdsteng uil, terwijl de anderen veeltijds in groei aehterlijk blijven. Van deze seheuten zijn de phyllodia langwerpig, naar de punt toegespitst, met den voet de steng op ongeveer drie vierde van den omtrek omgevende, van boven glad en van onderen met eene zeer fijne beharing. De steel van de middelnerf is bruin behaard, stomp-driekantig, met eene vlakke zijde naar boven, en eindigt in een even zoo behaard, eivormig ligehaampje, hetwelk in dien onontwikkelden staat blijft of tot een' beker uitgroeit. Deze bekers zijn buisvormig, aan den voet kogelvormig verwijd en hebben hunne cirkelronde opening, wier middellijn tot de lengte van den beker als $\mathbf{1}$ tot $\mathbf{2}$ staat, door eenen geribden, naar buiten en binnen omgebogenen rand omzoomd. Z Zij worden op de naar de spil gekeerde zijde door twee diep getande, bladaardige kammen versierd, en bezitten ook op dezen de bundelsgewijs vereenigde, fijne haartjes, welke insgelijks op het overige gedeelte van den beker aanwezig zijn. De nervenloop dezer groene, purper gevlekte bekers, wijkt weinig van dien der andere soorten af, uitgenomen, dat hier de, van den voet regt naar het deksel uitloopende nerf duidelijker is ontwikkeld, en met haar verseheidene zij-nerven te zamenloopen, alvorens den top te bereiken. Hier vereenigen zieh deze nerven gedeeltelijk in een klein ingesneden of ongedeeld, bruin behaard aanhangsel, gedeeltelijk in den voet van het deksel. Deze laatsten breiden zieh vervolgens weder uit in het bijna cirkelronde deksel, hetwelk aan den voet hartvormig ingesneden, gaaf van rand of met eenige priemvormige tanden omzet, van buiten behaard en van binnen glad, van eenige weinige klieren voorzien, vliezig en door een fraai aderen-net versierd is. De binnenvlakte van den beker is bijna gelijkelijk in eene eenigzins purperkleurige, doffe en in eene blinkend gele, met kleine zwarte kliertjes voorziene helft verdeeld, en onder de zeer regelmatige seheidingslijn zijn twee, met dezelve evenwijdig loopende rijen van klieren; onder dezen zijn de volgende klieren minder regelmatig geplaatst, en het is opmerkelijk, dat zij in deze soort, op eene bepaalde ruimte, naar den voet in getal toenemen, en er hier driemaal meer dan aan den top, bij gelijke uitbreiding zouden aanwezig zijn. Het naakte gedeelte van de steng der oudere planten is rolrond, knobbelig, blinkend, zwart-bruin, en het gebladerde gedeelte seherp driekant met vlakke zijden, groen of somwijlen paarskleurig, bijna geheel glad. De phyllodia zijn overhoeks, even als de aan dezelfde zijde staande en bijna boven elkander geplaatste, langwerpig, naar den top zeer toegespitst, met den voet twee derde gedeelten der steng omvattende en het overige vlakke gedeelte met eenen bladaardigen, stomp eindigenden rand omzoomende, van boven glad, van onderen met eene verspreide beharing, 2 duim breed en 10 duim lang, geel-groen gekleurd, met eene van onderen uitstekende middelnerf, en aan weêrszijjden twee of drie uit of even boven het aanheehtingspunt ontspringende, met den omtrek evenwijdig loopende en zieh in den top vereenigende zij-nerven, die door eene menigte, dwars over de 
bladuitbreiding loopende aderen zijn verbonden. Een of meerdere, digter bij de bloeiwijze geplaatste phyllodia, zijn soms van eene meer ovale gedaante, waarin de lengte tot de breedte als $\mathbf{5}$ tot $\mathbf{2}$ staat. De steel, in welken de middelnerf verloopt, heeft dikwerf de dubbele lengte van de bladuitbreiding, is half rolrond, eerst roest-bruin behaard, vervolgens glad, naar het uiteinde of meer in het midden met twee tot vijf kleine krullen, en eindigt in een langwerpig, onregelmatig, spits knodsje of in eenen beker. Deze bekers zijn buisvormig, aan den voet met eene korte bogt, even boven denzelven verwijd en vervolgens naar de opening in omvang afnemende. Bij eenen beker van 11 duim lengte bedroeg de grootste omtrek 6 en de kleinste 4 Ned. duim. IIunne beharing, het verloop der nerven en de omzoomende rand der opening behoeven, wegens de gelijkvormigheid mel het dienaangaande vermelde, geene nadere opgave. De beide, op de jongere of lager geplaatste bekers aanwezige kammen, zijn bij deze soort soms meer, dan bij andere soorten, van elkander verwijderd en dikwerf alleen als eenvoudige uitstekende randen aanwezig. De binnenvlakte der bekers is, van den voet tot op ongeveer een derde van de lengte, blinkend en klierdragende. Het aanhangsel en het deksel wijken weinig van de reeds besehrevenen af; alleen heeft het laatste de insnede aan den voet een weinig dieper en de binnenvlakte met eenige weinige, vrij groote, ronde, somwijlen met eene kleine uitholling, in het midden voorziene kliertjes of klierhoopjes. Het grootste door mij geziene deksel was 30 strepen breed en 32 strepen lang, en bedekte de opening van eenen beker van 12 duimen lengte. De bloeiwijze der mannelijke en vrouwelijke planten is sehijnbaar aan het einde der stengen geplaatst, trosvormig, bruin behaard, dikwerf twee palmen lang, met éénbloemige bloemsteeltjes. De algemeene bloemsteel is aan den voet zaamgedrukt, een weinig gevoord; het bloemdragende gedeelte daarentegen vier- of vijfkantig en naar den top eenigzins platgedrukt. De bloemsteeltjes zijn bij den oorsprong een weinig verbreed, naar boven meer rolrond, blinkend bruin behaard. De mannelijke bloemknoppen zijn bijna kogelrond, en in deze liggen de beide buitenste grootste kelkdeelen over de binnenste heengeslagen. De buitenste deelen zijn bijna eirkelrond, van buiten bruin behaard, van binnen glad, met kleine groefjes, lederaehtig, ongeveer 2,2 streep lang en 2 streep breed; de binnenste zijn ovaal en beiden na de opening teruggeslagen. De meeldraden-kolom is stomp-vierkantig, aan den voet een weinig verbreed, glad en eindigt in eenen bijna kogelronden knop, welke vervolgens meer sehijfvormig wordt. Om dezen knop zitten twaalf langwerpige helmknopjes, welke een drielobbig, zelden kogelrond stuifmeel uitstorten. De vrouwelijke bloemen zijn gekenmerkt door meer eironde knoppen. Zij hebben de vier bekleedselen langwerpig ovaal, stomp, aan de buitenzijde bruin behaard, aan de binnenzijde glad, met kleine groefjes, 1 streep breed, 2,5 streep lang. Het vruehtbeginsel is stomp-vierkantig, met de kanten tegen over de bloembekleedsel-deelen, naar den voet afgerond, naar den top eenigzins verdund, door een' vierlobbigen, platgedrukten stempel gekroond, bruin behaard, vierhokkig, met eene menigte eitjes. De kapsels zijn houtig, langwerpig, in het midden buikvormig, naar de einden in omvang afnemende, stomp-vierkantig, met eenigzins gevoorde zijden, blinkend lieht bruin, met kleine haartjes en groefjes, ongeveer 16 streep lang en 3 streep breed, in vier kleppen openspringende. Deze kleppen dragen in het midden de vliezige middelsehotten, welke de vrueht verdeelen, zijn blinkend bruin en eindigen in een tweelobbig gedeelte van den stempel. De talrijke zaadjes zijn tegen de wanden, met het vrije einde naar boven geplaatst, spilvormig, aan beide einden toegespitst, eenigzins zaamgedrukt, ruw, ongeveer 1 duim lang en een derde tot eene halve streep breed. Hun buitenste vlies is eenigzins dikker, 
dan bij de volgende soort. De raphé loopt eerst vrij door het celweefsel, verbindt zieh vervolgens beneden de kern met het gemelde vlies, loopt daarna langs deze tot boven de kern, waar zij zieh ombuigt en met het binnenste zaadbekleedsel verbindt. De kern is rolrond, aan den top en aan den voet stomp. Zij bestaat uit een wit kiemwit, hetwelk de regtstandige kiem omgeeft. Deze is rolrond, in het midden eenigzins ingesnoerd, met stompe zaadlobben en een, somwijlen in een klein puntje eindigend worteltje.

Deze soort, door mij het eerst op Sumatra's westkust gevonden, waarvan ik aan den Hoogleeraar van Hall sehriftelijk kennis gaf, berustte in dien tijd alleen op de mij toen bekende onderseheidende bladvormen, terwijl hare bloem- en vruehtdeelen mij geheel onbekend waren. Ik verheugde mij dus, door voorwerpen, welke mijn reisgenoot $\mathbf{D}^{\mathrm{r}}$. Miüller aan de rivier Palantau verzamelde, van haar aanwezen op Borneo's zuid-oostkust onderrigt te worden, en mogt daardoor de hoop voeden, deze plant, hier of daar, bloem- en vruehtdragende te zullen ontmoeten. Deze hoop werd dan ook later, bij onzen togt naar den berg Pamatton, verwezentlijkt. Aan den voet van dezen berg groeide, op den uit verweerd Diorietaardig gesteente gevormden, rood-bruinen grond, deze soort met eene tot dien bodem in verhouding staande ontwikkeling. Eenige der hier verzamelde voorwerpen hadden naauwelijks meer dan eenige duimen hoogte; anderen eenen aanzienlijker wasdom. Omtrent het voorkomen en de standplaats dezer soort, vind ik het volgende in mijn dagboek opgeteekend:

) Aan den voet, even als op de hellingen, van den ongeveer 325 meters hoogen berg Pamatton, steken overal steenblokken uit, die in hunne gebarstene oppervlakte de kenmerken dragen van vroeger gesmolten te zijn geweest. Zij zijn van buiten bruin of geel gekleurd en van binnen zwart met glanzende glimmerblaadjes, enkele witte kiezelkorreltjes en hoopjes ijzeroxyde, en behooren tot eene soort van Gabbro, die somwijlen in digtere, minder sehulpvormig brekende Serpentijn overgaat. Het moeijelijke verweren dezer steensoort, benevens de onvruehtbaarheid van de hierdoor gevormde aarde, wordt door het aanzien der voorhandene planten bewezen. - De onder haar niet zeldzame Nepenthes graeilis ontwikkelt, naar gelang zij een gunstiger of ongunstiger plekje gronds bedekt, de bladaardige uitbreiding met eene meerder of minder levendig groene kleur. Bij deze fraaije plant wast eene heerlijke soort van Melastoma (M. porphyratum Bl.), welke hier sleehts een' halven voet hoogte bereikt en elders, met geene grootere bloemen, tot vier voet hooge struiken uitgroeit; verder eene Hedyotis, welke ons aan $\mathbf{H}$. rugosa (Metabolos rugosa B1.) van de omstreken der hooge kraters herinnerde, en, als hoofdplant, eene nu geheel verdorde grassoort (Anthisteria). Boven deze lage gewassen, waren Apoterium sulatri, Petunga, Spathodea, Melanthesa en Psyehotria groepsgewijze te zamen verspreid, welke, daar hunne sehaduw de uitdrooging van den grond verminderde, aan de daardoor vochtiger geplaatste Nepenthes eene meerdere ontwikkeling deden te beurt vallen."

De op Sumatra verzamelde planten onderseheiden zieh van die van Borneo door eene meer aanzienlijke bladontwikkeling, waarsehijnlijk door de voor haren groei meer gesehikte, voehtiger standplaats te weeg gebragt. Behalve deze beide, door ons onderzochte oorden, bewoont deze soort ver- 
moedelijk ook Malacca en Singapoera; ten minste, naar de beschrijving, welke door W. Jaek, van de door hem in die streken gevondene Nepenthes destillatoria gegeven wordt $\left({ }^{\star}\right)$, meen ik te mogen vooronderstellen, dat hij nhiet de ware $\mathbf{N}$. destillatoria L., maar eene met de $\mathbf{N}$. graeilis overeenkomende plant heeft voor zieh gehad, èn omdat het gegeven kenmerk op de laatstgenoemde soort juist toepasselijk is, èn omdat hare wijze van verspreiding geene bedenking tegen deze gelijkheid oplevert.

\section{NEPENTHES BOSCHIANA. Khs.}

N. phyllodiis decurrentibus, ascidiis radicalibus ventricoso-tubulosis, caulinis tubuloso-infundibuliformibus, inflorescentiẩ cinereo-pubescente, pedunculis uni- vel bifloris, ovariis sessilibus.

Op deze soort is het bij de vorige, omtrent den wortelstok en de bekleeding der stengen van jongere planten opgemerkte toepasselijk. Zij heeft aan de wortelbladen, even boven de seheedevormige stengomvattende uitbreiding, een klein steeltje, en hooger een ovaal naar den top toegespitst, van boven glad, van onderen spaarzaam stipvormig behaard, ongeveer 3 duim breed en 7 duim lang, liehtgroen phyllodium, met eene van onderen zeer ontwikkelde middelnerf, en ééne of twee met den rand evenwijdig loopende en niet ver van denzelven verwijderde, zieh even beneden den top met de middelnerf vereenigende zij-nerven, welke door eene menigte aderen met elkander en met de middelnerf zijn verbonden. De steel, welke deze middelnerf vervolgt, is stomp-driekantig, met gevoorde zijden; jong zijnde behaard, ouder wordende glad. De eenigzins zaamgedrukte knoppen en de zeer jonge bladen zijn aan de beide randen en op de middelnerf, en de jonge bekers geheel door eene grijze beharing: bedekt. In het begin hunner ontwikkeling zijn de bekers bijna rolrond en van boven seheef afgeknot. Meer uitgegroeid, worden zij kruikvormig, even boven den voet kogel- of eivormig verwijd, en vervolgens na de opening weder meer regelmatig buisvormig. Op dezelve zijn de beide kammen, even als bij de vorige soorten, ontwikkeld. Hunne nervuur wijkt zeer weinig van die der N. graeilis af, en de rand, welke de opening omzoomt, is even als die der vorige soorten, geribd. Het aanhangsel, beneden het deksel, is meestal een gaaf, somwijlen aan het einde gespleten plaatje. IIet deksel is bijna eirkelrond, aan den voet hartvormig ingesneden, op de binnenzijde met eene menigte eirkelronde of meer ovale, door kleine wallen omgevene kliertjes, en aan de buitenzijde met eenige kleine, bruine haartjes voorzien. De binnenvlakte der bekers wordt door het kleurversehil in bijna twee gelijke declen verdeeld en heeft het bovenste gedeelte dof, met eenen purper-blaauwen dauw bedekt; het benedenste is zeer glanzig, bruin-geel, met een groot getal kleine poren, die van den voet naar boven op eene bepaalde ruimte toenemen. Aan meer uitgegroeide planten zijn de oudere stengen rolrond, glad, met eene menigte kleine groeven; de jongere, min of meer stomp-driekantig, glad, met kleine zwarte stipjes en in de oksels der bladstelen digt grijs behaard. De phyllodia versehillen vooral door eene meerdere ontwikkeling van die der jongere seheuten. Het afloopend gedeelte is stomp-driekantig, met eenen bladerigen rand bezoomd, en omgeeft ongeveer twee derde gedeelten van den omvang der steng. Het breede is langwerpig-ovaal en heeft eene met de reeds besehrevene, overeenkomende nervenverdee-

$\left.{ }^{*}\right)$ Hooker Companion, I. p. 271. Foliis sessilibus amplexicaulibus, ascidiis infundibuliformibus ore striato. Botanica. 
ling. De van onderen half rolronde middelnerf zet zich voort in eenen dikwerf aanzienlijk ontwikkelden, in het midden gekrulden steel, welke naar het einde in dikte toeneemt en veelal in eenen, aan den voet gebogenen beker overgaat. Deze beker heeft eenen verlengden treehtervorm, is in het benedenste gedeelte eenigzins wijder en heeft, bij eene lengte van ongeveer drie palmen, eene middellijn van, aan den voet 4 , in het midden 3 en aan de opening ongeveer 5 duimen. Zijne opening is met eenen breeden geribden rand omzoomd, en de binnenvlakte in het bovenste twee derde gedeelte, min of meer dof purperkleurig, en in het overige glanzend bruin met eene menigte half eirkelronde poren. Zijn deksel is in vorm weinig van dat der jongere bladen onderseheiden, maar bezit somwijlen even boven den voet, een zaamgedrukt, min of meer rond uitsteeksel. Aan een groot stengblad heb ik de volgende evenredigheid waargenomen: het afloopend gedeelte van het phyllodium 13 duim lang; het verbreede gedeelte 32 duim lang en 8 duim breed; de bekersteel 30 duim en de beker 27 duim lang; de rand 1,5 duim breed; het deksel 6 duim lang en 7 duim breed. De bloeiwijze der mannelijke en ook der vrouwelijke planten is trosvormig, dikwerf 9 palmen lang, behaard, heeft de benedenste helft van den algemeenen bloemsteel bloemloos, rolrond, en de bovenste bloemdragend, zaamgedrukt, kantig. Hare bloemsteeltjes zijn meest twee-, en naar den top éénbloemig, behaard, min of meer te zamengedrukt; de benedenste hebben even boven den voet een toegespitst sehutblaadje. De mannelijke bloem bezit de vier bloemdeelen ovaal, van buiten geheel en van binnen even boven den voet grijs behaard, hooger op glad, met kleine groefjes, 3 streep breed en 4 streep lang, en na de opening teruggeslagen. Zij heeft het zuiltje en den knop van de vereenigde helmàraden gelijk aan die der $\mathbf{N}$. graeilis, uilgezonderd dat de laatste somwijlen sleehts 8 helmknopjes draagt. De vrouwelijke bloemen onderseheiden zieh van de mannelijke door langere knoppen en door de meer langwerpige deelen van het bloembekleedsel. Haar vruehtbeginsel is door vorm en zamenstelling weinig onderseheiden van dat der bovenvermelde soort. De kapsels zijn langwerpig, in het midden een weinig dikker, stomp-vierkantig, grijs behaard, houtig, door den stempel gekroond, in vier, ieder een gedeelte van den stempel dragende, kleppen openspringende. Deze kleppen hebben, even als de vorige soorten, het tegen over hen liggende gedeelte van het middelsehot op hun midden. De talrijke, daaraan vastgeheehte zaadjes, zijn in het midden bijna rolrond verdikt, naar de einden elsvormig uitloopende, en ongeveer 12 strepen lang. De kern beslaat daarvan 1,2 streep, heeft eenen langwerpigen eivorm en een aanzienlijk ontwikkeld kiemwit, hetwelk de kiem, met uitzondering van een klein, tegen over den wortel gelegen puntje, geheel omgeeft. In haren vorm wijkt de kiem somwijlen door eene meerdere verdikking van het wortelgedeelte van de andere soorten af; dit is eehter als eene uitzondering aan te merken, daar zij meestal cilindervormig, in het midden een weinig ingesnoerd en aan de uiteinden afgerond voorkomt.

De boven beschrevene, tot heden onbekende plant verdiende, wegens haren uitnemend schoonen vorm en hare aanzienlijke grootte, ook met eenen uitstekenden naam in het stelsel der wetensehap te worden opgenomen. Derhalve, gebruik makende van de in de kruidkunde anngenomene loffelijke gewoonte, om den naam van hen, welke der maatsehappij of der wetenschappen belangrijke diensten bewezen, op onbesehrevene gewassen toe te passen, heb ik de vrijheid genomen om deze soort van 
Nepenthes te vereeren met den naam van den algemeen geaehten Staatsman, aan wien de maatschappij zulk cen doeltreffend middel ter verzorging der armen, het vaderland, in deszelfs Oost-Indisehe beziltingen, de invoering van een, door rijke vruchten bekroond stelsel van eultuur, en de natuurkundige wetensehappen zulke belangrijke ondersteuningen verschuldigd zijn, ten einde op die wijze eene dankbare hulde te brengen aan Zijne Excellentie, den Luitenant-Generaal, Minister van Staat, Graaf van den Bosch, laatst Minister van Koloniën, vroeger Commissaris-Generaal der Nederlandsehe Oosten West-Indische bezittingen.

De Nepenthes ß3oschiana werd door ons op den top van den berg Sakoembang $\left(^{\star}\right)$, op Borneo's zuidoostkust gevonden, en droeg niet weinig bij tot de opluistering der vegetatie aldaar. Tussehen eene groep van rijkbloeijende, maar bijna bladerlooze Melastomata porphyrata, herstelden hare aanzienlijke bladerige uitbreidingen het voor het oog verbroken evenwigt, en verborgen zij de ruwe en hoekige takken der planten, tegen welke zij steunden. Op eene andere plaats tooiden hare afhangende stengen, met de groene bladschijfvormige stelen en uitnemend groote, door purpervlekken bont gesehakeerde bekers, de door verschillende soorten van Balsamina, Begonia, Hymenophyllum en Hypnum schraal begroeide, steile Syënietwanden. Elders slingerden zieh meer ontwikkelde stengen tusschen de in hare nabijheid staande boomen, cn verborgen zij zich tusschen de digte kroonen der Myrtus aeuminata, Eurya nitida, Coptosapelta montana Khs. (†) en Macklottia Ambö̈nensis $\mathbf{K} h s .(\$)$. Door de meerdere grootte der bladvlakte, en vooral door de lange trechtervormige bekers, die niet zelden langs den omtrek der kroonen afhingen, werden zij cehter niet aan hel oog onttrokken en versehaften zij de gelegenheid, om de schoonste gewassen voor onze verzameling uit te kiezen en dus een sieraad van deze te worden. Terwijl ik mij met zoodanige bloemlezing onledig hield, waren mijne begeleiders bezig met de grootste bladen van eene, door hen gevondene groep dezer planten, ter verkrijging der bekers, te vernielen. Eenigen kozen zieh daarbij de nog ongeopende bekers uit en verzekerden mij, dat het in dezelve bevatte water een zecr heilzaam middel tegen oogontstekingen was; anderen zochten de grootste, reeds geopende bekers op, hetzij om hunne rijst daarin te koken, of wel om ze als speelgoed, zakjes of pijlkokertjes voor hunne kinderen mede te nemen. Van dit laatste gebruik is vermoedelijk de inlandsche naam Daoen-sompitan, hetwelk blaaspijpbladen beteekent, afkomstig. Voor het overige maken de inlanders, naar ik vernomen heb, geen ander gebruik van cenig gedeelte dezer plant, en evenmin schijnen zij aan het bijgeloof te hechten, hetwelk bij de bewoners van de Molukken en van Madagascar algemeen heersehende is, dat na de uitstorting van het vocht der bekers, regen zou moeten volgen, daar zij het water van die bekers, in welke hetzelve, zoo als dikwerf gesehiedt, door verdronkene mieren bezoedeld is, terstond uitstorteden.

Bij eene vergelijking der Nepenthes Boschiana met de andere soorten, onderseheidt zij zich van de $\mathrm{Ne-}$ penthes graeilis door den meer ovalen vorm van de phyllodia, en door de meer treehtervormige gedaante

$\left(^{*}\right)$ De Sakoembang is eene der hoogste kruinen van het op Borneo's zuid-oostkust gelegen Ratoesgebergte en heeft, volgens Barometer-waarnemingen, eene hoogte van 967,8 Ned. ellen. Hij bestaat voornamelijk uit Dioriet en Syëniet, en schijnt tusschen eene micaschiste-formatie opgeheven te zijn.

$(t)$ Een nieuw geslacht van de Ginehoneae.

(\$) Leptospermum Amboinensè Bl. 
der bekers. Door deze laatste bijzonderheid heeft de Nepenthes Bosehiana eenige gelijkenis met de N. destillatoria, N. Madagaseariensis en N. Rafflesiana: zij versehilt eehter van de beide eersten door hare minder zaamgestelde bloeiwijze, en van de laatstgenoemde, door de minder buikige bekers der jongere stengbladen en door de rijkere nervuur van den bladschijfvormigen steel.

\section{NEPENTHES PHYLLAMPHORA. WILLD.}

N. phyllodiis basi angustatis, inferioribus dentatis superioribus iutegerrimis, ascidiis radiealibus tubulosis basi ventricosis, caulinis subinfundibuliformibus, inflorescentiâ pilosâ, pedunculis uni-vel bifloris, ovarïs stipitatis. Khs.

Willdenow, Species plantarum, IV.p.874; Sprengel, Sys tema vegetabilium, III. p. 84; Brongniart, Annales des Seienees naturelles, I. p. 40; W. Jaek in Hooker Companiou to the Botanieal magazine, I. p. 271; Phyllamphora mirabilis Loureiro, Flora Cochinchinensis (1790.4º.), p. 606; Cantharifera Rumphius, Herbarium Amboinense, V. p. 121. Tab. 59. f. 2.

Somwijlen bezit deze soort eenen bijna ronden, knolvormigen, somwijlen eenen meer rolronden, bruin gekleurden wortel, waaruit kleinere, met eene menigte haarvormige vezels bezette worteltjes voortspruiten. Hare jongere stengen zijn geheel door de bladseheeden der afgestorvene of der nog levende bladen bedekt, en volgen met hare bladen dezelfde wijze van ontwikkeling, die wij reeds bij de andere soorten opmerkten. Aan de benedenste of eerste bladen der spruiten, heef de beker het grootste aandeel; op die der later ontsprotene is het phyllodium grooter. Dit is langwerpig, naar den voet versmald, de steng omvattend, naar den top toegespitst, aan den rand seherp getand, van boven geheel en van onderen bijna glad, de breedte tot de lengte als 1 tol 3 , vliezig, 3 of 4 kleinere, met den rand parallel loopende nerven aan weêrszijden van de middelnerf: door dien nervenloop versehilt deze soort van de N. Bosehiana, die in een breeder phyllodium minder hoofdnerven en eene grootere ruimte tussehen de middelnerf en de zijnerven bezit. De bekersteel is eerst behaard, vervolgens glad en heeft eene geringe lengte. De bekers zijn buisvormig, met eene verwijding boven den voet; bij hunne eerste ontwikkeling digt, bij meerdere ontwikkeling verspreid behaard, en bezitten de reeds bij andere vermelde, getande kammen. Hunne opening is eirkelrond en door eenen rolronden, geribden rand omgeven. Het deksel is insgelijks eirkelrond, somwijlen door eenen breeden voet met het bekergedeelte verbonden, langs den rand, zoowel als op dit verbreede deel van aanheehting, mel eenige draadvormige aanhangsels voorzien; bij een deksel van 5,5 duim breedte en 5 duim lengte, bedroeg het aanheehtingspunt 2,5 streep, en gingen de nerven onverbonden uit den beker in het deksel over. De bovenhelft van de binnenzijde dezer bekers is dof, somwijlen geel-groen, met een' purperen zoom, soms geheel purperkleurig; de benedenhelft blinkend bruin, rijk aan half eirkelvormige klieren of groefjes, waaraan de bovenranden zeer duidelijk zigtbaar zijn. Het deksel heeft sleehts weinige klieren. De zaamgedrukte knoppen volgen de reeds opgegevene ontwikkelingswijze en zijn aan de randen en uiteinden grijs-bruin behaard. Het bladerlooze gedeelte van de stengen der oudere gewassen is bijna rolrond, het gebladerde gedeelte stomp-vierhoekig, naar het einde soms zamengedrukt. Het versmalde gedeelte van het phyllodium omvat de halve steng, is halfrolrond, van boven eenigzins gevoord, met een smal bladerig randje; het breede deel van hetzelve is langwerpig-ovaal, 
naar de beide einden versmallend en somwijlen aan weêrszijden van den steel ongelijk afloopende; zelden stomp; met eenen seherp getanden rand; van boven lieht groen, van onderen iets donkerder gekleurd en op de beide vlakten bijna geheel onbehaard. De bekersteel verkrijgt somtijds eene aanzienlijke lengte. Indien hij zonder beker is, verlengt hij zieh in de rigting van het blad, en heeft aan het eenigzins verdikte einde twee of meerdere krullen. Draagt hij eenen beker, alsdan volgt hij de rigting van het blad tot op ongeveer het midden zijner lengte, waar hij eenige kronkelingen heeft, vervolgens loodregt afdaalt en aan het einde met eene korte bogt in den beker overgaat. De bekers dezer soort hebben eenige gelijkheid met die der $\mathbb{N}$. gymnamphora: zij nemen van den voet af naar boven, tot op ongeveer het midden der lengte toe, en verminderen naar de opening in omtrek: het eerste gedeelte heeft eenen omtrek van 8, en het tweede van 7 duimen. Hunne opening is van eenen vlakken, breeden, geribden rand omgeven. De ontwikkelde kammen der bekers van de jongere planten, worden hier sleehts door uitstekende randen, en somtijds alleen door uitstekende ribben vervangen. Het verloop der nerven versehilt weinig van hetgene dienaangaande reeds bij andere soorten is opgegeven. Van buiten zijn de bekers lieht groen, somwijlen met purperen vlekken: de bovenste helft van de binnenvlakte is purperkleurig en bedauwd; de onderste glanzend bruin en met klieren bedekt. Het aanhangsel beneden het deksel is van eene geringe grootte, in slippen verdeeld, of tot een behaard, lijnvormig plaatje ontwikkeld. Het deksel is ovaal, aan den top stomp, naar den voet versmald, van buiten bijna glad of met eene zeer fijne beharing, van binnen met eene menigte ronde en op de aderen met ovale groefjes bedekt. Bij een middelmatig blad nam ik de volgende grootte der deelen waar: de steel van het phyllodium 7 duim; het phyllodium $22 \mathrm{~d}$. lang en $6,5 \mathrm{~d}$. breed; de beker $20 \mathrm{~d}$. lang en $9 \mathrm{~d}$. omvang; het deksel 4,5 d. lang en $3 \mathrm{~d}$. breed. De in de nabijheid der bloemen geplaatste bladen bestaan alleen uit het phyllodium, hetwelk door den vorm weinig van dat der stengbladen afwijkt. Over het algemeen is het eehter gaaf van rand; bij enkelen verdwijnt de middelnerf beneden den top, en er ontstaat dan een, aan dit einde geheel stomp phyllodium. De bloemtrossen zijn in den jeugdigen staat tussehen de scheedevormig zaamgebogene phyllodia besloten, komen of uit, òf door de verlenging der steng, boven de oksels der bladen te voorsehijn, en worden somwijlen 5 palmen lang. Ongeveer de benedenste helft van den steel is zonder bloemen. Hij is in dit naakte gedeelte aan den voet stomp-vierkant, hooger rolrond, bijna glad, en wordt in het bloemdragende deel seherp-kantig en grijs behaard. De talrijke bloensteeltjes zijn aan den voet een weinig zaamgedrukt, en boven dezen rolrond, twee- of éénbloemig. De mannelijke bloemknoppen zijn bijna kogelrond, grijs behaard, en hebben de bloembekleedseldeelen in dezelfde ligging, als reeds bij andere soorten is opgegeven. Deze vier deelen zijn van eene ongelijke grootte, bijna cirkelrond, aan den top eenigzins puntig, van binnen glad, voorzien van eene menigte kleine, langwerpige groefjes, van buiten met eene verspreide en aan den rand met eene digte, grijze beharing, ongeveer 5 strepen lang en 4,5 breed. De helmadradenkolom is stomp-vierkant, glad en eindigt in eenen bijna kogelronden knop, om welken zestien, door vergroeijing dikwerf zeer gebogene langwerpige meelknopjes zijn vastgeheeht. De vrouwelijke bloeiwijze is, in het algemeen, vrij gelijk aan die der mannelijke; alleen heeft zij de bloemsteeltjes korter. De bloemknopjes zijn grijs behaard en eivormig. De vier bloemdeelen zijn ovaal, stomp of puntig, van buiten en van binnen, even als de mannelijke bloemen, na de opening teruggeslagen, 5 strepen lang en 3 tot 4 strepen breed. Het vruehtbeginsel zit op een klein rolrond steeltje, is stompBotanica. 
vierkant, naar den voet en den top eenigzins afgerond, door den vierlobbigen, naar boven eenigzins puntig toeloopenden stempel gekroond, digt lieht bruin behaard en vierhokkig. De talrijke eitjes beslaan tegen de wanden dezer hokjes eene langwerpige, driekantige, naar boven in eenen spitsen hoek uitloopende, tot over het midden gaande oppervlakte; zij zijn bij hunne eerste versehijning rond, en nemen bij de ontwikkeling eenen meer langwerpigen vorm aan. De kapsels zijn kort gesteeld, langwerpig, in het midden verdikt, naar het einde in omvang afnemende, stomp-vierkantig, blinkend bruin met kleine groefjes, houtig, ongeveer 30 streep lang en 5 streep breed, in vier kleppen openspringende. De kleppen dragen aan den top een driehoekig gedeelte van den stempel, en in het midden het tegen over haar gelegen deel van den seheidswand der hokjes; van binnen zijn zij blinkend bruin. De zaden zijn zeer talrijk, in het midden rolrond en naar de beide einden elsvormig uitloopende, aan de punt van aanheehting eenigzins stomp en ongeveer 15 strepen lang. Het buitenzaadvlies omgeeft in het middelgedeelte een los eelweefsel. De raphé loopt van den voet van het zaad tegen dit buitenvlies, en seheidt zieh even boven de kern van hetzelve af, om in het binnenste zaadvlies over te gaan. De kern is rolrond, aan de beide einden stomp, en bevat de, van de vorige soorten door vorm en evenredigheid der deelen weinig versehillende kiem in een wit, niet zeer ontwikkeld kiemwit.

De Nepenthes Phyllamphora onderseheidt zieh van de overige, mij bekende soorten, door den getanden rand van de phyllodia der jongere stengen, en wijkt van de haar verwante N. Gymnamphora af, door den meer verlengden vorm van de bekers der jongere bladen, door het hier langwerpig, bij de verwante soort meer eirkelrond deksel, en door de grijze, bij N. Gymnamphora bruine beharing.

Zij werd het eerst door Rumphius $\left(^{\star}\right)$, onder den naam Cantharifera, naar door hem in de Moluksche eilanden gevondene voorwerpen, uitvoerig besehreven, kennelijk afgebeeld, en tevens als op Sumatra's oostkust en op Malaeea groeijende, vermeld. Later is door Loureiro $(\dagger)$, onder den naam Phyllamphora mirabilis, een in Coehinehina voorkomend gewas besehreven, hetwelk, volgens hem, op geringe afwijkingen (\$) na, met de door Rumphius vermelde en afgebeelde plant, overeenstemde. Vervolgens is deze soort in versehillende streken van den Arehipel opgemerkt en verzameld: zoo komt zij, blijkens de door mij in het Herbarium van den Hoogleeraar Reinwardt geziene jonge bladen, op Tidore voor, en groeit zij, naar de door Zippelius gevondene jonge spruiten te oordeelen, op Nieuw-Guinea's zuidwestkust, en is zij op Amboina geen zeldzaam gewas. Zij werd mij door den Heer 1Diard, als op het eiland Banea voorkomende, opgegeven, en door eene vergelijking van de aldaar verzamelde en in het Rijks-Herbarium aanwezige voorwerpen, nader bekend. W. Jaek $\left.{ }_{*}\right)$ gaf ons kennis van haar aanwezen in de nabijheid van Benkoelen, en dat zij ook in de omstreken van Padang, op Sumatra's westkust, als ook op Borneo's zuid-oostkust voorkomt, is door onze latere togten in deze oorden bewezen.

(*) Herbarium Amboinense, V. p. 123.

(t) Loureiro, Flora Cochinchinensis, ed. orig. $4^{\circ}$. p. 606.

(S) Deze afwijkingen schijnen mij toe, een gevolg van de minder gunstige standplaats dezer planten te kunnen zijn.

$\left.{ }_{\star}\right)$ Hooker, Comparion to the Botanical magazine, I. p. 271, etc. 
Hoewel nu de, op deze verschillende plaatsen verzamelde voorwerpen cene opmerkelijke gelijkheid bezitten, kan men toch eenig verschil tusschen dezelve aantoonen. De op Amboina en Banca bijeengebragte voorwerpen hebben eene tamelijk gelijke ontwikkcling, en wijken alleen in de bcharing af; bij de op Sumatra verzamclde, wordt eene grootere uitbreiding en cene soms zeer digte beharing der jongere deelen waargenomen; de talrijkc, op verschillende plaatsen van Borneo vereenigde voorwerpen zijn door eene minder uitgegrocide bloeiwijze en zeer geringe beharing, van dic der genoemde eilanden onderscheiden. Deze geringe afwijkingen zijn eenigermate uit de verschillende standplaatsen te verklaren. Zoo groeijen deze planten op Banca en Amboina, even als, volgens de opgave van Loureiro, in Cochinchina, in eenen kiczelaardigen bodem, die voor hare ontwikkeling niet gunstig is; daarentegen wassen zij op Sumatra in de omstreken van Benkoelen en Padang, in eenen vochtigen, meer lecmaardigen grond, en in de nabijheid van Doekoe, waar zij zeer welig groeijen, in een moerassig, alluviaal terrein. Op Borneo was deze plant hier en daar langs de oevers van de Doeson-rivier verspreid, en in de omstreken van Poeloe-Lampei niet zcldzaam. Op de ecrste groeiplaats strekte zij ten sieraad aan de, uit eene jongere tertiaire-formatie bestaande hooge oevers, terwijl, op de tweedc, kleine heuvels en meer vlakke moerassige plaatsen met haar prijkten. In deze oorden, waar kleine heuvels de bewijzen van vulkanische opheffing, en de vlakte die van eene ncptunische werking opleveren; waar zich de vermeerdering des bodems, door de afspoelende werking des waters en de dagelijks voortgaande humusvorming in de mocrassen voortzet, grocide de Nepenthes Phyllamphora, in gezelsehap van Polygonum amoenum en P. pulchrum, Hydrocera angustifolia, Enhydra longifolia (Tetraotis paludosa, Rudt.) en andere, moerassige oorden minnende gewassen, met ecne geringe stengontwikkeling; terwijl zij tusschen de grijzc Melaleuca leucadendron, den fraai groen bebladerden en rozenkleurige bloemen dragenden Ploiarium clegans geplaatst, eene zoo aanzicnlijke verlenging der steng erlangde, dat hare uiteinden zich in de kroonen dezer boomen verborgen.

De Nepenthes Phyllamphora en de andere soorten van dit geslacht hecten bij de strand-Maleijers Daoen Gindi, hetwelk, de overeenkomst dezer bladen met hunne waterkruiken uitdrukkende, door kruik- of kannetjesbladen vertaald zou kunnen worden. Bij andere Maleijers, vermoedelijk van Bintang en Singapoera, worden zij, volgens W. Jack, Priokra en Kachong-broe genoemd: het eerste is waarschijnlijk eene eenigzins veranderde uitspraak van $\boldsymbol{P}$ rioekh-kar, wclk Prioekh een' pot om rijst te koken aanduidt, terwijl het woord $\boldsymbol{K a r}$, in de Maleische schriften voorkomende, aap beteekent, en bij gevolg Priokra door apenrijstpot vertaald zou kunnen worden. De Maleijers van het Menangkarbausche gedeelte van Sumatra noemen haar Taboeng-broe, hetgeen, daar zij het woord Taboeng voor een vat en vooral voor de holle leden van het bamboes, welk ter bewaring van vocht geschikt is, gebruiken, en met dat van Broe of Baroe, den in de benedenlanden niet zeldzamen Innuus nemestrinus bestempclen, apen-beker betcekent.

Omtrent den oorsprong van deze verschillende, op cenc zelfde zaak doelende benamingen, navorschende, is mij nu hetzelfde medegedeeld als aan Rumphius anderhalve ceuw vroeger, dat namelijk de apen eene bijzondere neiging zouden hebben om het vocht te drinken, hetwelk in deze bckers vervat is. Hoewel ik nu zulks nimmer van, in het wild loopende apen hcb waargenomen, kan ik echter 
de waarheid dezer mededeeling, ten opzigte van de meer tamme, in gevangensehap levende apen, bevestigen. Volgens Rumphius heet de Nepenthes aan Sumatra's oostkust Gada-gada ( $\left.{ }^{\star}\right)$, hetwelk als Maleiseh woord, windwijzer, en als Hindoeseh, knods beteekent. Dezelfde sehrijver verhaalt ons, dat zij op Leytimor Nitu-aläa, duivels-potjes, waarvan Gindi-Setang eene Maleisehe vertaling is, genoemd wordt, en dat haar Ambonsehe naam Lobe-leyposso of Aytiba, sehepperskruid wil zeggen. Op Sumatra en Borneo was deze soort bij de inlanders alleen door den zonderlingen vorm der bladen bekend. In de Molukken boezemde zij den inboorlingen niet alleen hierdoor, maar ook door hare geneeskraehten, belang in. Zij sehreven aan dezelve ook het vermogen om regen voort te brengen en andere gewigtige eigensehappen toe $(\dagger)$.

\section{NEPENTIIES GYMNAMPHORA. RwDT.}

N. phyllodiis subsessilibus, ascidiis radicalibus ovoïdeis, caulinis tubulosis basi vcntricosis, inflorcscentià fusco-sericeâ, pedunculis uni- vel bifloris.

Nepenthes melamphora, Rwdt., Catalog. Hort. Bogoreusis; N. Gymnamphora, Rwdt. ct Necs, Annalcs des Sciences naturellcs, III. p. 365.

De wortels dezer soort nemen zelden hunnen oorsprong uit eenen houtigen knol, maar hebben veeltijds van het begin af aan eene gelijke dikte, zijn onregelmatig rolrond, met eene menigte knoestjes, waaruit, met kleine zwarte vezeltjes voorziene worteltjes ontspruilen, zwart gekleurd, zeer houtig, in den wortelstok overgaande. Uit dezen wortelstok ontwikkelen zieh veelal verseheidene stengen, van welke gewoonlijk sleehts ééne tot vruehtdragende plant uitgroeit. Bij de gemelde minder ontwikkelde planten, is de steng geheel door de digt bij elkander geplaatste bladseheeden omgeven. Deze omvatten, bij haar ontstaan, ongeveer twee derden van de steng, blijven, na de verdrooging en afvalling van het overige meer vrije gedeelte, op de steng terug, en vormen dan rondom dezelve eene losse, eenigzins kurkaardige bekleeding, welke later van beneden af aan loslaat. De knoppen eindigen in een lieht bruin behaard, aan het einde eenigzins verdikt, of in een omgebogen steeltje, dat een driekant, puntig knodsje draagt, en zijn meestal rolrond of eenigzins zaamgedrukt, met bruin behaarde kanten. Bij verdere ontwikkeling vertoonen zieh de jonge phyllodia met eene bijna gladde bovenvlakte en eene fijn behaarde ondervlakte, met door lange bruine haren bekleede middelnerven en omzoomde randen. De geheel ontwikkelde phyllodia zijn langwerpig-ovaal, aan de punt dikwerf ongelijk toegespitst, of aan weêrszijden van den steel met kleine ronde oortjes voorzien; zij omvalten met den voet ongeveer twee derden van de steng en hebben eene uitstekende middelnerf; aan zeer jonge planten zijn zij vliezig en aan oudere meer lederaehtig. De bekersteel, het vervolg van de middelnerf, is driekant met eene vlakke bovenzijde en de beide onderste gevoord, bruin behaard; soms meer dan eene palm lang, zonder kronkels; dikwerf aan het begin bij de bladuitbreiding vertikaal naar beneden gerigt en aan het uiteinde verdikt. In deze verdikking begint de holte van den beker. De beker is, in den jeugdigen staat,

$\left(^{*}\right)$ Welligt Gindi-gindi, het meervoud van waterkrnik.

(†) Zie Rumphius op genoemde plaats. 
digt bruin behaard, onregelmatig omgekeerd kegelvormig, met eene seheeve bovenzijde, waarvan de langste zijde in een puntje eindigt. Ouder, is hij rolrond, naar boven een weinig breeder, en aan den top seheef afgeknot met de kortste zijde naar de spil gerigt. De ontwikkelde bekers zijn onregelmatig eirond, met de opening, even beneden den top, naar de binnenzijde in eene uitgeronde bogt, ongeveer 7 duimen lang en van 3,5 duim middellijns, bruin behaard, met twee bladaardige, dikwerf zeer ontwikkelde kammen met in lange priemvormige tanden uitgesnedene randen. De ongeveer een' boog van $80^{\circ}$ beslaande, ovale opening der bekers, is door een' eenigzins brozen, geribden rand omgeven, van welken de buitenste omgeslagen zijde gaafrandig, en de binnenste seherp getand is. De nerven versehillen in haren loop niet van die der $\mathbf{N}$. ampullaria; zij gaan naar het hoogste gedeelte van den beker, en ontstaan òf uit den voet òf uit de kamnerven. De nervuur tussehen de beide kammen is soms netvormig, en kan als de vertakking van eene, versehillend gebogene middelnerf besehouwd worden. De binnenvlakte van den beker is in hare lengte door twee kleuren verdeeld, die door eene tamelijk. regelmatig loopende lijn geseheiden worden. In het langste gedeelte van den beker is deze seheidingslijn 3 duim, en in het kortste ongeveer één' duim van den rand verwijderd. Het boven deze lijn gelegen gedeelte is dof, als met eenen purperen dauw bedekt, en het naar den voet gelegene, blinkend lieht bruin, met eene menigte langwerpige, uitstekende, zwart-bruine kliertjes. Deze zijn voor een derde door eenen uitstekenden rand bedekt, en nemen naar den voet in getal af, maar in grootte toe. De steng der meer ontwikkelde planten is rolrond, glad, bij eene aanzienlijke verlenging gedeeltelijk bladerloos, met eenige verspreide, in groepen vereenigde en door korte stelen gedragene bladen versierd. De phyllodia dezer bladen zijn langwerpig, naar den voet versmald en aldaar de halve steng omvattende en met een smal, langs de zijden uitstekend randje, naar den top toegespitst, van boven glad, van onderen met eene verspreide, bruine, stervormige en aan de randen met eene digte beharing. Zij hebben de uit den voet en de middelnerf ontstaande nerven, die zieh naar den top weder vereenigen, door eene menigte kleine aderen verbonden, en verkrijgen hierdoor in de vliezige bladvlakte een onregelmatig mazig net. De stengbekers zijn meer verlengd dan de besehrevene wortelbekers, en in dezelve staat de lengte tot de breedte als 7 tot 2,5; op dezelve is een klein elsvormig aanhangsel beneden het deksel. Dit deksel is ovaal, van boven stomp, aan den voet een weinig uitgesneden, van buiten zeer fijn behaard, van binnen glad, en even boven den voet met eenige weinige, langwerpige kliertjes, vliezig, 2,5 duim breed, 1,5 duim lang, met eene menigte omgebogene, zelden tot den omtrek doorloopende aderen. Bij de bloeijende gewassen is de steng aan haar uiteinde somwijlen stomp-vierkant, glad, en in hare pas ontwikkelde deelen bruin behaard; hunne knoppen zijn alleen door eene meerdere verlenging van die der jongere gewassen onderseheiden; hunne phyllodia wijken, door eene meer lederaehtige zelfstandigheid, van de op de steng in groepen vereenigde af, en eindigen in naar de punt behaarde, vervolgens glad wordende, bekerdragende of klawiervormende stelen; de laatste loopen naar het einde verdikt uit en krullen zieh daar binnenwaarts; de bekerdragende hebben deze krullen meest in het midden van de, somwijlen tot 2,5 palmen uitgegroeide lengte, en buigen zieh dan naar beneden om in de bekers over te gaan. Deze zijn van eenen langwerpigen treehtervorm, 8,5 duimen lang, ongeveer 6 duim in omvang, met eene seherpe bogt, aan den voet minder behaard dan de bekers der jongere stengen. Zij bezitten eene met deze overeenkomende nervuur, en eenen even zoo gevormden rand om de ovale opening, maar de kammen zijn sleehts als een kleine rand aan dezelve aanwezig. 
Het aanhangsel beneden het deksel is soms in tweeën gespleten en bijna een duim lang. Het deksel is ovaal, met eenen afgeronden top, eenen hartvormig ingesneden voet, van buiten zeer fijn behaard, van binnen met talrijke, vooral in het midden zeer digt bij elkander geplaatste klieren, welke somwijlen 0,3 streep middellijn hebben, bedekt. De binnenvlakte van eenen 15 duim langen beker, had de scheidingslijn ongeveer 8 duim van den voet verwijderd, en de blinkende kliervlakle aldaar, door eenen met kleine stipjes voorzienen rand, van het dof purperkleurig gedeelte gescheiden. De bloeiwijze der mannelijke en vrourvelijke gewassen is vrij overeenstemmende, en bestaat uit in de oksels geplaatste, lang gesteelde bloemtrossen. Haar algemeene bloemsteel is in het naakte gedeelte zaamgedrukt, met ronde kanten, en in het bloemdragend, dat soms twee tot twee en eene halve palm lengte heeft, seberp vierkant en eenigzins behaard. De uit denzelven ontstaande bloemsteeltjes hebben eenen verbreeden, zaamgedrukten voet, zijn hooger meer rolrond, behaard en in tweeën verdeeld. De benedenste dragen somwijlen langwerpige, toegespitste sehutblaadjes; op de hoogere vertoonen deze zieh alleen als kleine puntjes, en op de meer naar den top der bloeiwijze geplaatsle, zijn ook deze sporen niet meer voorhanden. Op de bloeiwijze der vrouwelijke bloemen zijn echter alleen aan den voet twee- en hooger éénbloemige steelijes. De laatsten zijn tevens van het kleine, elsvormig eindigende sehutblaadje voorzien, hetwelk aan de tweebloemige veelal ontbreekt. De mannclijke bloemen hebben bijna kogelronde knoppen, waarin de vier paarsgewijze, tegen over elkander geplaatste deelen over elkander liggen, die welligt, ten gevolge van de ontwikkeling der stuifdraden-kolom, worden geopend. Deze bloembekleedsel-deelen zijn ovaal, stomp, langs den rand digt, bruin, van buiten verspreid behaard, van binnen met zeer kleine, alleen bij vergrooling zigtbare groefjes, vleezig, ongelijk in grootte, de builenste iets breeder dan de binnenste, welke 4 strepen lengte en 3 strepen breedte hebben. De helmdraden-kolom is vierkantig, met de eenigzins gevoorde vlakke zijden tegen over de bloemdeelen, aan den voet een weinig dikker en eenigzins behaard. De hierop geplaatste ronde, sehijfvormige knop wordt geheel van zestien langwerpige, door vergroeijing ongelijke en versehillend gebogene meelknopjes bedekt. De vrouwelijke bloemen hebben de knopjes eivormig en de bloemdeelen ovaal, min of meer puntig, aan den rand digt bruin en van buiten zwakker behaard, van binnen glad, 4 strepen lang en 2 strepen breed, en na de opening teruggeslagen. Het vruchtbeginsel is stomp-vierkantig, met de kanten over de bloemdeelen geplaatst, aan den voet rond, naar den top een weinig verdund, door den platgedrukten en met vier insnijdingen voorzienen stempel gekroond, en glanzend kastanje-bruin bebaard. Het is in vier hokken afgedeeld, en heeft eene menigte eitjes, van den voet tot op ongeveer het midden tegen de tussebenwanden geplaatst. De kapsels zijn langwerpig, van den voet naar het midden in dikte toenemende en vervolgens weder naar den top in omvang verminderende, stomp-vierkantig, met gevoorde zijden, houtig, blinkend bruin, zwak behaard, ongeveer 12 strepen lang en 4 breed: zij springen in vier, van binnen dof bruin gekleurde kleppen open. Ieder dezer kleppen draagt een gedeelte van den stempel, en langs het midden, in een vliezig plaatje, het over dezelve geplaatste gedeelte van het tussehenschot; op dit gedcelte zijn de talrijke, met het vrije einde naar boven gerigte, eenigzins zaamgedrukte, in het midden verdikte, naar de uiteinden elsvormig toeloopende, ongeveer 5 strepen lange zaadjes gehecht. Deze zaadjes verschillen, door hun buitenvlies, merenchymatisch celweefsel, binnenvlies en kiem, bijna niet van die der $\mathbf{N}$. ampullaria. 
Deze soort werd in 1817, door den Hoogleeraar Reinwardt, op Java gevonden, en in den, door den Hoogleeraar Blume uitgegeven Catalogus van den Kruidtuin van Buitenzorg, als N. melamphora bekend gemaakt. Deze naam, die met het donker purperkleurige van de bekers in verband stond, is later, bij de uitvoerige besehrijving, welke Nees van Esenbeck van deze plant gaf, in dien van N. gymnamphora veranderd. Hierdoor ontstond een naam, die bij alle soorten op de bekers der steng, maar vermoedelijk bij geene op die der wortelbladen toepasselijk is. Hij zoude dus door den eersten vervangen moeten worden, zoo wij de namen ehronologiseh besehouwen en de beteekenis raadplegen wilden. Daar beiden eehter aan den Hoogleeraar Reinwardt toegesehreven worden en de laatste naam, op de afbeelding en in de besehrijving van Nees, is aangenomen, doen wij geen afbreuk aan de eer der vinding, en vermijden wij alle verwarring, wanneer wij den door Nees algemeen bekend geworden naam behouden. Het gevoelen van Nees, dat deze soort de Nepenthes cristata van den Heer Brongniart zou wezen, komt mij onwaarschijnlijk voor, omdat de N. gymnamphora tot dusverre alleen op Java gevonden is, terwijl de N. eristata op Madagaskar en de Philippijnen zoude voorkomen. Deze standplaatsen doen mij vermoeden, dat $\mathbf{N}$. cristata op wortelbladen van de in deze oorden voorkomende soorten berusten kan.

Door de Heeren Reinwardt, Blume, Kuhl, van Hasselt en ook door ons, is deze soort in de bosschen der meeste gebergten van het westelijk deel van Java verzameld, en volgens eene mededeeling van den Heer Spanoghe, zoude zij ook in het gebergte van het oostelijker gelegen Pakalongan voorkomen. In de onderscheidene, door ons bezochte streken, begon deze plant op eene hoogte van 1000 tot 1200 ellen, en breidde zij zich tot op eene hoogte van 2000 ellen uit. Op deze plaatsen groeide zij met eene, door den aard der gronden gewijzigde ontwikkeling. Tegen besehaduwde rotsige wanden geplaatst, bleef zij klein, doeh in eenen vruehtbaren bodem geworteld, groeide zij tot eene lengte van 3 tot 4 ellen uit. De, in gunstige streken waargenomene gewvassen, hadden aan den voet der steng, op den bodem, talrijke donker purperkleurige bekervereenigingen, en langs dezelve hingen liehter gekleurde, trechtervormige bekers.

Bij de Maleijers wordt deze plant Daoen-gindi, blad-kannetje genaamd, terwijl haar door de Sundanezen de naam van $\boldsymbol{P a k o e - S o r o k - R a d j a , ~ h e t g e e n ~ k o n i n k l i j k e ~ b e k e r v a r e n ~ b e t e e k e n t , ~ g e g e v e n ~ w o r d t . ~}$

\section{NEPENTHES RAFFLESIANA. JАGK.}

N. phyllodiis longe petiolatis, ascidiis inferioribus globoso-ventricosis, caulinis infundibuliformibus, inflorescentiâ cinereofusco-tomentosâ, pedunculis uni- vel bifloris.

W. Jack in Hooker, Companion to the Botanical magazine, I. p. 271.

De steng en groeiwijze dezer soort zijn gelijk aan die der N. phyllamphora. De knoppen, de randen der pas ontwikkelde bladen, de jonge stelen en bekers zijn alle grijs behaard. De phyllodia der jonge stengen hebben eene aanzienlijke lengte. Hun steel omvat den halven omtrek van de steng en is met 
eenen smallen bladrand bezoomd. Hunne vlakke uitbreiding is langwerpig, naar de beide einden zcer toegespitst, gaafrandig, aan weêrszijden bijna glad, en hecft, behalve de zeer ontwikkelde middelnerf, drie of vier met den rand evenwijdig loopende, van den voet naar den top gaande zijnerven. De beker- stecl is van onderen half rolrond, van boven gevoord, glad, somwijlen vijf palmen lang, buigt zich even boven den oorsprong naar bencden, en daalt dan loodregt tot aan zijne vereeniging of uitlooping in den beker. Deze heeft eenen onregelmatig ronden vorm, van welken de binnenzijde vlak en de buitenzijde buikig is. De eerstgemelde vlakte wordt door twee zeer ontwikkelde bladvormige, dicp gctande of ingesnedene kammen van het ronde gedeelte gescheiden. De opening van deze bekers is ovaal, eenigzins gebogen en door eenen zcer brecden rand bcpaald. Van buiten zijn deze bekers licht groen, naar den voet somwijlen met purperen vlekken; van binnen hebben zij twee derden van het benedenste gedeelte blinkend bruin, met talrijke kliergroefjes, en het bovenste gedeelte dof purperkleurig. Het aanhangsel beneden het deksel is ongedeeld, somwijlen aan het einde gespleten, lijnvormig en glad. Het deksel is ovaal, aan den top stomp, aan den voet cen weinig hartvormig ingesneden, met eenen min of meer behaarden rand, van buiten fijn behaard, van binnen glad met cirkelronde of langwerpige kliertjes, dikwerf rijkelijk met purperen vlekjes voorzien. Een tamclijk ontwikkeld blad had de deelen van de volgende grootte: steel van het phyllodium 7"; phyllodium 30" lang en 5" breed; bekersteel 50"; beker $10^{\prime \prime}$ lang, aan den voet met $15^{\prime \prime}$ en bij den mond met $10^{\prime \prime}$ omtrek; het deksel $6^{\prime \prime}$ lang en $4^{\prime \prime}$ breed. De vorm van de phyllodia der oudere en reeds bloemdragende stengen verschilt alleen door eene meerdere brecdte van dien der jongere stengen: maar die der bekers wijkt geheel van dien der jongere bladen af. Deze hebben eenen langwerpigen trechtervorm, bij eene lengte van 22" eenen omtrek van 12", en op de plaats van de vermelde bladaardige kammen, uitstekende randen, en de geheele binnenvlakte glanzend en met kleinc groefjes bedekt. Hun deksel verschilt alleen door de meer cirkelronde gedaante; voor het overige heeft het, even als de omzoomende, geribde brcede rand van de opening, al de kenmerken van die der jongeren: terwijl bij den bekersteel alleen cene nog meerdere verlenging en eenige kronkelingen bij de nederbuiging worden waargenomen. De uit de oksels, of door abortie eindelings voortkomende bloeiwijze, is trosvormig, min of meer grijs of grijs-bruin behaard, en heeft den algemeenen blocmsteel aan het benedenste gedeelte zaamgedrukt, stomp-kantig, is aan het bloemdragende somwijlen vier palmen lang, gedecltclijk zaamgedrukt, scherp-kantig, met eene menigte één-, zelden tweeblocmige steeltjes. De vorm dezer is gelijk aan dien der $\mathbf{N}$. phyllamphora en anderen. De mannelijke bloemen hebben de deelen ovaal-rond, stomp, van buiten digt grijs bchaard en van binnen glad met kleine grocfjes, $7^{\prime \prime \prime}$ lang en $5^{\prime \prime \prime}$ breed: de stuifdraden-kolom is glad, stomp-vierkantig en in eenen bijna kogelronden knop, om welken veertien tot zestien onregelmatig gebogene helmknopjes gehecht zijn, eindigende. De blociwijze der vrouwelijke planten is gelijk aan die der mannelijke. De bloemdeelen verschillen alleen door cene meerdere lengte, en hebben, bij eene meer ovale gedaante, $6^{\prime \prime \prime}$ lengte en 4,5"' breedte. Het vruchtbeginsel wordt door een kort, rolrond steeltje gedragen, en is langwerpig, naar den voet en top in omvang afnemende, stomp-vierkantig, licht bruin behaard, en door eenen vicrhoekigen, platgedrukten, van vier voren voorzienen stempel gekroond. Het is in vier hokjes afgcdeeld. De wanden zijn tot op ongeveer de helft hunner lengte met citjes bedckt. Rijpe vruchten heb ik niet verzameld. 
Van de besehrevene soorten wijkt de $\mathbf{N}$. Rafflesiana, door de aanzienlijke verlenging van de bladdeelen, vooral van den steel der phyllodia, af, en van verscheidene anderen verschilt zij nog daarenboven door den ronden vorm der bekers van de jonge planten, of door den treehtervorm van de stengbekers. Door den eersten heeft zij eenige overeenkomst met de $\mathbf{N}$. gymnamphora, en door den laatsten zoude zij met N. Boschiana kunnen vergeleken worden. Daarenboven hceft deze plant eene zoo groote verwantsehap met een door den Hoogleeraar Reinwardt, in 1821 op den berg Rumegan, ter noord-oostkuste van Celebes ontdekt en door hem Nepenthes maxima genaamd $\left(^{\star}\right)$ gewas, dat ik er toe overhel, om dezen op Celebes gevondenen vorm als eene verseheidenheid van de $\mathbb{N}$. Rafflesiana te beschouwen. Evenwel waag ik het niet, omtrent deze gelijkheid eenc zekere uitspraak te doen, omdat mij de bladen van de jongere stengen der $\mathbf{N}$. maxima en de rijpe vruchten van de $\mathbf{N}$. Rafflesiana ontbreken. De oudere en bloeijende takken hebben overeenkomst in de stengen, knoppen, phyllodia, in den vorm en in de inwendige oppervlakte van de bekers, in de bloeiwijze en in de bloemen, maar daarentegen eenig versehil in de gedaante van de deksels: deze zijn bij $\mathbb{N}$. maxima ten naastebij eirond, naar den top smaller, en aan den voet hartvormig uitgesneden, doeh bij $\mathbf{N}$. Rafflesiana meer eirkelrond, naar den top zeer weinig in breedte afnemende en aan den voet met eene hartvormige insnede.

De N. Rafflesiana werd, blijkens eenen brief van W. Jack, gedagteekend Singapoera 20 junij 1820 (†), op dit eiland ontdekt, later door dezen ijverigen natuuronderzoeker ook op Bintang ( $($ ) gevonden, en is door ons op Sumatra's westkust verzameld. Zij groeide daar, even als op Singapoera, in gezelsehap van $\mathbf{N}$. ampullaria, en versierde de moerassige bossehen der omstreken van Indrapoera.

Omtrent de plaats, waar en hoe zij voorkomt, heb ik, gedurende ons verblijf aldaar in 1835, het volgende opgeteekend: ) De rivieren Indrapoera en Salaut, op welke wij dezer dagen talrijke togtjes maakten, begrenzen ten noorden en ten zuid-westen de streek, waar de, in Sumatra's geschiedenis vroeger zoo beroemde en nu zoo onbeduidende, hoofdplaats van het rijk van Indrapoera gelegen is. Beiden hebben zij haren oorsprong in de groote bergketen, die Sumatra in eene westelijke en oostelijke helft verdeclt. Van daar stroomt de Indrapoera met eenen bijna regten loop, de Salaut in eene meer kronkelende rigting naar het vereenigingspunt. De eerste schijnt nog haren vroegeren loop behouden te hebben; de Salaut daarentegen heeft, door de verstopping van de meer zuidelijk gelegene monding, eene nieuwe rigting genomen, en stroomt, door de haar gelegde hinderpalen wederhouden, aan het einde van haren dalweg meer noordelijk, tussehen de nieuw gevormde en altijd vermeerderende alluviaal-formatie door. Terwijl de Indrapoera haren dalweg, door den snellen stroom, dagelijks verbreedt, versmalt de Salaut den haren, en vermeerdert zij hare oevers met kleine verhoogingen, ten koste van de hooger gelegene oorden. Door deze kleine wallen wordt een lager terrein afgesloten, in hetwelk de beide Nepenthessoorten, in gezelsehap van Sapindaeeae, Malvaeeae, Myrtaeeae, Slingergewassen, Rottang en andere palmen en varen groeiden.

(*) Nees, Annales des Sciences naturelles, III.

(t) Hooker, Companion to the Botanical magazine, I. p. 131.

(S) Hetzelfde werk, bl. 271. 
) De Sapindaceae worden hier vertegenwoordigd door de breed gekroonde, met nederhangend loof voorziene Irina, wier jonge bladen door cene purper-roode kleur van het donkere groen der ouderen onderseheiden zijn; de Malvavorm, door de kortstammige, rondkruinige Paritia similia, op welke de groote, aan de onderzijde donzige bladen, met de heerlijke goud-gele bloemen afwisselen, en ook door de onregelmatig, piramidaal groeijende Pterosperma Blumeana, wier omtrek door fraaije, sneeuw-witte, lelievormige bloemen, of hoekige, nederhangende vruchten versierd zijn. Voor den Mirtenvorm treden op, de Myrtus obtusissima en M. densiflora, met door een digt, glanzend groen loof gevormde kroonen; de door het gebladerte aan hem verwante, maar door eigenaardige eigenschappen afwijkende Gluta Runghas, wier ontwikkelde en ver uitschietende takken een gedeelte der rivier overschaduwen, en de door bladvorm aan deze, en door de aanzienlijke gele bloemen aan den Malvavorm herinnerende, fraaije Capelliaboomen.

„) Voor de palmen treffen wij hier heerlijke vormen aan in den Pinang renda (Cyrtostachys $\mathbb{B} 1$. .), welke aan zijne, in groepen vereenigde, regt opgaande, van boven roodkleurige stammen, op gelijke wijze ontwikkelde en gekleurde bladstelen en een gevederd loof kenbaar is; in den Nibong. (Oncosperma Bl. of Areca tegularia W. J.), welke zich onderscheidt door de gedoornde stengen en een meer hangend en donker groen gekleurd loof. Van de tot deze familie behoorende, maar door de slingerende groeiwijze zoo onderseheidene groep des Rottangs, vonden wij den, door zijne onbedekte bloemen gekenmerkten Calamus, ook den Daemonorops, die dezelve in scheeden besloten heeft, en enkele, door meer ontwikkeld loof en door onder schubjes geplaatste bloemen gekenschetste Plectocomia. Bij deze overschoone gewassen bleven de varen niet aehterlijk. Door verscheidenheid van grootte en de verdeeling van het loof, werd het gemis der bloemen bij dezen vergoed. Het waren kortstammige Gymnosphaera, met naar boven gerigt loof, of groepsgewijze vereenigde Diplazia, met zeer verdeelde bladvormen, of op den grond en tegen de boomstammen groeijende Aspidia en Polypodia, met in kleine lobjes gesnedene bladen, of tusschen de boomen slingerende Lygodia, welke, door een licht groen, eenvoudig gevederd loof, met andere slingerplanten de ruimte tusschen de boomen, door schoone groene wanden opvulden. De slingergewassen hadden zeer in het oogvallende afwisselingen. De Dissochaeta en Marrumia waren uitstekend door hare talrijke, meestal rozenkleurige, dikwerf rozenvormige bloemen; de Gynocephalum door de grootte en den glans der bladen; de Cissus door de trosvormig vereenigde, naar druiven gelijkende, zacht roode vruchten, en de Nepenthes door den vorm en de kleur der groepsgewijze op de naakte stengen verecnigde bekers. Deze laatsten ontwikkelden zich hier met eene nimmer door mij geziene pracht. Hare met purper gevlekte, groene, bijna ronde bekers, bedekten de wortelstoelen der palmen; hare stengen, met deze bekers, als zoo vele bonte bloemen versierd, woelden hare ranken door de bekerstelen, welke zich om de takken der hen omringende gewassen slingerden, en in de hoogte ondersteund werden, terwijl hare uiteinden zich in de soms 20 el hooge, talrijke kroonen der Capellia, of in de lagere, onverdeelde kroonen der Renda- en Nibong-palmen verborgen." 
VII. INEPENTHES AMPULLARIA. W. JAGK.

N. phyllodiis petiolatis integerrimis, ascidiis radicalibus et caulinis ampullaceis, inflorescentiâ paniculatâ fusco-tomentosà ; pedunculis corymbiferis.

W. Jack in Hooker, Companion to the Botanical magazine, I. p. 271.

De wortel dezer soort is rolrond, houtig, donker bruin, van eene menigte vezelige worteltjes voorzien. Uit denzelven ontspruiten één, somwijlen verscheidene wortelstokken, welke mede talrijke fijne worteltjes bezitten. Uit deze ontwikkelen zieh veelal eene hoofdsteng en enkele kleine stengen. De jonge stengen zijn door de digt bij elkander geplaatste bladseheeden geheel bedekt; de oudere grootendeels naakt, alleen naar het einde bebladerd. Deze laatste zijn meestal enkelvoudig, zeer zelden met zij-takken voorzien, rolrond, bijna glad of met enkele kleine, verspreide, stervormige haartjes, houtig, donker bruin en zelden dikker dan eene ganzensehaeht. De jongere stengen, en in het algemeen de pas ontwikkelde deelen, hebben, behalve deze stervormige, nog eene spoedig afvallende, priemvormige haarbedekking. De bladen der jonge stengen hebben den beker aanzienlijk, maar het phyllodium weinig ontwikkeld. Dit laatste omvat met den voet bijna den geheelen omvang der steng, is langwerpig, naar den top toegespitst, van boven glad, van onderen digt met bruine haren bedekt. De bekersteel is stomp-driekantig, met eene vlakke zijde naar boven, bruin behaard. De bekers zijn onregelmatig eivormig, met eene kleine vlakke zijde naar de spil gerigt, en met het ronde van dezelve afgekeerd: de eerste is begrensd en van het ronde geseheiden door twee bladaardige, onregelmatig ingesnedene en priemvormig getande kammen. $\mathrm{Zij}$ hebben op eene lieht of donkerder groene hoofdkleur cene menigte purperen vlekken, en bij hunne eerste versehijning eene zeer digte en, bij meerdere uitgroeijing, eene zeer verspreide, bruine beharing. De nerven hebben eene rigting, welke met die der vorige soorten overeenstemt, en de rand der ovale opening is sterk geribd en zoowel naar de buiten-als naar de binnenzijde omgebogen. Hare binnenzijde is glanzend en met kleine cirkelronde klierljes bedekt. Het deksel der bekers is langwerpig-ovaal, aan de beide einden stomp, gaafrandig, van buiten met kleine, stervormige haartjes, van binnen met kleine, ronde of ovale kliertjes, met purperen vlekjes op eene groene hoofdkleur, zeer sehoon geaderd; $2^{\prime \prime}$ lang en $5^{\prime \prime \prime}$ breed. De bladen der op de steng verspreide bladgroepen hebben veel overeenkomst met de reeds besehrevene; eehter zijn de phyllodia reeds meer uitgegroeid, en hebben deze eene langwerpige, naar de beide einden versmallende gedaante. De bekersteel en beker versehillen alleen door eene aanzienlijker grootte van de reeds vermelden. Het deksel wijkt in gedaante af, en is omgekeerd eivormig of langwerpig-ovaal. De bladen, aan welke het phyllodium zieh, ten koste van de bekers, heeft uitgebreid, zijn langiverpig-ovaal, naar den voet versmallend, naar den top toegespitst of versmallend en den bekersteel met een smal bladrandje bezoomende, van boven glad, van onderen, vooral aan den rand en bij de middelnerf, behaard; zij hebben de lengte tot de breedte als 4 tot 1. Behalve de sterk ontwikkelde middelnerf bezitten zij, aan weêrszijde van dezelve, twee of drie hoofdnerven, die van den voet naar den top loopen, de rigting van den rand volgen, en door talrijke dwarse aderen, die uit de middelnerf ontstaan, verbonden of gekruist worden. De bij andere bladen bekerdragende steel eindigt hier in een rolrond, toegespitst knodsje. In de knoppen omvatten deze bladen elkander, even als bij de andere soorten, maar zij hebben het eigenaardige, dat zij bij hunne ontrolling en ontwikkeling eene grijze, stervormige beharing op de binnenvlakte vertoonen, die kort na 
de uitbreiding afvalt. De naar de einden der steng geplaatste bladen hebben de phyllodia een weinig breeder, naar den top iets stomper, en den bekersteel, benevens den beker, gelijkvormig of alleen door eene meerdere verlenging afwijkende. De in de nabijheid der bloemen geplaatste bladen hebben zelden bekers. Hunne phyllodia wijken niet van de besehrevene af, en de bekerstelen vergroeijen hier in naar het einde verdikte en omgekrulde klawieren. De mannelijke en vrouwelijke bloeitrossen zijn in of boven de oksels der bladen geplaatst en bestaan uit, ééne of twee palmen lange, door bruine haren bekleede, trosvormige pluimen. Derzelver algemeene bloemsteel is aan den voet platgedrukt, en hooger aan het bloemdragend gedeelte kantig en gevoord. De uit denzelven ontspruitende steeltjes zijn aan den voet een weinig zaamgedrukt, en boven dezen bijna rolrond. Zij dragen 3 tot 7 bloemen als een bijseherm geplaatst, en even boven den voet en beneden de verdeeling een lijnvormig-langwerpig, stomp of zeer toegespitst, teruggebogen sehutblaadje. Op de benedenste is dit blaadje het meeste ontwikkeld; van daar neemt het op de hooger geplaatste bloemsteeltjes in grootte af; op de bovenste is het in het geheel niet aanwezig. De knoppen der mannelijke bloemen hebben den vorm en in hunne deelen de ligging van de vorige soorten. De bloemdeelen zijn, na de opening der bloem, min of meer teruggebogen, van buiten bruin behaard, van binnen glad, met eene menigte kleine groefjes, tamelijk dik; de grootste derzelve zijn bijna eirkelrond, $4^{\prime \prime \prime}$ breed en $5^{\prime \prime \prime}$ lang, en de kleinste ovaal, $3^{\prime \prime \prime}$ breed en $5^{\prime \prime \prime}$ lang. De helmdraden-kolom is aan den voet vierkantig, hooger rolrond en eindigt in een sehijfvormig knopje. Rondom dit zijn 12 tot 16 lijnvormige, soms zeer gebogene helmknopjes geplaatst. De vrouwelijke bloemen hebben eivormige knoppen en meer langwerpige bloemdeelen. Het vruehtbeginsel is langwerpig, naar den voet in een kort rolrond steeltje uitloopende, en naar den top dunner wordende, stomp-vierkantig, met gevoorde zijden, bruin behaard, en door den vierhoekigen of soms vierlobbigen stempel gekroond. Vier tussehensehotten verdeelen het in even zoo vele hokjes, en dragen, vooral in het benedenste gedeelte, eene talrijke menigte eitjes. De kapsels zijn langwerpig, in het midden buikvormig, naar de beide einden verdund, stomp-vierkantig, aan de zijden gevoord, houtig, bruin behaard, na de afvalling der haren blinkend bruin, $3^{\prime \prime}$ lang en 5"' breed. Zij springen op dezelfde wijze als de vorige soorten open. Hunne tussehensehotten zijn tot even beneden het midden met naar boven gerigte zaden bedekt. De zaadjes zijn regtopstaand, lijnvormig, naar de beide einden elsvormig uitloopende, 22" lang, waarvan het kerngedeelte $2^{\prime \prime \prime}$ beslaat, een weinig ruw. Het buitenzaadvlies bestaat bij deze soort, vermoedelijk ook wel bij de anderen, volgens mijne latere waarnemingen, uit een fijn doorsehijnend vliesje, en onder hetzelve uit langwerpige eellen. Het bedekt een zeer los, vooral om de kern ontwikkeld, fijn eelweefsel. Door dit en langs het buitenzaadvlies stijgt de raphé naar boven, welke boven de kern ombuigt en zieh vervolgens in de binnenste zaadhuid verliest. Bij deze vereeniging is het binnenvlies een weinig dikker. Het bestaat uit een zeer fijn, door eellen gevormd vlies, en bedekt een ander, bij sterke vergrooting zigtbaar, geheel effen, doorsehijnend vliesje, dat de kern omgeeft. De kern is wit, rolrond, aan de beide einden stomp, en bestaat uit een gering eiwit en uit de kiem. De laatste heeft den vorm van de kern, en wordt door bijna even groote zaadlobben en wortel zamengesteld. 
Deze, door W. Jaek in de wouden van Singapoera en Bintang ontdekte soort, werd door ons, in 1835, in de moerassige bossehen van Sumatra's westkust gevonden. Hier bereikte zij eene aanzienlijke grootte, en verspreidde zij hare, door de kronkelende klawieren der bladen ondersteunde stengen, tot in de kruinen der groote, gele bloemen dragende Capelliaboomen, of in de kroonen der Nibong- (Areea tegularia W. J., Oneosperma Bl.) en Renda- (Cyrtostaehys) palmen. Zoowel aan den voet als langs de bladerlooze steng, waren of hingen eene menigte groepen van met purperen vlekken voorziene, eivormige bekers. Zij versierden de steng en droegen tevens het hunne bij, om de voeding der snelgroeijende planten te vermeerderen. Deze laatste vooronderstelling berust op de proef, dat planten, wier stengen door mij waren afgesneden, maar wier bekers ik met water had gevuld, gedurende eenige dagen niet verwelkten, en dat ik het koper eener in een paar bekers geworpen oplossing, later in den steel terugvond. Hierdoor is de opnemende werking van de binnenvlakte der bekers genoegzaam bewezen. Wordt hierbij nu in aanmerking genomen, dat door de verrotting der in het voeht der bekers verdronkene insekten, eene voor den plantengroei zeer voedzame vloeistof wordt gevormd, dan kan deze stelling welligt tot waarheid worden.

N. ampullaria wijkt door hare bloeiwijze van de vroeger besehrevene soorten af, maar is door deze aan $\mathbf{N}$. destillatoria en $\mathbf{N}$. Madagaseariensis verwant, zijnde zij eehter gemakkelijk, door den vorm der bekers, van deze beiden te onderscheiden.

\section{NEPENTHES MADAGASGARIENSIS. Porret.}

N. phyllodiis petiolatis, ascidiis caulinis infundibuliformibus, inflorescentiâ fusco-tomentosâ paniculatâ, pedunculis corymbiferis multifloris.

Ncpenthes Madagascaricnsis Poir., Encyclopedie Botanique, IV. p. 459; Willdenow, Spccies plantarum, IV. p. 873; Brongniart, Annales des Scicnces naturclles, I. p. 45; Amramatico Flacourt, His toire de Madagascar, p. 150 , Tab. 43.

Deze soort, welke zeer naauwkeurig door den Heer Brongniart besehreven is, kennen wij tot dus verre alleen van het eiland Madagaskar. Zij wordt aldaar door de inboorlingen $\boldsymbol{P}_{\text {oenga genoemd. Dit woord }}$ herinnert aan het Maleische woord Boenga, hetwelk bloem beteekent, en doet de waarsehijnlijkheid ontstaan, dat de Madagaskaren, even als de Maleijers, deze bekers voor bloemen houden. 


\section{NEPENTHES DESTILLATORIA. LINr.}

N. phyllodiis petiolatis, ascidiis radicalibus ventricoso-tubulosis, caulinis infundibuliformibus, infiorescentiâ cinereosericeâ, pedunculis corymbifcris paucifloris.

Limn., Hortus Cliffortianus, p. 431; Linn., Species plantarum, N. 1354; Linn., Flora Zeylanica, p. 321; Willdcnow, Species plantarum, IV. p. 873; Nepenthes Indica Lamarck ct Poiret, Encyclopedie Botaniquc, IV. p. 458; Brongniart, Annalcs des Sciences naturelles. I. p. 43; Bandoera Burman, Thesaurus Zeylanicus, p. 42, Tab. 17; Mermann, Museum Zcylanicum, p. 16.

Deze soort sehijnt zieh alleen tot het eiland Ceylon te bepalen. Zij is door de bloeivijze met de beide voorgaande verwant, maar van beide, door de haar eigene grijze beharing, en daarenboven van de $\mathbf{N}$. ampullaria door den vorm der bekers, en van $\mathbf{N}$. Madagaseariensis door de minder rijke bloemschermen onderseheiden.

Het als landnaam voor deze plant opgegeven woord Bandoera, is niet bij uitsluiting op haar toepasselijk, wordende hetzelve voor alle slingerplanten gebezigd. Het Sanskrietsehe Bandhoera beteekent, als bijvoegelijk woord gebruikt: gebogen, gewonden; terwijl het, als cigennaam gebezigd, de Pentapetes phoenieca aanduidt. 


\section{VERKLARING DER PLATEN.}

\section{NEPENTHES GRACILIS. Tab. 1 et 4.}

Fig. 1. Mannelijke bloemknop. 2. Doorsnede van denzelven. 3. Geopende mannelijke bloem. 4. Helmdraden-kolom van boven. 5. Van de zijden. 6. Doorgesneden. 7, 8, 9 . Stuifmeel. 10. Dwarse doorsnede van de helmknopjes. 11. Dezelfde van één helmknopje. 12. Vrouwelijke bloemknop. 13. Geopende vrouwelijke bloem. 14. Regte doorsnede. 15. Dwarse doorsnede van het vruchtbeginsel. $16,17,18,19,20,21$. Eitjes van versehillenden ouderdonı. 22, 23, 24. Kapsels. 25. Driekleppig kapsel. 26. Vergroot zaad. 27, 28. Zaad, dat van het buitenbekleedsel ontdaan is. 29. Dwarse doorsnedevan het zaad. 30. Zaad, waar het losse eelweefsel uit weggenomen is, ten einde het voedingsvat (Raphé) en de kern te doen zien. 31. Kernhuid of Tegmen, waaruit de kern geligt is. 32. Buitenste zaadhuid (Testa). 33. Binnenste zaadhuid (Tegmen). 34, 35. Geheele kiem. 36. Kiem, van welke eene zaadlob is weggenomen. 37. Dwarse doorsnede van eene vrouwelijke bloem. 38. Dwarse doorsnede eener bloem van Nepenthes ampullaria, Jack.

NEPENTHES BOSCHIANA. Tab. 2 et 4.

39. Mannelijke bloem. 40. Doorsnede van een vruehtbeginsel, in welke verseheidene vleezige ligehamen tussehen de eitjes liggen. 41, 42. Kapsel. 43. Kapsel, van hetwelk eene klep is weggenomen. 44. Eene klep van ter zijde gezien, voor de aanheehtingspunten. 45,46 . Het zaad. 47. Een eitje, waarin de kernzak nog regtstandig is. 48, 49. Zaden met onvolkomen ontwikkelde kiemen. 50. Het zaad, van de buitenhuid beroofd, en dus de kern, de raphé en het losse eelweefsel zig tbaar. 51. Doorsnede van het zaad, waarbij de cene zaadlob geheel verloren is gegaan. 52. Geheele kiem. 53. Met eene zaadlob voorziene kiem. 54. Zeer vergroote, dwarse snede uit eene klep, op welke nog sporen van zaden aanwezig zijn.

NEPENTHES GYMNAMPHORA. Tab. 3 et 4 .

55. Mannelijke bloemknop enzv. 56, 57. Geopende mannelijke bloemen. 58. Helmknopjes-kolom. 59. Vrouwelijke bloemknop. 60. Geopende vrouwelijke bloemen. 61. Doorsnede van een vruehtbeginsel. 62,63 . Kapsels. 64. Doorgesneden kapsel. 65. Zaad, van hetwelk een gedeelte der buitenhuid en van het eelweefsel is weggenomen. 66. Gedeelte van de buitenhuid met de raphé en de kern. 67. Buitenhuid, zeer vergroot. 68. De kern ontbloot. 69. De kiem met ééne zaadlob. 70. Met twee zaadlobben.

NEPENTHES AMPULLARIA. Tab. 13.

NEPENTIIES BONGSO. Tab. 14.
NEPENTHES PHYLLAVPHORA. Tab. 15 et 4. Ontikininga volgens $D^{\text {r. Grahaim. }}$

71. Kiemend zaad. 72. Ontkiemd zaad met de beide zaadlobben. 73. Jong plantje met den eersten spilvormigen wortel en het eerste bekertje. 74. Verder ontwikkeld plantje met drie bekertjes. 75. Jong plantje, aan lietwelk vijf blaadjes zijn, en het vierde en vijfde reeds de vlakke bladuitbreiding of phyllodia onder de bekertjes hebben.

\section{ZAMENSTELLING VAN DE TOT DEN GROEI BEHOORENDE DEELEN.}

\section{Tab. 20, 21 en 22}

In de volgende figuren beteekenen: Cu. huidje (cuticula), E. opperhuid (epidermis), C. schors (cortex), L. bast (liber), Low (lignum), F. V. vaatbundel (fascioulus vasorum) M. meror (medulla), R. M. p. ogroote merogstralen (radii medullares primarii), R. II. s. kleine merogstralen (radii medullares secundarii), v. s. spiraalvaten (vasa spiralia), f.s. spiraaldraad (fibra spiralis), v. p. gestipte vaten (vasa punctala), f. vezels (fibrae), st. stoma, c. eellen (cellulae), v.s. p. eigene sappenvoerende vaatjes (vasa succi proprii).

NEPENTHES AVPULLARIA.

Fig. 1. In de lengte doorgesneden knop.

2. Dwarse snede uit de steng bij den knop.

3. In de lengte doorgesneden stukje van het voorgaande, zeer vergroot.

4, 5. Uit den houtbundel bij het merg genomen stukje, waaraan de gestipte vaten nog als eenvoudige, langwerpige cellen met eenige indrukken voorkomen.

6. Dwarse snede uit het bovenste bladdragend gedeel te der steng, een weinig vergroot.

7. Dwarse snede uit hetzelfde gedeelte, zeer vergroot.

8. Stukje uit den bast van het voorgaande.

9. Overlangsehe snede uit lietzelfde gedeelte der steng.

10-13. Zeer vergroote gedeelten van liel voorgaande.

14. Afgezonderd lid van een gestipt vat

15. Gedeelte van eene gesneden vezel, zeer vergroot.

16. Spiraalvat uit het merg, waarin aan het einde cene onregelmatige zamenlegging van draden zigtbaar is.

17. Spiraalvat uit het merg, waarvan de doorsnede het omgevende vlies, benevens de holte, en aan het einde een dik knodsje, alleen uit stof bestaande, zigtbaar maakt.

18. Spiraalvat, dat in een knodsje eindigt.

19. Dwarse snede van het bladerloos of ouder gedeelte der steng.

20. Gerleelte van het voorgaande, zeer vergroot,

21. Overlangsehe snede van hetzelfde gedeelte.

22. Vergroote eellen uit de sehorslaag. 
23. Vaten uit het eambium, waarin de vorming van den spiraaldraad eerst begint.

24. Vaten uit een meer ontwikkeld eambiumgedeelte met de vaatjes, die de eigenaardige sappen voeren door en over de spiraalvaten.

25. Lid van een gestipt vat, over hetwelk bovengenoemde vaatjes loopen.

26. Een lid van een gestipt vat, hetwelk gedeeltelijk geseheurd is, en de sappenvoerende vaatjes van binnen heeft.

27. Horizontale snede van cen gestipt vat met rezels, en eene eel, uit de nabijheid van het merg, dat door de eellen van de kleine mergstralen, en door eenige platte draden, vermoedelijk afgewondene spiraaldraden, omgeren wordt.

28. Dwarse snede van den wortel, een weinig vergroot.

29. Eene diergelijke snede, zeer vergroot.

30. Lengte-snede uit den wortel, zeer vergroot.

31. Een stukje uit het begin van eene wortelverdeeling om den overgang der vaten te doen zien, zeer vergroot.

32. Een stukje uit den wortel, zeer vergroot.

33. Sehor's van den wortel, zeer vergroot.

34. Lengte-snede uit een klein worteltje, zeer vergroot.

35. Vezels uit den wortel, zeer vergroot.

36. Epidermis van een wortelvezeltje met een haar: beiden zijn bruin gekleurd.

37. Dwarse snede uit den wortel, om de dikte der vezels te toonen: $a$. binnenste; $b$. buitenste.

38. Dwarse snede uit de steng bij de uitgroeijing van eene zij-spruit, vergroot.

39. Overlangsehe snede op dezelfde plaats.

40. Cellen van het merg uit de bogt, zeer vergroot.

41. Dwarse snede uit een deel der steng, waar een wortel uitgroeit.

42. Lengte-snede uit hetzelfde deel.

43. Dwarse snede, in welke $a$ tot de steng en $b$ tot den wortel behoort.

44. Stukje uit een' wortel, om de verandering van de gestipte vaten bij de buiging te doen zien, zeer vergroot.

45. Dwarse snede uit den steel van het phyllodium.

46. Een gedeelte van het voorgaande, zeer vergroot.

47. Overlangsehe snede uit hetzelve, zeer vergroot.

48. Dwarse en

49. Overlangsehe snede uit den steel, digt bij den beker, om de vermindering van de buitenste eellenlaag te doen zien.

50. Vaatbundel wit de buitenste laag van het voorgaande, zeer vergroot.

$51,52,53$. Gestipte vaten uit het eambium.

54 en 55. Gedeelte van een Klein blaadje uit den linop (zeer vergroot), met eellen en met spiraalvaten, in welke hier en daar de spiraaldraden begonnen zigtbaar te worden en nog onafrolbaar waren.

56. Epidermis van hetzelfde, waar de hringen de zetels der haren aantoonen.

57 en 58. Haren in hunne moedercel.

59. Haren buiten dezelve.
60. Overlangsehe suede eener groeve, in welke de haren zijn gezeten.

61. Stoma, in de lengte doorgesneden, zeer vergroot.

62. Epidermis met cen stoma, benevens eene groeve voor de haren.

63. Zeer jong bekertje met de eigene sappenvoerende vaatjes. 64. Stukje uit het voorgaande, zeer vergroot, ten einde de zamenstelling dezer vaatjes duidelijk te doen zien.

65 en 66. Klieren uit eenen jongen beker.

67. Klieren uit cen' volwassen beker, vergroot.

68. Dezelfde van de binnenzijde, na de wegneming van het eelweefsel, en den overgang van de eigene sappenvoerende vaatjes in de klier aantoonende.

69. Dezelfide, nog meer vergroot. NEPENTHES BONGSO.

70. Overlangsehe snede uit den beker, zeer vergroot.

71. Dvvarse snede uit denzelven, zeer vergroot.

72,73 en 74 . Uiteinden van spiraalvaten uit den beker.

75. Klieren uit den beker van buiten.

76. Lene klier van de binnenzijde, benevens eenig parenehym, de epidermis en de onbewerk tuigde eutieula, zeer vergroot.

77. Doorgesneden klier, waarvan de eutieula door weeking afgeseheiden is.

78. Stukje uit het deksel, om den loop en vorm der vaten duidelijk te maken.

79. Stukje uit hetzelve, om de klier enzv. te doen zien zcer vergroot. NEPENTHES GRACILIS.

80. Klier van buiten.

81. Klier van binnen.

82. Epidermis tan de buitenzijde der bekers.

83. Stoma van buiten.

84. Stoma van binnen. NEPENTHES BOSCHIANA.

85. Klieren uit den beker, van buiten.

86. Dézelfde van binnen.

87. Klier van het deksel.

88. Cellen uit de epidermis met verbindende groeven, en de onder dezelve liggende laag eellen.

89. Dwarse snede uit den beker. NEPENTHES GYMNAMPHORA.

90. De klieren van den beker. NEPENTHES PHYLLAVPHORA.

91. Klieren van den beker, van buiten.

92. Dezellde van binnen.

93. Klier van de, in den Kruidtuin te Leiden gekweekte soort, rermoedelijk $\mathrm{N}$. phyllamphora.

94. Snede van het deksel boven, en van de laag onder de klier. NEPENTHES RAFFLESIANA.

95. Klieren van buiten gezien. NEPENTHES DESTILLATORIA.

96. Klieren van buiten.

97. Dezelfde, zeer vergroot. NEPENTHES MADAGASGARIENSIS.

98. Klieren van buiten.

99. Klieren zeer vergroot. 


\title{
OVER EENIGE SOORTEN VAN DE FAMILIE
}

DER

\section{I.P T E R O C A R P E A E,}

\author{
DOOR
}

P. W. K O R T H A L S.

Reeds bijj den aanvang van het verkeer der Europeanen met de inboorlingen van Indië, werden er weldra eenige voortbrengselen van de gewassen der Dipterocarpeae bekend, en eenigen tijd na de opening van dezen invloedrijken wereldhandel, werd door Grimm de kamfergevende Dryobalanops, welke door hem te Baros, op Sumatra, was waargenomen, beschreven. Bijna eene eeuw later verkregen wij door Linnaeus kennis van de Vatcria Indica van Ceylon, en van de Vatica Chinensis van China ( $\left.{ }^{*}\right)$. Dit drietal vermeerderde vervolgens door het onderzoek des plantenrijks van het vasteland van Indië, inzonderheid van Bengalen, met verscheidene andere soorten dezer familie, die in de werken van Roxburgh, den ontdekker der meesten, en van Gaertner, onder de geslachtsnamen Dipterocarpus, Hopea en Shorea, voorkomen, en in de laatste tijden, door het onderzoek van de Heeren Blume, Kuhl, van Hasselt en Spanoghe, nog met een zestal nieuwe soorten van Dipterocarpus, welke door den Hoogleeraar Blume zijn beschrcven. Dit geslacht en de andere reeds genoemde, zijn bijna gelijktijdig, door de onvermoeide pogingen der Engelsche Kruidkundigen, met een aantal soorten hunner bezittingen op het vasteland en op de eilanden, vermeerderd, van welke eenige beschreven en andere slechts bij name zijn bekcnd geworden. De reeds beschrevene maken gezamentlijk een getal uit van drie-en-twintig soorten. Bij dezen komen nu nog de elf door ons ontdekte soorten, welke onder de reeds bekende geslachten Dipterocarpus G., Hopea Roxb., Vatica L. (Shorea Roxb.) en de nieuwe geslachten Retinodendron Khs. en Anisoptera Khs. gerangschikt moeten worden.

${ }^{*}$ ) De Heeren Wight en Arnott zijn van gevoelen, dat de door Linnaeus beschrevene plant, niet van hunne Vatica laccifera verschilt, en niet nit China, maar van Dekan en Bengalen afkomstig is. 
$\mathrm{Al}$ de soorten van de Dipteroearpeae zijn tussehen $31^{\circ} \mathrm{N}$. Br. en $10^{\circ} \mathrm{Z}$. Br., en $75^{\circ}$ en $115^{\circ}$ Oosterlengte verspreid. Verseheidene derzelve hebben op het vasteland van Indië het stroomgebied van den Ganges tot standplaats. De Vatica robusta, volgens den Heer Wallich de noordelijkst voorkomende soort dicr familie, wordt nog tot op $31^{\circ} \mathrm{N}$. Br., aan den oorsprong van dien stroom gevonden; de anderen behooren daarentegen in de lagere breedte van Bengalen en op het schiereiland Dekan te huis. De Vateria Indiea is van Ceylon bekend. Van Poeloc-Pinang zijn Vatica (Shorea) longisperma en IIopea faginea, en van Singapoera Hopea gratissima genoemd geworden. Door de vereenigde pogingen van de Nederlandsche Natuurkundigen, kunnen de soorten der Dipteroearpeae nu als Java, Borneo, Sumatra en Nieuw-Guinea bewonende, worden opgegeven. Zij zijn in deze oorden ongelijk verdeeld. Op Java werden tot dusverre alleen soorten van Dipterocarpus verzameld; op Sumatra zijn, behalve eene enkele soort van dit geslacht, andere van Vatica, Retinodendron en Dryobalanops gevonden; van Nieuw-Guinea is de ecnige Anisoptera Zippeliana bekend, en op Borneo werden aan de geslachten Dipteroearpus, Dryobalanops, Hopea, Anisoptera en Retinodendron, nieuwe soorten toegevoegd. Daarenboven komt het geslacht Dipteroearpus, blijkens eene door mij in het Rijks Herbarium geziene soort, Dipterocarpus fulvus BI., ook op Manilla voor.

Hetgeen door den Hoogleeraar Blume en de Engelsche Kruidkundigen omtrent de standplaatsen en het uiterlijk aanzien dezer gewassen is medegedeeld, hebben ook wij, bij de door ons waargenomene soorten, opgemerkt. Zij waren meest allen in gezelsehap vereenigde bewoners der tusschen het strand en 1500 meters hoog gelegene bosschen, en trokken vooral langs de boorden der rivieren, waar zij geheel overzien konden worden, door hunne grootte, bladen en de tusschen dezen uitstekende bloemen en vruchten, de aandacht. Eenige soorten (Dipteroearpus trinervis, D. Baudii, enzv.) hebben dikwerf ruim 35 meters hooge en 3 tot 5 meters dikke stammen, welke als zuilen verheven en door een, in de tropische streken zeldzaam gemis aan woekergewassen, gekenmerkt zijn. Bijna allen bezitten uitgebreide kroonen, en eenen, alleen tegen den bloeitijd eenigzins minder digten bladtooi, die van het begin tot zijne volkomene ontwikkcling de verschillende tinten van groen doorgaat. Bij de eerste ontwikkeling zijn deze bladen licht-, somwijlen. geel-groen, dof, en vervolgens krijgen zij langzamerhand eene donkerder kleur en eene glanzige oppervlakte. Tussehen dezelve prijken welriekende bloemen. Bij Dipteroearpus versieren deze den omtrek der bladkroon door hare aanzienlijke grootte, bij anderen door hare talrijke vereeniging: in beide gevallen geven zij aan de, op eenigen afstand geziene kroonen, een gevlekt voorkomen; in een later tijdperk onderseheiden zich de gevleugelde kelken door hunne kleinere bladuitbreiding en door de lichter groene of meer roodachtige kleur van de hen omgevende bladen.

De door ons gevondenc soorten hebben meestal tamelijk regelmatig rolronde, regte stammen, die door eene geel-grijze of licht bruine, dikwerf vrij gladde schors zijn bekleed. Het hout der takken en der jonge boomstammen is niet zeer digt, licht geel; dat der oudere stammen heeft bij de meesten, verseh zijnde, eene licht gele of bruin-gele kleur, die vervolgens donker of rood-bruin wordt; cen' fijnen draad, een zacht en gemakkelijk te bewerken weefsel, en over het algemeen eene tamelijke duurzaamheid. Zij bezitten wijd uitgespreide, van onderen vlakke, van boven stompe, zelden kegelvormige, digtbebladerde kroonen, met horizontaal uitgespreide hoofdtakken, die op ecnigen afstand van den stam in kleinere takken verdeeld zijn. 
De eerstgenoemde takken zijn over het algemeen rolrond, glad; de laaisten een weinig zaamgedrukt, zelden volkomen rolrond, op verschillende wijzen behaard, en vooral bij Dipterocarpus met kleine ringen, de overblijfselen van het aanhechtingspunt der nevenblaadjes, voorzien. De knoppen zijn bij de soorten van Dipterocarpus zeer lang, en de beide hen bedekkende nevenblaadjes, welke na de ontwikkeling der bladen afvallen, geheel of gedeeltelijk als eene scheede of kapje zaamgegroeid. Zij hebben bij de soorten der andere geslachten eenen minder verlengden vorm, en de nevenblaadjes, welke na de ontwikkeling der bladen nog eenigen tijd blijven zitten, zijn niet zaamgegroeid. In de knoppen zijn de bladschijven met de binnenzijde naar elkander gevouwen, op de nerven zeer digt behaard, zelden geheel glad, scheedevormig de later ontwikkelde deelen omvattende; de bladstelen hebben eene geringe ontwikkeling. Bij volkomen uitgegroeide bladen zijn de bladstelen dikwerf vrij lang, digt bij den voet van het blad met eene geleding, die zich in vele soorten door eene verdikking of door eene knievormige bogt vertoont, stomp-driekantig of bijna rolrond. De bladschijven zijn langwerpig, aan de einden puntig, stomp of ingesneden, veelal gaafrandig, glad, met eene bekleeding, die uit enkelvoudige of tevens bundelsgewijze vereenigde haren bestaat, lederachtig, met dikwerf zeer uitstekende middel- en hoofd-zijnerven. De laatste loopen van de middelnerf tot digt aan den rand, en buigen zich naar boven. Zij worden door eene menigke, dikwerf evenwijdig loopende kleine nerven en netvormig verdeelde aren verbonden.

De knoppen, welke de bloemen insluiten, hebben eenen meer rolronden, toegespitsten vorm dan de bladknoppen, en staan in de oksels der bladen of over dezelven. De bloeiwijze bestaat uit eenvoudige trossen of zeer verdeelde pluimen, en is meestal met eene meer of minder digte beharing bedekt. Haar bloemsteel is, onverdeeld zijnde, met bogten, en heeft de bloemen op uitstekende kussentjes geplaatst; doch verdeeld zijnde, bezitten de deelen van den algemeenen steel veelal dezen zelfden vorm. De bloemen zijn niet zelden langs twee tegen elkander overstaande zijden van den steel geplaatst, en hebben bij Hopea en Retinodendron ieder een klein schutblaadje, dat haar, vóór de ontwikkeling, insluit en na deze spoedig afvalt. Al de bekende soorten hebben de bloembekleedselen dubbel, uit eenen kelk en uit eene bloemkroon bestaande. De kelk bestaat uit vijf deelen. Bij eenigen zijn deze deelen aan den voet tot eene buis zaamgegroeid; hooger, als vijf ongelijke lobben, in den knop klepvormig, en in het midden naar binnen gebogen en tegen elkander gevouwen: Dipterocarpus; bij anderen zijn de deelen even zoo zaamgegroeid, maar voor de opening als kleppen of over elkander gelegen: Anisoptera, Retinodendron, en bij de soorten van Vatica en Hopea zijn vijf geheel vrije kelkbladen, van welke twee binnenwaarts en drie naar buiten zijn geplaatst. Bij eene ongelijke ontwikkeling van de kelkdeelen, zijn twee kleine van de spil afgewend, één naar dezelve toegekeerd en staan de beide uitgegroeiden dwars van de spil of den algemeenen bloemsteel. De kelk is bij velen, gedurende zijn geheel bestaan, met eene meer of minder aanzienlijke beharing bekleed; bij enkelen alleen in den jeugdigen staat behaard, doch bij verdere ontwikkeling volkomen glad. Het benedenste gedeelte van denzclven is bij eenigen, vooral bij de aan den voet zaamgegroeide, dik; het bovenste bladaardig. In dit laatste, vooral in de zeer uitgegroeide deelen, zijn drie tot vijf, zelden elf uit den voet ontspringende hoofdnerven, en eene menigte getakte en weder netsgewijze vereenigde kleinere nerven en aderen. De bloemkroon is bij de meesten onder het vruchtbeginsel aangehecht, bij Anisoptera daarentegen, rondom hetzelve geplaatst. Z Zij bestaat uit vijf, bijj Hopea aan den voet te zaamgegroeide, en bij anderen geheel 
onverbondene bloembladen, welke voor de opening der bloem gedraaid zijn of elkander alleen met de randen bedekken. Bij de draaijing van de bloemknoppen dezer gewassen, even als bij die van een aantal Malvaeeae, heb ik den eenvoudigen regel waargenomen, dat de overdekkende randen altijd naar de spil zijn gekeerd, en dus dat de zoogenoemde regtsehe of linksehe wending der bloembladen van den stand der bloem afhankelijk is. Zelden ontsluiten zieh de bloemdeelen geheel, maar veelal blijven zij aan den voet in eene buis vereenigd, en heeft de bloemkroon eenen radervormigen boord of zoom, in welken men den spiralen stand der bladen meer zaamgedrongen herhaald ziet. De bloembladen zijn bij enkelen van eene ronde, maar bij de meesten van eene langwerpige gedaante, met stompe of spitse punten, somwijlen aan den voet in een klein nageltje uitloopende, gaafrandig, glad of met eene stervormige $\left(^{\star}\right)$ beharing, alleen bij de soorten van Dipterocarpus aanzienlijk ontwikkeld, wit, geelaehtig of geel met eenen zaeht rozen-rooden tint.

De meeldraden groeijen met elkander, en in sommige soorten ook met de bloembladen te zamen: Hopea, Retinodendron. Zij zijn bij de genoemde en bij anderen in een bepaald, bij Vateria en Dipteroearpus in een meer onbepaald, maar veelal vijfvoudig getal aanwezig. Bij de eersten zijn zij regelmatig in twee rijen geplaatst; de buitenste rij staat meestal over de kelkdeelen, en heeft de helft van het getal meeldraden der binnenste rij. De helmdraden hebben bij Retinodendron enzv. eene geringe, bij Dipteroearpus eene aanzienlijke grootte, zijn lijnvormig of langwerpig, en somwijlen door te zamengroeijing van de buitenste met de tegenoverstaande van de binnenste rij, paarsgewijze verbonden. Bij Dipteroearpus bezitten zij in het midden, en bij andere geslaehten iets hooger, eene geleding, welke het verbindingspunt van den helmknoop met het helmdraadje is $(t)$. De helmknoop is over het algemeen, in verhouding tot de stuifmeelhokjes, zeer ontwikkeld, verlengt zieh naar den top elsvormig bij Dipterocarpus; in een zeer toegespitst, ongedeeld vliesje bij Anisoptera; in een aan het einde verdeeld draadje bij Vatiea; in een ongedeeld draadje bij Hopea; in een gespleten vliesje bij Vateria; in een klein knopje bij Retinodendron, en heeft naar of aan den voet eene hartvormige insnede met twee kleine oortjes. Op deze staat aan weêrszijden van den helmknoop een stuifmeelhokje, hetwelk in twee kleinere is verdeeld. Deze kleinere zijn bij Dipteroearpus en Hopea ongeveer even lang, maar bij de andere geslaehten zijn zij ongelijk en staan de kortste dezer deelen naar de binnenzijde naast elkander. De helmknopjes zijn meestal van eene vliezige zelfstandigheid, en bestaan uit een vlies, dat aan de binnenzijde langwerpige of naar het ronde overgaande, door lıoge wanden gevormde vakjes heeft: eene zamenstelling, die aan de Erieeae en Solana herinnert. In deze vakjes of kleine holen ligt het stuifmeel bij de zeer jonge belmknopjes besloten, en later komt het door deszelfs vergrooting buiten dezelve. Het stuifmeel is bijna kogelrond, op de oppervlakte effen of door uitstekende randjes of andere verhevenheden ruw, en springt op drie plaatsen open.

De stempel is bij de meeste ongedeeld, knopvormig, of getand; bij Anisoptera in drie deelen gespleten. Hij wordt door eenen bijna rolronden stijl gedragen. Deze bezit in het midden eene door

$\left.{ }^{*}\right)$ Deze beharing bestaat uit kleine stervormige haarbundels, in welke de haren om een klein half kogelrond knopje, waaruit zij ontstaan, geplaatst zijn.

( + De vaatbundel, welke de helmdraden doorloopt, is bij dit verbindingspunt geleed. 
vaten en vezels omringde holte, welke, door de weeking van de omgevende deelen geseheiden zijnde, gemakkelijk tot aan den moederkoek kan vervolgd worden. Het vruchtbeginsel is bij Anisoptera gedeeltelijk met den kelk zaamgegroeid, bij de anderen bijna geheel vrij, half eivormig, effen of gevoord, naar boven toegespitst, en gewoonlijk kort behaard. In den jeugdigen staat is het bij allen driehokkig, en bevat het in ieder hokje twee, naast elkander, op ongelijke hoogte in den. binnensten hoek van de hokjes bevestigde eitjes. De eitjes zijn eerst kleine, ronde, op den moederkoek gezetene en later gesteelde blaasjes. Vervolgens buigt zieh het dikke gedeelte van de eitjes naar den steel, waardoor het voedingsvat of de raphé loopt, en groeit het hiermede zamen $\left(^{*}\right)$. Zij zijn nu langwerpig eirond, aan de zijden platgedrukt, op den rug rolrond, en op den buik door de uitstekende raphé gekield, aan het bovenste einde kegelvormig en aan het benedenste stomp. Het vruehtbeginsel ondergaat door den wasdom aanzienlijke veranderingen. Somwijlen wordt het, door de geringe uitgroeijing van de zelfstandigheid der tussehensehotten, eenhokkig, en heeft het de eitjes in het bovengedeelte der holte, rondom eenen uit den bodem voortkomenden draad, welke de voedingsvaten van den moederkoek bevat, geplaatst; dan krijgt het, door de ongelijke uitgroeijing, hokjes van eene zoo versehillende grootte, dat één of twee derzelve alleen met moeite kunnen erkend worden. In deze kleine hokjes blijven de eitjes kleine sehubjes, en in het groote groeit sleehts een der twee tot zaad uit.

De vrueht is bij Vateria en Retinodendron bijna geheel boven den kelk geplaatst, en bij de andere geslaehten voor een groot gedeelte door den uitgegroeiden kelk omsloten. Zij is bij eenigen niet openspringend, lederaehtig of vleezig; bij anderen kapselaardig, eivormig of meer kogelvormig, aan den voet rond, aan den top puntig of stomp, glad of behaard. Zij heeft een dikker of dunner lederaehtig. epiearpium, een vezelig, bij Hopea zeer gering, maar bij Dipteroearpus zeer aanzienlijk sareoearpium, en een glad, bij enkelen glanzig, lederaehtig, of broos kraakbeenaehtig endoearpium. Een eenig zaad vult de geheele holte der vrueht, en heeft eenen meer of minder regelmatigen kogel- of eivorm. Het heeft het uitwendig zaadvlies meest vliezig; het inwendige dikker, vleezig en somwijlen tussehen de zaadlobben ingegroeid. De kern bezit geen eiwit. De kiem heeft kort na hare vorming de beide zaadlobben vlak, van eene ongelijke grootte, de kleinste lob binnenwaarts naar den moederkoek geplaatst. Later groeijen de zaadlobben bij Dipteroearpus, Dryobalanops, enzv. zoozeer in de lengte en breedte uit, dat zij in de enge, tot hare ontwikkeling bestemde ruimte zoodanig moeten zaamgerold en geplooid worden, dat zij moeijelijk te ontwarren zijn; bij Hopea, Vatiea, enzv. nemen zij daarentegen meer in dikte toe, en vergrooten zij zonder buiging. Z Zij zijn aan den voet uitgesneden, en hebben in deze insnede het rolronde, aan het einde spitse of stompe worteltje. Het knopje is niet zeer ontwikkeld.

Na de beschrijving van den vorm der deelen, zal ik eenige regelen over de zamenstelling van de takken enzv. laten volgen. Deze zijn, zeer jong, door een bijna ongekleurd of somwijlen, bij Dipteroearpus

$\left(^{*}\right)$ In dezen draad of buis heb ik, bij eene sterke vergrooting, binnen de buitenste omhullende cellenlaag, eene rij cellen, en eene, uit eenen eenvoudigen draad bestaanden spiraal gevonden, die naarmate van de verlenging der buis of van de raphé, meer of minder op- of afgerold was. Bij meer ontwikkelde eitjes vond ik daarentegen, in plaats dezer middelste eellenreeks, leden van gestipte vaten, en geen spoor van de spiraalsgewijze wending: vermoedelijk was de spiraaldraad geheel ontrold geworden en nu tegen de gestipte vaten geplaatst.

Botanica. 
Baudii, door cen bruin gekleurd huidje (cuticula) bedekt. Onder dit huidje ligt de, meestal uit langwerpig-vierkante eellen gevormde opperhuid, waarin eenige stomata en enkele lenticellen, door gaatjes of verhevenheden de effenheid verminderen. Z Zij is bij de oudere takken dikwerf geheel anders gevormd, en schijnt dan uit de buitenste laag van de cellen der schors, met welke zij groote overeenkomst bezit, te bestaan. IDe sehors of buitenste bastlaag bestaat uit twee lagen, die meer of minder scherp bepaald zijn. De eerste of buitenste wordt door een los weefsel van dunwandige eellen gevormd; de tweede of binnenste heeft daarentegen eenigzins meer zamenhangende en vele zeer dikwandige eellen. In beide zijn de, door dunne wanden gevormde eellen tamelijk op elkander gelijkend, van twaalf- tot zeshoekig; de twaalfhoekige zijn eehter meer aan de buitenste, en de zeshoekige aan de binnenste laag eigen. De dikwandige cellen zijn tamelijk regelmatige of langwerpige vierkanten met gestipte wanden, en zeer naauw met elkander verbonden. Zij bevatten in de onderzochten soorten nu en dan een weinig hars, en zelden de groene korrels, die in de dunwandige eellen zoo rijkelijk zijn besloten. Hierdoor is bij mij het denkbeeld ontstaan, of deze eellen ook missehien van eenen anderen aard konden zijn, en, door cene verhoogde levenskracht, meer bewerktuigde stoffen afseheidden? Voor het oogenblik durf ik deze vraag niet beslissen; maar het zal niet overtollig zijn, hier, ter zijdelingsehe versterking van dit denkbeeld, aan te voeren, dat deze dikwandige eellen ook bij de Guttiferae de gele harsige stof, en bij andere gewassen cene zeer gommige vloeistof met weinig ehromule bevatten. - Op deze tweede schorslaag volgt de bastlaag, welke in jonge takken, uit eene menigte dunwandige eellen en uit niet zeer ontwikkelde bastbundels bestaat. In de eerste eindigen de groote mergstralen. De bastbundel is, door ecne laag van langwerpige, digt aan elkander geslotene cellen des eelweefsels, van den bast gescheiden, en heeft bij de meesten den vorm eener halve maan, en bij Vatiea van eenen seherpen driehoek. Dezelve bestaat uit fijne, vooral bij Hopea uit zeer kleine, dikwandige vezels, van welke kleine harsstreepjes de digte verbinding afbreken. Naarmate deze bastvezels meer naar binnen zijn geplaatst, vertoonen zij dunner wanden en eene minder vaste stof; waardoor het in jonge takken moeijelijk is, om de grenzen van den bast- en den houtbundel aan te wijzen. De laatste begint met gestipte vaten. - Hij bestaat uit vezels, gestipte vaten, spiraalvaten, spiraaldraden, kleine mergstralen en sapvoerende vaatjes. Bij Ilopea en Dryobalanops maken de vezels het grootste gedeelte van den bundel uit; bij Vatiea zijn de gestipte vaten het talrijkst. De vezels zijn bij allen zeer dikwandig, cindigen in spitse punten, en hebben van binnen kleine groeven. Zij zijn in het eambium korter, een weinig dikker en niet gestipt. De gestipte vaten verschillen in den omvang, de lengte der leden en den vorm der stippen. BBij Dryobalanops en Hopea zijn zij het kleinste van omvang, maar hebben derzelver leden eene lengte van een derde tot cene streep, bij eene breedte van een tiende streep. De dwarse strepen, welke de verbinding der leden bij Dryobalanops aantoonen, zijn meestal in een' hoek van $10^{\circ}$ geplaatst. De stippen ziju op de vaten ongelijk verdeeld: nu eens staan zij vrij digt bij elkander en zijn zij over de geheele vaten verspreid; somwijlen worden zij als kleine groepen in het midden van eene effene vlakte waargenomen, of wel zijn zij allen aan eene zijde geplaatst $\left(^{\star}\right)$. Haar vorm is langwerpig-ovaal of gelijk aan kleine dwarsstrepen; hare grootte is zeer ongelijk: meestal echter zijn er 4 tot 6 in eenen kring. De scheidingstrepen (zoo als wij gevoegelijk de strepen, die de leden aantoonen, meenen te kunnen noemen) hebben

${ }^{*}$ ) De Heer Mohl heeft deze ongelijke verdeeling der stippen bij de Tilia, enzv. waargenomen. 
bij Hopea Balingeran dezelfde rigling. De stippen volgen in hare verdeeling eene even zoo onregelmatige verspreiding, maar zijn daarentegen dikwerf zoo digt bij elkander geplaatst, dat het vlies der valen, door eene geringe vergrooting, als alleen uit stippen bestaande, voorkomt en, bij eene sterkere vergrooting, 14 tot 16 stippen in den omvang laat waarnemen. Haar vorm is bijna rond. De gestipte valen van Dipteroearpus Baudii hebben de leden van een vierde tot ongeveer eene streep lang, en den omtrek tot de lengte als 1 tot 6 of 8 . De seheidingstrepen zijn minder regelmatig en vertoonen zieh als regte, gebogene, of wel als sehuinsehe lijnen. De stippen hebben veel gelijkheid met die der Dryobalanops, zoowel wat den vorm, de grootle, als de verdeeling betreft. De Anisoptera marginata heeft de gestipte vaten zeer gelijkvormig met die van den Dipteroearpus, maar versehillend door eene mindere grootle, en dikwerf door een geringer aantal van langwerpige stippen. Biji Vatiea vormen de gestipte vaten een zoo groot gedeelte van den houtbundel, dat men bij eene overlangsehe snede sleehts eenige vezels tussehen een groot aantal derzelve waarneemt. Zij bestaan uit leden van $\frac{\frac{T}{4}}{4}$ tot $\frac{\mathrm{T}}{3}$ streep lengte, die de lengte tot de middellijn als 3 tot 1 hebben. Hunne seheidingstrepen zijn regt of schuins; somwijlen aan het eene einde van het lid regt en aan het andere sehuins. De stippen zijn, even als bij de vorige soorten, zeer ongelijk verdeeld, en staan door haren vorm en getal, in het midden tussehen Hopea en de andere opgenoemde geslaehten. - Hetgeen ik van de spiraalvaten waargenomen heb, kan zeer gesehikt op de volgende wijze worden zaamgetrokken. Zij vertoonen zieh onder twee vormen, als zeer kleine in eenen draad of als grootere, in meerdere draden afrolbare vaten. De laatste zijn in den omtrek van het merg geplaatst en vormen het binnenste van het mergkanaal; de eerste heb ik dikwerf in het buitenste gedeelte van hetzelve en in het eambium tussehen den bast- en houtbundel waargenomen. De in den omtrek van het merg geplaatste spiraalvaten vormen drie tot vijf ringen, en bestaan uit eene halve tot anderhalve streep lange leden, waarin de middellijn tot den omtrek als 1 tot 20 of 30 staat. Deze leden zijn aan de uiteinden seheef en eindigen derwijze, dat de beide punten tegen elkander overstaan, en dus altijd aan de korlste zijde van de volgende, boven dezelve geplaatste sluiten. De wendingen der draden sehijnen mij toe, want als eene zekerheid durf ik zulks niet bepalen, in verband te staan met den vorm der leden, en in de beide punlige einden te beginnen en te eindigen. De andere, uit ééneı draad bestaande, spiraalvaten, heb ik het duidelijkste in het eambium gezien. Zij waren meestal, eerst bij eene zeer sterke vergrooting zigtbaar, en naarmate van den graad der ontwikkeling van het eambium meer of minder ontrold. Ik zal later op deze vaten terugkomen, en hier de besehrijving van de andere zamenstellende deelen van den houtbundel vervolgen. - De kleine mergstralen zijn bij allen, op eene min of meer duidelijke wijze zigtbaar, en vormen, van het merg tot in en door den bastbundel voortloopende, stralen, of hebben eene netvormige verbinding in den vaatbundel. Zij bestaan uit kleine, zeer platte of zoogenaamde tafelvormige eellen, die zeer digt aan elkander sluilen, ongelijk van grootte zijn en eenen vierkantigen vorm hebben, in welken het vlak een volkomen of een langwerpig vierkant voorstelt. De eellen hebben zeer dikke wanden met diepten, die in tegen elkander liggende eellen, tegen over elkander zijn geplaatsl. Dikwerf omgeven deze kleine mergstralen een gedeelte van de gestipte vaten, en somwijlen omsluiten hunne eellen de gestipte vaten zoo juist, dat men hen, zonder een naauwkeurig onderzoek, voor deelen van de wanden der gestipte vaten zoude houden $\left({ }^{\star}\right)$.

$\left(^{*}\right)$ Op rele ontleedkundige platen van planten komen zij als zoodanig roor. 
Behalve deze, bij allen aanwezige, zamenstellende deelen, vertoonen zieh langs de gestipte vaten, strepen, welke wij op de meeste ontleedkundige platen, als tot den wand van deze vaten behoorende, afgebeeld vinden. Len naauwkeurig onderzoek heeft deze strepen als zaamgedrukte of bijna rolronde draden doen kennen, en aangetoond, dat zij over de gemelde mergeellen of tussehen deze en de wanden der gestipte vaten waren gelegen. Later zal ik haren oorsprong aantoonen, en nu tot de besehrijving van het merg en de groote mergstralen overgaan. - Het merg heeft bij de meesten eenen eirkelvormigeu, en bij enkelen, naar de uiteinden der takken, eenen meer ovalen omtrek, waarin bij den oorsprong der mergstralen kleine uitstekende hoeken zijn. Deszelfs omvang is bij Dipterocarpus en Anisoptera het aanmerkelijkste; vervolgens komt die van Vatiea, en daarna die der anderen, in hunne verhouding tot den vatenring, in aanmerking. In de onderzoehte bloeijende takken bestond het merg bij Anisoptera uit bijna gelijkzijdige, en bij de andere uit langwerpig vierkante eellen, waarin de lengte tot de breedte bij Dryobalanops als 1 tot 4 staat. Deze eellen hebben meestal dikke gestipte wanden, in welke de stippen of verdiepingen, vooral bij Hopea en Dryobalanops, zeer opmerkelijk zijn. De groote mergstralen bestaan uit twee of drie rijen eellen, en splijten aan het einde van hunnen loop, om de bastvezellaag, welke aan weêrszijde ligt, met eene rij dezer eellen te begrenzen. Hunne eellen zijn bij Hopea en Dryobalanops vierkantig, bij Retinodendron Rassak en de andere langwerpig en, even als die van het merg, dikwandig en gestipt. - Bij de onderzoehte soorten vertoonden zieh reeds aan het ongewapend oog, in den omtrek van het merg, eenige ronde gaatjes, die met eene harsaehtige stof waren opgevuld. Bij vergrooting zijn zij even zoo vele ruimten, die door seheuring van de omringende deelen ontstaan. Het was eene bekende, ook door mij waargenomene daadzaak, dat dikwerf in het midden, bij het merg der boomen harsophoopingen plaats hebben: de oorsprong van dezelve was eehter onbekend. Ik beproefde de oplossing van dit vraagpunt. Behalve de besehrevene zamenstellende deelen van de takken, heb ik nog de sapvoerende vaatjes opgenoemd. Zij vertoonen zieh bij de onderzoehte jonge takken in de bast-en houtbundels, en in het merg, als zeer fijne vaatjes. Naar de uiteinden der takken laten zij derzelver geleden zamenstelling zeer duidelijk waarnemen. In de oudere deelen der takken vertoonen zij meer te zamenhangende buisjes. Op beide plaatsen bevatten zij reeds hars. Zij loopen in de rigting der vaten en zijn door mij langs de gestipte en spiraalvaten, en ook in deze vaten waargenomen. Vooral waren zij zeer talrijk in den omtrek van het merg en bij de reeds gemelde harsophoopingen. In deze waren zij afgebroken. Deze harsophoopingen hadden plaatsen ingenomen van cenige mergeellen, van de spiraalvaten uit het mergkanaal, van enkele gestipte vaten en vezels van den houtbundel, en lieten bij een naauwkeurig onderzoek nog de overblijfsels der vliezen en draden tussehen de harskorrels erkennen. Door het onderzoek van een stukje van het uiterste einde eens taks van Dipteroearpus Baudii, werd het ontstaan van deze uitstortingen nog duidelijker, omdat hier de gemelde sapvoerende vaatjes, in de spiraalvaten en gestipte vaten rozenkransvormig opgezwollen en aan het uiteinde gebroken zijnde, het begin van de uitstorting in deze vaten zoo duidelijk maakten.

Na de gronddeelen in hunnen volkomen staat besehreven te hebben, zullen hier nog eenige woorden over hunnen toestand in het eambium worden bijgevoegd. Hier vertoonde zieh in den jongen staat eene gomachtige stof, in welke bij sterke vergrootingen een begin van bewerktuiging zigtbaar werd. Later vertoonde deze stof ongelijke eellen, en waren er tussehen dezelve zeer kleine spiraalvaten zigtbaar. 
In het meer gevorderde cambium was de bewerktuiging reeds duidelijker, en vertoonden zieh de vezels als lange eellen, en de gestipte vaten als groote, korte eellen, die juist boven elkander stonden. De laatsten bezaten in dien staat effene wanden en hadden een of meerdere, meer of minder ontrolde spiraalvaten nevens zieh. Deze spiralen sehijnen zieh bij de oudere lagen meer en meer te ontrollen en vormen de draden, die wij boven reeds, als in de nabijheid van de gestipte vaten geplaatst, hebben besehreven.

Bij de kieming der zaden van Dipterocarpus komt de wortel uit het bovenste gedeelte der vrueht te voorsehijn, en de zaadlobben blijven in de vrueht besloten. Uit deze groeijen zeer lange stelen, tussehen welke het bladpluimpje later ontspruit. Bij de ontkieming der zaden van Vatiea komen, volgens de opgave van Roxburgh, de zaadlobben voor den dag, en ontwikkelen zieh deze tot kleine bladen. Bij de ontwikkeling der kiem van Dryobalanops, blijven de zaadlobben in de half openspringende vrueht besloten of ontspruiten zij uit deze, om zieh bladvormig uit te breiden. De wortel is spilvormig en verdeelt zieh naar het einde in vele kleinere, met grijze haren bezette worteltjes.

Waarnemingen omtrent eenige soorten van Hopea, Retinodendron en Dipteroearpus, doen mij vooronderstellen, dat er tegen den bloeitijd een stilstand in de ontwikkeling van het gebladerte plaats heeft, daar deszelfs digtheid alsdan door het afvallen van de oude bladen aanzienlijk vermindert. Zoo als ik boven reeds aanstipte, zijn de bladen bij hunne eerste ontwikkeling dof lieht groen, en worden zij later glanzend en donkerder groen. In eenen ouderen staat neemt deze groene kleur eenen meer of minder bruinen tint aan. In het tijdperk, hetwelk de afvalling der bladen voorafgaat, verkrijgen zij eene rood- of geel-bruine, en vervolgens, bij hunne afvalling, eene donkere of lieht bruine kleur.

De bloeitijd is bij de versehillende soorten zeer ongelijk: eenigen zijn tegen of in het begin van het drooge jaargetijde met sehoone, talrijke bloemen versierd; anderen daarentegen, wanneer de regentijd nadert. Alleen, volgens de opgave der inlanders en bij gissing, kan ik mededeelen, dat de bloeitijd tussehen eene en twee maanden duren zoude. De bevruehting heeft kort vóór of na de opening van de bloemkroon plaats, en wordt spoedig door de ongelijke ontwikkeling der eitjes kenbaar. Op haar volgt de afvalling van de omringende meeldraden en bloembladen, en eene vergrooting van den kelk, benevens eene digtere omsluiting van het vruehtbeginsel door denzelven. De uitgroeijing van twee of meerdere deelen van den kelk duurt bij verseheidene tot aan de rijpwording der vrueht, welke ongeveer vijf tot zes maanden na de bloeijing plaats heeft. Bij Dipteroearpus beginnen de rijpe zaden niet zelden reeds aan den boom te kiemen. Hierdoor is, omtrent het einddoel van de vleugels des kelks, bij mij het denkbeeld ontstaan, of zij niet tevens bestemd zouden wezen om, daar zij het bovengedeelte van de vrueht ligter maken, bij het nedervallen derzelve van hare hooge groeiplaats, de teedere deelen van de ontwikkelde kiem voor kwetsing te bewaren?

Van de versehillende deelen dezer gewassen wordt alleen het hout ten gebruike aangewend. Dit behoort, wanneer het niet te veel van hars is voorzien, tot de beste bouwstoffen, en levert aan de, Botanica. 
langs de Iraway wonende Birmanen, het noodige voor hunne aanzienlijke kano's, aan de bewoners van Chittagong, voor hunne doodkisten, en aan die van Borneo's zuid-oostkust eene voortreffelijke bouwstof voor hunne woningen. Daarentegen zijn de zamentrekkende, olierijke zaden een zoo geliefkoosd voedsel voor den, onder den naam van Cereopithecus cynomolgus bekenden aap, en voor den Sciurus ephippium (eene soort van eekhoren), dat wij al de op den grond gevallene vruehten min of meer door deze dieren aangebeten of doorknaagd vonden. Zeer belangrijk daarenboven zijn de voortbrengselen dezer gewassen, bestaande in balsem, hars, olie en kamfer. De eerste wordt als olie ter verlichting of ook wel als teer gebezigd; de hars, welke tot de zoogenaamde onderharsen behoort, wordt in flambouwen gebrand, als pek aangewend om de vaartuigen te kalefateren en door de Hindoesche priesters als wierook gebruikt. Men heeft beproefd om ze tevens als vernis aan te wenden, dan dezc proef is, wegens de, bij eene geringe warmte plaats hebbende smelting, mislukt. Vervolgens verdient de kamferolie, ofsehoon van minder belang, en de voor den Indisch-Chineesehen handel zoo gewigtige kamfer, bijzondere vermelding.

De verwantsehap dezer familie kunnen wij, hetzij naar haar uiterlijk aanzien, hetzij naar de kenteekenen, welke eene nadere beschouwing opleveren, beoordeclen. Door het eerste sluiten zieh de Diptcrocarpeae aan den door den Hecr von Humboldt genoemden Malvavorm met Dipterocarpus enzv., of aan den Lauriervorm door den Retinodendron. Door de laatsten nadert dezc familie, zoo als de Heer Blume in de Flora Javae heeft aangetoond, tot de Malvaecae, in den ruimsten zin en in het bijzonder bij de Sterculiaeeae. Latere sehrijvers hebben dit gevoelen, wat de hoofdzaak betreft, aangenomen; maar de Heer Lindley plaatst de Dipteroearpeae tussehen de Elaeocarpeae cn Tiliaceae, terwijl de Heer Blume dezelve tussehen de laatste familie en de Buttneriaeeae rangschikt. Met het eerste gevoelen kan men zich zeer goed vereenigen, zoo men den vorm van de helmknopjes en van den helmknoop, en de plaatsing van het ei in aanmerking neemt; met het laatste, wanneer het zaad in deszelfs zamenstelling wordt ten grondslag genomen $\left({ }^{\star}\right)$. Het komt mij voor, dat de Dipterocarpeae tusschen de Malvaceae cn de Elacocarpeae kunnen worden geplaatst: omdat zij met de laatste familie het gering, maar toch voor dezelve belangrijk uitgroeisel van den hclmknoop, benevens eenige overeenkomst in de zamenstelling der vrucht bezitten, en met de eerste, door den vorm van de kiem, alsmede door de ligging van de bloemkroondeelen voor de opening der bloem, overeenstemmen. Daarenboven bezitten de Dipterocarpeae, volgens den Ileer Blume, eenige overeenkomst met de Guttiferae. Deze verwantsehap is vooral door het geslacht Lophira Afz., dat tot de Dipteroearpeae is gebragt, versterkt. De eenige soort van dit geslaeht, welke het Rijks Herbarium uit de door den Heer Leprieur op Senegal gemaakte verzameling bezit, werd door dezen Kruidkundige op het eerste gezigt voor eene plant van de Guttiferae gehouden, en zal vermoedelijk bij de meesten wel den indruk van eene soort van Callophyllum maken, waarmede zij, door het aanzien der bladen en de bloeiwijze, overeenstemt. Daarentegen wijkt zij, door den stand derzelve, van Calophyllum af. Van Dipteroearpus versehillen de bladen door het gebrek der neven-

$\left.{ }^{*}\right)$ De Heer Lindley brengt deze familie tot de Synearposae, welke volgens hem de kelkbladen in een' volkomen krans bezitten. Deze schikking is geldig voor de met verbondene kelkbladen voorziene geslachten; doch kan op die, welke vrije kelkbladen bezitten, niet worden toegepast, omdat hier de bladen duidelijk in twee kransen staande, meer verwantsehap met de Calyeosae hebben. 
blaadjes. De bloemdeclen zijn door vorm, getal, ligging, en vooral door de verlenging der kelkdcelen, zeer gelijk aan die der Dipteroearpeae; daarentegen hebben de geslachtsdeelen meer overeenkomst met die der Guttiferae $\left(^{\star}\right)$, door den vorm van de helmknopjes, bij welke de helmknoop niet is uitgegroeid, door de plaatsing van het vruchtbeginsel op eene kleine verhevenheid, en door het inwendige zamenstel. IIt vruehtbeginsel is, even als bij eenige Guttiferae, eenhokkig, en heeft de talrijke eitjes op eene in deszelfs midden geplaatste korte zuil vastgeheeht. Behalve deze overeenkomst vinden wij nog eene tamelijke gelijkvormigheid in de zamenstelling van het zaad, vooral wat de kiem betreft. Uit deze vergelijking blijkt genoegzaam, dat de Lophira niet bij de Dipterocarpeae behoort, en tussehen deze cn de Guttiferae staat. Ilet komt mij dus raadzaam voor, om dit geslaeht als eene eigene familie af te scheiden onder den naam van Iophiraeeae.

De Lophira dus uitgesloten hebbende, behouden wij in de familie der Dipterocarpeae drie natuurlijke groepen: de eerste, welke wij de Vateriae zouden kunnen noemen, is gekenmerkt door de gelijkmatige, niet zeer uitgroeijende kelkdeelen, bevat de Vateria L. en Retinodendron Khs., en is de overgangsvorm tot de Elaeocarpeae; de tweede, die der eigenlijke Dipterocarpeae, bezit de kelkdeelen aan den voet min of meer buisvormig verbonden, en twee of meer derzelve bladvormig uitgegroeid: hieronder kunnen gerangschikt worden: Dipterocarpus G., Anisoptera Khs. en Dryobalanops G.; en de derde, die der Hopeae, heeft de kelkbladen geheel vrij, gedeeltelijk of allen bladvormig ontwikkeld, en bevai Hopea Roxb. en Vatica $\mathbf{L}$.

\section{RETINODENDRON. KHS.}

Vateriae species, Roxb. Flora Indica II. pag. 602.

Gatrx profunde quinque-partitus, excrescens. Conolla pentapetala, aestivatione convolutâ. STAurrva. quindeeim, biserialia: serie interiore staminibus 10 et serie exteriore staminibus 5 calycis laciniis, et 5 seriei interioris oppositis et connatis; ANTHERAE basi affixae, locellis inaequalibus; connexrvum glandulâ terminatum. Ovarionr triloeulare, loculis bi-ovulatis; ovula subeollateralia, descendentia. Struus subteres; stigna eapitatum, integrum vel dentatum. Capsula (auctor. Roxburghi in Vateriâ lanceaefoliâ) solida, trivalvis. Semina solitaria vel geminata; integumentun (simplex? Roxb.) in semine immaturo duplex. Emrkro erectus (inversus); cotruedones subaequales, crasse-carnosi, bilobi; radicuta lanceolata (Roxb.).

Arbores. Fouta alterna, oblonga, coriacea. Strpulae oblongae, laterales. Flores axillares vel terminales, paniculati.

$\left(^{*}\right)$ In de beschrijving van de zaden dezer familie, kent men aan dezelve eenen zaadrok en dumne zaadhuid toe. Het onderzoek van de ontwikkeling der zaden van Garcinia Mangostana heeft mij overtuigd, dat hetgeen men voor den zaadrok houdt, eene zeer uitgegroeide, saprijke buitenzaadhuid is, en dat het voor de geheele zaadhuid genomen gedeclte, het bimenste deel ran dezelve vormt. 
De Heeren Wight en Amott maakten, bij de vermelding van de Vateria lanceaefolia Roxb., de opmerking, dat deze soort misschien een afzonderlijk geslacht moest vormen (Prodromus Florae Pen insulae I. p. 84). Ik heb dit denkbeeld mijner voorgangers, na het onderzoek van de beide door ons verzamclde soorten, bevestigd gevonden en aangenomen, en aan het thans voorgestelde geslacht den naam Retinodendron gegeven, om daardoor de aanzienlijke hoeveelheid hars aan te duiden, die deze boomen afzonderen. Het is van Vateria genoegzaam onderscheiden door een kleiner getal meeldraden, door den in eene klier uitloopenden helmknoop, en door den vorm van de zaadlobben, welke, volgens Roxburgh, meer overeenkomst met die van Vatica L. (Shorea Roxb.) dan van Vateria bezitten. Tot dusverre zijn drie soorten van dit geslacht bekend: de eene, R. lanceaefolium, behoort tot de gewassen van Silhet en Chittagong; de andere, R. pauciflorum, werd aan de rivier van Indrapoera verzameld, en de derde, R. Rassak, groeit vrij menigvuldig langs de rivieren van Borneo's zuid-oostkust.

\section{RETINODENDRON RASSAK. Kns.}

R. foliis ovali-oblongis obluse acuminatis basi obtusis, stipulis oblongis, paniculis divaricatis, stigmate trumcatodenticulato.

Arbor speciosus, saepe 20 ad 25 metrarum altitudine; truraus rectus, subcylindricus, cortice sat crasso, griseo-fusco, ligno laete fusco; conona conoidea vel ovoidea, aperta; RamI patentes, subteretes, fusci, glabri solutione epidermidis; Ranulr compresciusculi, griseo-fusci, lepidoti; novelli compressi, dense fusco-lepidoti. Folia ovali-oblonga, acuta, breviter obtuse acuminata vel acuminatissima, basi obtusa vel acutiuscula, integerrima, supra glabra, subtus tenuissime lepidota, pilis stellatis, coriacea, $6 \mathrm{~cm}$. lata, $32 \mathrm{~cm}$. longa, nervis primariis patentibus, prominentibus, nervis secundariis subparallelis, venis reticulatis; petroli $3 \mathrm{~cm}$. longi, subteretes, lepidoti vel glabriusculi. Stripulat sessiles, oblongae, obtusae, intus glabrae, carinatae, extus lepidotae, coriaceae, deciduae, $20^{\prime \prime}$ longae, 5"' latae. Gemia. compressae, ovatae, acutae, stipulis tectac. Inflorescentia dense lepidota, axillaris vel terminalis, paniculata; Pedurculus communis basi compressus, versus apicem subtetragonus; PEDurculi alternantes, compressi, ad apices subtetragoni; PEDicelut tetragoni imâ basi articulati. Bracteat ovatae, acutiusculae, intus glabrae, extus lepidotae, minutae, admodum deciduae. Flores odorati, flavescentes. CALrx aestivatione valvatâ, tubo subpentagono, basi attenuato, limbo quinque-partito, partibus rectis, triangulatis, acutiusculis, intus glabris, extus lepidotis, carnosis, persistentibus, excrescentibus. Corould pentapetala, aestivatione convoluta; PETALA oblonga, saepe subfalcata, obtusa, intus glabra, basi bituberculata, extus sublepidota, carnosa, 14"' longa, 6" lata. STumira quindecim, basi subcoalita, in duabus seriebus disposita; decem seriei interioris inaequalia, minora petalis opposita, majora calycis laciniis opposita et staminibus quinque seriei exterioris connata; FILAMENTA laminaeformia, basi dilatata, apice linearia, glabra; antHerae oblongae, basi affixae, locellis inaequalibus, exterioribus majoribus; connexivo glandulâ truncatâ vel acutiusculâ terminato, basi subdilatato. Pollen sphaericum. Ovarium semi-ovoideum, subtrigonum, versus apicem attenuatum, dense lepidotum, triloculare; loculis oblongis apice angustioribus, bi-ovulatis; ovwLA subcollateralia, ab apice anguli interni loculi pendula, infra verticem affixa. Sryuus trigonus, glaber; stigma truncatum, denticulatum. Fructus immaturus, 
ealyce coriaeeo stellato insidens, subovoïdeus, apiee attenuatus, fere glaber, carnosus, epiearpio submembranaeeo, sareocarpio earnoso, endoearpio subeoriaeeo, abortu unilocularis, monospermus.

\section{Crescit ad flumina Baritto, Kapoeas, etc.: Bonneo.}

Tab. 8. Explicatio. 1. Gemma floris. 2. Flos. 3. Petalum introrsum visum. 4. Flos calyce et corolla ablatis. 5. Staminum pars introrsum visa. 6. Stamen majus antice. 8. Idem postice. 7. Stamen minus antice. 9. Idem postice visum. 10. Ovarium. 11. Ovarium verticaliter sectum. 12. Ovulum. 13. Fructus immaturus. 14. Idem verticaliter sectus. 15. Symmetria floris.

Langs de Baritto-, Kleine Dajak-, Kapoeas-rivieren enzv. en derzelver zijtakken, is deze boom bij de inlanders bekend onder den naam Rassak, en groeit hij zoowel langs de oevers, als op eenigen afstand van dezelve. In de eerste standplaats wordt de groei niet zelden, uithoofde der beperking, welke de ontwikkeling der wortels door het nabij zijnde water ondervindt, verhinderd, en gaat de hoogte zijner stammen soms geene $3 \mathrm{~N}$. ellen te boven. In de laatste, meer gunstige standplaatsen, bereikt hij daarentegen eene hoogte van 30 ellen. De regtopgaande, door eene bruin-grijze schors bekleede stammen hebben eene hoogte van 20 à 22 ellen, en de piramidale of ovale kroonen verkrijgen eene lengte van 8 à 10 ellen, bij eenen soms dubbelen omvang.

In voor den groei minder gunstige omstandigheden is de stam nu en dan met onregelmatige bogten, maar behouden de kroonen den gewonen vorm. Wij hadden den Rassak, gedurende onzen togt op de Baritto en hare zijtakken, de Tewe, Karrau enzv., in de maanden septcmber met enkele onrijpe vruchten gezien. In de maand october vonden wij denzelven bloemdragend langs de oevers van de Kapoeas. Hier vertoonden de, van de oevers verwijderde boomen, tusschen hun groen loof, groote witte vlekken; gunstiger daarentegen waren de door de natuur minder bedeelde, aan de oevers groeijende gewassen voor de beschouwing. De Rassak stond hier in gezelsehap van eenige vijgenboomen. De laatste waren met een blinkend, helder groen loof en kleine roode vruchten voorzien; de eerste bezat een minder glanzig, donkerder groen, grootere bladen, en naar de uitcinden der takken en takjes aanzienlijkc bloempluimen, met talrijke witte bloempjes. Deze laatste versierden de kroonen, waarin zij in kleine leegten tusschen het loof geplaatst waren, of buiten hetzelve als pluimen wapperden, en veraangenaamden des avonds den omtrek door eenen liefelijken vanieljegeur, welken zij alsdan van zich vcrspreidden.

De Rassak behoort, even als de vermaagsehapte soort op het vasteland van Indië, tot de zeer harsrijke boomen. Deze hars is door den geheelen boom, zoowel in het schors- en bastgedeelte, als in het hout verspreid, als eene doorschijnende, licht gele of licht bruine, lijvige vloeistof. Als zoodanig vult zij een eigen vaatstelsel, dat, gebroken zijnde, zich in, door scheuring van vaten en eellen ontstane ruimten, of in gestipte vaten ontlast. De beweging dezer vloeibare stof is zoowel dalend als stijgend. Bij onze reis naar het bovengedeelte der rivier, had ik in eenen aanzienlijken Rassakstam eene inkapping. laten maken, ten einde de rigting en de hoeveelheid der vloeistof te kunnen bepalen: Op onze terugreis bezocht ik den boom weder, en nu bleek het, dat de harsige vloeistof vooral uit het bovenste gedeelte der insnede gevloeid was, en dat zij uit het benedenste gedeelte slechts in geringe hoeveelheid was Botanica. 
opgeweld. Minder gelukkig slaagde deze proef omtrent de hoeveelheid, waarom ik deswege alleen het gevoelen der inlanders kan mededeelen. Volgens hetzelve is de hoeveelheid zeer versehillend: bij vochtig weder is zij het aanzienlijkst, bij eene zeer drooge lueht het geringst. De vloeistof verhardt, bij hare aanraking met de lucht, tot eene half doorsehijnende, gele of bruine hars, door de Maleijers Dammar en door de inboorlingen $N$ jating of Njato genoemd. Deze hars is zeer broos, wordt beneden de warmte van kokend water week, en komt somwijlen als klompen van $9 \mathrm{~N}$. ponden en, volgens de opgave der inlanders, ook wel van $15 \mathrm{~N}$. ponden voor. Groote klompen heb ik aan den voet, of even boven den grond, uit groote spleten van den stam gevloeid, en kleinere stukken hooger aan den stam, uit kleine scheuren van denzelven, gevonden. Door de inlanders wordt de hars verzameld voor hun eigen gebruik of tot handelsartikel. $\mathrm{Z}_{\mathrm{ij}}$ bezigen dezelve fijngestampt en in palm- of banaanbladen gewikkeld, als fakkels om hunne woningen te verliehten, of fijngestampt en met olie vermengd, om liunne vaartuigen te kalefateren. Als handelsartikel brengen zij dezelve naar de kustplaatsen, vooral naar Banjermassing. Als zoodanig bekleedt deze hars, benevens andere harsige stoffen, naast den rotting, eene aanzienlijke plaats in den handel met Soerabaja. Haar prijs is zeer wisselvallig, en hangt op de plaats zelve veel van dien des rottings af: is deze gezocht, dan stijgt de prijs van den dammar, omdat het opzoeken van denzelven alsdan alleen aan kinderen wordt overgelaten, en de volwassenen zieh met het rotting zoeken en snijden bezig houden. In de Indisehe streken vervangt deze dammar de gewone terpentijn-hars en het pek, en is hij, als een vervanger dezer stoffen, zeer belangrijk. Voor de Europesehe markten, en dus als algemeen handelsartikel, zal hij gewis moeijelijk in aanmerking kunnen komen, omdat hij, door de, bij eene geringe warmte plaats hebbende weekwording, zich niet tot het maken van vernissen aanbeveelt, en het gebruik van denzelven, in plaats van gewone hars, door de meerdere kostbaarheid, welke het vervoer zoude veroorzaken, belet zal worden.

\section{RETINODENDRON PAUCIFLORUM. KHS。}

R. foliis oblongo-ovalibess obtuso-acuminatis basi acutis, inflorescentiâ racemoso-paniculatâ, stigmate capitato.

ARBor speeiosus; coronı aperta; ranI subteretes, griseo-fusei, glabri, foliorum cieatrieibus tuberculati; ranul subeompressi, fusei, sparsim lepidoti. Four oblonga vel oblongo-ovalia, breviter obtuseacuminata, basi aeuta, raro obtusiuseula, supra nitida, subtus sparsim lepidota, coriaeea, 5" lata, $13^{\prime \prime}$ longa; nervis primariis in angulo $45^{\circ}$, distantibus, 12 ad 16 , seeundariis et venis uti in praecedente speeie; petrour subteretes, supra eanalieulati, sparsim lepidoti, 1,5" longi. Gemrae compressae, obtusae, dense griseo-fusco-lepidotae. Inflonescentra axillaris, paueiflora; sparsim lepidota; pedunculus connunis compressus, saepe aneeps; pEDunculr eâdem formâ, alterna; peDrceul breves, $2^{\prime \prime \prime}$ longi, eompressi vel tetragoni. Bracteas ninutae, $1^{\prime \prime \prime}$ longae, ovatae, obtusiuseulae, intus glabrae, extus lepidotae. GaLtrx tubo basi rotundato, limbo quinquepartito, aestivatione subvalvata; partibus ovatis, breviter obtuse acuminatis, intus glabris, extus dense lepidotis. Coroula pentapetala, aestivatione eonvoluta, petalis lineari oblongis, subfalcatis, obtusis, extus sublepidotis, intus glabris, earnosis, 7"' longis, 2,5"' latis. Stamra eodem numero el dispositione praceedentis speeiei; ANTHERAE ovatae, locellis exterioribus majo- 
ribus, connexivo glandulâ acutiuseulà terminato. Ovariuni formâ et structurâ haud a praecedente diversum. Struus trisulcatus, glaber. Stigma eapitatum, apice truncatum vel subrotundum.

\section{Crescit juxta Indrapoera: Sunatra.}

Deze soort verschilt van de vorige door den minder langwerpigen vorm, de niet zoo talrijke en ook schuiner loopende nerven en de mindere beharing der bladen, door de kleinere bloemen, en den gaven, knopvormigen stempel, en wijkt door dit laatste kenmerk ook van R. laneeaefolium (Vateria Roxb.) af, bij hetwelk de stempel verdeeld of diep getand is. $\mathrm{Zij}$ levert vermoedclijk een gedeclte van den dammar of hars, die in de omstreken van Indrapoera verzameld wordt.

\section{DipteroGarpus. Gaertier, Roxburgh, Buume, enzy.}

De kenmerken, door den Hoogleeraar Blume in de Flor a Javae opgegeven, bepalen zeer juist de gewassen, welke in het geslaeht Dipterocarpus moeten geplaatst worden. Zij sluiten het geslaeht Dryobalanops uit, hetwelk de Heer Lindley met Dipteroearpus vereenigt $\left(^{\star}\right)$. Bij Dryobalanops zijn de deelen van den kelk alle tot gelijkvormige, langwerpige slippen uitgegroeid, en ontstaat, door de afwijkende nervuur der bladen en ook door de gedaante der nevenblaadjes, welke veel overeenkomst met die van Retinodendron bezitten, een geheel ander aanzien. Even zoo verwijderen zij het geslacht Caryolobus Gaertner $(t)$, hetwelk tot dusverre alleen door de vrueht bekend is en waarschijnlijk nabij of tot Hopea of Vatiea behoort (\$).

\section{DIPTEROCARPUS BAUDII. Kus.}

D. foliis obovatis aeuminatis basi subeordatis supra in nervo mediano subtus in nervis stellatim pilosis, gemmis lineariablongis obtusis compressis pilosis, calycis fruetiferi partibus majoribus oblongo-linearibus obtusis sparsim pilosis.

Arвor excelsa, saepe alta 36 metrarum; truncus reetus, fere eylindrieus, cortiee albeseente, lacvi raro rimoso, ligno flaveseente demum fusco, valde resinoso; conona hemisphaeriea, basi truneata; RAMI patentes, teretes, glabriusculi, fusei, saepe fureati; rusruu subteretes, annulati, fusei, flavo-hirsuti, setis fasciculatis; ranul novelui compressi, densissime flaveseente-hirsuti. Folia obovalia, obovata, vel ovalia, breviter acuminata, basi obtusa vel subeordata, undulata; juniora supra in nervo mediano dense et in superfieie sparsim pilis longis, simplieibus tecta, subtus in nervis mediano et primariis dense pilosa, et in nervis seeundariis pilis stellatis teeta; adultiora supra in nervo mediano dense pilosa, subtus in nervo mediano et in nervis primariis faseieulatim-pilosa, et in nervis secundariis et venis stellatim-

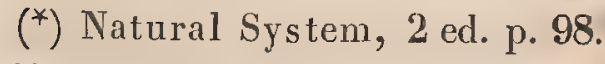

( $($ ) Gaertner, de fructibus et seminibus plantarum, p. 215, tab. 45.

$(\$)$ In de dertiende aflevering der Genera van den Heer Endlicher, welke ik bij het ter perse leggen van dit blad ontving, heeft deze Sehrijver, op bl. 1014, de Lophira onder den naam Lophiraceae, aan het einde van de familie der Dipteroearpeae geplaatst. 
pilosa; coriacea, $2 I^{\prime \prime}$ longa et $12^{\prime \prime}$ lata, nervis mediano et primariis prominentibus, posteris eum primo saepe in angulo $45^{\circ}$ ad $55^{\circ}$, paulo a margine ineurvis, nervis seeundaris subparallelis approximatis, venis reticulatis; PETIOLI semi-teretes, supra plani, dense pilosi 3" longi. GennaE lineari-oblongae, obtusae, subeompressae, pilis longis faseiculatis, et granulis munitae, intus glabrae: GEMrrat florum subteretes, acutiusculae. Inflorescentra axillaris, centri-peta; pedunculds cominums 5 ad 8 florus, flexuosus, basi subteres, pilis flavis longis faseiculatis, parte floriferâ eompressus, pilis eanis brevioribus adpressis; PEDUngul subdistichi, breves, pilosi; galyx tubo campanulato, intus infra faucem glabro, extus dense pilis stellatis tecto; limbo dense piloso, inaequale quinque-partito, partibus tribus minoribus obtusis, ct duabus majoribus linearibus, obtusis vel acutiusculis, saepe in medio subcarinatis, aestivatione plieato-valvata. Conolla pentapetala, aestivatione convoluta; petala basi in tubum eonvoluta, apice rotatim patentia, oblonga, obtusa, basi angustata; intus glabra, extus pilis stellatis, earnosa, rosea. Stamina indefinita saepe 30 , biserialia, basi coalita, ante anthesin versus apices eontorta; filanenta linearia, carinata, glabra; ANTHERAE lineares, loeellis subaequalibus, ab apice ad basin dehiseentibus, connexivo apice in subulam sat longam, et basi in appendicem linearem bi-auriculatum producto, in filamento articulato. Ovariun hemisphaericum, versus apicem attenuatum, dense pilosum, triloeulare; ovula geminata, subcollateralia, descendentia, paulum infra verticem affixa, oblonga, dorso rotundata, lateribus planiuseula, ventre earinata, basi rotundata; struus subteres, pilosus; stigma simplex. Fructus induviatus calyee cum tubo subgloboso, basi rotundato, piloso et cum limbo inaequaliter partito, partibus tribus minoribus subrotundis, obtusissimis, duabus majoribus oblongo-linearibus, obtusis, asperis, sparsim pilosis, coriaceis, saepe $20^{\prime \prime}$ longis, 2,5" latis, trinerviis et retieulato-venosis; ovö̈deus, versus apicem attenuatus, basi subrotundus, parte inferiore pilis longis et supèriore pilis brevioribus munitus; epicarpio eoriaceo, sarcoearpio fibroso, cndocarpio subeartilagineo, fragili; abortu unilocularis; PARS PLAGENTARIS vel pars remanens axis ovarii pariete fructus arete adpressa linearis. SEnIEv eavitatem fruetus complens, fere ovö̈deum, inversum, glabrum; TESTA subcoriacea, fusea; mesospermium tenue cum quibusdam vasis resinâ impletis; TEGMIEN membranaecum; HIUUı mieropylae approximatum, ehalazae fere oppositum; rapué in uno latere seminis partita et anastomosata. Albunien nullum. Eurryo erectus; radicula subteres, partim inter cotyledones reeondita; coTYLEDones implieato-eonvoluti, arete eohaerentes.

\section{Crescit in sylvis Melintang: Sumatra.}

Tab. 5. 1. Gemma floris. 2. Flos ante anthesin calyce ablato. 3. Petalum. 4. Stamina calyce et corollâ ablatis. 5. Tria stamina introrsum visa, medium ad seriem interiorem pertinet. 6. Sectio transversalis antherae. 7. Pars endothecii valde aucta. 8. Ovarium. 9. Sectio longitudinalis ovarii. 10. Sectio transversalis cjusdem. 11. Ovulum verticaliter sectum. 12. Ovulum adultius verticaliter sectum cum Embryonc juvenili. 13. Fructus cum calyce excreto. 14. Fructus, partim denudatus. 15. Semen fructus parte cinctum. 16. Sectio longitudinalis seminis. 17. Fasciculus pilorum. 18. Pars folii aucta. 19. Pars petali aucta.

Onder de talrijke door ons, op de westelijke helling van het beoosten Padang gelegen gebergtc, verzamelde gewassen, is de hierboven besehreven boom een der sehoonste en aanzienlijkste. Hij bezit niet zelden stammen van dertig ellen, bereikt met zijne groote, uitgebreide kroonen zes-en-dertig ellen hoogtc, en is door de groote, glanzige bladen en lelievormige bloemen van de hem omringende eiken onderscheiden. 
Met dezen maakte hij, op enkele minder hellende plaatsen, den hoofdboom van het bosch uit, of groeide in gezelschap langs de kleine bergbeken, tot op eene hoogte van ongeveer 800 ellen.

Daar hij tot dusverre in het wetenschappelijk stelsel onbekend was, heb ik, bij zijne benoeming, de gewenschte gelegenheid te baat genomen om eenen naam te huldigen, die ieder, wien de bevordering en uitbreiding der kennis van de gesteldheid en voortbrengselen der Nederlandsch-Indische gewesten ter harte gaan, belangstelling inboezemt, en om tevens opentlijk eenen verschuldigden dank te brengen aan Zijne Excellentie, den Heer J. C. Baud, thans Minister van Marine en Koloniën, vroeger Gouverneur-Generaal der Nederlandsche Oost-Indische bezittingen, als goedgunstig beschermer van de natuurkundige Commissie in die gewesten.

\section{DIPTEROCARPUS TRINERVIS. BL.}

D. foliis ovalibus aeutiusculis basi subrotundatis gemmisque linearibus attenuatis glabris, calycis fructiferi laciniis majoribus oblongo-laneeolatis obtusis, minoribus ovatis obtusis.

Blume, Catalogus Horti Bogoriensis, p. 78; Verhandelingen van het Bat. Genootschap, IX. p. 178; Bijdr. tot de Flora van Neêrlandseh-Indië, p. 223; Flora Javae, fasc. VIr.

\section{Crescit in silvis montanis: $\mathrm{J}_{\mathbf{A V A}}$.}

Deze soort, welke in de Flora Javae afgebeeld en beschreven is, werd tot heden alleen op Java gevonden, en groeit daar, met de aan haar verwante Dipterocarpus retusus, Bl., in de bosschen van den Salak, Probakti, Gédé enzv., tusschen eene hoogte van 600 en 1200 ellen. In deze groeiplaatsen bereikt zij, even als de verwante soort, niet zelden bij eenen omvang van vijf tot zes, eene hoogte van 40 Nederlandsche ellen, en verbergt zij hierdoor hare wijd uitgespreide, naar den omtrek digt met bladeren voorziene kroonen, boven en tusschen het loof van de andere boomen.

Al de soorten van Dipterocarpus zijn bij de Sundanezen onder den naam $\boldsymbol{P}$ alaglar bekend $\left(^{\star}\right)$. Behalve dezen geslachtsnaam heeft iedere soort, voor zoo ver zij dezelve onderscheiden, nog eenen tweeden naam. De D. trinervis wordt door hen Palaglar Mienjak genoemd - Mienjak beteekent olie of vet wegens de aanzienlijke hoeveelheid balsem, die bij eene inkapping uit het hout vloeit. Deze vloeistof

$\left(^{*}\right)$ Het woord Palaglar kan met vleugelvrueht vertaald worden. Het bestaat uit de woorden Pala en Glar: het eerste is mij als Sanskrit bekend, en beteekent vrucht; het andere, vermoedelijk nit dezelfde taal afkomstig, vertaal ik door vliegen: om de daarin voorkomende bewegende, verwijderende $g$, de zwevende $l$, en de eindsyllabe ar, welke, volgens Hamaker, uit $r^{\prime} i$, bewegen, ontstaan is. Voor de beteekenis van het tweede woord, zoude ik nog het latijnsehe volare, dat zeker met glar verwant is - de $g$ gaat toeh dikwerf in $v$ over: men denke aan het hollandsche ga en het fransche va - kunnen bijbrengen. - Wat het woord Pala betreft, dit is bij de Maleijers, voor vrueht minder in gebruik. Zij zeggen hiervoor meestal Boea, hetwelk van het Sanskrit Boe, zijn of worden, afkomstig is. Aan hetzelve is $P_{a l a}$, naar den dichterlijken geest der Oostersche talen, verwant. Dit toch bestaat uit de woorden: $P_{a}$, hetwelk door verkorting uit Boea ontstaan is, en uit de zwevende $l$, en kan dus besehouwd worden, als een zwevend zijn of worden te kennen gevende. Kan men de vrueht, welke de kiem insluit, dichterlijker aanduiden? 
verhardt door de aanraking met de lueht tot eene licht gele, bij eene geringe warmte week wordende hars. Als zoodanig wordt deze zelfstandigheid door de inlanders verzameld en tusschen palmbladen gewikkeld, om als flambouwen te kunnen dienen. Deze flambouwen geven bij het branden eenen aangenamen geur, en worden, volgens het zeggen der inlanders, om die reden met voorkeur gebezigd, bij het wegnemen van de eetbare nesten der zwaluwen uit de holen van het kalkgebergte.

Behalve in de bossehen, heb ik deze soort ook in den tuin van Buitenzorg, waar zij in 1823 door den Hoogleeraar Blume was overgebragt, waargenomen. Zij groeide hier zeer welig en had, in 1836, eene hoogte van twaalf ellen. Omstreeks junij van dat jaar vielen hare bladen, meer dan in vroegere maanden af en ontwikkelden zieh de eerste bloemen. Zij waren niet zeer talrijk. Haar lieht rozenroode tint en tamelijk groote lelieaehtige vorm behaagden niet minder aan het gezigt, dan de heerlijke vanieljegeur, welken zij des avonds en des morgens uitwasemden, aan den reuk. Zeer kortstondig versehaften zij dit genot: want twee of hoogstens vier dagen na de opening, vielen de meeste bloemen geheel en van enkelen alleen de bloemkroonen af. Hierdoor bleven er aan iederen tros een of twee vruehtbeginsels ter rijping over.

\section{DIPTEROCARPUS LITTORALIS. BL.}

D. foliis ovalibus acutis basi subcordatis ad costam utraque pubescentibus, gemmis elongato-conicis sericco-villosis, calycis fructifcri laciniis majoribus clongato-lanceolatis obtusis vel acutis. (Ramuli glabri).

Blume, Bijdr. p. 224. Flor. Javae 1. c. p. 17. Tab. IV.

\section{Crescit ad flumen Tjiboebaloekan: J⿳VA.}

Door den Heer Blume, en ook later door mij, werd deze soort aan het zuiderstrand van Java, in eene standplaats gevonden, die zeker hare oorspronkelijke niet is. $\mathrm{Z}_{\mathrm{ij}}$ behoort veeleer aan de zuidelijke afhellingen van den 2300 ellen hoogen Papandayang of aan den 3000 ellen hoogen Tjikoerai, waar het stroomgebied van den Tjiboebaloekan, of wel aan den zuidelijk afdalenden voet van den Tjerimai, waar de Tjitandui als bergstroom zijnen oorsprong heeft, en is vermoedelijk alleen aan de monden dezer rivieren, door de naar dezelve afgespoelde vruchten, voortgekomen.

\section{DIPTEROCARPUS ELONGATUS. Kнs.}

D. foliis ovalibus acutis basi obtusis, gemunis lineari-oblongis hirsutis vel pilosis. (Ramuli dense hirsuti.)

ARвоr adulta speeiosa, eoronâ expansà, junior eoronâ oblongâ. RAmr arboris junioris teretes, glabri, fusei; ranulr novelli dense fuseo-pilosi; adultiores faseieulatim pilosi. Foura arboris junioris ovalia, vel ovali-oblonga, breviter aeuminata, basi rotundata vel subeordata, undulata, supra glabra, subtus praesertim in nervo mediano et primariis prominentibus dense pilosa, pilis adpressis, eoriaeea, $60^{\prime \prime}$ longa, $18^{\prime \prime}$ lata; реттоц semi-teretes, supra plani, dense pilosi, 2" ad $6^{\prime \prime}$ longi: roura arboris adultioris latiora, 
rigidiora. Gemma lineari-oblongac, subcompressae, fusco-pilosae. Strpulae lineari-oblongae, obtu siusculae, intus glabrae, saepe $30^{\prime \prime}$ longae, admodum deciduae.

\section{Crescit ad flumen Baritto, et in monte Sakoembang: Bonneo.}

Deze soort, welke zeer na aan D. littoralis, Bl. verwant is, kan van dezen, door de digte beharing der jonge takken en door de meer uitstekende nerven der bladen, gemakkelijk worden onderscheiden. De door ons gevondene planten waren aan de Poenin-rivier, een' zijtak van de Baritto, vermoedelijk uit afgespoelde zaden opgekomen, en bevonden zich aan den berg Sakoembang in hare natuurlijke standplaats.

\section{DIPTEROCARPUS TAMPURAU. KHs.}

D. foliis oblongo-ovalibus breviter acuminatis subcordatis supra subtusque praesertim margine pilosis, gemmis dense pilosis, laciniis majoribus calycis fructiferi oblongo-linearibus et minoribus subrotundis obtusis.

Arbor excelsa, saepe 30 ad 35 metrarum alta; Truncus rectus, cylindricus; eortice sat crasso, fuscogriseo, laevi, raro rimato tectus; conona ampla, hemisphaeriea, basi truneata; RAsI patentes. FouIA oblonga vel oblongo-ovalia, breve acuminata, basi obtusa vel subcordata, margine integerrima vel subcrenulata, supra nitida, sparsim pilosa, in nervo mediano et subtus in eodem et in nervis primariis stellatim pilosa, $20^{\prime \prime}$ longa, $9^{\prime \prime}$ lata, eoriacea; nervis primariis in angulo $70^{\circ}$ ad $80^{\circ}$, secundariis subparallelis. Strpulae oblongo-lineares, obtusiusculac, intus glabrae, extus dense fusco-pilosae, subeoriaceae, 11" longae, 1,5" latae, 8 ad 10 nerviae. CAlxx exeretus, tubo fructum circumdante subgloboso, basi rotundato, vel depresso, glabro; limbo inaequaliter quinquepartito, partibus duabus majoribus oblongo-linearibus, obtusis vel retusis, glabris, eoriaeeis, trinerviis, $13^{\prime \prime}$ longis, $3^{\prime \prime}$ latis; partibus tribus minoribus subrotundis, obtusissimis, glabris, eoriaeeis, $2^{\prime \prime}$ longis, 1, $5^{\prime \prime}$ latis. Fructus ovoïdeus basi rotundatus, in vertieem attenuatus, parte inferiore glaber, parte superiore dense adpresse-pilosus, abortu monospermus, caetera et seminis forma et struetura haud a Dipterogarpo Baunil diversae sunt.

\section{Crescit ad flumen Baritto: Bonneo.}

De boven beschrevene soort versehilt van $\mathbf{D}$. trinervis door de behaarde knoppen; van D. Baudii door de meer verlengde gedaante der bladen en het stomper einde der groote kelk-slippen, en van D. retusus door de spitser toeloopende noot.

Zij is, bij de bevolking van Banjermassing en van de binnenlanden, onder den naam Tampoerau bekend. Het is mij echter gebleken, dat deze naam wel in het bijzonder, maar niet uitsluitend op haar wordt toegepast, dewijl ook andere boomen met sterk geribde bladen, Dilleniaceae, mij onder de benaming Tampoerau zijn aangeduid. D. Tampurau groeit vermoedelijk in het gebergte, dat het groote stroomgebied van de Baritto begrenst, en is, even als D. elongatus en D. littoralis, alleen uit afgespoelde zaden langs den Baritto-stroom opgekomen. Hij is hier niet zeer menigvuldig, en werd door ons voornamelijk in de nabijheid van den mond der, uit het oosten komende en in de Baritto vallende Karrau-rivier waargenomen. Op deze groeiplaats stond hij in gezelschap van Myrtaceae, Anonaceae enzv. 
Door eene aanzienlijke hoogte, soms van 30 cn mcerdere $\mathbf{N}$. ellen, verhief hij zich boven deze hem omringende gewassen, cn reeds in de verte waren zijne regtstandige stammen en de, bij onzen riviertogt in september, bijna bladerlooze kroonen duidelijk te onderscheiden.

Door dit gemis van bladeren werden wij te spoediger op de oorzaak der algemeene bekendheid dezer boomen opmerkzaam. Hunne kroonen droegen eene menigte verspreide klompen, welke, volgens de mededeeling der inboorlingen, door eene kleine soort van bijen vervaardigd worden. Het schijnt, dat die diertjes bij voorkeur deze, doch bij gemis derzelve, ook andere hooge boomen, zoo als Parkia, Elaeocarpus enzv., tot hunne verzamelplaats kiezen; misschien om hunne woning des te gemakkelijker terug te kunnen vinden, of wel om zich tegen de roofzucht van hunnen vijand, den maleischen beer, te beschermen. Aan de Karrau had iedere Tampoerau zijnen eigenaar, en werden deze boomen als eene zeer voordeelige bezitting en aanzienlijke crfenis beschouwd. Ieder derzelve leverde jaarlijks, volgens de opgave der inlanders, voor 5 tot 10 en soms meerdere gulden aan honig cn was op. Ter verkrijging van deze hoog geplaatste voordeelen, bedienden zich de eigenaars van ladders, die tot in de kroonen reikten; eenige dezer ladders hadden sporten, van welke het eene einde in den boom geslagen cn het andere aan een' uit de kroon nederhangenden rotting verbonden was; anderen waren alleen van rotting vervaardigd en hingen geheel vrij uit de kroonen af. In weêrwil dezer hulpmiddelen ter bestijging, kon ik geene takken verkrijgen, omdat aan den een' mijner begeleiders de beklimming, als eene schennis van het regt van eigendom, verboden, en aan den ander' de verontrusting der' bijen, welke aan zekere personen gewend zijn, een te gevaarlijk en zeker niet ongcwroken waagstuk toescheen. Ten einde dus de denkbeelden der inlanders, wier goedc gezindheid bij de voortzetting van onzen togt zoo noodig was, niet te kwetsen, vergenoegde ik mij, met de onder de boomen gelegene vruchten en bladen te verzamelen.

\section{DIPTEROCARPUS MARGINATUS. KHs.}

D. foliis oblongo-ovalibus acuminatis basi obtusiusculis margine pilosis, gemmis teretibus obtusis dense pilosis.

Arbor, fide indigenarum, speciosa, ampla, trunco recto, griseo, coronâ expansâ. - Arbuscula 10 pedalis; TRurcus rectus, cylindricus, laete fuscus; corona semi-ovoïdea, dense foliata; rani teretes, annulati, glabri, griseo-fusci; RAmuLr teretes, annulati, dense fusco-pilosi, pilis caducis, fasciculatis, longis. Folia oblongo-ovalia, acuminata, basi obtusiuscula vel cordatim emarginata, coriacea, 30" longa, $8^{\prime \prime}$ lata, nervo mediano et nervis primariis prominentibus; juniora margine, supra in nervo mediano, subtus praesertim in nervis dense pilosa; adultiora fere glabra; PETIOLI subteretes, prope foliorum basim incrassati et articulati, dense pilosi, $3^{\prime \prime}$ longi. Gemrne teretes, obtusae, fusco-pilosae. Strpulae lineares, obtusiusculae, intus glabrae, extus pilis fasciculatis vestitae, 8" longae, 7"' latae, 3-4 nerves, deciduae.

Crescit in monticula Bahai: BonNe.

Alleen op den, uit eene jonge tertiaire formatie bestaanden heuvel Bahai, werd deze soort door mij als kleine boompjes gezien. $\mathbf{Z}_{i j}$ is, volgens het zeggen der inlanders, zeer menigvuldig op de meer van de 
rivier verwijderd gelegene bergreeks, van welke de Bahai een voorgebergte vormt, en was op de Bahai verdwenen, ten gevolge van het menigvuldig gebruik der houtskolen van deze boomen, voor de nabijgelegene ijzersmelterijen. Voor het branden van dezelve kiezen de inlanders bij voorkeur het hout dezer boomen: waarom? dit durf ik niet beslissen; alleen is het mij niet onwaarschijnlijk voorgekomen, dat de eigenschap, welke dit hout bezit, van eenige dagen na de omkapping reeds tot kolen gebrand te kunnen worden, tot deze voorkeur veel kan bijdragen.

\section{DIPTEROCARPUS HASSELTII. Bu.}

D. foliis ovalibus ovatisve acutiusculis basi obtusis utrinque, gemmis cylindricis attenuatis glabris, calycis fructiferi laciniis majoribus oblongis obtusis, minoribus obtusis.

BI. Flora Javae 1. c. p. 22. Tab. VI.

Calrx tubo eampanulato, basi quinque sulcato, intus et extus glabro; limbo dense pubescente inaequaliter quinque-, raro sexpartito, partibus minoribus tribus vel quatuor triangularibus, acutiusculis; majoribus lincari-oblongis, obtusis, dense pubescentibus, excrescentibus. CoRoLLA pentapetala, basi petalorum approximatione tubulosa, limbo rotato, petalis obovale-oblongis, obtusis, saepe falcatis, intus glabris,

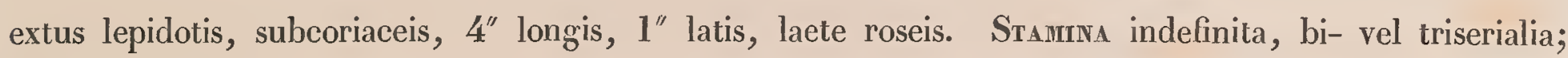
FILAMEENTA linearia vel oblongo-linearia, glabra; ANTHERAE lanceolatae, locellis inaequalibus, interioribus paulo brevioribus; connexivo apice in subulam pubescentem et basi in appendicem linearcm, biauriculatam producto. Pollen sphaericum. Ovariur sessile, subtrigonum, attenuatum, pubescens, triloculare, loculis biovulatis; ovula subcollateralia; struts subteres, pubescens; strgma trunealum. CAetrera in Flora Javae descripta.

\section{Crescit in provincia Bantam: $\mathbf{J}_{\Lambda \mathrm{V} \mathbf{\Delta}}$, et ad montes Pamatton et Balaran: Borneo.}

Deze soort is het cerst door van Hasselt, in de residentie Bantam op Java, gevonden en nu ook door ons op Borneo, aan den berg Pamatton, op 50 ellen, en aan den berg Balaran, tusschen 100 en 600 ellen, aangetroffen. Het is tot dusverre dc eenige soort van deze familie, welke op de beide eilanden werd waargenomen.

\section{A NISOPTERA. Kns.}

CaLrx semi-superus, quinque partitus; partes omnes admodum cxerescentes, duac in alas foliaceas expansae. Corolla pentapetala, aestivatione convoluta. Stanrma 25, biserialia; firantenta basi coalita; ANTHERAE oblongac, locellis inaequalibus, cxteriores longiores, connexivo in laminam acuminatissimam producto. Ovariur calyce coalitum, triloculare; ovous geminata, subcollateralia, descendentia; struus subtcres, crassus; stigmata tria. Froctus calyce excreto cinctus, abortu unilocularis. Semeir unicum fructus cavitatem explens; TESTA subcoriaeea; TEGNIEN membranaceum. EMTRRTo erectus, radiculà terete, cotyledonibus inaequalibus, involutis. 
Arbores. Folis oblonga, coriacea, nervosa. Strpulat liberae, minutae. Flores axillares, paniculati, albidi.

Hct geslacht Anisoptera bevat drie zeer verwante soorten. Eene derzelve behoort tot de door Zippelius op de zuid-westkust van Nieuw-Guinea verzamelde gewassen, en is door dien ijverigen Kruidkundige als Dipterocarpus parviflorus beschreven $\left({ }^{\star}\right)$. De beide anderen zijn door ons in de gebergten van het zuid-oostelijk gedeelte van Borneo gevonden. Zij groeiden daar, van eene slechts weinig boven zee verhevene hoogte, tot op ongevecr 300 ellen, en behoorden tot de in gezelschap wassende boomsoorten. Door hare groeiwijze zijn zij aan Dipterocarpus en Dryobalanops verwant; door hare kenmerken echter van dcze beiden genoegzaam onderscheiden. Van de soorten des eerstgenoemden geslachts verschillen die van Anisoptera door den vorm en de groeiwijze der nevenblaadjes, des kelks, der bloemkroon, der stuifdraden, en door de zaamgroeijing van een gedeelte der vrucht met den uitgegroeiden kelk. Van Dryobalanops wijkt Anisoptera af door de vruchten, vooral door den vorm van den uitgegroeiden kelk.

\section{ANISOPTERA MARGINATA. Kus.}

A. foliis oblongo-ovalibus acutiusculis basi obtusis glabris, nervis distantibus.

Arbor speciosa; rami teretes, fusci, glabri; ramrulr compressiusculi, fusco-leprosi. Foura ovalia vel oblongo-ovalia, acutiuscula, basi obtusa, truncata vel subcordata, utraque glabra - juniora subtus pubescentia - coriacea, 4,5" lata, 8,5" longa, nervis primariis prominentibus, distantibus, nervis secundariis reticulatis; petioli $1,5^{\prime \prime}$ longi, subtetragoni, glabriusculi. Geminat ovatae, acutae, pubescentes. Inrlorescentia axillaris, paniculata; pedurculus connunrs compressus, fusco-pubescens; PEDUNculr partiales et pedraelur subdistichi, alterni, obscure trigoni vel tetragoni, dense pilosi. Calyx profunde quinque-partitus; partes triangulares, acutac, cxtus dense pilosae, intus glabrae, 3,5"' longae. Corouts pentapetala, aestivatione convoluta; petala obovata, obtusiuscula, integerrima, intus glabra, extus partim pubescentia, membranacea, nervis palmatis. STAлrrma 25, biserialia, saepe in serie exteriore 10; in serie interiore 15; FInAIENTA oblongo-linearia, basi coalita, glabra, brevia; ANTHERAE oblongo-ovatae, pubescentes, locellis inacqualibus, exterioribus longioribus; connexivo in lamine acuminatissimo, producto; Polder sphaericum. Ovariur semi-inferum, hemisphaericum, quinque sulcatum, pubescens, triloculare; ovulı geminata, descendentia, subcollateralia, infra verticem affixa. STruus crassus, teres, pubescens; strgirata tria, filiformia, patentia.

\section{Crescit in montem Pamatton: BoRveo.}

Tab. 6. $1^{\text {a }}$. Gemma floris. $2^{\text {a }}$. Flos apertus. $3^{\text {a }}$. Flos vi expansus. 4a . Petalum. 5a . Flos, calyce et corollâ ablatis. 6 ${ }^{a}$. Stamen postice visum. $7^{\mathrm{a}}$ et $8^{\mathrm{a}}$. Stamina antice visa. 9a. Pollen. $10^{\mathrm{a}}, 11^{\mathrm{a}}, 12^{\mathrm{a}}$. Endothecium. $13^{\mathrm{a}}$. Symetria floris.

(*) De Hoogl. Blume heeft, gelijk ik in het Herbarium van Zippelius heb gezien, bij Dipterocarpus parviflorus Zipp. de aanmerking gevoegd, dat dezelve een nienw geslacht kon vormen. 


\section{ANISOPTERA COSTATA. KHS.}

A. folins ovalibus breve acuminatis basi obtusis subtus pubescentibus, nervis approximatis.

Arbor speciosa; conona conica, aperta; Truncus rectus, cylindricus, cortice griseo tectus; Ram patentes, subteretes, glabri; Ramuli compressi, angulati, pubescentes. Foura ovalia, vel obovalia, breviter acuminata, basi obtusa vel subcordata, supra nitida, subtus pubescentia, coriacea, $7^{\prime \prime}$ lata, $13^{\prime \prime}$ longa nervis primariis patentibus, parallelis, prominentibus; petıoLI subteretes, pubescentes, 2,5" longi. Infioresaentia axillaris, paniculata; pedunculus cominunis et PeDUnaui. partiales compressi, dense pilosi; PEDICelli teretes, pilosi, breves. CALYX profunde quinque-partitus, partibus ovatis, acutiusculis, extus dense pubescentibus, intus glabris. Corolla mihi deëst. Stamina 25; biserialia; filamenta linearia, basi latiora, connata, glabra; ANTHERAe ovato-oblongae, pubescentes, locellis inaequalibus, exterioribus longioribus, connexivo acuminatissimo. Ovarium ad dimidiam partem calyce coneretum, hemisphaericum, pubescens, triloculare; ovulA geminata, subcollateralia, descendentia; sTruUs subteres, glaber; stignata tria, filiformia, patentia. Calrgis excreti tubus hemisphaerieus et limbus inaequaliter partitus; partes duae majores lineari-oblongae, obtusae, et tres minores oblongae, acutiusculae; omnes trinerves, pubescentes. Fruatus calyeis tubo concretus, stylo coronatus, hemisphaericus, pubescens, abortu unilocularis, monospermus. SEnev immaturum cavitatem fructus explens, subglobosum; TESTA subcoriaceo; tEGMen membranaceum. EMbryo erectus; radicula teres, acuminata; cotyledones inaequales reniformes.

\section{Crescit in montem Sakoembang: BoRneo.}

Tab. 6. Figura speciei. 1. Ovarium, integumentis floralibus ablatis. 2. Ovarium verticaliter sectunı. 3. Ovulum. 4. Ovulum juvenile cum raphe libera. 5. Ovarium adultius verticaliter sectum. 6 et 7. Fructus verticaliter sectus. 8. Semen. 9. Embryo.

\section{DR Y OBA L A NOPS. Gaertier, Colebrooke, W. Jack.}

CALYX monophyllus, quinque-partitus, laciniis lineari-lanceolatis, patentibus. Corolla pentapetala, petalis basi junctis, ovato-lanceolatis, calyce longioribus. STamina hypogyna plurima, monadelpha, longitudine fere calycis; fILAHENTA in annulum brevem coalita; ATTHERAE conniventes, supra tubum filamentorum subsessiles, lineares, acutae, mucrone membranaceo, biloculares. Ovarium superum, ovatum, in stylum attenuatum, triloculare; loculis biovulatis; struUs filiformis; sTIGMA capitatum(W. JAGK). Galyx fructifer liber, tubo cupulari, limbo in alas quinque foliaceas, aequales, multinerves. Capsula cupulae calycinae semi-immersa, unilocularis, trivalvis, monosperma. SEmen inversum, fructum explens. Enвryo exalbuminosus, erectus; cotyledonibus inaequalibus, contortuplicatis, partem remanentem axis fructus amplectentibus, subcarnosis; plumulâ conicà ; radiculâ teretiusculâ.

Arbores. Folia alterna vel opposita, coriacea. Stipulae caducae. Flores paniculati, terminales vel axillares. 
IIet geslaeht Dryobalanops werd door Gaertner (de Fructibus III. pag. 49. T. 186. f. 2) gevormd naar eenige vruchten, die in de verzameling van den Engelschen Maecenas der Kruidkunde, J. Banks, voorhanden en als van Ceylon afkomstig opgegeven waren. Colebrooke nam hetzelve bij zijne beschrijving van den Kamferboom (Asiat. Research. XII. p. 536) aan. Door anderen, welke niets meerder van de plant kenden, werd het niet aangenomen; door Roxburgh tot Shorea (Vatica L.), en door Lindley tot Dipterocarpus gebragt. W. Jack, gelegenheid gehad hebbende om niet alleen de vrucht, maar ook de bloemen te onderzoeken, vereenigdc zich met het gevoelen van Gaertner, en leverde eene beschrijving van de vroeger onbekende bloemdeelen, welke ik onder het bovenstaande kenmerk heb medegedeeld (W. Jack in Hooker, Companion to the Botanical Magazine I. pag. 364). Dat kenmerk toont aan, dat Dryobalanops genoegzaam van Dipterocarpus en ook van Anisoptera onderscheiden is en tot deze geslachten staat, als Vatica tot Hopea. In hetzelve heb ik, voor hetgeen Gaertner Columna centralis, en de Ileer Endlicher (Genera n. 5393) Raphe crassiuscula noemt, de uitdrukking pars remanens axis fructus gebezigd; omdat deze den aard van dit deel, de onuitgegroeide middelzuil, waaraan de wanden in hel vruchtbeginsel verbonden zijn, en waardoor de voedingsvaten naar de eitjes gaan, volkomen uitdrukt $\left(^{\star}\right)$.

\section{DRYOBALANOPS CAMPIIORAE. Colebrooke.}

D. foliis ovatis obtuse acuminatis basi obtusis subtus glabriusculis, stipulis ovatis acutis.

$$
\text { Crescit prope Ayer Bangis, etc.: Sumatra. }
$$

Deze plant is het eerst door H. N. Grimm, gedurende zijn verblijf ter westkust van Sumatra, uit een wetenschappelijk oogpunt nagegaan, en in 1683 door eene beschrijving en ruwe, maar toch kenschetsende afbeelding, bekend gemaakt (Ephem. Acad. Natur. Curios. Dec. II. pag. 371). Van dezelfde streken werd zij door Macdonald als eene soort van Laurus beschreven (Asiat. Research. IV). Vervolgens maakte zij het onderwerp uit eener verhandeling van Colebrooke, waarbij eene beschrijving van den boom en van de vrucht werd medegedeeld, en deze laatste, benevens een tak, vrij juist afgebeeld. De gedaante der nevenblaadjes, aldaar als lijnvormig toegespitst aangeduid, zijn op de door mij geziene voorwerpen eivormig puntig. - Bij dat bekende, voegde W. Jack (Malayan Miscellanies, overgenomen in Hooker Comp. to the Botan. Magaz. I. p. 264 enzv.) de beschrijving van de nog onbekende bloemdeelen, onder bijvoeging, dat deze plant in dezelfde familie met Dipterocarpus, Shorea, behoorde.

Volgens de reeds bekende en de mij door den Heer Osthoff medegedeelde berigten, groeit deze boom benoorden Ayer Bangis, tegen den voet der bergketen, als gezellig gewas, hetwelk eene aanzienlijke hoogte en eenen geëvenredigden omvang bereikt. Hij schijnt mij toe, naar de mededeelingen van dezen Heer, met dezelfde soorten van gewassen vereenigd te zijn, als de Dipterocarpus Baudii, bij Padang, en dus dezen in de noordelijker streken te vervangen.

${ }^{*}$ ) Bij Anisoptela costata, pl. 6, fig. 5, is deze kolom zeer duidelijk afgebeeld. 
De jongere boomen heb ik, door de gocdheid van de Ileeren Franeis en van der Linden, van Ayer Bangis bekomen, en naar den tuin van Buitenzorg kunnen overbrengen. Zij groeiden daar zoo welig, dat zij in een jaar ruim anderhalve palm in lengte toenamen. Behalve dezen, zag ik in den tuin van den Heer van der Linden, welke bij Padang, zeer weinig boven zee verheven is, ongeveer 7 ellen hooge boompjes, met eene aanzienlijke groeikraeht. Deze boompjes hadden regt opgaande stammen, door eene min of meer donker bruine sehors bedekt, piramidenvormige kroonen, met naar den top allengskens korter wordende takken, en van onderen grijs-groen gekleurde, eivormige, toegespitste bladen. - Volgens de mij dienaangaande gegevene berigten, wordt de opsporing dezer boomen, ter verkrijging van den kamfer, door gebeden en offeranden aan den grooten geest, voorafgegaan. Bij dezelve vervult de Toengoe-nyr-kapoer, welke meestal ook de offeraar is, eene aanzienlijke rol. Deze wordt, volgens het bijgeloof der Batta's, door droomen ingelieht aangaande den gepasten tijd van het vertrek der' opspoorders, den door hen te nemen weg, en de kenmerken der gewensehte boomen. Zij verlaten zieh geheel op de kunde van dezen leidsman, wiens verdiensten hoofdzakelijk bestaan in zijne dikwerf herhaalde bosehwandelingen en in de meerdere of mindere gelukkige uitkomsten, die dezelve opleveren. Die wandelingen stellen hem gewis in staat om zieh, door het kloppen der boomen, onder aanleuning. van het oor, omtrent hunnen inwendigen toestand eenige zekerheid te versehaffen. Van dezen Toengoe-nyr-kapoer vergezeld, begeeft zieh een gezelsehap bosehwaarts. Ieder van hetzelve heeft een gelijk belang bij het welgelukken van den togt, en allen zijn dus aandaehtig met de opsporing van den boom bezig. Heeft men nu zulk een' boom gevonden, dan wordt hij door den gemelden Toengo onderzoeht, en ontvangt hij van dezen de eerste inkapping, als bewijs zijner goedkeuring tot eene verdere behandeling. Vervolgens wordt, op ongeveer twee vademen boven den grond, nog eene inkapping gedaan, welke tot het hart van den boom doordringt. Alsdan hebben zij den zetel der gewensehte kostbaarheden bereikt, van den kamfer namelijk en zijne olie. De olie wordt uit deze insnede door eene bamboezen buis, als door een gootje naar buiten geleid, en aldaar in eenen bamboezen koker of andere soort van vat opgevangen. Volgens de verzekering van sommige inlanders, zouden door de jonge boomen alleen Mienjak kapoer (kamferolie) of Kapoer moeda (jonge kamfer; aldus genaamd, omdat zij gelooven, dat deze olie naderhand in kamfer verandert) worden geleverd, en in de oudere boomen olie en kamfer aanwezig zijn. Zij besluiten uit eene aanzienlijke hoeveelheid der olie tot het aanwezen van den kamfer. Vinden zij derhalve eenen boom, die hun eene aanzienlijke hoeveelheid olie oplevert, dan maken zij de inkapping tot op het merg, waar gewoonlijk de kamfer ligt. Dusdoende sehenden zij talrijke, volgens sommigen dikwijls wel drie honderd boomen, eer zij er éénen vinden, die kamfer bevat.

Eens zulk eenen boom gevonden hebbende, wordt die, nadat de olie er uitgeloopen is, waartoe soms wel drie dagen zouden vereischt worden, geveld. Vervolgens kappen zij den stam in blokken van ongeveer eene halve of geheele el lengte. Deze blokken worden daarna in kleine stukken gespleten, ten einde het opsporen en uitnemen van den kamfer gemakkelijker te maken. De groote stukken kamfer, welke voor de beste gehouden worden en onder den naam van Tentorie bekend zijn, worden in het midden van den stam, nabij het merg, in onregelmatige holen gevonden. Zij zijn zelden zwaarder, dan 0,12 N. p., en gewoonlijk niet beneden het anderhalve lood. Kleine stukjes zijn tusschen het hout verspreid en komen daar als korrels of schilfertjes voor. Deze worden niet zelden van het hout afge- 
schraapt, zijn minder zuiver en, ten gevolge der wijze van verzamelen, met houtvezels vermengd. Van deze beide soorten onderseheiden de inlanders, onder den naam Oegar, den kamfer uit boomen gewonnen, die vroeger olie hebben geleverd, en vervolgens gedurende eenige ( 6 à 8 ) jaren onaangeroerd zijn gebleven. - De opgaven omtrent de gewonnen wordende hoeveelheid uit eenen boom, zijn zeer uiteenloopende: volgens dezelve zouden sommige boomen sleehts één Nederlandseh pond, anderen wel tienmaal zooveel opleveren. Maedonald zegt, uit één' boom 1,5 Ned. pond kamfer en $10 \mathrm{Ned}$. ponden olie gewonnen te hebben. De beste kamfer komt als eene half doorsehijnende, korrelaehtige, kristallijnen stof voor, vervliegt bij eene warmte van $30 \mathrm{C}$. Gr. geheel of met aehterlating van eene geringe hoeveelheid witte, harsaehtige stof en is door een' terpentijnaehtigen bijreuk, nog doordringender van geur, dan de Japansehe kamfer. Bij dezen eehten, voor den uitvoer bestemden kamfer, komt op Sumatra nog eene andere soort, onder den naam Krpoer-mati (doode kamfer), voor. Deze seheidt zieh uit de olie af, wanneer zij aan de lueht wordt blootgesteld, en is zeer weinig geaeht. Zij sehijnt mij toe, een mengsel van hars met eene geringe hoeveelheid kamfer te zijn. De kamferolie, zoo als zij uitgevoerd wordt, is lieht geel gekleurd, bezit eenen reuk, welke naar dien eener oplossing van kamfer in terpentijn zweemt, en vervliegt met aehterlating van eene harsachtige stof.

De naam Kapoer $\left(^{\star}\right)$ doet mij vooronderstellen, dat dit artikel bij de Batta's, eerst na hunne kennismaking met de Hindoes, is bekend geworden. Of zij, dan wel Hindoesehe of Arabisehe kooplieden hetzelve in den handel met de Chinezen bragten, durf ik niet bepalen. Alleen is het genoegzaam zeker,

$\left.{ }^{*}\right)$ Dit voortbrengsel, hetwelk de Chinezen vroeger alleen van Borneo schijnen verkregen te hebben, draagt bij hen verseheidene namen. De een, Lung-naou-hëang: Lung (draak), naou (hersens), hëang (welriekende stof), dus welriekende stof wit de hersens van den draak, duidt de waarde van dit voortbrengsel aan: want het woord lung. wordt altijd gebezigd voor hetgeen den Keizer betreft, en hoe konden zij een uitmuntend geneesmiddel beter aanduiden, dan door hetzelve als het uitvloeisel van het edelste gedeelte van hem, die volgens de denkbeelden der Chinezen, de verwezentlijkte almagt is, te besehouwen? Een ander, Ping-pëen: Ping (ijs) en pëen (splinters), dus ijssplinters, toont zeer juist het uitwendig aanzien der stof aan. En de derde, Polo-hëang: Po-lo (Borneo) en hëang (welriekende stof), dus welviekende stof van Polo, de plaats, van welke hetzelve afkomstig is: want dat Polo hetzelfde is als Borneo, is eene aan zekerheid grenzende onderstelling, omdat de Chinezen voor de $b$ altijd de $p$ bezigen, en de $r$ altijd door de $\ell$ uitspreken.

De Chinesche Kamfer daarentegen, is het voortbrengsel van eenen boom (Laurus Camphorae), die menigvuldig en zeer welig in de nabijheid van Sin-kin, in het landsehap Keang-se, groeit. De Chinezen noemen dezen boom Cham moe. Het woord moe is door hout of boom te vertalen; deszelfs voortbrengsel, den Kamfer, noemen zij Cham naou. Naou beteekent hersens. - Uit de vergelijking dezer versehillende benamingen blijkt het reeds, welke hooge denkbeelden zij van den uit Borneo ingevoerden Kamfer hadden, en waarom deze hooger in prijs was, dan hun Cham naou. De kunst van raffineren was den Chinezen onbekend en versehafte langen tijd aan eenige Amsterdamsehe fabrijken aanmerkelijke voordeelen, die door de Chinezen voor het gezuiverd voortbrengsel werden betaald. Naar ik vermeen, wordt de geraffineerde Kamfer bij de Chinezen Ping-pëen genoemd.

Den gegeven' naam Cham vinden wij min of meer gewijzigd, in de namen, welke dit voortbrengsel in andere talen draagt, terug. In het sanskrit heet het Kapura of Kampura, en ons Kamfer, het fransehe Camphre, het engelsehe Camphire, zijn even als Camphora, aan dat woord verwant. Al deze woorden duiden dus op één hoofdwoord Kam, Kar of $K a$, hetwelk in het sanskritseh ons denkbeeld van schudden, beven enzv. uitdrukt. De andere beide syllaben, welke in phora en fer het best bewaard zijn, wijzen ons op het grieksehe $i k$ draag. Het woord Kamfer zoude alzoo het denkbeeld uitdrukken van een dragen of voortbrengen van beving of schudding; en heeft de Kamfer niet deze uitwerking op het ligehaamsgestel? 
dat het in lateren tijd, blijkens de opgaven van Mareo Paolo, een belangrijk handelsartikel van Lambri en Fanfar $\left(^{\star}\right)$ was, dat van daar naar China werd overgevocrd. De kamfer was dus in dat tijdperk een handelsartikel van de oostkust van Sumatra, werwaarts hij, staande de grootheid van het rijk der Batta's, misschien wel over land vervoerd werd. Tijdens de eerste bezoeken der Europeanen op Sumatra, bevond zich de kamferhandel in handen der Atsjinezen, en de hoofdplaats voor den uitvoer was Baros; hiervan de naam Kapoer-Baros. Naarmate de magt der Atsjinezen verminderde, geraakte hij allengskens onder den invloed der Engelsche en Hollandsche kooplieden, en leverde hij hun aanzienlijke voordeelen op. De hoofdplaatsen, van waar hij gedreven werd, waren, na de Europische vestiging, Sinkel, Baros, Tapoes en Tapanoeli. Van deze plaatsen werd altijd een gedeelte naar Atsje en een ander gedeelte naar Padang gebragt. Van Padang zijn, in de jaren 1750 tot 1758, ongeveer 5780 halve Ned. ponden, en in latere tijden, na 1826, jaarlijks ongeveer 1250 halve Ned. ponden uitgevoerd. Indien de opgaven niet vergroot zijn, hetgeen ik echter vooronderstel, dan zoude er jaarlijks meer dan twee- en een halfmaal zooveel naar Atsje gevoerd worden. Van deze plaats wordt de kamfer naar Singapoera, en van Padang voornamelijk naar Batavia gezonden, om daar een artikel van handel met China te worden. De prijs van den kamfer bedroeg in 1750, te Padang, ruim 22 gulden per half Nederl. pond, en wisselde aldaar in de laatste jaren tusschen 25 en 30 gulden. Beaulieu kocht hem op Sumatra's westkust, in 1622, voor 28 gulden. Blijkens de opgaven van Macculloch (Schmidt, Comptoir-Handbuch, S. 252) was te Kanton, in 1836, de Baros-kamfer $\mathbf{5 7}$ gulden het halve Ned. pond, en ongeveer honderdmaal duurder dan de gewone kamfer. - In hoeverre deze hoogere waarde alleen aan eene eigenzinnige voorkeur der Chinezen, dan wel aan eene krachtiger werking als geneesmiddel zij toe te schrijven, is voor alsnog onbekend. De beslissing dezer laatste vraag werd, blijkens eene mededeeling van W. Jack, aan den Heer Hume voorgesteld. Is de uitslag van dat onderzoek ontkennend geweest, dan moeten wij den buitengewonen prijs aan eene vooringenomenheid der Chinezen toeschrijven en wordt dit artikel, alsook de vogelnestjes, door hen even duur aan ons betaald, als de thee aan hen door ons.

Dc kanferolie wordt bijna niet gebruikt. De Heer Macculloch stelt voor, om haar in plaats van terpentijn te bezigen. Ik geloof echter, dat de prijsverhooging, die door de minste aanvraag zoude veroorzaakt worden, dit gebruik zeer zoude in den weg staan.

Uit deze mededeeling blijkt het, dat de geheele behandeling enzv. van den kamfer, onder Indischen invloed staat. In hoeverre het wenschelijk zoude zijn, het verzamelen door middel van het omkappen der boomen, onder zekere beperkingen te brengen, en door destillatie en andere kunstbewerkingen het produkt te vermeerderen enzv., durf ik, wegens gebrek aan plaatselijke kennis, niet beslissen.

${ }^{*}$ ) Lambri (Marco Paolo, Boek III, Hoofdst. 15) wordt door Marsden voorondersteld het tegenwoordige Jambi te zijn, en Fanfar (Boek III, Hoofdst. 16) wordt door hem, vermoedelijk met regt, voor het nu als Kampar bekende gehouden. 


\section{DRYOBALANOPS? SERTCEA. Kus.}

1). foliis ovatis obtuse acuminatis basi obtusiusculis sublus in nervorum axillis pubescentibus.

Ramit arbusculae teretes, pubeseentes, fusci. Folia ovata, obtuse acuminata, basi cuneata vel obtusiuscula, utraque glabra, subtus in nervorum axillis et in nervo mediano dense pubescentia, nervis prominentibus, $9^{\prime \prime}$ longa, 4, $0^{\prime \prime}$ lata; pexrour 10" longi, teretes, pubeseentes. GEMnraE oblongae, obtusae, pubescentes, minutae.

\section{Crescit ad montem Balaran: BonNeo.}

De groote overeenkomst van de besehrevene bladen met die van D. camphorae, heeft mij doen besluiten om de weinige verzamelde takjes met den bovengenoemden soortnaam te bestempelen. Of zij werkelijk van den boom zijn, welke den kamfer op Borneo levert, kan ik niet verzekeren ( ${ }^{\star}$ ). Het blijft altijd nog cene vraag, of de vruchten, welke Gaertner en Houttuin hebben afgebeeld, tot dezelfde soort behooren als de door Colebrooke in plaat voorgestelde. De door Houttuin afgebeelde vrucht, welke met die van Gaertner groote overeenkomst bezit, schijnt van Borneo afkomstig te zijn en verschilt, door den vorm van den uitgegroeiden kelk, met de soort van Sumatra. Deze twijfel, omtrent de gelijkheid der soorten, heeft mij doen besluiten, om den naam van Colebrooke, bij de beschrijving der soort van Sumatra, boven dien van Gaertner te verkiezen.

\section{VA TICA. Linn., Wight en Arnott, Endligher.}

SHores. Roxburgh, Gaertner.

Bij de door bovengenoemde sehrijvers gegevene geslachtskenmerken behoef ik sleehts te voegen, dat de hokjes der helmknopjes ongelijk, de beide buitensten de langste zijn, en dat de helmknoop in een verdeeld aanhangsel eindigt. Deze kenteekenen zijn belangrijk, omdat Hopea den helmknoop onverdeeld en de hokjes der helmknopjes even groot bezit,

Dit geslacht bevat de Vatica (Shorea Wall.) robusta, V. (Shorea Wall.) obtusa, V. laccifera, Wight en Arn. (V. Indica? Linn., Sh. Talura, Roxb.), V. (Shorea Roxb.) Tumbugaia, W. en A., en V. (Shorea Roxb.) longisperma, V. lepidota en V. ovalis. V. Tumbugaia $(\dagger)$, aan welke een honderdtal stuifdraden toegeschreven wordt, zal vermoedelijk bij een nader onderzoek blijken, een nicuw geslacht te kunnen vormen, en kan dan gevoegelijk den naam Shorea in het wetensehappelijk stelsel bijbehouden.

Deze soorten bewonen het schiereiland Dekan tot op $31^{\circ}$ N. Br., Poeloe-pinang, Sumatra en Borneo, en leveren, behalve een deugdzaam timmerhout, eene aanzienlijke hoeveelheid dammar op. De beste van dezen dammar wordt, in plaats van wierook of benzoë, in de Hindoesche tempels gebezigd.

$\left({ }^{*}\right)$ Over den kamferboom en den kamfer van Borneo geeft Boerhave (Historia Plantarum, quae in Hortu Aead. Lugd. Bat. crescunt, pag. 456), uit welke bronnen is mij onbekend, eenige inlichtingen.

( ) Colebrooke bedoelt vermoedelijk deze soort mct zijne Shorea Zambuga (Asiat. Researehes, XII. p. 540). 


\section{VATICA LEPIDOTA. KHs.}

V. foliis oratis acutis lcprosis, stipulis falcato-ovatis, floribus paniculatis, calycibus subtomcntosis.

Arвor excelsa, trunco rccto, cortice fusco vel nigrescentc, coronâ late expansâ, basi truncatâ ; Rami patcntes, teretcs, nigrescentes; Rañul compressi, fusci, dense leprosi. Folra alterna, ovata, acuta, basi obtusa vel subtruncata, supra glabra, subtus leprosa, coriacea, 5,5" lata, $10^{\prime \prime}$ longa, nervis primariis prominentibus, nervis secundarïs parallelis, approximatis; PETIOLI $2^{\prime \prime}$ longi, subteretes, supra planiusculi, leprosi. Gennue compressae, falcato-ovatae. Stipulat falcato-ovatae, acutiusculae, extus leprosae, intus glabriusculae, subcoriaceae, 5 ad 7 nerves, admodum deciduae. Inflopescentia axillaris, paniculata, leprosa; pedurgudus communis et pedunculi partiales compressi. Bracteae minutae, subrotundae, obtusae, membranaceae. Flores subsessiles. Catrx pentasepalus, aestivatione imbricata; SEPALA ovata, acutiuscula, extus tomentosa, intus pubescentia, inaequalia, in alas excrescentia. Ovariun hemisphaericum, pubescens, triloculare: loculis bi-ovulatis (vel 4-ovulatis). Ovula collateralia (dum 4, per paria superposita), apici loculi aflixa; struUs brevissimus, subteres; sтigma tridentatum, dentibus obtusis.

\section{Crescit in sylvis Melintang: Sumatra.}

Deze soort behoort tot de fraaiste boomen, welke wij op de groote bergketen vonden, en is groepsgewijze langs de westelijke helling verspreid. Volgens de getuigenis der inlanders wordt zij aan de oostelijke of binnenzijde zeldzamer gevonden. Zij bezit een licht bruin, naar het roode hellend hout, hetwelk zich, volgens de inlanders, door buitengewone duurzaambeid aanbeveelt en, volgens onze ondervinding, ligte en zeer brandbare houtskolen oplevert.

\section{VATICA OVALIS. Kus.}

V. foliis ovalibus acuminatis in nervis pilosis, stipulis ovatis obtusis.

Foura oblongo-ovalia vel ovalia, acuminata, basi obtusa, emarginata vel cuncata, obtusiuscula, glabra, supra subtusque in nervis pilosa, nervis primariis et secundariis prominentibus, subparallelis, $31^{\prime \prime}$ longa, 12" lata; peтrou $2^{\prime \prime}$ longi, subteretes, sulcati, superne incrassati, dense fasciculato-pilosi. Gemar compressae, ovatae, obtusae. Stipulae ovatae, obtusae, basi truncatae, extus fasciculatopilosae, intus glabrae, 7 nerves, $10^{\prime \prime}$ latae, 15 ad $20^{\prime \prime}$ longae.

\section{Crescit in monte Prarawin: BoRveo.}


H O P E A. Roxburgh, Wight en Arivott, enzy.

De kcumerken door deze Schrijvers en den Heer Endlicher opgegeven, behoeven slechts de bijvoeging van eene beschrijving der kiem, om voor volledig gehouden te kunnen worden. Bij de Hopea odorata hcb ik de kiem kunnen onderzocken. Zij vult het geheele zaad. Haar wortel is in ecne groeve van de kleinste zaadlob gelegerd, bijna rolrond en aan het eindc eenigzins puntig. Hare zaadlobben zijn omgcbogen, vlcczig, ongelijk van grootte, dc binnenste de kleinste. De beschrevene en de alleen met naam vermelde soorten bewonen het vaste land van Indië, vooral het lager gedeelte des stroomgebieds van den Ganges, het schiereiland Dekan, de eilanden langs de kust van Malakka, of het stroomgebied van de Baritto op Borneo.

\section{HOPEA BALANGERAN. KHs.}

H. foliis ovato-oblongis breviter acuminatis subtus dense pubescentibus in axillis nervorum glandulosis, floribus paniculatis.

Arbor excelsa; truncus rectus, teres; cortex rimosus, griseus vel griseo-fuscus; rami patentes, tcretcs, glabriusculi; Ramuli tcretes, griseo-fusci, pubescentes; novelli compressiusculi, saepe sulcati, pubescentcs. Folia alterna, ovato-oblonga, brevitcr obtusc acuminata, basi obtusa, supra nitida, subtus laete viridia, dense pubescentia, coriacea, $7^{\prime \prime}$ lata, 16" longa, nervis primariis prominentibus, in axillis glandulosis, ncrvis secundariis parallelis, approximatis; PETIOLI subteretes, pubescentes, supra subsulcati, 2,5" longi. Stipulae oblongae, acutiusculae, intus glabrae, extus dense pubescentcs. Genmae compressae, ovatae, acutiusculae, dense pubescentes. Inflorescentra axillaris, paniculata, pilosa; pedurculus communis et pedurcul partiales compressiusculi. Bracteae subrotundae, acutae, intus glabrae, cxtus pubescentes, membranaceae, flavescentes, 4 "' longae, $3^{\prime \prime \prime}$ latae, admodum deciduae. Fuones subsecundi, sessiles vel brevissime pedicellati. CALrx pentasepalus; sepsca inaequalia, biserialia tria exteriora majora, dua interiora minora - ovata, acuta, extus dense tomentosa, intus glabra, coriacea $3^{\prime \prime \prime}$ longa, 1,5"' lata, excrescentia, aestivatione imbricata. Corouls hypogyna, pentapetala, aestivationc convoluta; pETALA basi cum annulo filamentorum in tubo urceolato coalita, oblonga, subfalcata, acutiuscula, intus glabra, extus pubescentia, membranacca, alba, 8 "longa, 2" lata. STumiva 15, biserialia; series interior cum 10, minora petalis opposita; series exterior cum 5 , majoribus seriei interioris opposita et adnata; fILAMENT basi dilatata, apici attenuata, connata; ANTHERAE ovatae, sessiles, connectivo in subula setacea producto, loculis rimis dehiscentibus, locellis aequalibus. Polden subglobosum. Ovarium hemisphaericum, attenuatum, pubescens, triloculare, loculis bi-ovulatis. Ovura oblongo-ovöidca, vertici angustiora, collatcralia, paululum infra apicem loculi in angulo interno affixa. STruss subteres, glaber; strgma truncatum, denticulatum.

Crescit ad ripas fluminis $\boldsymbol{P}$ attai etc.: Bonneo. 
Tab. 7. Figura Hopeae Balangeran. 1. Gemma floris. 2. Flos apertus. 3. Flos calyce ablato. 4. Pars corollae expansae intus visa. 5. Stamina in dorso visa. 6. Stamina in facie visa. 7. Ovarium partibus floris pro parte ablatis. 8. Ovarium verticaliter sectum. 9. Ovarium horizontaliter sectum. 10. Ovulum verticaliter sectum. 11. Symmetria floris. 12 et 13. Bracteae. 14. Pars aucta folii. - Hopea odorata. 15 et 16. Fructus, calyce excreto cinctus. 17. Fructus nudus. 18 et 19. Fructus cum semine verticaliter sectus. 20 et 21 . Embryones.

Hopea Balangeran is in gezelligheid groeijende, door ons, langs de Pattai, een' der zijtakken van de Baritto, in gezelsehap van soorten van Myrtus, van Garcinia, Carallia, Roxb. (Symmetria, Bl.) enzv. waargenomen. $\mathrm{Z}_{\mathrm{ij}}$ vertoonde zieh daar, als een aanzienlijk groote boom, met bijna loodregten stam, uitgebreide kroon, openstaande takken, nederhangende jonge takken, een helder groen, van boven blinkend loof en veelbloemige bloempluimen. Deze laatsten bezaten in september eene talrijke menigte, zacht rozen-roode bloempjes, die eenen aangenamen vanieljegeur verspreidden. Het hout dezer boomen, in de binnenlanden en te Banjermassing, onder den naam Kajoe- (hout) Balangeran bekend, is naast het zoogenoemde Kajoe-bessi (ijzerhout), het beste timmerhout dezer oorden. Hel heeft eene rood-bruine kleur, een' fijnen draad en niet zeer hard weefsel. De laatste hoedanigheden maken de bewerking van hetzelve gemakkelijk, en eene geringe hoeveelheid hars geeft het eene meerdere duurzaamheid, door den wederstand, welken het alsdan tegen den invloed van lueht en vocht bieden kan, terwijl tevens alle schadelijke insekten daardoor van hetzelve worden afgeweerd.

Van deze boomen wordt de bruine hars, Njating-Mahambong, verzameld.

\section{HOPEA SANGAL. KHs.}

II. foliis oblongo-oratis obluse acuminatis inaequilateralibus glabris, in nervorum axillis glandulosis, stipulis ovatis.

Arвor speeiosa, trunco ereeto, cortice laete fuseo, rimoso, coronâ patente subconicà; ranır patentes; Ramuli subteretes, glabri, fusei, novelli compressiusculi vel subtrigoni. Folia alterna, oblongo-ovata, inaequilateralia, obtuse aeuminata, basi latere unieo rotundata, altero angustata, utraque glabriuscula vel subtus subpubescentia, $5^{\prime \prime}$ lata, $11^{\prime \prime}$ longa, nervo medio et nervis lateralibus prominentibus, in angulo $45^{\circ}$, in axillis inferioribus glandulosis; petrou subteretes, glabri, $15^{\prime \prime}$ longi. Strpurae minutae, ovatae, admodum caducae.

\section{Crescit prope laco Kambat etc. ad ripas Baritto: Bonwe.}

In de lagere streken van de Baritto-rivier, gewoonlijk door de inlanders de Koempai en Doesson genoemd, wordt deze soort, hier en daar groepsgerwijze vereenigd, aangetroffen, en behoort zij, door hare grootte en door haar helder groen loof, tot de schoonste boomen dezer moerassige oorden. Zij is 
bij de Biadjoe $\left(^{*}\right)$ onder den naam Sangal bckend, en levert eene zeer schoone witte hars, welke Njaling mala-poesa of Njaling pleppek genoemd wordt. Beiden vloeijen uit de spleten der schors en hebben, versch zijnde, een bijna wit, halfdoorschijnend en op de breuk glasachtig aanzien. De Njating pleppek, welke het voortbrengsel van jonge boomen schijnt te zijn, is losser cn ligter, dan de Njating mata-poesa, dic in grootere, zwaardere, digtere brokken voorkomt. De eerste soort heeft bij de inboorlingen minder waarde, omdat zij moeijelijk brandt en bij het branden knapt, hetgeen aan het, in dezelve voorhanden zijnde vocht en aan de luchtblaasjes kan toegeschreven worden.

Hopea Sangal verschilt van H. speciosa en H. gratissima door hare schceve ongelijkzijdige bladen; van de H. odorata door meerdere grootte, door de langere punt harer bladen, en door de klieren, welke bij haar in de oksels der nerven aanwezig zijn.

$\left(^{*}\right)$ De bewoners der bimnenlanden noemen zieh gewoonlijk Orang-kahajan, Orang-doesson enzv., dus menschen met den naam van de rivier, die zij bewonen. Anderen, welke zieh reeds jaren op Banjermassing bevonden of daar dikwerf kwamen, zeiden, dat zij Biadjoe-kiahaijan enzr. genoemd werden, en besehouwden den naam Dajak, als eenen seheldnaam, die hun door de, in latere tijden aangekomene, thans het strand bewonende vreemdelingen, werd toegevoegd. Het eerste woord Biadjoe staat, volgens de opmerking van den Heer van den Boseh (Nederl. Bezittingen, II. bl. 162) en anderen, in verband met de sanskritsehe woorden Biodjoe en Viadja, welke met hel woord Wilden zijn vertolkt. Het wijst, even als andere nog gebruilielijke woorden, op eene vroegere gemeensehap met de Hindoes. Nader onderzocht, toont het woord Biadjoe, hoe juist dit volk in het tocpassen zijner namen was, daar deze het denkbeeld uitdrukt van een, alléén door kraeht, niet door het denkvermogen beteugeld bandelen. De menseh in zijnen natuurstaat kon zeker niet gesehikter gesehilderd worclen, door een reeds beschaafd volk, dat den invloed van den geest kende. Met de sanskritsehe woorden zal ik mij hier nict bezig houden, doeh alleen tot de grieksehe $\beta \iota \omega$ en $\delta \iota \omega$ en $\delta v \omega$, welke vrij juist met dezelve overcenstemmen en gemakkelijker kunnen worden nagegaan, verwijzen, en aan het latijnsehe vis en induo, cnzv. herinneren. Het woord Dajak is zoo zeer verwant aan het maleisehe Daja, list, slimheid: eigensehappen, die de bewoners cler binnenlanden in eene hooge mate bezitten, dat het mij waarschijnlijk voorkomt, dat de Maleijers, bij humne vestiging of, vroeger reeds, bij hun handelsverkeer met de inboorlingen, aan dezen, als ecn gevolg van derzelver kunstgrepen en lagen, den scheldnaam van Orang-daja of Dajak, sluipers, gegeven hebben. 


\title{
B I U II I N I A,
}

Dook

\author{
P. W. K O R T H A L S.
}

De soorten van het geslacht Bauhinia zijn bijna allen tusschen de keerkringen gevonden en aldaar zeer ongelijk verdeeld. Afrika bezit slechts de Bauhinia Senegalensis op de westkust, de Bauhinia farek op de oostkust, en de B. Madagascariensis op het eiland Madagaskar. Amerika, vanwaar de eerste soort, onder den naam van Bauhinia, door Plumier werd beschreven, heeft eene menigte soorten, welke tot de afdeelingen Caulotretus, Casparea en Pauletia behooren. Deze zijn daar van de zeestranden tot op eene hoogte van ruim $1200 \mathrm{~N}$. ellen gevonden en trokken, door de grootte harer bloemen en door de zonderlinge bandvormige gedaante der stammen, de aandacht der reizigers. In Azië groeijen de bekende soorten in Bengalen, op het schiereiland Decan, op Ceilon en de zuid-oostelijke eilanden. Op het vasteland van Indië komt ééne soort voor, namelijk de Bauhinia corymbosa, tot op $28^{\circ}-30^{\circ}$ N. Br., in den omtrek van Saharumpore, in de dalen van het Himalaija-gcbergte; de anderen zijn daar beneden de 1000 ellen, zoowel in de bosschen als in de meer opene plaatsen gevonden. Van Ceilon zijn de Bauhinia tomentosa en B. acuminata bekend. Op de Philippijnen zijn eenige soorten, waaronder de B. latisiliqua, verzameld. De Indische Archipel leverde, van Sumatra, Java, Borneo, Nieuw-Guinea, Timor, enzv. een aantal soorten; daarentegen kennen wij er nog niet eene van Celebes. Eene derzelven is op het vasteland van Indië, Ceilon en de drie groote Sunda-eilanden gevonden: B. acuminata; eene andere, B. tomentosa, is van het vasteland, van Ceilon en van Java bekend; en eene derde behoort Botanica. 
op het vasteland en Sumatra te huis. De anderen zijn meer tot den Indischen Archipel beperkt en meestal slechts op één van deszelfs eilanden aangetroffen. De door mij waargenomene soorten, welke ik hier besehrijven zal, verzamelde ik steeds beneden eene hoogte van 1000 ellen; de boomachtige soorten, B. tomentosa, acuminata enzv., groeijen in de lage alluviale oorden, tusschen klein bosch of op opene plaatsen; zelden verspreiden zij zich tot in de dalen der voorgebergten, zoo als: B. aeida, B. hirsuta; de slingerende soorten wassen in de bosschen langs de zeestranden en verspreiden zich vervolgens tot op gemelde hoogte. In deze streken erlangen zij niet zelden eene aanmerkelijke ontwikkcling. Hare stengen verheffen zich in ranken, door klawieren ondersteund, of slingeren, de boomen digt omwindende, tot in de kroonen derzelve. Hier vermengen zij haar loof met dat dier reuzen uit het plantenrijk, terwijl de rijke, met gele of roode bloemen versierde takken van tusschen hetzelve nederhangen.

De vrijgroeijende soorten komen als kleine boomen, somwijlen als heesters voor. Hare stammen zijn meestal regt, rolrond, door eene bruine of grijze, gave of gespletene sehors bedekt, en hebben een geel of licht bruin, week, ligt en tegen den invloed van lueht en vochtigheid niet zeer bestand hout. Derzelver kroonen zijn half rond of eivormig, over het algemeen met cenen zeer digten bladtooi bekleed. De slingerende soorten hebben den stam platgedrukt, onregelmatig rolrond of hoekig; nimmer heb ik denzelven zoo bandvormig als bij de Amerikaansche soorten gezien. De stam bezit onder eene gespletene, kurkachtige, bruine schors, een zeer poreus hout. De takken staan afwisselend, bij de slingerende soorten dikwerf in twee rijen, bij de boomen meer spiraalsgewijze. Zij zijn min of meer hoekig; bij hunne eerste verschijning zelfs te zamengedrukt, en niet zelden meer of min digt behaard. In de zamenstelling van de takken en takjes der beide vormen bestaat geen verschil: zij hebben eene tamelijk ontwikkelde schors, eene niet zeer aanzienlijke bastlaag; de houtbundel bestaat uit vezels cn vaten; zij hebben een vrij groot, somtijds vijfhoekig merg, de groote mergstralen, in bijna regte lijnen van het merg naar de schors loopende, en de kleine mergstralen zeer klein. Deze zamenstelling ondergaat bij de boomaehtige stammen weinig verandering. Bij de slingerende soorten verandert de steng eenigzins; ik zal de beschrijving derzelve hier laten volgen. - De schors en bastlagen verschillen alleen door de meerdere dikte en losheid bij de boom- en bij de slingerende soorten. Bij beiden bestaat de eerste uit zes- tot twaalfhoekige cellen met dikke, van binnen gestipte wanden, en de, bij de boomsoorten aanzienlijker bastbundel wordt door zeer dikwandige vezels gevormd, wier holte vijf- of zeshoekig is. Het hout van de slingergewassen heeft het merg zeer klein; de hoofdmergstralen en de kleinere mergstralen in slingerende bogten, en den houtbundel zeer rijk aan groote vaten. Het merg bestaat uit een los weefsel van naar het ronde overgaande, dikwandíge, gestipte cellen. De groote mergstralen loopen slingerend van het merg naar den omtrek, en de kleinen vormen een bogtig gewonden net tusschen den houtbundel. De eersten bestaan uit twee tot vier, en de anderen uit eene of twee rijen cellen. Deze cellen hebben den vorm van teerlingen of van regthoekige zuilen: de teerlingvormige zijn, vooral in de groote mergstralen, tusschen de langwerpige cellen, als ook aan de einden der stralen voorhanden; de anderen zijn het talrijkst. Zij sluiten zeer juist op elkander en vormen een zamenhangend, 
uit regelmatige mazen bestaand net. Beide soorten hebben zeer dikke wanden met tallijke ronde stippen, die in de naast elkander liggende cellen, sehijnbaar met elkander in verbinding staan. De langwerpige eellen hebben de lengte meest in de rigting van de spil der plant, maar, wanneer zij de gestipte vaten omgeven, zijn zij meer breed dan lang. Hare lengte staat tot de breedte als 3 of 2 tot 1 ( In den houtbundel heb ik spiraalvaten, gestipte vaten, eigen sapvoerende vaatjes en vezels waargenomen. De spiraalvaten zijn alleen in het mergkanaal in gering getal aanwezig; zij zijn zeer klein en hebben sleehts 0,01 streep middellijns. De gestipte vaten maken het hoofdgedeelte van den houtbundel uit. De groote gestipte vaten, welke door ééne laag van dwarse, en soms nog door eene andere van lange eellen omsloten zijn, hebben $0^{\prime \prime \prime}, 35$ tot $0^{\prime \prime \prime}, 5$ middellijns, en bestaan uit leden van $0^{\prime \prime \prime}, 25$ tot $0^{\prime \prime \prime}, 15$ lengte. Derzelver wanden zijn van eene talrijke menigte stippen, in de gedaante van dwarse streepjes voorzien. In de nabijheid van deze groote vaten bevinden zieh eene menigte kleine gestipte vaten, om welke ik geene insluitende eellenlaag heb waargenomen. Deze vaten hebben eene middellijn van $0^{\prime \prime \prime}, 04$ tot $0^{\prime \prime \prime}, 08$, en de lengte van derzelver leden is $0^{\prime \prime \prime}, 25$ tot $0^{\prime \prime \prime}, 125$. Zij hebben de einden der leden dikwerf seheer; somwijlen met eene meer of min belangrijke vernaauwing. Derzelver wanden zijn even dik, als die der groote vaten, met eene menigte eirkelronde stippen voorzien. Behalve deze beide vormen van gestipte vaten, zijn er nog zeer dunwandige vaten aanwezig; deze sehijnen mij toe, voor gestipte, pas gevormde vaten gehouden te moeten worden. - De kleine eigene sappenvoerende vaatjes zijn, vooral langs de gestipte vaten, aanwezig: zij bestaan uit leedjes van $0^{\prime \prime \prime}, 006$ tot $0^{\prime \prime \prime}, 008$ lengte en ongeveer de helft breedte, en verbinden zich dikwerf tot een net. - De vezels hebben ongeveer $0^{\prime \prime \prime}, 5$ tot $0^{\prime \prime \prime}, 8$ lengte, bij $0^{\prime \prime}, 01$ middellijn, en dikke, meestal gave wanden. Somwijlen zijn zij opgezwollen en kunnen dan alleen door de aan' de einden aanwezige vernaauwing en door de ligging der stippen op de binnenzijde der wanden, van de gestipte vaten onderseheiden worden. De groote gestipte vaten, welke ik in de jongere takken en in de stammen van Bauhinia pyrraneura heb vergeleken, ondergaan, bij de ontwikkeling der plant, eene aanmerkelijke verwijding, maar verkrijgen, in derzelver leden, bijna geene meerdere lengte.

De knoppen zijn zamengedrukt ovaal; zij bestaan uit de beide nevenblaadjes, die met de randen tegen elkander liggen, en uit de blaadjes, van welke de bladsehijf zamengevouwen en op den steel terug gebogen is. Na de seheiding van de nevenblaadjes buigt de bladsehijf, door de uitgroeijing, terug, en blijft zij nog, gedurende eenigen tijd, met de bovenvlakte tegen elkander gevouwen. - De bladen van zeer jonge planten bestaan meestal uit twee geheel geseheidene of alleen aan den voet zaamgegroeide blaadjes; die van oudere planten hebben de blaadjes hooger zaamgegroeid; bij enkele soorten zelfs zijn zij bijna tot eene onverdeelde bladsehijf vereenigd. Indien de blaadjes geheel geseheiden zijn, is er tussehen dezelve eene kleine elsvormige verlenging van den bladsteel; bij eene te zamengroeijing van dezelve groeit deze verlenging tot eene middelnerf der vereenigde blaadjes, die boven de zaamgegroeide bladsehijf uitsteekt. Langs deze middelnerf, vooral aan het benedenste derzelve, is de zelfstandigheid van het blad minder digt. De blaadjes zijn ongelijkzijdig; de buitenzijde is het grootst, langwerpig, aan de punt spits of rond, aan den voet rond of bijna afgeknot; waardoor de voet van de zaamgegroeide bladsehijf min of meer hartvormig is. Zij zijn op den bladsteel geleed, of vertoonen, bij hunne vastheehting, een aanmerkelijk verdund parenehym. De reeds besehreven middelnerf is eene voortzetting 
van den bladsteel. Deze zamenstelling doet mij de bladen van Bauhinia voor gevinde, éénjukkige bladvormen houden. De oppervlakte der bladsehijven is aan de bovenzijde meestal glad; aan de onderzijde glad of met eenvoudige haren bedekt, die somwijlen bruin gekleurd en door tussehensehotten en kleine cellen verdeeld zijn, en later gedeeltelijk wegvallen. Derzelver zelfstandigheid is lederaehtig. Hare hoofdnerven komen allen uit den voet van het blad, even als zulks bij de palminerven gewoonlijk gevonden wordt, cn loopen naar de buitenzijde van de blaadjes, tot aan of tot op eenigen afstand van den rand door. Hier loopen zij langs den rand, eenen kleinen zoom vormende, of buigen zij terug en vereenigen zieh met de meer binnenwaarts gelegene, door ronde of hoekige bogten. De, uit deze hoofdnerven voortkomende secundaire nerven vormen met elkander, hoeken van $45^{\circ}$ tot $90^{\circ}$ : de eersten loopen gewoonlijk tot den rand door; de regthoekigen, welke bij vele soorten voorkomen, verbinden de hoofdnerven met elkander en zijn tusschen dezelve evenwijdig, dikwerf vrij digt bij elkander geplaatst. De, uit deze nerven voortkomende aderen zijn, naarmate van de mindere of meerdere ontwikkeling van het parenchym, duidelijker of minder zigtbaar. - De bladstelen zijn op de steng geleed, bijna rolrond of kantig, aan de beide einden dikker, glad of behaard, eenige soorten met eene aanzienlijke lengte. - De nevenblaadjes komen onder twec vormen voor en zijn aan den voet van den bladsteel, of even boven den voet, op de steng geheeht. De cersten, welke de onontwikkelde bladen beschutten, zijn de grootstc, langwerpig of rond, glad of behaard; de anderen, welke spoediger dan de genoemde afvallen, zijn klein, bij de meesten gelijk aan kleine draadjes, of langwerpig toegespitst, en kunnen als de nevenblaadjes der beide blaadjes aangemerkt worden. - In de plaats van de bladen of van de groote nevenblaadjes, of van de bloemen, groeijen niet zelden, bij de slingerende soorten, klawieren, welke onverdeeld blijven of het einde in twee deelen gespleten of gegaffeld hebben.

De bloemen der Indisehe soorten zijn in trossen, bij sehermen of in pluimen vereenigd, welke aan het einde der takken, òf in de oksels der bladen, òf ook, doch zeldzaam, tegen over dezelve zijn geplaatst. De algemeene steel is bij de meeste soorten hoekig, eenigcrmate zamengedrukt. De bloemstelen zijn, op kleine kussentjes geleed, langs denzelven spiraalsgewijze geplaatst, bijna rolrond of kantig. Aan den voet derzelve is een, en op dezelve zijn twee schutblaadjes, van eene langwerpige, dikwerf zeer toegespitste gedaante. De bloemknoppen zijn rolrond of kantig, bij enkele soorten zeer toegespitst, glad, bruin of grijs behaard. De kelk komt onder twee vormen voor: bij de meeste soorten bestaat hij uit eene buis en eenen verdeelden boord; bij sommigen (B. anguina, P. emarginata, Jack of B. retusa, Roxb.) is de buis bijna of in het geheel niet ontwikkeld. De buis is bij verscheidene Amerikaansche soorten (B. outimouta, enzv.) kogelrond, bij de Indische rolrond, of kantig met uitstekende ribben en min of meer aanzienlijke holten. De vijf deelen van den kelkboord zijn vóór de opening van de bloem, als kleppen tegen elkander geplaatst. Na de opening buigen zij terug en blijven met elkander vereenigd tot eene seheede (B. acuminata, enzv.), of zijn twee of drie derzelve zaamgegroeid (B.pyrraneura, enzv.), of al de deelen scheiden zieh van elkander (B. ferruginea, enzv.). Deze deelen komen voor, onder eene meer of min verlengde gedaante, met eene vliezige of lederaehtige zelfstandigheid, hebben veelal eene middelnerf en zijn, na de opening der bloem, teruggebogen. - De bloemkroon, uit vijf bladen te zamengesteld, is openstaande of eenigzins klokvormig, wit, geel of hoog oranje. Hare bladen zijn, vóór de opening der bloem, door de grootte, somwijlen zeer geplooid; gewoonlijk echter toonen zij duidelijk de 
ligging van vlinderbloemen. Deze bladen zijn ongelijk; datgene, hetwelk de vaan voorstelt, is dikwerf het kleinste; de beide andere paren zijn bijna van dezelfde grootte. Zij bestaan uit een nageltje en eene schijf. Het eerste is bij eenigen zeer klein ( $\boldsymbol{B}$. tomentosa, enzv.) en bij anderen tamelijk groot (B). ferruginea, enzv.); daarentegen hebben de eersten de bladschijf grooter, dan de laatsten. De bladschijf is langwerpig, ovaal of rond, aan den top stomp of puntig, aan den voet puntig, rond of van één of twee oortjes voorzien, op de binnenvlakte glad, en op de buitenvlakte, vooral langs de nerven, behaard of geheel glad, en heeft eene gevederde nervuur.

De helmdraden zijn aan den rand van de binnenzijde der kelkbuis geplaatst, en bij cenc normale ontwikkeling tien in getal. In dit geval zijn zij ongelijk van grootte en staan de vijf kleinere tegen over dc bloembladen. Bij de meeste soorten zijn echter sommige van deze helmdraden geheel geabortecrd of gebrekkig ontwikkeld. Eenigen hebben de vijf, over de bloembladen geplaatste helmdraden zonder stuifmeelknopjes, of zeer klein (B. variegata); anderen hebben drie vruehtbare en van twec tot zeven onvruchtbare helmdraden: de eersten staan dan tegen over de drie van de spil verwijderde kelkbladen (B. fcrruginea); wcèr anderen hebben negen onvruehtbare en een' vruchtbarcn helmdraad, dic tegen over het, van de spil het verst vertwijderde kelkblad staat. De helmdraden zijn vóór de opening der bloem gekronkeld, en worden later regt. Zij zijn draad- of lijn- of elsvormig, veelal onbehaard. De hclmknopjes staan vóór de opening der bloem, met het voorste gedeelte naar binnen, en krijgen eerst na de opening eene tegenovergestelde, of eene horizontale rigting. Zij zijn ovaal of lijnvormig ovaal, bestaan uit den helmknoop en vier, zelden uit twee stuifmeelhokjes. De helmknoop, in welks midden het helmdraadje is vastgehecht, is dikwijls zoo ontwikkeld, dat hij het grootste deel van de helmknopjes uitmaakt. Aan weêrszijden van denzclven is een paar stuifmeelhokjes, die zich van boven af aan openen. Het exothecium dezer hokjes is vliezig bij B. acuminata, cn dik bij B. ferruginea. Het endothecium bestaat uit eene laag spiraal-cellen, uit welke men door weeking den draad gemakkelijk afseheidbaar kan maken. - Het stuifmeel, dat bijna kogelrond is, springt op versehillende wijzen open.

Het vruchtbeginsel komt ò bijna geheel zonder steel voor (B. outimouta), òf heeft den steel vrij in de kelkbuis geplaatst (B. aeuminata), òf met deze zaamgegroeid (B. ferruginea). Bij alle soorten is het zaamgedrukt, langwerpig, met de eene zijde gebogen en de andere bijna regt, min of meer behaard. IItet is eenhokkig en bevat een onbepaald getal, zelden meer dan zestien eitjes. Deze eitjes beginnen reeds zcer vroeg dc ongelijke ontwikkeling, waardoor de eimond naar boven gerigt wordt. - De stijl is zeer ongelijk van grootte en neemt naar den stempel in omvang toe. De stcmpcl is, bij de onderzochte soorten, knoop- of kopvormig, somwijlen eenigzins lobbig. Het ter opneming van de bevruchtende stof bestemde gedeelte, bestaat uit naakte eellen, die rondom een klcin gaatje geplaatst zijn, hetwelk met een kanaal, in het hokje uitkomende, in verband staat. De door mij waargenomene vruchten hebben drie geheel versehillende vormen. De vrueht was bijna lijnvormig, aan de beide einden toegespitst, van eene aanzicnlijkc lengte, bij B. acida; meer zeisvormig, mel eenc bijna regte en eene andere boogvormige zijde, bij B. ferruginea; zij had den vorm en de zelfstandighcid van onze gewone peulen, bij B. acuminata. De inwendige zamenstelling, door Adanson als meerhokkig opgegeven, hecft twee versehillende vormen. Bij de eenen is de peul door dwarse tussehensehotten en vele hokjes verdeeld, 
en ligt ieder zaad in een afzonderlijk hokje (B. hirsuta, enzv.); bij de anderen liggen de zaadjes in kleine holten, welke door het zaamgegroeide endocarpium geheel omsloten worden (B. ferruginea, enzv.). Het epiearpium is lederachtig, somwijlen zeer dik; bruin of geel. Het sarcocarpium, hetwelk een groot aandeel aan de vorming der tusschenschotten heeft, is zeer vaatrijk; bij $\mathbf{B}$. ferruginea en de verwante soorten dik, en bij B. tomentosa dunner. Het endocarpium is glanzig, licht of donker bruin gekleurd. De zaadstreng is bij cenigen bijna rolrond (B. acuminata, enzv.) en bestaat bij anderen (B. ferruginea, enzv.) uit een ongelijkzijdig, driehoekig plaatjc. Aan het eimde der zaadstreng is bij de half rijpe en volkomen rijpe zaden een tweelobbig uitgroeisel: de bovenste, naar den zaadmond of de micropyle gerigte lob, is de kortste, aan het einde met eene kleine insnede voorzien: de benedenste is even boven het punt van verdeeling, in twee min of meer verlengde, om den rand van den rug des zaads loopende beenen gespleten. De zaden zijn schijfvormig (B. ferruginea) of zaamgedrukt eivormig (B. acuminata); glad, van geel tot donker bruin gekleurd; volkomen rijp zijnde, zeer hard. Zij hebben het vrije einde naar boven gerigt. Hunne opperhuid bestaat uit kleurlooze, bijna teerlingvormige of meer langwerpige cellen. Onder dezelve ligt de testa, even als bij Vicia faba, uit twee lagen van langwerpige, digt aan clkander sluitende cellen gevormd. Het mesospermium bestaat uit een losser weefsel van kleine, soms teerlingvormige eellen en de raphé. Het hieronder gelegen tegmen of endopleura is uit zeer dikwandige cellen gevormd en bedekt een zeer fijn vliesje, dat als de kernhuid moet aangemerkt worden. De navel heeft de gedaante van het segment eener sehijf, met twee lange beenen, die bij eenige soorten een achtste, en bij andere ruim drie vierde van den omtrek des zaads omvatten. Hij wordt naar voren door een klein, aan den voet verbreed haakje begrensd. Dit haakje, hetwelk bij al de door mij onderzoehte zaden van Leguminosae, meer of min duidelijk zigtbaar is, het zoogenoemde spermotylium van den Heer Bischoff, is bij de Bauhinia juist tusschen de navelopening (omphalodium) en het likteeken van den eimond (micropyle) geplaatst. Het heeht de rijpe zaden aan de zaadstreng en bestaat uit een digt celweefsel. De navelopening, bij de onderzochte soorten een klein cirkelvormig stipje, ligt juist aehter het spermotylium. De mieropyle bevindt zich voor het haakje, of op eenen geringen afstand van hetzelve. $Z_{i j}$ is nu eens onder den vorm van cene kleine ronde verhevenheid, dan weder als eene kleine dwarse of lange groeve aanwezig. - De binnennavel of chalaza wordt op de oppervlakte van het zaad, door eene insncde en verhevenheid, met een donker vlekje aangetoond, en veelal in eene regte lijn over de micropyle, of meer op den buik van het zaad gevonden. Naar denzelven loopt de raphé, die, door eene donker gekleurde streep op de testa zigtbaar, gemakkelijk kan gevolgd worden. Zij bestaat uit lagen van langwerpige eellen en uit een' bundel zeer fijne spiraalvaten, wier draad cerst in latere tijdperken kan worden afgewonden. De kiem, welke door een fijn, bijna geheel onbewerktuigd vliesje, hetwelk ik boven reeds aanduidde, omgeven wordt, vult het geheele zaad. Haar worteltje, even bezijden den zaadmond gelegen, is rolrond, naar het einde een weinig toegespitst, en somwijlen met een draadje voorzien. Derzelver zaadlobben zijn van langwerpig tot bijna rond, stomp, aan den voet bartvormig, vlak, en sluiten zeer digt tegen elkander. Het, tusschen dezelve in eene groeve gelegen, niet zeer ontwikkeld knopje, heeft de gedaante van een zamengedrukt ligehaam. - De kiem bestaat uit cellen. Het in de zaadlobben aanwezige net, dat den nervenloop aantoont, bestaat uit kleine cellen, die zich alleen door de lengte van de haar omringende onderscheiden. Bij de ontkieming, of bij het begin van de cerste werking der zaden, veranderen de cellen, welke de nerven aanduiden, in vaten en vezels. 
Zij verlengen zieh meer dan de omringende cellen en vertoonen al zeer spoedig de vorming der spiraalvaten, die uit een' gemakkelijk af te winden draad bestaan. Bij dezelve komen de zaadlobben boven den grond uit en nemen zij eene groene kleur aan, zijn de eerste blaadjes bijna onverdeeld, en hebben de volgende de gedaante, welke aan de bladen van oudere planten eigen is.

De waargenomene soorten van Bauhinia zijn het geheele jaar door, met bladen voorzien. Zij bloeijen bij voortduring, zoo als B. aeuminata, enzv.; of, in den droogen tijd, bij het naderen van de regenmoeson, zoo als B. ferruginea, enzv. De laatsten hebben ongeveer vijf of zes maanden later, rijpe vruehten.

Linnaeus nam voor het geslacht Bauhinia de kenmerken van eene Amerikaansehe soort (Gen. Plantarum, ed. seeunda, pag. 178), met één vruehtbaar helmdraadje (B. divarieata). Hierdoor gaf hij aanleiding, dat Loureiro voor eene, door hem gevondene plant met drie helmdraden, welke aan Pauhinia verwant was, het nieuwe geslacht Phanera vormde. Vervolgens veroorzaakte dit eenzijdig kenmerk, bij de ontdekking van meerdere, door uiterlijken vorm overeenkomende gewassen, de invoering van nog andere geslaehten. Cavanilles vormde voor de, met tien vruchtbare helmdraden voorziene soorten, het geslaeht Pauletia, en behield voor de soorten met één' of drie vruchtbare helmdraden, den naam Bauhinia. De Heer Kunth, het gevoelen voor de verdeeling van deze gelijkvormige gewassen aannemende, verschilde echter van Cavanilles in de beschouwing van de, ter verdeeling vereiseht wor dende kenmerken. Hij nam daartoe niet alleen het getal der helmdraden, maar ook de meerdere of mindere scheiding van de kelkslippen, en het gesteeld en niet gesteeld zijn van het vruchtbeginsel, in aanmerking. Deze veelvoudige verdeelingsgrond deed hem Pauletia (B. aeuminata, enzv.) aannemen, en Bauhinia, voor zoo ver dit de Amerikaansche soorten van Cavanilles betrof, in Casparea, met één vruehtbaar helmdraadje en een gesteeld vruchtbeginsel, en in Bauhinia, met tien vruchtbare helmdraden en een ongesteeld vruehtbeginsel, verdeelen. De Heer De Candolle, door zijne talrijke hulpmiddelen in staat gesteld om het werk van zijne voorgangers vergelijkend te onderzoeken, oordeelde niet gunstig over de door hen opgegevene kenmerken; besehouwde dezelve als van geringe waarde, en als eene aanleiding ter vorming van een te groot getal geslaehten. Hij behield derhalve het geslaeht Bauhinia in deszelfs geheel, met een, alle soorten omvattend kenmerk, en stelde voor, om hetzelve in ondergeslachten te splitsen, welke op het getal der vruchtbare stuifdraden, het gesteeld of niet gesteeld zijn van het vruchtbeginsel, en op de plaatsing van den steel met betrekking tot den kelk, zouden gegrond zijn. Tusschen deze versehillende wijzen van besehouwing durf ik, wegens gebrek aan genoegzame, vooral vruehtdragende voorwerpen, geene uitspraak doen. Indien ik eehter naar de boven besehrevene soorten, welke vooral tot Pauletia, Cav. (B. aeuminata, enzv.) en tot Phanera, Lour. (Symphyopoda, D. C.) (B. ferruginea, enzv.) behooren, oordeel, dan zoude ik, wegens het verschil, dat zij in de bloem- en vruchtdeelen hebben, gaarne het gevoelen van Cavanilles en Kunth, om het geslaeht Bauhinia te verdeelen, aannemen. Naar de hulpmiddelen oordeelende, welke mij het Rijks-Herbarium, door de welwillende medewerking van den Hoogleeraar Blume, verschafte, wil ik thans alleen de onderverdeeling nagaan, en uiteenzetten, hoe zij gewijzigd zoude kunnen worden. 
De peul gevleugeld. . . . . . . . . . . . Mesoptera (B. latisiliqua, Cav.).

De peul ongevleugeld.

De kelk vlak. . . . . . . . . . . . . . LAsiobema (B. anguina, Roxb., B. retusa, Roxb., emarginata, W. Jaek).

De kelk buisvormig.

Het vruchtbeginsel ongesteeld.

De buis rolrond. . . . . . . . Griponeura (B. reticulata, D. C.).

De buis buikvormig. . . . . . . . Caulotretus, Rich. (B. outimouta, Aub. enzv.).

Het vruehtbeginsel gesteeld.

De steel vrij.

Een vruehtbaar helmdraadje. . . . CASPAREA, Kunth (B. divaricata, L. enzv.).

Vijf of tien vruehtbare helmdraden. Pauletia, Cav. (B. acuminata, L. enzv.).

De steel met den kelk zamengegroeid. . Phanera, Lour. (Symphyopoda, D. C. - B. ferruginea, enzv.).

L A S I В В EM A. KHS.

\section{BAUHINIA ANGUINA. Roxb.}

Deze soort, welke door Rheede (Hort. Ma I. VIII. tab.30 en 31) en door Roxburgh (Flor. Coromand. III. tab. 235) zeer goed afgebeeld, en door den laatsten en andere schrijvers uitvoerig besehreven is, werd door ons op Sumatra, in de bosschen van het gebergte Singalang, op eene hoogte van 400 ellen, gevonden. Zij bezit twee soorten van klawieren, geheel onverdeeld en aan het einde gespleten of gegaffeld; de eersten zijn vergroeide nevenblaadjes, en de anderen vergroeide bladen. Bij deze aanmerking kan nog gevoegd worden, dat de door Roxburgh (Flora Indica II. bl. 322) beschrevene puntige klieren in de bloem, onvolkomene helmdraden zijn.

Pa U L E T I A. Cinvanifies, Kunth, De Candolle, enzv.

\section{BAUHINIA ACUMINATA. L.}

Reeds vroeger hebben de Heeren Wight en Arnott (Prod. Flor. Penins. p. 295) opgemerkt, dat deze soort tot Pauletia behoort. $\mathrm{Zij}_{\mathrm{j}}$ was bekend als voorkomende op het vasteland van Indië en op Ceylon, en groeit ook, volgens onze onderzoekingen, in de lagere streken van Java, Sumatra en Borneo. In deze oorden wast zij bijzonder welig op opene, aan de zon blootgelegene velden, en bereikt zij, naarmate van het meer of min gunstige der standplaats, eene versehillende grootte; onder voordeelige omstandigheden vormt zij tamelijk aanzienlijke boomen met regte, rolronde stammen en half ronde kroonen. Op minder gunstige groeiplaatsen, vooral in eenen kiezelaardigen bodem, ontwikkelt zij sleehts tot struiken. Bij dit versehil van ontwikkeling heb ik geene verscheidenheid van vorm tussehen de bladen en bloemen kunnen waarnemen: bij de struiken en boomen waren de bladen nu eens rond, dan weder aan het einde meer toegespitst. 


\section{BAUHINIA TOMENTOSA. L.}

In de lagere, vooral in de alluviale streken van Java, is deze soort niet zeldzaam. Zij bloeit het geheele jaar door, en verspreidt eenen aangenamen geur.

\section{BAUHINIA HIRSUTA. KHS.}

B. foliis basi eordatis emarginatisve, foliolis oblongis obtusis $3-4$ nerviis ultra medium eoneretis subtus, petiolis, ramulis, stipulis, peduneulis, bracteis ealyeibusque hirsutis, petalis oblongis.

Arbuscula; coroin hemisphaerica, basi truncata; truncus rectus, cortice fusco tectus. Rasi divaricati, teretes, cinereo-fusci, glabri; Raluutu angulati, fulcati, fusci, hïrsuli. Form basi emarginata vel cordata, apici sinu $90^{\circ}$, juniora supra glabriuscula, subtus dense hirsuta; adultiora supra glabra, subtus praesertim in nervis et margine hirsuta; foliola oblonga, obtusa, ad tres quartas vel ultra connata, 0,085 longa, 0,045 lata, 3 vel 4 nervia; nervis secundariis subparallelis, distantibus; PETrou trigoni, supra sulcati, superne et inferne incrassati, hirsuti, 0,03 longi. Strpulae lanccolatae, subulatae, hirsutae; stipellae oblongae, acutiusculae, petiolo appressae, minutae. Infronescentra racemosa, oppositifolia: PEDunculus comunis pauciflorus, 3 ad 5 , subteres, hirsutus; PEdiceldi subteretes, subsulcati, hirsuti. Bracteae minutae, lanceolatae, subulatae, hirsutae. Alabastrudi cylindricum, attenuatum in setas quinque, hirsutum. Calycis tubus brevis, obconicus, subsulcatus, intus glaber; linibus quinque partitus: partes saepe connatae, lanccolatae, acuminatissimae, intus glabrae, reflexae, 0,025 longae, 0,0025 latae. Petala oblonga vel ovalia, obtusiuscula, breviter unguiculata, subaequalia, 0,03 longa, 0,01 lata, membranacea, alba, nervis pinnatis. Sталима 10, omnia fertilia, alterna longiora; filanienta subteretia, basi latiora, breviter coalita, apici subulata; ANTHERAE oblongae, acutiusculae, eordatae, infra medium affixae, vacillantes; poLLEN sphaericum, verrucosum. Grropновun librum in tubo calycis, teres, glabrum. Ovariun rectum, lineari-oblongum, glabrum, uniloculare; ovula 8 ad 12; strudus compressus, glaber; sтigna capitatum, subbilobum. LeGUner stipitatum, recto-lincare, basi cuneatum, apici subfalcatum, rostratum, latere seminifero costatum, latere opposito obtusatum, torulosum, eoriaceum; endocarpio nitido, laete fusco. Furiculus unibidgatis arcuatus, subteres, semine delapso, apici bilobus: lobus inferior brevior linearis, emarginatus; lobus superior bipartitus, partibus linearibus. SEMEN compresso-ovoideum, basi cum appendiculo recurvato, fuscum, in dorso duabus lineis notatum; TESTA crustacea; TEGHEN corneo-carnosum, sat crassum. CoTYLEDones oblongo-rotundatae, obtusae, basi subcordatae, subcarnosae; Radicula teres; Gennula compresso-ovoïdea.

\section{Crescit juxta Limbang, Waniasa, Trogon: J⿳士口䒑.}

Tab. 9. 1-2. Figura Bauhiniae hirsutae. 1. Gemma floris. 2. Flos, petalis nondum explicatis, sepalis reflexis. 3. Petala. 4. Flos, ealyce et corollâ ablatis. 5. Cellulae endotheeii antiee, et 6. a latere visae. 7. Pollen. 8. Calyx et ovarium longitudinaliter secti. 9. Legumen, una parte ablatâ. 10. Pars leguminis aucta. 11. Semen in dorso visum. 12. Semen eodem modo visum parte funieuli reflexâ. 13. Semen in basi visum. 14. Semen cum funieulo umbilieali in basi visum. 15. Seminis pars eum parte funiculi a latere visa. 16. Semen. 17. Semen verticaliter, et 18. transversaliter sectum. 19. Pars spermodermis eum spermotylio aucta. 20. Pars seminis et funieuli umbiliealis vertiealiter seeta, aueta. 21. Seetio transversalis partis seminis aueta. Botanica. 
In de hoogere strcken van Java kan deze soort beschouwd worden, als de $\mathbb{B}$. tomentosa vervangende. Door den vorm der bladen en de kleinere bloemkroonen met geheel witte bloembladen, is zij gemakkclijk van deze te onderscheiden.

\section{BAUHINIA ACIDA. RwDT.}

B. foliis basi cordatis, foliolis ovalibus obtusissimis $4-5$ nervis ultra medium concretis, stipulis oblongis, bracteis acutis cucullatis, inflorescentiâ raccmoso-paniculatâ et calycibus fusco-tomentosis. (Lcgumen recto-linearc).

Bauhinia purpurca. D. C. Prod. 2. p. 515, nec Linn.

Arbor 10 ad 15 metrarum alta; truncus rectus, cylindricus, cortice nigrescente tectus; corona hemisphaerica, basi truncata, dense foliata. Rumi divaricati, subteretes, cinereo-fusci, glabri; Ra ritur angulati, sulcati, laete fusco-tomentosi. Folı basi profunde cordata, apici cum sinu $90^{\circ}$; adultiora utraque glabra; juniora subtus laete fusco-tomentosa; foliola ovalia, obtusissima, ad tres quartas et ultra connata, 0,06 longa, 0,04 lata, 4-5 nervia, nervis secundariis subparallelis; PETIOLI subtetragoni, supra sulcati, inferne et superne incrassati, pubescentes, 0,025 longi. Strpulas lanceolatae, acuminatae, tomentosae, minutae, admodum deciduae. InfLorescentia racemoso-paniculata, terminalis vel axillaris; pedurgulus commuris angulatus, tomentosus; Pedurculi PARTIALEs câdem formâ el eodem vestimento; PEdrcelut teretes, tomentosi, saepe longi, bibracteolati. Bractene ovatae, acutae, cucullatae, tomentosae; Bracteolae minutae, ovatae, acutae, appressae. Flores polygami. Alabastruri clavalum, obtusum, fusco-tomentosum. Catycis tubus campanulatus, basi conicus, intus glaber; limbus quinque partitus, partibus saepe connatis, ovatis, acutis vel acutiusculis, intus glabris, rectis, 0,01 longis, 0,003 latis. Petala 5, obovata, obtusa, basi angustata, undulata, intus glabra, extus pubescentia, subaequalia, 0,011 longa, 0,003 lata. STAmira 10, omnia fertilia, subaequalia; fldäIEnta linearia, basi latiora, apici angustata; ANTHERa ovatae, vacillantes. - Stamusur rudimenta in flore femineo filiformia, basi in verticillo connata. - Grvophorum in tubo calycis librum, teres. Ovarium lineare, utrique angustatum, tomentosum, uniloculare; ovula 10-16, compresso-ovoïdea; struus teres; stigri depressum, subbilobum. LEGUMEN rectum, lineare, basi cuneatum, apici acutum, margini carinato dense et in superficie sparsim pubescens, coriaceum, saepe 0,35 longum, 0,02 latum, reticulatim nervosum; epicarpio subcoriaceo; mesocarpio strato exteriore fibroso, strato interiore farinoso; endocarpio subcoriaceo, glabro. Semira 10-12, formâ et structurâ praeccdentis speciei.

\section{Crescit in sylvis juxta Tjikao, etc.: J. Jva, et in insula Trnor (.fide Herb. Clar. Prof. Reinwardt, Zippelius et Spanoghe).}

Deze soort werd door den Iloogleeraar Reinwardt, en later ook door Zippelius en Spanoghe, op het ciland Timor gevonden. Op Java verzamelde de Hoogleeraar Blume haar in de omstreken van Tjikao, cn ik zag haar in het bewesten van de rivier Tjitarum gelegen voorgebergte Passir Heas. Zij is op laatstgenoemd eiland onder den naam Kandajakkan bekend, en wordt aldaar somwijlen door de inlanders bij de berciding hunner spijzen, even als de vruchten der tamarinde, gebruikt. 
Dcze soort is, gelijk de Heeren Wight en Arnott opgemerkt hebben (Prod. Flor. Pen. I. p. 296), door den Heer De Candolle ten onregte voor de B. purpurea, Linn. gehouden. Zij zoude, indien wij den habitus raadplegen, eene eigene groep kunnen vormen.

PHANERA. Loureiro nec De Candolle.

SYMPIIYOPODA. DE CANDOLXE.

VI. BAUHIVIA KOCKIANA. Krs,

B. foliis ovalis basi obtusis apici emarginatis tri-nerviis glabris, inflorescentiâ corymboso-racemosâ, petalis unguiculatis subrotundis.

CuULIS scandens, compressus, cortice suberoso tectus; Ram subteretes, fusei, glabri; RAMULI obscure tetragoni, quadri-sulcati, glabri; novelli sparsim pubescentes. Folı ovata, acuminata, acumine emarginato, basi cuneata vel obtusa, supra nitida, subtus glabra, in nervorum axillis fusco-pilosa, 0,1 longa, 0,045 lata, trinervia, nervis secundarïs subparallelis; petroli tetragoni, pubescentes, 0,01 longi. Crarht. pedunculanei, compressi, sulcati, glabri, superne fusco-sericei. INFLORESGENTI corymboso-raccmosa, terminalis vel axillaris; pedurgulus connurs angulatus, sulcatus, fusco-pubescens; PEDraELur triangulares, sparsim pubescentes. BracteAe lanceolatac, acuminatae, dense pubcscentes, minutac; BRActeola e filiformes. Alabastro pars inferior cylindrica; pars superior globosa. Calycrs tubus cylindricus, sulcatus, ferrugineo-sericeo-pubescens, 0,015 longus, intus glaber; limbus quinque partitus: partes ovatae, acutac, extus ferrugineo-sericeae, intus glabrae, partim saepe conglutinatae, reflexae, 0,01 longae, 0,003 latae. Petala quinque, inacqualia, - unum vexillum menticns aequilatcrale, altera inaequilateralia, - subrotundata, obtusa, basi angustata, unguiculata, intus glabra, extus in nervis pilosa, 0,02 longa, 0,015 lata. Stamina 8; tria fertilia, quinque sterilia: fertilia approximata; frLAmentu teretia, attcnuata, curvata, glabra; ANTHERAE subdidymac, in connexivo carnoso aflixae, vacillantes: sterilia minora, inaequalia; FILAлreivTs teretia, attenuata, glabra; antherarum rudimenta subrotunda. Groophonur cum calycis tubo concretum. Ovarium compressum, oblongum, utrique angustatum, sigmoïdeum, margini dense fusco-sericeo-pilosum, uniloculare; ovvLA 3 ad 6 ; struUs subcompressus; stigir capitatum, depressum. Legunen stipitatum, uno latere recto, altero arcuato. Senirra funiculo umbilicali lamelliformi affixa, disciformia.

\section{Crescit in sylvis montes Melintang: Sumatra.}

Tab. 10. Figura Bauhiniae Kockianae. 1. Pctalum postice visum. 2. Flos, genitalibus ablatis. 3. Flos, petalis ablatis. 4. Sectio transversalis anthcrac. 5. Calycis tubus verticaliter scctus et ovarium. 6. Ovarium verticaliter sectum. 7. Legumen immaturum verticaliter sectum. 8. Semen cum funiculo umbilicali. 9. Sectio verticalis seminis et funiculi. 10. Embryo juvenis cum integumento.

Deze soort heb ik in de bosschen gevonden, wclke den voet van het beoosten Padang gelegen gebergte bedekten. Zij behoort tot de grootste slingerplanten, heeft cene zaamgedruktc steng, blinkende 
bladen en schitterend gele, later rood wordende blocmen. Door den vorm harer bladen wijkt zij van de tot dusver bekende soorten af; doch door hare bloemdeelen behoort zij bij Bauhinia. Zij groeide in gezelschap van Dissochacta cn Marumia, waarmede harc bladen cenige gelijkhcid hcbben, en versprcidde, even als deze, haar loof en bloemen tusschen dat van de kroonen der hoogstc boomen.

Deze fraaije soort, toegewijd aan Zijne Excellentie den Heer Baron de Kock, vroeger LuitenantGouverneur-Gcneraal van Neêrlandsch-Indië, thans Minister van Bimnenlandsche Zaken, strekke in het wctenschappelijk stelsel om aan dezen cdelen Staatsman, als bevorderaar der wetenschappen te herinneren, en tevens als ecn opentlijk bewijs der dankbaarheid van eenen harer beoefenaars.

\section{BAUHINIA PYRRANEURA. Krs.}

B. foliis suborbiculatis basi eordatis apici emarginato-aeuminatis subtus in nervis, ct bracteis cucullatis ct inflorescentiả corymboso-racemosâ ferrugineo-sericeis, pctalis unguiculatis subrotundis.

Cartus scandens, compressus, cortice suberoso, rimato, fusco tectus. Rami subtetragoni, quadrisulcati, nigri, glabri; Ranuri obscure tetragoni, quadri-sulcali, glabriusculi; novelli tetragoni, profunde sulcati, dense ferruginco-pubescentes. Fours integra, suborbiculata, basi cordata, apici cum acumine brevi emarginato; adultiora subtus in nervis pubescentia; juniora supra glabra, subtus praesertim in venis et nervis ferrugineo-pubescentia, 0,16 lata, 0,17 longa, 9 nervia, nervis secundariis subparallclis; petrou subteretes, pubescentiâ fcrrugineà deciduâ tecti, 0,045 longi. Striputae admodum deciduac. Cirrei folianei, compressi, versus apicem incrassati, pubescentes. Inflorescenta corymboso-raccmosa, oppositifolia vel terminalis: pedunctius comrunis angulatus, sulcatus, pubescens; pedicelti triangulati, sulcati, dense pubescentes, bibracteolati. Bracteas cucullatae, ovalae, obtusae, intus glabrae; bracreolá minutae, lanccolatae, admodum deciduae. Alabastrum clavatum, acutum, decem sulcatum, dense ferruginco-pubescens. CALYCIS tubus cylindricus, decem costatus, costis obtusis, intus glaber; limbus quinque partitus: partes ovatae, acutae, intus glabrae, saepe conglutinatae, rcflexae, 0,008 longae, 0,004 latae. Petala quinque, subaequalia, - unum vexillum menticns aequilaterale, altera inaequilateralia, - subrotunda, obtusa vel obtusiuscula, basi angustata in unguiculam, margini undulata, intus glabra, extus in nervis et unguiculis pilosis, 0,034 longa, 0,025 lata, flava. Stamina 10, basi monadelpha, tria fertilia, septem sterilia; fILA MENTA primorum subtetragona, attenuata, glabra; ANTHERAE subdidymae, oblongae, infra medium affixae, vacillantes; rudimenta staminum subtetragona, corpusculis oblongo-ovoideis terminata. Grrophorur tubo calycis adnatum, parte liberâ hirsutum. Ovariưr sigmoideum, eompressum, margini dense pubescens; ovula 3 ad 10, compresso-ovoïdea. STruus recurvatus, subcompressus, glaber; sтiglis capitatum, depressum.

\section{Crescit in sylvis montes Melintang: Sumatra.}

Tab. 11. Figura Bauhiniac pyrrancurae. 1. Gemma floris. 2. Gemma floris aperiens. 3. Petala. 4. Flos, calyce et corollâ ablatis. 5. Flos, corollâ et staminibus ablatis. 6. Calycis tubus longitudinaliter sectus. 7. Ovarium longitudinaliter seetum. 8. Symmetria floris. 
Op ongeveer 200 ellen boven zee groeit deze soort in het gebergte Melintang. Zij is door de ont-wikkeling der bladen en somwijlen ook der bloemen opmerkenswaardig. De eersten hebben twee palmen lengte en even zooveel breedte, cn de bloemen, welke bij derzelver ontwikkeling goudgeel gekleurd zijn, hebben soms zes duim middellijn. De B. pyrraneura heeft cenige verwantschap met $\mathbb{B}$. integrifolia, Roxb. (Flora Indica II. p. 331); doch verschilt van deze door de meerdere grootte en door den vorm der bladen. Deze zijn bij de laatstgenoemde soort aan den top afgerond en hebben de middelnerf als eencn draad boven de bladschijf uitgegroeid.

\section{BAUHINIA ELONGATA. Kus.}

B. foliis basi cordatis, foliolis ovatis obtusis 5 ncrviis ultra mcdium connatis subtus, ct stipulis lanceolatis, et bracteis ovatis, ct inflorcsccntiâ racemosâ ferrugineo-tomentosis, petalis ovali-oblongis unguiculatis.

Arbuscula 8 metrarum alta; truncus brevis; corona oblonga, dense foliata; ramin flexuosi, subteretes, fusci, glabriusculi; RAMULi obscure tetragoni, sparsim pubescentes; novelli tetragoni, dense ferrugineopubescentes. Folia basi cordata, apici sinu 45; juniora utraque dense, adultiora subtus densc ferrugineo-pubescentia; foliola oblongo-ovata, obtusa, ultra medium coalita, 5 nervia, nervis secundariis parallelis, approximatis, 0,11 longa, 0,065 lata; регіоц tetragoni, superne et inferne incrassati, dense pubescentes, 0,04 longi. Strpulae lanceolatae, pubescentes; stipellat petiolo adpressae, filiformes, admodum caducae. Irflonescentia oppositifolia, racemosa; pedunculus connunis subteres, superne compressus, dense tomentosus; penicelli trigoni, sulcati, bibracteolati. Bracteas ovatae, acutae, cucullatac, intus glabrae, extus tomentosae; bracteolae oblongae. Alabastrudi clavatum, apici acutum, dense ferrugineo-tomcntosum. Catrcis tubus cylindricus, subsulcatus, intus glaber; limbus quinque partitus: partes lanceolatae, acutae, intus glabrae, saepe conglutinatae. Persta quinque, subaequalia, ovali-oblonga, acuta, basi angustata in unguem, margini undulata, intus glabra, extus in nervis pilosa, 0,04 longa, 0,008 lata. Stanira tria fertilia; rilamenta subteretia, versus apicem compressa, glabra; antherae oblongae, ad extremitates cmarginatae, vacillantes. Grophorin tubo calycis adnatum, parte liberâ dense hirsutum. Ovarium compressum, oblongum, utrique attenuatum, dense cinereohirsutum, uniloculare; ovula 6-8. STruds teres, hirsutus; stigria hemisphaericum, sulcatum. Legunien lineare vel oblongo-linearc, basi angustatum, cuneatum, apici curvatum, dense fusco-tomentosum. SEMriva formâ et structurâ eorum Bauhiniae ferrugineae.

Collegi ad flumen Baritto: Bonveo.

Tab. 24. Figura specici. 1. Alabastrum. 2. Alabastrum, calyce ablato. 3. Flos apertus. 4. Ovarium, tubo calycis longitudinaliter secto. 5. Ovarium longitudinaliter sectum. 6. Leguminis valva. 


\section{BAUHINIA FERRUGINEA. Roxburgh.}

B. foliis basi cordatis, foliolis ultra medium coneretis obtusis quinque nerviis, stipulis et braeteis obtusis, et inflorescentiâ racemosâ ferrugineo-pubeseentibus, petalis longe unguiculatis obovatis.

Roxb., Flora Indica, II. p. 331. B. exeelsa, Khs. MS.

CAULIS scandens; RA bif bifaii, obscure tetragoni, glabri, laete fusci; RAMULI novelli tetragoni, quadrisulcati, dense ferrugineo tomentosi. For.Is basi cordata, apici sinu $30^{\circ}$ ad $45^{\circ}$, adultiora utraque glabra; juniora subtus, praesertim in nervis pubescentia; Folrola oblongo-ovalia, obtusa, ultra medium connata, quinque nervia, nervis secundariis distantibus, ,0,06 longa, 0,035 lata; PETIOLI subcylindrici, superne et inferne incrassati, pilosi, pilis deciduis, 0,02 longi. Sripula ovatae, obtusae, supra glabrae, subtus dense pilosae. Cirren stipulanei et folianei indivisi, saepe compressi, glabri vel pilosi. Inflonescentua terminalis vel axillaris, racemosa; penungules connuvis angulatus, sulcatus, dense ferrugineo-pubescens; pedicelli trigoni, sulcati, bibracteolati. Bracteae ovatae, obtusae, intus glabrae, extus pubescentes; bracteola oblongae, obtusae. Alabastrudi dense ferrugineo-pubescens, pentagonum, sulcatum, acutum. Casycis tubus subcylindricus, decem costatus, costis obtusatis, basi gibbus, intus glaber; limbus quinque partitus, reflexus: partes oblongo-lanceolatae, acutae, intus dense pubescentes, 0,035 longae, 0,006 latae. Pexala quinque, subacqualia, obovata, obtusa, basi cuneata, in unguem angustata, intus glabriuscula, extus dense sericeo-pilosa, 0,04 longa, 0,012 lata. Stamrin quinque; tria fertilia, duo sterilia; FILAIENTa tetragona, attenuata, glabra; AпTHERAE oblongo-lineares, utrique emarginatae, in medio connectivi ampli aflixae, 0,02 longae, 0,005 latae; rudimenta staminum filamentis ietragonis, attenuatis et corpusculis bilobis. Grrophonuri pro parte tubo calycis adnatum. Pistrudur sigmoideum; ovariun oblongum utrinque angustatum, dense sericeo-pubescens; ovuls. 4 ad 10; struts compressus, apice dilatatus; strgira capitato-angulatum, depressum. Legunen stipitatum, lineare, basi cuneatum, apici arcuatum, margini dense ferrugineo-pubescens; endocarpium coriaceum glabrum; sarcocarpium strato celluloso et altero strato vasculoso formatum; epicarpium coriaceum, crassum, fuscum. Semrra in locellis posita, discoidea, marginata, fusca, nitida, funiculo umbilicali lamelliformi, triangulari affixa. Eurbryo rectus; ranicula teres, acuminata; cotyledones subrotundae, obtusae, basi cordatac.

\section{Crescit ad montes Pamalton et Sakoembang: Borveo.}

Tab. 23. Figura et analysis Bauhiniae ferrugineae. 1. Flos nondum apertus. 2. Flos, calyee ablato. 3. Flos, ealyce et eorollâ ablatis. 4. Ovarium eum tubo calycis. 5. Idem longitudinaliter sectum. 6. Ovarii pars. 7. Semen cum funiculo umbilicali. 8. Semen vertiealiter sectum. 9. Embryo.

De, door ons op Borneo verzamelde voorwerpen versehillen, door de veel grootere bloemen, van die, welke het Rijks Herbarium uit de verzameling van Roxburgh bezit. Tusschen de jonge en oude planten dezer soort bestaat er, behalve in de zamengroeijing der blaadjes, nog een groot verschil in de haren; deze zijn aan de jonge planten dikwerf vrij lang en van de bedekte deelen verwijderd; bij de oude, daarentegen, kort en tegen deze deelen aangedrukt. Deze soort hebben wij tusschen 50 en 200 ellen op den Pamatton en Sakoembang bloeijend, en als eene jonge plant op den berg Prarawin verzameld. Deze groeiplaatsen pleiten voor hare verspreiding op Borneo's zuid-oostkust. 


\section{BAUHINIA SEMIBIFIDA. RoXbURGH}

B. foliis basi cordatis, foliolis ultra medium connatis oblongis obtusis 5 nerviis, stipulis falcatis, et bracteis lanceolatis, et inflorescentiâ racemosâ dense fusco-pubescentibus, petalis oblongis basi subcordatis unguiculatis.

Roxburgh, Flor. Indica, II. p. 330; Wallich, Plantae rar. Tab. 253.

\section{Crescit juxta Doekoe el Pao: Sumatra.}

In de beide genoemde werken is deze plant uitvoerig beschreven of afgebeeld. Bij deze opgaven kan ik nog voegen, dat dc bladen der jonge planten met langere haren bedekt zijn en de ondervlakte purperklcurig hebben. De Baubinia semibifida is door ons gevonden in de bosschen, welke den alluvialen bodem van Sumatra's westkust bedekken.

\section{BAUHINIA FULVA. Bugie.}

B. foliis basi cordatis, foliolis obovalibus obtusis 5 nerviis ultra medium concretis, stipulis falcatis obtusis, bracteis ovatis et inflorescentià paniculato-racemosâ dense pubescentibıs, petalis obovalibus obtusis extus villosis.

CAulis scandens; RAmI subteretes vel obscure tetragoni sulcati, glabri; Ramulr bifarii, compressi, sulcati, subpilosi. Folis exciso-cordata, apici sinu $30^{\circ}$ ad $40^{\circ}$; juniora supra glabra, sultus in nervis dense ferrugineo-pubescentia; adultiora utraque glabra, basi dense pubescentia; foliola obovalia, apici obtusa, raro acutiuscula, basi oblusa, margini subintegerrima, saepe pubescentia, 0,085 longa, 0,045 lata, ultra medium concreta, quinque nervia, nervis secundariis distantibus; PETIOLI juniores ferrugineopubescentes, adultiores glabri, subteretes, ad extremitates incrassati 0,03 ad 0,010 longi. Stipulate ovato-falcatae, obtusae, intus glabriusculae, extus dense pubescentes; stipelda obtusae, minutae. Cirrir pedunculanei, compressi, superne incrassati, glabri vel pubescentes. Inflorescentia paniculatoracemosa, terminalis; Pedunculus conmunis angulatus, sulcatus; PEdiceldi trigoni, sulcati, saepe 0,003 longi, dense cinereo-pubescentes. Bracteae oblongo-ovatae, acutae, intus glabrae, intus pubescentes; Bracteolate flore approximatae, vix conspicuae. Alabastrum clavatum superne ovoïdeum, cinereopubescens. CaLYars tubus brevis, subpentagonus, intus glaber; limbus quinque partitus: partes ovalioblongae, acutiusculae, intus glabrae, 0,006 longae, 0,002 latae, saepe conglutinatae. Petara quinque, unguiculata, obovalia, obtusa, basi cuneata, intus glabriuscula extus dense villosa, 0,015 longa, 0,006 lata, alba. Stamina 5, tria fertilia, duosterilia; filantenta tetragona, attenuala, glabra; antherae ovatae, obtusae, basi cordatae, vacillantes; Rudinenta teretia, attenuata. Grvophori pars cum tubo calycis coalita glabra, libera dense hirsuta. Ovariux lineari-oblongum, compressum, utrique angustatum, dense hirsutum; ovula 6 ad 8 ; stylus compressus, superne glaber; stigni capitalum, subsulcatum.

\section{Crescit in sylvis montium Papandajang, Goentoer, elc.: J⿳士口䒑.}

In de bosschen der gemelde bergen, tusschen de 600 en 1000 ellen boven zee, heb ik deze soort, als eene aanzienlijke slingerplant, aangetroffen. Zij is zeer rijk aan bloemen, welker kroonen bij de opening wit zijn en later geel worden. 


\section{BAUHINIA STIPULARIS. KHs.}

B. foliis basi exciso-cordatis, foliolis oblongis acutiusculis ultra medium connatis 4-5 nerviis, stipulis suborbiculatis vel reniformibus, bracteis lanceolatis, inflorcscentià corymboso-racemosâ, petalis oblongis acuminatis basi subcordatis.

CAvULIS scandens; RAMI tcretes, rugosi, griseo-fusci; ramul obscure tetragoni, sulcati, fusco-pubescentes. Foura basi cordata, apici sinu $30^{\circ}$ ad $40^{\circ}$, supra glabra, adultiora subtus sparsim et juniora dense pubescentia; foliola oblonga, acutiuscula, 4-5 nervia, nervis secundariis distantibus, ultra medium connata, 0,075 longa, 0,035 lata; PETIOLI subteretes, inferne ct superne compresso-incrassati, 0,04 longi。 Strpulae suborbiculatae vel reniformes, intus glabriusculae, cxtus pubescentes; stipellat minulae, ovales, obtusae. Ctrrui simplices, subteretes. Invlorescientra axillaris, oppositifolia vel terminalis, corymboso-racemosa; PEDunculus connunis angulatus; PEDICELLI triangulati, trisulcati, longi, bibracteolati, dense pubescentes. Bracteae et bracteolae lanceolatae, acuminatae, pubescentes. Alabastruri subpentagonum, acutum, dense pubescens. Caryars tubus subpentagonus, inferne gibbus, decem sulcatus, intus glaber; limbus quinque partitus: partes lineari-oblongae, acuminatae, mucronulatae, intus glabrae, 0,025 longae, 0,003 latae. Petala quinque, alba, unguiculata, subaequalia: unum vexillum mentiens oblongum, acuminatum, basi profunde cordatum; altcra oblonga, acuminata, basi cordata, 0,01 lata, 0,025 longa, intus glabra, extus in nervo mediano sparsim pilosa. Stмunva 5: tria fertilia, duo

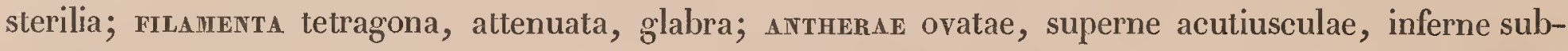
cordatae, vacillantes: sterilium filamenta câdem formâ, rudimenta antherarum gerentia. GxropHorı pars cum tubo calycis coalita glabra; pars libera dense pubescens. Ovaruum oblongum utrique angustatum, dense pubescens, uniloculare; ovula 3. Struds compressus, superne latior, glaber; stigin capitatum, truncatum. Leguner lineare, basi cuneatum, apici rotundatum, acutum, lignosum, fuscum. Semrrs haud ab iis Bauhiniae ferrugineae diversa.

\section{Crescit in monte Singalang: Sumatra.}

Ongeveer 600 ellen boven zec werd deze soort in de bosschen van den Singalang verzameld. 'Zij is bijzonder opmerkenswaardig door de aanzicnlijke groottc en den vorm der nevenblaadjes. Hare klawieren, ten koste van de nevenblaadjes, van de bladen en somwijlen van de bloemen gevormd, zijn meestal ongcdeeld en, even als die der andere soorten, bij welke zij enkelvoudig zijn, naar buiten omgerold.

\section{BAUHINIA CORYMBOSA. RoXbUrgh.}

B. foliis basi cordatis vel truncatis, foliolis rotundato - ovatis obtusis infra medium connatis, stipulis ct bracteis lanceolatis, inflorcsccntiâ corymboso-racemosâ rufo-sericcâ, pctalis oblongis oblusis unguiculatis.

De Candolle, Prod. 2. p. 515; De C. Mem. s. 1. Leg. p. 487, Tab. 70; Roxburgh, Flor. Ind. II. p. 329.

Crescit in monte Singalang: SunitRa, etc. 
BIJDRAGE TOT DE KENNIS

DER

\title{
T E R N S T R O E II I A C E A E,
}

Dook

\author{
P. W. K $0 R$ T H A L S.
}

Vele der geslachten van de familie der Ternstroemiaceae waren vroeger onder de Aurantiaceae gerangschikt. Uit dezen werden zij door den Meer Mirbel, wegens verscheidene kenmerken, die aan de echte Aurantiaceae vreemd waren, gescheiden, om onder twee afzonderlijke familiën, naar de voornaamste geslachten, Ternstroemieae en Theaceae genoemd, verdeeld te worden. Deze beide familiën behield de Heer De Candolle, wien de voorrang ten opzigte der afscheiding van de laatste familie, onder den naam Camellieae, toekomt, in zijnen Prodromus, daarbij opmerkende, dat de Ternstroemiaceae en Camellieae later, door de ontdekking van tusschenvormen, welligt vereenigd zouden kunnen worden. De Ternstroemiaceae werden in gemeld werk in vijf afdeelingen gesplitst: Ternstroemieae, Freziereae, Sauraujeae, Laplaceae en Gordonieae. Den beiden eerstgenoemden worden, als gemeenschappelijke kenmerken, schutblaadjes onder den kelk en vastgegroeide helmknopjes toegekend; zij worden onderscheiden door den stempel, die bij de Ternstroemieae zaamgegroeid, bij de Freziereae als in twee tot vijf deelen gespleten, voorkomt, en door den vorm der kiem, welke de laatste afdeeling een weinig gebogen, en de eerste geheel boogvormig bezit. De Sauraujeae en de Laplaceae hadden het gemis der schutblaadjes met elkander gemeen; doch de Sauraujeae waren gekenmerkt door de zamengroeijing der bloembladen, door de vasthechting van de helmknopjes op den rug, en door het gescheiden zijn van de stijlen; de Laplaceae, door de vrije bloembladen, die de drie tot vier kelkbladen dikwerf in getal overtroffen, door de vasthechting der helmknopjes aan den voet, en door de zamengroeijing der stijlen; daarenboven wordt aan deze afdceling een vleezig-hoornaardig eiwit toegeschreven.

Botanica. 
De Gordonieae, door den Heer De Candolle uit de Malvaceae en de Tiliaceae afgescheiden, worden door hem beschouwd, als eene aan de Ternstroemiaceae en de Camellieae verwante groep, die door het gemis van kiemwit van beiden afwijkt. - De Heer Cambessèdes, bij de bewerking van de Ternstroemiaceae voor de Flora Brasiliensis, al de hem ten dienste staande voorwerpen dezer familie, welke voornamelijk uit Amerikaansche soorten bestonden, onderzoekende, heeft zich voor de vereeniging der beide familiën, en tegen eene splitsing derzelve in groepen verklaard, omdat hij geene vaste kenmerken, die als grondslagen eener verdeeling konden dienen, tusschen de beide familiën en de geslachten vond. Dit gevoelen wordt door den Heer Lindley, die met de Ternstroemiaceae, zijne alliance theales vormt, aangenomen. De beide familiën zijn door den Heer Endlicher, onder den naam Ternstroemiaceae vereenigd gelaten, doch in zes afdeclingen: Cochlospermeae, Ternstroemieae, Sauraujeae, Laplaceae, Gordonieae en Camcllieae, gescheiden, wier kenmerken van de bloem en de vruchtdeelen zijn genomen. Deze namen herinneren, met uitzondering van den eersten, de door den Heer De Candolle aangenomene benoemingen der afdeelingen, doch het wezen der door dezelve aangetoonde afdeelingen is veranderd. De Ternstroemieae bevatten nu de Ternstroemieae en de Freziereae De C.; de Laplaceae, met andere geslachten, het geslacht Laplacea; terwijl Cochlospermum de afdeeling van dien naam vormt.

Het onderzoek der in den Archipel verzamelde soorten heeft mij de gelegenheid verschaft, aan de Indische gewassen dezer familie de verdeeling te toetsen, welke voornamelijk op Amerikaansche vormen was gevestigd, en welligt ook, om eene juistere omschrijving der afdeelingen te geven. Daarenboven heeft mij dit de Calpandria, Pyrenaria en Adinandra, als echte leden der familie doen kennen, cn in de Laplacea vulcanica en in Ploiarium, welke zeer verwant is aan Bonnetia, nieuwe vertegenwoordigers van Amerikaansche vormen doen vinden. De waarnemingen, door dit onderzoek gedaan, leveren de volgende uitkomsten. De Indische soorten zijn boomen, welke soms $30 \mathrm{~N}$. ellen, doch meestal tusschen de 3 en $20 \mathrm{~N}$. ellen hoogte hebben; of struiken, waaronder eenigen ééne el niet te boven gaan. Derzelver takken buigen zelden naar beneden, en de takjes, die rond of, en dit is niet zelden, zaamgedrukt zijn, worden bij sommigen door de zwaarte der vruchten nederwaarts gerigt. De stand der bladen tot elkander moet als afwisselend opgegeven en in verband beschouwd worden, als aan twee wijzigingen onderworpen: bij de eene in eene spiraal met het zesde blad boven het eerste: Ploiarium; bij de andere is de spiraal afgebroken: Lurya. Hun vorm ligt tusschen het ronde en dien van het lancet. Zij hebben de beide einden puntig en den rand gaaf, getand of gezaagd. De beide vlakken zijn bij de jonge bladen meestal door eenvoudige haren, of, zoo als bij Saurauja, door haren en saplooze schubjes bedekt; bij de oude bladen worden zij dikwerf glad. De knoppen zijn door schubjes bedekt of bloot: de eerste zamenstelling, welke ook aan de Thea en Camellia eigen is, bezit de Calpandria; de tweede is die der andere geslachten. De laatsten hebben, in plaats van eene bladaardige bedekking, eene digte harige of schubachtige bekleeding. In de knoppen liggen de bladen eerst omvattend, vervolgens rijdend: Sarosanthera, Adinandra, Saurauja; of rijdend met de randen naar binnen op het bovenvlak gevouwen: Gordonia, Schima, enzv., waarbij op te merken is, dat dan de zaamgevouwen deelen meestal glad zijn. Nevenblaadjes heb ik bij geene der soorten waargenomen. - De bloemen staan meestal in de oksels der bladen, doch komen bij enkele soorten in groepen uit den stam of oudere takken tc voorschijn: eene bloeiwijze, uit de eerste ontstaan, door het eigenaardige om op dezelfde plaats 
bij herhaling de bloemen te ontwikkelen; of zij zijn, door het niet vitgroeijen der bladen, in trossen aan het einde der takjes aanwezig, of, in bijsehermen uit de oksels der bladen groeijende, vereenigd: in beide gevallen verraden zij, door hare plaatsing, de oorspronkelijke bloeiwijze. De bloemstelen zijn bij eenigen kort en bij anderen, zoo als Ploiarium, Adinandra enzv., tamelijk lang. Op dezelve vertoonen zich, bij de meeste soorten, twee schutblaadjes, door derzelver stand en vorm versehillende. Zij staan dikwerf zoo digt bij den kelk, dat zij tot dezen sehijnen te behooren, en hebben dan de gedaante van kleine kelkbladen: Eurya, Adinandra enzv.; of zij zijn van dezen verwijderd, waardoor hun afwisselende stand duidelijker is, en komen dan als sehubjes (Saurauja), of als kleine blaadjes (Ploiarium) voor. Behalve deze beiden is er bij de trossen, aan den voet van ieder bloempje, een tcgenover de spil staand schutblaadje, hetwelk dikwerf zeer vroeg afvalt. - De kelk van al de door mij onderzochte soorten is geheel vrij, bedekt de bloemkroon in den jeugdigen staat en vervolgens het jonge vruehtbeginsel, en blijft, veclal ook bij de vergrooting van dit, terug, dikwerf aanzienlijk uitgroeijende, om of onder de vrueht. Bij Schima bedekt de kelk, alleen bij hare eerste ontwikkeling, de bloemkroon. Bij de vruchten, welke openspringen (Antheëisehima), duurt de kelk, aan dezelfde takken, onder de vrueht voort, of valt hij geheel of gedeeltelijk af; bij de vleezige vruehten blijft hij. De vijf kelkbladen, uit wclke hij bestaat, bedekken elkander meer of minder door de grootte der sehijf, bij wijze van dakpannen, en staan in eenen onregelmatigen krans. In dezen stand zijn twee wijzigingen: de eene heeft het vijfde kelkblad tegenover de spil der plant: Ploiarium; de andere van de spil verwijderd. Zij zijn meestal vrij, somwijlen eenigzins zaamgegroeid, ongelijk in grootte, gewoonlijk de twee kleinste, en de drie grootste gelijkvormig, op de aan de lueht blootgestelde gedeelten door haren of schubben bekleed. De bloemkroon staat onder het vruehtbeginsel en valt kort na de bevruehting af. Zij bestaat uit vijf bloembladen; somivijlen, bij Laplaeea, Gordonia, en ook bij Thea, zoo als mij het onderzoek van de Theeboomen op Java bewezen heeft, schijnbaar uit een grooter getal: want dan hebben de bedekte kelkbladen het aanzien der bloembladen aangenomen, of eenige helmdraden zijn tot bloembladen uitgegroeid. Vór de opening liggen de bloembladen als dakpannen over elkander: Gordonia, Eurya, Laplaeea; of als een peperhuis zarnengerold: Saurauja, Ploiarium; na dezelve groeijen zij tot rozenvormige bloemkroonen, met kortere of langere buizen. ' Lij zijn geheel vrij, of aan den voet, zelden meer dan tot op een vierde van derzelver lengte, zamengegroeid. Hunne gedaante is langwerpig of rond, dikwerf onregelmatig door de grootere ontwikkeling van eene der zijden, bij de met eene gerolde bloemplooijing voorziene Sauraujae en Ploiarium. - De helmdraden zijn vijfvoudig in getal, dat met de beide bloemkransen gelijk staat: Eurya; of helzelve eenmaal, meermalen en zelfs tot twintigmaal overtreft: Gordonia, Thea. Onder het vruehtbeginsel geplaatst, omgeven zij dit als een gave ring of buis, of wel als een, die in verseheidene stukken gebroken is, naarmate van de zamengroeijing der draden. Bij Calpandria zijn de builenste helmdraden in eene buis zaamgegroeid, en de binnenste geheel vrij; zij vormen met het benedenste gedeelte eene dikke buis, die niet gebroken is: Sarosanthera; of eene, in vijf stukken gespletene: Adinandra. In vijf bundels, tegen over de bloembladen staande, zijn zij bij Ploiarium vereenigd; terwijl de tusschenruimte over de kelkbladen door kleine uitgroeisels wordt aangevuld. Zij zijn alleen aan, of even boven hunnen voet met elkander en met de bloembladen zaamgewassen bij Gordonia, Saurauja, Sehima enzv.; geheel vrij bij Eurya, eenige Sauraujac, enzv. De zaamgegroeiden vallen gewoonlijk met de bloemkroon af en laten dan, zoo als bij Saurauja, eenen rand terug, die veel van 
eenen Diseus heeft. De helmdraden zijn tamelijk lang en verschillen in hun vrij gedeelte, naar de meerdere of mindere zamengroeijing. De helmknopjes zijn met de helmdraden geheel: Sarosanthera, of op het midden van den rug zaamgegroeid: Saurauja; of wel zij zijn op dezen geleed en bewegelijk, en dan op den rug, even boven het benedenste of op het midden, verbonden. Lijnvormig, langwerpig, aan de beide einden ongedeeld, of het eene einde in twee lobben geseheiden, zijn zij bij Saurauja; eivormig, aan het benedenste einde, dat soms door ombuiging het bovenste sehijnt, hartvormig ingesneden bij vele anderen; en tweelobbig of uit twee, van elkander verwijderde halve eirkels bestaande, bij Antheëisehima, Sehima enzv. Aan deze versehillende vormen heeft de helmknoop een wezentlijk aandeel: niet zoo zeer in lengte uitgegroeid zijnde, als de hokjes van den helmknoop, doet hij de helmknopjes tweelobbig worden; naar boven in een smal streepje uilloopende, geeft hij aan dezelve den vorm van een omgekeerd hart, dat naarmate hij min of meer boven de hokjes uitsteekt, spitser is; breeder zijnde, zoodat hij eirond of bijna rond is, en alleen aan de zijden, maar niet aan de einden door de hokjes omgeven wordende, bepaalt hij den tweelobbigen vorm. De beide hokjes zijn aan weêrszijden, of langs de zijden en op het binnenvlak van den helmknoop geplaatst. Zij zijn in den jeugdigen staat ieder in tweeën verdeeld, doeh worden later, door de verwijdering van den tussehenwand des helmknoops, bijna altijd tweehokkig, en toonen dan nog, alleen door eene in de lengte loopende groeve, de vroegere verdeeling. Langs deze groeve heeft hunne opening plaats, die zeer dikwijls aan den top der hokjes begint. Bij sommige soorten: enkele Sauraujae, bepaalt zij zieh tot dit punt, waardoor deze dan sehijnbaar door poren het stuifmeel uitwerpen; bij de meesten eehter verwijdert zij de beide helften langs de groeve in de geheele lengte. In hoever de opening door poren aan den voet: bij Bonnetia, hiermede overeenstemt, moet het onderzoek der voorwerpen leeren. - De gemelde hokjes bestaan uit een fijn buitenvlies (Exotheeium) en een dikker binnenvlies (Endotheeium). Het eerste is, bij tamelijk sterke vergrootingen waargenomen, effen, zonder eellen, en bedekt den geheelen helmknop. Het andere daarentegen bestaat uit eigenaardige eellen, die het binnenste gedeelte van de hokjes van den helmknop geheel bekleeden. Deze eellen, zoo geheel afwijkende van de gewone in de ontwikkelde en geopende hokjes, zijn, in een zeer vroeg tijdperk onderzoeht, niet zoo versehillend. Zij zijn dan doorsehijnend, gevuld, effen, bijna kogelrond. Vervolgens komen zij meer verlengd, minder doorsehijnend, en aan de binnenzijde gestreept voor. Bij meer ontwikkelde helmknopjes nemen zij toe in lengle, en worden de strepen duidelijker en cirkel- of meer netvormig. Later, bij eene volkomene ontwikkeling, zijn de eellen langwerpig en aan de binnenzijde met netsgewijze verbondene, onregelmatig loopende strepen voorzien. Deze strepen, van het buitenvlies geseheiden zijnde, hebben eenige overeenkomst met de spiraaldraden. - Het stuifmeel is gewoonlijk rond, effen of met kleine puntjes, en springt op drie versehillende punten, die gelijkmatig van elkander verwijderd zijn, open. - Ilet vruehtbeginsel is meest half kogelrond of eivormig, en heeft van één tot vijf hokken. In de eenhokkige vruehtbeginsels groeijen de moederkoeken of zaaddragers, uit den omtrek naar het middelpunt, en zijn zij aan het einde in twee deelen gespleten, die omgebogen zijnde, de gedaante eener halve maan hebben, en met de einden elkander naderen: Sarosanthera. In de meerhokkige, hebben de zaaddragers in den binnensten hoek der hokken hunnen oorsprong. Zij zijn in deze onmiddellijk, of door middel van een dun plaatje, of door een klein steeltje bevestigd, en hebben de lengle van het hokje: Ploiarium enzv; ; of komen voor in het bovenste gedeelte van hetzelve: Ternstroemia enzv.; in het midden: Saurauja, Gordonia, Calpandria; of, zoo als bij Stewartia, even boven 
het benedenste van hetzelve. Hun vorm is die van een' eilinder: Ploiarium, van eenen halven bol: Sauraujae, onregelmatig, in verseheidene takjes verdeeld: Eurya, of gelijk aan lijnvormig uitstekende randen: Gordonia. De door dezelve gedragen wordende eitjes bieden gcene mindere verseheidenheid aan in getal, plaatsing, ontwikkeling enzv. Aan de lijnvormige zaaddragers zijn zij in een bepaald getal, drie tot aeht, in twee naast elkander gelegene rijen en afwisselend aanwezig; aan de, naar het uiteinde verdeelden, is aan ieder takje een eitje tot een onbepaald getal, van twee tot tien en meer; zij zijn dikwerf zeer talrijk op de half bolvormige en eilindervormige zaaddragers en langs de randen van de verdeelde zaaddragers der cenhokkige vruehtbeginsels. Alleen bij Ploiarium zijn zij door mij, met het benedenste einde vastgeheeht, bij de anderen hangende gezien. Door hunne ontwikkeling bchooren zij tot de Campylotropa en Anatropa. De eersten, welke wij zeer wel gekromde eitjes konden noemen, bij Reinwardtia, Eurya, Sarosanthera enzv. aanwezig, hebben de raphe zeer kort. De anderen, of de gebogene eitjes, hebben in hunne buiging eenige belangrijke wijzigingen, welke wel waargenomen, doeh in de besehrijvende kruidkunde niet genoegzaam zijn opgegeven. Aan de gebogene eitjes, waarin de raphe en het ligehaam van dezelve ongeveer paralel komen, werd door den Heer Mirbel de naam Ovula Anatropa gegeven. Bij allen heeft de buiging niet in dezelfde rigting, noch in dezelfde mate plaats; want bij eenigen: Saurauja, buigt het ligehaam van het ei van de spil af en is de raphe naar dezelve gekeerd, zoodat de eimond over den navel ligt: deze wijze van ontwikkeling zoude het woord extropa vrij juist uitdrukken; bij anderen buigt het ligehaam van het ei naar de spil, en de raphe van dezelve af, waardoor de eimond beneden het aanheehtingspunt van hetzelve ligt. Deze binnenwaartsehe buiging heeft bij de door mij onderzoehte soorten twee graden: de binnennavel ligt aan het benedenste einde van het ei: Gordonia enzv.: eene uitgroeijing, die deze eitjes zeer wel ovula entropa, binnenwaarts gebogene eitjes, kon doen noemen; òf de binnennavel is aan het bovenste einde van het ei, waarmede eene kleine buiging des ligchaams van het ei, in de nabijheid van den zaadmond vergezeld is: Sehima; deze ontwikkeling, eene wijziging van de vorige zijnde, zoude deze half binnenwaarts gebogene citjes den naam kunnen doen dragen van ovula hementropa. - De stijlen zijn somwijlen zecr kort. Hun getal is gclijk aan dat der hokken van het vruchtbeginsel; doeh door zamengroeijing zijn zij dikwerf tot één ligehaam vereenigd. - De stempels bevinden zieh aan het einde der stijlen of even beneden derzelver top, aan de binnenzijde; in het laatste geval is het stempelkanaal, de buis, waardoor de bevruehtende stof in het vruehtheginsel dringt, van den top af aan tot op de helf der lengte, soms nog verder, open en het inwendige met kleine kliertjes bezet. - De vruehten zijn rond of eivormig, in den omvang hoekig of van diepe voren voorzien. In hare zelfstandigheid bezitten zij overgangen van het sappige tot het drooge houtige. Hare bekleedsels, ten minste de beide binnensten, hebben op deze verseheidenheid beurtelings invloed. Het buitenvruehtbekleedsel (epiearpium) is, zoo lang de staat der vrueht het onderseheiden laat, lederaehtig, somwijlen vliezig. Het middelvruehtbekleedsel (sareoearpium) bestaat uit een vezelrijk sappig of droog vleesch, of uit eene vezelige, drooge stof, en het binnenvruehtbekleedsel (endoearpium) is vliezig, lederachtig of broos; in het laatste geval is het dikwerf vrij dik en glanzig, en heeft het daarenboven eenigen invloed op den aard der vrucht. Door hetzelve worden de wanden der vruchthokken gevormd. Deze zijn door vergroeijing of door miswas, in grooter of kleiner getal, dan in het vruehtbeginsel, aanwezig: in grooter getal, bij Sarosanthera, door de zamengroeijing van de bogen der zaaddragers, die de vrueht van drie- tot vijfhokkig maakt, cn ieder 
hok door de zaamgegroeide verbinding van twee naast elkander geplaatste bogen beperkt; in kleiner getal, door eene aanzienlijke vergrooting van het zaad. De drooge vruehten springen in even zoo vele kleppen open als er hokken zijn. Bij de meesten seheiden zieh deze kleppen van boven af aan; tot op het midden der vrueht, zelden tot beneden, omgeven zij met het verbonden gedeelte een standertje, en dragen zij in het midden den tussehenwand van de beide hokken, die hunne helften bedekten. Bij Ploiarium beginnen de kleppen in het benedenste gedeelte der vrueht te openen, blijven zij met het bovenste om het standertje verbonden, en vormt ieder, omdat bij de opening de tussehenwanden gespleten zijn, een kaantje, dat het spitse eind naar boven gerigt heeft: eene wijze van openen, die de Geraniaeeae herinnert, en ten naastenbij op hetzelfde beginsel rust. - Het gemelde standertje, dat reeds meer of min duidelijk in het vruehtbeginsel aangewezen kan worden, is eene voortzetting van de spil, die zieh zoover uitstrekt als er zaden zijn vastgeheeht, vermoedelijk om deze te voeden. In deszelfs lengte versehilt het derhalve naar de aanheehting der zaden: bij Malaehodendron is het waarsehijnlijk zeer kort; deszelfs vorm verandert, naarmate een meer of min aanzienlijk gedeelte van de vruehtvormende bladen met deze verlenging der spil is zaamgegroeid. Aan hetzelve bevinden zieh de zaaddragers als eilinders of als lijnvormige randjes. De vleezige vruehten blijven gesloten. Hare zaaddragers ondergaan over het algemeen weinig verandering; doeh somwijlen groeit derzelver eellig gedeelte vleezig tussehen de zaden uit. - De zaden zijn in een bepaald of onbepaald getal voorhanden. In een bepaald getal, van twee tot zes, voorkomende, zijn zij in ieder hok in twee rijen afwisselend vastgeheeht; missehien wel, want dit is mij nog niet zeker genoeg gebleken, min of meer spiraalsgewijze rondom het standertje; of zij liggen, wanneer zij den rondaehtigen vorm nabij komen, boven elkander, of, zoo zij min of meer zaamgedrukt zijn, zoodanig, dat het hooger vastgeheehte, altijd een gedeelte van het lager geplaatste bedekt. Wanneer hunne rigting niet door eene te groote ontwikkeling in omvang bepaald wordt, hetwelk aan het eene zaad eene andere rigting doet nemen, dan aan het andere, zijn zij nederdalend of hangende. Hun getal onbepaald zijnde, is hunne rigting door het punt van aanheehting bepaald: alleen bij Ploiarium is het vrije einde, even als bij de eitjes, naar boven gerigt. In hunnen vorm hebben zij de drie uitmetingen tamelijk gelijkmatig, of twee derzelve, de dikte en de breedte kleiner dan de lengte. De laatste of zaamgedrukte zaden zijn, behalve in het onderseheid, dat de versehillende verhouding van lengte en breedte veroorzaakt, vooral in derzelver dikte afwijkend: want bij eenigen is deze vrij gelijkmatig: Eurya, Pyrenaria; bij anderen is een gedeelte dikker, hetzij aan een der einden: Gordonia, hetzij in het midden, zoo als bij Sehima, welke het dikke gedeelte door eene vleezige uitbreiding omgeven heeft, of bij Ploiarium, dat alleen de beide einden zoodanig verlengd heeft. Hunne oppervlakte is glad, soms blinkend, of door kleine groefjes en puntjes, of door vleezige lobjes, ruw. Zij zijn bruin of, wanneer de opperhuid vleezig is, soms rood gekleurd. Behalve de gewone bekleedsels hebben de zaden de opperhuid soms tamelijk ontwikkeld. Bij Reinwardtia komt zij voor als kleine, over elkander liggende, eellige lobjes; bij andere geslaehten is zij een effen vliesje of een vlies, dat uit zeer fijne, met een waterig voeht gevulde cellen bestaat. De buitenhuid is dik, broos of taai, of vliezig, soms een weinig lederaehtig. Zij komt glad, doeh ook niet zelden met kleine gaatjes voor, die dikwerf eenen vrij regelmatigen vorm hebben, en verharde helften van eellen sehijnen te zijn, van welke de andere helft vliezig is gebleven, en bij een naauwkeurig onderzoek, duidelijk zigtbaar wordt. De vliezige buitenhuid, die uit min of meer verlengde eellen bestaat, vormt het dunne 
gedeelte der zaden, hetwelk hun het aanzien geeft van gevleugeld te zijn. Op deze buitenhuid staan de navel en het kiemgaatje (mieropyle) in dezelfde verhouding als de navel en de eimond op het ci. De eerste heeft de gedaante van een' eirkel, van een cirkelsegment of van eene min of meer regelmatige ruit. De navelopening (omphalodium) vertoont zieh als eene, door eenen eirkel omsehrevene holte en is bij de meesten klein, doeh bij Calpandria enzv. tamelijk groot. Het kiemgaatje wordt dikwerf door eenen kleinen rand omgeven. Onder de buitenhuid is de middelzaadhuid soms naauwelijks meer te erkennen, en met de beide, haar insluitende zaadbekleedsels zamengegroeid of vereenigd, of als eene laag van cellen, met fijnere of dikkere wanden en eenvoudige of takkige vaatbundels, die de raphe vormen, aanwezig. De raphe, vroeger door mij voedingsvat, doeh beter navelvaatbundel genoemd, loopt in de zaden, met eene dikke buitenzaadhuid, door een kanaaltje, dat de gemelde harde huid omgeeft, tot dat zij de kernof binnenzaadhuid breekt; in de anderen mist zij schijnbaar alle beperking. In de gekromde zaden is zij zeer kort; in de buitenwaarts gebogene heeft zij de lengte der zaden, en in de binnenwaarts gebogene wordt zij langs den geheelen rug, of met eene esvormige bogt, tot op het bovenste gedeelte van de kernhuid, waargenomen. Tot in de nabijheid van den binnennavel loopt zij bij allen onverdeeld voort. Hier eehter, ten minste bij de groote zaden van Calpandria en Pyrenaria, verdeelt zij zieh in verseheidene takken, die tussehen de buitenzaadhuid en de kernhuid verder uitgroeijen; bij de kleine en bij de gevleugelde zaden is deze verdeeling nog niet door mij gevonden: ik besehouw den navelvaatbundel dus op dit oogenblik nog als onverdeeld. - De binnennavel (ehalaza) vertoont, wanneer de kleinheid der zaden de waarneming niet ondoenlijk maakt, zich als een kleine cirkel. Bij eene aanzienlijke vergrooting vertoont deze cirkel geheel anders gevormde cellen als de omgevende kernhuid, en bij de onrijpe zaden van Gordonia heb ik ze tot binnen deze huid gevonden, in de gedaante van een rondaehtig ligehaam (Tab. 27. fig. 16, 17, 18), dat naar boven in een' kleinen cilinder was uitgegroeid. Onder dezelfde gedaante of eenigzins naar dezen vorm gewijzigd, is de chalaza door mij ook bij onvruchtbare zaden van Sehima gevonden. In vruehtbare, half rijpe zaden is daarentegen, in plaats van den gemelden eilinder, de jonge kiem waargenomen. Deze waarnemingen in verband gebragt hebbende met anderen van dien aard, en bij cenige zaden, waarbij de ehalaza duidelijk en de navelvaatbundel grooter is, later uitgebreid, doen mij nu cene stelling wagen, die mij, daar zij de analogie voor zieh heeft, van eenig belang sehijnt te zijn: dat namelijk de binnennavel vergeleken kan worden met een' knop, in het eerste tijdperk zijner ontwikkeling, en dat de navelvaatbundel de drager van dezen knop is. In de zaadstrengen, die niets anders zịjn dan vrije, niet met het ligehaam van het zaad zamengegroeide navelvaatbundels, kan de zamenstelling dezer bundels het best nagegaan worden, en in deze vaatbundels dezelfde deelen, als in die van jonge, kiemende plantjes of ontwikkelende takjes, worden aangetoond; namelijk, bekleedsel, vaatbundel: uit spiraalvaten en lange eellen bestaande, en in het midden van dezen bundel, eellen. Wordt nu deze vergelijking verder voortgezet, dan is het buitenbekleedsel met de schors van den tak, de vaatbundel met het houtligehaam of de gewone vaatbundels, en het binnenste met het merg te vergelijken, en in het zaad, de buitenzaadhuid met de sehors, de middelzaadhuid, in welke korte eellen de vezels of verlengde eellen vervangen, met het houtligehaam of de vaatbundels; terwijl de binnenzaadhuid als eene laag van eellen, die van de middelzaadhuid geseheiden is - men denke sleehts aan de ontwikkeling en zamenstelling der bladen - kan worden aangenomen. ILater, bij eene andere gelegenheid, zal ik hierop terugkomen en de waarnemingen uitvoeriger mededeelen, welke voor deze 
stelling pleiten. - De binnenzaadhuid is vliezig of eenigzins lederachtig. - De kern is gekromd of regt. $\mathrm{Z}_{\mathrm{ij}}$ bestaat uit kiemwit en kiem, of wordt door de kiem alleen gevormd. Het kiemwit omgeeft de kiem gcheel, als eene dikkere of dunnere laag van witte, vleezige stof; of het komt tusschen de plooijen der zaadlobben en in eene zeer dunne laag tegen de binnenzaadhuid voor. De kiem heeft bij . allen het worteleinde naar het kiemgaatje, en de zaadlobben naar den binnennavel gerigt. Bij Saurauja, misschien ook wel bij de anderen, is zij door een fijn vliezig buisje omgeven, dat haar van het eiwit scheidt en, in een buisje versmald, met het kiemgaatje verbindt (Pl. 19. fig. 20). Door een aanzienlijk kiemwit omgeven zijnde, heeft zij eenen rolronden vorm en laat zij de zaadlobben, alleen door de insuedc, die de scheiding aanwijst, van het worteltje onderscheiden. Met weinig kiemwit omgeven of geheel naakt zijnde, bezit de kiem het worteltje zeer klein in verhouding tot het geheel; meestal in eene loodregte lijn met de zaadlobben, doch bij Schima gebogen, met den benedenrand derzelve parallel loopende. Ook bij alle dezen is het min of meer rolrond. De zaadlobben der naakte kiemen zijn plat, vlak en, ongevouwen of ongeplooid, in zeer zamengedrukte zaden; doch gevouwen en soms met talrijke plooijen, in dikkere zaden; bij Thea zeer dik. In de door mịj onderzochte Indische soorten is het pluimpje weinig of bịjna in het geheel niet zigtbaar.

Door deze beschouwing van de verschillende organen hebben wij verscheidene afwijkingen tusschen dezelve leeren kennen, die bij eene verdeeling in aanmerking konden komen. De belangrijkste derzelve schịnen mịj in de zamenstelling van den knop, de ligging der bloembladen vóór de opening van de bloemkroon, in die van het openspringen der vruchten, en in de ontwikkeling der eitjes te bestaan. De knoppen leveren het eerste onderscheidend kenmerk ter afzondering van de Camellieae, die dezelve door schubben bedekt en de bladen en bloemen vereenigd hebben; terwijl zij bij de overigen naakt en de beide deelen gescheiden zịn. De ligging van de bloembladen is dakpansgewijze bij de Gordonieae en Ternstroemieae, en zaamgerold bij de Sauraujeae en Ploiarieae. Tusschen de beide laatsten kan het openspringen der kapsels, die door splijting der wanden (septicida) plaats heeft bij Ploiarieae, of in het midden der hokjes (loculicida) bij Sauraujeae, een middel ter onderscheiding opleveren. En om de Gordonieae en Ternstroemieae te scheiden, zou de uiterlijke vorm van het zaad, doch vooral de grondvorm, die reeds in het eitje aangewezen wordt, in aanmerking kunnen komen; de eerste hebben binnenwaarts gebogene, en de tweede gekromde eitjes.

De Ternstroemieae uit den Archipel zijn: Reinwardtia, Sarosanthera, Adinandra en Eurya; de Sauraujeae: Saurauja; de Ploiarieae uit die streek, Ploiarium, en uit Zuid-Amerika, Bonnetia, Archytaea enzv.; de Gordonieae, Laplacea, Antheëischima, Closaschima, Schima, Pyrenaria; en de Camellieae: Calpandria. 
REIN WARDTIA. KHs.

Gatyx pentasepalus, persistens, sepalis inaequalibus, imbrieatis. Corolla pentapetala, petalis basi connatis, eum sepalis alternantibus, aestivatione imbrieatâ. Stamina multa; fina menta eorollae basi adhaerentia, linearia, basi eonnata; antherae basi affixae, biloeulares; connectrvuni mutieum. Ovarium liberum bi-triloeulare, loeulis 1 -4 ovulatis; ovwus a plaecnta prominente pendula, campylotropa. Struus teres; stigin partitum vel radiatum. Bıca sicca. Senen solitare, pendulum, hippocrepiformieomplieatum. EpIderHis seminalis carnoso-tubereulatum; testa erustacea; tegNen membranaceum. Eneryo cylindricus, bieruris, in axi albuminis earnosi; cotrledones et radigula superae.

Arbusculat. Folia alterna, versus apicem ramorum faseieulatim approximata, integerrima, coriaeea. Stipulae nullae. Pedunculi uniflori.

Het geslaeht Reinwardtia is zeer na verwant aan de, van het vasteland van Indië, door den Heer Wallich besehrevene Anneslea, en de van Zuid-Amerika bekende Ternstroemia. Van beiden versehilt het door de veelbladerige bloemkroon en den stompen helmknoop; van Anneslea daarenboven door den vorm van den stempel en doordien de vrueht niet met den kelk is zaamgegroeid; van Ternstroemia door den verdeelden stempel en de niet openspringende vrucht. Daarentegen bestaat er tusschen de zaadbekleedsels van Anneslea en Reinwardtia eene opmerkelijke gelijkvormigheid en, zoo ik, naar het onderzoek der Ternstroemia Brasiliensis mogt besluiten, ook met het geslaeht Ternstroemia. Bij de gemelde soort van dit geslaeht, even als bij die der eerstgenoemden, heeft het zaadbekleedsel drie deelen: eene vleezige, dikwerf roodgekleurde epidermis; eene kraakbeenige, bij allen tamelijk dikke testa, en een vliezig tegmen.

De beide soorten van Reinwardtia zijn door ons, in de bossehen van het weinig boven zee verheven Doekoe, op Sumatra, verzameld. Als kleine struikjes groeiden zij op oude boomstammen, in gezelsehap van Asplenium, Polypodium, Lycopodium, Vanda en Dendrobium. Hare wortcls waren grootendeels tusschen de talrijke wortelvezels der varen verborgen; hare takiken groeiden bijna regt en droegen naar de uiteinden de dikiverf in kransen vcreenigde bladen, benevens de bloemen, welke in de oksels der bladen gezeten waren of door de geringe ontwikkeling der bladen in trossen of aren stonden. De bloemen hadden eene geel-witte kleur; en vermengden met den aromatisehen vanieljegeur der geopende Vanda-bloemen, eenen zwakken eitroenreuk.

Bij de opgave van de geslaehtskenmerken heb ik het buitenste zaadbekleedsel, dat de Ileeren Wallieh en Endlicher eenen zaadrok noemen, als epidermis seminalis beschreven: eene verandering, die gegrond is op de waarneming van de uitgroeijing der bekleedselen van hel zaad. In den jeugdigen staat hebben de eitjes de gewone vliezige bekleedsels, uit enkele lagen van meer of min digt celveefsel bestaande. Vervolgens, na de ombuiging der eitjes, zijn deze vliezen dikker, en bestaan zij uit meerdere lagen van eellen. In een later tijdperk vertoonden mij de onrijpe zaden een zeer fijn tegmen van langwerpige eellen, eene nog weeke testa, die uit lagen van dikwandige eellen bestond, en rondom deze, Botanica. 
een saprijk bekleedsel, waarin alleen cenc sterke vergrooting de cellige structuur deed waarnemen. Met het rijper worden der zaden nemen de gemelde zaadbekleedsels in dikte, en de beide binnensten tevens in vastheid en in hardheid toe. Het buitenste, de epidermis seminalis, verandert bij deze uitgrocijing geheel van gedaante. Zij bestaat dan uit een aantal roode lobjes, die door kleine, dikwandige celletjes gevormd zijn.

De vroeger voorgestelde geslaehtsnaam Reinwardtia in het wetenschappelijk stelsel niet aangenomen zijnde, heb ik het als eenen aangenamen pligt beschouwd, om dezen naam op nieuw aan tot dusverre onbekende gewassen te geven. Ik wensch op die wijze eene gepaste hulde te brengen aan eenen beoefenaar der Kruidkunde, die haar gebicd, zoowel door het vermeerderen van het aantal bekende voorwerpen, als door wetensehappelijke bijdragen heeft uitgebreid. Zij biedt mij tevens eene gunstige gelegenheid aan, om opentlijk en dankbaar te erkennen, dat ik steeds in den Hoogleeraar Reinwardt een' welwillend' leidsman en belangstellend' raadgever heb mogen vinden.

\section{REINWARDTIA PATENS. Khs.}

R. foliis obovatis, stigmate radiato.

Arbuscula pseudo-parasitica, tri-pedalis, diffusa; Ranir subteretes, verrucosi vel laeves, grisei; RAMULI ultimi subtetragoni, glabri, fusci. Foun subopposita, saepe subverticillata, versus apices ramorum conferta, obovata, acutiuscula, integerrima, utrinque glabra, coriacea, longa 7 c. m., lata 4 c. m.; PETIOLI in ramis articulati, semi-teretes, supra sulcati, longi $7 \mathrm{~m}$. m. Frores alares, axillares vel foliorum abortu racemosi; peDurguu bibracteolati, subteretes, glabri; BRACTEOLAE alternae, oblongae, obtusae, adınodum caducae. Alabastrum subglobosum. Calyx pentasepalus, aestivatione imbricatâ; SEPAL subrotunda, obtusa, ciliata, coriacea, persistentia. Conolla pentapetala, aestivatione imbricatâ; PETALA basi cohaerentia, subrotunda, breviter unguiculata, obtusissima, crenulata, carnosa, decidua. Stannina numerosa, biserialia; filamenta basi connata inter se et cum corolla, brevia, linearia; antierae basi aflixae, lincares, ab apice dehiscentes. Ovariun ovoïdeum, pubescens, (abortu?) biloculare; ovula solitaria ternave, pendula ab placenta partita vel indivisa. Srylus brevissimus; stigna disciforme, decem-sulcatum. BACGA oblonga, glabriuscula, abortu monosperma. SEnien pendulum, oblongum, compressum, basi obtusissimum, vertice emarginatum; hippocrepiformi-complicatum, cruribus fere aequalibus; sPERHODERHIS SEMINALIS tuberculata, succosa, aurantiaca; TESTA crustacea, flavescens; TEGNIEN membranaceum. Nugleus hippocrepiformis, cruribus subaequalibus, tcres. Enserxo in medio albuminis carnosi, teres, bicruris; RAdicula obtusa; coTYledones arcte connatae, lineares, obtusac; plumula haud conspicua.

\section{Crescit juxta Dockoe: Sumitra.}

Tab. 12. Figura speciei. 1. Flos. 2. Symmetria floris. 3. Petala tria expansa, intus visa. 4. Antherac. 5. Ovarium. 6. Ovarium longitudinaliter scctum. 7. Ovarium adultius verticaliter sectum. 8 et 9. Ovula. 10. Fructus sectus. 11. Semcn, epidermidis parte ablatâ. 12. Epidermis seminalis aucta. 13. Lobulus epidcrmidis seminalis admodum auctus. 14. Semen verticaliter sectum. 15. Testa, nucleo exciso, verticalitcr et 16. horizontalitcr secta. 17. Nucleus verticaliter sectus. 18 et 19 . Embryones. 


\section{REINWARDTIA ELONGATA. Khs.}

R. foliis oblongis, stigmate trilobo.

Arbuscula pseudo-parasitica, diffusa; ramr recti, teretes, glabri, fusci; ramuli subcompressi vel subtetragoni, cinereo-fusei. Four subopposita, versus ramorum apices fasciculatim approximata, oblonga, utrinque acuta, integerrima, glabra, coriacea, subavenia, 9 c.m. longa, 4 c. m. lata ; perrour semiteretes, supra sulcati, 2 c. m. longi, glabri. Flores axillares vel racemosi; Pedunculi alterni, compressi, saepe ancipites, glabri. Alabastrum sphaericum. Caldyx pentasepalus, aestivatione imbricatâ; sepala inaequalia, subrotunda, obtusissima, coriacea. Corolla pentapetala, aestivatione imbricatâ; PETAlA subrotunda, obtusa, suberenulata. Stamina numerosa; fila Jienta basi connata, corollae adhaerentia, linearia; ANTHERaE basi affixac, oblongac, muticae. OVARIUM hemisphaericum, glabrum, tri- vel biloculare, loculis $3-5$ ovulatis; ovura pendula a placentis partitis. STruus subcylindricus, glaber; sTIGis trilobum.

\section{Crescit juxta Doekoe, etc.: Sumatra.}

Tab. 12. 2. Figura speciei. $1^{\mathrm{a}}$. Alabastrum. 2a $2^{\mathrm{a}}$. Calyx explicatus. $3^{\mathrm{a}}$. Corolla explicata. $4^{\mathrm{a}}$. Antherae auctae. 5 a . Ovarium. 6a ${ }^{\text {a }}$ Ovarium verticaliter sectum. $7^{\text {a }}$. Ovarium adultius verticaliter sectum.

\section{SAROSANTHERA. Khs.}

CALYX bibracteolatus, pentaphyllus, persistens, foliolis subaequalibus, aestivatione imbricatâ. Conolua pentapetala, petalis basi connatis, aestivatione imbricatâ. Stanrra plurima; FILAmenta monadelpha, petalorum basibus adhaerentia; INTHERAE introrsae, biloculares, muticae, basi affixae, rimis longitudinalibus dehiscentes. Ovarıun liberum, triloculare, loculis $6-10$ ovulatis; ovula a placenta, ex apice anguli centralis producta, pendula, campylotropa. STruts teres; stig.rA tripartitum. Bacas sicca, bi-trilocularis. SEMrna 4-10 in singulo loculo, saepe deformia, hippocrepice-complicata. EPIDERmis

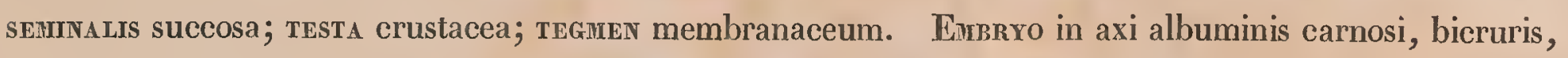
cylindricus; RaDicula et COTYLEDONES superac.

Arbores. Folda alterna, coriacea. Flores axillares, solitares.

De Sarosanthera verschilt van Cleyera door de, bijna in hare geheele lengte zaamgegroeide stuifdraden, en de hierdoor op eenen vleezigen ring, in twee tot vier rijen geplaatste helmknopjes; door den stompen helmknoop, en door het grooter getal eitjes, welke aan eenen verdeelden, nederhangenden moederkoek bevestigd zijn. Van Adinandra is Sarosanthera te onderscheiden door de wijze van zamengroeijing der helmdraden, en vooral door het zamenstel der vruchten.

De naam voor dit geslacht heb ik ontleend van de stijve haren, welke aan den bundel der stuifdraden eenige overeenkomst met eenen bezem geven. De eene soort hebben wij op de westkust van Sumatra, 
tusschen 200 cn 500 N. cllen hoogte, de andere op de zuid-oostkust van Borneo, langs de Doesonrivier en in de bergachtige oorden verzameld. Zij groeijen tot aanzienlijke boomen, met stanımen van vijftien $\mathbb{N}$. ellen lengte, en langwerpige, digt met bladen bedekte kroonen. In den droogen tijd bloeijen zij zeer welig, terwijl in den regentijd de groei dcr bladen toeneemt.

\section{SAROSANTHERA EXCELSA. KHS.}

S. foliis ellipticis, petalis obovatis hirsutis.

Arbor excelsa, saepe 20 metrorum; trurcus rectus, cylindricus, cortice cinerascente teclus, ligno rubicundo, valido, fibris tenuibus; conora oblonga, dense foliata; RAMI alterni, subpatentes, teretes, laeves, cimerei; ramudr compressiusculi, glabri. Foura alterna, elliptica vel oblongo-ovalia, basi angustata, apice acuta vel obtusc acuminata, integerrima vel obsolete crenulato-dentata, utrinque glabra, coriacea, 0,15 longa, 0,05 lata; PETroLr 0,01-0,005 longi, semiteretes, supra plani, glabri. Gemrna conicae, acutae, pubescentes. Flores axillares, solitares vel geminati, speciosi, albidi; peduncuti terctes, apice et basi incrassati, glabri, subcarnosi, albi. Bractene duae, inaequales, subrotundae, obtusae, glabrae, minutae. GaLrx pentasepalus, aestivatione imbricatâ; sepaLA inaequalia: tria exteriora minora, orbiculata, crenulata; duo interiora late-rotundata, integerrima, emarginata, carnosa. Coroula pentapetala, aestivatione imbricatâ; pETALA basi connata, obovata, obtusa, sacpe undulata, extus versus apicem hirsuta, carnosa, alba. STamina numerosa; filanerta monadelpha, corolla adhaerentia, glabra; antuerae basi affixae, lineari-oblongae, acutiusculae, dense hirsutae, loculis rimis longitudirlalibus dehiscentibus. Ovariur liberum, hemisphaericum, in stylum attenuatum, glabrum, triloculare; ovuLs 6-10 in singulo loculo; primo recta, demum hippocrepica, affixa in placenta, ex apice anguli

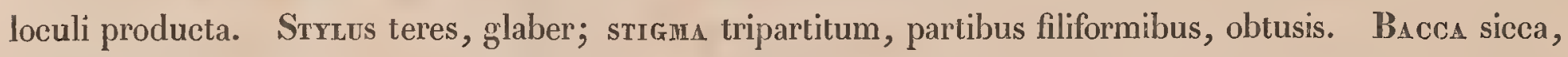
subglobosa, stylo persistente mucronata, glabra: - pericarpio coriaceo, sarcocarpio subcarnoso, fibroso, endocarpio crustaceo, - abortu uni- vel bilocularis; Disseprorentur membranaceum. Senina 4-10,

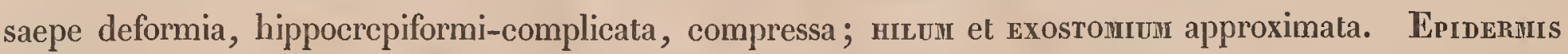
semiralis succosa; testa crustacea, extus rugosa, intus laevis; tegailen membranaceum. Nugteus bicruris, albus. Embryo in axi albuminis carnosi, cylindricus; radicula oblusa; cotrledones lincares, obtusae; plunura haud conspicua.

\section{Crescit ad ripas fluminis Doesson et ad montem Pamatton: Bonveo.}

Tab. 16. Figura hujus plantae. 1. Flos. 2. Flos, calyce ablato. 3. Flos, calyce, corollâ et dimidia parte staminum ablatis. 4. Staminum fasciculus extus visus. 5. Anthera aucta. 6. Antherae transversa sectio. 7. Ovarium. 8. Ovarium verticaliter sectum. 9. Placenta aucta, cum ovulis superne visa. 10. Eadem a latere visa. 11. Ovulum. 12. Fructus cum calycis parte. 13. Fructus verticaliter sectus cum seminibus. 14. Fructus verticaliter sectus, seminibus ablatis. 15, 16, 17, 18, 19. Semina. 20. Semen, parte epidermidis ablata. 21. Semen vertiealiter seetum. 22. Embryo. 
De voorwerpen van de opgenoemde groeiplaatsen verschillen, op het gezigt, een weinig door den rand der bladen en de rigting der bloemstelen, en bij het onderzoek, door de schutblaadjes. Aan de voorwerpen van Tanjong Petong zijn de stompe zaagtanden der bladen tamelijk duidelijk, en staan de bloemstelen bijna regt of slechts weinig naar buiten gebogen. Hunne schutblaadjes hebben eene zeer ongelijke grootte: het eene groeit weinig uit in vergelijking van het andere, dat tot een ovaal blaadje vergroot wordt. De, bij Karrau geplukte voorwerpen bezitten grootere bladen en omgebogene, kortere bloemstelen, zijnde de schutblaadjes bijna gelijk door vorm en grootte.

Van de beschrevene voorwerpen verschillen de op Sumatra, in het gebergte Singalang, gevondene, door den korteren bladsteel, den langwerpig ovalen vorm der bladen, en doordien de bloembladen van buiten geheel glad zijn. Als soort aangenomen zijnde, zoude men haar S. leiopetala tot naam kunnen geven.

\section{ADINA NDRA. W. JACK}

W. Jack, in Hooker Companion to the Bot. Magaz. I. pag. 153.

CALrx bibracteolatus, pentasepalus, aestivatione imbricatâ. Corolra pentapetala, aestivatione convolutâ, petalis basi cohaerentibus. Stanira 20-25; filduevta subpolyadelpha; antherae basi affixae, oblongae, loculis longitudinaliter dehiscentibus. Ovariur liberum, uniloculare; ovurs numerosa, in placentis tribus vel quinque, apice bifidis et reflexis affixa, campylotropa. STruos teres,

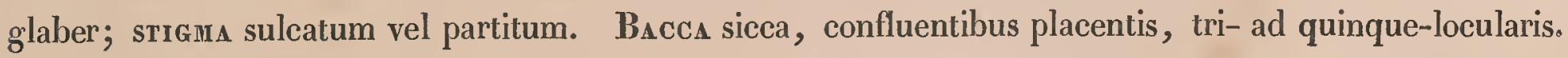
SEnira numerosa, hippocrepiformi-complicata, compressa, hilo et exostomio approximatis; TEsTa crustacea, fragilis; tegMren membranaceum. Errbryo in medio albuminis subcarnosi, bicruris, teres; RAdicula acutiuscula; COTYLEDones lineares, acutiusculae; plumula minuta.

\section{Arbusculae. Folia alterna, coriacea. Flores axillares, saepe solitares.}

Door de wijze van zamengroeijing der helmdraden, door het eenhokkig vruchtbeginsel en de van drietot vijfhokkige vrucht, door de aanzienlijke menigte zaadjes, welke de, uit het midden der vrucht voortkomende moederkoeken bedekken, verschilt Adinandra genoegzaam van Sarosanthera en ook van Cleyera, met welke laatste de Heer Arnott haar heeft willen vereenigen.

De vijf bekende soorten zijn op Sumatra en Borneo verzameld. In het westelijk gedeelte van eerstgenoemd eiland en op het zuid-oostelijke van het laatstgemelde zijn zij, van eene weinig boven het zeevlak verheven hoogte, tot op ongeveer 600 ellen boven hetzelve verspreid. Zij groeijen zoowel in de schaduwrijke bosschen, als in de meer opene streken, doch bloeiden het weligste op belommerde plaatsen. Over het algemeen zijn het kleine boompjes met korte stammen en bijna piramidale kroonen, die door een effen glanzig, donker groen loof, en in den bloeitijd daarenboven door talrijke witte, dikwerf nedergebogene bloemen zijn versierd. De bloeitijd duurt, blijkens waarnemingen op Adinandra Jaekiana Botanica. 
gedaan, zeẹr kort; de bevruchting begint reeds vóór de opening van de bloem. Het vruchtbeginsel vertoont zich, zeer jong zijnde, eenhokkig, met drie of vijf moederkoeken, die uit den omvang der holte voortkomen. Ieder dezer moederkoeken groeit tot in het midden van de holte, en verdeelt zich daar in twec omgebogene beenen. In een' meer uitgegroeiden staat van het vruchtbeginsel zijn de omgebogenc deelen van deze plaeentae elkander genaderd, waardoor in de holte drie tot vijf hokjes, soms zelfs, ten gevolge van de vergrooting der verdeeling van de plaeentae, een nog grooter getal, gevormd worden. Door de genoemde zaaddragers loopt van den bodem van het vruchtbeginsel af aan, langs het begin van de splitsing, een bundel vaten. Deze verdeelt zich in zijnen loop en geeft naar de eitjes takken af, welke niet zelden uit ćéne spiraal, die uit een' draad bestaat, worden gevormd. - De eiljes volgen de gewone ontwikkcling der eampylotropen. De kiem begint in dezelve, even boven de bogt, naar den eimond; hare ontwikkeling heeft kort na hare verschijning eenen ronden, vervolgens cenen ovalen vorm en, na meerdere uitgroeijing, dien van een' cilinder.

\section{AIDINANDRA JAGKIANA. KHs.}

A. foliis oblongo-ellipticis obtuse acuminatis, gemmis glabris, pedunculis in pulvinis articulatis, petalis glabris.

Arbuscula 5-7 metrorum; truncus rectus, cylindricus, laevis, fuseus; conona pyramidalis, patcns; rami patentes, teretes, glabri, fusei; ranuli subteretes vel subtetragoni, glabri. Folia alterna, subdisticha, patentia, oblongo-elliptiea, breviter obtuse acuminata, saepe cum mucronulo pubescente, obsolete crenulata, utrinque glabra, coriacea, 0,04 lata, 0,08 longa, nervis vix conspicuis; PETrour semi-teretes, supra sulcati, glabri. Gennı subteretes, elongatae, glabrae. Flones axillares, solitares vel geminati, nutantes; pedurcul teretes, sursum incrassati, glabri. CALrx bibracteolatus, pentasepalus, aestivatione imbricatâ; BRACTEOLAE suboppositae, calyci approximatae, subrotundae, ciliolatae, glabrae, coriaceae, persistentes; SEPALA ereeta, subrotunda, obtusissima, ciliolata, glabra, carnosocoriacea, 0,008 longa, 0,006 lata. Corolla pentapetala, subcampanulata, aestivatione convolutâ; petala oblongo-ovalia, obtusa, glabra, carnosa, alba, 0,015 longa, 0,01 lata. Sтинina 25, biserialia; FILAJIENTA monadelpba, ad medium usque connata, subtctragona, pilosa; aITHerae basi affixae, oblongae, glabrae, biloculares, rimis longitudinalibus dehiscentes. Polden sphaericum. Ovarium liberum, hemisphaericum, apicc attenuatum, glabrum, uniloculare; ovula numerosa, affixa in placentis quinque ex ambitu cavitatis productis, versus apicem bipartitis, partibus reflexis, eampylotropa. STruus teres, glaber; sTIGMA sulcatum vel quinquefidum. BACCA sieea, ovoïdeo-globosa, in stylum attenuata, glabra;epicarpio subeoriaceo, sarcoearpio fibroso, endoearpio subcoriaceo, - quinqueloeularis placentarum conerescentiâ. Semrna numerosa; hippoerepiformi-eomplieata, saepe reniformia, fusea, nitida, hilo et exostomio approximatis; TESTA erustacea, fragilis; TEGMEN membranaceum. ËrBRxo in axi albuminis, bicruris, eylindrieus; Radicula et COTYLEDones longitudine aequales.

Crescit in monte Galangan-Kwo: Sunatra. 
Eenmaal slechts hcb ik deze gewassen gevonden, en wol bij eencn togt over het gebergte GalanganKwo $\left(^{\star}\right)$. Zij stonden in eene groep bij elkander, rondom een graf, op den top van dit gebergte, en waren dus vermoedelijk daar aangeplant. Dit laatste doet de dichterlijke denkwijze dezer bewoners eer aan, daar zij in het gebladerte, dat eenen zeer donkeren tint bezit, het beeld van den dood of de verduistering van hel ligchaam hebben meenen te zien, en bij de witte, telkens vernieuwende bloemen, aan het onstoffelijke van den begravene hebben gedacht. Onder welken naam deze plant bij de Maleijers van Padang enzv. bekend is, weet ik niet, doch op Benkoelen draagt zij dien van Dauwn Sariboe, hetwelk, naar de gewone wijze van vertolking overgebragt, duizend-bladen zoude beteekenen. Dit zoude cchter geheel tegenstrijdig zijn, daar de boom niet naar de menigte van bladen, maar veeleer naar die der bloemen kan genoemd worden. Thet komt mij dus waarschijnlijker voor, dat de kletterende beweging der harde bladen aanleiding tot dien naam kan gegeven hebben, in welk geval de ovcrbrenging van denzelven, naar ons taaleigen, zoude mocten wezen: bladen, die kletterend bewegen.

\section{ADINANDRA TRICHOCORYNA. Khs.}

A. foliis ovalibus utrinque aeutiuseulis, gemmis hirsutiusculis, pedunculis in pulvinis artieulatis, petalis glabris.

Arbuscula; Rami erecti, versus apicem incurvati, subflexuosi, teretes, glabri, fusci; ranuli subcompressi, glabri, novelli hirsutiusculi. Gemma oblongae, compressae, saepe falcatae, acutae, ubique vel in margine hirsutiusculae. Foura alterna, erecto-patentia, ovalia, basi angustata, apice subemarginata acutiuscula, obsolete rotundato-crenulata, utrinque glabra - novella subtus, praesertim in nervo medio hirsutiuscula —, coriacea, 0,07 longa, 0,035 lata, supra laete olivacea, subtus flavo-virentia, nervis patentibus; peтrou subteretes, supra sulcati, glabri, 0,005 longi. Frores axillares, solitarii; PEDUNCOLI in pulvinis inserti, reflexi vel cernui, subteretes, sursum incrassati, glabri; BRACTEOLAE suboppositae, subaequales, rotundatae, ciliolatae, extus saepe carinatae, pubescentes, intus glabrae. CALYX pentasepalus aestivatione imbricatâ; SEPALA basi connata, corollâ apertâ erecta, corollâ delapsâ conniventia, demum patentia, inaequalia, obovato-rotundata vel subrotundata, obtusa, glabra, ciliolata, medio carnosa, margine membranacea. Corolrı pentapetala, campanulata, aestivatione convolutâ; petala obovata, obtusa, glabra, alba, margine membranacea. Sta niva numerosa; filajenta polyadelpha, introrse glabra, extrorse hirsuta; antrierae 4-5 seriales, basi affixae, oblongo-lineares, connectivo producto mucronatae, extus dense hirsutae, biloculares, rimis longitudinalibus dehiscentes. Ovariuni liberum hemisphaericum, in stylum attenuatum, glabrum, spurio-quinqueloculare; ovura numerosa, placentis ex axe loculi productis affixa. STruus cylindricus, sursum paulum attenuatus; stigin obtusum, subsulcatum. BАCCA sicca, calyce suffulta, turbinata, in stylum persistentem attenuata, glabra, quinque- ad decem-locularis, dissepimentis crassis. SEnıra multa, saepe superimposita, biserialia, com-

$\left.{ }^{*}\right)$ De naam Galangan-Kwo doet aan den Juno-vogel denken, welke aldaar zeer menigvuldig voorkomt en de omstreken door zijn sehel geluid, als kŏeō klinkende, doet weêrgalmen. Het geluid wordt door gălāngăn zeer wel gekenmerkt; dit gălāngăn brengt gewis het woord klank voor den geest, als metaalgeluid. 
presso-nephroïdca, laevia, spadicea; muUn lineare et EXostomun approximatis; TESTA crustacca; TEGMEN membranaceum. Enrbryo in medio albuminis carnosi, cylindricus, bicruris, cruribus inaequalibus; COTYLEDONES obtusae; RADICULA acuta.

Crescit in Poeloe-lampei, juxta Martapoera, in monte Pamatton: Bonneo.

Aan de voorwerpen van iedere opgegevene grociplaats is icts eigenaardigs, hetwclk, zoo de overgangen niet bekend waren, tot de invoering van verschcidene soorten aanleiding zou kunnen geven. De voorwerpen van Poeloe-lampci, hierboven beschreven, hebben de bladen het kleinste. Grooter zijn zij aan de op Martapoera geplukte takken; daarenboven hebben deze bladen niet zcer spitse punten en soms ecne op de onderzijde digt behaarde middelnerf. Aan andere voorwerpen van daar, zijn de bladen iets langer en aan de onderzijde van de middelnerf min of meer behaard; zij komen in vorm met die van Poeloe-lampei overecn. De derde vorm, aan den berg Pamatton groeijende, gelijkt op dien van Poeloelampei, doch verschilt door de meer rond-ovale gedaante der bladen en door de kortere bladstelen. Deze dric vormen kunnen als versehcidenheden, met de namen A. angustata, op Poeloe-lampei; obtusata, aan den Pamatton; acuta, bij Martapocra, aangeduid worden.

\section{ADINANDRA DASYANTIIA. Kns.}

A. foliis oblongo-ovalibus, pedunculis et petalis dense sericeis.

Arbuscula 8 metrorum; rani erecto-patentes, teretes, pallide fumei, glabri; ramuli subteretes, densc pubescentes. Folis alterna, oblongo-ovalia, basi acuta, apice acutiuscula, integerrima vel obsoletc crenulata, ciliolata, supra glabra, subtus in nervo medio dense pubescentia, - novella subtus pubescentia, - coriacea, 0,04 lata, 0,11 longa; PETIoli semi-terctes, supra plani, pubcscentes, dcmum glabri, 0,015 longi. Flores axillares, solitarii, bibracteolati; Pedurculi teretes, superne incrassati, pubescentes, admodum deciduae. CALYX pentasepalus, persistens, aestivatione imbricatâ; sePaLA erecta, subaequalia, rotundata, obtusissima, saepe emarginata, ciliolata, extus in mcdio pubescentia, carnosa, margine membranacea, 0,006 longa et lata. Corolla pentapetala, patens, aestivatione convolutâ; PETALı obovata, obtusa, intus glabra, extus dense sericea, carnosa, alba, 0,014 longa, 0,01 lata. Stamina 20-25; milanenta basi monadelpha, parte libera lineari, glabra; amtherate basi affixae, oblongae, acutae, dense hirsutae, pilis erectis, biloculares, longitudinaliter dehiscentes. OVARIUM hemisphaericum, apice attenuatum, pubescens, unilocularc; ovuLı numerosa, campylotropa, in placentis tribus vel quinque ex ambitu cavitatis productis, bifidis affixa. Srruus teres, glaber; stigma truncatum, sulcatum. Fructus et semira praecedentis speciei.

Crescit in sylvis montis Melintang: Sumatra. 


\section{ADINANDRA EXCELSA. Kus.}

A. foliis oblongo-ovalibus glabris, pedunculis in axillis scssilibus, petalis glabris.

Arbor 10 metrorum; truncus rectus, cylindricus, cortice cinerascente tectus; corona pyramidalis, foliosa; RAIII alterni, patentes, teretes, fusci, glabri; RAлItur subteretes, glabri, raro pubescentes. Gemina elongato-conicae, pubescentes, praefoliatione equitante. Foura oblongo-ovalia, acutiuscula vel breviter obtuse-acuminata, basi angustata, obsolete serrulata, utrinque glabra vel subtus punctulis rugosa, coriacea, 0,14 longa, 0,055 lata; peтrour semiteretes, supra plani, glabri, 0,01 longi. Fuores axillares, solitarii, subnutantes, bibractcati; pEDunculi subteretes, glabri; BRACTEAE subrotundae, obtusissimae, glabrae, ciliolatae. CALIYX pentasepalus, persistens, aestivatione imbricatâ; SEPALA Subaequalia, erecta, subrotunda, obtusissima, ciliolata, glabra, coriacca, 0,007 longa et lata. Corouta pentapetala, subcampanulata, aestivatione convolutâ; PETALA basi connata, oblonga obtusa, extus intusque glabra, carnosa, 0,012 longa, 0,006 lata, alba vel flavescentia. Sramina multa; filanienta subpolyadelpha: fasciculis tribus vel pluribus; fiLAMENTorun partes liberae lineares, glabrac; ANTHERAE basi affixae, oblongae, dense hirsutae, biloculares, rimis longitudinalibus dehiscentes. Ovaruum liberum, subglobosum, apice attenuatum, glabrum, uniloculare; ovura numerosa, campylotropa. OvulorunI insertio; fRuCrus et SEMrrự structura haud ab Adinandrà Jackianâ diversae.

\section{Crescit in montibus Sakoembang et $\boldsymbol{P}$ amatton, ad ripas Pankinan: Bonveo.}

Tab. 18. 1. Figura Adinandrae excelsae. 1. Alabastrum. 2. Flos expansus. 3. Flos, calycc ablato. 4. Flos, calyce et corollâ ablatis. 5 et 6 . Stamina. 7. Antherae scctio transversalis. 8. Ovarium, calycc, corollâ et staminibus ablatis. 9. Ovarium verticaliter scctum. 10. Ovarii sectio transversalis. 11. Loculi pars. 12. Placcntae sectio transversalis valde aucta ex ovario juniori. 13 et 14. Ovula. 15. Fructus. 16. Fructus transversaliter sectus. 17. Fruetûs transversalis seetio. 18. Semen. 19. Semen verticaliter seetum. 20. Symmetria floris.

Door den ongunstigen invloed van den diorietbodem des bergs Pamatton, zijn de hier groeijende Adinandra excelsa veel minder ontwikkeld dan die, welke langs de Pankinan-rivier en aan den berg Sakoembang zijn waargenomen. De laatsten hebben dit eigenaardige, dat de schutblaadjes digt bij den kelk staan en kleine kelkbladen gelijken; de bcide eerst opgegevenen komen in de plaatsing op eenigen afstand van den kelk, en in de gedaante van deze schutblaadjes overeen.

\section{ADINANDRA ACUMINATA. Khs.}

A. foliis ovalibus aeuminatis, pedunculis in pulvinis insertis verrucosis.

Arbuscula 6-8 metrorum; rani patentes, teretes, fusci, glabri; Ranulu subcompressi, pubescentes. Grmirae subteretes, elongatae, dense sericeo-pubescentes. Foria alterna, saepe subdisticha, ovalia vel oblongo-ovalia, saepe obliqua, acuminata, acumine mucronulatâ, basi acuta, serrulata, supra 
glabra, subtus pubeseentia, - adultiora sacpe glabra, - coriacca, 0,12 longa, 0,04 lata; PETIoLI semi-teretes, supra plani, 0,004 longi. Pedurculi alares vel axillares, in pulvinis insertis, solitarii, uniflori, tcretes, verrucosi, 0,01 longi. Bractene ovatae, obtusae, minutae. Calyx pentasepalus; sepsca subaequalia, subrotunda, obtusa, glabra, coriacea. PACCA sicca, glohosa, stylo mucronata, pubescens, quadri- vel bilocularis; Dissepinenturi subcarnosum. Senira plurima, hippocrepiformicomplicata, oblonga, compressa, utroque obtusa; testa crustacea; tegnen membranaceum. EMBRyo in medio albuminis carnosi, bieruris, eylindrieus; Radicula et Cotruedones longitudine fere aequales.

Crescit in sylvis montis Melintang: Sumatra.

EUR Y A. Thunberg, R. Brown, De Gandolle, Buume, etc.

FLores polygami. CALXX bibracteolatus, pentasepalus, persistens, aestivatione imbricatâ, sepalis subaequalibus. Corolra pentapetala, campanulata, aestivatione imbrieatâ, petalis sacpe cohaerentibus. Stamira 10-25, uni- vel biserialia; frlamenta basi subcohaerentia, glabra; antherae basi affixae, saepe basi cordatae, biloeulares, longitudinaliter dehiscentes, connectivo in laminam mucronulatam producto. - Flos femineus eum rudimentis filiformibus staminum. - Ovarium liberum, tri- quinqueloculare; ovula in singulo loculo plura 4-20, placentis ex angulo centrali productis pendula vel biseriatim superimposita, eampylotropa. Strues tri-quinque-fidus vel-partitus; stigmata aeuta. BAcGa pisiformis tri- quinqueloeularis. SEmrs plura, pendula vel biseriatim superimposita, hippocrepiformi-complicata, compressa vel angulata; EPIDERHIS SEMITALIS membranacea; TESTA crustacea; TEGMEN membranaeeum. Nugleus bicruris, eylindricus, albus. Embryo in axi albuminis granulati, cylindricus, radiculâ et cotyledonibus superis.

Arbusculae sempervirentes. Folia alterna, coriacca, serrata. Flores axillares, solitarii vel conferti, parvi, albi vel flavi; Pedurcur, uniflori.

Dit geslaeht werd door Thunberg voor eene, door hem op Japan gevondene plant, E. japonica, gevormd, die, volgens hem, onder andere kenmerken, kapselaardige vruehten had. Genoemd kenmerk is door den Heer De Candolle in zijne Monographie der Ternströmiaeeae overgenomen; onder bijvoeging, dat Kämpfer aan deze plant eene bes toesehreef. De Heer R. Brown bevestigde de juistheid der besehrijving van den laatsten, bij de bekendmaking van eene uit China afkomstige soort, E. ehinensis. Het kenmerk van den Heer R. Brown herhaalde de Heer Cambessèdes in zijne Monographie (Mémoires du Museum d'Histoire Naturelle, Tom. 16, pag. 403 etc.). Daarentegen gaf de Heer Blume, misleid door de verkeerde opgave van Thunberg, voor Eurya, onder den naam Geeria, een op eigene onderzoekingen steunend geslachtskenmerk, bij de besehrijving der op Java en Celebes gevondene soorten. Even zoo deden de Heeren Wight en Arnott, Prodromus Florae Peninsulac, pag. 86, die in hun kenmerk albumen none opnemen; terwijl de Ileer Blume, en ook ik, dit kenmerk in alle soorten gevonden bchben. 
Door verscheidene der opgenoemde schrijvers is de verwantschap van Eurya en Freziera (Swartz), en door den Heer Endlicher nog onlangs die van Freziera en Lettsomia (Ruiz en Pavon) opgegeven. Het onderscheid der beide eerstgenoemde geslachten is in de dikwerf plaats hebbende afzondering der geslachtsdeelen, in de aan den voet hartvormige insnede en in de aanhechting der helmknopjes gezocht. Deze kenteekenen ter onderscheiding hebben, door de juistere beschouwing der bekende soorten van Eurya, hunne waarde verloren, omdat in dezelfde bloemen, dikwerf de beide geslachten voorkomen, de helmknopjes niet zelden aan den voet eene hartvormige insnede hebben en steeds aan den voet zijn vastgehecht. Het onderzoek van ecn vruchtbeginsel van Freziera thaeoïdes doet mij vermoeden, dat men door eene naauwkeurige waarneming van de bloem- en vruchtdeelen eenige afwijking, die tot ondcrscheidend kenmerk kan dienen, zal vinden; daar ik bij de eitjes de Chalaza tegenover het Exostomium vond. Hierom heb ik de geslachten niet vereenigd. Omtrent Lettsomia (Ruiz en Pavon), hetwelk, volgens de beschrijving, niet van Freziera afwijkt, kan ik alleen naar de, in den Prodromus van gemelde schrijvers voorkomende opgave en afbeeldsel oordeelen, en schijnt mij de vereeniging van Freziera en Lettsomia niet ongepast. Het nader onderzoek zal hier beslissen omtrent de verdeeling in geslachten; doch als natuurlijke vormen zijn de Euryae voor de Flora van Azia's zuid-oostelijke deelen, hetgeen de Frezierae voor die der oostelijke streken, en de Lettsomiae voor die der westelijke oorden van Zuid-Amerika zijn.

De soorten van Eurya behooren aan de Chineesch-Japansche, de Emodische, de Indische en de Polynesische Flora. Twee derzelve, Eurya japonica en E. littoralis, zijn door de Heeren Thunberg en von Siebold op Japan gevonden. Op zijnen togt naar Pekin, werd de Eurya chinensis door Abel waargenomen. Andere soorten zijn door de Heeren Wallich en Royle aan den voet van het Himmalayagebergte verzameld: de E. acuminata op $30^{\circ} \mathrm{N}$. Br. tot op eene hoogte van $2200 \mathrm{~N}$. ellen. Enkele soorten zijn ons door de Heeren Wight en Arnott, als op het schiereiland Decan groeijende, bekend gemaakt. De Heeren Wallich en W. Jack vermelden Pinang als hare groeiplaats; dc Heeren Reinwardt en Blume verzamelden soorten van Eurya op Java en Celebes, en wij vonden dezelve op Java, Sumatra en Borneo. - Omtrent de gelijkheid of het onderscheid der in deze verschillende gewesten voorkomende soorten, waag ik het niet, eenige beslissing te doen, omdat, in een zoo natuurlijk geslaeht, alleen eene vergelijking van voorwerpen en zeer uitvoerige beschrijvingen of afbeeldingen, tot derzelver bepaling kunnen dienen.

Op de gemelde groote Sunda-eilanden groeijen de soorten van Eurya van het zeestrand af tot op eene hoogte van ongeveer drie duizend $\mathrm{N}$. ellen boven het zeevlak; de Eurya glabra en E. coneocarpa op Java, op ongeveer 2600 N. ellen, tegen den berg Gédé; de E. obovata BI., op hel gebergte van de noord-oostkust van Celebes; de E. reticulata, op eene hoogte van 3000 N. ellen, op den Merapi op Sumatra; de E. Blumeana, aan den Patoeha, Tankoeban-prahoe enzv. op Java, op 2000 N. ellen: de E. nitida, van het zeestrand af tot op eene hoogte van 1000 N. ellen, op Borneo; de E. angustifolia, op Sumatra aan het zeestrand en op ongeveer $600 \mathrm{~N}$. ellen boven het zeevlak. De bodem, welke haar tot standplaats strekte was, in al de door ons bezochte streken, kiezelaardig, of min of meer, in de nabijheid der kraters, verglaasd en moeijelijk tot verwering overgaande: zoodat de Euryae, als bewijzen van eenen niet zeer 
vruehtbaren grond kunnen worden besehouwd. Zij groeijen gezellig, als kleine groepen verspreid, in de vlakte, of als hoofdplanten in de nabijheid der kraters. Op de laatste groeiplaatsen zijn zij dikwerf sleehts kleine struikvormige, op de eerste meer ontwikkelde boompjes. Derzelver kroonen zijn langwerpig, soms open en door geel-groene bladen bedekt. Aan het einde der jonge takjes zijn de pas ontwikkelende bladen soms blaauv gekleurd, en er wordt alsdan een overgang van deze kleur door het donker-groene naar het geel-groene- waargenomen. Tusschen de geel-groene bladen staan de kleine bloemen in de oksels alleen, gepaard of in grooter aantal vereenigd. Zij versieren, telkens vervangen wordende, de planten het geheele jaar. Ongeveer vier maanden na derzelver bloei vertoont zieh de rijpe vrueht, eene kleine blaauwe ronde bes, en niet zelden prijken dan de pas ontluikende bloemen en de rïjpe vruehten naast elkander.

De bloemen der door mij onderzoehte soorten waren tweeslachtig, mannelijk, of vrouwelijk. Meestal hadden dezelfde planten deze drie verseheidenheden vereenigd; zelden waren zij tweehuizig. De mannelijke, vrouwelijke en tweeslaehtige bloemen hebben een zelfde zamenstel, met eene vijfvoudige verdeeling en eenen afwisselenden stand der versehillende kransen. In dezelve zijn twee- of vijfmaal zooveel helmdraden als deelen, in eene, twee tot drie rijen geplaatst. Deze hebben de helmdraden niet zelden aan den voet met elkander en met de bloembladen zamengegroeid. Hunne helmknopjes zijn langwerpig, vóór de opening dikwerf tot kleine vierkante vakjes ingesnoerd; zij beginnen van den top af aan open te springen, en openen zich verder in de lengte. Hun stuifmeel is kogelrond, somwijlen met eenen ring omgeven; bevoehtigd, wordt het eivormig en springt dan aan de beide einden open. Het vruehtbeginsel versehilt weinig in uiterlijken vorm en inwendig zamenstel; het is bijna rond, drietot vijfhokkig. Daarentegen zijn bij de aanhechting der eitjes, en later nog duidelijker in de vrueht, twee grondvormen te onderscheiden. De eerste, de Eurya Blumeana enzv., heeft den moederkoek van het jonge vruehtbeginsel in twee naast elkander staande plaatjes verdeeld, langs welke de eitjes boven elkander zijn vastgeheeht: dus in loodregte rijen. In de vruehten zijn de beide deelen van de plaeenta door een uitgegroeid vliezig plaatje van het middelpunt verwijderd, en aan de einden omgebogen. Hierdoor zijn nu de zaden nog in twee rijjen gesteld, doch nu door het gemeld verlengend vliesje van het onverdeeld gedeelte van de plaeenta verwijderd. Somwijlen is dit vliezig plaatje genoegzaam verlengd, om de hokjes in tweeën te verdeelen, en dus het getal te verdubbelen. Bij de tweede, Eurya nitida enzv., komt de plaeenta, als een bijna rolrond ligehaam, uit den binnensten hoek van het hokje, en verdeelt zij zieh vervolgens in even zoo vele takken, als er eitjes zijn. Aan deze takken hangen de eerst regte en vervolgens omgebogen eitjes. In de vruehten vullen de zaden de geheele hokjes zoodanig, dat de plaeenta geheel door hen bedekt wordt. Zij zijn dikwerf aan kleine vleezige takken, vermoedelijk de verdikte deelen van de plaeenta, bevestigd. Hun vorm, door de voor hunne ontwikkeling aanwezige ruimte bepaald, is dikwerf zeer onregelmatig, zaamgedrukt, niervormig of hoekig. In hun zamenstel hebben zij eene vliezige epidermis seminalis, eene bruine, brooze testa, een vliezig tegmen en eene witte, als een hoefijzer gebogene kern, waarin eene rolronde, gebogene kiem, door een korrelig kiemwit volkomen omgeven wordt. 


\section{EURYA EUPRISTA. Khs.}

E. ramulis pilosis, foliis elliptico-oblongis acuminatis serratis, floribus confertis, sepalis emarginatis, fructubus oblongo-rotundatis.

Arbusqula 3-6 metrorum; truncus brevis, cylindricus, laete fuscus; corona elongato-pyramidalis, aperta; RAmI alterni, patentes, teretes, fusci, glabriusculi; RAMULI compressi, dense et laete fusco-pilosi. Genua elongatae, compressae, dense pilosae. Foura alterna, patentia, elliptico-oblonga, acuminata, supra basin serrata, supra nitida, subtus pubescentia, - juniora subtus, praesertim in nervo medio dense pubescentia, - coriacea, 0,07 longa, 0,02 lata; peтіоu subteretes, pubescentes, 0,002 longi. Flores polygami, axillares, saepe 4-10 conferti, raro geminati vel solitarii; pedunculi uniflori, teretes, glabriusculi, 0,002 longi. Flores masculi. Caltx bibracteolatus, pentasepalus, persistens, aestivatione subimbricatâ; BRACTEOLAE ovatae, acutae, glabrae; SEPALA inaequalia, rotundata, emarginata, glabra. Coroltı pentapetala, subcampanulata, aestivatione imbricatâ; PETALA aequalia, ovatooblonga, obtusa, emarginata, glabra, trinervia. Stumira 20, biserialia; riLAmenta basi subcohaerentia, subuliformia, glabra; ANTHERı basi affixae, oblongac, basi cordatae, longitudinaliter dehiscentes, connectivo brevi mucronulato. Pistilli rudimentum semi-ovoïdeum, attenuatum. Frores feminei. Galyx et corolta floris masculi. Staminum rudimenta filiformia, glabra. Ovarium ovö̈leum, acutum, glabrum, tri- quadriloculare; oveu $10-16$ in singulo loculo, placentis ex angulo loculi productis et bipartitis affixa, biserialia, superimposita, campylotropa, disciformia. Strut tres ad quinque, filiformes, patentes; stigniatı acuta, recurvata. BAcGı pisiformis, oblongo-rotundata, tri- quadrisulcata, glabriuscula, stylos persistentes ferens, epicarpio membranaceo, sarcocarpio succoso, fibroso, endocarpio subcrustaceo, fragili, tri- quadri- raro quinquelocularis. SEmira 10 vel plura in singulo loculo, in placentis ex axi anguli loculi productis, bipartitis et membranaceis affixa, biseriata, superimposita, oblonga, compressa vel quadriquetra, scrobiculata, fusca; TESTA crustacea, fragilis; TEGNEN membranaceum. Nucheus cylindricus, hippocrepiformis, albus. Errsero in medio albuminis granulosi, bicruris, cylindricus; ranicula et cotruenones fere acquales.

\section{Crescit juxta Doekoe, Pinang etc.: Sumatra.}

Als struiken met langwerpige of ronde kroonen, of als kortstammige boompjes met piramidenvormige, naar beneden versmallende of geknotte kroonen, was de Eurya euprista, in de door ons bezochte streken van Sumatra, tamelijk verspreid. Zij groeit daar in de nabijheid van het meir Samawang, in de zoogenaamde twintig Kotta's, op eene hoogte van 500 tot $700 \mathrm{~N}$. ellen, in eenen bruinen, leemigen zandgrond, uit welken, wel is waar, goud wordt opgedolven, doch waar de rijst slechts een' vijfvoudigen cn soms nog geen' tweevoudigen oogst oplevert. Hier stond zij in gezelschap van Myrtus spectabilis. In de lage strcken, bewesten de bergketen, is zij op de opene, onbeschaduwde plaatsen, waar de afgespoelde grond de bovenlaag vormt, tot aan het groote bosch vrij menigvuldig. Over deze glooijende vlakte wast de Eurya euprista alleen staande, of als gezellige plant, of in vcreeniging met andere gcwassen. Nu eens bestaan deze groepen uit struikvormige gewassen, dan weder uit boomen, struiken en slingerplanten. Bij de cerstgenoemden zijn het vooral Myrtus tomentosa, Glochidion littorale en BoTaNica, 
Melanthesa; bij de laatste vereenigingen groeijen rondom Dicalyx odoratissimus, de gemelde gewassen, Melastoma polyanthum, Tetracera rigida, niet zelden Uncaria, en de eene of andere soort van Uvaria.De jonge loten waren in de streken van Paauw door de Tapieren afgebeten.

De in de omstreken van Samawang groeijende planten hebben de bladen puntig; die van de benedenlanden meer toegespitst. Daarenboven bestaat er bij de verzamelde voorwerpen eenig verschil in de haarbekleeding der takken en der bladen, welke bij die van Doekoe niet aanmerkelijk, doch bij die van andere plaatsen, aan de jongere takjes zeer aanzienlijk is.

De Eurya euprista is zeer verwant aan de Eurya serrata, door den Heer Blume in de Bijdragen, bl. 124, beschreven; zij kan door den meer platgedrukten vorm der vrucht en door de aanhechting der zaden aan de, in de hoeken van de hokjes vastzittende placentae, onderscheiden worden. Op Amboina groeit een vorm van Eurya, die met E. euprista, even als met E. serrata zeer gelijkvormig is: van beiden verschilt zij door den tolvorm, en van al degenen, die ik gezien heb, ook door de haarbekleeding der vruchten: hetgeen den naam E. trichocarpa zeer eigenaardig maakt.

\section{EURYA GLABRA. BL.}

E. ramulis glabris, foliis ellipticis serratis utrinque glabris, floribus confertis, sepalis orbiculatis, fructubus depressosphaerö̈deis.

Blume, Bijdragen tot de Flora van Neerl. Indië, pag. 125.

Arbuscula 2-6 metrorum; trungus brevis, cylindricus; conors elongato-conica, aperta; RAMI diffusi, alterni, teretes, nigro-fusci, glabri; RaJuul subteretes aut compressi, glabri. Gennas compressae, glabrae. Foura elliptica, obtuse vel emarginato-acuminata, sursum serrata, utrinque glabra, coriacea, 0,08 longa, 0,025 lata; petrolr semiteretes, glabri, 0,007 longi. Flores polygami, axillares vel foliorum abortu alares, conferti. Flores masculi. Galrx bibracteolatus, pentasepalus, persistens, aestivatione imbricatâ; BRACTEOLAE inaequales, concavae, extus subcarinatae, subrotundae acutiusculae, calloso-mucronulatae, glabrae, carnosae; sEPALA subaequalia, orbiculata, subconcava, glabra, 0,005 longa, 0,003 lata. Corolla pentapetala, subcampanulata, aestivatione imbricatâ; PETALı basi adhacrentia, oblonga, obtusa, 0,007 longa, 0,003 lata. Stumrina 20, raro 10, biserialia, alterna; filamenta subuliformia, glabra; ANTHeraE basi affixae, oblongo-ovatae, basi cordatae, biloculares, longitudinaliter dehiscentes, connectivo in mucronulum producto. Prstrlli rudimentum cylindricum, acutum, glabrum. Flores feminei. Caltx et corolla floris masculi. Ovariun liberum, depresso globosum, glabrum, tri- quadriloculare; ovura 8-10 in singulo loculo, campylotropa. Struus teres; stigmiata quatuor, patentia, filiformia, acuta. BACGA depresso-sphaeroïdea, subtri-quadrisulcata, stylo mucronata, glabra, coerulea. BAGGa et seminss structura haud diversa, ab eadem Euryae serratae.

Crescit in summo montis Gédé: J⿳士口䒑a. 
De Eurya glabra hebben wij alleen op den berg Gédé, op Java, verzameld. Zij begint daar op ongeveer $2400 \mathrm{~N}$. ellen met enkele groepen, en is vervolgens tot aan den top van dezen berg in grooter aantal verspreid. Op enkele plaatsen vormt zij de hoofdplant, en is zij van Myrica javanica, Gaultheria, Thibaudia, Photinia integrifolia enzv. vergezeld. Op andere oorden zijn de soorten van Thibaudia en Vireya Bl. (Rhododendron) talrijker. Dan rijst de Eurya glabra door piramidenvormige kroonen boven dezen uit, en is zij daarenboven, door hèt geel-groène loof, van de lagere gewassen te onderscheiden.

Zij bloeit gedurende het geheele jaar; doch het rijkste in het drooge jaargetijde, en de vruchten erlangen in drie tot vier maanden hare rijpheid. Harc vruchten worden, wegens het saprijke vleesch, dat dezelve omkleedt, door den Ixos bimaculatus en eene soort van duif, die op Columba Capellei gelijkt, gegeten. Daardoor is de verspreiding der plant tusschen de blokken van den lavastroom, onder den naam Goenong Batoe bekend, verklaarbaar. Daarentegen kan het bepaalde voorkomen van de Eurya glabra op het gebergte Gédé, aanleiding geven tot het geloof, dat de beide gemelde soorten van vogels, die hier leven, zich tot deze hooge oorden bepalen en uiterst zelden naar andere bergtoppen verhuizen.

De Eurya glabra bezit van al de mij bekende soorten de grootstc bloemen, welke, vóór de ontwikkeling, tusschen twee kleine, afwisselende, eironde, spitse, gekielde blaadjes zijn verborgen. Hare bladen hebben over het algemeen eene langwerpig elliptische gedaante, met puntige of stomp toegespitste uiteinden. Bij sommigen zijn de punten stomp en verkrijgt het blad daardoor eene omgekeerd eivormige gedaante; deze vorm is dikwerf tusschen den gewonen gemengd, en in het Herbarium van den Hoogleeraar Reinwardt zijn bij voorwerpen, die aan de zuidelijke helling van den berg verzameld werden, bijna al de bladen omgekeerd eivormig. Hun rand is door een kraakbeenig randje bezoomd en stomp gezaagd; zoowel op de onder- als op de bovenvlakte vertoont zich de nervuur netvormig. - De knoppen der bladen, vooral bij deze soort, door mij nagegaan, zijn vóór hunne uitgroeijing naakt, of door een klein, langwerpig, schubvormig blaadje bedekt, hetwelk niet boven de oksels der bladen, waar de knoppen zijn geplaatst, uitgroeit. In dezelve omvat ieder blad het volgende schrijlings.

Deze soort verschilt van de Eurya japonica door de ongevleugelde takjes, de grootere, met fijnere en scherpere tandjes gezaagde bladen; van de E. reticulata, door de van eenen uitstekenden rand voorziene takjes, door de meer langwerpige, scherper gezaagde blaadjes, en door de ronde, van boven dikwerf platgedrukte vruchten; van de $\mathbb{E}$. nitida, door de nervuur der bladen en den kegelvorm der vruchten; en van deze en al de opgenoemde soorten door de grootte der kelkbladen.

\section{EURYA NITIDA. Krs.}

E. ramulis glabris, foliis lanceolato-ellipticis serratis nitidis, floribus geminatis vel solitariis, sepalis late ovatis, fructubus sphaeroïdeis.

Arbuscula 3-6 metrorum; truncus brevis, cortice nigrescente tectus, ligno rubescente, sat valido; rami diffusi, alterni, teretes, grisei; ramuli compressi, glabri, fuscescentes. Foura lanceolato-elliptica, 
vel ovalia, acutiuscula, serrata, basi cuneata et integerrima, utrinque nitida, coriacea, $\mathbf{0 , 0 5 5}$ longa, 0,02 lata; petiou semiteretes, glabri, 0,003 longi. Gemmae subteretes, attenuatae. Flores axillares, solitarii vel geminati, polygami. Frores maseuli. CALrx bibracteolatus, pentasepalus, persistens, aestivatione imbricatâ; BRAGTEOLAE suboppositae, calyci approximatae, ovatae, acutae, glabrae, minutae; SEPALA inaequalia [duo exteriora minora, ovata, obtusa; tria interiora subrotunda, obtusissima] glabra 0,002 longa et lata. Coronıa pentapetala, campanulata, aestivatione imbrieatâ; PETALA basi adhaerentia, obovata, emarginata, crenulata vel integerrima, basi squamulata, glabra, 0,004 longa, 0,002 lata. Stamina 10, libera; filamenta teretia, sursum attenuata, glabra; antherae basi affixae, oblongae, basi cordatae, connectivo in mucronulum producto, biloculares, rimis longitudinalibus dehiscentes. Polden sphaerieum. Pistruli rudimentum hemisphaericum glabrum. Flores feminei. Gatyx et coroura floris masculi. Stamina nulla vel rudimenta eorum filiformia. Ovarium liberum, ovoideum, versus apicem attenuatum, glabrum, triloculare; ovvLA 6-10, campylotropa, placentis partitis ex axi loculi productis affixa. Styuus subteres, glaber; sтiganta tria approximata, demum patentia, filiformia. BıcG pisiformis, parte styli mucronata, saepe obsolete trisulcata, glabra, coerulea, trilocularis; DISSEPIIENTa membranacea. SeMrina 4-8 in singulo loculo, hippocrepiformieomplicata, ovata, compressa, hilo et exostomio approximatis; тESTA crustacea, scrobiculata; TEGMEN membranaceum, tenue. EnвRro in medio albuminis albi et granulati, eylindrieus, bieruris; Radiaula acutiuscula; cotrueDones obtusae.

\section{Crescit in montibus Pamatton, Salioembang, Batoe, Rantau: Bonveo.}

Tab. 17. Figura hujus speeiei. 1. Ramus femineus. 2. Ramus masculus. 1. Flos. 2. Flos, calyce ablato. 3. Calyx explicatus. 4. Petalum intus visum. 5. Flos masculus, calyce et corolla ablatis. 6 et 7. Stamina. 8. Pistilli rudimentum et stamen unieum. 9. Ovarium. 10. Ovarium verticaliter sectum. 11. Ovarii transversalis sectio. 12. Fructus cum calyce persistente. 13. Fructus verticaliter sectus. 14. Semina denudata. 15. Placenta cum ovulis. 16. Semen. 17. Semen verticaliter sectum. 18. Embryo.

De door mij, onder den naam Eurya nitida vereenigde gewassen, kunnen missehien later tot de vermeerdering van het getal soorten des geslachts Eurya, het hunne bijdragen. Wanneer men de verschillendste vormen met elkander vergelijkt, vindt men dezelve wezentlijk zeer afwijkend. Op iedere plaats, waar wij deze gewassen verzamelden, leverden zij het eene of andere verschil op in hunnen vorm. De aan den voet van den Sakoembang groeijende planten hebben de bladen elliptisch, naar den voet versmald in een steeltje van ongeveer $\frac{T}{T_{3}}$ der lengte van het blad, aan of naar de punt zeer toegespitst, met stompe zaagtanden. Aan dien van den Goenong Batoe, een' voorheuvel van een meer westelijk gelegen gebergte, zijn de bladen grooter, verder van elkander verwijderd, veel korter gesteeld, aan den top in eene kortere spits uitloopende, en met grootere stompe zaagtanden voorzien. Op de kruin en langs den voet van den berg Pamatton groeijen twee vormen. De voorwerpen van de kruin, ten gevolge van het eigenaardige des bodems, alleen door regenbuijen bevochtigd, zijn op het aanzien minder uitgegroeid; de takken zijn door eenen breeden rand bezoomd, de bladen zeer kort gesteeld, ovaal, met eene stompe punt, kleine stompe zaagtanden en tamelijk dik. Aan dezelve zijn de bloemen, welke gewoonlijk gepaard in de oksels der bladen staan, aan eenige takjes zeer digt bij elkander; zoodat zij, 
ingeval de boven dezelve geplaatste bladen niet ontwikkeld waren, aren zouden vormen. Deze afivijking, aan takjes van eene gelijke ontwikkeling voorkomende, is een gevolg van de standplaats, en schijnt mij toe, veroorzaakt te worden door eenen stilstand van groei, welke bij gemis van den noodigen regen plaats heeft. De andere vorm uit deze streken heeft de bladen langwerpig-ovaal, aan de beide einden toegespitst, met scherpere zaagtanden, en van eene dunnere zelfstandigheid.

Deze soort is bij de bewoners van de boorden der Doeson-rivier, onder den naam Toeangau bekend.

\section{EURYA CONEOCARPA. KHS.}

E. ramulis glabris, foliis lanceolato-ellipticis serratis glabris, floribus geminatis, sepalis ovatis, fructubus turbinatis。

Arbuscula facie Euryae glabrac. Rami patentes vel crecto-patentes, subterctes, saepe compressi, glabri, fusci vel glandacei; ramuli subcompressi, glabri, saepe marginati. Folia alterna, subdisticha, erecto-patentia, lanceolato-elliptica in planta mascula, oblongo-ovata in planta feminea, basi angustata, obtuse acuta vel acuminata, a medio ad apicem usque obtuse serratis, serraturis mucronulatis vel callosis, utrinque glabra, nitida, coriacea, 0,06 longa, 0,015 lata vel 0,05 longa, 0,02 lata, nervis reticulatis, supra exsculptis, subtus prominentibus; PETIoLI semiteretes, glabri, 0,003-0,005 longi. Gennar compresso-subulatae, glabrae. Flores axillares, geminati, raro solitarii; pedunculr tetragonocompressi, glabri; вracteae flori approximatae, subaequalcs, ovatae, obtusae, glabrae. Alabastruar ovoïdeum. Flos masculus. Caltx pentasepalus, aestivatione imbricatâ; sepala erecta, late ovata, obtusa, apice cum mucronulo calloso, utrinque glabra. Coroula campanulata, pentapetala, aestivatione imbricatâ; petala basi adhaerentia, obovata, obtusa, glabra. Stamiva 10-15, biserialia, alterna saepe breviora; FILAMENTA linearia, attenuata, glabra; ANTHERAE basi affixae, oblongo-ovatae, connectivo in mucronulum producto. Pistilli rudimentum attenuato-conicum, glabrum. Fros femincus. Calyx et corolla floris masculi. Ovarium semi-ovoïdeum, attenuatum in stylum tri- quinquepartitum, glabrum, tri-quinqueloculare; ovtra in singulo loculo 10-20, biserialia, placentae lineari axi loculi insertae affixa; stigmata 3-5, subuliformia, intus papillata. B B $\mathbf{A C A}$ turbinata, subattenuata, glabra, trilocularis. Senira 8-10 in singulo loculo, superimposita, placentae lineari lamellae ope in loculum productae affixa, deformia, saepe compressa, hilo et exostomio approximatis. Srructura seminum similis Euryae serratae.

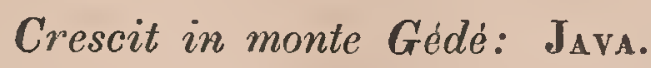

Deze soort groeit, even als de Eurya glabra, op of even beneden de kruin van het gebergte Gédé. De laatstgenoemde is echter meer langs het zuidelijk en zuid-oostelijk gedeelte verspreid, en wast tevens langs de helling van het, onder den naam Seda-ratoe bekende, gedeelte van het gebergte; de Eurya coneocarpa daarentegen, wordt menigvuldiger gevonden op de noordelijke grenzen der kruin. Door de groeiwijze en de plaats, waar zij voorkomt, is zij zeer verwant aan de soort, welke met haar in de gemelde oorden wordt aangetroffen; doch door den vorm der bladen en vooral door de bloeiwijze, met 
gepaarde vrouwelijke bloemen, en ook door den tolvorm der bessen, van deze gemakkelijk te onderschciden. Onder elkander versehillen de waargenomene gewassen in de groeiwijze, welke met den bodem, waarin zij geworteld zijn, in verband staat. Die van steenachtigen grond zijn meer zaamgedrongen, hebben de bladen digter bij elkander en iets breeder; de anderen, in meer verweerde aarde wortel schietende, zijn slanker, met langere en meer van elkander verwijderd staande bladen. Aan beide vormen vindt men, nevens den gewonen bladvorm, kleinere, omgekeerd eivormige, soms geheel gaafrandige bladen, digt bij den oorsprong der takjes.

\section{EURYA OBOVATA. Bu.}

E. ramulis glabris, foliis obovalibus serratis glabris, floribus axillaribus solitariis vel geminatis, fructubus oblongorotundatis.

Eurya celebica. Rwdt. Hb. (Anno 1821)

Arbuscula; rami teretes, saepe marginati, glabri; Ramuli subtriangulares, angulis saepe ancipitibus, glabri, fuscescentes. Fouri alterna, approximata, patentia, obovalia, obtusa, basi cuneata integerrima, supra basin obtuse serrata, utrinque glabra, coriacea, 0,02 longa, 0,01 lata; PETioli semiteretes,

glabri, 0,002 longi. Pedunculi axillares, solitarii vel geminati, glabri. Caryx bibracteolatus, pentasepalus, persistens; bracteolá suboppositae, calyci approximatae, ovatae, mucronulatae, glabrae; SEPALA inaequalia: duo minora ovata obtusa, tria subrotunda emarginata, glabra. Conolua pentapetala, aestivatione imbricatâ; petata subaequalia, obovata, obtusa, glabra, membranacea. Ovariưr subovoïdeum, glabrum, triloculare; ovura 10-12 in singulo loculo, superposita, subcampylotropa; stycus teres, brevis; stignata tria, filiformia. BACCA pisiformis, subdepressa, styli parte mucronata, glabra, trilocularis. SEMIra 6-10 in singulo loculo, superposita, ovata, compressa, hippocrepiformicomplicata, struCturA seminis Euryae nitidae.

Crescit in monte Klabat: CeLEBes (fide Clar. Reinwardl); in montibus Gédé et Pangerango: Java (fide Clar. Blume).

\section{EURYA RETICULATA. Kus.}

E. ramulis glabris, foliis ovalibus acutiusculis grosse serratis, floribus geminatis, sepalis subrotundis, fructubus turbinatis.

Arbuscula unius ad trium metrorum; truncus cylindricus, nigrescens; Corona subrotunda, dense foliata; RAMI diffusi, approximati, teretes, glabri, fusci; RAMULI alterni, patentes, teretes vel compressi, marginati vel subtriangulares, glabri. Gemma glabrae. Foura alterna, ovalia, acutiuscula, saepe emarginata, basi cuneata integerrima, sursum obtusc serrata, utrinque glabra, coriacea, 0,035 longa, 0,02 lata; petroli glabri, 0,062 longi. Flores axillares, geminati, raro solitarii; pedunculi glabri. GALXX bibracteatus, pentasepalus, aestivatione imbricatâ; BRACTEAE ovatae, acutae; SEPALA inaequalia, 
subrotunda, acutiuscula, glabra. Corolı pentapetala, campanulata, aestivatione subimbricatâ; PETALA basi adhaerentia, obcordata, glabra. Stмлirn 25, pluriserialia; filamenta subcohaerentia, filiformia, glabra; a NTUERA basi affixae, lineares, connectivo in mucronem producto. - BaCCa turbinata, glabra, coerulea, trilocularis, epicarpio membranaceo, sarcocarpio succoso, endocarpio membranaceo. SEMina 3-6 in singulo loculo, axi loculi affixa, subdisciformia, in centro excavata, hippocrepiformi-curvata; SPERHODERIIIs tenuissime membranacea; tESTA crustacea, scrobiculata, fusca; TEGIIEN membranaceum. Embryo in axi albuminis albi, hippocrepiformis, cylindricus; radicula obtusa; COTYLEDones breves, subaequales; pLumula haud conspicua.

\section{Crescit in summo montis Mlerapi: Sumatra.}

Tab. 17. 3. Figura Euryae reticulatae.

Rondom den krater van den vuurberg Merapi wordt de Eurya reticulata als kleine struiken opgemerkt. Zij dragen in haar geheele voorkomen het kenmerk der hooge groeiplaats en der weinige beschutting, tegen de in deze hooge streken heerschende koude en harde winden. De struiken zijn ineengedrongen, met zeer brooze takken. Hunne bladen staan digt boven elkander, hebben de nerven zeer uitgegroeid en als in een net verbonden. Aan dezelve zijn de tandjes diepcr, dan bij andere soorten, ingesneden en als een eenigermate rond lobje boven de insnede uitstekende.

\section{EURYA BLUMEANA. KHS.}

E. ramulis pubescentibus, foliis oblongo-cllipticis serratis, floribus solitariis vel geminatis, scpalis rotundlatis, fructubus globosis.

Arbuscola sex ad octo metrorum; Coroina aperta, hemisphaerica; rami patentes, teretes, glabri, fusci; ranudi alterni, subteretes vel compressi, pubescentes. Grmma elongatae, dense pubescentes. Folis alterna, oblongo-elliptica, raro elliptica, obtuse acuminata, basi cuneata integerrima, supra basin serrata, serraturis obtusis saepe mucronulatis, supra glabra, subtus praesertim in nervo medio pilosa, coriacea, 0,07 longa, 0,02 lata; Peтrou semiteretes, supra plani, pubescentes, 0,003 longi. Fuores unisexuales, raro hermaphroditi, axillares, geminati vel solitarii; pedurculi teretes, pubescentes, 0,002 longi. Flores masculi. CALtx bibracteolatus, pentasepalus, persistens, aestivatione imbricatâ; bracteolae suboppositae, ovatae, acutae, pubescentes, minutae; SEPALA pubescentia, inaequalia: duo minora ovata, obtusa; tria majora subrotunda, obtusissima, saepe emarginata. Corolra pentapetala, subcampanulata, aestivatione imbricatâ; PETALA oblonga, obtusa, integerrima, glabra, subcarnosa. Stamina 15, uniserialia; filalienta basi cohaerentia, filiformia, basi incrassata, glabra; atutherae basi aflixae, lineares, basi subcordatae, biloculares, loculis rimis longitudinalibus dehiscentibus, connectivo in laminam acutam producto. Pistildi rudimentum elongato-conicum, glabrum. Floris feminei calyx ct corolla eaedem ac floris masculi. Ovariuni globosum, attenuatum, glabrum, triloculare; ovve 6-10 in singulo loculo, superimposita, hippocrepiformi-complicata. STruus subtrigonus, glaber; 
stigmata tria, filiformia, patentia. Fructus pisiformis, subdepressus, styli parte mucronatus, glaber. FruCtûs et seminus structura eadem ae Euryae serratae.

Crescit in montibus Patoeha, Talaga-Bodas etc.: $\mathbf{J}_{\mathrm{AVA} \text {. }}$

De bovengenoemde soort groeit in de nabijheid der kraters van den Patoeha, Papandajang en TalagaBodas, in eenen naar de Eurya glabra gelijkenden vorm. $Z_{i j}$ is aldaar nergens hoofdplant, doch slechts in groepen of alleenstaande, tusschen andere kleine boomsoorten verspreid. Zoo vonden wij haar om den Talaga-Bodas, tusschen Myrica javanica, Acronodia punetata, Melastoma sylvaticum, Bongsoa elliptiea, Vireya (Rhododendron) retusa, enzv. Met de beide eerstgenoemden komt zij door hare hoogte overeen, terwijl zij door het lichter groene loof en de minder bladrijke kroonen verschilt. De anderen, met donker groene bladen: Melastoma en Bongsoa, of met bladen, wier bovenvlakte groen en ondervlakte bruin geschubd zijn: Vireya, groeiden onder hare kroonen en vormden op enkele plaatsen zeer digte groepen. Hier en daar stond zij, met Myriea javanica, tusschen Gleichenia vulcaniea, en droeg, even als deze, in hare schrale, ranke groeiwijze, het bewijs van eenen onderdrukten wasdom. De vruchten van de Eurya Blumeana, benevens die der Myrica javanica, strekken tot voedsel aan de Columba oxyura en C. porphyrea, wclke hicr zeer talrijk zijn, en in de Myrica hare nesten van takjes dezer boomsoorten en van de schubben der boomvaren gemaakt hadden. Aan het vleesch dezer vogels deelt zich de eigenaardige aromatisehe, naar terpentijn zweemende reuk van de vruehten der Myriea mede.

S A UR A U J A. Willdenow, De Gandolle, Budie, enzu.

De geschiedenis van het geslacht Saurauja, tot in 1822, is uitvoerig door den Heer De Candolle (Mémoires de la soe. physique de Genève, Tom. I. pag. 393 et suiv.) en onlangs, van dat tijdvak tot op den tegenwoordigen tijd, door den Heer Bennet (Plantae Javanicae rariores a Clarissimo Horsfield leetae, pag. 171) behandeld. Ik zal haar hier slechts met weinige woorden en eene kleine bijvoeging herhalen. De eerste soort van dit geslacht, welke Willdenow bekend maakte, berustte op eene, door Bredemeyer, uit Caracas overgezondene plant. De latere, door den Heer De Candolle beschrevene en afgebeelde soorten, waren door Sessé en Mocino in Mexico, door Noronha, Commerson, La Haye en Leschenault op Java, en door den Heer Wallich in Nepaul verzameld. Noronha gaf aan deze gewassen den geslachtsnaam Scapha; Leschenault dien van Van Alphenia; Sessé en Moeino noemden haar Davya en Leucothea. Bij deze namen moet die van Overstratia, welke Deschamps aan zijne op Java gevondene soorten gaf, worden gevoegd. Kort na de bekendmaking der verhandeling van den Heer De Candolle werden er eenige soorten door den Hoogleeraar Rcinwardt, onder den naam Marumia beschreven en, een paar jaren later, negen soorten, waarvan eenige door de Heeren De Candolle en Reinwardt vermeld, als soorten van Saurauja, door den Heer Blume bekend gemaakt. Bij deze in den Archipel gevondene soorten, voegde de Heer Wallich, in zijne lijst, vier soorten van Pinang, Nepaul, Silhet en Pundua; terwijl er, volgens de opgave van den Heer Bennet, nog verseheidene 
onbeschrevene soorten in het IIerbarium, dat de Heer Horsfield op Java bijeenbragt, bestaan. In de verzameling van Kuhl en van Hasselt bevinden zich verseheidene der, op Java gevondene, reeds bekend gemaakte soorten. Die van Zippelius bevat soorten van Ambon en van Nieuw-Guinea. Onder onze op Java, Borneo en Sumatra bijeengebragte gewassen zijn verscheidene nieuwe soorten van dit geslacht. - Bij dit geslacht behooren, volgens den Heer Kunth, de als Palava, door Ruiz en Pavon (Apatelia De Candolle) beschrevene gewassen cn, naar de beschrijving oordeelende, éénc door Roxburgh en meerdere door W. Jack, als soorten van Ternstroemia gekenmerkte planten.

De bekende soorten van dit geslacht zijn in Zuid-Amerika en in de zuid-oostelijke deelen van Azië verzameld. In het eerstgemelde werelddeel groeijen zij in de gebergten van Venezuela, Mexieo en Peru. In Azië zijn eenige soorten op het vasteland van Indië gevonden; zij verspreiden zieh daar tot in Nepaul. De anderen, ongeveer het drie vierde gedeelte van het geslaeht, zijn op de zuid-oostelijke eilanden, van Sumatra tot Nieuw-Guinea, tussehen de $100^{\circ}$ en $138^{\circ}$ lengte, bijeengebragt. Zij groeijen daar van het zeestrand af, of soms op een weinig boven hetzelve verhevene plaatsen, tot op ruim 2300 ellen. Somwijlen worden zij op onbesehaduwde, doeh gewoonlijk op beschaduwde plaatsen, als gezellige gewassen gevonden. Op Java wassen de Saurauja Noronhiana en S. cauliflora menigvuldig in de dalen, door welke de bergbeken stroomen; de S. micrantha, aan den waterval van den Tjikondoel, langs eene steile, rotsige helling; de S. Reinwardtiana, hirsuta en braeteosa, meer binnen in de bosschen, vooral op vlakke ruggen; de S. leprosa onbesehaduwd, in de nabijheid van de kraters van den Papandajang, Talaga-Bodas enzv.; allen tusschen 300 en 2000 ellen. Op Sumatra groeit de S. vulcani tegen den berg Merapi, op ongeveer 2000 ellen; de Saurauja Singalangensis enzv., in de bosschen, van 200 tot 800 ellen, en de S. media en S. Jaekiana, op dezelfde standplaatsen als de S. Noronhiana en S. cauliflora, op Java. In hel zuid-oostelijk gedeelte van Borneo wast de S. subcordata, ferox, Tewensis enzv., niet zeldzaam op de kleine hcuvels langs de Téwe-rivier, 50 tot 100 ellen hoven het zecvlak, en de S. exeavata, Sakoembangensis enzv., hier en daar op den berg Sakoembang, tot op ongeveer 1000 ellen hoogte. Aan den noord-oostelijken hoek van Celebes groeijen, blijkens het Herbarium van den Hoogleeraar Reinwardt, de S. spadicea en S. pentapetala. Het eiland Ambon is, volgens de onderzoekingen van de Heeren Reinwardt en Zippelius, de groeiplaats der Saurauja tristyla, en bezit, met Nieuw-Guinea, eenige aan de S. hirsuta en Reinwardtiana verwante soorten.

De door ons verzamelde soorten zijn boomen of struiken, met piramidenvormige, langwerpige of halfronde kroonen, die dikwerf van binnen zeer sehaars en naar den omtrek digt met bladeren zijn voorzien. Haar stam is, bij de boomvormende soorten, onregelmatig rolrond; hij bestaat uit eene bruine of grijze, niet zeer dikke schors, uit een wit of bleek-rood gekleurd, ligt, fijndradig hout, cn cen aanzienlijk merg, dat veelal in een rond mergkanaal is besloten. De takken zijn in spiralen, waarin van den vierden tot den zevenden boven den eersten staat, om den stam geplaatst, meestal, indien de boomen op opene plaatsen groeijen, openstaande, zelden naar boven gerigt of naar beneden gebogen. De ouden zijn bijna rolrond, de jongeren hoekig, bij hunne eerste ontwikkeling zaamgedrukt. De jonge takken, de knoppen, de bladen en de kelkdeelen zijn bij enkele soorten glad; bij de meesten met eene eigenaardige bedekking voorzien. - Bij eenigen bestaat deze bedekking uit eivormige, langwerpige of laneetvormige, toegespitste 
sehubjes; bij anderen uit schubben en borstelharen (S. ferox), of uit schubjes en zachtere haren, die enkelvoudig of stervormig zijn. De bedekking is in het laatste geval glanzend, wanneer de schubjes talrijk zijn: S. spadieea; als bestoven, zoo de haren zeer kort zijn en opeengedrongen staan: S. Jackiana; of donzig, ingeval de haren langer zijn: S. cauliflora. - De knoppen zijn bijna rolrond, zelden glad. In dezelve liggen de blaadjes met de randen tegen elkander gevouwen, en omgeven zij de jongeren. De bladen zijn even zoo om de takken, als deze om den stam, geplaatst. Hun vorm is lang, met de lengte tot de breedte als $\mathbf{1}$ tot 2-4. Zij zijn zelden met gave randen, doch over het algemeen gezaagd of getand: bij de oudere bladen met stompe, en bij de jongere met scherpe tandjes. Eenige soorten hebben de beide vlakken der bladen met de bovengemelde bekleeding voorzien, anderen slechts eene derzelve, en enkelen bezitten bijna geheel gladde bladen. Hunne nervuur verschilt door eenige geringe afwijkingen. De middelnerf, meestal in een klein uitstekend puntje eindigende, is op de ondervlakte als eene rib verheven. De hoofdnerven vormen met de middelnerf hoeken van $10^{\circ}$ bij S. eauliflora, van $30^{\circ}$ bij S. subcordata, van $45^{\circ}$ bij S. Reinwardtiana. De tusschen deze gelegene zijnerven zijn bijna evenwijdig met S-vormige bogten: bij eenige soorten, S. Reintvardtiana enzv., zeer digt bij elkander, en bij anderen, S. pendula enzv., van elkander verwijderd. - De bloemen groeijen uit de oksels der bladstelen, langs de takken, of langs den stam. Bij eenige soorten staan zij alleen, bij anderen in bijschermen, en somwijlen in kleine sehermen. Hare stelen zijn rond of zaamgedrukt, dragende meestal twee, soms echter een of drie schutblaadjes, in de nabijheid van de bloem of op het midden van het bloemsteeltje, in eenen afwisselenden stand. Op de soorten, welke bijsehermen hebben, zijn deze schutblaadjes op de hoofdstelen van eene aanzienlijke grootte, doch op de anderen zeer klein. De kelk, door zamengroeijing der kelkbladen vijf-, zelden vierdeelig, heeft zijne deelen vóór de opening als dakpannen (imbricata of quincuncialis) gelegerd, ongelijk van grootte, eirkelrond of langer dan breed. - De bloemkroon vertoont vóór de opening eenen ronden of eivormigen knop, waarin de deelen elkander met de randen dekken, allen naar dezelfde zijde gebogen zijn, en dus de bij de Dipterocarpeae opgegevene waarneming versterken. Zij is, door de zamengroeijing der bloembladen, vijf-, zelden vierdeelig. Deze deelen zijn omgekeerd-eivormig, aan den top stomp of met twee ongelijke lobben, glad, wit of zacht rozenrood, met drie of meer, van den voet naar den top loopende aderen. - De helmdraden, op den torus geplaatst, zijn in een drie- tot achtvoudig getal van de bloemkroondeelen, aan den voet met elkander en met de bloemkroon, waarmede zij te gelijk afvallen, zaamgegroeid; lijnvormig. De helmknopjes zijn even beneden hun midden met de draden verbonden, doeh niet beweegbaar; lijnvormig, aan de beide einden geknot, of het eene einde ingesneden of tweelobbig. Zij bestaan uit een paar hokjes en eenen kleinen, lijnvormigen helmknoop. De opening der hokjes begint aan den top met een gaatje, dat dikwerf niet grooter wordt, doeh soms het begin eener spleet is, die langs de geheele lengte voortgaat. De helmknopjes, het stuifmeel uitgestort hebbende, buigen zich aan de beide einden om. Zij bestaan uit een zeer fijn buitenvlies, en uit een endothecium met eene laag kleine, bijna ronde cellen. - Het vruehtbeginsel is bij de meeste soorten halfkogelvormig, somwijlen eivormig, naar het einde smaller toeloopende, geknot of zelfs ingedeukt; op eenige soorten vindt men het glad, op anderen behaard. Het heeft drie, vier of vijf hokjes, waarin de moederkoeken aan vleezige steeltjes, even beneden den top, in den binnensten hoek zijn vastgehecht. De moederkoeken zijn halfkogelvormig, met de bolle zijdé naar buiten, aan den omtrek ongedeeld of, door eene insnede, bijna tweelobbig. Zij worden 
door eene menigte eitjes geheel bedekt. Reeds in zeer jonge vruchtbeginsels hebben deze eitjes eenen langwerpigen vorm en den eimond naar den moederkoek gebogen. - Drie tot vijf stijlen, tot op cenigen afstand van het vruchtbeginsel zaamgegroeid: S. exeavata enzv., of van hetzelve af aan geheel vrij, zijn gewoonlijk aanwezig. Ieder derzelve eindigt in een' knopvormigen of puntigen stempel, welke de opening van het stempelkanaal, even beneden den top, aan de binnenzijde heeft. - De vrucht is kapselof besaardig: een verschil, dat men - ten minste het onderzoek der geziene soorten doet mij dit vooronderstellen - reeds uit de besehouwing van het vruchtbeginsel kan vermoeden: want bij de soorten, welke eenen boven hetzelve onvcrdeelden stijl hebben, zag ik besaardige vruehten, en bij die, wier stijlen van het vruehtbeginsel af aan verdeeld zijn, worden later kapselaardige vruehten waargenomen. De vrueht bezit een dun epicarpium, dat somwijlen bij de bessen rood of wit gekleurd is; een vezelig, droog of vleezig sarcoearpium, en een vleezig endocarpium. De tussehensehotten zijn vliezig. De kapsels springen in even zoo vele kleppen, als er hokjes zijn, open. Bij de opening seheiden zieh de kleppen tegen over het midden der hokjes, tot op de helft harer lengte. De laatste soort van vruehten, aan S. ferox, S. media enzv. eigen, hebben de moederkocken halfbolrond, van eene vaste vleezige zelfstandigheid, met talrijke kleine groefjes, waarin de zaadjes geheeht zijn. - De besaardige vruehten, door S. cauliflora, S. braeteosa enzv. gedragen, bezitten de moederkoeken halfbolvormig, saprijk, omhuld door eene talrijke hoeveelheid zaden en eene geleiaardige stof, welke de geheele holte der vrucht vult. - Deze geleiaardige stof is van eenen zuren smaak, vermengt zieh gemakkelijk met het water, lost in Ammonia op, en wordt hieruit door zuren afgescheiden, hetgeen mij doet vooronderstellen, dat zij door Peetenzuur geleiaardig is. $\mathrm{Z}_{\mathrm{ij}}$ bestaat uit kleine doorsehijnende cellen, tegen wier wanden korreltjes zijn. Naar mijne waarnemingen, behoort deze stof tot de moederkoeken en tot de zeer ontwikkelde epidermis seminalis.

De zaden hebben den vorm van piramiden met drie of vier zijden, en zijn aan het smalste einde vastgeheeht. De opperhuid (epidermis seminalis) is vliezig of saprijk. De buitenhuid (testa) is gegroefd - bij vergrooting waargenomen, met kleine, vier- tot zeshoekige, door opstaande wanden beperkte diepten $\left(^{\star}\right)$ - broos, bruin gekleurd. Op dezelve zijn de navel en zaadmond alleen bij sterke vergrooting zigtbaar. Beiden zijn zeer nabij elkander, als twee ronde holten. De binnenhuid (tegmen) is vliezig, zeer dun en, alleen bij zeer sterke vergrooting, eclaehtig. Tussehen deze beide zaadbekleedsels is eene laag .van zeer dunwandige cellen, waaronder enkele met bundels van naaldvormige kristallen, die door den Heer Bennet bij S. braeteosa enzv., en door mij bij S. ferox, S. pendula enzv. zijn waargenomen. Daarenboven loopt tusschen de testa en het tegmen, langs de eerstgenoemde, de raphe van den navel tot aan de kruin van het zaad, waar zij naar het tegmen is omgebogen.

De kern is eivormig, soms naar de zijde der raphe een weinig platgedrukt. Ifet kiemwit, dat het grootste gedeelte derzelve vormt, is wit en omgeeft de kiem geheel. De kiem ligt digt bij de ehalaza en heeft de helft tot twee derden van de lengte der kern. Zij is rolrond, aan de einden stomp of puntig,

${ }^{*}$ ) Deze diepten zijn de verharde, naar de binnenzijde gekeerde wanden der cellen, welke de testa vormen. Zij vertoonen niet zelden, bij eene sterke vergrooting waargenomen, het buitenste gedeelte der cellen als cen zeer fijn, doorschijnend vliesje. 
eenigzins gebogen: S. distasosa, S. pendula; of geheel regt: S. ferox enzv. De zaadlobben en het wortelcje derzelve zijn even lang, of het laatste vormt het grootste gedeelte der kiem. De kiem is in een zeer fijn vliesje besloten, hetwelk naar den zaadmond als een dun draadje uitloopt.

Naar deze besehrijving de door de sehrijvers opgegevene geslaehtskenmerken nagaande, kan het verschil derzelve gemakkelijk worden opgelost. Ruiz en Pavon hebben den kelk, als door sebutblaadjes ondersteund, besehreven; zij hadden zeker voorwerpen met éénbloemige steeltjes voor zieh, op welke de beide sehutblaadjes digt bij den kelk stonden: zoo als S. ferox enzv. zulks heeft. De Heer Kunth geeft op, dat de blocmbladen geheel vrij zijn; de Heeren De Candolle en Blume, dat zij aan den voet zijn verbonden; bij de Indisehe soorten zijn de S. media voor de bijna geheel vrije bloembladen en de S. Noronhiana enzv. voor de zaamgegroeide als voorbeelden op te noemen. Even zoo bestaat er een overgang van vrije tot zaamgegroeide helmdraden. De soorten met bes- en kapselaardige vruehten, zijn door ons in den Arehipel gevonden. Het versehil sehijnt voornamelijk door eene meerdere ontwikkeling of opvulling van het celweefsel der moederkoeken enzv. met waterige sappen, veroorzaakt te worden.

Ifet voorkomen der met kapsels en bessen voorziene soorten in den Arehipel, doet het denkbeeld vervallen, om naar dit onderseheid de Aziatisehe en Amerikaansehe soorten tot bijzondere geslaehten te maken. Dit versehil kan eehter gebruikt worden om de soorten, ten minste zoover zij mij bekend zijn, in het algemeen te verdeelen. De eene afdeeling, met de Noronhianae Bl. zamenvallende, zoude dan de met vleezige vruehten en gedeeltelijk zaamgegroeide stijlen voorziene soorten moeten opnemen. De andere, ten naastenbij aan de Reinwardtianae gelijk, konde de soorten opnemen, welke kapsels, vrije stijlen en veelal bekleede kelken bezitten.

Zoover mij bekend is, gebruiken de inlanders, van deze planten alleen de saprijke vruehten, gekneusd en met water gemengd zijnde, als middel ter verfrissching en verkoeling in heete koortsen. Zij kennen deze gewassen onder den algemeenen naam Kileho, en de soorten daarenboven nog onder andere namen, die het een of ander eigenaardigs van het uiterlijk aanzien kenmerken. Den gemelden algemeenen naam hebben zij, wegens den zuren smaak der vruehten, die den mond en het gezigt doet zamentrekken, aan dezelve gegeven.

\section{SAURAUJA SUBCORDATA. Krs.}

S. ramulis glabriusculis, foliis ovalibus acutis basi subcordatis serrulatis utrinque glabris, pedunculis axillaribus unifloris congregatis, calycibus glabris, sepalis inaequalibus.

Arbuscula 2-3 metrorum; RamI subteretes, subsuleati, einerei, glabri; ramulr subeompressi, squamulis nonnullis ovatis, aeutis vestiti. Folı ovalia, aeuta, mueronulata, basi obtusa vel subeordata, serrulata vel crenulata, utrinque glabra - juniora eum squamulis nonnullis - subeoriaeea, 0,25 longa, 0,05 lata, nervis secundarïs parallelis, approximatis; peTroLr eompressi, supra suleati, subsquamulati. 
Flones axillares, congregati; pedurcul uniflori, filiformes, squamulati, bibracteolati; bracteolae alternae, oblongae, acutac, fere glabrae, minutae. CaLYX pentasepalus, fructum includens; sepala ereeta, inaequalia: duo exteriora minora, subrotunda, obtusa; tria interiora late ovata, acutiuseula, subeoriacea, extus et intus glabra. Ovariun subglobosum, truneatum, trisuleatum, glabrum, triloculare; ovura numerosa, placentis oblongis, earnosis, breviter stipitatis, affixa. Struts basi simplex cylindrieus, medio tripartitum, glabrum; sтाGпата eapitulata.

\section{Crescit ad flumen Tewe: Bonveo.}

\section{SAURAUJA LEUCOPHLOIA. Kns.}

S. ramulis glabris, foliis elliptico-lanceolatis aeuminatis obsolete serrulatis utrinque glabris, peduneulis axillaribus unifloris, calycibus glabriusculis, sepalis subaequalibus.

Arbuscura 3-5 metrorum; rami patentes, teretes, glabri, einerei; namuli compressi, glabri vel squamulis nonnullis ovatis muniti. Foura ad ramulorum apices eonferta, elliptico-laneeolata, aeuminata; subserrulata, serraturis distantibus eallosis, supra et subtus glabra, eoriaeea, 0,3 longa, 0,07 lata, nervis primariis in angulo $20^{\circ}$, nervis seeundariis retieulatis; ретгоц subtrigoni, glabriusculi, 0,02 longi. INFLorescentia axillaris vel foliorum abortu alaris; pedurguli solitarii vel geminati, uni- raro biflori, compressi, glabriuseuli, bibracteolati; BRACTEoraE alternae, distantes, ovatae, aeutae, deeiduae. CıLrXX fruetum eingens, pentasepalus, basi truneatus vel exeavatus; sEpı.tA subaequalia, subrotunda, obtusa vel aeuta, intus glabra, extus basi fuseo-pubeseentia. CAssura globoso-trigona, trisuleata, vertiec rotundata, glabra, loculieida, trivalvis; valvulae ad medium usque dehiseentes. Stru tres, subterctes, glabri; stigmata eapitellata. Semiva plura, 10-20 in singulo loeulo, inserta in placentis hemisphaerieis ope laminae angulo interno loeuli affixis, angulata, saepe tetrangularia, foveolata, foveolis rotundatis vel hexagonis, fusea. Structura eorum similis Sauraujac feroeis.

Crescit in monte Singalang: Sumatra.

\section{SAURAUJA MEDIA. KHS.}

S. ramulis sparsim squamulatis, foliis obovalibus acuminatis basi cunealis sinnato-serratis utrinque glabris, pedunculis axillaribus vel alaribus congregatis, calycibus glabriusculis, sepalis subaequalibus.

Arbuscula; rami tetragoni vel subteretes, glabri, fusei; Ramuli eompressi, squamis subrotundis vestiti. Foura alterna, obovalia, acuminatissima, basi cuncata vel obtusiuseula, sinuato-serrata, scrraturis aeutis sacpe incurvis, supra subtusque glabra, - juniora supra et subtus squamulis subrotundis minutis vestita - coriacea, 0,2 longa, 0,08 lata, nervis seeundariis subparallelis distantibus; PETroLI compressi; squamulati, 0,05 longi. Infrorescentia axillaris vel alaris; pedunguli congregati, uniflori, filiformes, squamulati, bibracteolati; mRacteolne alternac, distantes, ovatae, minutac, deciduac. Alabastruna Botanica. 
subovoïdeum, basi truncatum vel excavatum. CAurrx rotatus, pentasepalus, aestivatione quincunciali; SEPALA subaequalia, rotundata, obtusiuscula, intus glabra, cxtus pubescentia vel glabriuscula. Corouta pentapetala, rotata, aestivationc convolutâ; PETALA basi connata, obovata, apice emarginata vel subbiloba, membranacea. Stamina 15, libera; milamenta linearia, glabra; antherae in medio affixae, cordiformes, rimis apicalibus dehiscentes. Ovarium hemisphaericum, pubescens, triloculare; ovuLA plura, placentis semi-ovoïdeis, ope stipitis cum angulo interno loculi connatis, affixa; sTrLr tres, subteretes, glabri; strgnata capitellata. Frugtus capsularis, calyce inclusus, hemisphaericus, depressus, pubescens, trivalvis, loculicide dehiseens; valvulae ad medium longitudinis usque dehiscentes. Senrnum numerus, insertio et structura similes Sauraujae ferocis.

\section{Crescit in sylvis montis Singalang: Sumatra.}

De verwantschap van Saurauja media en S. nudiflora is, zoo de habitus in aanmerking genomen wordt, zeer in het oogloopend. Beiden bloeijen uit de oksels en later uit de takken of uit den stam, en hebben de bladen vrij gelijkvormig; terwijl deze, benevens de jonge takken, eene wrataehtige haarbekleeding bezitten, dic uit eene menigte vereenigde haartjes bestaat. Daarentegen zijn zij door den rand der bladen, de grootte der blocmen en den aard der vrucht genoegzaam van elkander tc onderseheiden. De S. media groeit langs de beken van het gebergte Singalang, als kleine boompjes met talrijke kleine, bijna wittc bloempjes.

\section{SAURAUJA NUDIFLORA. D. G.}

S. ramulis verrucosis, foliis obovalibus breviter acuminatis basi euneatis serrulatis sparsim squamatis, pedumculis axillaribus vel alaribus unifloris, calyeibus glabris, sepalis subaequalibus.

De Candolle, Mém. de Genève I. pag. 422. Tab. V; De C., Prodromus I. pag. 526; Saurauja Noronhiana Blume, Bijdr. pag. 126; S. Blumiana Bennet, in Horsfield Plantae Javan. rar. pag. 174. Tab. 37.

Crescit in umbrosis montium: $\mathrm{J}_{\mathbf{A} \mathbf{\Lambda} \text {. }}$

\section{SAURAUJA GAUlifiora. De C., Blume.}

S. ramulis squamulatis et setosis, foliis ovali-oblongis breviter aeuminatis basi obtusis mueronato-serrulatis subtus rubigineo-villosis, peduneulis unifloris axillaribus vel in truneo aggregatis, calycibus glabris, sepalis subaequalibus.

De Candolle, Mém. de Gen. I. pag. 425; De C., Prod. I. pag. 526; Blume, Bijdr. pag. 126; Seapha, Noronha.

\section{Crescit in montosis: JAva.}

Langs de bergbeken, somwijlen in de kleine moerassige vlakten der bergen van het westelijk gedeelte van Java, groeit de Saurauja cauliflora als gezellige plant: soms verspreid, soms in groepen digt bij elkander staande. Op de jonge planten zitten de bloemen in de oksels der bladen; op de ouden, langs het bladerlooze gedeelte van den stam. Zij komen hier bij voortduring uit dezelfde knoestige uitwassen, dic het geheele jaar door, met bloemen en vruchten bedekt zijn. - Deze plant, een sieraad van den tuin te Buitenzorg, heeft aldaar hare bloemen ongeveer de helft grooter, dan op de oorspronkelijke groeiplaatsen. 


\section{SAURAUJA JAGKIANA. Kin.}

S. ramulis glabris, foliis ellipticis breviter acuminatis serrulatis subtus densc rubigineo-lepidotis, pedunculis axillaribus unifloris, sepalis acqualibus.

Ternstroemia rubiginosa W. Jack, in Hooker Companion, pag. 83; De Candollc, Prodr. I. pag. 524.

\section{Crescit in sylvis montis Singalang: Sunatra.}

Deze soort werd door mij in de bosschen van den Singalang, op eenen kleinen vlakken rug, ongevcer zeven honderd ellen boven zee, waargenomen. $\mathrm{Z}_{\mathrm{ij}}$ is door de bijna regelmatige elliptische gedaante der bladen van S. cauliflora, welke zij op Sumatra vertegenwoordigt, gemakkelijk te onderscheiden. Daarenboven dient de bekleeding als een goed kenteeken ter vermijding van verwisseling: S. Jackiana heeft tusschen de digte, donzige haarbekleeding, vooral op de hoofdnerven, eenige weinige ovale schubjes; S. cauliflora bezit eene menigte borstelharen of priemvormig uitloopende schubjes in de donzige bekleeding. Beide soorten zijn door de haarbekleeding min of meer rood-bruin gekleurd.

\section{SAURAUJA SPADICEA. BL.}

S. ramulis leproso-squamulatis, foliis oblongis serrulatis supra glabris subtus spadiceo-leproso-squamulatis, umbellulis axillaribus paucifloris, calycibus sparsirn squamulatis.

Marumia oblonga, Rwdt.

Crescit in montosis: Celenes (fide Herb. Clar. Reinvardt).

\section{SAURAUJA PENDULA. Bì.}

S. ramulis sparsim squamulatis, foliis orali-oblongis mucronulato-acutis scrrulatis supra et subtus glabriusculis, pedunculis corymbosis, calycibus junioribus glabris.

Blume, Bijdr. pag. 127.

Crescit in montosis: JAva.

De voorwerpen dezer soort, welke op de bergen Malabar, Tjikoerai en Passir-Kiamis zijn verzameld, verschillen door de grootte hunner bloemen, en door den vorm en de grootte der bladen: die van den Tjikoerai zijn het meest ontwikkeld en hebben de bladen bijna omgekeerd-eivormig; die van Passir-Kiamis zijn kleiner, met langwerpige bladen; de voorwerpen van den Malabar maken den overgang tusschen deze beide uitersten. De bladen hebben in den zeer jeugdigen staat, langs den rand, op de middelnerf der beide vlakten, en op de hoofdzijnerven van het ondervlak, eene menigte civormige en puntige schubjes, die later, bij de uitgroeijing derzelven, bijna allen afvallen. 


\section{SAURAUJA NIGRESCENS. KHS.}

S. ramulis sparsim squamulatis, foliis oblongo-obovalis bicviter acuminatis basi cumeatis crenulato-serrulatis utrinque glabris, pedunculis subcorymbosis, calycibus junioribus fusco-pubescentibus.

Arbuscuia; Ra rII in angulo $45^{\circ}$, teretes vel subtetragoni, glabri, nigreseentes; Ramuli compressi, squamulis ovatis, acutis vestiti. Fous distantia, oblongo-obovata, raro oblonga, breviter acuminata, mucronulata, basi cuneata, supra basin obsolete serrulata vel crenulato-serrulata, serraturis saepe vix conspicuis, utrinque glabra, - juniora subtus in nervis praedita squamulis et pilis sparsis, - coriacea, 0,2 longa, 0,07 lata; petrour semiteretes, glabriusculi, 0,03 longi. Flores axillares vel alares, raeemosocorymbosi; pedurcutus communss compressus, saepe anceps, glaber; Pedurculi Partiales tctragoni, fusco-lcprosi. Bracteae oblongo-ovatae, obtusiusculae, intus glabrae, extus fusco-leprosae. Atabastruir ovöideum, apice et basi truncatum, fusco-pubescens. Flores nondum expansi. Carrx pentasepalus, aestivatione subimbricatâ; SEPALA concava, subrotunda, obtusiuscula, glabriuscula. CoroLta pentapetala, aestivatione convolutà; petala spathulata, biloba, glabra. Sta mrva 20; Filantenta linearia; aNTIERAE in medio affixae, oblongae, loculis disjunctis, bisulcatae. Ovarrun hemisphaericum, glabrum; styli 3; stigmata capitcllata. Fructus capsularis, globoso-trigonus, subtrisulcatus, apice rotundatus, glaber, loculicidus; valvdLAE ad duas tertias dehiscentes, stylis persistentibus terminatae, partem dissepimenti membranacei gerentes. Semrra multa, affixa placentis oblongis, trigonis: uno latere rotundato, duobus planis, lamellac ope in axi loculi insertis, superimposita, saepe 6 serialia, angulata, foveolata, foveolis hexagonis.

Crescit ad flumen Tewe: Borveo.

\section{SAURAUJA VULCANI. KHs.}

S. ramulis glabris, foliis oblongo-oratis acuminatis basi cordatis serratis vel serrulatis utrinque glabris, - junioribus utrinque dense setigeris, - floribus corymbosis, sepalis junioribus leprosis.

Arbuscula 2-6 metrorum; truncus brevis, subcylindrieus, cinereus, ligno laete rufo; ramir patentes, versus apices foliati, teretes, glabri; RAMULr adultiores compressi, glabri; RAMULi novelli dense setosi, setis subulatis, admodum deciduis. Fours oblongo-ovata vel ovalia, breviter acuminata, basi cordata, saepe inaequilatera, serrata vel serrulata, serraturis acutis, saepe subulatis, utrinque glabra, - juniora dense setosa, - coriacea, 0,22 longa, 0,1 lata; petrolr 0,03 longi, compressi, glabri vel setigeri. Fuores axillares, corymbosi; pedurrculus cominurs compressus, leprosus vel glaber, saepe $\mathbf{0 , 1}$ longus; penunculi partiales multipartiti, compressi, setosi et leprosi. Bracteae oblongo-ovatae vel oblongae, acutac, setosae. Arabastruir subglobosum, basi truneatum, fuseo-leprosum. Catyx pentasepalus, aestivatione quincunciali; SEPALA subaequalia, rotundata, obtusa vel acuta, intus glabra, extus fuscoleprosa. CoRolda gamopetala, quinquepartita, aestivatione convolutâ; LACiviaE obovatae, bilobae, lobis fere aequalibus crenulatis, glabrae. Stamira 30-40; rildirenta basi coalita et corollae adnata, lincaria, glabra; AvtheraE in medio affixae, oblongae, basi emarginatae, apice bilobae, rimis apicalibus dehiseentes. OVArium hemisphaericum, subpentagonum, truneatum vel exeavatum, partc superiore 
dense pilosum, parte inferiore glabrum, quinqueloculare; ovuls multa, tegentia plaeentas brevitér stipitatas, trigonas: uno latere rotundato; duobus planis. Srrcus simplex, supra basin quinquepartitus; stignata capitulata, depressa. Frocrus subglobosus, quinquesulcatus, depressus, apice dense pilosus; basi glaber, quinqueloeularis, dissepimentis membranaeeis. SEnrra plura, aflixa placentis trigonis ope laminae ex axi anguli loculi productis, diseiformia vel oblongo-rotundata, foveolata, foveolis tetravel pentagonis, profundis.

\section{Crescit in monte MIerapi: Sumatra.}

Deze soort heeft de gedaante der bladen tamelijk gelijkvormig en de randen zeer fijn gezaagd of met vrij groote tanden. Hare kelkbladen zijn bijna even groot; de beide buitensten zijn gelijkvormig en eindigen in kleine puntjes, naar welke de, uit den voet voortkomende nerven uitloopen; de dric binnensten hebben stompe toppen en de nerven waaijersgewijze uitgespreid. - Door de gedaante der bladen en in het geheel door den habitus, is de Saurauja vulcani zeer verwant aan de Saurauja bracteosa D. C.; doch de digtere haarbekleeding der takken, der bladen en der kelken, benevens de meerdere grootte der bloemen van de laatstgenoemde, geven genocgzame kenteekenen ter onderscheiding. Van de Saurauja excavata verschilt zij door de gedaante en de haarbekleeding der bladen.

Alleen aan de westelijke helling van den vulkaán Merapi, op Sumatra, werd deze soort door ons verzameld. Omtrent deze groeiplaats en haar voorkomen heb ik het volgende opgeteekend: s) Heden wandelde ik van ons verblijf - wij bevonden ons op ongeveer 1000 cllen boven de zee, te Goegoer Singandang - naar het hooger gedeelte van den berg Merapi. De weg derwaarts leidde eerst over eene, met gras en eenige verspreide groepen van struiken: Vitex, Conyza, enzv. begroeide, heuvelige helling. Op ongeveer 1200 ellen sloot zieh aan dezen schralen groei eene strook van Bambocs, welke ongeveer de hoogte van 1390 ellen bereikte. Hier werd de helling steiler en tevens meer begroeid. De Saurauja vulcani en Gleiehenia waren, van hier tot op 1470 ellen, hoofdgewassen: nu eens met elkander vereenigd, dan weder elkander de plaats inruimende. De eerste vorınde kleine struiken van twee ellen hoogte, hadden korte stammen en zeer ijle kroonen met aan de einden bebladerde takken en kleine lieht rozen-roode bloemen. Of de struiken waren hooger en meer boomvormig. In het laatste geval waren de kroonen hoog genoeg boven den grond om er onder door te gaan, doch niet digt genoeg om als schaduw tegen de zonnestralen te dienen. Evenwel was, niettegenstaande de broosheid der takken en der bladen, de wandeling, zoowel tusschen de kleine als grootere gewassen, moeijelijk; omdat de eerste, door hunne digte, opeengehoople groeiwijze, en de laatste, door de rankvornende Gleiehenia als doorecngeweven of gevloehten waren. Door het voortdurende gebruik van het kapmes baanden wij ons eenen weg tusschen deze struiken, waar eene warmte van $86^{\circ}$ was, tot aan het, uit groote boomen bestaande bosch. Hier heerschte, onder eene grootere verscheidenheid van vormen, eene gewenschte schaduw. Vooral groeiden er eenige Laurineae, doch noch Sehima, noch eiken, beiden anders, op Java, ter hoogte van 1600 ellen, zoo gewone boomsoorten. Tegen deze boomen groeiden, tusschen mossen, vooral Hypna en Jungermanniae, Grammitis, Iindsaea en enkele voorwerpen van Pedilonum. Van dezelve hingen vooral sehoone, met witte rozenvormige bloemen voorziene Marumiae en enkele Passiflorae naar beneden. - De stam van de Marumia leverde, bij gebrek Botanica. 
van beken in de nabijheid, aan eenige hier werkende houthakkers, een verfrissehend voeht, hetgeen, door afkapping van den stam, uit denzelven voortvloeide. - Eenige Psychotriae, Cyrtandrae, Axanthides enzv., vormden een struikgewas, hetwelk zoowel door den vorm en groottc der bladen, als door de verscheidenheid van kleur, eene aangename afwisseling onder de boomen opleverde. De beschrevene plantengroei ondergaat, tot op ongeveer 1800 ellen, weinig verandering in soorten. Naarmate men hooger stijgt, wordt de helling minder glooijend, en dragen de boomen, in derzelver hoekig gebogene takken, de bewijzen, dat hun wasdom onderdrukt wordt. Terwijl op eene hoogte van 1700 ellen de gemelde Rubiaceae en Cyrtandrae hoofdgewassen zijn, en hier en daar eene boomvormige Chnoophora verspreid is, wordt deze vorm, op 1900 ellen, hoofdgewas. Van deze hoogte af aan blijft hij dit, en op 2100 ellen, waar de andere boomen grootendeels verdwijnen of, ten gevolge van den verglaasden grond, struikvormig worden, groeit deze nog zeer welig. Aan deze grens, daar wij toeh later den berg zouden bestijgen, eindigde onze wandeling. Wij hebben op dezelve bijna geene dieren gezien, noeh gehoord. De stilte werd alleen door het geluid van het houtkappen en, nu en dan, op 1600 ellen hoogte, door dat van eenen koekoek: ğ̌ - gö $-g \overline{o e} k$, afgebroken."

\section{SAURAUJA EXGAVATA. Kus.}

S. ramulis squamatis, foliis oblongo-obovalibus acutis mucronulatis hasi obtusis scrrulatis supra glabris subtus sparsim squamulatis, pedunculis corymbosis, calycibus squamulatis basi cxcavatis.

Arbuscula 2-4 metrorum; rami patentes, angulati, glabri, cinerei; ratiuli angulati vel compressi, squamati, squamis ovatis, subulato-acuminatis. Folis oblongo-obovata, aeuta, basi obtusa vel obtusiuscula, serrulata, raro apice serrata, supra glabra, subtus in nervis sparsim squamulatis, squamulis saepe setiformibus, - adultiora utrinque glabra, - eoriacea, 0,065 lata, 0,17 longa; petiour trigoni, supra plani, squamati, 0,02 longi. Inflorescentis corymbosa; pedunculus comiunis axillaris, subcompressus, squamulatus, pubesecns; PEDUnculi PARTIALES alterni, uniflori, subcompressi, squamulati, fuseo-pubescentes. Bracteas ovatae vel oblongae, acutae, basi cordatae, glabriuseulae. Calyx gamosepalus, fruetifer basi excavatus, sparsim squamulatus, intus glaber; SEPALA quinque, erecta, subaequalia: tria ovata, obtusiuseula; duo oblonga, obtusa, subcoriacea. Strul quatuor ad sex, liberi, filiformes, glabri; sтigmata punctiformia. Fructus immaturus hemisphaericus, quinquesuleatus, depressus, dense fuseo-leprosus, quinqueloeularis, dissepimentis membranaceis. SEnIrra numerosa, in mucilagine gelatinoso inmersa, angulata, ventro plana, dorso et lateribus rotundata; тESTA foveolata, badia, crustaeea; chaldza hilo subopposita; raphe testae adnata; tegmen membranaeum. Embryo in medio albuminis carnosi, cylindricus, saepe curvatus; RADICULA obtusa; corruEdones subaequales, obtusae.

Crescit in summo montis Sakoembang: Borneo. 


\section{SAURAUJA LEPROSA. Khs.}

S. ramulis squamulatis, foliis ovali-oblongis acuminatis basi obtusiusculis vel angustatis crenulatis supra glabris subtus leprosis, floribus axillaribus corymbosis, calycibus squamulatis et leprosis.

Arbuscula ; RanI in angulis $45^{\circ}$ patentes, teretes, sparsim squamulati, cinerco-fusci; RAMULI compressi, saepe sulcati, squamulati. Folis alterna, ovali-oblonga, raro ovata, acuminata vel acuta, mucronulata, basi angustata aut obtusiuscula, crenulata, supra glabra, subtus pube et squamulis minutis leprosa, 0,21 longa, 0,06 lata, coriacea, nervis primariis in angulis $45^{\circ}$; nervis secundarïs subparallelis, distantibus; fetroli subteretes, supra sulcati, squamulati, 0,03 longi. Foores corymbosi, raro solitarii; pedunculus conirunis et pedurculi partiales subteretes, dense squamulati; Bracteae alternae,

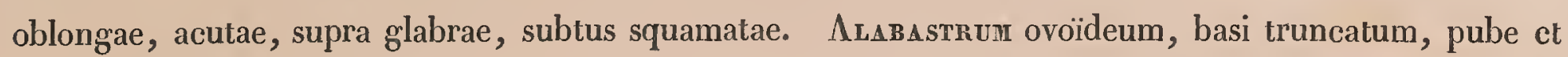
squamulis rufis vestitum. GaLrX pentasepalus, aestivatione quincunciali; SEPALA recta, inaequalia, rotundato-ovata, acuta vel obtusissima, intus glabra, extus squamulis et pube leprosa munita, - interiora saepe glabra, - nervis a basi ad marginem procurrentibus, flabellatis. ConoLla pentapetala, subcampanulata, aestivatione convolutâ; PETAL basi connata, obovata, biloba, lobis inaequalibus obtusis, glabra, membranacea, laete rosea, 0,006 longa, 0,004 lata. Stamina 25; fínameivia basi connata inter se et cum corolla, linearia, glabra; AnTHerse supra medium affixae, lineares, apicc subbilobae. Ovariun subovoïdeum, apice truncatum, dense pilosum, quadri- vel quinquelocularis; PLaceivae oblongae, curvatae, subtrigonae, ab apice axeos loculi pendulae; ovura numerosa, placentas ubique tegentia. Struus basi subpentagonus, supra basin quinquepartitus, glaber; stigista punctiformia. Frucrus immaturus calyce excreto cinctus, stylo excreto munitus, subpentagonus, depressus, fuscohirsutus, quadri- vel quinquelocularis, dissepimentis subcoriaceis. Senrrs numerosa, affixa placentis semiovöideis, - intus planis, extus rotundatis, ope stipitis brevis cum axi loculi connatis, - mucilagine eincta, hemisphaerica vel angulata; тEsT crustacea, fusca, foveolata, foveolis saepe hexangularibus; TEgirer membranaceum. Enbryo et aLbuner similes Sauraujae excavatae.

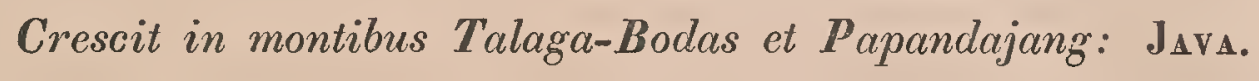

In de omstreken der kraters van den Talaga-Bodas en den Papandajang groeit dezc soort met een gering verschil van vorm. De voorwerpen van den Talaga-Bodas hebben bladen met langere stelen, dikwerf van ecne omgekeerd-civormige gedaante. Behalve dezen afwijkenden bladvorm, welke aan de voorwerpen een geheel eigenaardig aanzien geeft, bestaat er geen verschil. De haarbekleeding is uit priemvormige, aan den voet verbreede schubben en uit gewone harcn, die soms tot sterretjes vereenigd zijn, zamengesteld.

\section{SAURAUJA DISTASOSA. KHs.}

S. ramulis squamulatis, foliis oblongo-obovalibus breviter acuminatis subtus sparsim leprosis, floribus corymbosis, calycibus basi rotundatis squamulatis.

\section{Crescit in monte Probakti: $\mathbf{J}_{\mathbf{A V} \mathbf{A}}$.}

Deze soort gelijkt door haar uiterlijk aanzien op S. bracteosa, S. vulcani en S. pendula. Van de laatste verschilt zij door de bekleeding, welke S. pendula geheel mist. Van de beide cersten kan zij onder- 
scheiden worden door de bekleeding der versehillende deelen, en door andere kenmerken van vorm en grootte, welke aan eenige deelen eigen zijn. Bij de $\mathbf{S}$. bracteosa is de bekleeding over de gansche plant digter, zijn de bloemen bijna even groot en de schutblaadjes dikwerf tot blaadjes uitgegroeid. Bij S. vulcani eindigen de schubben in priemen, zijn de bladen korter gesteeld, de bloemen kleiner en, als knop, door ecne bruine haarbekleeding bedekt. Voor het overige bezit deze soort, bij een nader onderzoek, in de bloem- en vruehtdeelen eene opmerkelijke gelijkheid met deze deelen van S. bracteosa.

\section{SAURAUJA FEROX. KHs.}

S. ramulis densc setosis et squamulatis, foliis oblongo-ovalibus acuminatis serratis supra ct subtus setigeris, floribus subcorymbosis, calycibus setosis.

Arbuscula 3-7 metrorum, coronâ aperta; Truncus cylindricus, cinereus; RA III teretes vel tetragoni, squamulis oblongis, acuminatis, saepe denticulatis et setis laete fuscis vestiti; RaMuLI compressi, setosi. Foura oblongo-ovalia vel oblongo-obovalia, acuminata, saepe acuta, basi obtusa, serrata, serraturis subulatis, supra sparsim subtus praesertim in nervis dense setosa, coriacea, 0,18 longa, 0,06 lata, nervis primariis in angulo $45^{\circ}$, nervis secundariis parallelis, approximatis; PETIoLI teretes, supra sulcati, dense setosi, 0,02 longi. Inflorescentia axillaris, subcorymbosa; Pedunculus connimis et Pedunculi partiales subcompressi, setosi. Bracteae alternae, approximatae, oblongae vel lanceolatae, setosae. Alabastrum rotundato-ovoïdeum, dense setosum. Calyx pentasepalus, aestivatione subimbricatâ; SEPALA subaequalia, ovata, acutiuscula, intus glabra: tria extus in totâ superficie, duo in medio setosa. Corolla pentapetala, aestivatione convolutâ; PETALA basi connata, obovata, apice profunde emarginata vel biloba, integerrima, glabra, nervis a basi sejunctis. Stanira 15-20, basi connata; fitaлienta filiformia, attenuata, glabra; antherae in medio affixae, lineari-oblongae. Ovarium hemisphaericum, tri- vel quadrisuleatum, glabrum, tri- vel quadriloculare; ovula numerosa; placentae ope stipitis carnosi axis loculi affixae, hemisphaericae, apice emarginatae, ovulis tectae. Sryur 3 vel 4, liberi, filiformes, glabri; stigrista capitellata. Cipsula sphaeroïdea, sulcata, glabra, loculicida, tri- vel quadrivalvis; valdvede ad duas tertias dehiscentes. SEMrna multa, areolis placentarum hemisphaericarum affixa, oblonga, tetra- vel pentagona; теSTA fusca, foveolata, crustacea; RAPHE testae adnata; CHALAZA hilo opposita; tegnex membranaceum, tenue. Albunen carnosum, album. Enibryo albumine cinctus, cylindrieus; COTYLEDones chalazae approximatae, subaequales, obtusae; Radicula obtusa.

\section{Crescit in monte Pamatton, prope riam Arinawe: BorNeo.}

Tab. 30. Figura Sauraujae ferocis. 1. Flos cxpansus. 2. Flos, calyce ablato. 3. Petalum unicum cum staminibus oppositis. 4. Filamentum a latcre et 5 . ab anteriore visurn. 6. Filamcntum adultius postice et 7 . lateraliter visum. 8. Antherac sectio transversalis. 9. Antherae apex. 10. Ovarium verticaliter scctum. 11. Fructus. 12. Fructus verlicaliter sectus. 13. Fructûs loculus cum placenta denudata. 14. Valvula intus visa. 15. Axis fructûs vcrticaliter seeta cum plaeenta integra. $16 \mathrm{ct} \mathrm{17.} \mathrm{Semina} \mathrm{immatura.} \mathrm{18.} \mathrm{Semen} \mathrm{admodum} \mathrm{auctum.} \mathrm{19.} \mathrm{Semen}$ vcrticaliter scetum. 20. Embryo nudus eum parte saeeuli embryonis ad extremitatem radieulae. 


\section{SAURAUJA SETIGERA. Khs}

S. ramulis setosis et squamatis, foliis obovatis acuminatis basi obtusis vel emarginatis supra sparsim subtus dense setosis, floribus axillaribus geminatis, calycibus dense setosis.

Arbuscula 5-7 metrorum; rami patentes, teretes, rimosi, glabri, cinerei; Ramuli subteretes, vestiti squamis ovatis, cuspidatis et setis subuliformibus. Foura obovata vel oblongo-obovata, breviter acuminata, basi saepe inaequalia obtusa vel emarginata, margine setigera, setis subuliformibus, supra sparsim setosa, subtus dense setosa et hirsuta, coriacea, 0,2 longa, 0,09 lata, nervis primariis in angulo $40^{\circ}$, nervis secundariis sigmoïdeis, parallelis, approximatis; petroli subteretes, setosi, 0,03 longi. Ftores axillares; pedunculi biflori, subteretes, dense setosi; bracteae oblongae, acutiusculae, setosae. Calrx pentasepalus, aestivatione subimbricatâ; SEPALA inaequalia: tria rotundato-ovata, acuta, intus glabra, extus dense setosa; duo spathulata, obtusa, glabra, petaloïlea. Corolda pentapetala, rotata, aestivatione convolutâ; PETALA basi connata, subaequalia, late obovata, apice bi- vel triloba, lobis inaequalibus, glabra. Staniru 20-25, uniserialia; FILANIENTa basi connata, filiformia, glabra; aNTHERaE infra medium aflixae, lineari-oblongae, rimis apicalibus dehiscentes. Ovariur semi-ovö̈deum, apice subtruncatum, glabrum, quinqueloculare; ovula numerosa, tegentia placentas in axi loculi subséssiles et semi-ovö̈deas; styur $\mathbf{5}$; stignata capitata. Fructus capsularis, sphaeroïdeus, depressus, glaber, quinquelocularis, loculis polyspermis. Sewrinur forma et structura similes Sauraujae ferocis.

Crescit in sylvis Mlintang: Sumatra.

\section{SAURAUJA TEWENSIS. · Krs.}

S. ramulis strigosis squamulatis, foliis obovatis acuminatis basi cuneatis serrulatis supra glabriusculis subtus sctosis, pedunculis axillaribus unifloris, calycibus strigoso-squamulatis.

Arbusqula; rasi teretes, fusci, sparsim squamulati; ramuli compressi, squamulis lanceolatis, cuspidatis vestiti. Folis obovata, saepe oblongo-obovata, breviter acuminata, basi cuneata raro obtusiuscula, serrulata, supra in nervo medio setosa, subtus squamulata et setosa, setis brevibus appressis, coriacea, 0,09 longa, 3,5 lata, nervis primariis distantibus in angulo $45^{\circ}$, nervis secundariis approximatis, fere rectis, subparallelis; PETIOLI semiteretes, squamulati, 0,015 longi. Ftores axillares, geminati vel solitarii; Pedunculi compressi, squamulati; bracteas minutae, oblongae vel penicilliformes. AlabasTRUri subglobosum, squamulatum. CaLrX pentasepalus, aestivatione quincunciali; sEPALA biformia (tria majora, subrotunda, acutiuscula; duo minora, ovato-oblonga), intus glabra, extus squamulata. Corollı pentapetala, subcampanulata, aestivatione convolutâ; PETALA obovata, profunde emarginata, integerrima, glabra. STAMina multa, basi connata et corollae adnata; fILAJIENTa linearia, glabra, brevia; antherae in medio affixae, oblongae. Ovariuni sphaeroïdeum, quadri- vel quinquesulcatum, truncatum, glabrum, quadri- ad quinqueloculare; ovula numerosa, affixa placentis subsessilibus, trigonis, dorso rotundatis et lateribus planis; strui 4-5; stigriata capitellata. Capsula sphaerö̈dea, 4-5 sulcata, glabra, loculicida, $4-5$ valvis; vatudua ad medium usque dehiscentes. Senirumi numerus, forma et structura similes Sauraujae ferocis.

Crescit ad flumen Tewe: Bonveo. 


\section{SAURAUJA REINWARDTIANA. BL.}

S. ramulis tubereulatis et squamulatis, foliis oblongis aeuminatis basi obtusiuseulis obsolete serrulatis glabriuseulis, peduneulis corymbiferis saepe trifloris, ealyeibus breviter setosis, sepalis exterioribus late rotundatis.

Blume, Bijdragen tot de Flora van Neêrl. Indië, bl. 126.

Crescit in sylvis montium Wajang, patoeha, etc.: $\mathbf{J}_{\mathbf{A v A} .}$

In de bossehen, welke de bergen van het westelijk gedeelte van Java bedekken, is deze soort, tot op eene hoogte van ongeveer 1500 ellen, vrij algemeen. Bij andere kenmerken, kan het digt bij elkander staan der tussehennerven ter onderseheiding dienen, hetwelk insgelijks aan S. Tewensis eigen is.

\section{SAURAUJA SAKOEMIBANGENSIS. KHS.}

S. ramulis leprosis et squamulatis, foliis oblongo-ovalibus aeuminatis utrinque setosis, floribus subeorymbosis, calyeibus breviter setosis, sepalis exterioribus ovatis.

Arbuscula; ramr glabriuseuli, einerei; ramiur eompressi, subsuleati, fuseo-leprosi, squamulati, squamulis laneeolatis, subulatis. Folıs oblongo-ovalia, breviter aeuminata, basi inaequilatera et obtusa, subintegerrima, supra et subtus setosa, 0,13 longa, 0,055 lata, nervis primariis in angulo $45^{\circ}$, nervis seeundariis subparallelis, distantibus; petrour 0,01 longi, semi-teretes, dense hirsuti. Flores subeorymbosi. Bractrane oblongae, utrinque setosae. Pedurculr compressi, dense setosi. Calry pentasepalus, aestivatione imbricatâ; SEPALA inaequalia: tria exteriora majora, ovata, obtusiuseula, intus glabra, extus setosa; duo interiora minora, ovato-oblonga, intus glabra, extus in medio eum stria setarum. CoRouLA pentapetala, aestivatione convolutâ; PETALA floris nondum explieatae basi sublibera, obovata, biloba, glabra. Stamina 20, biserialia alternantia, in serie posteriore majora; antherae oblongae. Ovarium hemisphaerieum, glabrum, quinqueloeulare; ovuLs numerosa; sTYu quinque, lineares; sTigmata eapitellata.

Crescit in monte Sakoembang: BoRneo.

\section{SAURAUJA SINGALANGENSIS. KHs.}

S. ramulis tuberculatis et squamulatis, foliis obovato-oblongis aeuminatis utrinque setosis, floribus subeorymbosis, calyeibus longe setosis, sepalis exterioribus ovatis.

\section{Crescit in sylvis Singalang: Sumatra.}

Deze soort en de S. Sakoembangensis zijn zeer na verwant aan de S. Reinwardtiana. Zij zijn door de haar eigene haarbekleeding van de laatste te onderseheiden. Van elkander versehillen zij door de ontwikkeling dezer haarbekleeding, welke bij de S. Sakoembangensis veel aanzienlijker is, dan bij de S. Singalangensis. 


\section{PLOIARIUM. KHS。}

CALYX pentasepalus, aestivatione imbricatâ. Corolla pentapetala, aestivatione convolutâ, petalis subbilobis. Stamina numerosa; filanenta pentadelpha, apicem versus libera; antherae cordiformes, rimis longitudinalibus dehiscentes. Ovarrus ovoïdeum, quinquesulcatum, quinqueloculare; ovura numerosa, affixa placentis subcylindricis. Strut quinque; stigirata capitellata. Gapsula quinquesulcata, septicida, valvulis cymbiformibus a basi dehiscentibus. Semiva numerosa, multiserialia, adscendentia, linearia, apice et basi membranacea; TESTA membranacea; TEGHEN membranaceum, sinuatocostatum. Albunien carnosum. Eirbryo rectus, cylindricus, utrinque obtusus.

Arbores. Folis alterna, versus apicem ramulorum approximata, coriacca. Pedurculi axillares, uniflori.

Ilet geslacht Ploiarium vertegenwoordigt, in den Indischen Archipel, de in Amerika voorkomende geslachten Bonnetia, Archytaea en Mahurea. Bonnetia verschilt van hetzelve door de niet zamengegroeide helmdraden, in de wijze van openspringen der helmknopjes door poren aan den voet, en door de driekleppige vrucht; Mahurea heeft in de mindere zamengroeijing der helmdraden, in den van boven schotelvormig verwijden helmknoop, en in de hangende eitjes, eigene kcnmerken; Arehytaea is te onderscheiden door den niet wegvallenden kelk, door den enkelvoudigen stijl en door de plaatsing der eitjes in twee rijen. - De naam, aan dit geslacht gegeven, doclt op den vorm van de kleppen der kapsels, die naar eene kleine kano gelijken.

\section{PLOIARIUM ELEGANS. KHs.}

P. foliis alternis oblongis, floribus axillaribus solitariis.

Arвов 6-8 metrorum; truncus rectus, cylindricus, cortice cinereo tectus; conons rotundata vel pyramidalis; RAMI patentes vel diffusi, subteretes, cicatrisati, glabri, cinerei; RAMuLI compressi, saepc angulati, glabri, rubri. Gemise teretes, acutae vel acuminatac, glabrae, involutae, partibus junioribus involutis. Folia versus apicem ramorum conferta, alterna, oblonga vel obovato-oblonga, acuta, basi truncata vel subcordata, margine recurva et rubra, basi integcrima, apice serrulata, utrinque glabra, coriacea, 0,095 longa, 0,025 lata, nervo medio costatim prominente rubro; PETroLI compressi, glabri, brevissimi. Flores axillares, solitarii, longe pedunculati; pedunculr compressi, sacpe ancipites, versus apicem subteretes, bibracteati, glabri, rubri. Bracteas oblongae, acutac, apice serrulatae. CALYX pentasepalus, campanulatus, deciduus, aestivatione imbricatâ; SEPALA subaequalia, rotundatoovata, acuta vel emarginata, saepe crenulata, utrinque glabra, coriacea, rubro-marginata. ConoLLA pentapetala, aestivatione convolutâ; PETALA unguiculata, obliqua, obovata, apice emarginata, crenulata, basi integerrima, glabra, subcoriacea. Stamira numerosa; firamenta pentadelpha (fasciculi petalis oppositi et glandulis pyramidalibus et acutis alternantes; parte concreta oblonga, partibus liberis filiformibus), glabra; anTherae basi affixae, cordiformes, emarginatae, biloculares, rimis longitudinalibus dehiscentes. Ovariunr oblongo-ovoïdeum, quinquesulcatum, glabrum, quinqueloculare; ovdus numerosa, 
linearia, inserta placentis subteretibus, axi loculi affixis. STru 5, subteretes, glabri; strgmata truncata. Gapsulı oblongo-ovö̈lea, attenuata, quinqueloba, glabra, lignea, septicida, quinquevalvis; vaLVULaE a basi dehiscentes, navicellatae, endocarpio crustaceo, apice columnae pentagonae affixac. Senima numerosa, multiserialia, adscendentia, linearia vel oblonga, glabra, minuta, apice et basi cum

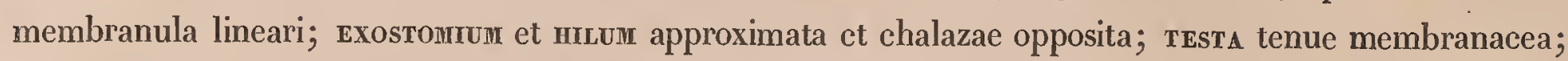
raprie simplex, testae adnata; tegmen membranaceum, costis longitudinalibus undulatis. AtrbuneN periphericum. Enвryo centralis, erectus, fere rectus, cylindricus, utrinque obtusus.

\section{Crescit juxta Pocloe-lampei: Borneo.}

Tab. 25. Figura spccici. 1. Alabastrum. 2. Flos. 3. Petalum. 4. Bractea. 5. Staminum fasciculus. 6. Staminis pars libcra. 7. Ovarium, integumentis floralibus et stamiuibus ablatis. 8. Ovarii transversalis sectio. 9. Fructus. 10. Capsula dehisccns. 11. Capsula, valvulâ unâ ablatâ. 12. Valvula intus visa. 13. Capsula verticalitcr secta. 14. Columnae et valvulae scetio transvcrsalis. 15. Placenta cum seminibus. 16. Semina aucta. 17. Semen immaturum cum sacculo embryonis. 18. Nucleus immaturus. 19, 20, 21. Semina valde ancta. 22. Scmen disscctum cum parte testac, raphe libcra, tegminis dimidia partc et tegumento nuclci. 23. Nuclci tegumcntum cum massis granulatis rotundalis. 24. Tegminis pars admodum aucta. 25. Nucleus verticaliter sectus.

L A PL A C E A. Kunth, Cambessènes, etc.

\section{LAPLACEA VULCANICA. Khs.}

L. foliis ovalibus obtusis vel cmarginatis integcrrimis.

ARbuscula 2-4 metrorum, diffusa; Truvaus brevis, angulatus, nigrescens; RAMr subpatentes, trigoni vel tetragoni, rimosi, cicatrisati, glabri; Ramul trigoni, subcompressi, cinereo-leprosi. GenmaE conicae, obtusiusculae, sericeae, foliis amplectentibus teretibus, folio exteriore involvente axi opposito. Folia versus apices ramorum conferta, patentia, ovalia vel ovata, basi obtusa, apice obtusiuscula vel emarginata, integerrima, utrinque glabra, erasso-coriacea, nervis supra cxsculptis, 0,06 longa, 0,04 lata; petroci semi-teretes, glabri, 0,004 longi. Flores axillares, solitarii; Pedurculi breves, teretes, pubescentes; bracteas duae, suboppositae, calyci approximatae, ovatae, acutiusculae, extus sericeae. Alabastruni ovoïdeum, obtusiusculum, sericeum. Galyx pentasepalus, aestivatione imbricatâ. Sepata inaequalia, duo petaloïdea, subrotunda, obtusissima, integerrima, saepe irregulariter fissa, intus glabra, extus sericea. Corolda pentapetala, aestivatione subconvolutâ; PetaLA inaequalia, breviter unguiculata, rotundata, obtusissima vel emarginata, glabra. Stamira numerosa; rilanerta biserialia, monadelpha vel pentadelpha, corollae adnata, lineari-oblonga, attenuata, glabra; АNTHERAE in medio affixae, vacillantes, ovatae, utrinque emarginatae, biloculares, rimis longitudinalibus dehiscentes. Ovariur ovoïdeum, quinquesulcatum, dense sericeum, quinqueloculare; ovula 4-6 in singulo loculo, axi loculi affixa, descendentia. Stxui 5, breves, subconnati; stigmata 5 , obtusiuscula. Capsula obovöidea, subtruncata, pentagona, dense pubescens, quinquelocularis, loculicida; valvuraE primum in medio, 
deinde ab apice ad basin usque disjunctae, oblongae, intus septigerae el glabrac, extus suleatac ct pubescentes; colvmella pentagona. Semriva 3-5, descendentia, in medio alfixa, compressa, oblonga, utrinque obtusa, apice in alam expansa; unBrurcus supra exostomium positus; твSTA apice cxpansa, subcoriacea; RAPHE in dorso seminis ad chalazam umbilico oppositam, inter ccllulas mesospermii procurrens; tegher membranaceum. Albumer paululum. Embryo albus, erectus; cotruedones subrotundae, obtusac, basi subcordatae, planae; Radrcula teres, obtusiuscula.

\section{Crescit in summo montis Merapi: Sumatra.}

Tab. 26. Figura Laplaceac vuleanieat. 1 et 2. Alabastrum. 3. Flos, calyee ablato. 4 et 5. Petala. 6. Staminum pars extus, et 7. intus visa. 8. Stamen. 9. Anthera antice et 10. postice visa. 11. Ovarium et stamina. 12. Ovarium longitudinaliter scetum. 13. Ovarii seetio transversalis. 14. Ovarium adultius longitudinaliter sectum. 15. Fructus. 16. Fructus, valvis duabis abscissis. 17. Fruetûs pars transversaliter seeti, valvâ unâ ablata. 18. Valvula intus visa. 19. Columella a partibus eircumpositis denudata. 20, 21, 22. Semina. 23. Semen, parte testae abscissâ. 24. Seminis pars, a. mieropyle, b. umbilieus. 25. Seminis transversalis seetio. 26. Seminis immaturi pars, cousistens: e mesospermio cellulari, parto raphis, tegmine et embryone. 27. Seminis immaturi pars. 28. Embryo.

\section{ANTHE ËISGIIMA. KHS.}

Gordoniae species. BuUme, etc.

Calrx trisepalus vel profunde tripartitus, aestivationc imbricatâ, sepalis basi connatis. Conouta hexapetala, aestivatione imbricatâ, petalis subaequalibus. Stanrrixa numerosa, multiserialia; filıлrenta basi inter se et petalis adnata; anthera dorso affixae, vacillantes, longitudinaliter dehiscentes. Ovariun quinqueloculare; ovurs $3-7$ in singulo loculo, descendentia; strues simplex; stigms capitatum. CA psula lignosa, oblonga, pentagona, quinquelocularis, loculicida, valvulis ad medium longitudinis usque dehiscentibus, circum columellam dispositis. Semrna 3-5, vertice alata, basi alae affixa columellae angulatac; resta vertice seminis chartacea et basi ejusdem lignosa; TEGMEN membranaceum.

Arbores. Foulı alterna, ovali-oblonga, coriacea. Flores axillares, solitarii.

De gewassen, uit welke de geslachten Antheëischima cn Closaschima gevormd zijn, warcn vrocger onder den geslachtsnaam Gordonia beschreven en afgebeeld. Eene nadere vergelijking met voorwerpen van de Amerikaansche grondsoort heeft mij echter doen zien, dat deze verecniging van Indische cn Amerikaansche gewassen kan worden gesplitst, en heeft mij tot het voorstellen van twee verschillende geslachten voor de Indische soorten van Gordonia doen overgaan. Het eerstgenoemd geslacht, Antheëischima, heeft de kelkbladen, even als Gordonia, in eenen krans staande, doch bezit er slechts drie. De bloemkroon bestaat bij hetzelve uit zes, bij Gordonia uit vijf bloembladen. De stuifdraden zijn, bij het laatste geslacht, gehcel vrij of in vijf bundels verbonden; bij Antheëischima, aan den voet met elkander in eenen ring en met de bloembladen zamengegroeid. De overige blocmdeelen en de vruchten der warc soorten 
van Gordonia, heb ik niet onderzocht; doch, naar de besehrijving oordeelende, versehillen zij van die der Indische gewassen. Het aanzien der voorwerpen van Antheëisehima en van Gordonia verschilt weinig; dat der gewassen, welke ik onder den geslaehtsnaam Closaschima heb vereenigd, is geheel anders, door de meer struikaardige groeiwijze en door de mindere ontwikkeling der bladen en bloemen; bovendien verschilt Closaschima van Antheëisehima door eenige kenmerken der bloem: de eerste heeft vijf, soms, door de vergrooting van een der schutblaadjes, schijnbaar zes kelkbladen en vijf bloembladen, spiraalsgewijze geplaatst, en vijf stempels, welke bijna zonder stijlen zijn.

De gewassen van het geslacht Antheëischima behooren onder de fraaiste boomen, welke op Java, tussehen eene hoogte van 1500 tot $2000 \mathrm{~N}$. ellen worden gevonden. Hunne stammen zijn dikwerf tot op cene lengte van 15 tot $20 \mathrm{~N}$. ellen ongedeeld, doch verdeelen zich op die hoogte in bogtige takken en takjes, aan wier einden de bladen en bloemen geplaatst zijn. Door deze groeiwijze ontstaat eene zeer digte bladkroon, door welke de zonnestralen naauwelijks henendringen. Deze, alsmede de talrijke menigte bloemen, die hare oppervlakte versieren, deed mij den naam kiezen, dien ik heb voorgesteld. Bij de Sundanezen heeten deze boomen Kimangal, hetwelk boom van geluk beteekent.

\section{ANTHEËISGHIMA EXCELSA.}

\section{Gordonia excelsa. Bu.}

A. ramulis sericeo-pilosis, foliis ovali-oblongis serratis vel scrrulatis, scpalis inacqualibus, petalis late rotundatis unguiculatis.

Blume, Bijdr. tot de Flora van Neêrl. Indië, bl. 130.

Arbor speciosa; truncus reetus, subeylindricus; Contex crassus rimatus, fuscus; Lignum rubicundum, fibris tenuibus; conona semi-ovata vel hemisphaerica, dense foliosa; rami patentes vel diffusi, teretes, cinerei, epidermide saepe rimis transversalibus solutâ et ad lamellas reductâ; Ramuli alterni, teretes vel subteretes, dense serieeo-pilosi. Folra ovali-oblonga, acutiuscula, saepe emarginata, raro obtusissima, basi cuneata, serrata vel serrulata, utrinque glabrata, - juniora in et prope nervo medio in pagina inferiore pubescentia, - coriacea, 0,12 longa, 0,045 lata, nervis primariis approximatis. Genina subteretes, acuminatae, dense sericeo-pilosae, foliis equitantibus et conduplicatis. Frores axillares, solitarii, speciosi; pedunculi subteretes, dense sericei, breves. Auabastrum globosum, dense sericeum. CALYX trisepalus, deciduus, aestivatione quincunciali; SEPALA inaequalia, rotundata, obtusissima, crenulata, intus glabra, extus sericeo-pubescentia, coriaeea. Conoux rosacea, hexapetala, aestivatione imbricatâ; peTıLı breviter unguiculata, late rotundata, emarginata vel excisa, basi cuneata, extus sericea, intus glabra, basi pubeseentia, subearnosa, margine membranacea, 0,025 longa, 0,02 lata. Stamiva numerosa, pluri-serialia; filamenta monadelpha, subulata, glabra; antherae dorso affixae, vacillantes, ovatae vel oblongae, utrinque obtusae vel emarginatae, longitudinaliter dehiscentes. Poulew sphaericum. Ovaritur subglobosum, dense sericeo-pubescens, quinqueloculare; ovula $3-7$ in singulo loculo, biserialia, alterna, descendentia, angulo interno loeuli affixa, oblonga, compressa; struus pentagonus, quinquesulcatus, basi pubeseens; stigra quinquelobatum, lobis obtusis. Capsuca oblongo- 
ovoïdea, pentagona, acuta, pubescens, quinquelocularis, loculida; valvulaE ab apice ad medium sejunctae, oblongae, septigerae, trigonae, dorso excavatae vel planac, lateribus planis infra medium excavatis, apice ancipites, infra apicem truncatae, endocarpio nitido fusco; colvnella quinquangulata. Senira 3-5, in medio affixa, imbricata, oblonga, vertice obtusa, basi obliqua obtusiuscula, apicc in alam chartaccam expansa, glabra, fusco nitida; HILU lineare, supra micropylam punctiformem positum; TESTAE pars nucleum involvens lignoso-coriacea, pars alaeformis chartacca; RAPHE in dorso seminis ad chalazam hilo oppositam procurrens; MEsospermidn cellulosum; TEGMEN membranaceum. NucLeus ovö̈deus; RUDmentum embryonis chalazae approximatum.

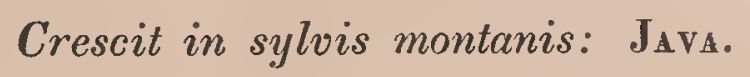

Tab. 27. 1, 2. Alabastrum. 3. Flos expansus. 4. Petalum cum staminibus. 5. Stamen admodum auctum postice visum. 6. Antherac pars admodum auctum ad indicandum structuram endothecii. 7. Ovarium, integumentis floralibus et staminibus ablatis. 8. Ovarium verticalitcr sectum. 9. Capsula dehiscens. 10. Capsula, duabus valvulis_ablatis. 11 et 12 . Semina. ' 13 et 14. Semina immatura dissecta: $b$. hilum; $c$. chalaza. 15. Tegmen, cum sacco embryonis. 16. Semen immaturum admodum auctum: $\boldsymbol{a}$. funiculus umbilicalis et placenta; $b$. hilum; $c$. micropyla; $d$. raphc; $e$. testa; $f$. mesospermium; $g$. tegmen; $h$. nucleus; $i$. saccus embryonis. 17. Seminis pars, mcmbranis explicatis. 18. Saccus embryonis valde auctus. 19. Raphe seminis junior. 20. Raphe seminis adultioris.

\section{CLOSASCHIMA. KHs.}

Gordoniae spec. Kus.

GaLrx bibracteatus, pentasepalus, aestivatione imbricatâ, sepalis spiraliter dispositis. Corolla pentapetala, aestivatione subimbricatâ. Stanira numerosa; filanignta monadelpha, inter se et cum corolla connata; antuerae dorso affixae, vacillantes, longitudinaliter dehiscentes. Ovariunr quinqucloculare; ovula 2-6 in singulo loculo, descendentia; strur 5, breves; stignata 5. Capsula lignosa, oblonga, pentagona, quinquelocularis, loculicida, valvulis fere ad basin usque dehiscentibus, circum columellam pentagonam dispositis. Senrrra 2-5, vertice alata, basi partis expansi et alaeformis testae affixa; TEGNer membranaceum. Enrbryo in albumine tenui, erectus, rectus, radiculà terete, cotyledonibus planis.

Arbores. Folis alterna, oblonga, coriacea. Flores axillares, solitarii.

Uit de vroegere ophelderingen, bij Antheëischima gegeven, en uit de bovenstaande kenmerken, blijkt, dat de kelk en de stijlen de voornaamste middelen ter onderscheiding tusschen dit geslacht en Gordonia zijn, terwijl de groeiwijze een bijkomend middel ter erkenning aanbiedt. Deze laatste hecft mij den naam doen kiezen van Closaschima, omdat de schaduw door de mindere digtheid van de kroon gebroken is. De eene der volgende soorten is op Sumatra, in de bosschen van het gebergte Melintang verzameld; de andere in de lage streken der zuid-oostkust van Borneo, op plaatsen, welke aan de zon zijn blootgesteld. 


\title{
I. CLOSASCHIMA OVALIS, KHs.
}

\author{
Gordoniac spec. Kris.
}

C. ramulis subpubescentibus, foliis oblongo-ovalibus acutiusculis serrulatis, sepalis subaequalibus, petalis obovatis. (Nervi foliorum approximati.)

Arbor 10-15 metrorum; truncus rectus, cortice fusco vel fusco-cinereo; Corona apcrta; ratiI patentes, distantes, teretes, cinerei; ranuli subcompressi, subpubescentes. Gemina lineares, acutae, dense sericeo-pubescentes, foliis conduplicatis et equitantibus. Folis alterna, distantia, oblongo-ovalia, apice acutiuscula vel emarginata, serrulata vel crenulata, basi integerrina, supra glabra, subtus glabrata, - juniora subtus pubescentia, - coriacea, 0,02 lata, 0,07 longa, nervis primariis approximatis; PETIoli in ramis articulati, semiteretes, glabri, 0,002 longi. Flores axillares, solitarii; pedurculi breves, subteretes, pubescentes. BRACTEAE calyci approximatac, sublunares, intus glabrae, extus sericeae, minutae, deciduae. CALYX petasepalus, deciduus, aestivatione imbricatà; SEPALA subaequalia, suborbiculata, obcusa, intus glabra, extus sericea, carnoso-coriacea, 0,005 lata, 0,003 longa. Corouta pentapetala, aestivatione imbricatâ, PETALA inaequalia, obovata, obtusa vel emarginata, sacpe margine undulata, intus glabra, extus in medio paginae sericea, subcarnosa, 0,008 longa, 4-6 lata. Stamiva numerosa 3-4 serialia; FILAMENT basi connata, filiformia, glabra; ANTHERAE dorso affixae, vacillantes, subrotundae, utrinque emarginatac, rimis longitudinalibus dehiscentes. Pollev sphaericum, elevatopunctatum. Ovariur ovoïdeum, apice truncatum, sericeum, quinqueloculare; ovvi $\mathbf{2}-\mathbf{5}$ in singulo loculo, fere in medio loculi angulo interno affixa, biserialia, alterna, sursum imbricantia, compressa; styuus haud manifestus; stigriata 5, acutiuscula, recurva. Capsula oblonga, pentagona, mucronulata, basi rotundata, pubescens, loculicida, quinquelocularis, quinquevalvis; valvulaE fere ad basin usquc disjunctae, septigerae, oblongae, triangulares, lateribus interioribus fusco-nitidis superne planis et inferne excavatis, acie truncatâ, colvnelda seminifera angulata, saepe marginata. Senirs geminata ad quaternata, descendentia, alterna, compressa, dimidiato-oblonga, apice acutiuscula, basi obliqua et acutiuscula, superne in alam chartaceam extensa, glabra; nILvi micropylac approximatum et superpositum; TESTA in parte alari chartacea, in parte nucleum involvente sublignosa; RAPHE in dorso seminis; tegien membranaceum. Albujen tenue, album, periphericum. Embryo erectus; cotyledones ovales, obtusiusculae, planae; RAdiculı teres, acuta.

\section{Crescit in sylvis Melintang: Sumatra.}

Tab. 28. Fig. 1. Alabastrum. 2. Flos expansus. 3. Corolla postice visa. 4. Stamina floris nondum apertae. 5. Stamen postice et 6. antice visum. 7. Ovarium, integumentis floralibus et staminibus ablatis. 8. Ovarium rerticaliter sectum. 9. Capsula, duabus valvulis ablatis. 10. Valvula antice visa. 11. Semen immaturum. 12 et 13. Semina. 74. Semen sectum. 15. Embryo denudatus. 


\section{CLOSASCHIMA MARginata. Kins.}

C. ramuls glabris, foliis oblongo-ovalibus obtusiusculis obsolete scrrulatis, sepalis subaequalibus, petalis subrotundis. (Nervi foliorum distantes.)

Arbor; rami patentes, subteretes, fusei, rimati; Ranuli subeompressi, glabri. Gemina elongatoeonieae, glabrae, foliis equitantibus, apice eonduplieato-involutis. FolI alterna, versus ramulorum apiees eonferta, oblongo-ovalia vel oblongo-obovata, obtusiuseula, saepe emarginata, supra basin integerrimam obsolete serrulata, serraturis distantibus, margine saepe reeurvo rubro, glabra, coriaeea, 0,08 longa, 0,03 lata, nervis primarïs distantibus; petrour semiteretes, glabri, 0,005 longi. Flores axillares, saepe ad ramulorum apiees positi, solitarii; peduncul subteretes, pubescentes, breves. Bracteae ealyei approximatae, lunatae, intus glabrae, extus pubeseentes. Alabastrum subglobosum, dense serieeum. CALYX pentasepalus, persistens, aestivatione imbrieatâ; sEPALA subrotundata, obtusissima, margine saepe irregulariter incisa, intus glabra, extus serieeo-pubeseentia, eoriacea, subaequalia, 0,005 longa et lata. Corolta pentapetala, aestivatione imbricatâ; PETALA subrotunda, obtusa, integerrima, extus pubeseentia. Stamina numerosa, bi- vel triserialiä; FiLAMenta basi eonnata, subteretia, versus apieem subulata, glabra; ANTHERAE versus basin affixac, vaeillantes, ovatae, eordatae, biloculares, rimis longitudinalibus dehiseentes, eonneetivo oblongo, aeuto, basi eordato. Ovaruar oblongo-ovoïdeum, dense serieeum, quinqueloeulare; ovula 4-6 in singulo loeulo, angulo interno loculi affixa, deseendentia, oblonga, eompressa. Stylus pentagonus, quinquesuleatus, serieeus, brevis; sтicmata 5, apieularia. CAspsula oblonga, pentagona, mueronata, basi obtusa vel subtruneata, quinqueloeularis, loeulieida; valvulae fere ad basin usque disjunetae, lineari-oblongae, mueronatae, septigerae, trigonae, dorso eum sinu rotundato, lateribus una parte plana, duabus partibus profunde excavatis; coluneLLA eentralis pentagona. SEmrva 2-4 in singulo loeulo, biserialia, alterna, obovata vel lineari-oblonga, extremitate superiore obtusa et in alam membranaeeam cxpansa, extremitate inferiore acuta vel obliquoobtusa, glabra. Seminvir struetura eadem ae Closasehimae ovatae.

\section{Crescit in monte Tirin et juxta IIIartapoera: BonNeo.}

De voorwerpen van de gemelde plaatsen versehillen van elkander door de grootte der bladen. Aan anderen, te Poeloe-lampei en bij den berg Pamatton verzameld, zijn de jongere takken vierhoekig en, even als de knoppen der bladen, met eene soms vrij digte haarbekleeding voorzien. Voor het overige bestaan er kleine versehillen in den kelk en in de vrueht; doeh zij schijnen mij niet van genoegzaam aanbelang, om deze voorwerpen als eene eigene soort voor te stellen; als verseheidenheid besehouwd, kunnen de laatsten $\mathrm{C}$. dasyopthalma worden genoemd. Bij deze soort zijn de vijf stempels vóór de opening der bloem, op dezelfde wijze als de bloemkroonbladen, over elkander liggende. 


\section{SCHIM A. ReINwaRDT, Blume.}

\section{Gordoniac species. Wallich, De Candolle, etc.}

Galrx pentasepalus, persistens, aestivatione imbrieatâ, sepalis aequalibus. Corouta pentapetala, aestivatione imbricatâ, petalis inaequalibus: unum majus, caetera ante explieationem calyptratim tegens. Stamina numerosa, pluriserialia; filamenta basi inter se et petalis adnata; antherae basi affixae, longitudinaliter dehisecntes. Ovarium quinqueloculare; ovura 2-4 in singulo loeulo, descendentia; stylus quinquesuleatus; sтrgrs quinquelobum. Carsula lignosa, subglobosa, quinqueloeularis, loeulicida, valvulis ad medium longitudinis dehiscentibus, cireum eolumellam dispositis. Senrsa 2-4, in sinu ventris affixa columellae, reniformia; TESTA in alam chartaeeam periphericam expansa; TEGuEN membranaeeum. Albunen tenue. Labryo subplanum, radieulâ in marginem eotyledonum inflexâ, cotyledonibus contiguis subplanis.

Arbores. Folia alterna, coriacea. Flores axillares, foliorum abortu racemosi.

Het geslacht Sehima, in 1820, door den Heer Reinwardt voor door hem op Java gevondene gewassen gevormd, werd in 1825, door den Heer Blume besehreven (Bijdragen tot de Flora van Neèrland sch Indië, bl. 129). Volgens deze beschrijving versehilt het van Gordonia door den vorm van den kelk en door eenige kenmerken der vrucht, welke de vorm, de maat van openspringen der kapsels en het standertje, rondom hetwelk de laatsten geplaatst zijn, vertoonen. Deze kenmerken, door latere sehrijvers (de Heeren Sprengel en Endlicher) van te weinig belang besehouwd zijnde, missehien wel, omdat de zamenstelling van eenige soorten van Gordonia hicrmede overeenkomt, hebben dit geslacht van Gordonia niet afgescheiden kunnen houden. IIet wordt door den Heer Endlicher onder het geslacht Gordonia, in de afdeeling Lasianthus gebragt. Door het geheel versehillende aanzien der planten, mij met deze verbinding niet kunnende vereenigen, heb ik de voorwerpen aan een naauwkeurig onderzoek onderworpen, ten einde voor den indruk, dien de vorm op mij te weeg bragt, kenmerken te vinden, waardoor aan denzelven een wetenschappelijke grond wierde bijgezet. Door dit onderzoek is het mij gelukt, een van de weinige geslachten, die met den naam van den stichter in het stelsel bestaan, als genoegzaam afwijkende te leeren kennen, om hetzelve, zoo als ik vertrouw, met regt, onder den vroegeren naam Schima te herstellen: een' naam, die het eigenaardige van een der bladen der bloemkroon, dat de anderen vóór de opening als eene huif bedekt, zeer juist uitdrukt. Bij dit in het oogvallend versehil van Gordonia, moeten nog eenige kenmerken, die de vrucht en de zaden opleveren, gevoegd worden: de vorm, namelijk, van het standertje, dat het benedenste gedeelte bijna rolrond en het bovenste vijfdeelig, eenigerwijze stervormig heeft; de vorm der kleppen, welke naar beneden eene diepe insnede hebben, en vooral de gedaante en de zamenstelling der zaden. Bij Gordonia zijn de zaden langwerpig, met het bovenste of het eene einde in een' vleugel eindigende; bij Schima hebben zij eene niervormige gedaante, met een vliezig, dikwerf vrij aanzienlijk uitgroeisel, dat het geheele zaad omringt. De raphe omgeeft bij Antheëischima, in haren loop, van den navel naar den binnennavel, die tegenover elkander aan de beide einden van het ligchaam des zaads gelegen zijn, den geheelen rug van hetzelve; 
daarentegen is de raphe bij Sehima kort, loopende met eene kleine bogt, van den navel naar den binnennavel, welke in het bovenste einde van het zaad is. I) kiem van Schima heeft de zaadlobben met zeer ongelijke zijden, soms zelfs alleen de naar binnengerigte ontwikkeld, en het worteltje tegen den rand van het benedenste der zaadlobben teruggebogen; die van Gordonia bestaat uit vrij regelmatig gevormde zaadlobben, en uit cen worteltje, hetwelk met deze in cene regte lijn ligt.

Bij Schima Noronhae, de grondsoort van het geslacht, moeten nog S. (Gordonia D. C.) Wallichii, S. erenata benevens $\mathbf{S}$. antherisosa gevoegd worden.

Schima Wallichii (Gordonia Chilaunea Hamilton, Don Flor. Nepaulensis, pag. 215) groeit in het hooggelegen Nepaul, waar zij eenen naam draagt, die haar als eenen lang bloeijenden en eenen aangenamen geur verspreidenden boom doct kennen. Op de eilanden van den Archipel komen de anderen voor: S. Noronhae op Java, S. crenata op Borneo, en S. antherisosa, zeer verwant aan S. Noronhae, op Sumatra. Sehima erenata werd door ons, op oorden weinig boven het zeevlak gelegen, in het zuid-oostelijk gedeelte van Borneo verzameld; de beide anderen versieren de hoogere bergstreken van Sumatra en Java.

Naar de tijden, waarop wij deze gewassen waargenomen hebben, oordeelende, bloeijen zij het geheele jaar in dezelfde mate. Hunne bladeren verwisselen vooral in den regentijd. De schutblaadjes, welke zeer klein zijn, vallen zeer spoedig af. De kelk neemt na de opening van de bloem weinig in grootte toe; doch blijft tot aan het afvallen der vrucht, onder dezelve, terwijl hij bij Gordonia soms in grootte toeneemt en voor de scheiding der vrucht van de plant dikmaals, wegvalt. Door de zamengroeijing van de bloembladen en de helmdraden vallen deze te zamen af. Bij de kapsels is het openen derzelve opmerkelijk. Dit gaat vergezeld van het ontstaan eener dwarse spleet in de tusschenwanden, welke vermoedelijk de opening bevordert, daar het hierdoor vrij gewordene bovengedeelte van den wand, tegen het standertje drukkende, de verwijdering der kleppen ten gevolge kan hebben.

\section{SCHIMA CRENATA. KHs.}

S. foliis oblongo-ovalibus serrato-crenatis, columclla apice truncata quinquangulari, seminibus oblongo-reniformibus.

Arвor 10-15 metrorum; nRuncus rectus, cylindricus, basi saepe angulatus, angulis expansis in laminas; coRTEx subfuscus, rimatus, sat crassus; LIGNu pallide vel obscure rubicundum, molle; CORONA hemisphaerica, basi truncata, peripheriâ sinuato-undulatâ, intus nuda; RAMI patentes, recti, apice saepe nutantes, teretes, rimati, fusci, glabri; ramuli novelli subeompressi vel compressi, dense pubescentes; adultiores glabrati. Gemrat conicae, dense sericeae, foliis equitantibus et apice conduplicatis intus sericeis. Folia versus apicem ramulorum conferta, alterna, oblongo-ovalia vel obovalia, apiculata, serrato-crenata, supra glabra, subtus pubescentia vel glabrescentia, 0,11 longa, 0,045 lata, coriacea; petroli semiteretes, glabrati, 0,02 longi. Flones axillares, solitarii vel foliorum abortu terminales, raeemosi; PEDUncul subcompressi, pubeseentes vel glabrati; BRACTEARUßI rudimenta squami- 
formia in parte superiore pedunculi. Alabastrum globosum, sericco-pubesecns. Catrx persistens, pentasepalus, patens, aestivatione imbricatâ; sEpıLı uniserialia, aequalia, rotundata, obtusa, extus pubescentia, intus dense sericea. Conolca pentapetala, rosacea, aestivatione imbricatâ, petalis quatuor unico calyptriformi tectis; PETALA inaequalia, uno majore subcalyptrata, subrotunda, integerrima, saepe undulata, intus glabra, extus basi sericea, pallide rosea vel alba. Stanrira numerosa, 3-5 serialia; FILAMENTa basi monadelpha, corollac adnata, subuliformia, glabra; ANTHERAE basi affixae, subdidymae, connectivo ovali, biloculares, loculis rimis longitudinalibus dehiscentibus. Ovarrum hemisphaericum, dense sericeum, 4-5 loculare; ovura 3-4 in singulo loculo, angulo interno loculi aflixa, descendentia, biserialia, alterna, oblonga. STruus subpentagonus, quinquesulcatus, glaber; strGis quinquelobum, lobis obtusis. CÁpsula sphaeroïdea, parte styli persistente mucronata, basi obtusa vel subattenuata, sericea vel glabrescens, quinquelocularis, loculicida, quinquevalvis, lignosa; vaLvulıE septigerae, ad medium usque liberae, oblongo-ovales; DIsSEPMIENTum apice rectum, carinatum, in medio cum sinu obtuso, versus basin cum lobo semiovato acutiusculo et sinu acuto, crassum, fuscum, glabrum; COLUneLLA basi subpentagona, sursum crassior, obconica, truncata, apice quinquangulata, acie rectâ vel subcurvatâ. Senrrva $2-4$ in singulo loculo, columellac alternatim affixa, sursum imbricata, oblongoreniformia, sinu obtusissima, rugosiuscula; HILUn in medio sinûs; mIrRopyLA in extremitate inferiore sinûs; TESTA in membranam peripteralem expansa, chartacea, subrugosa; RAPHE ad chalazam, vertice seminis approximatam et hilo subcontrariam, procurrens; tegren membranaceum. Albunen tenue, album. EmmYo longitudinalis, subplanus; cotruedones contiguae, subplanae, margine saepe involutae, dimidiatoovatae vel subrcniformes; RAdrcurs subteres, obtusa, in marginem cotyledonum inflexa.

\section{Crescit prope Martapoera, Poeloc-lampei: Bonneo.}

Tab. 29. Figura Schimae crenatae. 1. Flos. 2. Flos, scpalis duobus, petalis et parte staminum abscissis. 3. Stamina. 4. Anthera et pars filamenti longitudinaliter scctac. 5. Pollen siccum ct 6. humectatum. 7. Pollen cum sacculo. 8. Ovarium et calyx longitudinaliter secti. 9 et 10. Ovula. 11. Fructus longitudinaliter scctus. 12. Columclla denudata. 13. Capsula calyce suffultà, valvulis duabus ablatis. 14. Capsula calyce suffultâ, valvularum duarum superiore parte abscissâ. 15. Scmen abortivum. 16. Scminis abortivi pars supcrior valde aucta. 17. Scmen immaturum. 18. Scmen, testac et tcgminis parte ablatâ. 19. Embryo, cotyledonibus sejunctis. 20. Symmetria floris.

\section{SCHIMA NORONHAE. Rwdt.}

S. foliis ovali-oblongis acuminatis subintegerrimis, columellae apice stellaeformi, seminibus reniformibus.

Arbor speciosa, saepe 20 metrorum; rami, ramulr et gemmat Schimae crenatae. Folia alterna, ovali-oblonga vel ovalia, acuminata, apiculata, basi angustata, integerrima vel cum nonnullis serraturis distantibus, supra nitida, subtus glabra, - juniora subtus sericea, - 0,08 longa, 0,025 lata, coriacea, nervis primariis distantibus, in angulo $45^{\circ}$ patentibus; PETIour compressi, glabri, 0,01 longi.

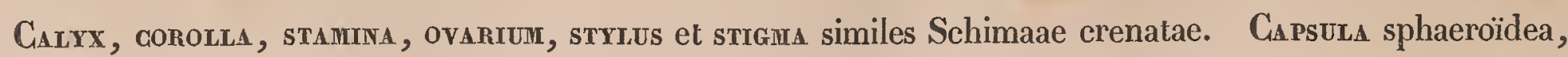
truncata vel cxcavata, parte persistente styli mucronata, basi rotundata, sparsim sericea vel glabrata, 
lignosa, quinquelocularis, loculicida; vaLVULAE ad duas tertias disjunetae, ovales, septigerae; nISSEPIMENTUn apice carinatum, in medio sigmoïdeo-excisum, versus basin eum lobo semiovato aeuto et sinu aeuto, crassum, subtriangularc; Colunella obconica, truncata, pentagona, versus apieem quinquepartita; partcs sinubus rotundatis sejunctae, acuminatae; vertice cum quinque cavitatibus exsculptis. Senira 2-4, sinubus eolumellae aflixa, biserialia, subalterna, reniformia, sinu acuto; struetura eadem ae Sehimae erenatae.

\section{Crescit in montanis: $\mathbf{J}_{\mathbf{\Lambda V A}}$.}

Tab. 29. Fig. 21. Capsula a laterc visa, valvulae parte unius abscissâ. 22. Eadem ab apice visa. 23. Scmen. 24. Semen, testae ct tegminis parte abscissâ. 25. Seminis sectio longitudinalis. 26. Embryo. 27. Embryo, cotyledonibus scjunctis.

De voorwerpen dezer soort, welke ik uit den tuin van Buitenzorg heb, en aldaar vermoedelijk van den berg Salak zijn overgebragt, hebben de bladen laneetvormig, aan de beide einden zeer toegespitst, en de bloemen iets kleiner dan gewoonlijk. Voor het overige hebben zij geene kenmerken, die mij tot de voorstelling eener eigene soort kunnen doen besluiten.

\section{SCHIMA ANTHERISOSA. KHS.}

S. foliis lanceolatis acuminatis serratis, columcllac apice ovoideo truncato.

\section{Crescit in monte Merapi: Sumatra.}

Deze staat tusschen de beide besehrevene soorten in. $\mathbf{Z}_{\mathrm{ij}}$ heeft door den vorm der bladen de meeste verwantschap met de langbladerige Schima Noronhae, doeh versehilt door de zeer duidelijke zaagtanden. Zij is aan Schima crenata verwant door den vorm der vrucht, welke naauwelijks versehilt, en door den vorm van het standertje der vrueht, dic echter meer regelmatig eivormig is.

\section{PYRENARIA. Bume.}

Bijdragen tot de Flora van Neĉrlandsch Indië, bl. 1119.

CALYYX pentasepalus, bibracteatus, aestivatione imbricatâ. Corolla pentapetala, aestivatione imbrieatâ. Stamina numerosa; filanenta monadelpha, corollae adnata, filiformia; antherae medio dorsi affixae, vaeillantes, biloculares, longitudinaliter dehiscentes. Ovarioj liberum, quinqueloeulare; ovula bina, superimposita, angulo interno loculi affixa, anatropa. Strui 5, approximati; stigmata emarginata. Pomum quinqueloculare. Semina (Pyrena) 2 in singulo loculo, sursum imbricata; testa ossea; tegren membranaceum. Embryo longitudinalis, rectus; radicula teres; cotyledones foliaceae, contortuplieatae.

Arbores. Folia alterna, oblonga, serrata, coriacea. Flores axillares, solitarii. 
Naar den eersten indruk te oordeelen, welken het aanzien der planten maakt, behoort het geslacht Pyrenaria tot de Gordonieae. Deze verwantschap wordt verder bevestigd door de bij een nader onderzoek gevondenc kenmerken. Die der bloemdeelen zijn nict zeer afwijkende van Gordonia, enzv. De ontwikkeling van het zaad geschiedt cven als bij deze geslaehten, doch brengt eenen vorm voort die meer ovcreenkomt met dien van het zaad van Malaehodendron. De vrueht wijkt door de zamenstelling harer bekleedselen van de andcre geslachten der Gordonieae af, zijnde het sarcocarpium zeer ontwikkcld; doch dit versehil is van geen genoegzaam aanbelang, dewijl in het geslaeht Saurauja openspringende en vlcezige vruehten worden gevonden.

\section{PYRENARIA SERRATA. Bu.}

P. foliis ovali-oblongis serratis, bracteis lunulatis obtusis, fructubus sphacroïdeis.

Arbor 15-20 metrorum; truncus rectus, cylindrieus, eortiee longitudinaliter rimoso tcetus; RAM patentes, terctes, fusci, glabri; ramuli compressi, - novelli saepe eompressi, sulcati, subpubescentcs. Genmae conicae, dense sericeac, foliis equitantibus, apice conduplicatis, intus glabriusculis. Foura altcrna, ovali-oblonga, breviter acuminata, serrata, serraturis argutis, basi integerrima, utrinque glabra, 0,15 longa, 0,05 lata, coriaeca; petrour semiteretes, supra sulcati, glabri, 0,01 longi. Fuores axillares, solitarii; pedurculi subteretes, pubescentes, 0,05 longi; BRACTEAE duae calyci approximatae, lunulatae, obtusac, subtus sericeae, supra glabriusculae. Alabastrunir subglobosum, dense sericeum. Calyx pentascpalus, persistens, aestivatione imbricatâ; SEPALA inaequalia, (duo exteriora minora, rotundata, obtusa; tria intcriora majora, semi-orbiculata, obtusissima) supra glabra, subtus dense sericea. CoroLLA pentapetala vel quinquepartita, tubo brevissimo, aestivatione imbricatâ; PETALA subaequalia, ovata, obtusa, intus glabra, extus piloso-sericea, carnosa, margine membranacea. Strumiva numerosa; filanenta monadelpha, petalis adnata, linearia, glabra; ANTHERse infra medium affixae, vacillantes, ovatae, biloculares, longitudinaliter dchiscentes. Polden sphaericum. Ovarıux subhemisphaericum, sericeo-pilosum, quinquclocularc; ovdus geminata, angulo interno loculi affixa, superimposita, hemisphaerica, anatropa. Strur 5, coäliti; stranata capitellata. Ponur sphaeröideum, obsolete decemsuleatum, glabrum, cpicarpio coriacco, mesoearpio earnoso, endocarpio chartaceo, quinque- abortu tri- vel quadriloculare. Semrra 2 in singulo loculo, angulo interno loculi affixa, superposita, oblonga, compressa, fusca; nrumi infra micropylam punctiformcm; TESTA ossea, sat crassa; RAPHE ramificans intra testam ct TEGMEN membranaceum, ad chalazam basilarem hiloque contrariam procurrens. Albunev nullum vel tenue. Embryo longitudinalis, erectus; radicula eylindriea; cotrlenones contortuplieatae, foliaceae.

Crescit in sylvis montanis: $\mathbf{J}_{\mathbf{A V A}}$.

Tab. 30. Figura specici. 1, 2. Alabastrum. 3. Flos expansus. 4. Pars staminum. 5, 6. Pollen. 7. Ovarium, tegumentis floralibus et staminibus ablatis. 8. Ovarium sectum longitudinaliter. 9. Orarii transversalis sectio. 10. Ovulum admodum auctum. 11. Fructus. 12. Fructus verticaliter sectus. 13. Scmen. 14. Scmen immaturum verticaliter sectum, ad indicandum directionem raphis. 15. Scmen longitudinaliter sectum cum Embryone. 16. Embryo (15 et 16 Clarissimus Blume mihi communicavit). 
II. Pyrenaria oÏdocarpa. Kis.

P. foliis oblongo-ovalibus argute serratis, bracteis ovatis acutis, fructubus ovoideis.

\section{Crescit in monte Tankoeban Prahoe: $\mathrm{J}_{\mathbf{A V A}}$.}

De overcenkomst tusschen de voorwerpen dezer soort en der voorgaande, maakt eene beschrijving onnoodig, en het onderzoek der voorwerpen op hunne standplaatsen wenschelijk en zelfs noodzakelijk, om de verwantsehap nader te bepalen. Bij de vroeger plaats gehad hebbende bewerking der familie, had ik deze en de beide volgende met $\mathbf{P}$. serrata vereenigd en allen als verscheidenheden van haar aangemerkt. De tcgenwoordige herziening heeft mij doen overgaan om allen onder cigene namen voor te stcllen, minder om het getal soorten te vermeerdercn, dan wel om de aandacht van de in Indië wcrkzaam zijnde Kruidkundigen op deze boomen te vestigen. - Behalve door de eivormige vrucht, is de P. oïdocarpa van de $\mathbf{P}$. serrata door den vorm van de schutblaadjes en buitenste kelkbladen onderscheiden, zijnde de laatsten bij de eerste soort ovaal, min of meer puntig, en de sehutblaadjes soms tot langwerpige, puntige blaadjes uitgegroeid.

\section{PYRENARIA MASOGARPA. Kus.}

P. foliis obovatis crenato-scrratis, bracteis obtusis, fructubus ovoïdeis mammellatis.

\section{Crescit in monte Balaran: Bonweo.}

Deze soort heeft de bloemsteeltjes meer dan viermaal langer, dan de beide voorgaande, en met twee kleine, halfronde schutblaadjes op het midden der lengte. Hare kelk- en bloembladen verschillen nict mct die van P. serrata, doch het geringer aantal stuifdraden en vooral de eivorm der vrueht, kunnen ter onderschciding dienen.

\section{PYRENARIA LASIOCARPA. Khs.}

P. dense pilosa, foliis ovalibus serratis, bracteis ovalibus obtusis, fructubus obovoïdeis dense pilosis.

\section{Crescit in monte Patocha: $\mathbf{J}_{\mathbf{A V A}}$.}

Deze soort verschilt van de voorgaande door de digte haarbekleeding, welke niet alleen de takken en bladen, maar ook de bijna rijpe vrucht bedekt, en door de gedaante der vrucht, dic ten naastenbij omgekeerd eivormig is. Zij bezit de bloemdeelen gelijk aan die der P. serrata, en de bloemstecltjes iets korter, doch mede van twee kleine sehutblaadjes voorzien, even als bij P. masoearpa. 
CA LPANDRIA. BLUME.

Bijdragen tot de Flora van Neêrlandsch Indië, bl. 178.

C $\mathbf{\Delta L Y X}$ tetra-pentasepalus, persistens, aestivatione imbrieatâ. CoroLLA tetra-pentapetala, aestivatione imbricatâ. Stamira 25-40, biserialia, exteriora in tubo cylindrico concreta, interiora 10 libera; FILAMENTA staminum libcrorum filiformia, et staminum concretorum brevia; ANTHERAE in medio affixac, vacillantes, biloculares, longitudinaliter dehiscentes. Ovariun liberum, tri- ad quinqueloculare; ovurA 3-5 in singulo loeulo, angulo interno loculi aflixa, biserialia, alterna, superposita, anatropa; sTru 5 , coaliti; stignata obtusa. Capsola lignosa, abortu trilocularis, loeulicida, trivalvis; valvulae septigerae. Senura (Pyrena) tria in singulo loculo, superposita; testa ossea; tegmen membranaceum. Eurbryo rectus; radicula teres; cotyledones foliaeeae.

Arbusculat. Folis alterna, serrata, coriacea. Flores axillares vel terminales, solitarii vel geminati.

Dit geslacht, vroeger bij de Meliaceae gerangsehikt, is nader aan de Ternstroemiaeeae vcrwant. Deszelfs voorwerpen hebben het aanzien van de gewassen der Ternstroemiaceae. Hunne helmdraden zijn in cen onbepaald getal en in ieder hokje van drie tot vijf eiljes aanwezig; de zaadlobben zijn bladvormig en, volkomen rijp zijnde, vrij groot en zamengeplooid; de Meliaceae, daarentegen, hebben een bepaald getal helmdraden, dat mcestal het dubbele van de bloemkroonverdeelingen is, een kleiner aantal eitjes, twee tot vier, cn vooral dikke, vleezige zaadlobben. - Met de geslachten der Ternstroemiaceae vergelcken, gelijkt Calpandria door de groeiwijze van de geheele plant, door de ontwikkeling der bladen, welke met de bloemen in knoppen besloten zijn, en door de zamenstelling van de bloem, welke de binnenste helmdraden dikwerf vrij heeft, op Camellia.

\section{CALPANDRIA LANCEOLATA. BuUne.}

C. foliis ellipticis acuminatis serratis, stylo pubescentc.

Arbuscula 3 metrorum; rami patentes, glabri, cinerei, lineati; ramuli compressi, dense pilosi. Gemina conieae, aeutae, glabriusculae, foliolis equitantibus, extus dense piloso-sericeis ct cxtus glabriusculis. Folıa alterna, distantia, elliptica, utroque acuminata, serrata, serraturis obtusiusculis, supra ct subtus glabra, - juniora subtus, praesertim in nervo medio pubescentia, - coriacea, 0,08 longa, 0,035 lata; petrour semiteretes, supra sulcati, glabri, 0,005 longi. Fuores terminales vel axillares, solitarii, raro geminati; pedunculi teretes, pubeseentes. CALYX tetra-pentasepalus, aestivatione imbricatâ; SEPALA inaequalia, subrotunda, oblusissima, saepe margine incisa, intus glabra, extus pubescentia. Corolxa tetra-pentapetala, aestivatione imbricatâ; petalı ovalia, obtusa, glabra. Stamina biserialia (exteriora in tubo cylindrico, apice decemdentato coalita; interiora decem libera); FILAmenta staminum liberorum filiformia, glabra, sat longa, partes liberae filamentorum concretorum brevissimae; antirerae in medio dorsi affixae, vaeillantes, ovatae, utroque obtusae vel cmarginatae, biloculares, rimis longitudinalibus dehiseentes. Ovariuan liberum, oblongo-ovoïdeum, dense pubescens, tri-quinque- 
loeulare; ovulı 5 in singulo loculo, anatropa, biserialia, alterna, superimposita, angulo interno loeuli aflixa, subglobosa; strui 3-5, conereti, crassi, dense pilosi; stignata oblusa. Capsula trigona, aeuta, lignosa, abortu triloeularis, loculieida, trivalvis; valvulae ad medium usque disjunetae, rotundoovatae, aeutae, endoearpio coriaceo, partem septorum ferentes; couvireld triangularis, erassa. Senina 2-3, in singulo loeulo, superimposita, deformia, angulata, rugosa; HrLun mieropylae approximatum, saepe excavatum; TESTA ossea; RAPHE ad ehalazam hilo oppositam proeurrens; TEGIIEN membranaceum. Eimbryo ereetus; radicula teres, obtusa; cotrledones foliaeeae, subrotundae, utroque obtusae.

\section{Crescit ad ripas fluminis Doesson: Bonweo.}

Tab. 31. Figura speciei. 1, 2. Alabastrum. 3. Flos expansus. 4. Staminum cylindrus, integumentis floralibus ablatis. 5. Pars cylindri intus visa. 6. Flos, calyce, corollà et parte cylindri ablatis. 7. Flos, integumentis floralibus et cylindro staminum ablatis. 8. Ovarium verticaliter sectum. 9. Ovarii sectio transversalis. 10. Ovulum admodum auctum. 11. Capsula, valvulâ unâ ablatâ. 12. Capsulae pars, valvula una et spermophorum. 13. Valvula intus visa. $14,15,16,17,18$. Semina. 19. Semen immaturum verticaliter sectum. 20. Embryo.

\section{IJ. GALPANDRIA QUISCOSAURA. Kus.}

C. foliis oblongo-ovatis acutis serratis, stylo glabro.

Arbusqula 2-4 metrorum; rami stricti, teretes, glabri, einerei; Ramuli patentes, strieti, subteretes, pubeseentes; - novelli compressi, dense pilosi. Gemina compresso-ovoïdeae, tegumentis inaequalibus ovatis glabris, foliolis aequitantibus extus dense hirsutis et intus glabris. Folis oblongo-ovata, acuta, obtuse serrata, utrinque glabra, - juniora subtus pilosa, - coriacea, 0,08 longa, 0,03 lata; pedunculi 0,005 longi, semiteretes, glabrati vel pilosi. Flores axillares vel terminales, solitarii; pedunculi breves, teretes, pilosi. Calyx tetrasepalus, aestivatione imbrieatâ; sepala biserialia, inaequalia, subrotunda, utrinque glabra. - Ovarius oblongo-ovö̈deum, dense pilosum, triloeulare; ovula. 3-6 in singulo loculo, superimposita. Struds unieus, subeylindricus; stigns trilobum, lobis obtusis.

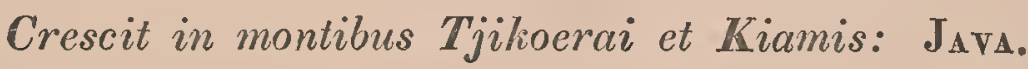

Deze voorwerpen zijn tussehen de 1000 en $1800 \mathrm{~N}$. ellen hoogte, in de digte bossehen van de beide opgenoemde bergen, verzameld. Hunne boomen tot de kleinste gewassen behoorende, hebben, door de bijna loodregte rigting der takken, een zeer stijf aanzien en, door het donker groen der bladen, cen somber voorkomen. Zij bezitten kleine, in de oksels geplaatste bloemen, die door hare witte kleur zeer uitkomen en op eenigen afstand, door eenen aangenamen, specerijaehtigen reuk, haar aanwezen verraden. Daar deze reuk het eenige opmerkelijke is, wat de inlanders aan deze boomen vonden, hebben zij hun den naam Drangdan angien gegeven, waardoor zij aan dezelve invloed op den wind toekennen: eene voorstelling, die zeker de verspreiding van den geur zeer juist aantoont. 


\section{N A U C}

\section{EN EENTGE VERWANTE GESLACHTEN,}

Het geslaeht Nauelea werd door Linnaeus voor het eerst in $1762\left(^{\star}\right)$ genoemd, en voor eene plant opgegeven, die hij vroeger als Cephalanthus orientalis aanduidde. Bij deze opgave haalt hij, onder anderen, Rheede's afbeelding ( $\dagger$ ) van de Katoe Sjaka aan, en geeft hij, met een vraagteeken, de afbeelding op van den Bancalus van Rumphius (\$). Later, in 1764, deelde Iinnaeus ${ }_{*}$ ) het geslachtskenmerk mede, naar de beschrijving van de door Rheede afgebeelde Katoe Sjaka, met de volgende beschrijving der vrueht: Semina solitaria, oblonga, subtrigona, inferne altenuata, apice oblusa, bilocularia. Dezelfde besehrijving diende Jussieu voor zijn geslachtskenmerk van Nauclea, waarin hij zegt: Capsula subtrigona, ab adjacentibus undique compressa, 2-locularis, 2-sperma, non dehiscens; doeh hij voegde bij dit geslaeht de door Rumphius en Aublet afgebeelde slingerende gewassen, met in hoofdjes vereenigde bloemen. Lamarek beeldde onder den naam van Nauclea orientalis eene plant af, welke hij vroeger als Cephalanthus ehinensis had besehreven, en als de door Rumphius voorgestelde Banealus beschouwde. Naar de plant, volgens welke deze afbeelding is gemaakt, besehreef Poiret $(t)$ het geslaeht Nauclea met: une eapsule à deux loges, à deux semenees; un reeeptaele globuleux.

$\left({ }^{*}\right)$ Spec. pIant. Ed. II. T. I. p. 243.

(t) Hortus Malabaricus III. Tab. 33

(§) Hort. Amboinensis III. Tab. 55.

$\left({ }_{\star}\right)$ Gen. plantarum. Ed. VI. n. 223.

(t) Encyclopédic Botanique. T. V. P. 434. 
Hij merkte daarbij op, dat Cephalanthus en Nauclea zeer verwant waren, en bragt onder het geslaeht Nauclea: N. orientalis, N. citrifolia, de Katoe Sjaka Rheede, en de door Aublet afgebeelde Ouropari onder den naam van $\mathbb{N}$. guianensis. Ongeveer in dien tijd leverde Gaertner $\left(^{\star}\right)$ eene besehrijving en afbeelding van Nauclea orientalis, daarbij als kenmerk voor Nauclea opgevende: Capsula infera, calyce corticata, bicocca, bilocularis, polysperma. Semina setaceo-caudata, en de platen van Rheede en Rumphius aanhalende. Dit kenmerk der vrucht werd door Schreber ( $t$ ), met eene kleine verandering, afgeleid uit de beschrijving der door Gaertner gegevene soort, overgenomen. Roxburgh heeft dit kenmerk van Sehreber, bij de bepaling der door hem afgebeelde soorten van Nauclea, gevolgd. Hetzelfde deed Willdenow (\$), die de Nauclea parvifolia en africana kon vergelijken. Met het kenmerk van Linnaeus komt Nauelea weder bij Roemer en Schultes $\left.{ }_{*}{ }_{*}\right)$ voor, en daarbij tevens de opgaven van Jussieu en Lamarck. Sprengel neemt een gemengd kenmerk aan: fructus drupacei, congesti, dicocci, coccis polyspermis, seminibus membranaceo-marginatis, en vereenigt hiermede de boomvormige en slingerende gewassen, welke door Schreher in Nauclea en Uncaria waren verdeeld. De Candolle nam de scheiding der verschillend groeijende gewassen aan, en gaf een kenmerk van Nauclea, aan de afbeelding en beschrijving van Gaertner ontleend. Richard vereenigde de beide vormen: hij gaf een geslachtskenmerk, vooral van die soorten genomen, welke de Nauclea orientalis van Lamarck naderen; daarenboven beschreef hij de Katoe Sjaka van Rheede, onder de geslachtsnamen Anthocephalus, naar de plant zelve, en van Cephalidium, naar de beschrijving van Poiret. De kenmerken, door de Heeren Blume (t), Wight en Arnott (*) gegeven, bewijzen, dat zij het denkbeeld van Gaertner volgen. Dàt van den Heer Endlicher ( + ) is gewijzigd, ten einde Uncaria te kunnen opnemen, en bevat de opgave van flores bracteolis interstincti; voor het overige schijnt hetzelve op de waarnemingen van Gaertner te berusten.

Er zijn dus voornamelijk drie verschillende planten, onder den naam Nauclea orientalis beschreven, en van dezelve vicr afbeeldingen gegeven. De eene, de Katoe Sjaka van Rheede, welke aan Linnaeus tot voorwerp van beschrijving heeft gestrekt, is door Poiret als Nauclea citrifolia beschreven, en door Roxburgh als met Nauclea cadamba overeenkomende beschouwd. Zij maakt den grondvorm uit van het geslacht Cephalidium en Anthocephalus. De andere, door Gaertner als N. orientalis aangemerkt, is door Willdenow en Roxburgh onder den naam van Nauclea parvifolia beschreven en afgebeeld. 'De derde plant, welke dien naam draagt, is door Lamarck, eerst onder den naam Cephalanthus chinensis, vervolgens onder dien van Nauclea orientalis beschreven en door Poiret uitvoerig vermeld. En de afbeelding van Rumphius, welke volgens de beschrijving ćéne vrucht heeft en waar dus de vruchtbeginsels zijn zamengegroeid, is van eene plant, welke tot de eerste afdeeling der Nauelearia D. C. behoort.

$\left.{ }^{*}\right)$ De fructubus et seminibus. pag. 151. Tab. 30. f. 8 .

(†) Genera plantarum. n. 295.

(\$) Spec. plant. I. pag. 928.

(*) Systema Vegetabilium. V. pag. xuI.

(†) Bijdr. t. d. Flora van Neêrl. Ind. pag. 1008.

$\left({ }^{* *}\right)$ Prodr. Penins. Ind. pag. 390.

(t十) Genera plantarum. n. 3280. 
Indien er nu naar het gewone beginsel van naamgeving gehandeld werd, dan zou Anthocephalus den naam Nauclca moetcn dragen. Doch daar dit tot eene te groote vcrandering en tot verwarring aanleiding zoude geven, stel ik voor, om den geslachtsnaam Nauclea aan die planten tc laten, welke aan de Nauclea orientalis Lamarck, zoo'als zij door de Heeren De Candolle en Blume is aangenomen en beschreven, verwant zijn. Hierdoor blijft in het geslacht Nauclea het grootste aantal soorten. Want, met het denkbeeld om den geslachtsnaam Nauclea voor al de planten, welke sommige schrijvcrs er onder willen rangschikken, aan te nemen, zal men zich moeijelijk vereenigen, zoodra men de planten zelven ziet, alswanneer men, als algemeen kenmerk, alleen de bloeiwijze kan opgeven. Ik geloof dcrhalve, dat de verdeeling van het geslacht Nauclea naar de groeiwijze en het voorkomen, gepaard met eenige kenmerken, die de vrucht leveren, in den tegenwoordigen stand der wetenschap, als wenschelijk kan worden beschouwd. Zij wordt dus door mij voorgesteld, met inachtneming van de rceds bestaande verdeeling, als volgt: met zamengegroeide vruchten, Anthocephalus met bijvoeging van Cephalidium, Platanocarpum, voor de eerste afdecling van de Nauclcaria; en met vrije, openspringende vruchten, Uncaria, voor de slingerplanten met aan den binnennaad der vrucht vastgehcchte placentae en aan den voet vastgehechte zaden; Nauclea voor de boomvormige gewassen met hangende placentae en als schildjes vastgehechte zaden, en Stephegyne, vroeger Mitragyne genoemd, voor boomvormige gewassen met hangende placentae en opgerigte zaden, benevens talrijke, rondom de bloemen staande schutblaadjes.

\section{PLATANOCAR PUM. Endither.}

Genera Plantarum. p. 557; Naucleae sectio D. C. Prodromus IV. p. 343.

Frones supra receptaculum subglobosum concreti. CALIYX superus, limbo quadri- vel quinquedentato. Conolla. aestivatione subimbricatâ, tubo elongato-infundibuliformi, limbo quadri- quinquepartito. Staniriva 4-5 corollae fauci inserta, segmentis corollinis alternantia; FILAMenta brevia; ANTHERAE basi affixac, acutae. Ovarıun inferum, biloculare, pluriovulatum; ovula placentis linearibus affixa. Styuds cylindricus; stignis subclaviforme. Fructus concreti in massam sphaericam, subcarnosam, calycis rudimentis areolatam, biloculares. Senriva pauca, placentis membranaceis ope carunculae formae variabilis affixa, subrhombea, compressa; TESTA in membranam peripteralem expansa; TEGNEN membranaceum. Enrsryo in medio albuminis carnosi, erectus.

Arbores. Folin opposita. Stipulae interpetiolares. Flores capitulati, terminales vel axillares.

Dit geslacht zal vermoedelijk later met Sarcocephalus Afzelius vereenigd worden. Het behoort in allen gevalle bij de zoogenaamde Sarcocephaleae, even als de door Rumphius afgebeelde Bancalus. 


\section{PLATANOGARPUM SUBDITUM. KHs.}

P. ramulis glabris, foliis ellipticis obtusiusculis glabris, stipulis oblongo-ovalibus acutiusculis glabris, pedunculis tcrminalibus solitariis.

Arior 6-8 metrorum, trunco recto, coronâ ovöideâ; RıMI subteretes vel obtuso-quadrangulares, nodis incrassatis compressi, cincrascentes; RAMULI obtuse quadrangulares, lateribus sulcatis, glabri. For.s dispersa, opposita, elliptica, obtusiuscula, integerrima, saepe undulata, utrinque glabra, subtus in nervorum axillis subbarbata, 0,12 longa, 0,05 lata, nervis primariis erectis, prominentibus, nervis secundarïs subparallelis, flexuosis, vix conspicuis, saepe exsculptis; petrou semiteretes, supra sulcati, glabri, 0,006 longi. Strpula oblongo-ovales, acutiusculae, glabrae. Ftores in capitulo hemisphaerico connati, terminales vel axillares, odorati; PEDunculus comuris obtuse quadrangularis, pubescens; bRActeat oblongo-ovatae, carinatae, acutae. Calyas tubo quadrangulari, brevi, quadridentato: dentibus acutis. Corolla aestivatione imbricatâ, elongato-infundibuliformis, limbo quadri- ad quinquepartito: partibus obtusis, glabra, flavescens. Sтыmiva $4-5$, fauci corollae inserta, segmentis corollinis altcrnantia; fILAMEvts brevia; antmerae basi affixae, ovatae, acutae, biloculares. Ovaridir coalitione cum appositis deforme, biloculare; ovula 10-20, placentis linearibus dissepimento eonnatis affixa. STruds teres, glaber; stigna conicum, acutum, vel parte inferiore cylindricum, parte superiore conicum. Fructus compositus coalitione singulorum ovariorum, sphaericus, areolatus et tuberculatus: areolis et tuberculis sulcatis. Senina 6-12, placentis membranaceis promincntibus affixa, adscendentia, subrhombca; теsтa in alam periphaericam expansa, cellulosa; tegmen tenue. Nucleus ovoïdeus. Arbuner carnosum, albidum, periphaericum. Embryo erectus.

\section{Crescit in fruticetis: Java, Sumatra, Borneo.}

Tab. 32. Figura speciei. 1. Flos completus cum duobus ovariis. 2. Corollae pars. 3. Stamen. 4. Stamen cum quatuor anthcrarum loculis. 5. Ovariurn longitudinaliter dissectum. 6. Fructus longitudinaliter sectus. 7 et 8. Semina. 9. Semen longitudinalitcr scctum.

\section{ANTHOCEPHALUS. Righard.}

Nauclea Limn. Richard. Mémoires de la société d'Histoire naturelle, Tom.V. pag. 235; Naucleae spccies Roxburgh, De Candolle, Blume.

Flores supra reccptaculum subglobosum congregati, sessiles. CALYX superus, tubo infundibiliformi, limbo quinquepartito: segmentis acutis vel acuminatis, corpusculis claviformibus terminatis. CoroldA aestivatione imbricatâ, tubo elongato-infundibiliformi, limbo quinquepartito. Stanirvı 5, segmentis corollae alternantia; rILAMENT versus faucem corollae inserta, brevia; ANTHERAE basi affixae, apiculatae. Ovariun apice quadri-, basi bi-loculare, loculis multiovulatis; ovula in placentis ab apice ad medium usque bipartitis affixa. STruus teres; strgin bipartitum: segmentis approximatis. Fructus subcarnosus, calyee carnoso coronatus, indehiseens, parte superiore tetrapyrenâ, parte inferiorc biloculari et subcarnosâ, 
pleiosporus. Semina deformia; testa membranacea, foveolata, in marginem peripteralem expansa; tegmer membranaceum. Albuner carnosum. Enbryo erectus in medio albuminis.

Arbores. Folia opposita, petiolata, costata. Stipulae interpetiolares. Flores in eapitulis terminalibus vel axillaribus congregati.

De bloemen blijven ook later, bij de rijpwording der vruchten, van elkander afgezonderd. Zij verliezen niet zelden de knodsvormige aanhangsels van de slippen des kelks, die vóór de opening der bloemen min of meer zamengeklecfd zijn. Het vruchtbeginsel bestaat eigenlijk uit twee hokken, die in het bovenste gedeelte weder in twee hokjes zijn verdeeld. De vrucht heeft hetzelfde zamenstel, doeh, door de verharding van het endocarpium, in het bovenste gedeelte vier driehoekige nootjes. De placenta is in het benedenste onverdeeld en splijt aan het begin van de holte der nootjes in twee takken, welke binnen deze nootjes de zaadjes dragen.

Bij dit geslacht behoort de Nauclea eadamba Roxb. (N. eitrifolia Poiret) en dus ook het geslaeht Cephalidium Richard.

\section{ANTHOCEPHALUS MORINDAEFOLIUS. Kus.}

A. ramulis glabris, foliis ovatis breviter acuminatis basi subcordatis glabris, pedunculis terminalibus solitariis, receptaculo glabro, claviculis calycis oblongis obtusis.

Arbor saepe 20 metrorum, speciosa; truncus rectus, cylindricus, cortice fusco, admodum adstringente; corona hemisphaerica, dense foliata; RAmI patentes, subtcretes, glabri, laete fusci; RanuLI obtuse quadrangulares, sulcati, glabriuseuli. Folia decussata, ovata vel oblongo-ovata, breviter acuminata, basi obtusa vel subcordata, margine undulata, utrinque glabra, 0,14 longa, 0,08 lata, nervis primariis patentibus subparallelis utrinque prominentibus, nervis secundariis curvatis parallelis approximatis; PETIOLI'semiteretes, supra plani, sulcati, glabriusculi, 0,02 longi; strpulá deciduae. Fuores in capitulo globoso terminali solitari dense congregati, in receptaculo subsphaerico areolato glabro sessiles; pedurculus commurs subteres, glaber. Calrx superus, aestivatione valvatâ; tubus infundibuliformis, quinquesuleatus, intus pubescens, extus glaber; LוmBus quinquepartitus, segmentis inaequalibus: quaedam lanceolata acuminata, caetera lanceolato-linearia, apice oblongo-claviformia, erectus, hirsutus. Corolla aestivatione subimbricatâ, extus glabra, intus pubescens 0,001 longa; TuBus elongato-infundibiliformis, saepe obtuse quinquangularis; LImBus quinquepartitus, segmentis oblongis obtusiusculis. Stamira 5, segmentis corollae alternantia; rmamenta infra faucem affixa, brevia, glabra; ANTHERAe basi affixae, lineares, mucronulatae, basi obtusae, biloculares, loculis basi disjunctis. Ovariun inferum, obconicum, quinqueeostatum, glabrum, biloculare, pluriovulatum; ovula plaeentis cum dissepimento connatis affixa. Styuus teres, glaber; stigma obtuse oblongo-claviforme. Fructus oblongus, compressus, calyce incrassato pentagono quinquedentato hirsuto coronatus, glaber, subcarnosus, parte inferiore bilocularis endoearpio membranaceo, parte superiore quadriloeularis endocarpio 
osseo; vel bilocularis, loeulis in parte superiore bipartitis. Semris numerosa, affixa plaeentis duabus basi simplicibus, supra basin bipartitis, polymorpha: angulata vel subrotunda scrobiculata; TESTA subcrustacea; TEGMEN membranaceum. NúcLeus ovö̈deus, embryone ereeto, dicotyledoneo.

\section{Crescit in sylvis Melintang: Sunatra.}

Explicatio Tabulae 48. Fignra speciei. 1. Flos. 2. Corollae pars explicatae. 3. Ovarium longitudinaliter sectum. 4. Ovarii sectio: pars infera. 5. Ovarii sectio: pars supera. 6. Fructus. 7. Fructus longitudinalitcr sectus, parte supcrâ integrâ. 8. Fructus longitudinalitcr sectus, parte superâ disscctâ. 9. Semina cum parte placentae et funiculis umbilicalibus. 10. Testa. 11. Semen, parte testae ablatâ. 12. Semen, tcstâ ablatâ. 13. Nucleus. 14. Semen, in longitudine dissectum.

Behalve de bovenbeschrevene voorwerpen bezitten wij nog andere, welke van jonge boomen, die langs de Doeson-rivier op Borneo groeiden, zijn geplukt. Aan dezen zijn de bladen langwerpig eirond, min of meer bchaard, voor het overige door andere kenteekenen niet te onderschciden.

De Anthocephalus morindacfolius behoort tot de gewassen, welke het lagere gedeelte van de beoosten Padang gelegene bergketen bedckken. Zelden is hij daar boven eene hoogte van tweeduizend voct waargenomen, zijnde hij meestal tusschen de 1000 en 1500 voet beperkt. In deze streek staat hij ten naastenbij in talrijkheid gelijk met de eiken. Zijn stam rijst bijna loodregt naar boven en draagt halfronde, tamelijk uitgebreide kroonen, die haar loof aan dat der eiken aansluiten. Hetzelve is echter door den mecr opeengehoopten stand der bladen en door den glans, welke deze kenmerkt, wel te onderscheiden. Buitendien doen de bloemhoofdjes, meestal aan het einde der takken gezeten, de in den bloeitijd bij elkander groeijende kroonen, reeds in de verte erkennen. Met deze bloemhoofdjes is de kroon, in het begin van het drooge jaargetijde, als bczaaid, en zij komen als geel-witte kogels, overal tusschen het glanzig groene loof te voorschijn.

Aan dezelfde boomen zijn door ons ook nog, behalve de bloemen, enkele vruchten, ronde en een wcinig vleezige bollcn, uit eene menigte digt bij elkander staande vruchtjes gevormd, waargcnomen. Daar deze echter slechts in gering getal aanwezig waren, schijnt de boom voortdurend te bloeijen, doch ook tevens een tijdperk te hebben, welk men meer bepaald zijnen blocitijd kan noemen. De bloemen, dikwerf tot hoofdjes van zes Nederlandsche duimen middellijn vereenigd, verraden de nabijhcid der blocijende boomen, door haren onaangenaam doordringenden reuk, aan rottendc dierlijke zelfstandigheden herinnerende en zich door aanraking aan de handen mededeelende, vermoedelijk omdat aan dezelve stuifmeel blijft klcven. - Het hout dezer boomen is weck, fijndradig, gemakkelijk te bewcrken; doch niet bestand tegen den invloed van vochtigheid en lueht. - De bewoners van de Doeson-rivicr noemen dezen boom Kilädèn. 


\section{Na UCLEA. Lamargk et Augtorum neg Lininaer.}

Lamarck. Illustrations des Genres, Tab. 153.

Flores supra receptaculum subglobosum aggregati, sessiles. CALrX superus, tubo brevi, limbo quinquepartito: segmentis saepe appendiculis claviformibus terminatis. CoRoLLA aestivatione imbricatâ, tubo elongato-infundibuliformi, limbo quinquepartito. Stamina 5, infra vel versus faucem corollae inserta; filamenta brevia; antherae basi affixae, muticae. Ovariun biloculare, pluriovulatum; ovula placentis semicylindricis affixa. Styuus cylindricus; stigma clavatum. Gapsulae distinctae, dicoccae, loculicidae et septicidae. SEMra adscendentia, linearia; TESTA utrinque in alam expansa; tEg.nen membranaceum. EлrвRтo in albumine carnoso, erectus.

Arbores vel arbusculae. Folia petiolata, opposita. Stipulae interpetiolares. Fiores capitulati, terminales vel axillares.

Het geslacht Nauclea, zoo als het hier wordt voorgesteld, heeft tot grondsoort de Nauclea orientalis Lamarck, Blume, enzv., en bevat verscheidene soorten van de tweede afdeeling der Nauclearia en der afdeeling Pentacoryne De Candolle. Deszelfs gewassen zijn boomaardig, soms van eene aanzienlijke hoogte. Hunne bladen staan tegenover elkander, zijn dikwerf glanzig en eenigzins lederachtig. Vóór de ontwikkcling liggen zij tegen elkander in de nevenblaadjcs besloten. De nevenblaadjes zitten tusschen de bladstelen. Zij zijn met de randen, tot op ongeveer twee derden van de lengte, soms zelfs hooger, zamengegroeid, en de bovenste rand is door eene harsachtige zelfstandigheid aan elkander gekleefd. Uit de scheede, welke zij vormen, groeijen drie of, bij eene minder regelmatige ontwikkeling, een of twee bladdragende takjes of bloemhoofdjes. De laatste zijn door een, uit zamengegroeide schutblaadjes gevormd bekleedsel bedekt, hetwelk later in vier tot zes deelen gespleten wordt. Zij zijn bijna kogelrond en in den jeugdigen staat door kleine sterretjes bedekt. Deze sterretjes bestaan uit de knodsvormige aanhangsels der kelkslippen, welke alsdan zijn zamengekleefd en de bloemkroonen als huifjes bedekken. Bij eene verdere uitgroeijing vallen deze knodsjes, naarmate de bloemen meer of min digt bij elkander staan, in grooter of geringer getal van de kelkslippen af, zoodat aan de ontwikkelde bloemen soms vijf, maar ook niet zelden slechts één knodsje wordt waargenomen. Op de vruchten blijven zij zelden aanwezig. Deze hebben eenen omgekeerden piramidenvorm, een zeer dun buitenbekleedsel en een kraakbeenig cndocarpium. Zij bestaan uit twee kraakbeenige nootjes, welke aan de binnenzijde vlak zijn, en daar, in eene vool, het middelstandertje opnemen. De nootjes splijten door een' naad tegen het standertje en door eenen anderen tegenover hetzelve, in twee klepjes. Aan den top van het standertje zijn de beide placentae vastgehecht, welke vrij in de hokjes hangen. Op haar zitten de zaden als schildjes. Hunne buitenhuid is in kleine, lijnvormige plaatjes uitgegroeid en bestaat in dit uitgegroeid gedeelte uit kleine, inwendig gestipte buizen. ' Zij is aan het eene cinde, dat tegenover den wortel ligt, open. De binnenhuid is vliezig; slechts bij eene sterke vergrooting neemt men waar, dat zij celaardig is.

Nauclea verschilt van Platanocarpum door de niet zamengegroeide vruchten; van Anthocephalus, door de kapselaardige vruchten; van Stephegyne, door den verdeelden boord van den kelk, door de 
schutblaadjes, welke de bloempjes omringen, en andere kenmerken meer; van Uncaria, door de groeiwijze, de ongesteelde vruchtjes en het gemis van het middelstandertje. Het geslacht is verwant aan Adina Salisbury, aan Breonia Richard, en aan Cephalanthus Linnaeus.

\section{NAUCLEA STRIgOSA. Krs.}

N. ramulis hirsutis, foliis oblongis utrinque glabris, stipulis oblongo-ovalibus obtusis glabrescentibus, pedunculis terminalibus solitariis, receptaculo glabro, claviculis calycis tetraëdris.

Arbuscula 3-6 metrorum; truirgus brevis, subteres, cortice laete fusco; corora irregulari-hemisphaerica, foliosa; RAMI diffusi, subteretes, annulati, fusco-cinerei, glabri; RAMULI subteretes vel compressiusculi, hirsuti. FouIA decussata, oblonga, breviter acuminata, basi angustata, integerrima vel subcrenulata, utrinque glabra, - juniora utrinque praesertim subtus hirsuta, - 0,1 longa, 0,055 lata, nervis primariis prominentibus, erectis, glabrescentibus, nervis secundariis subparallelis, distantibus, flexuosis; peтiol semiteretes, inferne rotundati, glabrescentes, 0,015 longi. Stipulae intrapetiolares, adpressae, oblongo-ovales, obtusiusculae, supra glabrae, subtus hirsutae, glabrescentes, 0,012 longae, 0,006 latae. Flores in capitulo subgloboso congregati, in receptaculo subgloboso glabro sessiles; pedunculus connunis obtuse quadrangularis, glaber. CaLYx profunde quinquepartitus, segmentis lanceolatis, acuminatis vel angustatis in appendices lineares apice corpuscula tetraëdria inaequilatera gerentes, glaber. СовоцLA aestivatione valvatâ, clavata, glabra, 1,012 longa, tubo subpentagono; Limbus quinquepartitus, erectus, segmentis obovatis, obtusiusculis, incrassatis. Stamiva 5, cum segmentis corollae alternantia, infra faucem inserta; FILAMIENTA brevia; ANTHERAE basi affixae, lineares, mucronulatae, basi subcordatae et bimucronulatae, biloculares, longitudinaliter dehiscentes. Ovarium inferum, obconicum, glabrum, biloculare, loculis pluriovulatis; ovvus in placentis productis affixa. STruus teres, sursum crassior, glaber; sTigms clavatum, acutiusculum.

Crescit in montibus Pamatton et Sakoembang: Borneo.

\section{NAUCLEA PURPURASCENS. Khs.}

N. ramulis glabris, foliis lanceolato-ellipticis obtuse acuminatis glabris, stipulis oblongis obtusis glabriusculis, pedunculis terminalibus solitariis vel ternis, receptaculo hirsuto, claviculis calycis tetraëdris.

Arbuscula; Rami diffusi, subteretes, rimosi, fuliginosi, glabri; ramuli compressiusculi, nodis dilatatis, glabri. Fous decussata, lanceolato-elliptica, obtuse acuminata, integerrima, utrinque glabra, coriacea, 0,12 longa, 0,05 lata, nervis primariis erectis, prominentibus, nervis secundariis distantibus, curvatis vel flexuosis; petrou semiteretes, glabri, 0,015 longi. Stipulae interpetiolares, oblongae, obtusae, glabriusculae, 0,02 longae, 0,005 latae. Flores in capitulo ovöideo-rotundato congregati, in receptaculo subgloboso, areolato, hirsuto sessiles; PEDUnculus connunvis obtuse quadrangularis, glaber. CALYX aestivationc valvatâ, dense hirsutus; tuBus subinfundibuliformis, intus hirsutus; Lñrus quinqueBotanica. 
partitus: segmentis lanceolatis, angustatis, sursum incrassatis, terminatis corpusculis tetraëdris. Conouta aestivatione valvalà, elongato-infundibuliformis, glabra, 0,012 longa; Lnrbus erectus, quinquepartitus, segmentis obtusis. Stamina 5 , cum segmentis corollae alternantia, infra faucem inserta; fLlamenta brevia, filiformia; ANTHERAE basi affixae, oblongo-lineares, membranulâ obtusâ terminatae, basi obtusae, biloculares, loculis apice disjunctis. Ovarnar inferum, obconicum, hirsutum, biloculare, multiovulatum; ovira placentis lamelliformibus affixa. Sryuus teres, glaber; stigma conicum, acutum.

Crescit in sylvis montanis: $\mathrm{J}_{\mathrm{AVA}}$ et SuMatra.

\section{NAUCLEA SYNKORYNES. KHS.}

N. ramulis glabris, foliis ellipticis vel ovalibus glabris, stipulis obovato-oblongis obtusis glabris, peduneulis terminalibus solitariis vel ternis, reeeptaeulo pubeseente, elavieulis calycis tetraëdris.

Arbuscula; rami erecti, tcretes, glabri, fusco-cinerei; ramulr compressi, bisulcati, nodis dilatati, glabri. Folı decussata, elliptica, raro ovalia vel obovata, acutiuscula, utrinque glabra, integerrima, margine subrecurva, 0,15 longa, 0,08 lata, coriacea, nervis primariis erectis, parallelis, prominentibus, nervis secundariis rectis vel subcurvatis; PETIoLI semiteretes, supra suleati, glabri, 0,026 longi. Stipulae interpetiolares, obovato-oblongae, obtusae, glabrae, 0,014 longae, 0,005 latae. Frores in capitulis globosis, solitariis ternisve, terminalibus conferti, in receptaculo sphaerico pubescente sessiles;

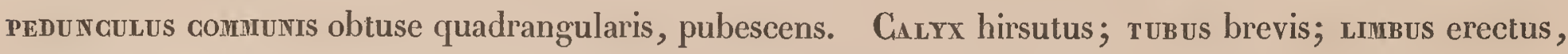
quinquepartitus: segmentis linearibus apice incrassatis in corpuscula tetraëdra cucullata terminatae. ConoLtA elongato-infundibuliformis, glabra, limbo erecto, segmentis ovatis obtusiusculis, 0,01 longa. STramira 5, cum segmentis corollae alternantia, infra faucem inserta; filamenta filiformia, brevia; antherae basi affixae, oblongo-ovatae, appendice truncato terminatae, basi cordatae, biloculares. Ovarium obconicum, glabrum, biloculare, pluriovulatum. Struds teres. - CAapsuda quinquangulari-pyramidalis, calyce quinquedentato hirsuto coronata, glabra, scpticida et loeulicida, bilocularis, crustacea. Placemtae compresse fusiformes. Senira plurima, imbricata, oblonga vel ovata, minuta; testa in alam periphaericam producta, cellulosa; TEgmen membranaeeum. NucLEUs oblongus.

\section{Crescit ad ripas fluminis Doesson: Borveo.}

\section{NAUCLEA OBTUSA. BL.}

N. ramulis glabris, foliis rotundato-elliptieis obtusiuseulis glabris, stipulis obovato-oblongis obtusis glabris, peduneulis terminalibus solitariis binis vel ternis, reeeptaeulo pubeseente, segmentis ealyeis tetraëdris.

Arbor; rami erecti, teretes, cinerascentes; ramuli compressi, glabriusculi, saepe terni. Folia decussata, rotundato-elliptica, obtusiuscula, basi angustata, utrinque glabra, nervis primariis erectis, prominentibus, nervis secundariis curvatis vix conspicuis, 0,18 longa, 0,11 lata; PETIOLI semiteretes, glabri, 0,04 longi. Strpulae interpetiolares, obovato-oblongae, obtusae, glabrae, 0,015 latae, 0,03 longac. Flores in capitulis globosis solitariis vel ternis congregati, in receptaculo subgloboso pubescente 
sessiles; pedurculus comurns obtuse quadrangularis, glabriusculus. CALYX aestivatione valvatâ, hirsutus; төвUs brevis, infundibuliformis; LInвus erectus, quinquepartitus, segmentis inaequalibus: duo ad quatuor lanceolata acuta, caetera lanceolata et angustata in appendices lineares corpusculis pyramidalibus basi excavatis terminata. Corolla aestivatione subvalvatâ, elongato-infundibuliformis, glabra, 0,009 longa; Lmibus erectus, quinquepartitus, segmentis subrotundatis acutiusculis. Stamira 5 , cum segmentis corollae alternantia; Filanevta in medio tubi corollae aflixa, brevia, glabra; ANThERAE basi affixae, late ovales, mucronulo brevi obtuso apiculatae, basi subcordatae, biloculares, loculis basi disjunctis apiceque conjunctis. Ovarium inferum, obconicum, pubescens, biloculare, pluriovulatum; ovula in placentis membranaceis imbricata. Struds cylindricus, glaber; stigma sphaericum. Gapsula obverse quinquangulato-pyramidalis, quinquesulcata, calyce incrassato dense hirsuto coronata, pubescens, loculicide-dehiscens, biloeularis, papyracea. Pracevtaf aflixae columellae filiformi apice incrassatae, lanceolatae, apice crassiores. Semrra placentas omnino tegentia, oblonga, utrinque acuta vel vertice acuta et basi obtusa; TESTA utrinque in membranam expansa; TEGMEN membranaceum. Nucleus compresse ovö̈deus, albumine periphaerico, embryone dicotyledoneo.

Crescit in sylvis montanis: $\mathbf{J}_{\mathbf{A v A} \text {. }}$

\section{NAUCLEA LANCEOLATA. BuUIE.}

N. ramulis glabris, foliis lanceolato-ellipticis obtuse acuminatis glabris, stipulis late obovatis obtusis glabris, pedunculis solitariis, receptaculo pubescente.

Arbuscula; rami erecti, cinereo-fusci, verruculosi, verruculis oblongis, glabri; Ramuli subcompressi, glabri. Folin subdecussata, lanceolato-elliptica, obtuse acuminata, utrinque glabra, in nervorum axillis pubescentia, 0,07 longa, 0,025 lata, nervis primariis paucis 7-9 erectis prominentibus, nervis secundariis subreticulatis; perroli semiteretes, glabri, 0,005 longi. Strpula interpetiolares, late obovatae, obtusae, glabrae, 0,007 longae, 0,005 latae. FLoR ES in capitulo sphaerico terminali congregati, in receptaculo subgloboso pubescente inserti; pedunculus communis obtuse quadrangularis, glaber. GaLyx hirsutus; тUвus brevissimus; LImbus quinquepartitus, segmentis inaequalibus: quaedam lanceolata acuta, caetera lanceolata et in fila angustata claviculis subrotundis sub excavatis terminata. CoroluA aestivatione subimbricatâ, infundibuliformis, intus glabra, extus hirsuta, 0,008 longa; LImbes erectus, quinquepartitus: segmentis ovalibus, obtusis. STAMrna 5 , infra faucem inserta, segmentis corollae alternantia; Filanenta glabra, brevia; antherae basi aflixae, ovales, obtusae, basi subcordatae, biloculares. Ovarium obconicum, hirsutum, breve, biloculare, pluriovulatum. Struos teres, glaber; stigria hemisphaericum, basi conicum. Capsirla pyramidiformis, calyce incrassato pubescente coronata, glabriuscula, bilocularis, loculicide dehiscens, quadrivalvis, papyracea. PLaCentae duae, afíxae columellae lineari ancipiti, tetraëdrae. SEmrs 6-10, imbricata, ovata; теsта cellulosa, in alam periphaericam vertice et basi magis elongatam expansa; TEGMEN membranaceum. NuCLEUs compresse sphaericus, albumine carnoso periphaerico, embryone dicotyledoneo.

Crescit in montanis: Java et Sumatra. 
De voorwerpen van Java en Sumatra, op ongeveer 500 tot 600 Ned. ellen hoogte verzameld, zijn niet van elkander te onderscheiden. Enkelen van het eerstgenoemde eiland verschillen van de anderen, door den meer langwerpigen vorm der bladen en der nevenblaadjes, terwijl zij in de overige kenteekenen overeenkomen. Dezc soort heeft de kleinste vruchten, welke naauwelijks 4 strepen lang zijn, en ook het geringste getal zaden. Daarentegen is bij haar de kern der zaden, in vergelijking tot de vliezige uitbreiding van de buitenste zaadhuid, zeer ontwikkeld, zoodat zij ongeveer de helft der geheele grootte van het zaad bedraagt, terwijl bij andere soorten de kern een vierde, of minder nog, der lengte van het zaad inncemt.

\section{STEPHEG YNE. KHS.}

Mitragyne Khs. Naucleac species Gaertner, Roxburgh, Wallich, De Candolle.

FLores supra receptaculum subglobosum commune aggregati, sessiles, bracteis cincti. CaLrX superus, tubo brevi, limbo integerrimo vel obsolete denticulato. Conolla aestivatione valvatà, tubo infundibuliformi, limbo quinquefido, erecto. Stamina 5, fauci corollae inserta; ficamenta brevia; antherae basi affixae, apiculatae. Ovarium biloculare, multiovulatum; ovula adscendentia, in placentis pendulis affixa. Strues teres; stigma mitraeforme. Capsula dicocca, coccis crustaceis bipartilibus. Senuva in placentis oblongis ab columellae apice pendulis aflixa; resta in marginem membranaceam expansa; teglien membranaceum. Albunen carnosum. Embryo in medio albuminis.

Arbores. Folia petiolata, costata. Stipulae interpetiolares. Frones capitati, bracteolati, terminales vel axillares.

\section{STEPHEGYNE SPECIOSA. KHs.}

S. foliis ellipticis glabris vel glabriusculis, stipulis oblongis acutis. Mitragyne speciosa Khs.

Arbor speciosa, saepe 15 metrorum; truncus rectus, subcylindricus, cortice subfusco, ligni fibris tenuibus; CORova hemisphaerica vel conica, in ambitu foliata, laete viridis; RaMI oppositi vel subverticillati, patentes, - superiores erecti, - obtuse quadrangulares, duobus lateribus oppositis sulcatis, cinerascentes; RAMuLi compresse quadrangulares, quadrisulcati, glabri. Folia versus apices ramorum decussatim disposita, opposita, elliptica vel ovata, acuminata, basi obtusa aut subcordata, utrinque glabra, juniora subtus pubescentia, subtus in nervorum axillis barbata, integerrima, 0,065 lata, 0,14 longa, nervis primariis in pagina inferiore costatim productis, inferioribus saepe subhorizontalibus et superioribus erectis, nervis secundariis subparallelis; PETIOLI semiteretes, supra plani saepe leviter sulcati, glabri, 0,03 longi; strpulae oblongae, acutae, subglabrae. Flores in capitulis terminalibus solitariis vel ternis congregati, sessiles in receptaculo hemisphaerico piloso, bracteis pluribus verticillatis spatulatis mucronulatis glabris cincti. Arabastrunt ellipsoïdeum. Calyx superus; tubus 
brevis, integerrimus. Coroula aestivatione valvatâ, extus glabra; тubus infundibuliformis, cylindricus vel subpentagonus, intus praesertim ad faucem hirsutus; unisus glaber, 4-5 partitus: segmentis oblongis, acutis, apicem versus subcarnosis. Stanirva 4-5, in fauce corollae segmentis alternantia; FItamenta linearia, brevia; ANTHERAE paulo supra basin affixae, oblongae, apice connectivo producto mucronulatae, basi obtusae, biloculares, loculis parallelis approximatis, longitudinaliter dehiscentes. Pouter sphaericum, leviter madefactum unimammillatum. Discus subpelviformis, saepe pentagonus. Ovariur obconicum, pentagonum, glabrum, biloculare, loculis multiovulatis; ovula adscendentia, placcntis subcylindricis descendentibus affixa. STruts teres, utrinque attenuatus, glaber; strans mitraeforme, cavum, apice apertum. Capsula sessilis, obovoïdea, saepe elongato-cordiformis, costata, calyce persistente coronata, nigrescens, glabra, septicida, dicocca: coccis cndocarpio crustaceo, columellae affixis, extus rotundatis, intus planis et ibidem ab apice inde dehiscentibus. Sxurrva numerosa, placentis semiteretibus basi cum appendiculo hastato munitis affixa, adscendentia, imbricata, elongatoobovata, obtusa, ambitu membranacea. Nucleus in medio seminis, ovoïdeus.

\section{Crescit ad ripas fluminis Doesson, etc. Bonneo.}

Tab. 35. Figura speciei. 1. Flos. 2. Corollae pars. 3. Ovarium longitudinaliter sectum. 4 et 5. Capsulae. 6. Coccae, capsulâ ab epicarpio denudatâ. 7. Cocca cum columella intus visa. 8. Coccae dimidia pars cum columella. 9. Placenta cum scminibus. 10. Placenta, seminibus ablatis. 11. Semen valde auctum. 12. Nucleus verticaliter sectus.

De voorwerpen van Banjermassing en van Mantalet, beiden moerassige streken, verschillen van die, welke te Martapoera, op droogen grond verzameld zijn, in de grootte der bloemen. Dit verschil is echter niet zeer opmerkelijk.

\section{STEPHEGYNE PARVIFOIIA. Krs.}

S. foliis ovatis vel obovalibus obtusis subtus pubescentibus, stipulis obovatis obtusis.

Nauclea parvifolia Willd. Spec. Plant. I. pag. 929; Roxburgh. Plants of Corom. I. pag. 40. Tab. 52; Roxb. Flora Indica I. pag. 513; De Candolle. Prodr. IV. pag. 344; Wight et -Arnott. Prodr. penins. Indiae I. pag. 391 ; Nauclea orientalis Gacrtner de Fruct. et Seminibus I. Tab. 30.

\section{Colligitur in sylvis humilioribus provinciae Krawang: $\mathbf{J}_{\mathbf{A V A}}$.}

Ecn bloeijende tak dezer plant is door Roxburgh, en de vruchten, benevens de zaden en derzelver zamenstelling, zijn door Gaertner afgebeeld. Dit een en ander, gevoegd bij de uitvoerige beschrijvingen, door deze Kruidkundigen gegeven, maakt de verdere opgave der kenteekenen overbodig.

Dezc boomen groeijen in de lagere, moerassige streken van de Residentic Krawang. Zij blocijen tegen het einde van den regentijd. Hun hout is zeer fijn van draad, zacht en gemakkelijk te bewerken; doch niet bestand zijnde tegen de vochtigheid der lucht, wordt hetzelve alleen voor doosjes en dergelijke huishoudelijke voorwerpen gebezigd. 


\section{U NCA R I A. Schreber.}

Schreber. Grenera n. 311; Wallich et Roxburgh. Flor a Indica. 2a ed. II.p. 125; De Candolle. Prodrom us IV.p. 347.

Flones supra receptaculum subglobosum commune, pedicellati, raro sessiles. GaLrx superus, tubo brevi, limbo quinquedentato vel partito. CorouLA aestivatione imbricatâ, tubo infundibuliformi, limbo quinquepartito. Stamuna 5, fauci corollae inserta; FILAMIENTa brevia; antherae basi affixae, basi biappendiculatae. Ovariun biloculare, pluriovulatum; ovula in placentis semitcretibus in medio partis planae loculi affixis inserta, adscendentia. Styuus teres; stigna clavatum. Carsula stipitata vel sessilis, dicocca, coccis bipartilibus. Semura numerosa, raro definita, placentis semiteretibus utrinque attenuatis affixa; TESTA basi in membranam bifidam, apice in membranam integram expansa; TEGMEN membranaceum. Embnyo in medio albuminis carnosi, erectus.

Frutices scandentes. Fours opposita. Strpulat interpetiolares, saepe bifidae. Flores capitati, axillares; PEDunculi steriles uncinati.

De gewassen van het geslacht Uncaria zijn allen slingerende struiken. Hunne stammen hebben dikwerf 0,15 N. E. omtrek, bestaan uit ecne dikke, gespleten, kurkachtige schors, een zeer los hout en roud of hoekig merg. De vierkantige vorm is aan den stam minder duidelijk, dan aan de takken. Die vorm vcrtoont zich bij de takken dikwerf met zeer scherpe hoeken, en gaat bij de jongere takken in een langwerpig vicrkant over, zijnde zij naar hunne einden platgedrukt, met scherpe hoeken. De knoppen zijn zamengedrukt, bestaan uit twce tegenover clkander staande nevenblaadjes, welke zelden met de randen zijn zamengegroeid, doch meestal bij den toenemenden groei der in hen beslotene blaadjes, in twee deelen splijten en vervolgens afvallen. De bladen staan juist tegenover elkander. Bij eenige soorten: Uncaria Hallii, enzv. zijn zij vrij groot, dik, lederachtig en, vooral wanneer deze planten op opene, zonnige plaatsen grocijen, zeer glanzig; bij anderen zijn zij van eene dunnere zelfstandigheid: Uncaria ferrea, enzv. Deze laatsten hebben de nerven netsgewijze verdeeld en verbonden; de eersten hebben ze evenwijdig, soms als ribben blootliggende. De bladstelen zijn meest half rolrond, van boven gevoord. Uit hunne oksels komen de bloemdeelen, welke meestal alleen, zelden gepaard of in grooter getal aanwezig zijn. Aan de jongere planten groeijen de bloemstelen reeds uit; doch zij worden dan slechts haken, waardoor de plant, bij hare verlenging, aan nevenstaande gewassen steun vindt. De oudere planten hebben gewoonlijk den eenen bloemsteel bloemdragend en den tegenoverstaanden in de gedaante van een' gebogen haak; soms zijn de beide bloemstelen bloemdragend, en dit meest aan de uiteinden der planten of wanneer deze langs den bodem slingeren.

Op eenen ongelijken afstand van het begin en van het einde dragen de bloemstelen een vier- of zesdeelig omhulsel, dat in den jeugdigen staat geheel is zamengegroeid en de bloemen omvat. De meeste soorten hebben dit omhulsel zeer klein en lederachtig; anderen vliezig en aanzienlijk uitgegroeid: U. ferrea, U. glabrata. De bloemstelen eindigen in een' min of meer regelmatig ronden knop. Op hen zitten de bloemen meestal aan kleine steeltjes, welke zeer zelden twee bloempjes dragen, zelden zonder steeltjes. Zij bestaan uit eenen boven het vruchtbeginsel zittenden kelk. Bij eenige soorten heeft deze eene trech- 
tervormige buis en den zoom in vijf tanden verdeeld: U. Hallii, enzv.; bij anderen is die buis zeer klein en de zoom in vijf deelen verdeeld: U. canescens, enzv.; en bij nog anderen bestaat de kelk alleen uit vijf deelen: U. ferrea, enzv. De slippen van den kelk staan meestal klepvormig. De bloemkroon is min of meer regelmatig trechtervormig. Zij heeft den zoom in vijf deelen verdeeld, en deze vóór de opening als dakpannen geplaatst. Naar de opening, tegenover de insneden, draagt zij de meeldraden, welke uit zeer korte helmdraden en aan den voet vastgehechte helmknopjes bestaan. De laatsten zijn langwerpig ovaal, hebben de stuifmeelhokjes beneden in kleine puntjes uitloopende, en den helmknoop toegespitst of puntig. In de tweehokkige vruchtbeginsels zijn de placentae, in het midden van den tusschenwand, aan een uitstekend randje bevestigd en door de eitjes bedekt. De vruchten hebben eenen verlengden eivorm, tien ribben, en zijn van den terugblijvenden kelk voorzien. Zij zijn zamengesteld uit een lederachtig sarcocarpium en mesocarpium, en uit een kraakbeenig endocarpium, en verdeeld in twee hokjes, welke door het laatste worden gevormd. Zij scheiden, door de scheuring van den tusschenwand, in twee deelen, zonder standertje na te laten. Ieder dezer deelen springt aan de binnenzijde, in den naad, tegenover de placentae, en aan de buitenzijde, tot op het midden, soms niet zoo diep, soms dieper, open. De placentae zijn na de opening der vruchten geheel vrij. Haar vorm is half rolrond, aan de einden min of meer toegespitst, en aan de binnenzijdc van twee kleine voren voorzien. Op dezelve zijn de zaden aan het benedeneinde vastgehecht. Bij de meeste soorten hebben zij het naar boven gerigte gedeelte onverdeeld en het andere in tweeën gespleten. Deze uitgegroeide gedeelten worden door de testa gevormd, en geven aan het wezentlijk gedeelte van het zaad, waar de eivormige kern ligt, eene lijnvormige gedaante. Het uitgegroeide gedeclte van de testa bestaat uit lange buizen; het andere, dat de kern omringt, uit hoekige cellen. Het tegmen is zeer fijn en, alleen bij eene sterke vergrooting, als een celachtig weefsel erkenbaar.

In het algemeen ontwikkelen deze gewassen hunne bladen voornamelijk in den regentijd en bloeijen zij in het drooge jaargetijde. Hunne vruchten komen ongeveer drie tot vier maanden na het bloeijen tot rijpheid.

De soorten van het geslacht Uncaria, zoo als zij worden opgegeven, zijn in Zuid-Amerika, op het vasteland van Indië en in den Indischen Archipel, tot aan Nieuw-Guinea gevonden. De Archipel is echter het ware vaderland van dit geslacht. Zijne soorten behooren daar, vooral op de groote Sundaeilanden, te huis, en zijn van het zeestrand tot op ruim $1000 \mathrm{~N}$. ellen verzameld. Hare groeiplaats is zoowel op de opene velden, als in de bosschen. Op de eersten ontwikkelen zich vooral de bloemen en de bladen; in de laatsten heeft eene meerdere uitgroeijing van de steng plaats. Zij staan in de bosschen niet zelden alleen; daarentegen zijn er op opene plaatsen dikwerf eenigen bij elkander, tusschen de kleine groepen van struiken verspreid.

Het geslacht Uncaria verschilt van Platanocarpum en Anthoeephalus, door de openspringende vruchten; van Nauclea en Stephegyne, door het gemis van het standertje tusschen de beide hokjes van de vrucht, en van alle de opgenoemden, door de aan deze gewassen eigene slingerende groeiwijze. 


\section{UNCARIA FERRUGINEA. BD.}

U. calyce infundibuliformi limbo partito, ramulis pubescentibus, folis ovatis acutis basi obtusis vel subcordatis supra nitidis subtus pubescentibus, fructubus stipitatis.

Nauclea ferruginea Blume. Bijdragen tot de Flor. v. Neerl. Indië, pag. 1013; De Candolle. Prodromus. Tom. IV. pag. 348.

Cavlis seandens, subtetragonus, cortice fusco, suberoso; RAMuli tetragoni, fusco-pubeseentes: pili sparsi vel aggregati; RAmulr tetrangulares vel subcompressi, aneipites, pubescentes. Foura ovata, acuta, raro breviter acuminata, basi obtusa vel subcordata, supra glabra nervis pubescentibus, subtus fusco-pubescentia, 0,095 longa, 0,055 lata, nervis primariis subparallelis, nervis secundariis parallelis, approximatis; petroli semiterctes, supra plani, pubescentes, 0,01 longi. STrpUlaE semirotundae, obtusiusculae, in ramis adultioribus bifidis, supra glabriusculae, subtus pubescentes. Pedunculi comrumes axillares, basi compressi, versus apicem subteretes, sulcati, fusco-pubescentes. Urcr pedunculanei axillares, compressi, attcnuati, sulcati, fusco-pubescentes. Irvolvcrum floribus approximatum, utrinque pubescens, deciduum, 4-6 partitum: partes ovatae, acutae. Pedurculi partiales in summo capituliformi pedunculi communis aggregati, tetragoni, pubeseentes, juniores breves, adultiores longi. Alabastrum constrictum: pars inferior obscure pentagona, fumeo-pubescens; pars superior ovoïdea, badio-pubescens. CALYX infundibuliformis, leviter quinquecarinatus, pubescens, limbo quinque-fido vel profunde-dentato: partes aestivatione valvatâ et induplicativâ, acutae. ConoLLA aestivatione imbricatâ, elongato-infundibuliformis, extus ferrugineo-pilosa, intus glabra; тuвus gracilis, 0,012 longus; LInвus quinquepartitus: partes rectae, oblongae, obtusae. Sт corollae alternantia; FILAMENTA brevissima; ANTHERAE basi affixae, lineari-oblongae, obtusae, biloculares: loculis approximatis, linearibus, basi in subulas productis. Ovarium inferum, rotundato-pentagonum, quinquesulcatum, badio-pubescens, quinqueloculare: loculis multiovulatis. Struos teres. Stiqma oblongo-ovoïdeum. Capsula plantae Borneënsis ellipsoïdea, decemsulcata, calyce persistente munita, dense badio-pubescens, bilocularis, loculicida, bivalvis: valvulae bifidae. SEMra numerosa, placentis lineari-lanceolatis apice subulatis basi aeutis affixa, adscendentia, subrotunda, utrinque in appendicem linearem protensa, scrobiculata; TESTA et TEGMEN membranacea.

\section{Crescit in locis humilioribus: Java, Sunitra, Borneo.}

De voorwerpen van de drie genoemde eilanden verschillen weinig in uiterlijk aanzien; doch leveren, bij eene naauwkeurige vergelijking, eenige kleine kenmerken ter onderscheiding. Die van Sumatra hebben de bloemstclen en de kelken iets langer, dan die van Java; aan die van Borneo zijn daarenboven de bloemkroonen ten naastenbij de helft langer, en de bladen van eenen langwerpig ovalen vorm, welke, aan den top afgerond zijnde, de voorwerpen een eigenaardig aanzien geeft. Die van laatstgenoemd eiland hebben aan de takjes, op Martapoera verzameld, de bloemkroonen iets korter dan die, welke wij langs de Doeson plukten. 


\section{UNCARIA HALLII. KHS.}

U. calyce campanulato limbo partito, ramulis glabriusculis, foliis ovato-rotundatis acutis basi obtusis subtus pubescentibus, nervis secundariis approximatis, fructubus stipitatis.

GAULIS tetragonus; RAMI obtuse quadrangulares, glabri vel glabriusculi; RANuLI quadrangulares, subsulcati, pubescentes. Folis opposita, ovato-rotundata, saepe rotundato-ovata, acuta, basi obtusa vel subcordata, supra nitida, subtus fumoso-pubescentia, 0,09 lata, 0,12 longa, nervis primariis et nervis secundariis approximatis parallelis; PETrou subteretes, glabri, 0,02 longi. StrPuLAe subintrapetiolares, bifidae: laciniae ovato-oblongae, acutae, supra glabrae, subtus pubescentes. Uvar pedunculanei, compressi. Pedunculus comnunis axillaris, basi compressus, versus apicem subteres, subglaber. Involucrum quadri- sex-partitum: laciniae ovatae, acutae, utrinque badio-pubescentes. Pedunculi partiales in receptaculo subgloboso dense pubescente inserti, obtuse quadrangulares, badio-pubescentes. Alabastrum pentagono-oblongum, subconstrictum. CALYX elongato-campanulatus, intus badio-pilosus, extus fumoso-pubescens, aestivatione valvatâ; LIMBưs quinquepartitus: laciniae triangulares, acutae. CoroLtı infundibuliformis, intus glabra, extus dense pilosa, limbo quinquepartito: laciniae ovales, obtusae, margine glabrae, aestivatione imbricatâ. Stamina quinque; milmenta fauci corollae inserta, cum laciniis alternantia, brevissima; ANTHERAE basi affixae, oblongae, obtusae, biloculares: loculi paralleli, sejuncti, apice approximati vel connati, lineares, basi subulati. Ovarium oblongum, obtuse quinquangulare, fusco-pubescente, biloculare: loculi multiovulati; ovuls in placentis semiteretibus affixa. Struds teres. Stigma ovoïdeum, apice subexcavatum. Capsula calyce munita, elongato-ellipsoïdca, decem-costata, badio-pubescens, bilocularis, septicida, endocarpio secedente, apice bifido. Placeitae lanceolato-lineares, acuminatae. Seniva numerosa, erecta, subrotunda, utrinque in membranulas lineares expansa. Albumen carnosum, album. Enibryo ovoïdeum; cotyledones et radicula obtusae.

\section{Crescit ad flumen Doesson: Bonveo.}

Explicatio Tabulac 33. Figura Uncariae Hallii. 1. Alabastrum. 2. Flos expansus. 3. Corollac pars cum staminibus. 4. Calyx et ovarium dissectum. 5. Ovarium in Iongitudine dissectum. 6. Ovarii transversalis sectio.

7. Ovulum. 8. Fructus. 9, 10. Fructus dchiscentes. 11. Valva unica intus visa, cndocarpio scjuncto. 12. Endocarpium. 13. Placenta. 14. Placentae pars admodum aucta. 15. Semen valdc auctum. 16. Semon dissectum. 17. Syınmctria floris.

Deze plant, een der schoonste slingergewassen, door ons langs de Doeson-rivier gevonden, heb ik genoemd naar den Hoogleeraar H. C. van Hall, welke als onvermoeid en gelukkig bevorderaar der Kruidkunde in het algemeen en van onze inlandsche gewassen in het bijzonder, bekend en geacht is. Moge hem deze toewijding, als eene erkenning zijner edele pogingen, aangenaam zijn en tevens ten bewijzc verstrekken, dat een zijner vroegere leerlingen zich dankbaar de oogenblikken herinnert, waarin denzelven een deel van het groote boek der natuur, uit zulk een veelvormig en veelkleurig schrift te zamengesteld, door hem werd verstaanbaar gemaakt. 


\section{UNGARIA NEMOROSA. KHS.}

U. calyce campanulato limbo partito, ramulis subglabris, foliis rotundato-ovatis acuminatis basi subcordatis subtus hirsutiusculis, nervis secundariis distantibus, fructubus stipitatis.

CuULIS scandens; RAMr obtuse quandrangulares, glabri; RAMULr acute quadrangulares, subglabri. FolI opposita, rotundato-ovata, breviter acuminata, basi subcordata, supra glabra, in nervo medio pubescentia, subtus hirsutiuscula, coriacea, 0,09 lata, 0,14 longa, nervis primariis et nervis secundariis distantibus, parallelis; Petroli semiteretcs, supra subpilosi, subtus pubescentes, $\mathbf{0 , 0 0 5}$ longi. StrpdraE subinterpetiolares, ovatae, profunde bifidae: laciniae lanceolatae, supra glabriusculae, subtus basi fusco-pilosae. Pedungulus communis axillaris, compresse-tetragonus, fusco-pubescens. Involucrum 4-6 fidum, laciniis lanceolatis, acuminatis, utrinque pubescens. - Frorum structura nondum explicatorum vix ab Uncariae Hallii floribus diversa.

Crescit in sylvis montis Singalang: Sumatra.

\section{UNGARIA PEDIGELlatA. Roxburgh.}

U. calyce campanulato limbo partito, ramulis hirsutis, foliis ovatis acutis basi cordatis supra nitidis subtus pubescentibus, fructubus stipitatis.

Roxburgh. Flora Indica. Il. pag. 520; Dc Candolle. Prod. IV. pag. 348; Nauclca pedicellata Blumc. Bijdragen, b]. 1013

Cadus scandens, compresse-quadrangularis, cortice fusco-suberoso; Ramr obtuse quadrangulares, subglabri; RAMULI ADULTIORES acute quadrangulares, suleati, ferrugineo-hirsuti; RaMULI NovelLi compresse quadrangulares, dense hirsuti. Fouıs opposita, ovata, saepe oblongo-ovata, acuta, basi cordata vel obtusa, supra nitida, in nervis medio et primariis dense ferrugineo-pubescentia, subtus laete fuscopubescentia, 0,14 longa, 0,11 lata, nervis parallelis; peTIouI subteretes, ferrugineo-pubescentes, 0,015 longi. Strpulae interpetiolares, profunde bifidae: laciniae semilanceolatae, pubescentes. Pedunculus communis axillaris, raro terminalis, compressus, versus apicem teres, subsulcatus, dense ferrugineo-hirsuto-pubescens. Involucruni tetra- hexa-fidum: laciniae ovatae, acutae, fusco-pubescentes. Peduncula partiales subteretes, fusco-pubescentes. Calyx clongato-campanulatus, quinquecostatus, extus fusco-pubescens, intus glandaceo-pubescens, limbo quinque-partito vel profundc-dentato: laciniac acutae. Corollı aestivatione subimbricatâ, clongato-infundibuliformis, limbo quinquepartito: laciniae oblongae, obtusae, intus glabrae, cxtus dense pilosae. Stanrrva quinque, lacinïs corollae alternantia; FILAMENTa fauci corollae inserta, brevia; ANTHERaE basi affixae, oblongae, obtusae, basi cordatae, segmentis subulatis, biloculares: loculi approximati, rimis longitudinalibus dehiscentes. Polcen sphaericum. Ovarion oblongum, obtuse quinquangulare, albido- vcl fusco-pubescens, biloculare, multiovulatum. Struus teres, glaber. Stigma ovoideum, subpentagonum. Ca psula et semina cum praecedente specie conformia.

Crescit in fruticelis regionum humiliorum: $J_{\mathbf{A V A}}$, Borneo, Sumatra. 
Tusschen de voorwerpen van Java en Borneo bestaat geen verschil, hetwelk tot derzelver onderscheiding zou kunnen aanleiding geven; tusschen deze en die van Sumatra meende ik eerst genoegzaam verschil, om hen als soorten te onderscheiden, gevonden te hebben, in de diepere indeelingen van den kelk, in deszelfs vorm en in dien der vruchten, welke meer verlengd is. Beide deze afwijkingen zijn echter niet van die waarde, dat zij de Uncaria eumececarpa kunnen doen behouden, daar ik bij enkele voorwerpen overgangen tot den gewonen, meer gedrongen vorm heb waargenomen.

Op onbeschaduwde plaatsen, vooral op opene, met enkele groepen van boomen en struikgewassen begroeide vlakten der lagere streken, is de Uncaria pedicellata, als gezellig groeijende plant verspreid, en bereiken hare bladen en bloemen eene aanzienlijke ontwikkeling. Zij klimt bier, door de haakvormig uitgegroeidc, onvruchtbare bloemstelen ondersteund, tot in de hoogste boomen, of kruipt, wanneer deze middelen ter ondersteuning van de zwakke steng ontbreken, langs den grond.

\section{UNCARIA GAMBIR. Hunter.}

J. calyce campanulato profunde dentato, ramulis subglabris, foliis ellipticis obtuse acuminatis utrinque glabris, fructubus stipitatis.

Hunter in Linn. Transactions. IX. pag. 218, Tab. 22; Roxburgh. Flora Indica. II. pag. 517; De Candolle. Prodromus etc. IV. pag. 347.

GAULIS scandens vel culturâ frutescens; RAmI obtuse quadrangulares vel subteretes, fusci, glabri; RAMULI quadrangulares, subsulcati, subglabri. Folia opposita, elliptica, breviter obtuse acuminata, basi angustata, utrinque glabra, subtus in nervorum axillis barbata, 0,09 longa, 0,05 lata, nervis primariis costatim prominentibus, nervis secundariis linearibus, vix prominentibus; PETrour semiteretes, supra plani, bisulcati, subglabri. Strpulae interpetiolares, ovatae, obtusae, raro bifidae, supra sparsim pubescentes, subtus glabriusculae. Pedurculus connunis axillaris, compressus, versus apicem teres, glaber. Uvcus pedunculaneus, compressus, attenuatus. INvoudGrun quadripartitum, laciniae inaequales: duae minores lanceolatae; duae majores ovatae, obtusiusculae, utrinque glabriusculae, ciliolatae. Pedurculi partiales in capitulo hemisphaerico subpubescente aggregati, subteretes, subpubescentes. Arabastruar obconö̈deum, quinquecostatum, griseo-pubescens. Callyx aestivatione valvatâ et induplicativâ, campanulatus, limbo quinquedentato partitove: laciniae dentesve oblongae, apice incrassatae. Conolla aestivatione imbricatâ, elongato-infundibuliformis, limbo quinquepartito: laciniae oblongae, obtusae, intus glabra, extus subsericea. Stamiva quinque, laciniis corollae alternantia; Filanerta fauce corollae inserta, brevia; ANTHERAe basi affixae, ovato-oblongae, basi subcordatae cum subulis duabus, biloculares: loculi approximati. Struds teres, glaber; strgnia ellipsoïdeum. Ovariuni obconicum, quinquecostatum, subsericeum, biloculare, multiovulatum. CA PsULA calyce munita, ellipsoïdea vel elongato-ellipsoïdea, saepe compressa, bisulcata, laevia vel quinquecarinata, glabriuscula, apice dense fumoso-pubescens, bilocularis, septicida. Pracerta lineari-lanceolata, utroque subulata. Senrra numerosa, adscendentia, subrotunda, utroque in membranas lineares extensa. Eurpro in medio albuminis carnosi, ovoïdeus.

Collegi juxta Siri-Lama: Sumatra. 
Tab. 34. 1-2. Figura specici. 1. Flos nondum expansus. 2. Floris pars intus visa. 3. Ovarium verticaliter sectum, stylus ct stigma. 4. Fructus immaturus. 5. Fructûs immaturi sectio transversalis. 6. Capsula dehisccns. 7. Capsulae dimidia pars intus visa. 8. Capsulae sectio transversalis. 9. Semen valde auctum. 10. Semen testâ ablatâ. 11. Nucleus verticaliter sectus.

Volgens sommigen groeit de Uncaria Gambir wild op de eilanden rondom het schiereiland Malacca. In hoeverre deze opgave waar zij, zal door de aldaar gevestigde of reizende Natuuronderzoekers moeten bevestigd worden. Zeker is het echter, dat deze plant vroeger op Sumatra, Malacca, Bintang, enzv. werd gekweekt; dat deze teelt nu op Bintang en Singapoera eene aanzienlijke uitbreiding heeft verkregen en op eenige plaatsen van Malacca en Sumatra nog wordt voortgezet. Op het laatstgemelde eiland is zij door mij te Siri-Lama, een distrikt van de vijftig Kottas, op ruim 400 N. ellen boven zee gelegen, waargenomen. $\mathrm{Z}_{\mathrm{ij}}$ is zeer eenvoudig. De zaden worden op een met zorg bewerkt stukje grond gezaaid en de jonge plantjes blijven daar, tol zij zes tot acht Nederlandsche duimen hoog zijn. Dan worden zij, ten einde de worteltjes niet te beschadigen, met veel voorzigtigheid overgeplant en gewoonlijk op drie voet afstands van elkander gezet. In den eersten tijd ua die verplanting, worden deze plantsoenen zeer zuiver gehouden; later echter doet het onkruid aan de groeijende boompjes minder nadeel. Ongeveer twee en bij sommigen eerst drie jaar na de overplanting, begint de planter voordeel van zijnen arbeid te trekken, ter bereiding van den Gambir. De boompjes worden dan twee-, drie- of viermaal 's jaars van hunne bladen of ook wel van de jonge loten beroofd. Diegenen, welke slechts tweemaal oogsten, beweren, dat zij daardoor hunne aaxplantingen langer behouden en bijna dezelfde voordeelen genieten als diegenen, welke hunne boomen meermalen ontbladeren. Beiden hebben de gewoonte, zulks tegen den regentijd te verrigten, alswanneer zij dan tevens een groot gedeelte der takken wegsnijden. Deze bladen en takken worden met water gekookt en het dus verkregen vocht vervolgens uitgedampt, tot de dikte van siroop, en in houten bakjes of bamboezen kokers gegoten, ten einde te stollen. Verkoeld zijnde, wordt de verkregene stof in kleine vierkante stukjes of in ronde schijfjes gesneden. De Gambir van Singapoera en Bintang komt onder den eersten vorm voor, is bruin, doch niet geheel oplosbaar, misschien wel door de bijgevoegde Sago, welke aan denzelven meerdere vastheid geeft. De Gambir van Siri-Lama is in schijfjes, bruin-geel, meer oplosbaar en zuiverder van smaak: eigenschappen, welke de bewoners aan eene meerdere zorgvuldige bereiding en vooral aan eene schielijker koking toeschrijven.

Het distrikt, waar ik dezen tak van landbouw heb waargenomen, heeft eenen kiezelaardigen ijzerhoudenden bodem, en is niet bijzonder geschikt voor de aankweeking van andere gewassen. Even zoo moet het met de andere streken zijn, waar de Gambir wordt aangebouwd en hij, benevens de peper, de voornaamste middelen van bestaan oplevert. In vergelijking met deze laatste aangekweekte plant zoude de Gambir, volgens de ingewonnen narigten oordeelende, niet zoo veel voordeel geven. Want alsdan levert een stuk grond, hetwelk op Malabar 174 N. p., en op Poeloe Pinang, door de Chinezen bewerkt, 580 N. p. peper opbrengt, slechts 125 N. p. Gambir. Vermoedelijk zal echter de nijverheid der Chinezen op Bintang en Singapoera het voortbrengsel aanzienlijk hebben vermeerderd. Op deze laatste eilanden wordt de bereiding in het groot gedreven, en misschien wel overdreven; omdat het 
gebruik van den Gambir met de betelbladen, kalk en tabak, eene soort van weelde is en zijne grenzen heeft. De Gambir van Bintang wordt voor een gedeelte naar Java vervoerd en het overige brengen inlandsche kooplieden naar de oostelijke deelen van den Archipel, of wel wordt in jonken naar China, enzv. gezonden. Die van Singapoera wordt in dezelfde streken afgezet, en is ook reeds naar Engeland verzonden, ten einde te beproeven, of hij daar, als looistof aangewend, de eikenschors, van welke acht ponden niet meer looistof bevatten, dan één pond Gambir, zoude kunnen vervangen. Het schijnt echter, dat deze proef, uithoofde der hooge regten, welke op den invoer van den Gambir geheven worden, bedragende dezelve twee ponden sterlings per honderd $\mathbf{N}$. ponden, tot geene gunstige uitkomst aanleiding heeft gegeven.

De oorsprong van dezen tak van landbouw moet waarschijnlijk bij de volkplanters worden gezocht, die zich van het vasteland over den Archipel verspreid hebben. Zij hadden in hun vaderland eenen boom, onder den naam Khădir, Khādir of Khocdir (Mimosa catechu Roxb.), uit welken zij, door koking, de Khadirasara of geest van den Khadir vervaardigden. Dezen naam bragten zij mede, en op de eilanden vonden zij bladen van planten in gebruik, onder den naam $\mathbb{K} a t j a$ of $\boldsymbol{K}$ atjoe, of, naar de Engelsche spelling, Katcha of $\boldsymbol{K}$ atchoe, welke de Indianen hunne $\mathbb{K}$ hadirasara herinnerden. Zij kwamen op het denkbeeld, om hetgeen zij in hun vaderland met den stam van den Khadir deden, in hunne nieuwe woonplaats met de planten, welke de $K$ atjoe-bladen leverden, te beproeven, en gaven aan het voortbrengsel den naam Khadir, die in Gambir is overgegaan. - De naam Catechu, welken de Gambir in Europa draagt, staat vermoedelijk in verband met het gemelde $\boldsymbol{K} a t j a, \mathbb{K}$ atjoe, beiden van Sanskritschen oorsprong. Het eerste beteekent blinken, en dus aan eene eigenschap der bladen ontleend; het andere duidt binden aan, naar de groeiwijze dier planten, wanneer zij aan zichzelven zijn overgelaten.

\section{UNCARIA DASYONEURA. KHs.}

U. calyce campanulato limbo dentato, ramulis glabris, foliis ovalibus obtuse acuminatis supra glabris subtus in nervis hirsutis, stipulis suborbiculatis.

Gadurs frutescens. Rami obtuse quadrangulares, sulcati; Ramuli obtuse quadrangulares, sulcati, glabri. Fous opposita, ovalia, obtuse acuminata, basi angustata, supra glabra, subtus in nervis, praesertim in nervo medio hirsuta, nervis primariis distantibus, prominentibus, nervis secundariis subparallelis vix conspicuis, 0,085 longa, 0,05 lata; ретіоц semiteretes, supra plani bisulcati et glabri, subtus rotundati et hirsuti. Strpulae intrapetiolares, suborbiculatae, utrinque glabrae. Pedurculus communis axillaris, parte inferiore compressus, angustatus, glaber; parte superiore subteres, fumosopubescens. Irvolucrun inaequaliter quadripartitum: partes duae minores oblongae, partes majores ovatae, acutiusculae, glabrum. Pedurculi partianes in receptaculo hemisphaerieo inserti, brevissimi, fumoso-pubescentes. CALYx campanulatus, limbo obsolete quinquedentatus: dentes obtusae, intus glaber, extus pubescens. Corolda elongato-infundibuliformis, intus glabra, extus pubescens, limbo quinquepartito: laciniis obovatis, obtusis. Stramiva quinque, laciniis alternantia; fitantrenta fauei coBotanica. 
rollae inserta, brevia; ANTHERAe basi aflixae, oblongae, obtusae, basi eordatae et bimueronulatae: mucronulae breves, biloculares. Ovarium oblongo-ovoïdeum, dense fumoso-pubeseens, biloeulare. Strutus teres, glaber. Stigin elavaeforme.

Crescit ad ripas fluminis Salaut: Sumatra.

\section{UNCARIA ATTENUATA. Kus.}

U. calyce campanulato limbo dentato, ramulis pubescentibus, foliis ellipticis obtuse acuminatis supra glabris subtus pubescentibus, stipulis oblongo-ovatis.

CAULIS fruteseens, scandens; RAMI obtuse quadrangulares, subglabri; RAmULI tetragoni, sulcati, dense fusco-pubescentes. Foris opposita, elliptica, breviter obtuse acuminata, supra glabra, subtus pubeseentia et in nervorum axillis pilosa, 0,12 longa, 0,05 lata, nervis primariis et nervis secundariis approximatis parallelis; petioli semiteretes, supra plani, pubeseentes, 0,015 longi. Stipulae interpetiolares, oblongo-ovatae, obtusae, utrinque badio-pubeseentes. Peburcurus comuris axillaris, parte inferiore eompressa, parte supcriore subterete, dense pubescens. Invouvgrum badio-pubescens, quadripartitum: partibus inaequalibus: duae ovatae, obtusae, caeterae oblongae. Penurcuri partiales in receptaculo hemisphaerico inserti, subteretes, pubescentes. CAIrX aestivatione valvatâ imbricatâve, campanulatus, limbo quinquedentato: dentes obtusae, intus glaber, extus laete fusco-pubescens. Corolda elongato-infundibuliformis, intus glabra, extus cinereo-pubescens, limbo quinquepartito: laciniae obovatae, obtusae, margine recurvae. Sta Mrva quinque, cum lacinïs corollae alternantia; Filamenta fauci corollae inscrta; antherae basi affixae, oblongae, obtusae, basi cordatae segmentis mueronulatis, biloculares: loeuli lineares, paralleli, in connectivo oblongo affixi. Ovariun ellipsoïdeum, fusco-pubescens, biloculare. Struus filiformis, glaber; stigma elongato-clavaeforme.

Crescit ad flumen Salaut, in sylvis Melintang: Sumatra.

Tab. 34. 3. Figura hujus speciei.

Van deze soort hebben wij twee vormen verzameld. De een, langs de rivier Salaut gevonden, heeft de bladen langwerpig-elliptisch; de ander, in het gebergte Melintang groeijende, rondachtig-elliptisch, iets grooter dan de eerstc.

\section{UNCARIA CALLOPHYLLA. BuUME.}

U. calyce partito partibus oblongis, ramulis glabris, foliis ellipticis obtuse acuminatis utrinque glabris, fructubus stipitatis.

Rami obtuse quadrangulares, sulcati, glabri; RAmuli compressi, obtuse quadrangulares, sulcati, glabri.

Fous opposita, elliptica, saepe lanceolato-elliptiea, obtuse acuminata, utrinque glabra, subtus in axillis 
nervorum primariorum barbata, 0,07 longa, 0,03 lata, nervo medio et nervis primariis rufis, nervis seeundariis approximatis parallelis tenuibus; Petroli semiteretes, supra plani, glabri. Peduraulus courMUNIs axillaris, basi compressus, versus apieem subteres, fumoso-pubescens. Urvos pedunculaneus attenuatus, eompressus, pubescens. CALrx quinquepartitus: laeiniae oblongae obtusae, intus glaber, extus pubescens. Ovarium elongato-ellipsö̈deum, eompressum, bisuleatum, biloeulare. Gapsulı calyce munita, ellipsoïdea, leviter decem-costata, pubeseens, biloeularis, multiovulata, septieida. Placentae subuliformes, apice aeutiusculae. Senirs numerosa, adscendentia, ovoïdea, utrinquc in membranas lineares extcnsa.

\section{Colligitur in monte Pamatton, juxta Martapoera: BonNeo.}

Onder den soortnaam U. eallophylla heb ik drie verschillende vormen vereenigd, van welke twee, alleen door de gedaante der bladen, te onderscheiden zijn. Deze is namclijk bij de voorwerpen van Martapoera rondaehtig-elliptiseh, met de breedte tot de lengte, als $\mathbf{5}$ tot $\mathbf{8}$, en bij de voorwerpen van den berg Pamatton langwerpig-elliptisch, met de breedte tot de lengte, als 1 tot 2. De derde vorm, aan den voet van den Sakoembang geplukt, heeft de bladen eivormig en minder toegespitst; doch hij versehilt, vooral door het geringer aantal zijnerven, hetwelk in de verzamelde bladen zelden drie paar te boven gaat, en in die der andere voorwerpen vijf tot zes paar bedraagt. Hij kan voorloopig, als verscheidenheid der Unearia eallophylla, den naam U. oligoneura dragen.

\section{UNCÁRIA ACIDA. Hunter.}

U. calyce partito laciniis oblongis, ramulis subglabris, foliis ovatis obtusiusculis basi obtusis supra glabris subtus subglabris, fruetubus stipitatis.

Roxburgh. Flora Indica II. pag. 129; De Candolle. Prodromus IV. pag. 347; Nauelea aeida Hunter. Transactions of the Linnean Soeiety IX. pag. 223; Blume. Bijdragen tot de Flora van Neêrlandseh Indië, bl. 1011.

CAulrs scandens; eortex irregulariter fissus, fuscus, suberosus; RAMI obtuse quadrangulares, glabri, fusei; Ramuli eompresse quadrangulares, sub lente pubeseentes. Folia opposita, ovata, obtusiuscula, basi obtusa, saepe subeordata, supra glabra, subtus sub lente praesertim in nervis pubeseentia, 0,08 longa, 0,05 lata, nervis primariis $6-8$ sub angulo $45^{\circ}$ patentibus, nervis sccundariis retieulatis vix prominentibus; PETroli subteretes, glabriusculi, 0,015 longi. Stipulat intrapetiolares, ovatae, acutiuseulae, saepe bifidae, utrinque glabrae. Penunculus communis axillaris, parte inferiore eompressus, parte superiore subteres. Unaus peduneulaneus, eompressus, glaber. Irvolucrum bi- ad quadripartitum: laeiniae ovatae, obtusiuseulae, eiliolatae, utrinque glabrum. CALrx quinquepartitum: laciniae ovatae, obtusae, pubescens. Conolr. tubuloso-infundibuliformis, limbo quinque partito: laeiniac ovatae, obtusae, intus glabra, extus pubescens. Stamira 5, laeiniis corollae alternantia; pILAverta in fauee eorollae affixa, brevia; ANTHERAE basi affixae, oblongo-ovatae, basi subcordatae bimucronulatae. OVARIUN ellipsoïdeum, dense laete fuseo-tomentosum, biloculare, multiovulatum. Struus teres, glaber; sticma clavaeforme, acutiuseulum.

\section{Crescit in fruticetis: Java, Sumatra, Borkeo.}


De voorwerpen der verschillende eilanden zijn volmaakt gelijkvormig. Zij zijn allen in de lagere streken, op onbeschaduwde plaatsen verzameld. Onder die van Borneo zijn eenige takken belangrijk, door de vergroeijing van de bloemdcelen, die bladaardig zijn geworden, en bij sommige bloemen geheel, bij anderen voor een gedeelte zijn misvormd: zoodat de kelk en de bloemkroon met de meeldraden het vergroeide vruchtbeginsel omringen, óf de kelk en de bloemkroon om het, tot blaadjes vergroeide vruchtbeginsel en vijf bundeltjes van bladen, de plaatsen der meeldraden innemende, zijn gezeten, óf alleen de kelk duidelijk kan waargenomen worden.

Door de gedaante der bladen is deze soort verwant aan de U. callophylla, doch door de nerven, welke netvormig zijn, is zij gemakkelijk van de U. callophylla, die dezelve evenwijdig en veel duidelijker bezit, te onderscheiden. - Z Zij wordt door de Sundanezen $\boldsymbol{K}$ ait-bessir, ijzerbrander of ijzereter, genoemd. Dezen naam verdient zij, wegens de scherpte van het sap, waardoor het ijzer, bij de doorkapping van een' tak, terstond zwart uitgebeten wordt.

\section{UNCARIA CANESGENS. Kus.}

U. calyce partito laciniis ovatis obtusis, ramulis pubescentibus, foliis late ovalibus breviter acuminatis supra glabris subtus lepidotis, fructubus stipitatis.

CaULIS scandens; RAMr obtuse quadrangulares, glabri; RAmULI compressi, acute quadrangulares, pubescentes. Folia opposita, rotundato-ovalia, saepe obovalia, breviter obtusc-acuminata, supra glabra, subtus cano-lepidota et in nervorum axillis dense pilosa, longa 0,1 , lata 0,06 , nervis primariis prominentibus, nervis secundariis subparallelis, vix conspicuis; peTrour subteretes, supra sulcati, 0,015 longi. Pedunaulus connunis axillaris, compressus, superne subtcres, fusco-pubescens. Involucrun 4-6 partitum: laciniae ovatae, obtusac, supra pubescens, subtus dense fusco-pubescens. Pedunculi partiales teretes, laete fusco-pubescentes. Florum characteres similes Uncariae acidae.

Crescit in sylvis Melintang: Sumatra.

\section{UNCARIA ROXBURGHIANA. Khs.}

U. calyce partito laciniis linearibus, ramulis hirsutis, foliis ovatis acuminatis basi subcordatis utrinque hirsutis, fructubus sessilibus.

Ramr obtuse quadrangulares, hirsuti; Ramuli compressi, acute quadrangulares, dense hirsuti. Foura opposita, ovata, acuminata, raro acuta, basi cordata, utrinque hirsuta, 0,08 longa, 0,045 lata, nervis primariis et nervis secundariis prominentibus; petroli semiteretes, hirsuti, 0,005 longi. Strpulae interpetiolares, ovatae, bifidae: laciniae oblongae, acutae, utrinque glabrae. Pedurculus communis basi compressus, superne subteres, dense hirsutus. Invouvcrun quadripartitum: laciniae ovatae, acutae, utrinque glabrum. Flores in receptaculo piloso aggregati. CaLrx quinquepartitus: laciniae lineares, 
dense pilosus. Ga psula sessilis, oblonga, compressa, suleata, pilosa, biloeularis, septicida. Placentae lineari-oblongae, utrinque acutiuseulae. Senris multa, adseendentia, ovata, utrinque in membranas extensa.

\section{Crescit in sylvis Melintang: Sumatra; in monte Sakoembang: Bonneo.}

\section{UNGARIA GLABRATA. Bx.}

U. calyce partito laciniis oblongo-linearibus, ramulis glabriusculis, folis ovatis acuminatis basi obtusis utrinque subglabris, fructubus stipitatis.

Blume. Bijdragen tot de Flora van Neêrl. Indië, bl. 1012; De Candolle. Prodromus IV. pag. 348.

Cavlis et Rami obseure quadrangulares; Ramuli obseure quadrangulares, subsuleati, - novelli eompresso-quadrangulares. Folis opposita, ovata, aeuminata, basi obtusa, utrinque subglabra, - juniora utrinque sparsim pilosa, - in nervorum axillis pilosa, 0,085 longa, 0,04 lata, nervis primariis eostatim prominentibus, nervis seeundariis subparallelis vix eonspieuis; PETIOLI semiteretes, glabriusculi, 0,005 longi. Stipulat intrapetiolares, ovatae, aeutae, saepe bifidae, utrinque glabrae, submembranaceae. Pedunculus connunis axillaris, parte inferiore eompressus, parte superiore subteres, pilosus. Irvolucrumi 4-8 partitum, laciniis lanceolatis et aeutis, utrinque glabriuseulum, membranaeeum. Pedunculi PARTIALES in receptaculo hemisphaerieo inserti, subteretes, pubeseentes. Calxx quinquepartitus, laeiniis oblongo-linearibus obtusis, pubeseens. - CAPSULA elongato-ellipsoïdea, deeemeostata, subpubeseens, biloeularis, septieida, multiovulata. Placentaf lineares, utrinque attenuatae. Semira numerosa, adseendentia.

Crescit in sylvis montis Singalang: Sumatra; in sylvis montanis: Java.

\section{UNCARIA FERREA. Bu.}

U. calyce partito laciniis linearibus, ramulis dense pilosis, foliis ovatis acutis basi subcordatis utrinque pilosis, fructubus stipitatis.

De Candolle. Prodromus IV. pag. 348; Nauclea ferrea Blume. Bijdragen tot de Flora van Neerl. Indië, bl. 1014.

Cavlis eompresse tetragonus, fuseus; RAMI adultiores obtuse quadrangulares, glabri; RAIrULI subteretes vel obtuse quadrangulares, dense fuseo-pilosi. FouIs opposita, ovata, aeuta, breviter aeuminata, basi subeordata, supra sparsim et subtus dense pilosa, 0,075 longa, 0,04 lata, nervis primariis similibus eostis prominentibus, nervis seeundariis vix conspieuis, subparallelibus, distantibus; PETrour subteretes, dense pilosi, 0,004 longi. Strpulı intrapetiolares, subrotundatae, bifidae, laciniis acutis, eiliatae, utrinque glabriuseulae, membranaeeae. Pedurculus comnunis axillaris, parte inferiore compressus, parte superiore subteres, dense fusco-pilosus; involucrun quadripartitum, laciniis inaequalibus (majores subrotundato-ovatae et aeutae vel emarginatae, minores oblongo-ovatae et acuminatae), eiliatum, utrinque subpubeseens, membranaceum; pEDUrculi PARTIALEs in reeptaeulo hemisphaerico inserli, subte- 
retes, pilosi. CaLrxx quinquepartitus, laciniis linearibus, pilosus. Corolda elongato-infundibuliformis, tubo gracili, limbo quinquepartito, laciniis ovalibus et obtusis, intus extusque glabra. Stanriva 5, cum laciniis corollae alternantia; FILAMENTA brevissima; ANTHERAE basi affixae, oblongae, obtusae, basi subcordatae et bimucronulatae. Ovariun oblongo-ovoïdeum, dense pilosum; struus teres, glaber; stigma ellipsoïdeum. Gapsula elongato-ellipsoïdea, decemcostata, pilosa, bilocularis, septicida. Puacentae Janceolatae utrinque acutae. Ovura numerosa, adscendentia, utrinque membranacea, membranâ apiculari acuminatà, membranâ basilari bifidà.

Crescit in sylvis montanis: $\mathrm{J}_{\mathbf{A V A}}$; in monte Singalang: Suniatra; in monte Pamatton: Borkeo.

De voorwerpen van Java en van Sumatra zijn door het aanzien en door de kenmerken der deelen aan elkander gelijk. Die van Borneo hebben hetzelfde voorkomen, doch in de vrucht eenig verschil, daar deze aan de voorwerpen van de eerstgenoemde eilanden met tien ribben voorzien en aan die van Borneo effen is. Wegens deze verscheidenheid echter, hoezeer zij als een duidelijk kenmerk kan beschouwd worden, zijn de voorwerpen van de verschillende eilanden door mij niet als soorten gescheiden, daar ik bij andere soorten, op dezelfde stammen, den overgang van ongeribde naar geribde vruchten duidelijk heb waargenomen. - Deze soort groeit in de nabijheid van het zeestrand en verder binnenlands, tot op $800 \mathrm{~N}$. ellen boven hetzelve, in de bosschen van de genoemde en ook van andere eilanden van den Archipel. 


\title{
BIJDRAGEN TOT DE GESLACHTEN
}

\section{CR A T O X Y LON EN TRIDES IIIS,}

\author{
DOOR
}

\author{
P. W. K O R T H A L S.
}

De geslachten Cratoxylon en Tridesmis vormen met Eliaea eene afzonderlijke groep onder de Hypericineae, gekenmerkt door schubjes, die met de bundels van de helmdraden afwisselen, en door zaaddoozen met gevleugelde zaden. Met het eerstgenoemde geslacht, hetwelk door eene drukfout als tweebroederig is vermeld, zal Ancistrolobus Spach. moeten worden vereenigd. De beide geslachten, vooral door het zamenstel der zaaddoozen van Eliaea afwijkende, verschillen van elkander door het aantal en de aanhechting der zaden, alsmede door het al of niet aanwezig zijn van schubjes aan den voet der bloembladen. Tridesmis bezit aan den voet der bloembladen de gemelde schubjes, en zijne zaden zijn langs den binnenrand van den tusschenrand in een onbepaald, vrij groot getal aangehecht. Cratoxylon mist deze schubben, en bezit een bepaald getal, vier tot acht, zaden in het benedenste gedeelte van het hokje aangehecht.

\section{CRATOXYLON POLYANTHUM. Khs.}

C. foliis ellipticis acuminatis basi acutis, squamulis acutis.

Arbuscula 6-8 metrorum. Rami teretes, cinerei; ramuli basi subteretes, sursum compressi, saepe ancipites, glabri. Fous decussata, elliptica, acuminata, basi acuta saepe appendiculis duobus filiformibus aucta, integerrima vel absolete crenulata, utrinque glabra, coriacea, 0m,09 longa, 0m,04 lata; PeTrour semiteretes, supra plani, glabri, 0,005 longi. Pedurculi supra-axillares, solitarii vel abortu foliorum in racemos dispositi, 1-3 flori, compressi, glabri; PEDICELLI subquadrangulares, glabri. 
CÁrx pentasepalus, persistens; sepala biscrialia, crecta, subaequalia, ovata, obtusa, concava, glabra, nervis a basi procedentibus. Conolla pentapetala, hypogyna, aestivatione subconvolutấ; PETALA obovata, basi inaequaliter angustata, integcrrima, glabra, nervis subdichotomis intermixtis glandulis linearibus cellulosis. Stanina plurima, hypogyna, in phalangos tres coalita; columnae staminum lineares, glabrac; fILAMENTa libera, exteriora linearia; ANTHERAe medio dorsi affixae, biloculares, loculis saepe discretis, longitudinaliter dehiscentes. Souanulae 3, hypogynae, staminum phalangibus alternae, triangulares, attenuatae, apice saepe recurvae. Ovarium sessile, pyramidale, obtusangulum, lateribus sulcatum, glabrum, triloculare; ovux 4-8, affixa loculi angulo centrali et basilari. Strut 3, triangulares, glabri; stiginata capitellata. CA Psura calyce excreto cincta, obovoïdea, acuta, basi subteres, glabra, coriacea, trilocularis, loculicida, trivalvis, valvis in medio septigeris, basi seminiferis. Semna 4-8 in singulo loculo, compressa, obliquo-obovata, obtusa, altero tantum latere superne membranaceo-alata; TESTA membranacea, in alam extensa; TEGMEN tenue; HILU approximatum exostomio; Raphe expansione alaeformi cincta. Nugleus cylindricus, utrinque obtusus. Enrbryo erectus, dieotyledoneus.

\section{Crescit in monte Pamatton, ad ripas fluminis Doeson, juxta Poeloe-lampei: Borneo.}

Tab. 36. Figura speciei. 1. Alabastra. 2. Alabastrum petalis ablatis. 3. Flos explieatus. 4. Petalum. 5. Anthera ab anteriore et 6 . a posteriore. 7. Flos, tegumentis ablatis, faseieulo staminum unico reflexo. 8. Flos, tegumentis et staminibus abseissis. 9. Ovarium adultius eum squamulis. 10. Seetio longitudinalis ovarii. 11. Seetio longitudinalis ovarii eum ovulis. 12. Sectio transversalis ovarii. 13, 14. Semina. 15. Seetio longitudinalis partis seminis, cum mesospermio, tegmine, saeeulo embryonis et embryone.

De voorwerpen van de drie genoemde plaatsen verschillen van elkander door de grootte der bladen. Die van de Doeson-rivier, in de nabijheid van Mantalet verzameld, hebben dezelve het grootste; doch missen daarentegen dikiverf de aanhangseltjes van den voet: die van den berg Pamatton houden het midden tusschen de opgenoemde en die van Poeloe-lampei, bij welke de gemelde aanhangseltjes zelden ontbreken.

\section{CRATOXYLON GLAUCUM. Kus.}

C. foliis obovatis vel elliptieis, squamulis obtusis eneullatis.

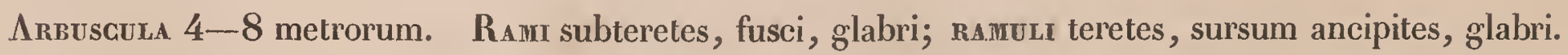
Foura decussata, obovata, raro clliptica, obtusa, apiculata, basi acuta, integerrima, utrinque glabra, subpellucide punctata, coriacea, 0,045 longa, 0,03 lata; perrou compressi, glabri, 0,002 longi. Flores terminales vel axillares, racemosi; pedunculus connumis anceps, glaber; pedunculu partules subteretes, basi bituberculati, glabri. CAstrx pentasepalus, aestivatione quincunciali; sEpsxA subbiserialia, subaequalia, ovalia, obtusa, integerrima. Conorta pentapetala, aestivatione subconvolutâ; PETALA oblique rotundato-obovata, obtusissima, glabra, membranacea, subrosea, nervis e basi pctalorum procedentibus versus apicem bifidis, glandulis oblongis vel subrotundis inter nervos seriatim dispositis. 
Stamina numerosa, hypogyna, in phalanges tres coalita; corunirae staminiferae ligulatae, apice latiores; FiLAmenta libera exteriora pluriserialia; in serie interiore latiora, lincaria; in seriebus exterioribus filiformia, glabra; ANTHERAE medio affixae, ovatae, obtusae, basi emarginatae, biloculares, longitudinaliter dehiscentes. Squamulat 3, phalangibus staminum alternae, hypogynae, subrotundae, extrorse cucullatae, obtusae, glabrae, carnosae. Ovariun sessile, elongato-pyramidatum, lateribus sulcatum, glabrum, triloculare. Ovula 4-6, axi interno baseos loculi affixae. Strut 3, subtrigoni, glabri; stiginata 3 , capitellata. CAPSULA oblonga, subtrigona, glabra, coriacea, trilocularis, trivalvis; valvis ovatis, acuminatis, stylis persistentibus, dissepimenta coriacea in medio gerentibus. SEnIr $4-6$ in singulo loculo, placentae hemisphaericae axillari affixa, erecta, collateralia, lineari-oblonga, utrinque obtusa, margine membranaceo-alata; TEST membranacea, alato-expansa, cellulis hexagonis sat regularibus formata; MESospermini in uno latere et in apice conspicuum, laxe cellulosum; tEgner membranaceum, tenue. Hı⿻コ一 approximatum micropylae. RApHe filiformis, cum margine seminis paralleliter, demum supra basin incurva, procurrens ad nucleum. Nucueus in medio seminis, teres, utrinque acutus. Embryo erectus, rectus, dicotyledoneus.

Crescit ad ripas Karrau, ad montem Rantau, etc.: BoRneo.

Over het algemeen zijn de bladen dezer soort omgekeerd eirond, doch soms heeft zij dezelvc elliptisch. Hare bloemen zijn van elkander verspreid, of getropt bij elkander staande. De laatste bloeiwijze komt voornamelijk bij de voorwerpen van Poeloe-lampei voor, en gaat niet zelden met den elliptisehen vorm der bladen gepaard. Beiden vereenigd, geven aan de voorwerpen een geheel eigen aanzien, hetgeen hen ligt voor verschillende soorten kan doen houden. De gemelde bladvorm komt echter aan dezelfde boomcn, soms aan dezelfde takken voor, en de bloemen zelven leveren, bij een nader onderzoek, geen genoegzaam verschil, dat deze scheiding kan ondersteunen.

Al de waargenomene voorwerpen groeiden op kiezelaardige gronden. $\mathrm{Zij}$ waren niet zeer bladrijk, doch rijk aan bloemen of vruchten. Van de beide laatsten voorzien, hebben wij hen van augustus toi november waargenomen; het hoofdtijdperk van bloeijen schijnt echter, volgens deze waarneming oordeelende, in junij en julij plaats te hebben.

Bij de afwijking, welke de vorm der bladen en de bloeiwijze opleveren, komen vooral die van de schubjes en van de zaden in aanmerking. De schubjes hebben de gedaante van kapjes, welke naar buiten geopend zijn, en op deze opcning een, van één tandjc voorzien, klepje dragen. Hunne bestemming durf ik niet bepalen; misschien omsluiten zij de helmknopjes in den jeugdigen staat. De zaden hebben bij deze soort de kern in het midden, en den geheelen omtrek vliezig. - Deze vliezige uitbreiding bestaat uit de testa en het mesospermium. Aan de zijde, waar de raphe loopt, zijn beide, en aan de tegenoverliggende is alleen de testa aanwezig. Dit laatste gedeelte is zeer fijn en doet den regelmatigen vorm der zeshoekige cellen het beste waarnemen. Het andere is dikker, door het losse celwecfsel van het mesospermium. De raphe loopt als een fijn draadje, eerst langs den rand van het zaad, evenwijdig met of over de kern, vervolgens op eenigen afstand van denzelven, buigt zich dan in ecne ronde, 
scherpe of ook wel in eene ecnigzins slingerende bogt om, en daalt weder naar de kern af. De kern wordt door een fijn vliesje, hetwelk uit een, door geslingerde cellen gevormd weefsel bestaat, omgeven. Dit tegmen is van boven geheel gesloten; de testa is daarentegen aan de micropyle open, zoodat er ecne duidelijke trechtervormige opening tusschen de micropyle en het begin van de kern bestaat, die met eene menigte cellen is voorzien. Binnen het tegmen toonen de nog onrijpe zaden een fijn vliesje, zonder eenig duidelijk celwecfsel, waarin de kiem, aan het naar de micropyle gelegen einde, zich begint te vormen.

\section{CRATOXYLON HORNSCHUCHII. BL.}

C. foliis ovatis acuminatis basi obtusis utrinque glabris, squamulis obtusis cucullatis.

Arbor speciosa; truncus rectus, cortice fusco; conona pyramidalis, foliosa. Rami in angulo $45^{\circ}$ patentes, teretes, glabri, cincrei vel fusco-cinerei; Ramuli tetragoni, compressi, apicem versus ancipites, glabri. Gemine pyramidales, glabrae, foliolis duobus oppositis. Foula decussata, patentia, ovata vel clongato-ovata, acuminata, basi obtusa saepe biauriculata, integerrima, utrinque glabra, coriacea, 0,08 longa, 0,035 lata, nervis primariis fere horizontalibus, - secundariis reticulatis; petroli semiteretes, glabri, 0,003 longi. Flores axillares vel terminales, paniculati vel ramoso-paniculati, umbellulati; Pedurculus communis anceps, glaber; PEDUnculi Partiales subteretes, glabri; bracteas rudimentares, tuberculatae vel squamulatae, acutae. Calyx pentasepalus, persistens, aestivatione quincunciali; sEPALA biserialia: duobus in serie interiore et tribus in serie exteriore, recta, subaequalia, ovalia, obtusa, concava, extus subcarinata, utrinque glabra. Coroula pentapetala, aestivatione subconvoluta; petala subaequalia, oblique ovalia, obtusiuscula, utrinque glabra, nervis e basi progedientibus apicem versus bifidis, glandulis linearibus inter nervos dispositis. Stamiva numerosa, hypogyna, in phalanges coalita; columnae staminum lineares, apicem versus vix latiores, glabrae; FIla IIENTa extrorsa, pluriserialia, in serie internâ linearia, in serie externa filiformia, glabra; aNtherae peltatae, oblongae, utrinque emarginatae, rimis longitudinalibus dehiscentes; poLLen sphaericum, sacculo unico auram emittente. Sovamula 3 , hypogynae, phalangibus staminum alternae, oblongae, obtusae, cucullatac, glabrae. Ovariur sessile, triangulato-pyramidale, aciebus obtusiusculis, lateribus subsulcatis, glabrum, triloculare; ovou 4-8 in singulo loculo, placentae rotundatae basilari et axillari affixa, erceta, subcollateralia. STyli 3, subteretes, glabri; stignita 3, capituliformia, raro bifida. CAPSULA subovoïdea, obtuse triangulata, stylis persistentibus munita, glabra, coriacea, trilocularis, loculicide trivalvis, valvis in medio dissepimentum cartilagineum gerentibus. SenIra 4-8 in singulo loculo, placentis basi dissepimenti accretis inserta, subcollateralia, erecta, oblique obovata, obtusa; TESTA altero tantum latere et apicc nuclei in alam membranaceam protensa; TEGMEN tenue; HILUn approximatum micropylae; rapHe marginalis, nucleo approximata, incrassata. Nucueus teres, utrinque acutus. Emirio erectus, rectus, dicotyledoneus.

Crescit in sylvis Melintang: Sumatra; et in sylvis montanis: Java. 
TRIDESMIS FORMOSA. Kms.

T. foliis ellipticis vel ovalibus, floribus fasciculatis vel solitarïs.

ARBor 8-16 metrorum; Rami patentes, subteretes, cinerascentes, glabri; RAMULI compressi, superne ancipites, glabri. GEmin elongato-pyramidatae, subulatae, glabrae, foliolis appositis. Foura decussata, patentia, elliptica in ramulis junioribus, ovalia vel oblongo-ovalia breviter acuminata basi angustata in ramulis adultioribus, subintegerrima, utrinque glabra, coriacea, oblonga, 0,035 lata, nervis primarïs subhorizontalibus, nervis secundariis reticulatis, instante anthesi decidua; PETrou semiteretes, glabri, 0,005 longi. Fuones axillares vel supra axillares, fasciculati, raro solitares; PEdurculi subteretes, glabri. CALYX campanulatus, pentasepalus, aestivatione subimbricatà; SEPALA biserialia, tribus in serie exteriore, duobus in serie interiorc, subaequalia, oblongo-ovalia, obtusa, integerrima, extus subcarinata, utrinque glabra, persistentia. Corolla pentapetala, aestivatione subconvolutâ; PETALA oblongo-ovalia, obtusa, basi unguiculata et squamulata, squamulis lingulatis truncatis, utrinque glabra, membranacea, nervis basi ortis. STamira numerosa, hypogyna, in phalanges tres coalita, squamulis alternantia; colunirae staminum lineares, apicem versus paulo latiores, glabrae; ritaniENTA filiformia, glabra; ANTHERAE peltatae, oblongae, utrinque obtusae vel emarginatae, biloculares, longitudinaliter dehiscentes. Squamulae 3, hypogynae, triangulares, attenuatae, glabrae. Ovarium sessile, elongato-pyramidale, obtuse triangulare, lateribus subsulcatis, glabrum, triloculare; ovvus numerosa, in axi loculi biseriata, adscendentia. Strui 3, subteretes, glabri. Stiginata 3, capitata. Capsula basi calyce cincta, elongato-ovoïdea, obscure triangularis, stylis persistentibus mucronata, subsulcata, sulcis senis, glabra, coriacea, trilocularis, loculicide trivalvis, valvis in medio dissepimentum subcoriaceum gerentibus intus glabris. Senrma numerosa, biseriata in singulo loculo, placentis margini interiori dissepimenti adnatis affixa, compressa, oblique spathulata, obtusa; TEsTA semialata, membranacea; MESOSPERMIU laxe cellulosum; TEGMEN tenue; HILUI micropylae approximatum; RAPHE marginalis. Nucleus basilaris, marginalis, teres, utrinque acutus. Emвnуo ercetus, rectus, utrinque obtusus.

\section{Crescit juxta Peinang, Doekoe: Sunitra; ad ripas fluminis Doeson, in monte Pamatton: Borieo.}

Explicatio Tabulae 37. Figurae speciei. 1. Alabastrum floris. 2. Flos expansus. 3. Petalum ab interiore. 4. Flos calyce et corollâ ablatis. 5. Ovarium, loculo uno dissecto. 6. Ovarii sectio horizontalis. 7. Capsula. 8. Capsula dehiscens, valvulâ unâ abscissâ. 9. Valvula ab interiore cum seminibus. 10. Valvula seminibus ablatis. 11. Semen. 12. Embryo.

Op Sumatra groeijen deze gewassen in de lagere streken. Vruchtdragend zijn zij in de nabijheid van Doekoe, in december verzameld, en bloeijend vonden wij hen in julij aan het zeestrand. Op Borneo namen wij hen waar langs de groote rivier, langs de kleinere rivieren, die uit het oosten vloeijen en in de Baritto uitmonden, en in de zuid-oostelijke bergachtige streken, tot op ongeveer $300 \mathrm{~N}$. cllen boven het zeevlak. De voorwerpen van alle deze oorden hebben geen wezentlijk verschil. Die van Doekoe en van de oevers van het benedengedeelte van de Baritto-rivier, in de gunstigste standplaatsen groeijende, hebben de 
grootste bladen. De vruchten van Doekoe en die van de Pamatton en Balaran zijn iets langer, dan de anderen; de zaden zijn in de eersten soms regelmatig ovaal, en in de laatsten scheef spadelvormig. De in julij opgemerkte boomen waren bijna bladerloos - volgens zeggen der inlanders laten zij in mei de bladen vallen - doch door tallooze bloemen bedekt; hetgeen hen op bloeijende perzikenboomen deed gelijken. Aan de in het laatst van augustus, langs de Baritto, geziene boomen, vonden wij alleen opengesprongene vruchten, en de, in october en november, in de bergachtige oorden van Borneo waargenomene boomen, waren allen van nog geslotene vruchten voorzien. Zij waren dus bij de eerste, langs de rivier groeijende, een drietal maanden ten achtere, vermoedelijk door de drooge en minder gunstige groeiplaats.

Deze boomen worden op Sumatra Maron genoemd. Vermoedelijk is deze naam van sanskritschen oorsprong en aan het wortelwoord, mar, dood, verwant; of is hij eene zamenstelling van ma, dood, en roeh, groeijen, bewegen. Het laatste komt mij het aannemelijkste voor en doet ons de inlanders als trouwe waarnemers der natuur kennen, die in de woorden een afbeeldsel der voorstellingen geverı. De boom, welken zij als dood en bewegend voorstellen, behoort tot de weinige, die alle bladeren verliezen, daarna met tallooze bloemen bedekt worden en later eenen nieuwen bladtooi verkrijgen. 


\title{
S AL A G I A EN IIIPPOCR A TEA,
}

\author{
DOOR
}

\author{
P. W. K OR T H A L S.
}

De geslachten Salacia en Hippocratea zijn, door houding en groeiwijze, zeer gelijkvormig. Hunne bloeiwijze, hoewel in het wezen overeenstemmende, kan echter als toevallig kenmerk ter onderscheiding der bloeijende voorviverpen dienen: Salacia heeft de blocmen meestal op korte, zaamgedrongene bloemstelen vereenigd; Hippocratea in pluimen. Een beter kenmerk, dat reeds als van groote waarde door de Heeren Wight en Arnott is opgegeven, ter onderscheiding der bloeijende voorwerpen, leveren de eitjes. Deze zijn bij Salacia boven elkander gezeten, meestal paarsgewijze in ieder hokje, en bij Hippocratea op den bodem van ieder hokje naast elkander vastgehecht.

\section{S A L A Gi A. L., Wight en Arvott.}

Dit geslacht is, volgens de opgave van de Heeren Wight en Arnott; alleen in Afrika en Azië gevonden. De Salacia oblonga Wall. zal, vermoedelijk wel als een eigen geslacht, van hetzelve moeten. worden afgezonderd. 


\section{SAlaCiA POLYANTHA. Khs.}

S. foliis ovalibus obtuse acuminatis basi acutinsculis obtuse serratis, pedunculis unifloris aggregatis, floribus triandris.

Frutex scandens; Rani subteretes, glabri, subverrucosi, pulvinati; Ramuli alterni, suboppositi vel ad ramorum apices verticellati, subpatentes, basi subteretes, apicem versus triangulares, glabri, verruculosi; verruculis albidis, badii. Folis ovalia, raro ovata, obtuse acuminata, in quibusdam acutiuscula, basi acutiuscula, breviter angustata, obtuse serrata, serraturis approximatis subaequalibus, utrinque glabra, nitida, coriacea, 0,1 longa, 0,05 lata; petioli semiteretes, glabri, 0,005 longi. Florxs axillares, in pulvinis hemisphaericis, aggregati; pedurculi uniflori, subteretes, glabri, 0,01 longi. CaLrx pentasepalus, persistens, aestivatione imbricatâ; SEPALA patentia, subaequalia, ovalia, obtusa, glabra. Corolda pentapetala, hypogyna, rotata, aestivatione subimbricata; PETALA rotundato-ovalia, obtusa, utrinque glabra, medio disci carnosa margine submembranacea, 0,002 longa. Discus perigynus annuliformis, carnosus, glaber. Stantriva 3; filanienta medio vel basin versus partis interioris disci affixa, linearia, inferne latiora, glabra, foecundatione peractâ reflcxa; ANTUERAE peltatae, immobiles, oblongae, subquadrilobae, biloculares, longitudinaliter dehiscentes. Ovariuni sessile, hemisphaericum, subtrilobum, in stylum attenuatum, glabrum, triloculare. Ovus. $\mathbf{A}$ bina, in axi loculi superimposita: altero descendente, altero adscendente. Strutus brevis, triangularis; stigma capitatum, subtrilobum. Fructus solitaris, globosus, baccatus, glaber, abortu 1-3 spermus. SEmrva immatura, difformia, rotunda vel ovö̈dea; ARILlus carnosus; testa crustacea; tegmen subcoriaceum. Nuqueus deëst.

Crescit juxta Martapoera, Poeloe-lampei, in monte Pamatton: Borino.

\section{SALACIA OVALIS. KHs.}

S. foliis oblongo-ovalibus breviter et obtuse acuminatis, basi acntis, subintegerrimis, pedunculis aggregatis unifloris, floribus triandris.

Frutex scandens; rami subteretes, glabri, verrucosi, cinerei; Ramuli compressi, bisulcati, glabri. Folis patentia, subopposita, oblongo-ovalia, breviter et obtuse acuminata, basi acuta, subintegerrima, utrinque glabra, coriacea; 0,09 longa, 0,04 lata, nervis primariis patentibus distantibus; PETIOLI subteretes, glabri, 0,007 longi. Flores axillares, in pulvinos hemisphaericos dense aggregati; Pedunculi uniffori, filiformes, glabri, 0,01 longi. CALrX rotatus, pentasepalus, persistens; sEPALA late rotundata, obtusissima vel submarginata, subciliolata, glabra. Conolda rotata, pentapetala, glabra; PETALA late obovato-rotundata, septemnervia. Discus perigynus, peltiformis, subquinquangularis, glaber. StaIITNA 3; FILAmenta in parte interiore disci affixa, lamelliformia, basin versus dilatata, glabra; antheraE peltatae, oblongae, subquadrilobae, longitudinaliter dehiscentes. Ovarium sessile, breve pyramidale triangulare, glabrum, triloculare. Ovvus geminata, rarius solitaria in singulo loculo, axillaria, superimposita: altero adscendente, altero descendente, solitario descendente. Struus brevis; stigma subtrilobum. Fructus longe pedunculatus, pisiformis, glaber.

Crescit prope Tjikao: JAVA. 


\section{SALACIA KALAHIENSIS. Khs.}

S. foliis ellipticis acuminatis basi acutis serratis, pedunculis unifloris aggregatis, floribus triandris.

Frutex scandens; RAnI horizontales, obsolete tetrangulares, glabri, lenticellis verrucosis albis muniti, fusci; Ranutr obtuse tetrangulares, apicem versus compressi, glabri, cinerei. Folia subhorizontalia, subopposita, elliptica, saepe late ovalia, obtuse acuminata, basi acuta, serrata, serraturis distantibus obtusis, utrinque glabra, coriacea, 0,08 longa, 0,045 lata, nervis primariis patentibus. Fuores axillares, aggregati; pedurculi uniflori, filiformes, glabri, 0,01 longi. Calrx rotatus, pentasepalus; SEPALA subrotunda, obtusiuscula, utrinque glabra. Corolla subcampanulata, pentapetala, acstivationc imbricatâ; PETala hypogyna, ovalia, obtusiuscula, integerrima, utrinque glabra. Drscus perigynus, annuliformis, utrinque attenuatus, glaber. STAMINA 3; FILAMENTA in parte interiore et superiore disci affixa, linearia, glabra, erecta, foecundatione peractâ reflexa; ANTHERAE peltatae, extror'sae, oblongae, subquadrilobae, longitudinaliter dehiscentes. Ovariun stipitatum, triangulato-pyramidale, glabrum, triloculare. Ovura in singulo loculo geminata, raro solitaria, axillaria, superimposita, approximatim inserta: superiore adscendente, inferiore descendente. Styuds brevis; sтigra capitatum, trilobum. Fructus substipitatus, globosus, glaber, trilocularis, abortu unilocularis. Senirs descendentia, plura vel solitaria, multiformia, saepe subglobosa; Arillus succosus; teST crustacea, fusea; tegrier subcoriaceum; nitus micropylae approximatum. Nugleus conformis, exalbuminosus; cotrledones hemisphaericae, conglutinatae; EnIBRYo pyriformis; RADICULA teres, obtusa; GEMIULA subrotunda.

\section{Crescit ad lacum Kalahiën: Bonveo.}

Explicatio Tabulae 38. Figura speciei. 1. Alabastrum floris. 2. Flos expansus. 3. Flos, calyce et corollâ ablatis. 4. Petalum revolutun. 5. Stamcu. 6. Anthera dehiscens. 7. Ovarium longitudinaliter disscctum. 8. Ovarii transversa sectio. 9. Ovulum. 10. Fructus. 11. Fructus longitudinaliter scctus, semine demto. 12. Semen a latere. 13. Semen cum parte dissepimenti. 14. $a$. Hilum, b. micropyla. 15. Semen longitudinaliter sectum. 16. Vasa raphis: $c$. vasa exteriora, $d$. vas interius.

\section{SALACIA EXSCULPTA. Kнs.}

S. foliis oblongo-ovalibus obtuse acuminatis basi acutiusculis integerrimis rel obsolete serratis, pedunculis unifloris aggregatis, floribus triandris, latere disci exsculpto.

\section{Crescit in monte Singalang: Sunatra.}

Deze plant is door haar aanzien en hare groeiwijze zeer verwant aan S. Kalahiensis. Hare takjes zijn witter, soms geel-wit; de bladen kunnen in hunne gedaante naauwelijks onderscheiden worden; zij hebben meestal ongezaagde randen. In de bloeiwijze neemt men eenig verschil in de lengte der bloemsteeltjes waar, zijnde die van S. exsculpta eenigermate kortcr. De kelkbladen zijn soms een weinig puntiger; de bloembladen hebhen eene meer regclmatige, ovale gedaante. De discus lcvert echter van al de deelen het voornaamste verschil op. Hij bestaat bij deze soort uit eenen breeden ring, 
die van boven eene kleine groeve heeft $\mathrm{en}$ in den omtrek eene brcede, doch niet zeer diepe voor bezit. Deze afwijking van den discus der S. Kalahiensis heeft mij de beide planten doen scheiden. Zij is, wel is waar, van een nict zeer aanzienlijk orgaan, doch in dit geslacht van een, in de verschillende soorten niet zeer veranderlijk deel der bloem genomen. Bij dit verschil vocgt de vrucht, wanneer zij bekend wordt, welligt nog andere kenmerken ter onderscheiding.

\section{v. Salacia prinoïdes. De Gandolle.}

S. foliis ellipticis obtusc acuminatis basi angustatis serratis, pedunculis unifloris aggregatis, floribus triandris, disco supernc attenuato.

\section{Colligitur juxta Santjan: JAva; juxla Peinang: Sumatra.}

De voorwerpen, welke door mij zijn waargenomen, komen met de beschrijvingen van Tonsella of Salacia prinoïdes zóózcer overeen, dat ik niet aarzel, hen onder dien naam te brengen. Deze soort behoort dus onder de, aan het vasteland van Indië en aan den Archipel gemeenschappelijk eigen zijnde gewassen. Op de laatste groeiplaatsen is zij, tot nu toe, allcen aan de wcstelijke en zuidelijke stranden waargenomen, en op de eerstc groeit zij op de bergen cn aan het strand. Volgens de opgave van de Heeren Wight en Arnott wordt deze plant in de Tamoultaal Kadelanchi genoemd, en aan het zuiderstrand van Java noemen de inlanders haar Mata-Kantjil. De laatste benaming toont aan, dat de inlanders tusschen deze plant en de oogen van den Kantjil (Moschus javanicus), eenige overeenkomst vonden, en de andere, Kadelanchi, welke de oogen of het heldere van den Kadala (vermoedelijk Moschus napoe) beteekent, wijst op eene soortgelijke verbinding van denkbcelden. Van deze diertjes, welke in de lommerrijke bosschen, waar de Salacia prinoides grocit, rondzwerven, zijn waarschijnlijk de groote oogen, met de heldere of geel-oranjekleurige vruchten onzer plant, die in donkere bosschen zeer spoedig in het gezigt vallen, vergeleken geworden.

Gedurende den droogen tijd bloeijen deze planten, en ongeveer zeven tot acht maanden later dragen zij rijpe vruchten.

\section{SALACIA MACROCARPA. Khs.}

S. foliis ovali-oblongis mucronulato-acutis basi obtusis subserratis, pedunculis breviter racemosis multifloris raro unifloris, floribus triandris, disco pclviformi.

Frutex scandens; RAIII subhorizontales, obtuse quadrangulares, fusci; Ramuli subhorizontales, quadrangulares, angulis obtusis, saepe octies sulcati, tuberculati, glabri, fusci. Folia subopposita, ovali-oblonga, raro ovata, mucronulato-acuta, basi obtusa, subserrata, serraturis obtusis, utrinque glabra, 0,13 longa, 0,04 lata, foriacea, nervis primariis patentibus distantibus; PETIou subteretes, supra sulcati, glabri, 0,005 longi. Fuores axillares, racemosi, racemo 6-10 floro, vel solitares; 
PEDUraulus et PEDicelur glabri, demum incrassati. Calux 4-5 sepalus; sepala rotundata, obtusissima, saepe fimbriata, utrinque glabra. Corolla rotata, pentapetala, aestivatione imbricata; PETALA suborbiculata, basi unguiculata, utrinque glabra, disco carnosa, margine membranacea. Discus pelviformis, glaber, coriaceus. Stanita 3; rilanenta disci parti internae affixa, lamelliformia, basi dilatata approximata, cupulam mentientia, glabra; a aTtherae peltatae, extrorsae, oblongae, in longitudine dehiscentes. Ovaritur trigono-pyramidatum, obtusangulum, glabrum, triloeulare. Ovula in singulo loculo geminata, axillaria, supcrimposita. Struus brevis; sтigara capitatum. Frucrus subglobosus, 1-3 locularis: loculis mono- vel dispermis. Semira multiformia, rotundata vel angulata; ARiLlus tenuis; TESTA crustacea; TEGMEN coriaceum.

\section{Crescil juxta II artapoera, Poeloc-lampei: Bonneo.}

Dc gedroogde takjes dezer plant hebben eene geel-groene kleur, hetgeen hun het aanzien der Symploccae geeft. De discus omringt, in den vorm van een bekken, het vruchtbeginsel, heeft den buitenrand bijna gaaf en den binnenrand tegen het vruchtbeginsel opgebogen. Zijne zelfstandigheid is lederachtig, bruin gekleurd. Aan de binnenzijde van den omgebogen rand zijn de helmdraden vastgehecht, die zóó breed zijn, dat zij cen' driehoekigen ring onder het vruchtbeginsel vormen. De helmknopjes zijn, vóór de opening der bloem, op den stempel gelegerd, openen zich kort vóór de ontsluiting der bloembladen, en buigen zich daarna buitenwaarts. De testa is, als bij de andere soorten, tamelijk dik en broos. $\mathrm{Z}_{\mathrm{ij}}$ bedekt een mesospermium, waarin eene menigte draden tusschen het celweefsel zijn verspreid. Het tegmen is lederachtig, van buiten ruw, door het zaamgegroeide mesospermium, aan de binnenzijde glad. Door de klcur der bladen en den vorm van den discus is deze soort van de andere, door mij onderzochte, te onderscheiden, en misschien zullen mecrdere voorwerpen en rijpere vruchten haar later tot grondvorm eener eigene ondcrafdeeling maken.

\section{HIPPOGR A TEA. I.}

De Indische soorten van het geslacht Hippocratea zouden in twee natuurlijke groepen kunnen worden gesplitst, van welkc de ecne de soorten konde bevatten, die de kern aan den voet van het zaad, en de andere, die de kern aan den top van het zaad hebben. De overeenstemming dezer soortcn met de Amerikaansche, is mij geene bewezene daadzaak; zij kan door hen, welke talrijke voorwerpen van de nieuwe-wereld bezitten, buiten twijfel worden gesteld.

\section{HIPPOCRATEA INDICA. WiLLD.}

H. carpellis oblongis utrinque obtusis, paniculis corymbosis dichotomis, foliis ellipticis acuminatis serratis vel integerrimis.

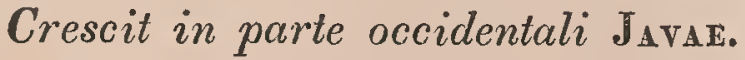

Deze plant groeit in het wild als eene slingerplant, doch in den tuin te Buitenzorg heb ik haar als een klein struikje gezien. $Z_{i j}$ wordt door de Sundanezen Aroi-mengander of mangender genoemd: waardoor Botanica. 
hare slingerende groeiwijze aangetoond en eene der eigenschappen van de bloeijende plant wordt kenbaar gemaakt. Het woord mengander, de Sanskritsche woorden men (achten, eeren) en gandha (ruiken) herinnerende, kan zecr goed door welriekend worden vertaald.

De voorwerpen van Java bezitten, even als de Heeren Wight en Arnott aan hunne, op het vasteland verzamelde planten hebben opgemerkt, bladen met gave en met gezaagde randen. Zij verschillen niet van de bloeijende voorwerpen van het vasteland, in het Rijks-Herbarium aanwezig. Dit heeft mij hen onder den genoemden soortnaam doen opgeven.

\section{HIPPOCRATEA GLAGA. Krs.}

II. carpellis oblongo-obovalis retusis, corymbis dichotomis, foliis ovalibus acuminatis.

FruteX scandens; RaJi teretes, transverse rimati, cinerei glabri, saepe uncinato-recurvi; RaMruLI patentes, alterni vel suboppositi, obscure quadrangulares, in foliorum insertione nodosi, apicem versus compressi, pubescentes, fusci, novelli fusco-cinerci. Folra subhorizontalia, opposita vel subopposita, ovalia vel oblongo-ovalia, raro oblongo-ovata, acuminata, basi angustata, raro obtusiuscula, integerrima, interdum obsolete crenulata, utrinque glabra, subtus nitida, 0,11 longa, 0,055 lata, nervis primariis patentibus, distantibus, nervis secundariis subparallelis; PETIOLI subteretes, superne sulcati, pubescentes, 0,015 longi. Flores axillares, dichotomo-corymbosi; pedunculus comrunis compressus, subsulcatus, glaber; pedunculi partiales semi-teretes, supra sulcati; pediceldi obscure quadrangulares, glabri, saepe brevissimi; bractene ovatae, acutae, basi concavae, glabrae, minutae. Calyx campanulatus, pentasepalus; sEPALı ovata, acutiuscula, utrinque glabra. CoRolla campanulata, pentapetala, aestivatione imbricata; PEtala obovata vel ovalia, obtusa, intus pubescentia, extus glabra. Discus subhypogynus, peltiformis, margine quinquedentatus, extus intusque glaber. Stamira 3; frLamenta parti interiori disci affixa, lamelliformia, versus apicem et basin dilatata, glabra; ANTHERAE peltatae, oblongae, longitudinaliter dchiscentes. Ovarios sessile, hemisphaericum, subtrilobum, glabrum, triloculare. Ovula 4-8, axi interni loculi ad basin affixa, erecta, subcollateralia. Stxuos brevis, glaber; stigma trilobum. Capsulae 3, abortu pauciores, basi approximatac, oblongo-obovatac, retusae vel emarginatae, striatae, glabrac, uniloculares, in medio lateris dehiscentes, bivalves, valvis carinatis. Semri 4 $4-8$ in singula capsula, placentis axillaribus basilaribus compressis aflixa, collateralia, erecta, compressa, oblonga, apiee recurva, glabra; TESTA membranacea, versus basin seminis, in alam expansa; MEsosperIrrun cellulare; teghien membranaceum. HruUn micropylae approximatum. Raphe per medium expansionis alaeformis ad verticem seminis procurrens. Nucleus in vertice seminis compresse ellipsoïdeus, subexallouminosus. Timbro compressus, oblongus; cotyledones planae, obtusae; radicula teres, obtusa, brevis. 
Explieatio Tabulae 40. Figura Hippocrateae glagae. 1. Flos. 2. Petalum unicum ab interiore. 3. Flos, ealyce et eorollà ablatis. 4. Orarium cum disco. 5. Orarium longitudinaliter dissectum. 6. Orulum valde auctum. 7. Capsula dchiscens. 8. Semina cum parte placentae. 9. Semen. 10. Semen Iongitudinalitcr dissectum, d. raphe, $f$. mesospermium, $g$. tcgmen, $i$. cavitas nuclci. 11. Scctio transversalis apieis seminis, $d$. raphe, e. testa, g. tegmen, $i$. cavitas, h. embryo. 12. Embryo.

\section{HIPPOCRATEA MACRANTHA. KHs.}

H. carpellis ovalibus obtusis, corymbis dichotomis, foliis oblongo-ovalibus obtusc acuminatis rcl acutis integerrimis.

Frutex scandens; Rami subhorizontales vel patentes, tcretes, fusci, albo-striati, glabri; ramuli subtetragoni vcrsus apicem compresse tetragoni, nodosi, glabri. Foura subhorizontalia, opposita, oblongoovalia, saepc elliptica, obtuse acuminata vel acuta, basi obtusa vel angustata, integerrima, glabra, 0,13 longa, 0,05 lata, coriacea, nervis primariis patentibus, nervis secundariis reticulatis; PETroL. in pulvinis inserti, semiteretes, supra subsulcati, glabri, 0,001 longi. Strpeldae? subuliformes, parvae, caducae. Flores axillares, dichotome corymbosi; pedurculus connunis compresse tctragonus, aciebus obtusis, glaber; pedunculi partiales compresse quadrangulares, subsulcati, pubescentes; Pedicedi obtuse quadrangulares, pubescentes. Bracteae oppositae, ovatac, acutae, concavae, pubescentes. CALrXx profunde quinquepartitus vel pentascpalus, glaber, persistens; SEPALA (laciniae) ovata, acutiuscula. Conolla campanulata, pentapetala, aestivatione imbricatà; PETALa oblongo-ovata, acuta, integerrima, extus subcarinata, glabra, intus basi glabra, apicem versus pilosa. Discus hypogynus, quinquangularis, basi glaber, apice hirsutus. Stamra 3; fildinerta apici disci inserta, lincaria, basi dilatata, glabra; antherae peltatae, oblongae, utrinque emarginatae, biloculares, longitudinaliter dehiscentes. Polden sphaericum, subcanccllatum. Ovariur stipitatum, hemisphaericum, obscurc trigonum, glabrum, triloculare. Ovura 4-8, basi axeos loculi in placentam productae affixa, subcollateralia, erecta, recta. Struus subteres, glaber; stigin punctiforme. Capsulae tres vel abortu pauciores, basi approximatac, subhorizontales, oblongo-ovales, obtusae, striatae, glabrae, uniloculares, bivalves, in medio lateris dchiscentes, valvis navicellatis acutc carinatis. Semv 4-8 in singula capsula, in basi capsulac funiculis umbilicalibus linearibus brevibus aflixa, crecta, ovato-oblonga, obtusiuscula, basi truncata; TESTA versus basin seminis alaeformis, subcoriacea; MESOSPERMuIU cellulosum; TEGHEN membranaceum; HILU micropylae approximatum; rapHe a basi seminis ad verticem procurrens. NucLEus in parte superiore seminis, oblongus, compressus, utrinque acutiusculus, exalbuminosus; cotrLedones planae; Radicula tercs.

\section{Crescit juxta Banjermassing: Bonneo.}

Explicatio Tabulae 39. Figura speciei. 1. Flos. 2. Petalum unicum ab interiore. 3. Flos, corollâ ablatâ. 4. Anthera nondum aperta. 5. Anthera dehiscens, $a$. filamentum, b. connectivum, $c$. loculi. 6. Anthera dehiseensa postcriore. 7. Pollen. 8. Flos, corollâ ablatâ, longitudinaliter dissectus. 9. Ovarii loculus unus longitudinaliter disseetus. 10. Ovula. 11. Capsulac immaturae pars cum seminibus immaturis. 12. Semina immatura cum parte placentae et funiculis unbilicalibus. 13. Capsula dehiscens. 14. Pedunculi apex eum 
calyce, disco et basi capsularum: A. stylus, B. epicarpium, C. mesocarpium, D. endocarpium, E. cavitas capsulac cum funiculis pcrsistentibus. 15. Eadcm organa. 16. Scminum duorum bascs. 17. Semen immaturum longitudinaliter dissectum, nucleo ablato: $a$. hilum, $c$. micropyla. 18. Seminis basis: $a$. hilum, b. omphalodium, $c$. micropyla. 19, 20. Semina matura. 21. Scminis vcrtex: $d$. chalaza. 22. Seminis scctio transversalis: $d$. raphe, $e$. tcsta, $f$. mesospermium, $g$. tegmen, $h$. nuclcus. 23. Scctio transvcrsalis partis scminis inferioris. 24. Testae fragmentum.

\section{HIPPOCRATEA SALACIOÏDES. Kns.}

II. floribus paniculatis, foliis ovalibus acuminatis scrrulatis.

Frutex scandens; Rami subteretes, glabri, fusci; ramuli teretiusculi, versus apicem compressi, in nodos dilatati, glabri. Forra opposita, patentia, ovalia vel rotundato-ovalia, breviter acuminata, basi acutiuscula, serrulata, utrinque glabra. Frores axillares, paniculati; pedunculus comunns compressus, glaber; pedunculr partuces suboppositi, compressi, glabri; bracteae ovatae, acutae, glabrae. Caltx profunde quinquepartitus, laciniis obtusis, glaber. Corollı pentapetala, aestivatione imbricatâ; PETALA oblongo-obovata, obtusa, post anthesin recurva, glabra. Discus hypogynus, subpentagonus, subcarnosus, glaber. Stamina 3; frlamenta basi partis interioris disci inserta, linearia, basi latiora, glabra; antherae basi affixae, biloculares, rimis transversalibus dchiscentes. Ovarrum sessile, subtrilobum, triloculare; ovus bina in singulo loculo, basi loculi aflixa, collateralia; stYuus brevis, glaber; STIGns capitellatum, trifidum.

\section{Crescit in sylvis montis Singalang: Sumatra.}

Dezc plant zal waarschijnlijk een nicuw geslacht moeten vormen, wanneer zij vruchtdragende wordt gevonden. Hare bloeiwijze wijkt geheel af van de andere, mij bekende soorten. Zij is daardoor nader vermaagschapt aan Salacia, doch door de plaatsing van de eitjes en de helmknopjes behoort zij bij Hippocratea. 
O V E R D E G E S L A C H T E N

\section{PRA R A INIA EN OHPIII GARPUS,}

P. W. K 0 R T I A L S.

PR A R A VINI A. Kas.

Fores monoici, raro hermaphroditi. Calyx superus, tubo brevi, limbo 4-6 partito. Corolla aestivatione imbricatâ, tubo cylindrico, limbo 4-6 fido, erecto. Stanina 8-12, infra faucem inserta; filamenta brevia; antherae basi affixae, connectivo producto. Ovarium 8-10 loculare, disco epigyno conico; ovula numerosa, placentis carnosis affixa. StruUs subteres; stigita 4-12 partitum. BacGa calycis limbo coronata, 8-10 locularis, mucilagine impleta. SEmiva numerosa, placentis partitis carnosis inscrta; TESTA crustacea, foveolata; TEGMEN membranaceum. EMrRro in medio albuminis carnosi, erectus.

Arbuscula. Folia opposita, petiolata. Stipulae subintrapetiolares. Flores axillares, bracteati.

Het geslacht Praravinia behoort tot de Hamelieae D. C. Door houding en kenmerken heeft het cenige gelijkheid met de geslachten Axanthes Bl. en Urophyllum Jack en Wallich. Het heeft de houding van het eerste geslacht, doch verschilt van hetzelve door de bloeiwijze en vooral door de verdeeling van de bloem en van de vrucht, beiden vijfvoudig in Axanthes. Volgens de beschrijving oordeelende, moet het door houding en bloeiwijze vrij gelijkvormig zijn met Urophyllum; doch van dit geslacht, even als Axanthes, door bloem en vrucht afwijken. Na deze natuurlijke verwantschap komt die tot Alibertia Rich. en Schradera Vahl, welke misschien wel op eene gelijkvormigheid van enkele kenmerken berust, in aanmerking. Alibertia heeft, even als Praravinia, de bloemen in de oksels en de beide geslachten in afzonderlijke bloemen, maar eene andere bloemverdeeling; daarentegen bestaat de ovcrecnkomst met Schradera in een gelijk getal bloemkroondeclen en helmdraden. 
PRARAVINIA DENSIFLORA. Kus.

P. foliis oblongis acuminatis, floribus axillaribus.

Arbuscula 2-6 metrorum; RAJI patentes, subteretes, glabri; ramulr obtuse quadrangulares, sulcati, glabrati, - novelli compresse quadrangulares, suleati, pilosi. Foura opposita, oblonga, saepe ellipticolanceolata, acuminata, basi aeuta, integerrima, utrinque glabra, - juniora utrinque pilosa, - subcoriacea, longa 0,16 , lata 0,045 ; petroli semiteretes, superne suleati, pilosi vel glabrati, 0,015 longi. Stipulate subintrafoliares, oblongo-lineares, aeutae vel acutiuseulae, supra glabrae, subtus pilosae, membranaecae. Flores axillares; inasculi faseieulati, saepe $3-6$ eongregati; reminer solitares. Bracteae florum masculorum: inferiores calyeiformes, vertieillatim dispositae, vertieillis binis, in vertieillo inferiore ovatae cueullatae acutiuseulae utrinque pubescentes, in vertieillo superiore duae inferiores suborbiculatae et duae supcriores ovato-rotundatae utrinque pilosae, nervis e basi productis retieulatae; - superiores ovatae, obtusae, utrinque pilosae vel intus glabriusculae; - FLonum FEMIINEORUM: inferiores similes braeteis florum maseulorum; - superiores duae, tubo calycis eum ovario connato affixae, suborbiculatae, utrinque dense pubescentes vel glabratae; PEDuvcuL subtetragoni, pilosi. Flos masculus. Calyx eampanulatus, aestivatione imbricatâ; tubus brevissimus; lnorus 4-6 partitus: laeiniae ovatae, obtusae, utrinque praecipue basi pilosae. Corolla subcampanulata, intus extusque pilosa, aestivatione valvatâ; тußus eylindricus brevis; LInвus 4-6 partitum: laciniae rotundatae, breves. Stamina 8-12, laeiniis corollae alterna; filanenta infra faueem eorollae affixa, linearia, brevia, glabra; antherae basi affixae, oblongae, conneetivo producto acuminatae, biloculares, longitudinaliter dehiscentes. Discus epigynus, obtuse eonicus, saepc suleatus, glaber. Srruus subteres, suleatus, glaber; stiginata 4-12, reflexa vel patentia, aeuta, in flore nondum explieato inflexa eonniventia. Fuos femineus. Calyx densc pilosus, aestivatione imbrieatâ; tubus ovatus, basi eum ovario connatus; tumbus 4-6 partitus: laeiniae late ovatae, obtusae, retieulatim nervosae, persistentes, exereseentes. Conolta subeampanulata, intus extusque pubeseens, aestivatione valvata; тuBus brevis; LInisus 4-6 partitus: laeiniae rotundatae, breves. Stanina 4-6, abortiva; laciniis eorollae alterna; fila mienta brevia, glabia; antherarum rudimcnta oblonga, aeuminata. Discus epigynus, subhemisphaericus, subsulcatus. OvaRгum 8-10 loculare; ovura numerosa, plaeentis connatis eum dissepimentis et in singulo loeulo binis affixa. Styuus sulcatus, glaber; stigmata 4-10, radiata, ante floris explicationcm reflexa et eonniventia, acuta. Fruatus baccatus, subglobosus, ealyee persistente exereto coronatus, pilosus, 8-10 loeularis, mueilagine impletus, dissepimentis subeoriaceis. SEnIra numerosa, plaeentis ramosis carnosis eoalitis affixa, subglobosa, foveolata; EPIDERMIS SEMINALIS tenuis; TESTA erustaeea, sat crassa; TEGMEN membranaceum; пIudr approximatum mieropylae, mammillatum. Enßryo in medio albuminis, ereetus, pyriformis.

Crescit in monte Praravin, juxta Tangong Java: Bonveo.

Explicatio Tabulae 41. Figura speciei. 1. Gemma floris. 2. Gemma floris adultior. 3 et 4. Calyces florum masculorum cum bracteis. 5. Flos femineus. 6. Corollac pars ab interiore. 7. Fructus. 8. Bracteae calyciformes verticillares. 9. Pistilli rudimentum in flore masculo. 10. Idem longitudinaliter dissectum. 11. Ovarii sectio transversalis. 12. Pars ovarii transversaliter dissecti aucta. 13. Fructus longitudinaliter sectus. 
14. Partis fructûs transversalis sectio cum placentis coalitis admodum aucta. 15. Loculus unicus fructûs longitudinaliter dissectus cum placenta dissecta. 16. Semen admodum auctum. 17. Semen longitudinaliter dissectum cum embryone integro.

Deze plant heeft, door hare groeiwijze, het voorkomen van de tot het geslacht Axanthes behoorende gewassen. Zij bezit, even als deze, de licht groene bladen op eenigen afstand van elkander verwijderd en, door dezen stand, zeer opene kroonen. Aan dezelve zijn de jonge bladen met haren bedekt, doch de ouderc glad. Hare bloemen zijn in de oksels der bladen gezeten, gewoonlijk éénhuizig, met de beide geslachten op verschillende takken zoodanig geplaatst, dat het bovenste gedeelte der kroon de mannelijke bloemen draagt. Zij zitten geheel alleen, wanneer zij vrouwelijk zijn; doch van 3-6 vereenigd, zoo zij alleen de helmdraden omsluiten. In beiden zijn aan den voet van den bloemsteel twee kelkjes, ieder uit vier schutblaadjes bestaande, waarmede de bloemen, vóór de ontwikkeling, omsloten worden. De helmknopjes der mannelijke bloemen hebben voornamelijk eene aanzienlijke uitgroeijing van den helmknoop, die bij de aanhechting der stuifmeelhokjes dik en aan het einde dezer puntig is. In de vrouwelijke bloemen zijn deze organen zelden volmaakt ontwikkeld; zij blijven hier meestal in dien staat, dat men de deelen kan onderscheiden; soms echter zijn zij alleen door kleine draadjes voorgesteld. De discus der mannelijke bloemen verschilt door zijne grootte en door zijnen vorm van dien der vrouwelijke, welke het vruchtbeginsel als een dun schijfje bedekt. Hij komt in de eerste onder de gedaante van een kegelvormig ligchaam voor, dat met den stijl is zaamgegrocid. De stempels van de bloemen der beide geslachten zijn tamelijk gelijkvormig. In beiden liggen hunne toppen, vóór de opening der bloem, binnenwaarts gebogen, en vormen zij dus een afgeknot kopje, cven als bij Axanthes.

Het vruchtbeginsel heeft de twee placentae van ieder hokje met de tusschenwanden verbonden en van elkander gescheiden. In de vrucht zijn deze twee zamengegroeid en vormen zij een langwerpig, driehoekig, vleezig ligehaam, hetwelk door zaden bedekt is en daarenboven verscheidene zaden insluit. De vrucht, waarop gewoonlijk twee schutblaadjes, die de mannelijke bloem op den steel heeft, zijn gezeten, wordt door een taai slijm gevuld, hetwelk, naar het mij voorkomt, door een der vruchtdeelen wordt afgescheiden. In dit slijm toch heb ik geene bewerktuiging gevonden.

In de maand september zagen wij deze planten vruchtdragend, slechts enkele bloeijend. Zij groeiden in de nabijheid van de Doeson-rivier, langs den oever, en eenige ellen boven haar, op den berg Praravin. 
O MP H A CARPUS. Khs.

CALYX hypogynus, pentasepalus, scpalis lincaribus, intus coloratis, aestivatione valvatis apice induplicativis. Coroux pentapetala, petalis hypogynis, calyce multo brevioribus, basi intus glandulâ instructis. Sramina numerosa, in apiee dilatato stipitis inserta; milamenta filiformia, libera; antmerae basi affixae, longitudinaliter dchisecntes. Ovanium in apice stipitis inscrtum, bi-triloculare; ovura gemina vel terna, in axi loculi superimposita, adscendentia. Struus simplex; srigris truncatum. Fructus baecatus, abortu unilocularis, monospermus, sareocarpio fibroso, endoearpio coriaceo. SEMIEN solitare; spermodernis membranacea. AlbuMEn periphaericum. EMbryo rectus in albumine, erectus; Radicula cylindricâ; cotruedonibus planis, foliaccis.

Arbusculae pube stellatâ. Folia alterna, integerrima. Strpulae geminae. Frones axillares vel terminales, paniculati, umbellulati, umbellulis involucratis.

Dit geslacht bevat struiken, die soms, wannecr zij gedrongen staan, tot kleine boomen uitgroeijen. Zij hebben in beide gevallen ijle kroonen en de bladen en bloemen naar het einde der takken geplaatst. Een stervormig hair bekleedt hunne jonge deelen, hetwelk, bij het ouder worden, langzamerhand afvallende, eerst van de vlakte der bladen en vervolgens van de nerven verdwijnt. De bloembladen en het vruchtbeginsel zijn met enkelvoudige haren bedekt. Deze soort van haren vormt eenen krans om den verbrceden top van den stecl, die de helmdraden en het vruchtbeginsel draagt. Op de vrueht van Omphacarpus zijn de enkelvoudige haren verdwenen en stervormige in hunne plaats ontstaan. In hunne plaats meen ik, volgens door mij gedane waarnemingen, tc mogen zeggen, want de sterren der vruchten zijn vlak en hcbben in het midden ecn rond knopje, het overblijfsel van dit enkelvoudige hair, en op jongere vruehten soms dit hair zelf. Het vruchtbeginsel, zeer jong zijnde, toont duidelijk verscheidene regelmatige holjes aan, doch, bij het uitgroeijen, laat het weldra slechts één hokje zien, terwijl de andere allecn door genoegzame vergrooting te herkennen zijn. In dit eenige uitgroeijende hokje verwijderen zich de citjes van elkander, grocit het benedenste gewoonlijk tot zaad uit, en wordt dus het overblijvende eitje, in de rijpe vrucht, in het boveneinde van het hokje gevonden.

Dit geslacht is zecr na verwant aan Grewia, van welke het, zoo Grewia in den uitgebreidsten zin genomen wordt, eene afdeeling zou wezen. Het behoort digt bij Mierocos, hetgeen door de zamenstelling der vrucht genoegzaam onderscheiden kan worden.

Het zuur der vruchten, hetwelk dat der tamarinden cvenaart, heeft mij den naam doen kiezen, onder wclken het geslacht beschreven wordt. 


\section{OMPHACARPUS OPACUS. Kus.}

O. foliis oblongo-ovalibus breviter acuminatis, stipulis lineari-lanceolatis, fructulbus obovoindeis opacis.

Arbuscula 2-3 metrorum, coronà apertâ; rami alterni, patentes, teretes, glabri, cinerei; Ramuli patentes, teretes, - novelli compressiusculi, dense hirsuti, hirsutie stellata. Gennras axillares, solitariae, sessiles, compressae, obtusae, hirsutae. Fous distantia, altcrna, oblongo-ovalia, rariter oblongoobovata, saepe obliqua, breviter et obtuse acuminata, quaedam acutiuscula, basi obtusa vel altero latere obtusa altero angustata, integerrima, supra glabra et in nervo medio hirsuta, subtus dense hirsuta, pilis stellatis, 0,13 longa, 0,06 lata, nervis primariis paucis 10, patentibus apicem versus incurvis, nervis secundariis subparallelis; petrour semiteretes, dense hirsuti, 0,01 longi. Strpulat intrapetiolares, lineari-lanceolatae, acutae, utrinque hirsutae. Flores corymboso-paniculati, terminales; pedurcults conmunis subteres, dense hirsutus; peduradul partiales alterni, subteretes, hirsuti; pediceldi terni vel qualerni, umbellulati, subteretes, breves, dense hirsuti; BRAGTEAe biformes; majores florem involucrantes rotundato-ovatae, indivisae, acutae vel bi-tridentatae; minores oblongo-obovatae, acutae, utrinque hirsutae; bracteolae saepe quaedam filiformes vel lineares, hirsutae. Alabastrum obovoïdeum, quinquangulare, hirsutum. CALrx hypogynus, campanulatus, pentasepalus, aestivatione valvatâ apice induplicalivâ; sEPAL linearia, apice obtusiuscula et cucullata, intus glabra, colorata, extus dense hirsuta. Corolda pentapelala, brevis; PETaLA oblongo-linearia, breviter acuminata, extus dense hirsuta, intus glabra ct basi glandulà minutâ instructa. Stamira numerosa, uniserialia, apici hirsuto stipitis quinquangularis glabri inserta; fILAMENTa filiformia, glabra; ANTHERAE basi aflixae, bilobae, connectivo apiculato. Ovarivar apici stipitis insertum, ovoïdeum, hirsutum, bi-triloculare, loculis biovulatis; ovvus angulo centrali affixa, adscendentia, superimposita; styuus teres, glaber; strgma truncatum, papillatum. Fructus baccatus, obovoïdeus, glaber, opacus, abortu unilocularis, pericarpio pergameno tenui, sarcocarpio succulento fibroso, endocarpio coriaceo tenui. SEnen solitarium, compresso-ovoïdeum, glabrum; testa membranacea; tegnien membranaccum. A Lbuner periphaericum, carnosum. Enbrio erectus, rectus; cotrledones oblongae, obtusae, basi subcordatae; RAdicula teres, obtusa.

\section{Crescit in sylvis montis Sakoembang: Bonveo.}

\section{OMPHACARPUS HIRSUTUS. Kris.}

O. foliis ovalibus vel ovatis, stipulis tripartitis, fructubus obovatis hirsutis.

Aribusculd 2-6 metrorum, coronâ apertâ; вı̀n patentes, teretes, striati, glabri, nigrescentes; RAMULI alterni vel in apice ramorum oppositi aut verticillati, subteretes, dense hirsuti. Gemmat axillares, scssiles, compresso-ovoïdeae, hirsutae. Folis alterna, ovata vel ovalia, acuta vel acuminata, saepe mucronulata, basi obtusa, integerrima, supra glabra, nervo mediano hirsuta vel glabrescentia, subius in nervis hirsuta, hirsutie stellata, subcoriacea, 0,06 lata, 0,15 longa, nervis primariis patentibus, nervis secundariis parallelis; PETroLI semiteretes, hirsuti, 0,01 longi. Strpulae intrapetiolares, obconicae, tripartitae: laciniae inaequales acutae, utrinque pubescentes. Ftores axillares vel terminales, corymBotanica. 


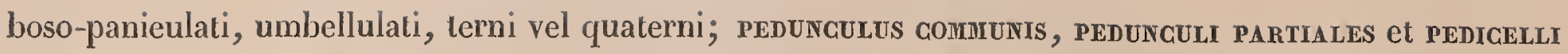
subteretes, hirsuti. Bracteas biformes, ovales aeutae vel oblongo-obovales saepe faleatae aeutae, utrinque hirsutae, involuerum mentientes. CAsyx hypogynus, pentasepalus, aestivatione valvatâ apiee induplicativâ; sepalı ereeta, linearia, obtusiuseula, apiee ineurva, margine inflexa, intus glabra, eolorata, extus dense hirsuta. Conolta pentapetala; ретацA lineari-oblonga, basi latiora, obtusiuseula, extus hirsuta, intus ad basin uni-biglandulosa, tertiam partem sepali adaequantia. Stanira numerosa, uniserialia, apiei dilatato eiliato stipitis quinquangularis glabri inserta; rILAMENTA linearia, glabra; antherae basi aflixae, didymae. Orariun apiei stipitis insertum, rotundato-ovöideum, hirsutum, triloeulare; ovula gemina ternave, axi anguli interni loeuli affixa, superimposita; struus teres, glaber; stigms truneatum. Fructus subbaeeatus, obovatus, hirsutus, uniloeularis, monospermus, periearpio pergameno, sareocarpio subsieeo fibroso, endoearpio eoriaceo. SEmen ovoïdeum, glabrum; testı et tegher membranaeea. Albunien eorneo-earnosum, albidum. Eirbro ereetus, in medio albuminis reetus; cotyLedones ovales, obtusae, basi eordatae, foliaeeae; rAdicula teres, obtusiuseula.

\section{Crescit ad ripas fluminis Doeson: Borneo.}

Explicatio Tabulae 42. Figura spcciei. 1. Umbellula florum cum bractcis quibusdam. 2. Flos. 3. Alabastrum. 4. Flos, calyce ablato. 5. Stamen. 6. Petalum ab intcriore. 7. Pctalum ab extcriore. 8. Flos, calycis parte, corollâ ct staminibus abscissis. 9. Ovarium longitudinalitcr disscctum. 10. Ovarii sectio transversalis. 11. Fructus. 12. Endocarpium, caeteris partibus fructûs ablatis. 13, 14, 15. Endocarpium. 16. Seminis sectio longitudinalis. 17. Embryo denudatus. 


\title{
EIKEN VAN DEN INDISCIIEN AROIIIPEL,
}

D00R

\author{
P. W. K 0 R T H A L S.
}

De eiken, welke het onderwerp dezer bijdragen uitmaken, hebben een zeer versehillend voorkomen. Zelden zijn zij door mij geheel alleenstaande, en dus zich geheel vrij ontwikkelende, waargenomen; doch, voor zooverre dit is kunnen gedaan worden en indien eene vergelijking der takken als bijkomend middel wordt gebruikt, blijft er geen twijfel, dat zij een' even zoo versehillenden indruk maken, als hunne akers in derzelver vormen onderseheiden zijn. Eenigen hebben niet zeer digte kroonen; de bladeren bevinden zieh, bij het minste windje, in eene sidderende beweging en geven alsdan een kletterend geluid: Q. argentata; anderen hebben de kroonen met boven elkander liggende lagen van bladen, die, wanneer de zonnestralen op hen vallen, eenen zilverglans verkrijgen: Q. Reinwardtii; lommerrijk en tevens met wijd uitgestrekte takken komt $\mathbf{Q}$. induta en anderen voor; door den vorm der bladen herinnert Q. gemelliflora de wilgen, doch door den groei en bloei der bladerlooze loten de Q. robur; ook de vorm van den laurier wordt zeer cigenaardig in $\mathbf{Q}$. omalokos voorgesteld, die met digte kroonen, naar boven strevende twijgen en loten, en glanzend loof werd waargenomen.

De besehrevene soorten behooren alle tot de grootere boomen, en eenige verheffen zich, vooral in de bosschen, tot de aanmerkelijke hoogte van niet zelden dertig tot veertig meters. De stammen, welke van deze hoogte één of twee derden, ja, soms meer innemen, stijgen loodregt naar boven, hebhen aan den voet dikwverf verscheidene scherp eindigende sehijven, waardoor een afgekapte boom- 
stronk de gedaante van eene ster en eenen bijna rolronden vorm, niet zelden van drie meters middellijn heeft. 'Lij zijn door eene grijze of grijs-bruine, dikke schors bedekt, die bij de meeste door diepe voren gedeeld is. Op de bergruggen en andere plaatsen, waar de boomen eenen meer onafhankelijken groei hebben en de kroonen nict naar het licht streven, bereiken de stammen deze buitengewone lengte niet. Zij hebben dan één vierde of één zesde van de lengte der boomen, en de kroonen nemen dan in hoogte, doeb naar evenredigheid niet altijd in omvang, toe. De kroonen zijn halfrond of neer piramiedvormig. De eersten zijn aan Q. oïloearpa enzv, eigen. Zij ontstaan door de verdeeling van den hoofdstam in verscheidene takken en het onontwikkeld blijven van den middelknop: een versehijnsel, dat de loten reeds doen voorzien, die in mannelijke of in vrouwelijke bloemen eindigen. De piramiedvormige kroonen, welke de meeste soorten bezitten, hebben den stam doorgroeijende, en uit dezen ontwikkelen zich de zijtakken als stralen. De takken der eersten zijn gebogen, met de kniegewijze bogt naar beneden gerigt; die der anderen zijn regter en over het algemeen regelmatiger. Vooral naar het einde zijn zij in vele twijgen verdeeld, en ontwikkelen zieh talrijke loten. De takken hebben gewoonlijk cene rolronde gedaante en zijn door eene grijze of bruin-grijze, meer of min met voren gegroefde schors bedekt. De jonge takken zijn hoekiger en de loten drichoekig, soms met snijdende kanten. Bij de meeste soorten zijn de laatste met eene digte, soms glanzige hairbekleeding voorzien. De knoppen van eenige soorten: Q. argentata enzv., zijn gelijk aan die van Q. robur. Zij zijn naar het einde der loten zaamgehoopt, of staan alleen of paarsgewijze, soms in grooter getal, in de oksels der bladen. Hunne bedekking bestaat in kleine schubjes, dic als dakpannen over elkander liggen, en onder deze bevinden zich de bladen en bloemen: de laatste mecstal de benedenste ruimte innemende. De knoppen van de meeste soorten zijn in de oksels der bladen, zelden aan het einde der loten gezeten. $\mathrm{Z}_{\mathrm{ij}}$ missen de gemelde schubvormige bedekking, en worden alleen door de nevenblaadjes omsloten. Bij de soorten, welke bedekte knoppen hebben, zijn de nevenblaadjes vliezig, doch vrij uitgebreid; bij de anderen zijn zij van eene vastere zelfstandigheid en kleiner. De bladen zijn in spiralen van drie tot zes om de takken geplaatst; bij Q. argentata zijn zij naar het einde in risten vereenigd; bij anderen, en wel bij de meesten, meer geregeld langs de takken verdeeld. Zelden zijn zij horizontaal, doeh gewoonlijk meer of min naar boven gerigt. Zij worden door, dikwijls zeer lange bladstclen: Q. oïdoearpa enzve, gedragen en zijn door deze op de takken geleed, zoo als bij de zoo even genoemde soort, òf met dezelve zaamgegroeid: $Q$. hystrix enzv. In hunnen vorm overtreft de lengte altijd de breedte, en wordt nu een gave, dan een gezaagde rand waargenomen. De vlakte derzelve is bij de pas ontvouwde bladen dikwerf met eene bruine hairbekleeding bedekt, die later vermindert, en bij vele soorten, alsmede op de oudere bladen geheel ontbrcekt; of zij is door cene glanzige, harsaardige zelfstandigheid overtogen, die wel vermindert, doch niel geheel verdwijnt. De zelfstandigheid der bladen is lederachtig, zelfs bij cenige soorten dik en vrij vast. Door haar loopen de gevederde nerven, die dikwerf, wanneer zij in dikte afneemt, als ribben uitsteken, en dus aan het blad een eigenaardig voorkomen geven.

De bloeiwijze is bij allen in katjes. Zij komt uit de oksels der bladen, of, door de onderdrukte ontwikkeling der hooger geplaatste bladen, uit de einden der loten, waar de katjes alleen, of in grooter getal vereenigd zijn. De Q. turbinata en de verwante soorten hebben de katjes met mannelijke bloemen nederhangende, de andere soorten regt opstaande. Zij zijn bij de laatste ongedeeld of in pluimen gedeeld. 
De bloemstelen zijh bij de mannelijke bloemen der Q. Lurbinata zeer dun, bij de andere soorten dikker, zelden volmaakt rolrond, meestal hoekig, eenigermate gevoord, en met langere of kortere haren bedekt. Met uitzondering van Q. leptogyne, welke tweeslaehtige bezit, hebben al de andere soorten éénslaehtige bloemen. Gewoonlijk is het bovenste gedeelte van het katje met mannelijke bloemen, en het benedenste met vrouwelijke bloemen bedekt; zelden zijn de vrouwelijke bloemen in het midden van het katje. Soms zijn eehter alleen mannelijke bloemen aan de katjes, terwijl bij Q. pruinosa somwijlen, doeh bij $Q$. turbinata en verwante soorten meest altijd vrouwelijke bloemen afgescheiden voorkomen. De mannelijke en vrouwelijke bloemen staan afzonderlijk, of in kleine hoopjes bij elkander, soms wel op eenen vleezigen steel, als waren zij ingegroeid. Zij hebben gewoonlijk drie schutblaadjes: een grooter, onder de bloem, en twee kleinere, bezijden de bloem $\left(^{\star}\right)$.

De mannelijke bloemen der Q. turbinata, enzv. hebben veel overeenkomst met die der Q. pubeseens. Zij bestaan uit een vliezig bloembekleedsel, dat in vier tot zes slippen is gedeeld, uit zes tot twaalf helmdraden en een klein beginsel van een'slamper. Hare helmdraden zijn draadvormig, staan tegenover en tussehen de verdeelingen van het bloembekleedsel, en dragen de helmknopjes, die in de lengte openspringen en dan de ruggen der beide hokjes tegen elkander hebben. De mannelijke bloemen van $Q$. hystrix, enzv. hebben het bloembekleedscl eenigerwijze bekkenvormig, met vier of zes tanden, gewoonlijk acht tot twaalf helmdraden en een beginsel van stamper, hetwelk door eene, soms viltige, haarbekleeding bedekt wordt. Behalve de genoemde drie, hebben de vrouwelijke bloemen soms nog meer schutblaadjes, waardoor zij als met een' krans omringd zijn. Zij bestaan uit een, boven het vruchtbeginsel vrij bloembekleedsel en uit de wezentlijke bloemdeelen. Het vruchtbeginsel is met het benedenste gedeelte van den kelk zaamgegroeid en van eenen meer of min regelmatigen ronden vorm, bezit dric hokjes, die bij verseheidene soorten behaard zijn. In ieder dezer hokjes zijn twee eitjes naast elkander, bijna op gelijke hoogte, in den middelhoek vastgehecht. Zij behooren door hunne ontwikkeling tot de Anatropen. Boven het vruehtbeginsel zijn drie stijlen, zelden meer. Zij groeijen van het vruchtbeginsel af, geheel vrij uit, of blijven van daar, tot op zekere hoogte, vereenigd en verspreiden zich vervolgens wijd van elkander. $\Lambda$ an het einde, of aan de binnenzijde naar het einde der stijlen toe, zijn de stempels met kleine ronde holten of langwerpige groeven voorzien. Rondsom deze werktuigen bevindt zieh het bloembekleedsel als een klokvormig ligchaam, met vier of zes seherpe of stompe tanden. In dit bloembekleedsel zijn dikwerf vier tot zes kleine ligehaampjes, onvruchtbare helmknopjes op korte steeltjes, en bij Q. leptogyne vruehtbare helmknopjes. De laatstbeschrevene wezentlijke bloemdeelen, benevens het hen omringende gedeelte van het vruehtbeginsel, ondergaan bij de ontwikkeling der vrucht weinig verandering; het benedenste gedeelte van het bekleedsel en het vruehtbeginsel vergroeijen daarentegen bijna geheel. Het benedenste gedeelte van het bekleedsel wordt bij de meeste soorten, door de meerdere uitgroeijing van het vruchtbeginsel, weldra van het bovenste afgescheurd, en vormt nu een bekleedsel rondsom een grooter of kleiner gedeelte van het vruchtbeginsel; bij andere, Q. Blumeana, vergroeit het zoodanig, dat het bloembekleedsel in den jeugdigen staat door hetzelve als door eene klok omringd wordt. Dit benedenste gedeelte, met den naam Cupula, kuipje, bestempeld, komt ontwikkeld

$\left.{ }^{*}\right)$ Q. robur, pubescens, enzv. bezitten ook schutblaadjes. Botanica. 
onder verschillende vormen voor: bij de vruchten van $Q$. encleisocarpa bedekt het de akers geheel; die van Q. Blumeana zijn er bijna geheel door bekleed; bij andere soorten is een kleiner gedeelte van de akers door het kuipje omgeven en bij Q. omalokos is hetzelve slechts eene platte schijf onder de akers. Van binnen is het kuipje glad of met eene zijdeaardige haarbekleeding bedekt. De buitenste oppervlakte is met uitstekende ringen: Q. Ewyekii, enzv.; met uitstekende randen: Q. argentata; of met stekels: Q. hystrix, voorzieı. Het is bij de meeste soorten van eene harde, soms houtige zelfstandigheid, alleen bij Q. eneleisocarpa papieraardig. Omtrent het wezen van hetzelve verschil ik in gevoelen van diegenen, welke de cupula voor een eigen ombulsel of voor eene verzameling van sehutblaadjes houden, daar ik, na het onderzoek van de ontwikkeling der vrouwelijke bloemen, ook van $Q$. pubescens, het voor zeker houd, dat hetzelve een uitgegroeid gedeelte van het benedenste des bloembekleedsels is, hetwelk gewoonlijk, niet altijd, zoo als Q. eneleisoearpa leert, reeds zeer vroeg van het bovenste gedeelte wordt afgesehıiden. - Het vruchtbeginsel is, korten tijd na de bevruehting, bij de meeste soorten, éénhokkig. In het bovenste van de holte zijn de tussehenwanden dan als uitstekende randjes zigtbaar, en in het benedenste komen zij als kleine plaatjes tusschen de eitjes voor. De uitgroeijing der eitjes is, in deze vruehtbeginsels, zeer onregelmatig. Door haar worden zij schijnbaar, wijl het gedeelte, waarin de kern ligt, eene overmatige vergrooting verkrijgt, homotropa. - De akers verschillen door hunnen vorm en grootte, en kunnen over het algemeen zeer wel ter onderscheiding der soorten dienen. Zij zijn schijfvormig, half kogelrond, kogelrond of eivormig, en hebben het bovenste gedeelte uitgehoold, rond of puntig, en het benedenste gewoonlijk uitgehoold, zelden rond. Hun periearpium is lederachtig of kraakbeenig. Het sareocarpium van Q. argentata, enzv. is houtig, vast, niet zeer dik; bij Q. omalokos, enzv. bestaat het uit eene vezelige zelfstandigheid, die vooral aan de zijde der vrucht van eenigen omvang is; bij Q. annulata vormt hetzelve het grootste gedeelte van de akers als eene losse, vezelige, door eelweefsel verbondene stof; in de akers van Q. induta, enzv. bestaat het uit eene korrelig-houtige en eene vezelige zelfstandigheid; in die van $\mathbf{Q}$. raeemosa is het in eenige holten verdeeld. Het endocarpium heeft bij Q. omalokos, enzv. eene zeer digte haarbekleeding; bij Q. induta eene bijna gladde oppervlakte, en bij $Q$. argentata, enzv. eenige zijdeaardige haren. De holte der akers is soms door de uitgroeijing: van het sareoearpium tot eene kleine ruimte bepaald. $\mathrm{Z}_{\mathrm{ij}}$ is soms, bij $\mathrm{Q}$. raeemosa en induta, volmaakt driehokkig; doeb ook bij deze onvolkomen driehokkig, door de te geringe uitgroeijing van de tussclıenwanden. Bij anderen is zij éénhokkig, met uitstekende ribben in den omtrek en een klein zuiltje in het midden: Q. Reinwardtii, enzv.; en bij Q. argentata éénhokkig, soms met twee niet ontwikkelde, onvruchtbare hokjes. De zaaddrager is óf als een zuiltje in het midden van de holte der akers, óf langs den omtrek van dezelve, óf in het benedenste gedeelte van de holte. Hij heeft eehter geenen vasten vorm en sehijnt door de ontwikkeling van het zaad bepaald te worden. - Bij de meeste soorten komt sleehts één zaad tot rijpheid; bij $\mathbf{Q}$. induta, racemosa, enzv. daarentegen soms drie tot zes. Het is bij $\mathbf{Q}$. argentata in het benedenste gedeelte van de holte vastgehecht, heeft het hilum over de chalaza en de mieropyla aan het andere uiteinde van het zaad. Bij de andere soorten is het hangende, met het hilum naast de micropyla. Het is bij Q. racemosa, induta, enzv. klein; bij de andere soorten vult het de holte van de vrueht en neemt het soms eenen kegelvorm aan, die den zaaddrager beneden als een klokje bedekt. Het zaadbekleedsel is dun, lederaehtig. Door hetzelve verspreiden zich de takken van de raphe, voornamelijk bij Q. argentata, enzv. op eene zeer zigtbare wijze. 
De kern bestaat uit vleezige zaadlobben en eene peervormige kiem, die in eene holte der zaadlobben ligt.

De kieming van de waargenomene soorten versehilt niet van die der Quereus robur. Het einde van den aker splijt niet zelden in drie lappen. - Omtrent den tijd, welke van de kieming tot de eerste bloeijing verloopt, heb ik geene narigten. De meeste soorten zijn gedurende het geheele jaar met bladen bedekt, welke alleen bij Q. argentata, enzv. omstreeks den bloeitijd verloren gaan. Bij het uitgroeijen ondergaan de bladen dezelfde veranderingen, als die der ons omringende eiken; bunne ontvouwing begint met eene bruine of olijfbruine kleur, welke vervolgens in den groenen tint overgaat, aan de verschillende soorten eigen. De bloei heeft na en somwijlen ook even vóór den regentijd plaats, en van daar, tot aan de rijpwording der vruehten, verloopt gewoonlijk een tiental maanden.

Uit de voorafgaande besehrijving blijkt, dat de Indische eiken twee hoofdvormen bevatten, van welke de een aan Q. robur verwant is: Q. argentata, Q. oïdoearpa, Q. lineata, Q. turbinata, Q. gemelliflora; terwijl de ander hiervan geheel afwijkt. De laatste, gekenmerkt door bloeiwijze, vorm van knoppen, enzv. zoude onder twee groepen kunnen worden vereenigd: eene met kleine zaden: Q. induta, enzv.; de andere met grootere zaden en eene, gewoonlijk met dons bekleede vruchtholie: Q. hystrix, enzv.

De waargenomene soorten verspreiden zieh van het zeestrand tot op 2700 N. ellen hoogte. Op Sumatra groeit de Q. raeemosa op de zieh tot zee uitstrekkende voorgebergten en soms langs hunne, door de zee bespoeld wordende wanden. Op deze standplaatsen en in de alluviale streken om Doekoe werd Q. oligoneura gevonden. De andere soorten van dit eiland zijn door ons langs de bergketen op eene hoogte tusschen de drie honderd en duizend $N$. ellen verzameld en ééne in het gebergte Singalang. Zij vormden, vooral tusschen 400 en $600 \mathrm{~N}$. ellen, een hoofddeel van het boseh, dat zij, als het ware, onder elkander verdeeld hadden. - Het zuid-oostelijk gedeelte van Borneo leverde ons verseheidene soorten. Wij vonden aldaar de Q. Blumeana langs de Doeson-rivier, tot digt bij de streek, waar eb en vloed nog merkbaar zijn. De overige soorten verzamelden wij in het meer oostelijk liggende gedeelte, in weinig boven de zee verhevene en in bergaehtige oorden, tot aan en op den Sakoembang. Over het algemeen seheen iedere soort hier een eigen grondgebied te hebben. Het eiland Java heeft het grootste aantal eiken tusschen de 1000 en $2000 \mathrm{~N}$. ellen hoogte. Daar zijn de bergen en hoogere voorgebergten of bergketens de hoofdzetels der bekende eiksoorten. In hoeverre ieder oord daar eigene vormen heeft, zal een naauwkeuriger onderzoek moeten leeren; doeh men kan als zeker aannemen, dat op verschillende gebergten bijzondere vormen dezer boomsoorten voorkomen.

Ten einde een algemeen overzigt der verspreiding van het geslaeht Quereus te geven, zal ik, bij mijne eigene waarnemingen, nog eenige opgaven van anderen voegen. Door deze gezamentlijk weten wij thans, dat Noord- en Zuid-Amerika, Europa, Afrika en Azië dit geslaeht opleveren. In Noord-Amerika groeijen de eiken van Canada tot aan de landengte, waar de bergketen afgebroken wordt. Zij behooren in de Vereenigde Staten tot de bewoners van de gebergten en van de vlakten, die de rivieren begrenzen, en treden daar, over het algemeen, in het vierde tijdperk van wasdom, langs de oevers te voorsehijn, om 
de noten-, olmen- en moerbeziënboomen op te volgen. Meer zuidelijk naar Mexiko en vooral in dezen Staat zelven, verandert hunne standplaats, naarmate men de evennaehtslijn nadert. Zij stijgen hier steeds hooger tegen de berghellingen op en verliezen op sommige plaatsen, $2500 \mathrm{~N}$. ellen boven zee, hunne bladen. Bij Jalapa, ongeveer op de zoo even gemelde hoogte, staan de eiken in gezelschap van Alnus, Ternströmia, Melastomaeeae en Croton; rondsom het hoogvlak van Mexiko groeijen eenige eiken, met Arbutus, boven 3700 N. ellen, en op den berg: Orizaba, tussehen 4000 en 5000 N. ellen, herinneren Pinus, Pnereus, Viola en Ranuneulus den wasdom der gematigde streken. - Als bewoners van Zuid-Amerika, roornamelijk van de Andes, leerden wij de eiken door de Heeren IIumboldt en Bonpland kennen. Zij zijn, volgens de waarnemingen dezer Geleerden, tusschen de 940 en $3240 \mathrm{~N}$. ellen boven zee, over de bergketen der Andes verspreid, en schijnen dáár, vooral langs de westelijke helling, in gezelsehap der Cinehona voor te komen. - In Europa zijn de eiken tot op $60^{\circ} 47^{\prime} \mathrm{N}$. Br. aan de kust van Zweden en tot op $63^{\circ} \mathrm{N}$. Br. aan die van Noorwegen gevonden. Van deze breedte zijn zij, meer zuidwaarts tot aan de Middellandsehe zee, door geheel Europa en, bezuiden deze zee, in Noord-Afrika aangetroffen. Door de geheele lengte van Europa tot in Azië, van Portugal tot aan den Baikal, waar de. Heer Turtschaninof Quereus mongoliea verzamelde, zijn groeiplaatsen van eiken. Het noordelijke van Europa bezit Quereus robur of aan haar verwante soorten, die hare bladen laten vallen; het zuidelijke bezit altijd groenende eiken, in de weinige boven zee verhevene streken en, boven deze, in hoogere streken vindt men de eiken van het noorden. In Europa en in Amerika groeijen de kegeldragende Pinus of besdragende Juniperus hooger, dan de eiken. - Door de onvermoeide pogingen van de Engelsche Kruidkundigen is de hooge bergketen van middel-Azië eene rijke sehatkamer van Quereus geworden. Een aantal soorten zijn daar, tussehen 2000 en $3700 \mathrm{~N}$. ellen boven den oceaan verzameld. Op den Bissahir wast Q. semeearpifolia in eenen dwergaehtigen staat met Juniperus, Betula en Rosa. Kumaon heeft, op $3654 \mathrm{~N}$. ellen, dezelfde boomsoort eerst in gezelschap van verschillende soorten van Pinus en, hooger, geheel afgezonderd gevonden. Op den Tschur komt Q. lanata met Rhododendron op 2000 .. ellen voor; bij Sumla en Landour groeijen, tusschen eene hoogte van 2200 en 2500 N. ellen, verschillende soorten van eiken met Rhododendron, Aeer en Ulmus. Bezuiden het dal van den Ganges zijn eehter nog geene eiken gevonden. Daarentegen heeft Assam reeds enkele geleverd. Ook schijnt China, zoo men de bewoners en de taal raadpleegt, soorten van dit geslacht te bezitten. Uit Japan zijn, door de onderzoekingen van den Heer von Siebold, een aantal soorten bekend geworden, die belangrijk zijn voor het systeem, en voornamelijk merkwaardig mogen heeten wegens haar voorkomen. Zij behooren door dit laatste tot de Noord-Amerikaansche, de Noord- en Zuid-Europesche en de Indisehe vormen. Zuidelijker zijn de eiken op de Philippijnen, ongeveer $450 \mathrm{~N}$. ellen boven zee, door Meyen waargenomen. Verder zuid-oostelijk sehijnen zij niet verspreid te zijn; mij ten minste is noeh van Nieuw-Guinea, noch van Nieuw-Holland eene soort bekend.

Het hout der eiken behoort, zoo als de Hoogleeraar Blume reeds heeft aangemerkt, tot het bruikbaarste in Indië, vooral dát der op zekere hoogte of op bergruggen groeijende soorten.

De waargenomene soorten waren dikwerf de groeiplaatsen van Viscum en Loranthus. Beiden ontwikkelden zieh zeer weelderig op dezelve, en de soorten van Loranthus versierden niet zelden, door 
haren rijkdom aan bloemen, de takken, ten koste van welke zij bestonden. Behalve deze gewassen, welke de uitgroeijing benadeelen, zijn, voor de verspreiding der eiken, de eekhoorns, zoo lang de vruehten nog. aan de boomen zijn, en op Sumatra de tapiers, wanneer de akers op den grond liggen, zeer sehadelijk. Andere vijanden, voor de ontwikkeling der vruehten, zijn eenige insekten, die het binnenste der vrucht, of soms alleen het sareoearpium, hetwelk hun als verblijfplaats ter hunner ontwikkeling dient, geheel uitknagen. Nog andere insekten (eureulioniden) leven in en voeden zich met de zaadlobben, zonder de kiem van het zaad, om welke zij heenknagen, aan te doen. Ook strekken de akers tot voedsel van den olifant, en schijnt diens Sanskritsehe naam poennaga, aanleiding te hebben gegeven tot dien van poening of poenig, door welken op Sumatra de eik wordt aangeduid. De naam passan, onder welken de eiken op Java bekend zijn, schịnt mij, daar de inlanders meestal van boea (vruchten) passan spreken, aan de wijze, waarop de aker in het kuipje gevat is, ontleend te zijn, en dus het woord pasan (boei, net) te herinneren.

\section{QUERGUS HYSTRIX. Krs.}

Q. ramulis pubescentibus, foliis lanceolato-ellipticis breviter acuminatis supra praesertim in nervis pubescentibus subtus argentato-lepidotis, stipulis oratis acutiusculis, amentis paniculatis, floribus solitariis, squamulis cupulae junioris lanceolatis, cupulis infundibuliformibus, glandibus hemisphaerico-conicis.

Arbor; rami teretes, glabriuseuli; ramuli versus apieem ramorum conferti, sparsi, patentes, subteretes, subsulcati, pubescentes. Genna axillares, subglobosae, pubeseentes. Folı alterna, in spiram quaternatam disposita, patentia, lanceolato-elliptiea, breviter aeuminata, basi aeuta, supra praesertim in nervis pubeseentia, subtus argentato-lepidota et in nervis puberulis, - nervis primariis patentibus, nervis secundariis parallelis approximatis, - 0,18 longa, 0,06 lata; PETIoLI semiteretes, pubeseentes, 0,01 longi. Stipulae laterales, ovatae, aeutiuseulae, utrinque pubeseentes. Amerta axillaria vel terminalia, paniculata vel solitaria, reeta, pubescentia, androgyna vel monoïea, floribus femineis solitariis. Flores masculd in spica androgyna superiores, tribraeteati; BRaGtene laterales superiores, ovatae, minores; bractea inferior laneeolata. Perigoniur sexpartitum, laeinïs semi-ovalibus obtusis intus glabris extus pubescentibus. Stamira 6-9, laciniis perigonii opposita vel alterna; fildMenta annulo submembranaeeo affixa, erecta, filiformia, glabra; ANTHERAE supra basin affixae, mobiles, subdidymae, rimis longitudinalibus dehiscentes. Pistruli rudimentum hemisphaerieum, pubeseens. Frores feninei multibracteati; BRactene pluriseriales, ovales vel oblongae, acutiusculae, pubeseentes. In cupula bRaGteaE coalitae, lanceolatae, acuminatae. Perigonium sexpartitum, partibus semi-ovatis aeutis, pubescens. Ovariun inferum, in cupula immersum, hemisphaericum, triloeulare; ovula bina, descendentia, eollateralia. Strui tres, ereeto-patentes, pubeseentes; stigmata conica, acutiuseula, glabra. Cupula subsessilis, breviter infundibuliformis, pubeseens, squamulis triangularibus aeuminatis carnosis versus apieem numerosioribus; cavitatis basi plana, latere exeavato glabro. GLANs in eupula semi-immersa, hemisphaerico-conica, basi truneata subexcavata, apiee perigonio exerescente pubeseente mammillata, nitida, pericarpio erustaceo, sarcocarpio fibroso inani, endocarpio membranaceo, abortu unilocularis. Senriva ab apiee loculi pendula, plurima abortiva, unieum (saepe nullum) maturum, eavitatem explentia.

Crescit in sylvis Melintang: Sumatra. 
Tab. 43. Figura speciei. 1. Flos masculus apertus. 2. Gemma floris feminei junior. 3. Gemma adultior tloris feminei. 4. Cupula junior. 5. Cupulae junioris sectio longitudinalis. 6. Cupula junior, parte superiore abscissâ.

7. Glans cum parte cupulae. 8 et 9. Glandes. 10. Glans longitudinaliter dissecta cum semine immaturo.

De Quercus hystrix groeit in de bosschen der westelijke helling van het gebergte beoosten Padang, op ongeveer $300 \mathrm{~N}$. ellen boven de oppervlakte der zee. Zij blocit en draagt ten gelijken tijde hare vruchten in october, weshalve de laatste tot derzelver rijpwording omtrent een jaar noodig schijnen te hebben. Ongeveer in denzelfden tijd vallen de bladen gedeeltelijk af, en andere vervangen hen, welke door eene donzige, bruine haarbekleeding bedekt worden.

Deze soort is zeer na verwant aan Quercus pruinosa, en heeft eenige overeenkomst met Q. pallida en Q. sundaica van Java. Van de eerste is zij gemakkelijk door den meer elliptischen vorm en de minder digte haarbeklceding der bladen, de kleinere nevenblaadjes, den kegelvorm der akers en de weekere stekels der kuipjes te onderscheiden. Zij verschilt van Q. pallida door de haarbekleeding, welke bij deze soort alleen op de bloemen cn hare stelen aanwezig is, en van Q. sundaica, welke platgedrukte, halfronde akers, hardstekclige kuipjes, half lancetvormige nevenblaadjes en bijna gladde takken heeft. Daarenboven is zij in hare standplaats, wat de hoogte betreft, afwijkend van de Quercus pruinosa, die op hoogere gedeelten van den berg Gédé, ongeveer op $2500 \mathrm{~N}$. ellen, en van de Q. pallida, welke op $1200 \mathrm{~N}$. ellen hoogte wordt gevonden, en stemt zij met de Q. sundaica in dit opzigt overeen, dewijl deze tevens in de lagere bergstreken voorkomt.

\section{QUERGUS MAPPACEA. KHs.}

Q. ramulis pubescentibus, foliis late ovalibus breviter acuminatis supra glabris subtus pubcscentibus, stipulis semioblongis, amentis paniculatis, floribus solitariis, squamulis cupulac junioris oblongis obtusis.

ARвоR; RAmI subteretes, glabri; RanuLI alterni, erecti vel erecto-patentes, subteretes, subsulcati, vel subtriangulares trisulcati, dense pubescentes. Fols sparsa, alterna, erecto-patentia, late ovalia, breviter acuminata, basi acuta, juniora utrinque dense pubescentia, adultiora glabrescentia vel glabra subtus laete fusca, integerrima, nervis primariis patentibus curvatis, nervis secundariis approximatis parallelis, 0,15 longa, 0,09 lata; petrour semiteretes, pubescentes, 0,01 longi. Stipulae laterales, semi-oblongae vel ovatae, acutiusculae, utrinque pubescentes. Amerra axillaria vel terminalia, paniculata, alterna, erecto-patentia, pubescentia, androgyna vel mascula; PEdungulus conmunis et Partiales triangulares, sulcati, pubescentes. Frores masculr sessiles, in amento androgyno superiores, in spira ternata versus apicem conferti, congregati, inferiores subsolitarii, tribracteati; BRAGTEAE inaequales, inferior major semi-ovalis cucullata pubescens, laterales oblongae obtusae pubescentes minores minutae. Perigonium pelviforme, obtuse sexdentatum, pubescens. Stamrina 6-12, perigonii laciniis opposita et alterna, inaequalia, omnia fertilia vel quaedam abortiva, ante explicationem geniculata; FILA MENTA basi perigonii affixa, filiformia attenuata, apice incurva, glabra; ANTHERAE supra basin affixae, introrsum cernuae, mobiles, subdidymae, rimis longitudinalibus dehiscentes. Prstrulr rudimentum cuneiforme, 
pubescens. Flores feninei in spira ternata vel quinata, solitares, bracteati; BRAGTEA inferior semiovalis, acuminata, extus pubescens, intus glabriuscula; вRAстеA superior calyciformis, obtuse dentata, pubescens; BRACTEAE cupulae junioris coalitae, cum basi perigonii connatae, oblongae, obtusiusculae, pubescentes. Perigonron superum, campanulatum, obtuse quinquedentatum, extus pubescens, intus glabriusculum. Ovariun inferum, cupulâ occultum, depresse sphaeröideum, pubescens, tri- vel uniloculare; ovula bina, in angulis loculi vel margine interno dissepimentorum nondum evolutorum inserta, infra apicem affixa, collateralia, oblonga, apice incurva; sTYLI tres, erecto patentes, pubescentes; STIGMAтA terminalia, conica, acutiuscula.

\section{Crescit in Poeloe-lampei: Borveo.}

De Quercus mappacea, aldus genaamd wegens de overeenkomst der bladen met die der soorten van het geslacht Mappa, komt als een boom van tien N. ellen, in Poeloe-lampei voor. Deze eik bloeide in october. Bij hem verdient, onder anderen, opmerking het kelkvormige schutblaadje, dat het jonge vruchtbeginsel omvat en van de oudere vruchtbeginsels, wanneer deze afvallen, wordt afgescheiden en terugblijft. Van Q. pallida, met welke Q. mappacea de meeste overecnkomst heeft, is hij gemakkelijk door de haarbekleeding der takken te onderscheiden, terwijl hij door den vorm van de schutblaadjes der kuipjes, benevens andere kenmerken, van Q. sundaica verschilt.

\section{QUERCUS OLIGONEURA. KHs.}

Q. ramulis pubescentibus, foliis ovalibus acutis basi angustatis utrinque glabriusculis, stipulis semi-lanceolatis, floribus femineis solitariis in amentis, squamulis cupulae junioris semi-lanceolatis acutiusculis.

Arвor; Ramult erecto-patentes, subteretes, pubescentes. Gemine axillares, ovoïdeae, pubescentes. Folı alterna, patentia, ovalia vel oblongo-ovalia, acuta, basi angustata, marginc recurva, utrinque glabriuscula, nervis primariis distantibus patentibus curvatis, nervis secundariis parallelis, coriacea, 0,3 longa, 0,1 lata; petioli subteretes, glabriusculi, 0,02 longi. Stipulae laterales, semi-lanceolatae, utrinque pubescentes. Amenta terminalia, androgyna, floribus superioribus masculis confertis, floribus inferioribus femineis solitariis; PEDUncul basi nudi subteretes, apice florifero triangulares, pubescentes. Flores mascul tribracteati; bractea inferior semi-lanceolata, acuminata, pubescens. - Flores femivei multibracteati; BRACTEAE tres liberae, semi-oblongae, acutiusculae; BRACTEAE in cupulam coalitae scmilanceolatae, acutae, farinosae. Perigonium superum, breve urceolatum, sexdentatum, dentibus triangularibus acutis, pubescens. Ovarium in cupula immersum, inferum, depresse sphaerö̈dcum, farinosum, triloculare; ovura in singulo loculo geminata, mediae axi loculi affixa, collateralia; strur tres, patentes, ad medium usque connati, elongato-conici, glabri, in parte connata cavi; sTignaTA terminalia, punctiformia.

\section{Crescit juxta Doekoe: Sunitra.}

De Quercus oligoneura werd in november, met jonge vruchten, in de lage streek om Doekoe verzameld. Door de grootte en dikte der bladen en de ronde bladstelen is deze soort opmerkelijk, als ook door de 
kleine holten, welke de stijlen boven het zaaddoosje hebben, hetwelk zccr eigenaardig is. Zij heeft eenige gelijkenis met Q. angustata, doch deze heeft het beneden het kuipje staande schutblaadje toegespitst, half lancetvormig, de kuipjes ongesteeld en half kogelrond; daarenboven bezit de Q. oligoneura een puntig schutblaadje, zijnde het kuipje omgckeerd kegelvormig.

\section{QUERCUS ANCEPS. KHs.}

Q. ramulis glabriusculis, foliis ovalibus vel obovatis breviter et obtuse acuminatis basi angustatis, stipulis semi-lanceolatis acuminatis, floribus masculis in glomerulis sparsis, femineis in glomerulis confertis, squamulis cupulae junioris subrotundae attenuato-elongatis triangularibus.

ARBor; RAMr subteretes, sulcati, glabri; RAMUUt versus apicem ramorum conferti, alterni vel subverticillati, diffusi, subteretes, novelli compresse triangulares, in nodis dilatati, glabriusculi. GEMmse axillares, sessiles, hemisphaericae, glabrae. FouIs alterna, in spira quinata, diffusa, ovalia vel obovata, breviter et obtuse saepc emarginatim acuminata, basi angustata, subrepanda, margine recurva, utrinque glabra, nervis primariis diffusis apice inflexis, nervis secundariis subreticulatis, coriacea, 0,12 longa, 0,055 lata; Petrour semiterctes, subsulcati, glabri, 0,005 longi. Strpulat laterales, semi-lanceolatae, acuminatae, pubescentes. Anievra axillaria solitaria vel terminalia, subverticillata, erecta, androgyna vel mascula; pedurculus obtuse triangularis, molliter pubescens. Flores Masculr in glomerulis oblongis suffultis bracteâ inferiore semi-lanceolatâ acuta pubescente apice glabra et duabus lateralibus altius insertis semi-ovalibus acuminatis pubescentibus, tribracteati; вRAсTEA unica, major, inferior, spathulata, cucullata, pubcscens; bracteas duae laterales, minores, oblongae obtusae, pubescentes. Perigonium pelviforme, 4-6 dentatum, dentibus obtusis, intus glabrum, extus pubescens. Stamina 8-12, quaedam saepe abortiva vel rudimentaria; riLsmenta ad basin rudimenti pistilli inserta, linearia, attenuata, glabra. Antherae supra basin affixae, introrsum pendulae, cordiformes, rimis longitudinalibus dehiscentes. Pistrulr rudimentum turbinatum, basi glabrum, apice pubescens. Flores fentraner in glomerulis saepe trifloris tribracteatis, - bracteà unâ inferiore semi-ellipticâ acuminatâ subcucullatà pubescente, bracteis duabus lateralibus semi-rotundis pubescentibus, - multibracteati; BRACTEOLAE liberae semi-lanceolatae, acutae, pubescentes, apice glabriusculae; BRACTEAE in cupulam subrotundam coalitae elongato-conicae, pubescentes, confluentes. PERIgorrur superum, basi cum cupula bractearum connatum, breve urceolatum, 4-6 dentatum, dentibus acutis, intus glabriusculum, extus pubescens. Ovariom in cupula occultum, depresse sphaeroïdeum, glabrum, triloculare; ovula in singulo loculo geminata, versus apicem axcos loculi in medio ventris affixa, collateralia, clongato-ovoïdea, apice recta. STrur 3-4, basi connati, erecto-patentes, elongato-conici, basi pubescentes; stigmata terminalia, punctiformia. Cưvuls fructûs immaturi sphaeroïdeo-turbinata, intus sericeo pubescens, squamulis elongato-pyramidalibus saepe sulcatis, pubescentibus. Guans ejusdem fructûs subimmersa, hemisphaerica, perigonio breviter stipitato mammillata, basi excavata, glabra.

Crescit in Poeloe-lampei, in monte Pamatton: Borveo. 
Quercus anceps komt onder twee vormen voor: de een, hierboven beschreven, groeit in Poeloe-lampei; de ander, aan den berg Pamatton verzameld, verschilt van den eerstgenoemde door de meer langwerpige en meer toegespitste bladen. Aan ecnige takken der, op de laatste plaats vcrzamelde gewassen, waren de katjes pluimvormig. Zij hadden de benedenste bloemhoopjes als kleine katjes van den hoofdbloemstecl verwijderd, en de bovenste aan denzelven vastgegroeid.

\section{QUERCUS RAGEMOSA. W. ЈACK.}

Q. ramulis glabris, foliis lanceolato-ellipticis utrinque glabris, stipulis semi-lanceolatis, floribus femineis in glomerulas confertis, squamulis cupulae junioris semi-lanceolatis acutis, squamis cupulae adultioris dilatato-triangularibus acutis, glandibus disciformibus basi excavatis.

Arbor; rami, Ramul, folia, inflorescentia, flores mascult et flores feminet haud a Quercu ancipite diversi. Ovarium cupulâ occultum, depresso-sphaeroïdeum, - adultius disciforme vertice basique excavatum, glabrum, triloculare; ovvus in singulo loculo geminata, apici loculi in axi inserta, ventri paulo supra basin affixa, subcollateralia, elongato-ovoïdea, vertice recta. Strui et stigirata vix ab $\mathbf{Q}$. ancipite diversi. Cupula urceolato-pelviformis, extus basi subplana squamulis patentibus dilatatotriangularibus mucronulatis pubescentibus carnosis, intus basi paulo elevata, planiuscula sericea. Guass cupulâ semitecta, disciformis, vertice excavata mammillata, basi excavata, cavitate subplana margine cincta, glabra, nitida, pericarpio crustaceo, sarcocarpio fibroso, endocarpio coriaceo glabriusculo, trilocularis, dissepimentis completis triangularibus lignosis. Seniva plurima abortiva, unica matura, versus apicem loculi inserta, medio ventris affixa, ovoïdea, glabra; тEsta coriacea, fusca; TEGMEx membranaceum.

\section{Crescit juxta Oedjong-mammon: Sumatra.}

In de lage streken van de westkust van Sumatra is Quercus racemosa door ons verzameld. Deze boom groeide aldaar, te Doekoe, in eenen alluvialen bodem, en te Oedjong-mammon aan de oevers der zee. De boomen, welke het rotsige zcestrand, achter de naakte en losse rotsklompen, versierden, waren tusschen de acht en tien $\mathbf{N}$. ellen hoog. Zij vertoonden zich in julij niet zeer bladrijk, doch droegen toen rijpe vruchten en enkele bloeijende takken. Daardoor was de overgang van den stam in de takken, uithoofde der splitsing of verdeeling van denzelven, als ook de stijve, hoekige buiging der takken zigtbaar.

Quercus racemosa hceft eenige overeenkomst met Q. anceps van Borneo en Q. placentaria van Java. Van de eerste is zij door de akers, die reeds zeer jong eenen schijfvorm hebben, te onderscheiden. Van Q. placentaria verschilt zij door het kuipje en de akers. Het eerste heeft bij Q. placentaria de holte half kogelvormig; de laatsten zijn bij deze soort half kogelrond, het benedenste einde afgerond. 


\section{QUERCUS MICROGALYX. Kus.}

Q. ramulis glabris, foliis lanceolato-ellipticis acuminatis, stipulis semilineari-lanceolatis, floribus masculis et femineis in glomerulas confertis, squamulis cupulae junioris semi-lanceolatis, squamis cupulae adultioris triangularibus, glandibus hemisphaericis.

Arbor; rami, ramult, folia, inflorescentia el hlores masculi haud ab Quereu ancipite diversi. Flores feminei glomcrati, glomerulis bracteatis; BRactea inferior triangularis, acuta, cucullata, pubescens; BRActeat laterales semi-rotundatae, pubescentes. Bracteae cupulae junioris semi-lanceolatae, pubescentes. Perigonrum superum, breve urceolatum, pubescens, sexdentatum, dentibus minutis obtusis. Ovariun cupula inclusum, scmi-ovoïdeum, glabriusculum, triloculare; ovura in singulo loculo geminata, versus apicem loculi ab axi descendentia, paulo infra verticem affixa, subcollateralia, oblonga. Strur tres, erecto-patentes, basi connati, elongato conici, pubescentes; stigriata introrsa, linearia. Cuvela dilatato-pelviformis, basi applanata, squamulis in zonas concentricas confluentibus mucronulatis pubescentibus, cavitatis basi subplana, sericea. Guavs dimidia parte cupulâ cincta, hemisphaerica, vertice perigonio persistente mammillata vel punctata, basi plana, nitida, pericarpio crustaceo, sarcocarpio subfibroso, endoearpio coriaceo, trilocularis, dissepimentis coriaccis completis vel incompletis. SEniva plurima abortiva, solitaria, ab apice loculi descendentia, ovö̈dea, glabra; TESTA coriacea; TEGMEN

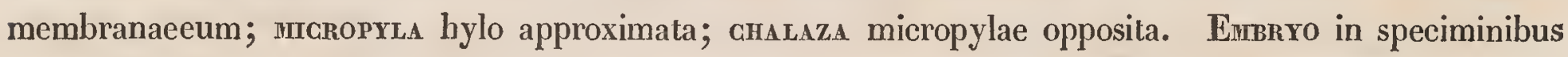
meis abortivus, subereetus.

\section{Crescit in Poeloe-lampei: Bonneo.}

\section{QUERGUS LEPTOGYNE. Khs.}

Q. ramulis dense pubescentibus, foliis oblongis acuminatis basi acutis, stipulis semi-lanceolatis, amentorum floribus masculis glomerulatis et floribus hermaphroditis vel femineis solitariis, squamulis cupulae junioris oblongis.

Arвor; вамI subteretes, glabri, obscure fusci; ramuli erecto-patentes, teretes, versus apieem angulati sulcati, dense pubescentes. FouIa alterna, sparsa vel in spira ternata, patentia, oblonga, acuminata, basi acuta, utrinquc glabra, juniora utrinque pubescentia, nervis primariis patentibus curvatis prominentibus, nervis secundariis subparallelis, 0,12 longa, 0,04 lata; peTroLr semitcretes, glabri, 0,005 longi. Strpulae laterales, semi-lanceolatae, pubescentes. Amenta terminalia vel axillaria, solitaria, androgyna vel mascula; pedunculus triangularis, dense pubescens. Flores hasculi glomerulati, raro solitarii, glomerulis tribracteatis, tribracteolati; BRACTEA major inferior, ovata, acuminata, pubescens; bracteae minores oblongae, acutae. Perigoniun pelviforme, sexpartitum, laciniis acutis vel subacuminatis, pubescens. Sтанти 12, basi rudimenti pistilli inserta, laciniis perigonii alternantia et opposita; FILAMENTa filiformia, glabra; ANTHERAE medio affixae, introrsum cernuae, subdidymae, longitudinaliter dehiscentes. Pistruti rudimentum obconicum, dense pubescens. FLoREs hermaphroditi vel feminei solitarii, tribractcati; BRACTEA inferior ovata, acuminata, pubescens; BRACTEAE laterales auriculatae pubeseentes; bracteae eupulae junioris oblongae, pubescentes. Perigonmu superum, basi liberum, 
pelviforme, sexdentatum, dentibus triangularibus aeutis, pubeseens. Stanira 12; filamevts annulo pcrigyno affixa. Ovariun inferum, cupulà obtectum, hemisphaericum, triloculare; ovula geminata subcollateralia. Stru 3, diffusi, basi connati, subteretes, sparse pubescentes; stigmata apicularia, punctiformia.

Crescit in sylvis montis Sakoembang: Bonve.

\section{QUERCUS GRACILIS. KHs.}

Q. ramulis glabriusculis, foliis ovali-oblongis acuminatis basi acutis, stipulis lanceolato-linearibus, amentis paniculatis floribus femineis solitariis, squamulis cupulae junioris oblongis in zonas concentricas connatis.

Arror; rami subteretes, glabri; rantul patentes, triangulares, sulcati, glabriusculi. Folia alterma, in spira quinata, patentia, ovali-oblonga, mucronulato- vel emarginato-acuminata, basi acuta sacpe inacquilatera, altero latere rotundato altero angustato, margine undulata, utrinque glabra, nervis primariis patentibus rectis versus apicem incurvis, nervis securdariis subparallelis, coriacca, 0,2 longa, 0,07 lata; petioli semiteretes, glabri, 0,005 longi. Stipula laterales, lanccolato-lineares, margine et apice incurvae, glabriusculae. Arrenta axillaria vel terminalia, paniculata, androgyna vcl mascula; pedurauli triangulares, suleati, cano-pubcscentes. Flores Irasculi in amentis androgynis superiores, glomerulati vel solitarii, in spiram dispositi, tribracteati; bRactea inferior major et BRAct Eae superiores laterales minores triangulares acutae pubescentes. Perigoridua pelviforme, sexdentatum, dentibus triangularibus acutiusculis, pubescens. Stamina 12, dentibus perigonii alterna et opposita; filantenta basi pistilli rudimentarii inserta, filiformia, glabra; ANTHERAE basi affixae, pendulae, obcordiformes vcl subbilobae, lobis obtusis, longitudinaliter dehiscentes. Pistrlur rudimentum subsphaericum, pubescens. Flores feningi solitares, alterni, tribracteati; bracters similibus floris masculi; bractea eupulae junioris conicae, oblongae, in zonas concentricas coalitae, pubescentes. Perigoniuri superum, basi liberum, breviter urceolatum, sexdentatum, dentibus brevibus triangularibus acutiusculis, pubeseens, basi supra cupulam annulo villorum praeditum. Ovariuni cupulà obtectum, semi-cllipsoïdeum, subtrigonum, glabrum, triloculare; ovurs in singulo loculo geminata, in media axi loculi descendentia, infra verticem affixa, ovoidea, subtrigona. Strui 3, erecti, fere ad apicem usque connati, conici, pubescentes; stignata terminalia, punctiformia.

\section{Crescit in monte Balaran: Bonveo.}

Quercus gracilis heeft de nevenblaadjes, in vergelijking met de andere soorten, vrij groot, soms 0,01 lang. Hare katjes zijn in pluimen verdeeld en door een wit dons bedekt. De vrouwelijke bloemen hebben het kuipje omgekeerd tolvormig, met drie ringen van zaamgegroeide schubjes, en het bloembekleedsel kruikvormig, met eenen digten viltring boven het kuipje.

$Z_{i j}$ is van Quercus lcptogyne, aan welke zij het naaste verwant is, gemakkelijk te onderscheiden door de gladde takjes, den vorm der nevenblaadjes, den gemelden ring om het benedenste van het bloembekleedsel, en door den vorm der helmknopjes. 


\section{QUERCUS BLUMEANA. Kns.}

Q. ramulis glabris, foliis oblongo-elliptieis aeuminatis, stipulis lineari-laneeolatis, amentorum floribus femineis solitaris, squamulis eupulae junioris semi-laneeolatis, cupulis glandes ineludentibus, squamulis in zonas concentricas confluentibus.

Аввов 6-10 metrorum, coronâ aperta; rami subteretes, glabri, laete fusci; ramuli alterni, sparsi, patentes, subteretes, glabri, novelli subtriangulares sparse pubescentes. Fonta versus apicem ramorum, alterna, patentia, oblongo-elliptica, acuminata, basi acuta, margine plana, utrinque glabra, nervis primariis patentibus curvis apice incurvis, nervis secundariis reticulazis, coriacea, , 0,10 longa, 0,045 lata; petroli subteretes, supra sulcati, glabri, 0,005 longi. Strpulae laterales, lineari-lanceolatae, glabriusculae. Aлrenta axillaria simplicia, terminalia paniculata, androgyna vel mascula; Pedurculus triangularis, dense pubescens. Flores masculi in amento androgyno superiores, solitarii, in amento juniore saepe subverticillati, in amento adultiore in spira ternata vel quinata, tribracteati; BRACTEA inferior major, triangularis, acuminata, intus glabriuscula, extus dense pubescens; BRACTEAE laterales minores, semilanceolatae, pubescentes. Perigoniun pelviforme, sexpartitum laciniis triangularibus acutiusculis, intus subglabrum, extus pubescens. Stanira 12, lacinïs opposita ct alternantia; FiLAmenta basi rudimentariae pistilli affixa, filiformia, glabra; ANTHERAE paulo supra basin affixae, ovatae, basi cordatae, rimis longitudinalibus dehiscentes. Pistilu rudimentum sphaerö̈deum, pubescens. Frores rearinei solitarii, in spira quinata, breviter stipitati, bracteati; вRACTEAE liberae calyculatae, inaequales: superior major semi-rotundato-cucullata, duae laterales auriculatae, inferior minor semi-lanceolata; BRACTEAE cupulares in zonas concentricas connatae, semi-lanceolatae, pubescentes; cUpULA junior hemisphaerica, paulo adultior cylindrica, florem totum includens, apice excavata. Perigonrum superum, discoideourceolatum, in medio concentrico-carinatum, sexdentatum, dentibus triangularibus obtusis, extus pubescens, intus glabriusculum. Ovaritu inferum, cupula inclusum, ovoideum, glabriusculum, triloculare; ovuls in singulo loculo geminata, ab apice axeos loculi descendentia, infra verticem affixa, elongatoovoïdea. Struı tres, ad medium longitudinis connati, patentes, elongato-conici, parte connatâ pubescente, partibus liberis glabris; sтig лита apicalia, punctiformia. Cupula stipitata, hemisphaerica, basi excavata, squamulis mucronatis coalitis in zonas concentricas; superficie exteriore prorsus, interiore basi plana solummodo, pubescens. Guans cupulâ inclusâ, hemisphaerica vel depresse hemisphaerica, conico-mammillata, basi plana elcvato-marginata, glabra, apice pubescens, pericarpio crustaceo, sarcocarpio basi glandis loculoso et versus apicem medullari, endocarpio coriaceo dense piloso, abortu unilocularis. SEMrEx solitare, descendens, conicum, basi attenuatum.

\section{Crescit ad ripas fluminis Doeson: BoRneo.}

Explicatio Tab. 44. Figura speciei. 1. Flores masculi. 2. Flos femineus. 3. Flos femineus longitudinaliter dissecta. 4. Orarii sectio transversalis. 5. Cupula. 6. Eadem longitudinaliter dissecta. 7. Cupula cum ovario longitudinaliter dissecta. 8. Glans cum parte eupulae. 9. Cupulae pars. 10. Glans cum parte cupulae a superiore. 11. Eadem ab inferiore. 12. Glans ab inferiore.

Deze belangrijke soort verdient ecnen naam, harer waardig. Ik draag haar daarom op aan den ijverigen beoefenaar der Kruidkunde, welke de Flora van den Archipel onderzocht, en de kennis derzelve, door 
zijne geschriften, zoozeer heeft bevorderd en uitgebreid. - Wij hebben deze soort langs de oevers van de Doeson-rivier, en vooral in het hoogere gedeelte, hetwelk inzonderheid dezen naam draagt, waargenomen. Elders, op onze landreis langs Borneo's zuid-oostkust, werd zij niet gezien. Ook langs de boorden van de genoemde rivier vonden wij slechts weinige voorwerpen. Deze bijzonderhcid en de zoo even medegedeelde opmerking doen mij vooronderstellen, dat Q. Blumeana op de bergen van het middelgedeelte van Borneo, uit welke de Moerong-rivier ontspringt, hare wezentlijke standplaats heeft. De langs de rivier groeijende boomen waren alle in een' onderdrukten toestand. Korte, niet zelden kronkelend gebogene stammen, droegen bijna eivormige kroonen, welker ijl loof niet in staat was, de lichtstralen af te sluiten. Hunne bloemen waren, tijdens onze reis, in augustus en september, geopend, tot vruchtjes gezet, of als akers uitgegroeid. De pas ontlokene vrouwelijke bloempjes hebben het bloembekleedsel naakt. Vervolgens wordt dit bekleedsel, door de uitgroeijing van de benedenste deelen der bloem, in eene trechtervormige holte verborgen. Door de vergrooting van het onderste gedeelte komt hetzelve later weder te voorschijn, en blijft het als een rond knopje op de akers. De akers zijn, even onder dit knopje, naakt, voor het overige echter door het kuipje ingesloten. Zij hebben, ten gevolge van miswassing, slechts cén hokje, hetwelk ongeveer een vierde gedeelte der vrucht inneemt en met donzige haren digt bekleed is. Rondom hetzelve is ecn lederachtig endocarpium. Het hieraan sluitende gedcelte van het sarcocarpium bestaat uit een zamenhangend merg, en het nader aan het epicarpium, voornamelijk in het benedenste van den aker gelegen gedeelte, is in kleine, onregelmatige vakjes, door mergachtige tusschenwanden verdeeld.

\section{QUERCUS ENGLEISAGARPA. KH.}

Q. ramulis lepidotis, foliis elliptieis acuminatis, amentorum floribus femineis solitariis, cupulis concentrice zonatis, cupulis adultioribus glandem depresso-sphaericar includentibus.

Arвor 20-25 metrorum, coronâ depresso-hemisphaericâ apertâ; RAMI subteretes; RanuLu versus apicem ramorum sparsi, alterni, patentes, teretes, sulcati: novelli compresse angulati, lepidoti. FolIA versus apieem ramulorum confcrta, alterna, patentia, elliptica, acuminata, basi acuta, integerrima, quaedam sinuata, utrinque sublepidota, nervis primariis patentibus incurvis, nervis secundariis subparallclis, coriacea, 0,12 longa, 0,05 longa; pertout subteretes, supra sulcati, sublepidoti, 0,015 longi. Gemnae axillares, sphaericae, lepidotae. Anerta axillaria vel terminalia, mascula vel androgyna; pedurculus angulatus, sulcatus, lepidotus. Flores masculr glomerati, tribracteati; rRactea inferior major, triangularis, acuta, pubescens; BRACTEAE laterales minores, falcato-semilanceolatae, subpubescentes. Perigoniun sexpartitum, laciniis semirotundatis acutiusculis, glabriusculum. Stamira 6-12, laciniis perigonii alterna vel alterna et opposita; FILA.MENTA basi pistilli rudimentarii affixa, filiformia, glabra; antierae medio dorsi aflixae, mobiles, subdidymae, longitudinaliter dehiscentes. Pistillt rudimentum turbinatum, pubescens. Flores fenriver solitarii, bracteati; bractea una libera, distans, triangularis, puberula; bracteas cupulae in zonas concentricas denticulatas concretae, pubescentes. Perigonidni superum, basi cum braetearum cupula connatum, pelviforme, sexdentatum, dentibus triangularibus obtusiusculis, 
pubescens. Ovariur inferum, cupulâ inclusum, sphaeroídeum, pubescens, triloculare; ovứa in singulo loculo geminata, infra apicem loculi axi adnexa, infra verticem affixa, descendentia, subcollateralia, ovoïdca; stru 3-4, basi connati, erecto-patentes, conici, glabriusculi; stigrata apicalia. Cupula junior turbinata, subpubescens. Cupves adultior stipitata, stipite versus apicem incrassato, hemisphaerica, vertice acuta, irregularitcr et concentrice zonata, sublepidota, chartacea, glandem prorsus includens, intus basi umbonata, glabriuscula, versus basin sericeo-pubescens. Glans hemisphaerica, verticc mammillata, versus basin rotundata, basi excavata, cavitate pelviformi, dense sericeo-pilosa, epicarpio crustaceo, sarcocarpio inani fibroso, endocarpio coriaceo, abortu unilocularis, loculo glabro. SEMex unicum, pendulum, excavato-pelviforme, suleatum, basi obtuse dentatum, glabrum; тESTA coriacea; TEGMEN membranaccum.

\section{Crescit in sylvis Melintang: Sumatra.}

Explicatio Tab. 45. Figura spcciei. 1. Florum masculorum glomerulus. 2. Flos masculus expansus. 3. Flos femineus junior. 4. Flos femineus junior dissectus. 5. Flos femineus magis evolutus. 6. Flos femineus, cupulac parte abscissâ. 7. Flos femineus longitudinaliter disscctus. 8 ct 9. Glandes. 10. Cupula cum glande longitudinaliter dissecta. 11 et 13 . Semen a vertice et ab apice. 12. Semcn a latere.

Deze Quercus hebben wij in het midden der bosschen, als boomen met kegelvormige kroonen en aanzienlijk hooge stammen waargenomen. Langs de helling der dalen zijn zij minder hoog: de stam is daar korter, dan de kroon. De kroon heeft eenen langwerpigen eivorm. De takken zijn met eene zilverachtige schors bedekt. De bladen, vooral de jonge, zijn dof zilverachtig, en het eind der takken met jonge blaadjes, schittert in de zonnestralen. De mannelijke blocmen behooren tot de grootste onder de eiken. Zij hebben dikwerf slechts zes ontwikkelde helmdraden, en daarenboven, tussehen deze, eenige draden of kleine kopjes. Bij de zeer jonge vrouwclijke bloemen zijn de stijlen en stempels, in vergelijking met den kelk en het vruchtbeginsel, zeer ontwikkeld. Zij hebben het vruchtbeginsel geheel ingesloten. Hetzelve is in den jeugdigen toestand behaard, en krijgt, ouder wordende, langere haren, zoodat de aker met ecn bckleedsel van lange, zijdeachtige haren bedekt is. De holte der akers neemt ongeveer een derde van de vrucht in, is geheel glad en heeft een lederachtig bekleedsel.

In de maanden october en november hebben wij deze soort, beoosten Padang, bloeijend en vruchtdragend gezien. Zij verkreeg toen nieuw loof, en was aan de uiteinden der takjes, met zamengevouwen blaadjes voorzien.

Q. incleisacarpa verschilt van de door mij waargenomene soorten, vooral door de gehecl ingeslotene akers. 


\section{QUERCUS REINWARDTII. Kus.}

Q. ramulis sublepidotis, foliis ellipticis, breviter acuminatis subtus argentato-lepidotis, amentorum floribus femineis solitariis, cupulis junioribus elongato-turbinatis cum zonis concentricis, cupulis adultioribus pelviformibus concentrice zonatis, glandibus ovoïdeis basi excaratis.

Arbor excelsa; rami diffusi, subteretes, fusci, lenticellati, glabri; ramuli versus apicem ramorum sparsi, patentes, basi incrassati, subteretes, sublepidoti; novelli triangulares, sulcati, lepidoti. FouA versus apicem ramulorum, alterna, in spira quinata, patentia, elliptica, breviter et obtuse acuminata, basi angustata, margine recurva, supra nitida, subtus argentato-lepidota, nervis primariis parallelibus diffusis curvatis, nervis secundariis reticulatis, coriacea, 0,11 longa, 0,05 lata. Gemae axillares, subrotundae. Anenta axillaria vel terminalia, simplicia, curvata, androgyna vel mascula; peduncuudus angulatus, furfuraceus. Flores Itasculi glomerati, tribracteati; BRActenE aequales, triangulares, acutiusculae, pubescentes. Perigoniun pelviforme, integerrimum vel obsolete denticulatum, intus. glabrum, extus pubescens. Stamina 6-12; fiLAmenta filiformia, glabra; a atherae supra basin affixae, subdidymae, longitudinaliter dehiscentes. Pistrlli rudimentum sphaericum, dense pubescens. Flores

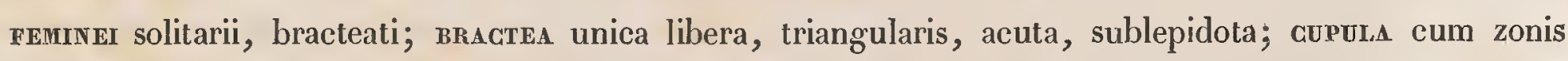
concentricis denticulatis. Perigoniun superum, pelviforme, dentatum, dentibus acutiusculis, lepidotum. Ovartun cupulà tectum, conicum, pubescens, triloculare; ovuLa in singulo loculo geminata, versus apicem axi loculi inserta, descendentia, infra extremitatem superiorem affixa, elongato-ovoïdea; sTYLI 3-6, breves, connati, conici, glabri; stiginata apicalia, obtusa. Cupula stipitata, stipite basi cupulae crassiore, pelviformis, extus cum zonis concentricis marginatis, lepidota, intus basi umbonata glabriuscula. Grıss tertia parte cupulam immersa, ovoïdea, apice acutiuscula, basi excavata, cavitate hemisphaerica, sericeo-pubescens, epicarpio crustaceo, sarcocarpio in parte inferiore glandis majore, endocarpio subcoriaceo lanuginoso, abortu unilocularis, loculo sulcato. SENEN unicum, conicum, basi excavatum, sulcatum, glabrum; SPERModerins subcoriacea. Embryo erectus, cotyledonibus carnosis, plumulà minutâ.

\section{Crescit in sylvis Melintang: Sumatra.}

Quercus Reinwardtii komt onder twee vormen voor: de een is hierboven beschreven; de ander verschilt door de langwerpige bladen en ook door de vruchten, die ronde, kruikvormige kuipjes bezitten en korte, kegelvormige akers hebben, van welke ongeveer het drie vierde of vier vijfde gedeelte in de kuipjes is besloten.

Zij behoort tot de hoogste boomen van de bosschen beoosten Padang en bereikt 25-35, soms 40 N. ellen hoogte. Haar stam heeft dikwijls meer dan twee ellen omvang, en onder eene grijze schors een hard hout. De kroon der, in het midden der bosschen groeijende boomen is kegelvormig, aan het benedenste einde een weinig bol. Aan den top is zij geheel doorzigtig, en lager kunnen de bogtige takken duidelijk onderscheiden worden. De bladen zijn op de bovenvlakte glanzig en op de ondervlakte verzilverd. De akers zitten aan het einde der takken in trossen, meestal in één vlak aan twee zijden van den steel. Zij zijn van binnen met cene donzige haarbekleeding bedekt en geheel door het zaad gevuld. 
Deze soort, in het gebergte beoosten Padang verzameld, groeit aldaar digt bij den top, vooral tegen de zachthellende ruggen. Zij bloeide en droeg vruchten in het begin der maand november.

\section{QUERGUS COSTATA. Bu.}

Q. ramulis glabris, foliis oralibus brcviter acuminatis, stipulis lanceolato-linearibus, amentorum floribus femineis solitariis, cupulis junioribus concentrice zonatis, cupulis adultioribus concentrice zonatis costatis, glandibus apice depressis cum cupulis connatis.

\section{Crescit in sylvis Melintang: Sumatra.}

De op Sumatra verzamelde voorwerpen verschillen weinig met die van Java, welke in de Flor a Javae zijn beschreven. Eenige derzelve hebben dikkere bladen en grootere schutblaadjes. Het vruchtbeginsel is, jong zijnde, tot op twee derde gedeelten met het kuipje vastgegroeid. Deszelfs holte heeft drie hokjes, met de placentae beneden den top. In icder der hokjes zijn twec eitjcs. Deze liggen niet, zoo als bij de genoemde soorten, naast elkander, maar, aan eene kleine vooruitstekende placenta, over elkander. De akers zijn half eivormig, van boven vlak met een klein puntje. Het ronde gedeelte is met het kuipje zamengegroeid. Zij hcbben een dik, houtachtig, korrelig epicarpium, een vczelig, niet zeer aanzienlijk sareocarpium, en ecn vliezig, licht bruin behaard endocarpium.

\section{QUERCUS EWYCKII. Kus.}

Q. ramulis glabriusculis, foliis clliptico-lanceolatis acuminatis, stipulis semi-lanccolatis, amentorum floribus femincis solitariis, cupulis cum zonis conccntricis, glandibus hemisphacricis.

Arbor 20-25 metrorum, coronà dense foliatà; RAMI erecto-patentes, subterctcs, fusci; RAMulr versus ramorum apices conferti, alterni, erecto-patentes, curvati, subteretes, novelli angulati, sulcati, glabriusculi. Folis alterna, in spira quinata, erceto-patentia, elliptico-lanceolata vel elliptica, acuninata, basi acuta, margine recurva, supra glabra, subtus pubescentia, nervis primariis patentibus curvatis approximatis prominentibus, nervis secundariis parallelibus approximatis, coriacea, 0,14 longa, 0,04 lata; petroli subteretes, supra sulcati, glabriusculi, 0,015 longi. Stipulıe laterales, semilanccolatae, pubescentes. Gemma axillares, conicae, pubescentes. Anenta axillaria vel terminalia, simplicia vel paniculata, erecta, mascula vel androgyna; peDunculus angulatus, sulcatus, pubescens. Fuores Insculi solitarii vel glomerulati, tribracteati; BRACTEA inferior semilanceolata, cucullata, pubescens; bracteae duae laterales semi-ovales, acutae, pubescentes. Perigoniun pelviforme, obsolete sexdentatum, pubescens. Stamina 12; filauenta basi perigonii affixa, filiformia, glabra; antherae supra basin aflixae, didymae, longitudinaliter dehiscentes. Pistiulu rudimentum sphaerö̈deum, dense tomentosum. Fures FEMrrear solitarii, bracteati; BRACTEA unica libera, triangularis, acuta, pubescens; cupducA elongatoobovoidea, eoncentrice zonata, margine superiore zonarum dentato, glabriuscula. Perigonium superum, depresse urceolatum, sexdentatum, dentibus acutiusculis, pubescens. Ovariuni cupulà tectum, sphae- 
roideum, glabriuseulum, triloeulare; ovwuA in singulo loculo geminata, infra apicem axis loeuli deseendentia, versus extremitatem superiorem affixa, ovoïdea. STrur 3, fere ad apicem usque connati, pubescentes; stigmata apicalia. Cupula stipitata, pelviformis, basi depressa, concentrice zonata, zonis approximatis, pubescens, intus basi umbonata, sericeo-pubescens, margine glabriusculo. Gratss cupulâ semi-inclusa, hemisphaerica, apice longe mammillata, basi excavata, nitida, epicarpio crustaceo tenui, sarcocarpio fibroso inani loculoso magno, endocarpio subcoriaceo, unilocularis, loculo tomento laete ferrugineo vestito. SEmen unicum, deforme.

\section{Crescit in sylvis Melintang: Sumatra.}

Explicatio Tab. 46. Figura speciei. 1. Amenti masculi pars. 2. Flores masculi a latere. 3. Flos masculus ab anteriore. 4. Flos masculus, rudimento pistilli ablato. 5, 6, 7. Anthcrae. 8. Cupula. 9. Ovarium, parte cupulae abscissa. 10. Orarium cum cupula longitudinaliter descissa. 11. Cupula adultior. 12. Glans immatura, dimidia parte cupulae longitudinaliter abscissa. 13. Glans cum cupula. 14. Gupula. 15. Glandis basis. 17. Glans longitudinaliter descissa cum sarcocarpio fibroso et loculoso. 18. Semcu. 19. Seminis rudimentum. 20. Seminis rudimentum descissum.

De eik was in vroegere tijden voor de volken van het noordelijk, het midden- en het zuidelijk Europa ecn hoogstvereerd voorwerp in het plantenrijk. Onder zijne schaduw kwamen Hellenen, Batavieren en Celten raad vragen, ontvingen zij tijdelijke hulp en ondersteuning, en ontvlamde bij hen nieuwe geestdrift voor hunne ondernemingen. Doch ook bragten zij onder deze boomen hunne bewijzen van dankbaarheid. Vruchten en wapentuigen werden daar nedergelegd, geloften voor hun volgend leven onder dezelve uitgesproken. Door eene naamgeving volg ik hun voorbeeld. Dit zij den edelen bevorderaar van kunsten en wetenschappen, haren, in zijne vroegere hooge betrekking, zoo werkdadigen beschermer, die in haar de waarborgen en steun van Ncêrlandsch welvaart zag, tot bewijs, dat ik, die ook in hem eenen welwillenden beschermer mogt vinden, na het verloop eener reeks van jaren, mij deze goedheid dankbaar herinner.

\section{QUERGUS ANNUlata. Khs.}

Q. ramulis glabris, foliis oblongis acuminatis, stipulis falcato-lanceolatis, amentorum floribus femineis solitariis, cupulis junioribus concentrice zonatis, cupulis adultioribus breviter pelviformibus conccntrice zonatis, glandibus depresse hemisphaericis.

AввоR; rami subteretes, glabri, nigrescentes, lenticellis albis; RaMULi erecto-patentes, subteretes, novelli angulati sulcati, glabri. Fous crecto-patentia, oblonga, acuminata, basi acuta, margine recurva, utrinque glabra, nervis primariis erecto-patentibus nitidis, nervis secundariis subparallelis, 0,12 longa, 0,04 lata; perroli subteretes, supra canaliculati, 0,01 longi; stipula latcrales, falcatolanceolatae, subtus sublepidotae. Amenta axillaria vel terminalia, erecta, mascula vel androgyna; peduraulus angulatus, dense pubeseens, glabrescens. Flores Masculr glomerulati vel solitarii, tribracteati; BRACTEA inferior semi-oblonga, acuta, subpubeseens; BRAGTEAE laterales semi-oblongae, obtusius- 
culae, subpubcscentes. Perigonium breviter pelviforme, sexdentatum, dentibus obtusis, intus glabrum, extus pubescens. Stamina 12, quaedam abortiva vel deformia; filamenta basi perigonii in annulum connata, filiformia, glabra; antherae cordiformes, basi in sinu affixae. Pistrult rudimentum cylindricum, truncatum, pubescens. Flores feMrtret solitariis, bracteati; BRAGTEa triangularis, acuta; cupula cum zonis concentricis, irregulariter denticulatis, subleprosis. Perigonrum superum, basi liberum, breve urccolatum, sexdentatum, dentibus acutiusculis, leprosum. Ovariun cupulâ tectum, depressosphaeroideum, pubescens, subtriloculare; ovula in singulo loculo geminata, apposita, in medio axis loculi descendentia, infra extremitatem superiorem affixa, elongato-ovoïdea; sTyLI tres, basi connati, conici, pubescentes; stigmata apicalia, obtusiuscula. Cupula sessilis, pelviformis, basi plana, concentrice zonata et sulcata, leprosa, crassa, lignosa, intus basi plana et latere pubescens. Guans dimidia parte cupulà cincta, depresso-hemisphaerica, conico-mammillata, basi plana, nitida, epicarpio tenuiter crustaceo, sarcocarpio inani loculamentoso, endocarpio mcmbranaceo, unilocularis, loculo dense piloso.

\section{Crescit in sylvis Singalang: Sumatra.}

Tab. 46. 21. Glandes. 22. Folium hujus speciei.

Qucreus annulata droeg in de maand augustus bijna rijpe vruchten, benevens bloemen en jonge vruchten. Zij was langs de rivier de Ane en hooger tot op 1000 ellen in het gebergte Singalang verspreid.

\section{QUERCUS OMALOKOS. KHS.}

Q. ramulis glabris, foliis obovatis breviter obtuse acuminatis, stipulis lanceolatis, amentorum floribus femineis solitariis vel ternatis, cupulis junioribus concentrice zonatis, cupulis adultioribus planiusculis conoentrice zonatis, glandibus semi-ovö̈leis.

Arвor; Rami teretes, fusco-olivacei; RaMuli versus ramorum apices conferti, patentes, subteretes vel angulati, novelli compresse quadrangulares sulcati, glabri, novelli leprosi. Folı approximata, alterna, patentia, obovata vel elongato-obovato, breviter obtuse acuminata, basi angustata, marginata, utrinque glabra, nervis primariis patentibus apice curvatis, nervis sccundariis reticulatis, coriacea, 0,1 longa, 0,04 longa; petrout semiteretes, glabri, 0,004 longi. Sttpulae laterales, obliquae, lanceolatae, acutiusculac, leprosae. Gemma axillares, subrotundae, leprosac. Anenta axillaria vel terminalia, erecta, androgyna vel mascula; pedurgulus angulatus, leprosus. Flones masculis desunt. Fuores feninet solitariis vel ternati, tribracteati; BRACTEA inferior major, cucullata, triangularis, acuta, leprosa; вRACTEAE duae laterales, auriculatae; cupula cum zonis concentricis denticulatis leprosis. Pertaontur superum, basi liberum, breviter pelviforme, sexdentatum, dentibus minutis obtusis, leprosum. Ovarium cupulâ cinctum, breviter conicum, basi rotundatum, versus apicem leprosum, triloculare; ovuLa bina, in medio axis loculi descendentia, in medio ventris affixa, apposita, elongato- ovoïdea; sTYLI 3 , breves, basi connati, glabriusculi; strgmata apicalia, obtusa. Cupula sessilis, plana, concentrice zonata, leprosa, intus cum disco elevato plano sericeo-pubescens. GLans basi cupula cincta, semi-ovoïdea, conice mammillata, basi excavata, cavitatis margine cavo, nitida, apice leprosa, epicarpio lignoso, sarcocarpio 
fibroso, endocarpio subcoriaceo, unilocularis, loculo cum scptis quibusdam incompletis dense pubescente. Sener solitarius, loculum explens, vertici affixum, obconicum, basi excavatum, sulcatum, glabrum; SPERitodermis coriaeca. Embryo erectus; Radicula minuta obtusa; cotyuedones carnosae, crassae.

\section{Crescit in sylvis Melintang: Sunatra.}

Deze soort heeft eene digte kroon met zeer glanzend loof. De takjes zijn hoekig, somwijlen zelfs zamengedrukt, met snijdende kanten. Hare kuipjes bezitten eene vlakke, bijna schotelvormige gedaantc. $Z_{i j}$ hebben in het midden der holte eene bijna vlakke schijf. De eikel, half eivormig, zelden half kogelrond, is éénhokkig, met uit den omtrek vooruitspringende scherpe ribben, die op de doorsnede driekantig zijn. Doorgesneden, vertoont hij eene stervormige holte. In het midden van deze holte, welke door een digt viltig haar wordt bekleed, is, in eikels, wier zaden onvolkomen ontwikkelen, eene piramide, aan welker top de zaadjes zijn vastgehecht. In eikels, die daarentegen rijp zaad bevatten, wordt de gehcele holte door dit zaad, aan welks top de niet ontwikkelde eitjes liggen, gevuld.

In october droeg deze soort vruchten, in de bosschen van het gebergte beoosten Padang, waar zij tot op $400 \mathrm{~N}$. ellen hoogte boven zee groeide.

Door den vorm van het kuipje verschilt Q. omalokos van de andere Indische soorten, en door het inwendige zamenstel van de akers heeft zij eenige overeenkomst met Quercus platycarpa.

\section{QUERCUS ARGENTATA. Kus.}

Q. ramulis tuberculatis, foliis oblongis breviter acuminatis, stipulis falcato-lanceolatis, amentorum floribus fcmineis solitariis, cupulis junioribus et adultioribus concentrice zonatis, glandibus rotundato-ovoïdeis basi disciformibus.

Arвor 30 metrorum; rami patentes, subteretes, fusco-grisei; ramuli patentes, subteretes tuberculati, novelli compressiusculi pilosi. Fouı longe petiolata, alterna, oblonga, quaedam oblongoobovata, breviter acuminata, basi acuta, subintegerrima, supra nitida, subtus argentata, nervis primariis patentibus apice curvis nitidis, nervis secundariis parallelis approximatis, coriacea, 0,14 longa, 0,045 lata; petioli subterctes, basi incrassati, lepidoti, 0,03 longi. Stipulae laterales, falcato-lanceolatae, intus glabrae, extus pubescentes. GEmas axillares, ovoïdeae, tegmentis semi-rotundis et semioblongis obtusis imbricantibus. Anevta feminea, axillaria vel alaria; penunculus subteres, glaber. FLores solitarï, tribracteati; BRAGTEA inferior triangularis, acuta; BRAGTEAE laterales auriculatac, pubescentes; aupula cum zonis concentricis obtuse dentatis, pubescens. Perigonivar superum, basi liberum, breve pelviforme, sexdentatum, dentibus triangularibus acutis, glabriusculum. Ovariun hemisphaericum, glabriusculum, triloculare; oveus bina, fere in medio loculi ab axi descendentia, opposita, ovoïdea; styur 3, basi connati, glabri; strgiata capituliformia. Cupula sessilis, crateriformis, cum zonis concentricis calyculatis dentatis, pilosa, intus basi excavata sericeo pubescens. Gutars cupulâ subinclusa, rotundato-ovöidca, mammillata, basi cum disco, nitida, epicarpio erustacco, sarcocarpio parvo fibroso, 
endocarpio coriaceo, abortu unilocularis, loculo sparse piloso. Semen unieum, loculum explens, ovoïdeum, glabrum; SPERMODERMIs coriacea; GHALAZA micropylae opposita. EMRRYo erectus; cOTYLEDONES semi-ovoïdeac; Radiculı et plunulı inclusae, turbinatae.

\section{Crescit in sylvis Melintang: Sumatra; in monte Sakoembang: Borneo.}

Explieatio Tab. 47. Figura Quercus argentatae. 1. Cupula junior. 2. Cupula junior, parte abseissa, eum ovario. 3. Ovarium longitudinaliter deseissum. 4. Cupula adultior. 5. Cupula parte abseissâ, eum ovario. 6. Ovarii pars longitudinaliter disseeta. 7. Cupula fere matura. 8. Cupulae seetio longitudinalis cum glande et 9. Eadem, glande ablatâ. 10. Glandis basis. 11. Glans longitudinaliter dissecta. 12. Semen immaturum a latere, 13. postiee et 14 . basi. 15 et 16. Senina longitudinaliter dissccta. 17. Enbryo, cotyledonibus abseissis.

De voorwerpen, welke van Quercus argentata op Borneo verzameld zijn, kunnen van die van Sumatra onderscheiden worden door de groene ondervlakte der bladen en door de jonge eikels. De laatste hebben, bij de voorwerpen van Borneo, eene meer regelmatige, half ronde of kegelvormige gedaante. Beide deze kenmerken zijn mij echter niet voldoende voorgekomen, om de, voor het overige zoo gelijke vormen, als soorten te onderscheiden.

Bij deze soort behooren waarschijnlijk, naar de takjes te oordeelen, eenige takken met mannelijke en zeer jonge vrouwclijke blocmen, welke wij in julij te Indrapoera verzamelden. Hare bladen zijn nog zeer klein. De mannelijke bloemen hebben eene volkomene ontwikkeling. Zij zijn, even als bij Q. pubescens, in hangende katjes. Onder iedere bloem zit een bijna rond schutblaadje met eenen behaarden rand. Het bloembekleedsel is in vier of vijf ongelijke deelen verdeeld. In hetzelve zijn acht tot tien helmdraden, van welke vier of vijf dikwerf iets langer zijn, dan de anderen. De helmknopjes bestaan uit twee lobjes, soms gelijkmatig, soms onregelmatig ontwikkeld, namelijk met het eene lobje, als een klein knoopje, op den rug van het volmaakte. Van het onontwikkelde vruchtbeginsel is in dezelve naauwelijks een spoor zigtbaar. De vrouwelijke bloemen staan in kleine katjes, zonder mannelijke bloemen. ' Zij bebben een vierdeelig bckleedsel en zeer groote stempels.

\section{QUERCUS OÏDOGARPA. KHs.}

Q. ramulis glabris, foliis oblongis aeuminatis, apicem versus serratis, amentorum fruetubus solitariis, cupulis eoncentrice zonatis, glandibus ovoïdeis.

ARвor; RaMIr subteretes, fusci; ramuli patentes, teretes, lenticellati, nigrescentes, glabri. Fouma versus apicem ramorum conferta, longe petiolata, oblonga, acuminata, basi acuta, versus apicem serrata, supra nitida, subtus pubescentia, nervis primariis erecto-patentibus rectis apice curvatis, nervis secundariis parallelis approximaris, coriacea, 0,19 longa, 0,06 lata; PETIOLI semiteretes, basi incrassati, glabri, 0,04 longi. Gemina axillares, obovoïdeae glabrae, tegumentis semi-rotundis et semi-oblongis. Fructus solitarii. Gupura sessilis, pelviformis, concentrice zonata, zonis calyculatis denticulatis, pu- 
bescens, intus basi planiusculâ sericeo-pubescens. GLans dimidia parte cupula cincta, ovoïdea, obtuse mammillata, basi plana cum disco parvo, epicarpio crustaceo, sarcocarpio fibroso, endocarpio coriaceo, abortu unilocularis, loculo glabro. SEIrEx unicum, loculum implens, ovoïdeum, vertice acutum, glabrum.

\section{Crescit in sylvis Melintang: Sumatra.}

Tab. 47. 18. Figura ramuli.

Quercus oïdocarpa is door houding en groeiwijze zeer na verwant aan Quercus argentata, in welker nabijheid zij wast. Beiden zijn hooge boomen met zeer ijle kroonen en cenen scherpen bladslag. Zij hebben ronde knoppen, welke eenige overeenkomst met die van Quercus pedunculata bezitten en uit talrijke schubjes bestaan. De vorm der bladen is van beiden tamelijk gelijk, alleen verschillende door de zaagtanden, welke bij Q. oïdocarpa aanwezig zijn. Hare vruchten wijken van elkander af door het uiterlijke, doch komen door hun inwendig zamenstel overeen. Bij Q. oïdocarpa is het kuipje kleiner in verhouding tot de akers, met minder ringen en bekkenvormig; bij $Q$. argentata is het bekervormig. De eikels der laatste soort hebben aan het beneden einde eene vrij aanzienlijke schijf; die der eerste slechts een zeer dun schijfje.

In october droegen beide soorten vruchten. Q. argentata had toen nog jonge en bijna rijpe vruchten. Q. ö̈docarpa hebben wij toen met enkele vruchten verzameld. De mannelijke bloemen zijn door ons in geene van beiden waargenomen. 
B IJ DRAGE TOT DE KENNIS

DER

\title{
IN D ISC II E IIELASTO II AOEAE,
}

Door

\author{
P. W. K O R T H A I S.
}

Het uitwendig aanzien dezer gewassen heeft veel bijgedragen, om het aantal bekende soorten zoo aanmerkelijk te vermeerderen: want, over het algemeen behooren zij tot die planten, welke door den verzamelaar gemakkelijk zijn waar te nemen. Eenige weinigen slechts verheffen zich tot aanzienlijke boomen, waardoor zij hunne bloemen aan eene gemakkelijke waarneming onttrekken. Deze, en vooral de Astronia spectabilis, schieten met loodregte stammen tusschen de andere boschbewoners op en vermengen hunne vrij digte kroonen met die hunner naburen. Van minderen omvang zijn de Astronia humilis en de Ewyckia galeata, beiden met ijlere kroonen getooid. De andere soorten behooren tot de struiken of kruidachtige vormen. Als regte struiken zijn de Melastoma de meest uitgegroeide. Over het algemeen hebben zij verscheidene stengen uit denzelfden stoel ontwikkeld en ondergaan zij eene vrij snelle ontwikkeling. Kleinere struiken vormen andere geslachten: Medinilla, Pachycentra, Pogonanthera, Osbeckia enzv. Het laatste is soms een klein struikje, soms eene jarige plant. De eersten daarentegen zijn alle struikvormig. Hunne groeiplaats is bijna altijd op andere gewassen; soms op levende boomen, welke met mossen en varen bekleed zijn, soms op afgestorvene boomstammen. In de oksels der takken vestigt zich de hoofdstam, of wel vast tegen den stam aangeleund, en de schors indringende, groeit hij naar boven. Tevens is aan deze struiken het voortbrengen van luchtwortels, gewoonlijk langs den stam loopende tot zij eenige humus vinden, eigen. Hun stam is gewoonlijk wit gekleurd, met talrijke verdikkingen. Andere gewassen zijn klimmende. Zij hebben eene aanzienlijke lengtcontwikkeling en verheffen hunne bloemen somtijds in de kroonen der hoogste boomen. 
De Marumiae komen bij deze groeiwijze het meeste in aanmerking en behooren met Cissus, eenige Bauhiniae en Apocyneae, tot de grootste slingerplanten der bosschen. De Dissochaetae en verwante geslachten bereiken gewoonlijk zulk eenen grooten wasdom niet. Bij al deze klimmende planten heeft de stam een zeer los weefsel, hetwelk de opvoering eener groote hoeveelheid sappen bevordert. De kruidachtige gewassen zijn even verschillend van grootte: de Sonerila zijn dikwerf geen palm groot, terwijl Ochthocharis niet zelden tot twee ellen hoogte uitgroeit. De wortels van de onderzochte soorten zijn rijk aan vezels, soms tot wortelstok overgaande, bij de Melastoma; de luchtwortels zijn bij eenigen een gewoon verschijnsel, en verscheidene Medinillae hebben kleefwortels (alligatores). De laatste zijn opmerkenswaardig door hun ontstaan in ééne lijn boven elkander en door het splijten van den tak, ten einde dezen, nabij het mergkanaal ontstaande uitgroeisels doorgang te geven. De vorm van den stam is verschillend, al de figuren, van het ronde tot het zamengedrukt vierhoekige, doorloopende. Hetzelfde geldt van de takken, zijnde deze cehter over het algemeen vierhoekig, met stompe kanten, scherp snijdend of bladaardig uitgegroeid. Bijzonderc opmerking verdienen in dit laatste opzigt de takken eeniger soorten van Medinilla, welke de kanten als golvende randen gebogen hebben. De jongere takken zijn dikwerf hoekig, de oudere rond; zelden blijven zij bij het uitgroeijen den hoekigen vorm behouden. Hunne plaatsing is gewoonlijk naar het einde der takken, bij eene regelmatige ontwikkeling tegenover elkander, doch meestal afwisselend. Aan de inhechting is eene verdikking. De jongere takken en soms ook de oudere, worden door eene meerdere of mindere digte bekleeding bedekt, uit schubben, borstels, en bij vele uit stervormige haren bestaande. Het hoofdkenmerk der Melastomaceae leveren de bladen. Hunne schijf, hoe afwijkende ook in vorm, heeft gewoonlijk een bepaald getal hoofdıerven en evenwijdig loopende zijnerven. De eerste doorloopen soms de schijf tot aan den top, waar zij met de middelnerf zamenvloeijen. Bij eenigen steken deze nerven, voornamelijk op de ondervlakte, uit; bij anderen zijn zij in de zelfstandigheid van het blad bijna verborgen. De vleezige Medinillae-bladen behooren tot de laatste, en de lederachtige Dissochaetae, benevens de vliezige Sonerilae tot de eerste. De kleur der bladen wordt bij vele soorten door eene bruine hairbekleeding gewijzigd. Bij vele soorten is zij op de beide oppervlakten groen, alleen in tint verschillende; bij enkele tweekleurig: van boven groen en van onderen purper; bij de Sonerila picta geschakeerd. Hunne bekleeding is gelijk aan die der jongere takken, dikwerf uit borstels en stervormige haren bestaande, voortdurend of bij het ouder worden der bladen afvallende. Zij staan tegenover elkander en zijn gelijkvormig of ongelijkvormig. Het laatste is voornamelijk der Sonerilae eigen en gaat vergezeld van eene onregelmatige ontwikkeling van de beide helften der bladschijf van het grootere blad. De aanhechting der bladschijf gaat bij eenige Marumiae naar het schildsgewijze over; bij de meesten heeft zij aan den voet plaats. Geene der Indische soorten bezit de aan eenige Amerikaansche soorten eigene uitgroeijingen van of aan den bladsteel; doch wel, even boven denzelven, ronde uitgroeijingen van de bladschijf. Daarenboven zijn de verbreidingen van den bladsteel en de daarmede verbondene uitgroeijing van den tak, aan het punt van aanhechting, bij sommige planten (Dalenia, Aplectrum, enzv.) op te merken.

De bloemen staan alleen of zijn in kleine schermen, in tuilen, in pluimen of in trossen vereenigd, door grootere schutblaadjes vóór de opening geheel bedekt of door kleinere aan den voet ondersteund; somtijds, vooral wanneer er drie bloemen vereenigd zitten, is de middelste bloem zonder schutbladen. 
Hare orde van opening is middelpuntvliedend. De kelk bestaat uit cene buis en een' zoom. De eerste heeft de gedaante eener piramide, is vierhoekig of rond tot den kogelvorm, en ondergaat door de uitgroeijing aanzienlijke veranderingen. De zoom verschijnt als eene voortzetting der buis, zonder merkbare verwijding, of eenigzins verwijd met kleine tanden, in verseheidene deelen, van drie tot vijf, gespleten, gaafrandig, nadat de deelen afgevallen (Melastoma), of nadat de zaamgegroeide deelen, als eene huif, rondsom afgesneden, gescheiden zijn (Dalenia, Kibessia). De bloemkroon maakt vele soorten tot ware sicrplanten. Rozenrood, purperkleurig, helder blaauw of wit zijn hare bladen, wier grootte in sommige Melastomae en Marumiae uitmunt.

De bloembladen zijn vóór de opening gedraaid; na dezelve rozenvormig, soms klokvormig, dikwerf ongelijkzijdig, stomp of spits, op eenen rand in de buis van den kelk vastgeheeht. - De stuifdraden staan op denzelfden rand als de bloembladen; tegenover en tussehen deze zijn, in gelijk of in een dubbel getal, allen vruehtbaar of voor de helft onvruehtbaar, in de nog ongeopende bloemen, naar binnen gebogen. De helmdraden zijn lijnvormig of rolrond, glad, zelden behaard. De helmknopjes zijn vóór de opening, terug gebogen in de holte van de buis, om den stijl geplaatst: Astronia, Kibessia, Ewyekia; of in kleine holten tusschen de kelkbuis en het vruchtbeginsel besloten. De onvruchtbaren hebben grootere of kleine sporen van de stuifmeelhokjes en een' zeer ontwikkelden helmknoop. De vruchtbaren staan dikwerf tegenover de bloembladen. Zij zijn aan den voet of hooger, tot zelfs in het midden, vastgehecht; bij eenigen buitenwaarts (extrorsae): Dissochaeta, bij anderen binnenwaarts (introrsae): Melastomae, Medinilla. Hunne knopjes zijn langwerpig tot rolrond, regt of S-vormig gebogen, aan den top door één of twee gaatjes het stuifmeel uitstortende, of door twee spleten openspringende; zij bestaan uit twee hokjes, ieder weder met tusschenwanden voorzien. De helmknoop is gemeenlijk, zoowel naar de binnen- als naar de buitenzijde, zeer versehillend uitgegroeid, en gaaf of in slippen of draden gespleten; hij heeft in sommige Melastomata eene aanzienlijke lengte, in sommige Marumiae eene opmerkelijke verdeeling, en in andere geenen buitengewonen vorm.

Het vruchtbeginsel is bij Kibessia en verwante geslachten met de kelkbuis zamengegroeid, bij de anderen gedeeltelijk met dezelve door plaatjes verbonden, bij eenigen door eenen discus, uit borstels bestaande: Melastoma, Osbeckia; eene buis vormende: Driessenia; met vier stompe tanden gekroond: Anerineleistus, in het vrije gedeelte glad of bekleed, van drie- tot vijfhokkig. De eitjes behooren tot de campylotropa: Melastoma, Otanthera; of de anatropa: Astronia, Dissoehaeta, en bedekken den zaaddrager gehecl, zijn gewoonlijk talrijk en alleen bij Pachycentria in bepaald getal aanwezig. De zaaddragers zitten bij Astronia op den bodem van het vruchtbeginsel in het midden, bij Ewyckia en Kibessia tegen de wanden van hetzelve, en bij de overige geslaehten zijn zij door kleine stoelen of plaatjes aan de spil van het vruchtbeginsel vastgeheeht. De stijl is bij de meeste soorten rolrond en de stempel als een puntje of kopje, zelden gedeeld.

De vrueht heeft veel verscheidenheid. $\quad Z_{i j}$ is bij al de Indische soorten geheel of gedeeltelijk door den kelk bedekt en met dezen zamengegroeid. De kelk deelt bij de meesten in de uitgroeijing en verandert soms geheel van vorm, door de mindere vergrooting van zoom, en van zelfstandigheid door de zamen- 
groeijing met de vrucht. De vrueht is eene bes, eene drooge bes of zaaddoos. Besaardig is zij bij Medinilla, Pachycentria, Pogonanthera, in welke al de deelen saprijk worden; bij Dissochaeta, Apleetrum, Creochiton is zij minder saprijk; nog drooger bij Marumia; bij Melastoma is de vrucht droog, maar groeijen de zaaddragers vleezig uit, en bij Kibessia en Ewyckia neemt de kelk, voornamclijk in dikte toe. De openspringende vruehten zijn allen loculicidae; zij springen geheel open en laten het staandertje naakt: Ochthocharis; of tot op of over het midden, blijvende door de kelkbuis omsloten: Osbeckia, Anerincleistus, Phyllagathis; of aan den top door klepjes, aan de binnenzijde losgaande: Sonerila; of aan den top door klepjes, aan de buitenzijde vrij: Driessenia; of de kelk en vruchten verdroogen en scheuren als vezels van elkander: Astronia. De zaaddrager heeft bij de meeste soorten de zelfstandigheid der vruchtbekleedsels, doch wijkt bij Melastoma, zoo als de Heer Blume te regt aanmerkt, af, dewijl hij hier vleezig wordt en daardoor het openbarsten der vrucht veroorzaakt. Hij heeft vele kleine, door vliezige randjes omgevene holten. De zaden zijn talrijk en zeer klein, of minder talrijk en grooter, digt tegen elkander geplaatst, kromloopend (campylotropa): Melastoma, Osbeckia, Otanthera; gelijkloopend (anatropa): bij de andere geslachten. De laatsten, gcwoonlijk de regte genocmd, zijn onregelmatig hartvormig bij Sonerila; hoekig, piramiedvormig, soms bijna halfrond, bij velen; strooachtig bij Astronia. Het eene gedeelte derzelve, dat de kern bevat, is rond of onregelmatig hoekig; het andere, dat de raphe inneemt, is bij de meeste soorten vlak; bij Ewyckia, Driessenia, enzv. als een klein vleugeltje; bij Sonerila rond, grooter dan het kerngedeelte. De testa is bij de meeste soorten hoornachtig, met kleine, hoekige gaatjes of met slingerende, netsgewijze verbondene ribben; bij Astronia vliezig, uit langwerpige cellen bestaande. Op haar is de navel bij Melastoma van eene cirkelvormige gedaante; bij de anderen is hij minder duidelijk en soms als een krans van cellen zigtbaar. Van dezen gaat de raphe langs het zaad, tot aan den voet of tot aan de zijde van den voet, naar de chalaza, die bij Astronia aan den voet, en bij de anderen meer naar de zijde van het zaad ligt. De raphe is bij al de onderzochte soorten onverdeeld. Het mesospermium heeft alleen bij Astronia eene celaardige, eenigzins belangrijke ontwikkeling. Het tegmen is bij allen vliezig. De kern is rolrond: Astronia; eivormig: Medinilla; gebogen rolrond: Melastoma. Bij de meesten zijn de zaadlobben het dikste en vormen deze een derde van de kern; maar bij de Melastoma is het worteltje het dikste.

De groeikracht van eenige soorten dezer familie is opmerkelijk. Zij vertoont zich bij Phyllagathis in de bladen, die in drie maanden drie vierkante ellen oppervlakte ontwikkelden; bij Melastoma en Ochthocharis openbaart zij zich in de uitgroeijing der stengen en loten; bij velen in de vorming der bloemen. Ook bij de laatsten is zij ongelijk, zoodat zij òf den kelk of de bloemkroon begunstigt. Even als bij al de door mij waargenomene, gedraaide bloemkroonen, zijn de bloembladen in de jonge knoppen geheel regt en vrij. Eerst later groeijen zij rondom elkander, en vormen aldus den gewoonlijk kegelvormigen knop. Voor zoover ik heb waargenomen, openen zich de bloemkroonen des morgens en blijven zij, eenmaal geopend zijnde, tot haar afvallen of verwelken, in dienzelfden toestand. - De stuifdraden openbaren, in hunne ontwikkeling nagegaan, de oorzaak van de eigenaardige rigting en opening der helmknopjes. In zeer jonge knoppen zijn zij regtstandig; vervolgens zijn de helmknopjes omgebogen en tussehen het vruchtbeginsel vastgekneld. In een later tijdperk, wanneer de kelkbuis recds grooter geworden is, zijn de helmknopjes meer verlengd en nog steeds tusschen de kelkbuis en het vruchtbeginsel, 
in eigene hokjes besloten, of digt naast elkander geplaatst. Dan begint, wanneer het helmknopje gevormd is, de uitgroeijing van den helmknoop en van den helmknop. Over het algemeen is het mij voorgekomen, dat de ombuiging van de helmdraden, alleen bij de aanhechting van den helmdraad en helmknoop plaats heeft, dat de helmdraad regtop groeit en dat de helmknop naar binnen gebogen is. De meerdere vergrooting van den helmdraad in den jongen knop schijnt dus de eerste ombuiging te veroorzaken. De beknelling van de helmknopjes tusschen kelkbuis en vruchtbeginsel is daarentegen de oorzaak van de verdere eigenaardige zamenstelling. Het bovenste gedeelte van den helmknop wordt daardoor ingesloten en soms zeer verlengd. De zeer jonge helmknopjes zijn regelmatig, en eerst later nemen zij, door de onregelmatige ontwikkeling, den eigenaardigen vorm aan. Echter kan het onderzoek van de ontwikkeling, even als de vergelijkende beschouwing van de verschillende geslachten, gemakkelijk den gewonen grondvorm aantoonen. Zeer jong zijnde, bestaan de helmknopjes uit twee, in tweeën verdeelde hokjes. Dan zijn voornamelijk de twee hokjes zigtbaar en de tusschenwanden bijna geheel tot randjes zaamgetrokken of als vliesjes aanwezig. Tevens verlengt zich het bovenste gedeelte in eene buis, en het gewone zamenstel der hokjes wordt tot het benedenste gedeelte der helmknopjes bepaald. De opening door poren, aan velen eigen, wordt door de ontwikkeling veroorzaakt, en is een gevolg van de buisvormige uitgroeijing van een gedeelte der helmknopjes. Jong, zijn zij geheel gesloten, en zelfs in eenen zeer ontwikkelden toestand zijn er vliezen in de opening aanwezig, of bestaat de opening uit gescheurde lobjes: Phyllagathis. Het openspringen door een' of twee poren staat in verband met de meerdere of mindere uitgroeijing van den tusschenwand der helmknopjes. Is deze niet in verhouding tot den groei der helmknopjes, dan ontstaat er één poor; is de uitgroeijing gelijkmatig, dan springen de knopjes door twee poren open. De geslachten Melastoma en Dissochaeta leveren hiervan duidelijke bewijzen. De bevruchting, na de opening der bloem geschiedende, wordt door de, zamentrekkend op de stuifmeelhokjes werkende en daardoor de uitstorting van het stuifmeel bevorderende, zonnewarmte begunstigd. - De ontwikkeling der kiem begint boven in het ei, digt aan den mond, of beneden in hetzelve, digt bij de chalaza. In het eerste geval zijn de cellen van de chalaza, die men zeer goed den kiemknop kon noemen, verlengd tot aan den mond van het ei, en komen daar met de stuifmeelbuizen, wier werking geheel opwekkend schijnt te zijn, in aanraking; in het andere geval dringen deze buizen dieper in de eitjes, tot op de hoofdstof der chalaza.

De eilanden Java, Sumatra en Borneo zijn, voor zoover het onderzoek strekt, het rijkste aan deze familie. Over het algemeen heeft ieder derzelve zijne eigene soorten en ook enkele hunne eigene geslachten. Borneo heeft Driessenia, Dalenia; Sumatra Anerincleistus; beiden bezitten in Phyllagathis en Ewyckia aan Java vreemde geslachten. Dit eiland heeft daarentegen Creochiton. Daarenboven is Java het hoofdland voor de Medinilla, en bezit met Sumatra de meeste soorten van Dissochaeta. Aan Melastoma zijn zij even rijk, en Marumia behoort vooral op Sumatra en Borneo te huis. Op deze eilanden groeijen die gewassen, van het zeestrand tot boven de $2000 \mathrm{~N}$. ellen hoogte. Zonnige drooge en beschaduwde vochtige plaatsen hebben hare Melastomaceae. Betreden wij de vlakte van Borneo's zuidoostkust, dan vinden wij soorten van Melastoma met purperkleurige blocmen, Ewyckia met helder blaauwe bloemen, over de vlakte verspreid of langs den boschzoom groeijende, en somwijlen Pachycentria met hare kleine bloempjes en stijve witgrijze stengen. Elders vermengt zich met deze eene helder groene, 
naauwelijks eenige voeten hooge Astronia. Van de vlakte het gebergte beklimmende, verschijnen in de schaduw, de door bloemenpracht voortreffelijke en zich om de stammen windende Marumia; op de opene plaatsen Melastoma en in de schaduw de nederig groeijende Sonnerilae. Langs de rivieren hebben Ochthocharis hier en daar de moerassen ingenomen; groeijen meer ontwikkelde Melastoma op de hoogere oevers; zijn Ewyckia een sieraad van de hellingen der heuvels; klimmen Marumiae, met Dalenia door bloemenpracht wedijverende, tegen de boomen op, en verlevendigen Pogonantherae de naakte bogten van de verdeelde takken. Ook aan Sumatra's bodem strekken deze gewassen tot eenen uitmuntenden tooi, als herscheppende zij de vlakte in een bloemenveld. Hetzelfde is hier met Melastoma het geval. Boschwaarts, langs de rivieren, blijft deze soms hoofdplant, en in de schaduw zijn vooral de steenrijke oevers, met kleine, doch door kleur en vorm opmerkelijke Sonerila gesierd. De vleezige Medinilla zijn daar het talrijkst. Meer binnen in de bosschen prijkt de bodem met de purperbladerige Phyllagathis; groeijen de blaauwe, bloemendragende Kibessia soms zeer talrijk, en trekken Marumia en Dissochaeta door steng en bloemen de aandaeht. Hooger in het gebergte vermindert Kibessia, en wordt zij door Astronia vervangen. Java vertoont, door de uitgroeijing der soorten dezer familie, zijne buitengewone vruchtbaarheid. De Melastoma, welke op den, aan diamanten rijken grond van Borneo naauwelijks eenige duimen bereiken, zijn hier tot eenige ellen uitgegroeid. In zijne bosschen is dit geslacht menigvuldiger, dan op de andere eilanden. Hier groeijen tevens talrijke, kleine Sonerilae, klimmende Dissochaeta en soms Marumia. Langs de boorden der rivieren trekken de Medinilla, zoo door getal als ontwikkeling, door hare rijke bloempluimen en wasachtige beziën, de opmerkzaamheid. Doch boven allen munt de Astronia spectabilis uit, en draagt haren naam met het grootste regt.

\section{OSBEGKIA. Linn.}

Het geslacht Osbeckia werd door den stichter vermoedelijk voor de Osbeckia chinensis gemaakt en is vrij juist door hem gekenmerkt. Later heeft het door verschillende schrijvers zoodanige veranderingen ondergaan, dat het een mengsel is geworden van planten, noch aanzien, noch kenmerken gemeen hebbende. Met zijne wezentlijke kenmerken hersteld - een' discus uit schubjes bestaande, vierhokkige, in het bovenste gedeelte loculicide openspringende zaaddoozen, kromgebogene zaden - zal het eene $\mathrm{n}$ atuurlijke groep vormen met $\mathbf{O}$. linearis, Zeylanica, enzv. $\quad 0$. Wallichii, $\mathbf{O}$. stellata en ternifolia zullen uit het geslacht Osbeckia moeten verwijderd worden, en een nieuw geslacht vormen. Haar aanzien, de vorm van den kelk, de, in eenen dubbelen krans verdeelden discus en de wijze van openspringen, geven hiertoe genoegzamen grond, en doen mij voor deze gewassen den naam Ceramiocalyx, die op den vorm van den kelk doelt, voorstellen. Osbeckia glomerata, mede door mij in het Rijks Herbarium gezien, behoort evenmin tot Osbeckia. Zij mist al de eigenaardige kenmerken van dit geslacht; eene opmerking, welke voor meerdere Amerikaansche soorten kan geldig zijn, en aan het onderzoek van hem, die de zoodanigen bezit en de kennis dier voorwerpen wil bevorderen, wordt aanbevolen. Het geslacht Osbeckia verschilt van Lasiandra, waarmede het vermaagschapt is, in aanzien en kenmerken, vooral door den vorm der zaden, welke, naar de afbeeldingen van Martius te oordeelen, anatropa in het Amerikaansche geslacht zijn. 
OSBEGKIA LINEARIS. Bz.

In de lagere streken van Java en Sumatra tiert deze soort gezellig op kleiaardige gronden, tusschen het gras. Haar bloei is in den droogen tijd, en vóór den regen zijn hare kapsels rijp en opengesprongen. Het aanzien dezer plant en dat der in de Molukken verzamelde, is gelijkvormig, doch in de kenmerken bestaat eenig verschil, waardoor beide zouden kunnen gescheiden worden.

Behalve de buitengewone verlenging van den snuit der helmknopjes, heeft deze soort nog soms den stijl spiraalsgewijze gewonden en den stempel naar de opening der helmknopjes gebogen.

\section{MEL ASTOMA. BURM.}

CaLras tubus truncato-ovöideus, squamulis paleis vel setis vestitus; limbus quinque- rarius sexfidus, Jaciniis cum totidem appendicibus alternantibus, deciduus. Petala 5-6. Stamina numero duplo petalorum, saepe longitudine subaequalia. Artherae oblongo-lineares, poro dehiscentes, connectivo inaequali in aliis calycis laciniis oppositis sacpe elongato, in aliis petalis oppositis breviore antice biauriculato vel emarginato, postice nudo. OvarIUnr calyci semiadhaerens, disco carnoso excavato coronatum setigerum. Struds teres, apice subincrassatus. Stigma punctiforme. Capsula baccata 5-locularis, irregulariter disrumpens. SEmins cochleata, hilo circulari micropylae punctiformi approximato.

Het geslacht Melastoma bevat drie eigenaardige groepen, die zoowel door haar uiterlijk aanzien, als door hare bepaalde kenmerken kunnen worden onderscheiden. De eene heeft M. polyanthum tot grondvorm, de andere M. asperum en de derde M. pulcherrimum. In ieder derzelve is vooral de bekleeding een in het oogvallend middel ter onderscheiding, en de vorm van den helmknoop een bij het onderzoek belangrijk kenmerk.

De bekende soorten zijn bezuiden het Himalaya gebergte, op de Sunda-eilanden en in Polynesië verzameld. Opmerkelijk is het, dat zoo weinige soorten op het vasteland van Indië voorkomen, en dat M. denticulatum op Nieuw-Caledonië, M. taitense op Otaheite, en talrijke soorten in de Sunda-cilanden gevonden worden. Op deze laatste behooren de meesten tot die kenmerkende gewassen, welke het aanzien of de physionomie der streek uitmaken. Gezellig verspreiden zij zich daar, hetzij met Myrtus tomentosa, hetzij met Psidium, over vlakten en bergruggen, soms tot aan het oorspronkelijke bosch, doch dikwerf worden zij door het Glagagras (Imperata) verdrongen. In de bosschen nemen weder auderen aanzienlijke ruimten in en worden daar door de steile hellingen begrensd. Hun voorkomen staat eigenaardig met hunne standplaats in verband. In vruchtbare gronden of in lage streken vonden wij M. polyanthum, enzv. met de schubvormige, teedere bekleeding; op droogere gronden verzamelden wij M. Boryanum, enzv. met de stevige borstelharen, en in de hoogere bergstreken van den Gédé enzv., aan de koude winden blootgesteld, werd gewoonlijk M. setigerum met zijne harde, broze bedekking en bultige bladen waargenomen. 
Melastoma is door uitwendige overeenkomst, met Lasiandra, Chaetogastra, Pleroma, enzv. verwant. Het laatste geslacht heeft daarenboven veel overeenkomst met Melastoma door de kenmerken, welke De Candolle opgeeft, doch is, indien Rhexia viminea (Lasiandra Maximiliana Mart.) wezentlijk eene Pleroma zij, ligtelijk van Melastoma, door eenige kenmerken te onderscheiden. Deze plant heeft, volgens de afbeelding, geen' discus op het vruchtbeginsel, vermoedelijk ovula anatropa, boven, door spleten openspringende zaaddoozen, enzv.

\section{MELASTOMA POLYANTHUM. BL.}

Onder dezen naam heb ik verscheidene vormen van Java en Borneo vereenigd, die, hoewel zij eenig verschil opleveren, niet genoegzaam onderscheiden zijn, om als bijzondere soorten beschouwd te worden. De vormen van Java, waarop de Hoogleeraar Blume reeds de aandacht vestigde, hcbben een aanmerkelijk verschil in de grootte der bloemen: de langs de rivier Tjisidani groeijende gewassen hebben gewoonlijk kleinere bloemen, dan die, welke in de velden verspreid staan. Die van Borneo zijn naar hunne standplaats te onderscheiden. De langs de Doeson-rivier verzamelde voorwerpen komen het meest met die van Java overeen. Zij groeiden over het algemeen in vruchtbare gronden. Hunne bekleeding is, even als die der Javaansche, niet zeer opmerkelijk. In den vorm der bladen bestaat bij hen eenen overgang van het eironde, aan het einde afgestompt, naar het elliptische. In het water groeijende of op plaatsen, die soms onderloopen, ontwikkelt zich de plant en worden al de deelen langer, doch ook losser, terwijl de bekleeding insgelijks toeneemt.

Bij Banjermassing en hooger langs de rivier wast een breed- en een smalbladerige vorm. Beiden hebben de takken met eene digte, tegen de steng aangedrukte of meer openstaande, schubvormige, bruine bekleeding. Hunne bladen zijn voornamelijk van onderen digter behaard. Aan den berg Pamatton groeit, in eenen diorietbodem, een vorm, welks uiterlijk aanzien het zoude billijken, dat hij als eene bijzondere soort wierde aangeduid, ware het niet, dat de kenmerken, hoe bepaald ook aan eenige individuën eigen, bij andere minder bepaald voorkomen, en, vooral met die van Banjermassing, te veel overeenstemmen. De bekleeding verdient, door hare bijzondere ruwheid op de takken en door hare digtheid op de bladen, de opmerking. Daarenboven zijn de kelkslippen dikwijls zeer ontwikkeld en gewoonlijk vóór de opening van den kelk te zamengedraaid. In eenige bloemen staan zij vervolgens, door de uitgroeijing der tusschenruimten, aan den voet van elkander, doch in andere bloemen aan denzelfden tak zeer na aan elkander geplaatst. Eene andere verscheidenheid werd bij Poeloe-lampei, in eenen kiezelaardigen grond verzameld. Deze is soms naauwelijks eenige duimen hoog. Hare bloemen, over het algemeen van dezelfde grootte, als de kleinbloemige vorm van Java, zijn niet zeer talrijk, zoodat sommige stengen drie, anderen slechts eene bloem dragen.

Deze, door uitwendige oorzaken te weeg gebragte mindere ontwikkeling, gaat gepaard met een ander onderscheid in den vorm en de grootte der kelkslippen, welke dikwerf langer zijn, dan de kelkbuis en eene bijna lijnvormige gedaante hebben.

Botanica. 
Bij de opgegevene onderscheidingen kunnen nog die gevoegd worden, welke het onderzoek der bloemen oplevert. $Z_{i j}$ zouden, inzonderheid de eigene vormen der oortjes van den helmknoop, tot kenmerken kunnen dienen. In de voorwerpen van Java en Pamatton zijn de oortjes van de kortere helmdraden sikkelvormig, die der langere stomp. In de voorwerpen van Banjermassing zijn die der kortere knodsvormig, die der langere met stompe, naar boven gekeerde punten. De voorwerpen van de Doeson-rivier hebben de oortjes der korte, als kleine kegeltjes en die der langere met spitse, naar boven gekeerde punten. De met lange kelkslippen voorziene gewassen van Poeloe-lampei hebben, wat de gedaante dezer oortjes betreft, vele overeenkomst met die van de helmdraden der planten van Banjermassing.

In gunstige standplaatsen groeit M. polyanthum tot twee ellen hooge struiken. Zijne langwerpige, soms bijna ronde kroon, is gewoonlijk geheel met rozenroode of licht purperroode, rozenvormige bloemen bedekt, welke tusschen de licht groene bladen verspreid zijn.

Hij vormt in het algemeen geenen hoofdstam, maar verspreidt zijne loten naar alle zijden uit een' stronk, even boven den grond. Zonnige of niet digt belommerde oorden, vooral de eerste, zijn zijne voornaamste standplaatsen. Hier groeit hij in kleine groepen of gezellig; op Java vooral in gezelschap van Psidium, met hetwelk hij geheele streken van vroeger bebouwd geweest zijnde gronden bedekt groeiplaatsen, welke hem, volgens Rumphius, ook op Ambon eigen zijn. Op Borneo groeit hij gezellig aan den Pamatton en te Poeloe-lampei, doch op geene dier plaatsen is zijne ontwikkeling aanzienlijk genoeg, om eenen merkbaren invloed op het aanzicn der streek uit te oefenen. Hier hebben deze planten haar aanzijn aan den bodem ontwoekerd, terwijl op Java de bodem aan de plant overmaat van voedsel schenkt.

\section{MELASTOMA ERECTUM. W. JAGK.}

De besehrijving van Jaek doet mij vooronderstellen, dat de plant, op Bantam door van Hasselt, en door mij op den Javaanschen berg Bebakti, ongeveer ter hoogte van $650 \mathrm{~N}$. ellen verzameld, dezen naam moet dragen. Door hare groeiplaats in digte bossehen wijkt zij reeds van M. polyanthum af, terwijl hare groeiwijze meer gestrekt en haar loof ijler zijn. Voorts komen daar nog andere kenmerken bij, vooral de bekleeding der plant in het algemeen en van den kelk in het bijzonder. Deze doet de plant gemakkelijk onderscheiden. Zij geeft haar een zeer ruig voorkomen en bestaat uit toegespitste, langwerpige, drooge, vliezige schubjes of strooblaadjes op de kelken, uit kleinere sehubjes op de takjes en uit wollige haren op de ondervlakte der bladen. 


\section{MELASTOMA LANUGINOSUM. Bu.}

Deze soort is zeer vermaagschapt aan M. Wallichii D. C., van hetwelk zij door de bekleeding, voornamelijk der hoofdnerven, verschilt. Deze kan desgelijks dienen om haar, op het eerste gezigt, van M. erectum af te zonderen. Ook komt de, over het algemeen stomp eivormige, gewoonlijk korter gesteelde vorm der bladen, alsook de meer zamengedrongene bloeiwijze hierbij in aanmerking. Bij nader onderzoek dienen tot deze afscheiding ook de oortjes van den helmknoop, welke bij M. erectum sikkelvormig, puntig, en bij M. lanuginosum bijna rond zijn. Het voorkomen dezer plant is struikaardig. Uit eenen korten stam of stoel schieten bijna loodregt, tot eene hoogte van twee tot drie ellen, onderscheidene stengen, welker hooger gedeelte vooral, van takken, met eenigzins van elkander verwijderde bladparen voorzien is. Het lagere gedeelte dezer stengen is dikwerf bladerloos. De geheele plant heeft eene geelgroene, soms naar het bruine trekkende kleur. Hare aan het einde der takjes geplaatste bloemen zijn licht rozenrood. $\mathrm{Z}_{\text {ij }}$ versierde het hoogere gedeelte van den tegenwoordigen top des beruchten bergs Papandayang, waar zij tegen het donkergroen van de Myrica eene aangename schakering te weeg bragt. Daarenboven was zij op de steile en zonnige plaatsen van den berg Salak vrij menigvuldig en aanmerkelijk ontwikkeld.

\section{MELASTOMA JACKIANUM. Kнs.}

M. ramulis squamulatis, foliis oblongo-oratis acutis basi obtusis supra setosis subtus setosis nervis squamulatis, floribus corymbosis ternis vel solitariis, calyce paleaceo, staminibus alternis connectivo elongato biauriculato.

Arbusculı duorum triumve metrorum, habitu varia; Ram saepe distantes, subtetragoni, squamulis parvis triangularibus vestiti, cinerei; RAmulI oppositi, erecto-patentes, apicem versus saepe incurvati, quadrangulares, quadrisulcati, squamulis triangularibus muniti; - novelli compresse tetrangulares, dense squamulati; rami ramulique saepe nodosi vel dilatati in ramulorum et foliorum insertione, ibidemque squamuloso-setosi. Folı decussata, erecto-patentia, oblongo-ovata, basi obtusa, apice acuta apiculata, subintegerrima vel minute crenulata, supra setosa setis margine crebrioribus, subtus setosa in nervis cum squamulis elongato-triangularibus, coriacea, 0,10 longa, 0,035 lata, quinquenervia: nervi curvati in apice folii cum nervo mediano confluentes. GEmrnaE elongato-conicae, dense setosae et squamulosae, foliolis conduplicatis; peTroli semiteretes, supra sulcati, squamulati, 0,01 longi. Frores tcrminales, raro axillares, corymbosi, terni vel solitares; PEDurcul subtetragoni, paleacei. Alabastrum ovoïdeum, bracteis duabus subrotundatis obtusis extus in medio paginae squamulosis involucratum. CALrX tubo elongato-campanulato, paleis lanceolatis imbricatis dense vestito, limbo quinquepartito: partes ante anthesin convolutae, apice saepe contortae, breviter triangulatae, acutae, in medio paleaceae, marginae ciliatae. Corolla pentapetala, fauci calycis inserta, aestivatione convolutâ; PETAXA cum laciniis calycis alternantia, late obovata, obliqua, obtusissima, sparse ciliata, glabra, laete rosea. Stamiva 10, inaequalia, 5 majora calycis laciniis, 5 minora petalis opposita; fitantenta subaequalia, magnitudine parumper diversa; ANTHERAE oblongae, apice recurvae, basi obtusae, intus sulcatae, apice poro unico pollen emittentes, connectivo majorum elongatum falcatum in insertione in auriculas duas 
acutas producto, conncctivo minorum brevi ad basin lateris interni cum auriculis duabus obtusis. Ovarium dimidia parte cum calyce concretum, disco perigyno carnoso coronatum, subrotundum, parte libera setosum, quinqueloculare, loculis multiovulatis; ovduA placentas triangulares tegentia. STYuus teres, sigmoïdcus, glaber; stigma papillatum, capitatum. CAapsula calyce inclusa, rotundo-ovoïdea, apice constrictâ annulo setarum coronata, irregulariter tamen saepe circumscisse disrumpens, quinquelocularis; dissepimenta subcoriacca. Pulagentae triangulares, carnosae, purpureae, lamellae ope axi affixae. Semina numerosa, minuta, basi in placenta immersa, compresse cochleata, apice rotundata, basi truncata, albida; hILUm circulare, cxcavatum; Exostonrun curvatum. Testa crustacea, foveolata; TEGMEN membranaceum. Emrryo hippocrepiformis, cylindricus, radiculâ obtusiusculâ, cotyledonibus obtusis.

\section{Crescit in parte occidentali Sumatrae.}

De gewassen, onder den naam M. Jackianum vereenigd, vormen, door de groeiplaatsen in hunne ontwikkeling gewijzigd, struiken, van twee tot drie, somwijlen van meerdere N. ellen hoogte. In de lage streken van Bangkahoeloe tot aan Priaman, groeiden zij gewoonlijk in korte, zaamgedrongene, digte struiken, tusschen Myrtus tomentosa, Melanthesa, Glochidion enzv., als gezellige planten. In de hoogerc, bij Padang-bessie, hadden zij meerdere lengte. Hier was hunne groeiwijze slanker en de afstand van de takken, bladen en bloemen onderling grooter. Daarbij hebben de laatsten een veel losser weefsel en zijn de stengen en takken ook met een los en ligtelijk verdroogend celweefsel opgevuld. Over het algemeen is aan deze gewassen een geelgroen, op de bovenvlakte eenigzins donkerder loof eigen, en hebben zij purperkleurige bloemen, welke de kroon gewoonlijk aan alle zijden omgeven. Deze gewassen bieden, bij een naauwkeurig onderzoek, eenig verschil, hetwelk, de uitersten genomen wordende, tot de afzondering van enkelen, onder eigene soortnamen, zoude aanleiding geven. Sommigen hebben de bladen minder behaard, de schutblaadjes kleiner, soms lancetvormig of langwerpig, de strooaardige schubjes der kelken lang en smal, of korter, de kelkslippen verlengd of kort. Deze vorm, welke Gymnanthum konde genoemd worden, komt in de bovenlanden voor. Anderen hebben de schubjes der takjes openstaande, de bladen fijner behaard, dikwijls tamelijk lange kelkslippen en stompe oortjes aan den helmknoop. En, als derde vorm, zouden de slanke gewassen van Padang-bessie kunnen genomen worden, die door langwerpiger bladen en de digte plaatsing der schubjes van den kelk te onderscheiden zijn. Al deze onderscheidingen gaan echter in elkander over, en zelfs de vorm der schutblaadjes is, blijkens de aan denzelfden tak voorkomende verscheidenheid, een zeer onzeker kenmerk.

Door haar voorkomen is deze soort vermaagschapt òf aan M. polyanthum, ò aan M. sylvaticum, naarmate zij meer of minder slank is uitgegroeid. Zij verschilt van beiden, als ook van Melastoma malabathricum, vooral door de bekleeding van den kelk.

De opengesprongene vruchten, in welke de zaden, als geelwitte korreltjes, over eene donker purperkleurige, vleezige stof liggen, worden soms, wegens het eetbare vleesch der zaaddragers, geplukt. Ook zijn zij dikwerf het voedsel van de langstaartige lijster. 


\section{MELASTOMA PUNCTATUM. Kns.}

M. ramulis squamatis, foliis oblongo-ovatis acuminatis basi obtusis supra setigeris subtus setigeris vel punctatis nervis squamatis, floribus corymbosis vel solitariis, calyce scarioso-squamato laciniis linearibus acuminatis, staminibus alternis connectivo elongato hamato-appendiculato.

Arruscula 3-6 metrorum, stirpibus pluribus e trunco brevi productis, strictis, subteretibus, glabriusculis, cinereo-fuscis; RANI pauci, praesertim versus apicem conferti, erecto-patentes vel patentes, subteretes, glabrescentes; RAmuLI oppositi vel decussati, axiles saepe abortivi, erecto-patentes, obtuse quadrangulares, novelli compresse quadrangulares et quadrisulcati, dense squamati, squamis elongato-ovatis acuminatis serratis scariosis in nodis ovato-linearibus vel setiformibus. Folis versus apicem ramulorum aggregata, decussata, patentia, oblongo-ovata, acuminata, basi obtusa, crenulata, supra setigera, subtus in nervis primariis squamata et in nervis secundariis venisque setigera vel abortu setarum punctata, coriacea, quinquenervia, nervis mediis supra basin folii productis, nervis lateralibus margine approximatis minoribus e basi progredientibus, 0,035 lata, 0,09 longa; PETIOLI semiteretes basi incrassati, supra canaliculati, squamis setisque scariosis tecti, 0,015 longi. Gemma cuneiformes, setosae. Frores in ramulorum apicibus terminales, solitares, terni vel plures, subcorymbosi; penuvculi triangulares, aciebus acutis, dense scarioso-squamulati. Bracteas sessiles, basi pedunculorum insertae, solitares vel geminatae, elongato-ovatae, acuminatae, supra ad basin glabrae versusque apicem setosae, subtus squamatac, subcoriaceae, uninerves. Alabastrum ovoïdum. Calycis extus squamis lanceolatis dentatis scariosis vestiti; тUBUs campanulatus, obscure pentagonus, basi obtusus; LInBus quinquepartitus, partibus linearibus, acuminatis, intus supra basin setosis, tubo longioribus, deciduis, acstivatione contortà, appendicibus quinque cum lacinïs alternantibus lanceolatis. Conolla subcampanulata, pentapetala, aestivatione contortâ in alabastrum obtusum; PETALA infra faucem calycis inserta, oblongo-obovata, obtusa, apice barbata, basi in unguiculam angustata, utrinque glabra, 0,02 longa, 0,01 lata, subcoriacea, purpurea. Stamira 10, alterna inaequalia; fiLAmenta calycis et corollae partitus opposita, recta vel paulo curvata, subtetragona, glabra, carnosa; ANTHERAE minores corollae oppositae, elongato-ovatae, obtusae, basi subcordatac, antice sulcatae, postice subrotundatae, connectivo abbreviato, antice in auriculas duas falcatas acutas producto; antherae majores formae ejusdem, connectivo fere longitudine loculorum, curvato, antice in auriculas duas hamatas obtusas producto, semiterete, glabro. Ovariun ad duas tertias partes usque vel semi-adnatum, ovoïdeum, acutiusculum, setosum, disco annuliformi setoso terminatum, quinqueloculare; ovula numerosa, placentas subcylindricas lamellae ope axi affixas tegentia. STruus apice recurvus, teres, basi crassior, glaber; sticin calycem spectans, apiculare, subcapitatum, papillosum. Capsula calycis tubo ovato-globoso disrupto cincta, rotundato-ovoïdea, apice in tubum campanuliformem attenuata, setosa, irregulariter disrumpens, coriacea vel subcrustacea, quinquelocularis. Dissepinenta cartilaginea. Spermophorum lamellae versus marginem dilatatac ope axi loculi affixum, obtuse triangulare, extremitatibus acutum, foveolatum, carnosum, purpureum. Semira minuta, numerosa, in foveolis placentae disposita, placentas seriatim tegentia, approximata, nephrö̈dea, extremitate inferiore majore et crassiore, compressa, albida; mILun basin seminis occupans, circulare, marginatum, margine in latere exteriore latiore; опрнAцорпun in parte interiore hili rectangulare, chalazac approximatum; micropila hilo approximata, uncinata. Testa foveolata, foveolis circularibus radiatim 
e circulo centrali versus marginem progredientibus, crustacea; TEGNEN membranaceum. EMrRro seminis cavitatem replens, subhippocrepiformis, teres, extremitatibus obtusus, carnosus, albus; RADICULA duas tertias partes embryonis occupans; cOTYLEDoNEs adpressae.

\section{Crescit in sylvis Burangrang: $\mathbf{J}_{\Lambda \mathrm{V} \Lambda}$.}

De groeiwijzc dezer plant doet vermoeden, dat zij van tijd tot tijd afsterft. Aan de meeste stronken toch vonden wij overblijfselen van stengen tusschen de nog levende, die in grooter of kleiner getal uit de stronken opgroeiden. Over het algemeen waren deze stengen regtstandig, vooral naar het einde van takken voorzien, soms in dezelve verdeeld. Door de van elkander verwijderde bladen waren zij zeer los en zonder kroon. Het loof is op de bovenvlakte donker-, op de ondervlakte lichtgroen. Tusschen of tegen hetzelve komen de purperkleurige bloemen zeer goed uit. - Alleen aan den berg Burangrang, op ongeveer 1500 ellen hoogte, is deze soort door ons waargenomen. Zij groeide daar gezellig in eene vochtige streek, alle andere, kleinere gewassen verdringende.

Deze soort heeft in den vorm van den stijl het eigenaardige, dat hij aan het uiteinde zoodanig omgebogen is, dat de stempel daardoor boven de poren van de helmknopjes komt.

Van de reeds beschrevene soorten is dezc, door de grootte en den vorm der helmknopjes en van den helmknoop, alsook door de bedekking van de takjes en den kelk te onderscheiden.

\section{MELASTOMA ASPERUM. BL.}

Het aanzien dezer soort heeft veel van de vorige plant, en de verderc kenmerken zijn mede in vele opzigten vrij gelijk. Bijzonder echter komt de vorm van de helmdraden ter onderscheiding in aanmerking: hunne helmknopjes zijn een weinig meer gedrongen en hebben niet, als bij de vorige soort, de uitstortingsporen aan den top, maar even beneden denzelven; ook wijkt de helmknoop èn door de mindere uitgroeijing èn door den vorm af. Deze toch heeft aan de kortere helmdraden twee kleine, puntige oortjes en aan de langere een vleezig, ingesncden lobje, hetwelk soms van enkele, draadvormige aanhangsels is voorzien.

VII. MELASTOMA SETIGERUM. Br.

Deze plant wordt aan den Gedé tot op 1700 ellen, aan den Salak tot op 1500 ellen, en aan den Papandayang tot op dezelfde hoogte, boven den oceaan, gevonden. Zij groeit daar gezellig op de vlakke ruggen of op de tusschen de jukken liggende kleine vlakten. Haar aanzien is gelijk aan dat van M. punctatum, doch hare kenmerken doen haar gemakkelijk van hetzclve onderscheiden. Tot deze onderscheiding komt onder anderen de oppervlakte der bladen bovenal in aanmerking. Deze hebben aan de ondervlakte kleine groefjes en op de bovenvlakte priemvormige borstels, welke als het ware de punten van de verhevenheden uitmaken. Na dit kenmerk volgt de bedekking der takken, uit kleine, ruitvor- 
mige, van boven getande, digt over elkander liggende, bruine schubjes bestaande. Daarenboven herinneren de kelkslippen M. punctatum, terwijl de vorm der helmdraden daarentegen nader aan dien van Melastoma Jackianum verwant is.

\section{MELASTOMA PULCHERRIMUM. KHS.}

M. ramulis setoso-paleaceis, foliis ovatis vel oblongo ovatis acuminatis basi obtusis supra hirsutis, subtus in nervulis hirsutis in nervis setoso-paleaceis, floribus solitariis vel ternis, calyce setoso-paleaceo, staminibus calycis laciniis oppositis connectivo elongato et petalis oppositis connectivo brevissimo.

Arbuscula 1-2 metrorum; truncus brevis; corona sphaerica vel obovoidea; stirpes plures ex eodem trunco productae; RAMI subteretes, subtetragoni, in nodis incrassati, glabri, vel glabrescentcs, cinerei, fuscomaculati; RAMULI versus apicem ramorum aggegrati, oppositi vel abortu alterni, ramulo axili abortientc subverticillati, erecto-patentes, apicem versus incurvati, compressi, aciebus obtusis, bicarinati, paleis setiformibus recurvis apice incurvis rubris vel purpureis tecti. Folis deeussata, subpatentia, distantia, ovata vel oblongo-ovata, acuminata, basi obtusa, in quibusdam subcordata, in aliis angustata, integerrima vel subcrenulata, crenulis setos emittentibus, supra hirsuta, hirsutie flexuosa, subtus in nervis primariis setoso-paleacea, et in nervis secundariis hirsuta, coriacea, quinque-septemnervia, nervis tribus vel quinque in foliorum apicem excurrentibus, 0,13 longa, 0,06 lata; PETIOLI semiteretcs, supra sulcati, basi dilatati, setoso-paleacei, 0,03 longi. Flores in apice ramulorum terminales, solitares vel terni; PEDUNCUL breves, subteretes, setis subuliformibus patentibus incurvatis muniti; BRACTEAE geminatae, basi pedunculi affixae, suboppositae, sessiles, erectae, ovatae, acuminatae, supra glabrae, subtus setosae, membranaceae, uninerviae. Alabastrum junius bracteis inclusum, adultius ovoïdeum, setosopaleaceum. Calygis tubus campanulatus, setoso-paleaceus, paleis pluribus ex uno puncto productis subuliformibus curvatis flavescentibus; Lпnвus quinquepartitus, quinqueappendiculatus, deciduus, aestivatione convolutâ; PARTES elongato-triangulares, intus glabrae, extus setosae; APPENDices lineares, apice dilatatae, obtusae, setigerae. Conolla pentapetala, aestivatione contorta obtusa; petala infra limbi divisionem annulo inserta, patentia, obovata, obtusa, basi lata, subearnosa. Stanirs 10, inaequalia, perigyna, laciniis calycis et petalis opposita; $\mathbf{5}$ majora petalis opposita, filamentis subteretibus glabris, antheris subteretibus versus apicem tenuioribus sigmoïdeis poro apicali dehiscentibus, connectivo subterete curvato antice in auriculos duos obtusos vel obtusiusculos producto longitudine antherarum loculi; 5 minora, antheris forma majorum et magnitudine paulo minoribus, connectivo brevissimo antice in auriculos duos parvos obtusiusculos producto. Ovariun dimidia parte cum calycis tubo concretum, ovoïdeum, subpentagonum, vertice in discum carnosum excavatum attenuato, dense setosum, quinquelocularc; ovulA numerosa, placentas teretes utrinque attenuatas lamellae ope axi affixas tegentia; sTYLus basi disco cinctus, rectus, teres, glaber; sTigma apicale, truncatum, papillatum. CAPSULA immatura oblongo-pentagona, vertice cylindro brevi discoideo coronata, dimidia parte cum calyce concreta, parte libera setosa, quinquelocularis, epicarpio et mesocarpio coriaceo, endocarpio crustaceo. Pracentae axi loculi lamellae ope affixae, oblongae, extremitatibus obtusae, foveolatae, carnosae. SEMrrs numerosa, parva, basi affixa, seriatim disposita, nephroïdea vel hippocrepica, basi truncata, apice rotundata, compressa, foveolata.

Crescit in monte Bahay: BoRveo. 
Explicatio Tab. 49. Figura speciei. 1. Alabastrum cum folio florali et bracteis. 2. Alabastrum, calycis parte abscissâ. 3. Alabastrum, parte calycis ct corollâ ablatâ, antheris retroflexis. 4. Floris, corollâ ablatâ. 5. Floris, longitudinalis sectio, corollâ et staminibus quibusdam ablatis. 6. Ovarium, parte seminiferâ apertâ. 7. Capsula immatura, calycis parte longitudinaliter abscissa. 8. Capsula eadem longitudinaliter dissecta. 9, 10. Semina.

Aan den heuvel Bahai, langs de oevers van de Doeson-rivier, groeide deze plant in cenen kiezelaardigen bodem. Als een ronde of eivormige struik met blinkend groene bladen en groote donker rozen- of purperkleurige bloemen, versierde zij in augustus en september, met de geel-groene Ewyckia gepaard, de onvruchtbare grijs-witte helling. Door den vorm is deze struik aan M. polyanthum verwant, doch door de grootte, de helder roode kleur der bloem en inzonderheid door de bekleeding der takjes niet alleen van deze, maar ook van al de beschrevene onderscheiden. De bekleeding, uit priemvormige, openstaande, kromgebogene strooblaadjes gevormd, geeft aan de jongere deelen der plant eene levendig purperroode kleur, en doet ecnige verwantschap met $\mathbf{M}$. macrocarpum en $\mathbf{M}$. sanguineum van Don vooronderstellen. De bekleeding der kelkbuis herinnert die der Osbeckia. Zij bestaat uit verscheidene, aan één punt ontspringende borstelharen of uit bandjes, welke verschillend van lengte, in borstelharen verdeeld zijn. In beiden zijn deze deelen met eene ronde bogt naar boven gerigt.

Deze soort is door ons alleen op den heuvel Bahai, langs de rivier waargenomen. Daardoor wordt de mij gedane opgave waarschijnlijk, dat zij niet noordelijker, in het midden van Borneo hare standplaats heeft, maar dat zij meer westelijk menigvuldiger is en zich dus langs de ruggen, welke tusschen de groote Dajak-, de Kapocas- en de Doeson-rivier gelegen zijn, verspreid heeft.

\section{MELASTOMA BORYANUM. Kir.}

M. ramulis setosis, foliis ovalibus vel ovatis acutis vel cmarginatis basi aculiusculis supra appresse hirtis subtus hirtis vel glabresccntibus ncrvis sctosis, floribus tcrminalibus, calycis laciniis lincari-triangularibus acuminatis, staminibus connectivo clongato calycis lacinïs et connectivo brevi petalis oppositis.

Frutiaulus magnitudine unius vel duo dodrantium, stirpibus pluribus ex eodum trunco brevi saepe rhizomatoïdeo nodoso productis; GaUu.Es subteretes, basi crassiores, in ramulorum insertione nodosi, rimosi, cortice saepe in lacinias longitudinaliter secedente, glabrescentes, fusci; ramULI basi caulis saepe alterni, apicem versus oppositi vel decussati, erecto-patentes, obscure tetragoni, novelli compresse tetragoni sulcati, setis appressis brevibus in internodiis et setis longioribus subuliformibus in nodis ipsis munite. Foria versus ramulorum apice conferta, opposita, ultima subverticillata, ovalia vel ovata, basi acutiuscula in quibusdam obtusa, apicem acuta vel emarginata, crenulata, supra appresse hirta, subtus in nervis primariis sctosa, inter nervos hirta, adultiora glabrescentia, coriacea, trinervia, latiora subquinquenervia, nervis lateralibus margine approximatis vix conspicuis, 0,04 longa, 0,015 lata; PETIOLI subteretes, supra sulcati, setosi, 0,005 longi. Gemmae sessiles, axillares, dense setosae. Frores in apicibus ramulorum terminales; PEDUnculr subteretes, dense setosi, breves; BRACTEAE nullac vel subulatae; alabastrum elongatoovoïdeum, attenuatum. CALYX aestivatione subcontortus, setis subuliformibus basi in tuberculos incrassatis 
tectus, tubo campanulato basi rotundato vel acutiusculo, limbo quinquepartito quinqueappendiculato, deciduo, partibus lineari-triangulatis acuminatis utrinque setosis longitudine tubi vel longioribus, appendiculis inter calycis lacinias dispositis spathulatis setosis. Coroula infra faucem calycis inserta, pentapetala, aestivatione contorta; PETALA calycis partibus alterna, obovata, inaequilatera, obtusa truncatave, apice barbata, margine saepe undulata, glabra, subcoriacea, rosea, 0,035 longa, 0,02 lata. STumira 10, inaequalia, majora calycis partibus, minora petalis opposita; fILANENTA linearia, in medio longitudinis latiora, glabra; ANTHERAE ovato-cylindricae, antice sulcatae, apice dehiscentes; connectivo majorum longitudinem loculorum superante, arcuato, obscure tetragono, intus ad basin in auriculas duas obtusas producto; connectivo minorum brevi, intus breviter obtuse biauriculato. Ovariun calycis tubo duabus tertiis partibus adnatum et paulo ultra eundem productum, oblongo-ovoïdeum, disco vertice carnoso setoso cylindrico, parte libera setosum, quinqueloculare; ovula numerosa, placentas oblongas extremitatibus obtusas foveolatas carnosas lamellae ope axi loculi affixas tegentia, campylotropa. Stru,us basi annulo discoïdeo cinctus, teres, versus apicem subclavatus, glaber; sтiGnta cylindricum, parte inferiore subconstrictum. Capsola calycis limbo obtuse quinquedentato cincta, ovoïdea vel subrotunda, parte libera dense setosa, irregulariter cum tubo calycis longitudinaliter vel in parte superiore circumscisse disrumpens, epicarpio et sarcocarpio coriaceo, endocarpio crustaceo foveolato, quinquelocularis. Placenra carnosa, obscure purpurea, profunde foveolata. Sencria numerosa, minuta, tertia parte in foveolis placentae immersa, erecta, seriatim disposita, difformia, alia ovata angulata, alia inaequaliter nephroidea, foveolata, foveolis serialibus approximatis circularibus; нrLuı micropylae approximatum, oblongum, marginatum, omphalodio occupatum; micropyla in apice, parte uncinata, seminis. Testa crustacca; Tegmen membranaceum. Nucleus oblongo-ovoïdeus vel teres, curvatus, extremitatibus obtusus, parte cotyledonea emarginatus, parte radiculari saepe apiculatus.

\section{Crescit in monte Pamatton: Borneo.}

Explicatio Tab. 50. Figura speciei. 1. Alabastrum. 2. Alabastrum adultius. 3. Flos expansus. 4. Calycis tubus longitudinaliter descissus cum ovario. 5. Calyx cum fructuo immaturo. 6. Idem apice visus. 7. Fructus immaturus transverse dissectus. 8 et 9 . Capsulae ruptae cum calycibus. 10, 11, 12. Semina.

Onder de gedaante van kleine, ééne tot twee span hooge, schraal van bladeren voorziene struikjes, groeit deze plant aan den voet van den Pamatton. Z Zij is hier over de geheele zuidelijke helling verspreid, groepsgewijze met Nepenthes gracilis de plaatsen innemende, waar de rotsen niet te naakt zijn. Even als deze Nepenthes heeft zij eene soort van wortelstok, waardoor de plant bij te sterke droogte bchouden wordt. Door de grootte harer bloemen draagt zij bij, om aan het onvruchtbare land het aanzien van den weelderigen plantengroei der tropen mede te deelen.

Vroeger is deze soort, even als M. nitidum, door mij voor eene verscheidenheid van M. porphyratum gehouden. Deze planten verschillen evenwel onderling genoegzaam van elkander, om haar bijzondere namen te geven en daardoor een nieuw onderzoek over de juistheid dezer afscheiding uit te lokken. M. porphyratum, in de Molukken gevonden, heeft de bladen minder bekleed en de kelkbuis met lange, kromgebogene, priemvormige strooschubjes bedekt; M. nitidum, aan den berg Sakoembang gevonden, Botanica. 
verschilt door de schubvormige bedekking der takken, de priemvormige borstels der bladen en gewoonlijk door den oorsprong der beide zijnerven, welke even boven den voet van het blad, uit de andere, naar binnen gelegene hoofdnerven, plaats heeft.

\section{MELASTOMA NITIDUM. Kns.}

M. ramulis squamulatis, foliis ovatis acutis basi obtusis rcl angustatis, floribus solitariis, calycis setosi lacinïs oblongo-linearibus acuminatis.

Frotex 1-2 metrorum, stirpibus pluribus ex eodem trunco brevi productis erectis vel erecto-patentibus teretibus glabrescentibus cinereis; RA rr sparsi, alterni, subteretes, squamulis subulatis basi incrassatis arcte appressis sparsis vestiti; RAMULI versus ramorum apices dispositi, alterni vel oppositi; RAmuLI axiles saepe abortivi, obscure tetragoni, squamulati, in nodis squamis subuliformibus paucis saepe tribus obsiti, fusci. Foura decussata, patentia, ovata, quaedam ovalia, basi obtusa vel angustata, apice acuta apiculata, integerrima vel crenulata, supra setis brevibus subuliformibus e vaginis albidis productis vestite, subtus in nervis primariis squamulis subulatis basi incrassatis praedita, inter nervos hirsuta, glabrescentia, coriacea, quinquenervia, nervis omnibus e basi folii productis vel lateralibus supra basin bifidis, 0,04 lata, 0,065 longa; - juniora et evolventia supra dense vestita, subtus in nervis primariis dense et inter nervos sparsim vestita; PETrou 0,015 longi, semi-teretes, supra canaliculati ibidemque setis squamulatis dense obsiti, margine setis subulatis vestiti. Flones in apice ramulorum solitares, terminales; PEDunculus teres, setosus, basi setarum subuliformium annulo cinctus. CALYX fructum immaturum includens, campanulatus, basi rotundatus, vcrsus limbum paulo constrictus, setis subuliformibus basi incrassatis erecto-patentibus vestitus; цmвus quinquepartitus, quinqueappendiculatus; partes deciduae, oblongo-lineares, acuminatae, intus apicc, extus omnino setosae; appendiculae calycis partibus alternantes, semiteretes, in setas excurrentes. CA Psula duabus tertiis partibus calyci adnata, rotundato-ovö̈dea, quinquesulcata, disco carnoso excavato obsolete quinquedentato setoso coronata, parte libera setosa; epicarpio et mesocarpio tenui, endocarpio crustaceo, quinquelocularis. Placentae lamellae ope affixae axi quinquangulari, oblongae, compresse trigonae, coriaceae. SEnirsa numerosa, serialia, placentas tegentia, nephroïdea, basi truncata, vertice obtusa, approximate foveolata.

\section{Crescit in monte Sakoembang, ad ripas Pankinan: Bonmeo.}

De onder deze soort vereenigde gewassen kunnen tot drie verscheidenheden worden gebragt. Twce derzelve hebben den berg Sakoembang tot standplaats. Aldaar groeit er cene op den top, met eene ruwe, stijve bekleeding; terwijl de andere aan de helling, met gladdere, soms geheel onbehaarde bladen wast. Bij dit verschil kan nog de meerdere uitgroeijing der kelkbuis en de daardoor ontstaande verberging van de eivormige zaaddoos in dezelve, gevoegd worden. De derde verscheidenheid, vroeger door mij, wegens den dubbelen borstelkrans op de kruin der zaaddoos, Distemma genoemd, heeft de bladen soms bijna geheel onbekleed en van boven alleen van witte streepjes voorzien. Daarbij heeft zij duidelijke, vierkante takken, en over het algemeen in alle deelen eenen meer gestrekten vorm. Van M. pulcherrimum en M. Boryanum kan deze soort door de bekleeding, welke bij de eerste strooaardig en bij de tweede borstelharig is, als ook door de scheeden, waaruit de haren ontspringen, onderscheiden worden. 


\section{OTHANTHERA. BLURE。}

\section{OTHANTHERA BRACTEATA. KHs.}

0. ramis ramulisque obscure tetragonis setigeris, foliis ovalibus acutis utrinquc setigeris, floribus racemoso-paniculatıs bracteolatis.

Arbuscura 2-3 metrorum; Rasi patentes, abortu alterni, obseurc tetragoni, duobus lateribus rotundatis caeteris planis, setigeri, in nodos dilatati, crebre setosi; RAMuLr patentes, ultimi saepe ineurvati, compresse et obscure tetragoni, in nodis latiores, quadrisulcati, setosi, novelli setis omnino tecti. FouIA diffusa, versus apicem ramorum sita, decussata, ovalia, adultiora saepe ovata subcordata, juniora ovalia vel oblongo-ovalia, acuta, basi obtusa, serrulata, supra breviter setosa, subtus praesertim in nervis primariis et secundariis setosa, coriaeea, septemnervia, nervis secundariis subparallelis approximatis, 0,11 longa, 0,05 lata; petrou semiteretes, supra sulcati, dense setosi, 0,015 longi. Fuores terminales vel axillares, subsessiles vel pedunculati, racemosi, racemis subpaniculatis, bracteis $\mathbf{4} \mathbf{- 5}$ sessilibus subrotundis vel reniformibus cucullatis acutis vel obtusiusculis intus glabris extus setosis suffulti. CALrX in alabastro ovoïdeus, dense setis longis saepe partitis vestitus; тuBus rotundato-ovoïdeus, basi obtuserotundatus, limbum versus constrictus; LImBus quinquepartitus, quinqueappendiculatus; appendiculis linearibus, apice trifidis, cum partibus triangularibus aeutis intus glabris alternantibus. CoroLLA in alabastro semi-ovoïdeo obtuso aestivatione convoluta, pentapetala; PETALA margini annulari inserta, obovata, obtusa, breviter unguiculata, dentata, membranacea, paucinervia. Sтлırı 10, in alabastro inflexa, calycis et corollae partibus opposita, inaequalia; FILAnenta calycis fauci inserta, linearia, alterna, calyci opposita versus antheras triappendiculata, appendiculis ovatis acutis verticillatis, glabra; AINTHERAE basi affixae, oblongae, poro subapiculari dehiscentes, basi in auriculas duas compressas desincntes. Ovariuni calyci semiadnatum, ovoïdeum, disco decemdentato coronatum, setosum, quinqueloculare; ovula numerosa, placentis oblongis carnosis inserta, campylotropa; styLus teres, glaber; stigna simplex vel quinquedenticulatum. Fructus calycis limbo coronante velatus, rotundato-ovoïdeus, basi rotundatus, apice truncatus, centro conico, setosus, siccus, quinquelocularis, endoearpio cruslaceo. SEMriva numerosa, parva, placentas oblongo-ovoïdeas laminis ope axi affixas tegentia, cochleata, extremitate hili circularis magis evolutâ; TESTA foveolata, crustacea; TEGMEN membranaceum. NucLeus subcircularis, teres, exalbuminosus; RAdicula obtusa; cotrledones aequales.

\section{Crescit in sylvis Singalang: Sunatra.}

Explicatio Tab. 51. Figura speciei. 1. Alabastrum et bractearum verticillus flore ablato. 2. Alabastrum longitudinaliter sectum. 3. Alabastrum calycis parte ablatâ. 4. Flos. 5. Anthera antice visa. 6 ct 7. Anthera a latere visa. 8. Ovarium longitudinaliter sectum. 9. Placenta ab interiore visa. 10. Calyx fructifer. 11. Idem calycis parte ablatâ. 12. Fructus transversalis sectis. 13. Fructus longitudinalis sectis. 15 ct 16 . Semina immatura a latcre visa.

Het eigenaardige van deze soort is de, uit drie lobjes bestaande krans, welke het bovenste gedeelte der helmdraden omgeeft, de dikwerf voortdurende kelkslippen en het, met deze afwisselende aanhangsel. Dit laatste komt vooral in aanmerking, dewijl het de plant aan het geslacht Melastoma nabijbrengt. 
Bij de ontwikkeling ondergaan de buitenste vruchtdeelen geringe vcrandering. De zaaddragers worden een wcinig vleeziger en de zaden brozer. De laatste schijnen in de, aan de plant blijvende vruchten te kiemen. Daarbij springt het bij den navel gelegen deel als een deksel open, hetwelk, naar den zaadmond gekeerd, blijft vastgehecht.

In de bosschen van den Singalang groeit deze soort op de vochtige vlakten. $Z_{i j}$ trekt aldaar noch door haar aanzien, noch door hare menigte, bijzonder dc aandacht. $\mathbf{Z}_{\mathrm{ij}}$ is $\mathrm{ijl}$, verraadt eenen overmatigen stenggroei en mist het sieraad van bijzonder groote of talrijke bloemen. De geringe hoeveelheid onder de, anders voor haar in dit opzigt zoo gunstige omstandigheden, was misschien alleen plaatselijk en veroorzaakt, doordicn deze plantensoort tot de voedingsmiddelen van den tapir behoort, en inzonderheid de jonge planten daartoe strekken zullen.

Het geslacht Othanthera, waartoe deze plant, uithoofde van haar aanzien, behoort, moet eene wijziging in het onderscheidende kenmerk ondergaan, waardoor hetzelve meer beperkt en bepaald wordt tot de beide oortjes der helmknopjes.

\section{DISSOCHAETA. BuUnE.}

\section{DISSOCHAETA FALLAX. BL.}

Deze soort kan tot de aanzienlijkste slingerplanten der bosschen van Melintang en van die, welke de oevers der rivier Salaut op Sumatra bezoomen, gerekend worden. Bij eene groote uitgroeijing der steng heeft zij talrijke bloemen, die in pluimen, met rozenroode bloemkroonen, vereenigd zijn. De bijzondere wijze van vasthechting der helmknopjes, ongeveer in het midden, is aan deze soort eigen.

Bloeijend en vruchtdragend te gelijk, werd zij in de maanden julij en augustus verzameld. De bloemdragende takken warcn de hoogste, terwijl de vruchtdragende, welker ronde, drooge vruchten naar beneden gekromd waren, lager stonden.

\section{DISSOCHAETA INTERMEDIA. BL.}

Door het aanzien en de groeiwijze aan de vorige verwant, kan de Dissoehaeta intermedia alleen door cen oplettend ondcrzoek der bloem worden onderscheiden. Niet alleen de aanhechting der helmknopjes aan den voet, maar ook bovendien de zeisvormige bogt derzelve, is alsdan het middel ter onderkenning.

Eenige bloemen der voorwerpen van Java hebben een ziekteverschijnsel, daarin bestaande, dat de stijl bolvormig uitgroeit en van binnen hol is.

Java en Sumatra zijn het vaderland van deze soort; op Sumatra echter is zij zeldzamer, dan de Dissochaeta fallax. 


\section{DISSOCHALTA GRAGILIS. BL.}

Deze soort, door den ontdekker te regt de slanke genaamd, verzamelden wij langs de boorden van de Tewe-rivier op Borneo, langs die der Indrapoera-rivier op Sumatra, en in de lagere streken van Java. Op al deze groeiplaatsen was zij vrij menigvuldig langs de zoomen der bosschen, waar zij rondsom de kleinere stammen hecnkronkelde. De talrijke witte, in pluimen vereenigde bloemen en de regtstandige, blaauwe vruchtjes versieren, beide te gelijk, de geelgroene plant en doen zulks, naar den tijd del inzameling te oordeelen, het geheele jaar door.

Ilet slanke aanzien, de geelgroene kleur, de witte bloemen doen de Dissochaeta gracilis van de verwante soorten onderscheiden, en de vorm der, naar den voet verdund uitloopende cn met twee draden voorziene helmknoopjes geeft een bepaald kenmerk van onderscheiding.

\section{DISSOCHAETA BRACTEATA. Kus.}

D. foliis quinquenerviis cordato-ovatis aculis subtus stellulatis, paniculis terminalibus vel axillaribus, antheris 8 alternis sterilibus basi affixis, connectivo bisetoso.

Frutex sarmentosus; Rami obscure tetragoni, nodis incrassatis annulatis, glabrescentes; RAMrul erectopatentes, obscure tetragoni, pube stellulatâ badia vestiti. Folı decussata, cordato-ovata vel ovata basi obtusa, acuta, supra glabra, subtus stellulata rufa, crasse coriacea, quinquenervia, nervis secundariis parallelis distantibus, 0,08 longa, 0,04 lata, decidua; Perroli in ramis arliculati, subteretes, pubescentes, 0,005 longi. Flores pedunculati, in alabastro oblongo-obtusi, pube ferruginea dense tecti, juniores bracteis duabus obovatis obtusis pubescentibus membranaceis fugacibus involucrati, paniculati; pedunculus connunis obscure tetragonus; pedunculi secundarii dichotomi, compresse-tetragoni, nodis dilatati. GaLrx intus glaber, extus dense ferrugineo-pubescens; rubus elongato-obconicus; uninus integerrimus, erectus in floribus junioribus, pateriformis in floribus adultioribus. Corolla in alabastro semiovoïdeo obtuso aestivatione convoluta, fauci calycis inserta, tetrapetala; perılı ovata, acutiuscula vel obtusa, saepe emarginata, utrimque glabra, carnosa. Sranira 8, fertilia 4 petalis opposita, sterilia 4 iisdem alterna; frLamenta foveolis annuli faucis calycinae inserta, linearia, glabra; antherae fertiles curvatae, poro dehiscentes, conncctivo basi introrsum bisetoso; ANTHERAE steriles lineares, rectae, basi introrsum bisetosae, roseae. Ovarium dimidia parte calyci adhaerens membranarum ope locellos antherarum formantium, obtusum, hirsutum, quadriloculare; ovula numerosa, placentas 'oblongas carnosas laminae membranaceae ope axi affixas tegentia, anatropa; struus teres, parte inferiore pilosus; sTigra capitellatum, in flore juniore erectum, demum recurvum. Fructus calycis excreti limbo planopateriformi velatus, ovoïdeus, apice truncatus, styli rudimento umbonatus, stellulis sparsis vestitus, quadrilocularis. Skmira numerosa, placcntas carnosas oblongas basi latiores tegentia, irregularitcr tetraëdra, basi angustiora; TESTA coriaeea, foveolata, marginibus daedaleis foveolas augentibus; TEGMEN membranaceum. Hutus micropylae approximatum; RAPHE linearis ill semine maculà nigrâ indicata; CHALAZA hilo subopposita laterali-basilaris. Nugleus exalbuminosus; Radicula obtusa; cotyledones inaequales, oblongae, obtusae.

Crescit juxta Doekoe: Sunatra. 
Lixplieatio Tab. 55. Figura speciei. 1. Alabastrum. 2. Flores tres cum bracteis. 3. Calyx. 4. Idem, dimidia parte abscissa ut ovarium apparcat. 5. Idem longitudinaliter sectus. 6. Fructus calyce velatus. 7. Idcm, calycis parte abscissta. 8. Idem in longitudine dissectus. 9. Ejusdcm scctio transversalis. 10. Semen. 11. Idem, testâ ablatâ, raphe distinctâ. 12. Embryo.

\section{v. DISSOCHAETA GYANOGARPA. BL.}

D. ramulis petiolisque setis simplicibus sparsis vestitis, foliis trinerviis (eum nervis 2 marginalibus) ovato-oblongis acuminatis basi cordatis, panieulis terminalibus glabris, staminibus 8 , alternis effoetis. BцuмE.

C.Aouss sarmentosus; RAnI alterni, sparsi, versus caulis apicem conferti, subterctes, nodis paulo crassioribus annulatis, setosis; RAMULI erecti, obscure tetragoni, apicem versus compresse tetragoni, lateribus latioribus sulcati, nodis incrassati, setis diffusis vestiti. Foura opposita, ovato-oblonga, obtuse acuminata, basi cordata, utrinque glabra, coriacea, trinervia cum duobus nervis minoribus lateralibus, nervis secundariis parallelis distantibus, 0,12 longa, 0,05 lata; petrour setigeri, 0,005 longi. Frores in paniculis terminalibus subdichotomis, pedunculo communi quadrangulari quadrisulcato nodis incrassato sparsim setigero, pedicellis subteretibus farinosis, saepe terni, medio ebracteato, duobus lateralibus bracteatis; BRACTEAE obovatae, laciniatae, vel in lacinias lineares fissae. CALYX in alabastro obscure octogonus parte inferiore obconica majore; тubus obconicus, glabriusculus; Lnibus truncatus, glaber, coerulescens. Corolta in alabastro acutiuscula, aestivatione convolutâ, tetrapetala; PETALA versus apicem tubo calycis inserta, ovata, acuta, carnosa, glabra. Stamisa 8, alterna petalis opposita sterilia; fiLumenta linearia, glabra, subcarnosa; ANTHERAE basi affixae, sigmoïdeae, teretes, bisulcatae, apice poro ovali dehiscentes; connectivum basi bilabiatum, labio exteriore acuto, labio interiore trilobo lobis lateralibus oblongis obtusis lobo medio triangulato acuto; ANTHERARUr rudimentum filiforme et connectivum subbilabiatum in staminibus sterilibus. Ovarnum membranarum ope calyci adhaerens, ovoïdeum, glabrum, quadriloculare. Ovura numerosa, placentas carnosas tegentia, anatropa. Struos teres, glaber; sticima truncatum, papillatum. Fructus calyce velatus, baccatus, subglobosus, glaber, coeruleus, apice calycis limbo marginatus, truncatus, quadrilocularis, dissepimentis membranaceis. Pracentae laminae subcarnosae ope axi loculi affixae, subcarnosae, saepe laciniatae. Senurs numerosa, parva, placentas tegentia, tetraëdra vel dimidiate ovoïdea, structurae uti in Dissochaeta bracteata.

\section{Crescit in sylvis humilioribus $\mathrm{J}_{\mathrm{AvaE}}$ et Sumatrae.}

Explieatio Tab. 56. Figura speciei. 1. Flores cum bracteolis. 2. Alabastrum. 3. Alabastrum corollâ dccidua calyptratum. 4. Idcm corollâ ablatâ. 5. Flos expansus. 6. Stamen stcrile. 7. Anthera postice visa. 8. Stamen a latere visum. 9. Ovarium cum calyce longitudinaliter dissectum. 10. Fruclus. 11. Fructûs longitudinaliter seetus. 12. Idcm transversaliter scctus. 13 et 14. Semina: a. hilum, b. micropyla. 


\section{DISSOGHAETA BIPULVINATA. KhS.}

D. ramulis petiolis nervis subtus setosis et rufo tomentosis, foliis trinerviis (cum nervis duobus marginalibus) ovatooblongis acuminatis basi cordatis subtus basi bipulvinatis.

\section{Crescit in monticulo Rantau: Borveo.}

De bovengenoemde soorten, D. cyanocarpa en D. bipulvinata, hebben een gelijkvormig aanzien. Het zijn beiden rankende gewassen, van de andere soorten van dit geslacht, door de borstelvormige, openstaande, zwart-bruine haren, reeds als zij blad dragen, te onderscheiden. Daarenboven is de helder blaauwe kleur der vrucht aan D. cyanocarpa eigen, zijnde deze tot dusverre alleen vruchtdragend waargenomen.

In de lage streken van Oedjong-Karang groeide de D. cyanocarpa langs den zoom van het hoofdbosch, gewoonlijk de kleine boomen omwindende, in de schaduw. Aan den Rantau vond men haar onder gelijke omstandigheden. Zij droeg op de eerste plaats in november en december bloemen en bijna rijpe, blaauwe vruchten.

\section{DISSOCHAETA ROSTRATA. Kus.}

D. hirsuta, ramulis teretibus, foliis rotundato-ovatis acuminatissimis basi cordatis quinquenerviis.

\section{Crescit in monte Prarawin: Borveo.}

Aan den berg Prarawin, hooger dan de berg Rantau, langs de Doeson-rivier gelegen, verzamelden wij takken van dezc Dissochaeta-soort, die door de haarbekleeding en den vorm der bladen, van al de vorigen afwijkt, en vermoedelijk aan de beide vorigen verwant is.

\section{DISSOCHAETA NODOSA. Kнs.}

D. ramulis subteretibus, foliis ovatis acuminatis cordatis trinerviis (cum duobus nervis marginalibus) supra glabris subtus puberulis, paniculis terminalibus axillaribusve, staminibus 8 , alternis sterilibus, antheris ovatis.

CAULIS sarmentosus; RAIII subteretes, glabrescentes; RAMULI subteretes, obscure tetragoni, ultimi compressi, nodis incrassatis annulatis, fusco-farinosi. Fourı decussata, petiolata, petiolis triangularibus supra planis farinosis, 0,01 longis, ovata, obtuse acuminata, basi cordata, supra glabra, subtus pube sparsâ vestita vel glabrescentia, trinervia, nervis lateralibus duobus margini approximatis, coriacea, 0,1 longa, 0,05 lata. Flones terminales vel axillares paniculati; pEDurculus commurrs obscure tetragonus, quadrisulcatus, nodis incrassatis, farinosus, pedunculi et pedicelli subterctes; BRACTEAE anguste obovatae, deciduae. CiLYX brevis, campanulatus, tubo subtetragono, limbo dilatato, extus farinosus, intus glaber. Coroula in alabastro conico acuto aestivatione convoluta, tetrapetala; PETALA obovata, obtusa, glabra, subcarnosa. Sramira 8: 4 fertilia, 4 sterilia; filamenta annulo faucis calycinae inserta, linearia, basi paulo latiora, 
glabra; ANTHerae basi affixae, eompresse elongato-ovöideae, apiee attenuatae ibidemque poro oblongo dehiseentes; 4 minores, eonnectivo quadrifido introrsum appendieibus duobus filiformibus rectis, extrorsum appendieibus flexuosis adaueto; 4 majores, eonneetivo extrorsum lamello rhornbiformi, introrsum appendieibus duobus filiformibus munito. Ovarir hirsuti quadrilocularis tres partes calycis tubo adhaercntes, parte quarta liberâ truneato-eoniea; ovura numerosa anatropa. STxus in vertice ovarii arliculatus, teres, versus apicem incrassatus; strgma capitellatum. Fructus calyee vclatus subcarnosus, sphaerö̈leus, ealyeis limbo pateriformi obvallatus, vertice truneatus, acumine eonieo terminatus, 4-locularis, dissepimentis membranaeeis. SEmra numerosa, plaeentas lamelliformes tegentia, structurae seminis Dissoehaetae braeteatae.

\section{Crescit juxta Indrapoera: Sumatra.}

De Dissoehaeta nodosa is door haar aanzien verwant aan D. bracteata, met welke zij de lieht groene kleur gemeen heeft. Zij wijkt eehter van dezc af, door de helmknopjes, door den kegelvorm der vruehten, en door de tocgespitste punt der bladen. Zij heeft vooral den vorm en het zamensicl der stuifdraden zeer eigenaardig, terwijl de uitgroeijing van den top der vrueht, in een kegelvormig puntje, de opmerking verdient.

\section{DISSOCHAETA BILIGULATA. Kns.}

D. ramulis fusco-farinosis, foliis oblongis obtuse acuminatis basi obtusis trincrviis (cum nervis 2 minoribus margini approximatis), floribus paniculatis, staminibus 8 , alternis fertilibus, antheris subbiporosis, connectivo bilamellato.

\section{Crescit in sylvis humilioribus juxta Paauw: Sumatra.}

Door het aanzien en de kenmerken is deze soort vermaagsehapt aan D. leprosa en D. sagitta BuuxrE. Zij heeft de helmknopjes, op eene eigenaardige wijze zamengedrukt, eivormig, aan den top afgeknot, door de verlenging van den tusschenwand der knopjes, in twee poren openende, met eenen helmknoop, welke uit eene bijna ongedeelde, afgeknotte buitenlip en eene in twee tongjes gedeelde binnenlip bestaat.

\section{A R U M I A. Bu.}

Dit, door de fraaiheid zijner soorten uitmuntende geslacht, is door deszelfs stiehter met regt als een der vertegenwoordigers van de familic der Melastomaceae, in de Rumphia afgebeeld. Zijn kelkvorm en het zamenstel der vrueht geven aanleiding, hetzelve met Henriettia, Calycogonium en Clidemia, vooral met het eerste geslacht te vergelijken, doch het viervoudige getal doet het afzonderen. Hierdoor nadert het aan Dissoehaeta, dat door de gedaante van den, met tanden voorzienen kelkzoom afwijkt. Daarenboven is het uiterlijk aanzien geheel versehillend: de eigenaardige donzige bekleeding, de groote, uit de oksels voortkomende, gewoonlijk drie- of vijftallige, aan stijve stelen gehechte bloemen, doen vele soorten van Marumia gemakkelijk onderseheiden van die van Dissoehaeta, welke gewoonlijk minder bekleed en slanker van groei zijn, terwijl de, in pluimen vereenigde bloemen, door haar getal het gemis aan grootte vergocden. Indien wij Apleetrum tot Dissochaeta brengen, dan verkrijgen wij daardoor 
voor dit geslacht eenen tegenover de Marumia stellulata staanden vorm, met witte bloemen. Het geslacht bevat drie hoofdvormen. Twee derzelve hebben de kelken met enkelvoudige of stervormig verdeelde borstels; de derde heeft eene donzige bekleeding. Kenmerkend is het bij allen, dat zelfs de kleinste haartjes stervormig zijn, en de borstels niet zclden door deze sterretjes bedekt worden.

\section{MARUMIA AFFINIS. KHs.}

M. foliis oblongis acuminatis basi cordatis subtus fusco-tomentosis, pedunculis axillaribus trifloris, calyce ferrugineotomentoso, limbi laciniis triangularibus acutis integris.

Caudrs scandens; Ramuli flexuosi, versus apicem conferti, teretes, laete fusco-tomentosi. Foura erecta, decussata, oblonga, breviter acuminata, basi cordata, supra glabra, subtus laete fusco-tomentosa, coriacea, quinquenervia, 0,07 longa, 0,03 lata; PETIour quadrangulares, fusco-tomentosi, 0,01 longi. Flores axillares, terni; pedunculi subteretes, fusco-tomentosi. Calixx in alabastro tubulosoobconicus, parte superiore conicus, latere excavatus, fusco-tomentosus, aestivatione valvatus; calyx explicatus tubulosus, tubo apice angustiore, intus glaber; Lnмвus 4-partitus, persistens, intus tomentosus, glabrescens, laciniis triangularibus acutis vel acuminatis integris. Conolda in alabastro conico aestivatione convoluta; PETALA 4, obovata, obtusa, glabra, membranacea, caduca. Stanrriva 8, dissimilia, aestivatione inflexa; fILAMENTA linearia, glabra, subcarnosa; A.NTHERAE FERTILEs teretes, sigmoïdeae, apice poro dehiscentes, connectivo introrsum bisetoso extrorsum nudo vel setoso; - sTERILES subteretes utrinque attenuatae, connectivo lamellato intus bisetoso extus setigero. Ovariur dimidia parte calyci adhaerens, parte liberà semi-ovö̈dea stellato-tomentosa, quadriloculare; ovula numerosa, anatropa, placentas subcarnosas extus sulcatas tegentia; struus teres, glaber; stigna punctiforme. Fructus calyce velatus, siccus, pericarpio crustaceo, ovoïdeus, acumine truncato terminatus. Placentae subcarnosae. Senira numerosa, tetraëdra, apice latiora; TESTA daedaleo-reticulata; HILUM micropylae approximatum; cHALAZA laterali-basilaris; NucLeds curvatus, teres, utroque angustatus.

\section{Cressit in montibus Sakoembang, Pamattong: Borine.}

Explicatio Tab. 60. Figura speciei. 1. Alabastrum. 2. Alabastrum adultius. 3. Flos expansus. 4, 5. Stamina sterilia. 6, 7. Stamina fertilia. 8. Calyx dimidiatus cum ovario. 9. Fructus immaturus calyce velatus. 10. Idem partc calycis abscissa. 11. Idem, parte pericarpii abscissâ 12. Axis fructûs, parte placentae denudatâ. 13. Fructûs sectio transversalis. 14, 15. Semina immatura. 16. Ovarï sectio. 17, 18, 19. Ovula. 20. Indumentum.

\section{MARUMIA LEPROSA. KHS.}

M. foliis oblongo-oratis basi cordatis subtus in nervis ochraceo- et inter nervos flavido-tomentosis, pedunculis axillaribus unifloris, calycis laete ochraceo-tomentosi laciniis ovatis dentatis.

\section{Crescit in declivie montis Sakoembang: Borneo.}

Deze soort heeft den vorm der bladen bijna gelijk aan dien der Marumia affinis. Zij is evenwel door de bekleeding op den eersten blik te onderscheiden, zijnde deze bij M. affinis roestkleurig en bij M. leprosa Botanica. 
roestkleurig op en geelbruin tusschen de nerven. Daarbij komen de langere bladstelen en ook de langere, gewoonlijk slechts ćéne bloem dragende bloemstelen, als onderscheidingsteekenen. - Wij hebben haar alleen tegen de helling van den Sakoembang, op ongeveer $600 \mathrm{~N}$, ellen hoogte, in de digte bosschen aangetroffen, terwijl de M. affinis aldaar hooger, op meer opene plaatsen, of lager, langs den rand van het bosch grocide. In eene, met deze standplaats overeenkomende gelegenheid vonden wij de M. affinis aan den berg Pamatton, met een zuiverder bruingekleurd dons op de ondervlakte der bladen. De jonge bladen van beidc soorten bezitten op hunne bovenvlakte een grijs dons, hetwelk spoedig verdwijnt.

\section{MARUMIA PACIIYGYNA. KHs.}

M. foliis ovali-ovatis breviter acuminatis basi cordatis quinquenerviis subtus ferrugineo-tomentosis, pedunculis axillaribus, calyce stcllulato, limbi lobis laciniatis fusco-tomentosis, antherarum fertilium connectivo bisetoso.

CAuLrs scandens, ligno poroso, cortice crasso rimoso suberoso; RAMI subteretes, glabrescentes; RAMULI erecto-patentes, alterni ultimi oppositi, subteretes, in nodos incrassati ibidemque compressi, fusco-tomentosi. Folia patentia vel diffusa, decussata, ovali-ovata, quaedam ovalia, breviter acuminata, basi cordata vel subcordata, supra glabra, subtus ferrugineo-tomentosa nervis fuscis, crasse coriacea, quinquenervia cum duobus nervis minoribus margini approximatis, 0,13 longa, 0,08 lata; PETIOLI subteretes, fuscotomentosi, 0,01 longi. Flores axillares, saepe terni, in alabastro ovoïdei; peduncult in pulvinis articulati, teretes, basi incrassati, apice latiores, saepe triflori vel subdichotomi; BRACTEAE oblongae, obtusae, parvae, deciduae. Galyx in alabastro aestivatione subvalvata; tubus tubuloso-campanulatus, extus setis stellatis ferrugineis et tomento vestitus, intus cinereo-tomentosus; Lmusus 4-partitus, laciniis triangularibus obtusiusculis laciniatis fusco-tomentosis. Corolla in alabastro semi-ovoïdeo convolutoaestivata; petala 4, obovalia, obtusa, intus glabra, extus leprosa, membranacea. Sramira 8, in alabastro inflexa, dissimilia; fILAMENTa linearia, glabra; ANTHERAE steriles teretes, subrectae, connectivo basi in lamellas duas laciniatas producto; ANTHERAE fertiles teretes, basin versus crassiores, sigmoïdeae, apice porosae, connectivo basi bisetoso. Ovariuni duabus tertiis partibus calycis tubo adhaerens, disco carnoso setigero coronatum, quadriloculare; ovula numerosa, anatropa, placentas carnosas tegentia; struus teres, in medio crassior, glaber; stigma punctatum. Fructus calyce velatus, subsiccus, quadrilocularis, dissepimentis membranaceis. Placentae laminae subcarnosae ope axi affixae, subcarnosae, oblongae, in transversali sectione cordatae. Senrrs immatura obconica; HILUx exostomio approximatum; chaLAZA basilaris, hilo opposita.

\section{Crescit ad ripas Tewe: Bonneo.}

Explicatio Tab. 58. Figura speciei. 1. Alabastrum. 2. Flos, petalis ablatis. 3. Petalum. 4. Calycis longitudinalis sectio, ut ovarium appareat. 5. Ovarium longitudinalis dissectum. 6. Calyx dimidiatus, ovario adultiore denudato. 7. Ovarii sectio longitudinalis. 9, 10, 11. Semina immatura. 12. Vestimenti particula. 


\section{MARUMIA VULCANICA. Khs.}

M. folïs oblongo-ovatis acutis basi cordatis subtus [uti et ramulis] fusco-tomentosis, pedunculis axillaribus tri-quinquefloris, calycis fusco-tomentosi et stellato-setosi laciniis semi-ovatis laciniatis, antherarum fertilium connectivo quadrisetoso.

\section{Crescit in monte Merapi: Suliatra.}

Aan de noordelijke helling, op 2000 N. ellen hoogte, slingerde de M. vulcanica, in gezelschap eener soort van Passiflora, langs de talrijke soorten van Laurineae. Hare afgekapte steng was voor de hier werkende houthakkers eene wezentlijke bron van drinkwater, en vergoedde het gemis van nabijliggende beken. Door de kenmerken is deze, in een waar tropenklimaat, aan de oevers van de Téwé groeijende soort, verwant aan M. pachygyna; doch zij overtreft M. vulcanica verre door hare gestalte. Alle deelen zijn in de plant van de Borneosche rivier meer uitgegroeid, met uitzondering der, den kelk bekleedende sterren.

\section{MARUMIA JAGKII. Kнs.}

M. ramis petiolis foliisque subtus fusco-tomentosis, foliis ovato-oblongis acuminatis basi cordatis, pedunculis axillaribus tri-quinque-floris, calycis tomentosi et stellulati limbi laciniis semi-ovatis obtusis integris.

\section{Crescit in sylvis Melintang: Sumatra.}

Door gestalte en bekleeding is M. Jackii gelijkvormig aan M. affinis, maar door de kenmerken staat zij der beide voorgaande soorten nader. Hare groeiplaats, op 300 ellen hoogte, tegen het gebergte Melintang, beoosten Padang, schijnt bijzonder gunstig voor hare ontwikkeling, bereikende de steng somwijlen 20 en meerdere ellen lengte.

\section{MARUMIA STELLULATA. KHs.}

M. foliis ovato-oblongis acuminatis basi cordatis subtus sparsim stellulatis; pedunculis axillaribus tri-quinque-floris, calycis tomentosi et stellato-setosi limbi lacinüs semi-ovatis obtusis integris.

\section{Crescit ad flumen Indrapoera: Sumatra.}

Van al de opgenoemde soorten wijkt deze door de witte bloemkroonen af. Zij heeft echter de groeiwijze en al de wezentlijke kenmerken met dezelve gemeen. In hare, weinig boven de zee verhevene standplaats, versierde zij, door talrijkheid en pracht van bloemen, de oevers der rivier van Indrapoera en de naakte boomstammen, welke haar ten steun verstrekten.

\section{A L E N I A. KHs.}

Catrcis tubus suburceolatus; limbus circumscissus, calyptratim deciduus. Petala 4, obtusiuscula, aestivatione convoluta. STAmina 8, aestivatione inflexa; anTHERAe poro dehiscentes, connectivo introrsum extrorsumque appendiculato. Ovariun membranarum ope calycis tubo adhaerens, apice nudum, 4-loculare; ovura anatropa, numerosa; styuus teres; stigas punctiforme. Fructus calyce velatus, baccatus, 4-locularis. Semisa numerosa, angulata; HILum micropylae approximatum; charaza laterali-basilaris.

Frutex scandens. Foura opposita, ovato-rotundata, cordata, glabra. Flores paniculati. 
Door de groeiwijze behoort deze plant bij Dissochaeta, maar door haar eigenaardig aanzien en hare bijzondere kenmerken is zij de grondvorm van een eigen geslacht, hetwelk, door de opening van den bloemknop, Jucunda en Diplogenea herinnert, en door de uitgroeijing der knoopen in vlakke schijven, aan Aplectrum stipulare verwant is.

Als geslacht heb ik dit, uit de binnenlanden van Borneo afkomstige gewas, den naam gegeven van eenen, te Rotterdam algemeen geachten Geneesheer, den Heer J. G. Dalen, die, als beoefenaar en beschermer der natuurlijke geschiedenis en kruidkunde, een opwekkend voorbeeld gceft aan zijne stadgenooten, en door het besteden van den, hem van de vervulling zijner maatschappelijke pligten overblijvenden tijd en van de hem door een gunstig lot geschonkene middelen, de wetenschappen tracht te bevorderen.

\section{DALENIA SPECIOSA. KHS.}

D. ramulis in nodis dilatatis, foliis ovato-rotundatis acuminatis basi obtusis, floribus paniculatis.

CaULIS scandens; RaMuLI radicantes, obscure tetragoni, nodis incrassatis earnoso-marginatis, ultimi compresse quadrangulares subsulcati, glabri. Folis opposita, ovato-rotundata, acuminata, basi rotundata vel subcordata, utrinque glabra, quinquenervia cum duobus nervis lateralibus margini approximatis, subcoriacea, 1,2 longa, 0,12 lata, basi subtus inter nervum medium et ambos laterales biglandulosa; petrout 0,025 longi, semiteretes, glabri. Flores terminales, paniculati, in alabastro elongato-octagono;

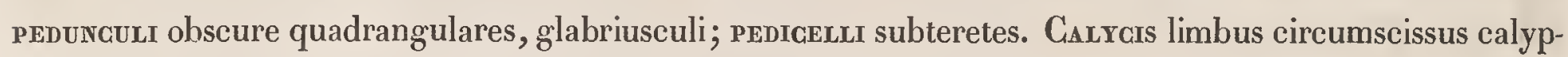
traeformis; tubus obconicus truncatus intus glaber. Conouxa in alabastro conico aestivatione convoluta; petala 4, ovata, acuta, glabra, membranacea. Stamina 8, dissimilia, omnia fertilia, inflexo-aestivata; FILAIIENTA teretia, glabra; ANTHERAE teretes, versus apicem poro dehiscentem angustiores, sigmoïdeae; connecrivun introrsum bisetosum vel bipartitum, extrorsum simplex acutum vel truncatum. Ovíriún membranarum ope calyci adhaerens, ovoïdeum, glabrum, quadriloculare; ovucs numerosa, placentas bifidas tegentia, anatropa; styuus teres, glaber; stigna punctiforme. Fructus calyce velatus, baccatus, rotundato-ovoïdeus, apice truncatus et umbilicatus, quadrilocularis. SEmiva numerosa, tetraëdra; testa coriacea, daedaleo-reticulata; TEGMEN membranaceum; HIUUn micropylae approximatum; RAPHE linearis cellulis majoribus cincta; chataza laterali-basilaris. Nucteus ovö̈deus.

\section{Crescit ad flumen Tewe: Bonneo.}

Explicatio Tab. 58. Figura speciei. 1. Alabastrum. 2. Alabastrum, calyce circumscisso. 3. Alabastrum, calycis calyptrâ ablata. 4. Flos expansus. 5. Stamen antice visum. 6. Stamen ex alabastro postice visum. 7. Idem a latere visum. 9. Idem antice. 8. Idem, filamento abscisso. 10. Stamen a latere. 12. Stamen majus. 13, 14, 15. Sectiones antherae a basi ad apicem. 16. Stamen minus. 16a. Pollen. 17. Sectio longitudinalis alabastri. 18. Calycis et ovarii longitudinalis sectio. 19. Apex ejusdem objecti. 20. Fructus calycis parte abscissâ. 21. Idem longitudinaliter dissectus. 22. Fructus calyce velatus. 23. Ejusdem sectio transversalis. 24. Particula placentae cum seminibus. 25, 26, 27. Semina. 29, 30. Nuclei. 
MEDINILLA. Ga dighaud, BLue.

Ifct geslacht Medinilla vormt, met Pogonanthera, Pachycentria en Apateon, cene natuurlijke groep, door vleezige bladen, donker- of licht-rozenkleurige bloemen en besaardige vruchten gekenmerkt. Zij zijn door het aanzien en voornamelijk door den helmknoop van elkander te onderscheiden. Deze laatste heeft bij Pachycentria, alleen aan de achterzijde, een spoorvormig uitgroeisel; bezit bij Pogonanthera, op dezelfde plaats, vele knodsdragende aanhangsels; draagt bij Apateon aan de achterste zijde gecn, doch aan de voorste zijde een kort uitgroeisel en is bij Medinilla aan de voorzijde met twee en aan de achterzijde met één uitgroeisel voorzien. Het laatstgenoemde geslacht, door den Hoogleeraar Blume juister omschreven en met de daartoe gebragte Indische planten verrijkt, bezit tot nu toe zijne meeste soorten op Java en Sumatra, enkele in de Molukken, en ééne op Borneo. Op de eerstgemelde eilanden zijn deze planten boschbewoonsters, zoowel der lagere als der hoogere bosschen, tot op ongeveer $1600 \mathrm{~N}$. ellen. Hare standplaats, op levende of vermolmde boomstammen, hetzij in de oksels der takken of tegen de stammen, bevordert de vorming van talrijke, uit de oksels der bladen voortkomende worteltjes. Deze, gewoonlijk meer vastklemmend, dan voedselopnemend, zijn zeer schaars van wortelvezeltjes voorzicn, indien zij op levende planten gehecht zijn. Door dezelve is de steng tegen den stam, die de plant draagt, aangedrukt, en bij de pluimdragende soorten alleen aan den top vrij, dikwijls omgebogen. De steng van vele soorten heeft eene grijswitte kleur en ecne rolronde of vierkante gedaante, bij enkele soorten met vleezige uitbreidingen aan de kanten of rondsom dc steng. De bladen zijn bij de meeste zeegroen, verschillend van gcdaante, doch inzonderheid opmerkelijk door de nervuur. De bloemen zijn bij de soorten der afdeeling Campsoplacuntia aanzienlijk groot, gewoonlijk licht-rozenkleurig. De helmdraden zijn, even als in Dissochaeta, door derzelver gestalte, een middel ter onderscheiding der soorten. De helmknoop vooral is zeer verschillend: bij eenigen eindigt hij aan den voet in puntige sporen; bij anderen in knodsjes, die soms eene aanzienlijke lengte hebben. Van belang is vervolgens de gedaante en zelfstandigheid van den zaaddrager, reeds door den Heer Blume ter verdeeling gebruikt, en het zaad, dat, bij een nader onderzoek, zal bijdragen om de reeds bestaande afdeelingen te bevestigen of te wijzigen. De testa is bij eenigen aan twee zijden, bij anderen slechts aan eene zijde der kern uitgegroeid. Zij omgeeft daardoor de kern met een los omhulsel, waarin de raphe, door een fijn celweefsel, naar de zijdelings of meer aan den voet van het zaad gelegene chalaza loopt.

\section{MEDINILLA POLYANTIIA. Kirs.}

M. ramulis teretibus, foliis quaternis oblongo-obovalibus acutis triplinerviis, floribus subumbellatis.

CisuLIs pseudoparasiticus, teres; RAMr teretes, nodis incrassatis, cinerei, glabri; RAMULr curvati, teretes, glabri. Folıa quaterna, saepe terna vel quinata, oblongo-obovalia, acuta, basi cuneata, triplinervia, utrinque glabra, coriacea, 0,13 longa, 0,05 lata; petror.r semiteretes, glabri, 0,025 longi. Fuores alares, umbellulati; pedunculr obscure tctragoni, glabri. CaLrx tubuloso-campanulatus, fauce latiore, limbo truncato, glaber. Corolla in alabastro semi-ovoïdeo convoluto-aestivata; petala 4, obovata, obtusa, glabra, carnosa, rosea. Stanrra 8, aestivatione inflexa, dimorpha; fulanenta filiformia, glabra; ANTHERAE fertiles sigmoïdeae, apicem versus attenuatae, poro dehiscentes, connectivo introrsum Botanica. 
bifido extrorsum simplici appendicibus subclavatis; ANTHERAE steriles subrectac, connectivi appendicibus brevioribus. Ovariun membranarum ope calycis tubo adhaerens, disco circulari coronatum, quadriloculare; ovula numerosa, placentas carnosas subbifidas tegentia, anatropa; sTruUs teres, glaber; stignis punctiforme. Fructus cum calyce connatus, carnosus, globosus in vertice truncato calycis limbo tubuloso angustiore cinctus, quadrilocularis. Placentae carnosae, bifidae, lamellae ope axi affixae. SEMINa numerosa, obconica; тESTa daedaleo-reticulata, coriacea; TEGMEN membranaceum; HILU micropylac approximatum; RAPHE linearis; CHALAzA laterali-basilaris.

\section{Crescit juxta Doekoe: Sunitra.}

Explicatio Tab.61. Figura speciei. 1. Alabastrum. 2. Flos junior. 3. Flos expansus. 4, 5, 6. Antherae fertiles a latere, a posteriore, ab anteriore. 7, 8, 9. Antherae steriles a latere, a posteriore et ab anteriore. 10. Flos, petalis et staminibus ablatis. 11. Calyx et ovarium, limbo calycis partim abscisso. 12. Ovarium transversaliter sectum. 13. Fructus. 14. Idem longitudinaliter dissectus. 15. Idem transversaliter dissectus. 16, 17. Semina. 18. Testae particula.

\section{PA Gi YGENTRIA. BLUME.}

\section{PACHYCENTRIA TUBERCULATA. KHs.}

P. foliis superioribus subsessilibus oblongis acutis basi subcordatis, paniculis terminalibus.

Fruticulus pseudoparasiticus; caulis geniculatus, nodosus, cicatricibus excavatis fuscis; RAMr obscure tetragoni, glabrescentes; RAnuLl compresse tetragoni, fusci, pube ferruginea vestiti. Folia decussata, breviter petiolata, superiora subsessilia, oblonga, vel oblongo-ovata, acuta, basi subcordata, utrinque glabra, carnosula, trinervia, 0,10 longa, 0,04 lata. Funes terminales, paniculati; pendrauli compressi, in nodis latiores, pubescentes. Alabastrunir elongato-octagonum. Calycis glabri tubus obconicus, limbus dilatato-campanulatus obsolete quadridentatus. Conolla aestivatione convoluta; petala 4, oblonga, obtusiuscula, glabra, rosea. Stamira 8, subaequalia; fildMenta subteretia, glabra; ANTHERAE subteretes, curvatae, poro dehisecntes, connectivo postice in calcar curvatum producto. Ovariurr calyci adhaerens, disco carnoso coronatum, quadriloculare; ovula pauca, 4-8 in singulo loculo, anatropa; struus teres, glaber; stigma capitatum.

\section{Crescit in monte Pamatton: BorNeo.}

Explicatio Tab. 63. Figura ramuli florentis Pachycentriae tuberculatae $1-6$ et fructiferae P. varingiaefoliae 7-10. 1. Alabastrum. 2. Flos expansus. 3. Idem, petalis ablatis. 4, 5. Stamina. 6. Ovarium longitudinaliter dissectum. 7. Fructus. 8. Idem in longitudine dissectus. 9. Semen immaturum cum embryone. 10. Semen. 
POGONANTHERA. BLUIE.

POGONANTHERA PULVERULENTA. BL,

P. foliis oblongo-ovalibus basi biauriculatis trinerviis coriaceis.

Frutex pseudoparasiticus; gadus subteres; Rami obscure tetragoni, glabrescentes; Ramuli subteretes, ultimi compressi, ferrugineo-farinosi. Folra decussata, oblongo-ovalia, obtuse acuminata, basi biauriculata, utrinque glabra, coriacea, trinervia, nervis secundariis distantibus, 0,14 longa , 0,06 lata; pexroli compressi, supra sulcati, glabriusculi, 0,015 longi. Flores axillares vel terminales, paniculati; peduraulr compressi, glabriusculi. CaLYcis tubus obscure tetragonus, limbo campanulato quadridentato. Corolta in alabastro obtuso aestivatione convoluta; petals 4, oblique subrotunda, obtusa, extus pubescentia, rosea. Sramrra 8, aequalia, fauci tubi inserta; milamentr tetragona, linearia, medio saepe incrassata, glabra; ANTHERAE basi aflixae, ovatae, obtusae, poro apicali dehiscentes, connectivo basi posteriore in appendices clavatas producto. Ovariuri calycis tubo adhaerens, disco carnoso apice tubuloso coronatum, quadriloculare; ovuLA numerosa; struds teres, glaber; stigna minutum, denticulatum. Frucrus calyci adnatus et limbo ejusdem quadridentato apice obvallatus, bacca globosa, quadrilocularis. Semiva numerosa, funiculorum filiformium ope placenti subcarnosis affixa, ovoïdea; TESTA reticulata; TEGMEN membranaceum; HILun micropylae approximatum; chalaza basilaris. Entbryo oviformis.

\section{Crescit in sylvis juxta Doeloe: Sumatra.}

Explicatio Tab. 65. Figura speciei. 1, 2. Alabastra. 3. Flos expansus. 4, 5. Petala. 6. Flos, corollâ ablatâ, in longitudine dissectus. 7, 8, 9. Stamina lateraliter, antice, postice visa. 10. Stamen: a. epidermis, b. endothecium, c. exothecium. 11. Tructus limbi parte abscissâ. 12. Idem longitudinaliter dissectus. 13. Ejusdem sectio transversalis. 14. Pollen cum endothecii particula. 15. Semen. 16. Semen longitudinaliter dissectum. 17. Embryo.

\section{OGHTHOCHARIS. BLUM.}

\section{OCHTHOCHARIS PANICULATA. Kns.}

O. ramulis quadrangularibus, foliis oblongis acuminatis quinquenerviis serrulatis, floribus paniculatis.

Pianta suffruticosa; rami tetragoni, glabri; ramuli tetragoni, sulcati, glabri, ultimi compressi tetragoni rufo-farinosi. Fousa patentia, distantia, decussata, oblonga vel oblongo-ovata, acuminata, mucronulata, basi obtusa, serrulata, membranacea, quinquenervia, nervis secundariis parallelis distantibus, utrinque glabra, basi rufo-pubescentia, 0,12 longa, 0,03 lata; pErioli semiteretes, glabriusculi, 0,03 longi. FLones terminales vel axillares, paniculati, bracteati, bracteis oblongis parvis; PEDuradu compresse tetragoni, fusco-farinosi. CALYcrs tubus campanulatus intus glaber extus sparsim farinosus, limbo quinquedentato, dentibus obtusis. Corolla in alabastro obtuso aestivatione convoluta; petala 5, ovalia, acutiuscula, membranacea. Stamina 10, in aestivatione inflexa; ritanienta subteretia, medio paulo 
crassiora, glabra; ANTHERAE basi aflixae, oblongae, compressac, apicc uniporosae, connectivo postice calcarato. Ovariua basi calycis tubo adhaerens, ovoïdcum, obtusum, quinqueloculare; ovuLı numerosa, anatropa; styuUs teres, medio crassior; stIGar capitatum; GAPSULA cum calyce concreta, sicca, Joculicide dehiscens, quinquevalvis, valvis in medio septigeris ab axi secedentibus. Couvnrsı denudata, placentas lamellae ope affixas gerens. SEnina numerosa, trigona, duobus lateribus planis, tertio rotundato; HILum micropylae approximatum; ciralaza laterali-basilaris. Nugleus ovoïdeus.

\section{Crescit juxta Poeloe-lampei, etc.: Borneo.}

Explicatio Tab. 64. Figura speciei. 1. Alabastrum. 2. Idem, calycis partc et corollâ abscissa, staminibus inflexis. 3. Flos. 4. Sectio longitudinalis ovarii et calyois. 5, 6, 7. Stamina. 8. Capsula calycc velata. 9. Capsula nuda. 10. Valvula cum scpto. 11. Columna cum seminibus, valvis ablatis. 12. Eadem seminum parte ablata. 13. Columna cum trophospermio. 14. Eadem ab apice visa. 15, 16, 17. Semina.

\section{SONER ILA. RoxbURG.}

Hct geslacht Soncrila bezit een aantal soorten in de Engelsch-Indische Bezittingen, voornamelijk op Ceilon, waar deze gewassen, in de bosschen van het gebergte, zeer talrijk schijnen te zijn; ééne soort groeit op Poeloe-Pinang en verscheidene soorten komen op Sumatra en Java voor. Zij groeijen op de laatstgenoemde eilanden gewoonlijk gezellig. Sonerila tenuifolia en S. pauciflora zijn op den berg Patoeha, over de, nabij den top gelegene vlakte verspreid, in de moerassige plaatsen, met enkele soorten van Procris gezellig groeijende; S. begoniaefolia wast op steenachtige plaatsen, tegen verwerende trachietrotsen op den Papandayang, tegen conglomeraatgesteente in het gebergte Melintang.

De waargenomene en door afbeeldingen bekende soorten doen mij vooronderstellen, dat het geslacht Sonerila eene splitsing in verschillende geslachten, die door hun voorkomen kennelijk zijn, zoude toelaten. Daarenboven zal dit geslacht, door zijn zamengegroeid vruchtbeginsel, de ovula anatropa en het zamenstel en de wijze van openspringen der vruchten, eene bijzondere afdeeling van de Melastomaceae vormen, wanneer deze familie, bij eene herziening, vcrdeeld wordt volgens het vrij of zamengegroeid zijn van het vruchtbeginsel, de ontwikkelingswijze der eitjes, de gcaardheid der vrucht en de gedaante benevens het zamenstel der zaden.

\section{SONERILA BEGONIAEFOLIA. BL.}

S. herbacea, hirsuta, foliis septuplinerviis oblique cordatis acuminatis ciliatis, altero minuto cordato, racemis axillaribus, calycibus setosis.

Planta herbacea, socialis; cavlrs subteres, glabrescens, fusco-hirsuta. Folia opposita vel abortu alterna, inaequalia, majora oblique dimidiata vel cordata, breviter acuminata, altero angulo basilari rotundato auriculato, altero angustato, integerrima, ciliata, supra setis sparsis obsita, subtus hirsuta, septuplinervia, membranacea; minora cordata, aequilatera. FLORES axillares, racemosi, bracteati, bracteis obovato- 
oblongis, peduneulo eompresso fuseo hirsuto. Calycrs hirsuti tubus eampanulatus, limbo e partibus 3 late triangularibus aeutis. Corolla in alabastro obtuso eonvoluto-aestivata; petala 3 , ovata, aeuta glabra. Stumiva 3, in aestivatione inflexa; rilamenta linearia, glabra; antherae basi affixae, biporosae, conneetivo exappendieuláto. Ovâniùi ealyeis tubo adnatum, diseo parvo eireulari, triloeulare; ovúA

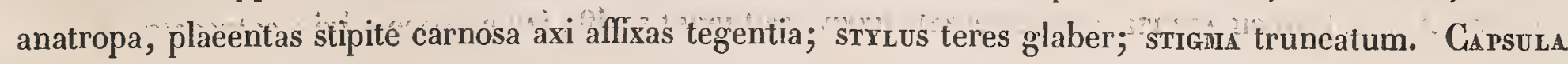
cum ealyce murieato eonnata, vertiee limbo calyeis membranaeeo suboeeulta, apiee valvis tribus bifidis dehiseens, dissepimentis membranaeeis. Columella eapitata, placentas oblongas fovealatas gerens. Semira subdidyma; parte nueleum ineludente minore testâ, eellulis hexagonis; parte rapheos duplo majore, daedaleo-retieulatâ. HiLuı myeropylae approximatum; cindızı laterali-basilaris. EMrBr yonis radicula subteres, cotyledonibus subrotundis.

\section{Crescit in sylvis Mllintang et Singalang: Sunatra.}

Explicatio Tabulae. Figura speciei. 1. Alabastrum. 2. Flos. 3. Capsula. 4. Capsula transversaliter dissecta. 5. Capsulae vertice cum limbo calycis. 6. Eadem, limbo abscisso. 7. Capsula longitudinaliter divisa. 8, 9. Columellae cum plaeentis. 10. Columella cum placentis ab apice visa. 11, 12, 13, 14. Semina.

\section{SONERILA PICTA. KHs.}

S. glabra, foliis oppositis aequalibus vel inaequalibus ellipticis pinninerviis, floribus raeemosis secundis, calycibus glabris.

Planta herbacea; cadus flexuosus, nodosus, subtetragonus, glaber; Ramuli obseure tetragoni, fuseo-leprosi. Forra deeussata, eaulina opposita aequalia, superiora inaequalia, elliptiea utroque aeuminata, supra glabra, subtus in nérvis pubeseentia, membranaeea, pinninervia, 0,05 longa, 0,02 lata; petroli semiteretes. Flores axillares vel terminales, raeemosi, seeundi, braeteati, braeteis laneeolatis. Calyais tubus trigono-eonieus, sparsim leprosus, limbo tridentato. Conolla in alabastro eonieo aestivatione eonvoluta; PETAiA"3, oblonga, aeutiuseula, intus glabra, "extus pilis glandulosis obsita. STAMIra 3,

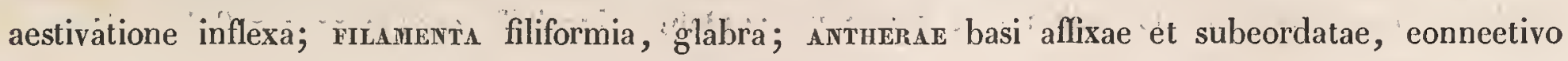
exappendieulato. Ovariů ealyeis tubo adnatum, triloeulare; ovula numerosa, anatropa; struus subteres, glaber; stigna eapitatum. CÁPSUla cum ealyee eonnata, trigono-obpyramidata, glabra, apiee valvis tribus dehiseens. Coldnella vertiee eapitata; placentae subteretes, unisuleatac, foveolatae, lamellae ope columellae affixae. SEnIN Sonerilae begoniaefoliae.

\section{Crescit in saxis ad flumen Batang-Bessie: Sumatra.}

Explicatio Tab. 52. Figura speciei. 1. Alabastrum. 2. Flos. 3, 4. Ovarium cum calyce. 5. Sectio transversalis ovarii. 6. Capsula cum limbo calycis a vertice visa. 7. Eadem, limbo abscisso. 8. Capsulae valvula. 9. Capsulae pars cum columella et placentis. 10. Columella. 11, 12, 13, 14. Semina.

In gezelsehap van Argostemma, Triehomanes en Proeris groeide de S. pieta langs de steenige oevers der beken van het gebergte Melintang. 'Zij vormde daả, mét deze kleine 'gewassen, fraaije groepjes, welke door hét grijsgroen van Argostemma, het olijfgroen vân Triehomanes, het geelgroen van Proeris Böranica. 
en het veelkleurige van de Sonerila, aangenaam geschakeerd waren. Hare, door den wind uitgestootene zaden drijven dikwerf langs de bergwanden, hetgeen bij mij het vermoeden doet ontstaan, dat de natuur die zaden met eene zoo aanzienlijke, blaasvormige raphe voorzien heeft, om hen daardoor drijvende te houden, en dat de hun eigene ruwheid strekken moet, om hen des te gemakkelijker vast te hechten.

\section{SONERILA OBLIQUA. KHS.}

S. herbacea, foliis dissimilibus majoribus oblique-ovatis acutis minoribus ovatis, floribus racemosis secundis, antheris medio affixis, capsulis trigonis glabris.

Crescit in sylvis Ambadjang: Suniatra.

\section{ANERINGLEISTUS. KHS.}

CALYcis tubus campanulatus, limbo quadripartito persistente. Corolda calycis fauci inserta; petala 4, ovata, aestivatione convolutâ. STAMrix 8, aequalia; antherae oblongae, uniporosae, connectivo brevi. Ovariur basi calycis tubo adhaerens, disco quadrisquamoso, 4 loculare, multiovulatum; struus teres; stigma subcapitatum. Ca psula calyce irregulariter rupto vestita, loculicide quadrivalvis, quadri-locularis. SEmira angulata, hilo micropylae approximato, chalazâ laterali-basilari.

Arbuscula foliis oppositis obovatis, floribus umbellulatis, sylvas montanas insulae Sumatrae inhabitans.

De Anerincleistus behoort tot de Lavoisierieae en is verwant aan Behuria, Huberia en Centradenia, welke allen in den vorm der zaden en ook door andere kenmerken, middelen ter onderscheiding opleveren. Verder komt, tot eene vergelijking, het geslacht Pyramia, dat echter eene vijfvoudige verdeeling. heeft, in aanmerking.

\section{ANERINCLEISTUS HIRSUTUS. KHs.}

Arbuscula 2-4 metrorum; rajir teretes, cinereo-fusci, glabri; ramuli teretes, hirsuti. Folia opposita, obovata, breviter acuminata, basi cuneata, supra glabra, subtus hirsuta, quintuplinervia, coriacea, 0,09 longa, 0,035 lata; petroli semiteretes, hirsuti, 0,01 longi. Flores axillares vel terminales umbellulati; Pedunguli subtetragoni hirsuti; bractene semilanceolatae, minutae. Calyx extus hirsutus intus tubo tubuloso-campanulato glaber, limbo quadripartito, partibus triangularibus acuminatis. Coroucda in alabastro conico aestivatione convoluta; petala 4 oblongo-ovalia, acuta, glabra. Stamina 8, aequalia, aestivatione inflexa; fildMenta linearia, apice latiora, glabra; antmerae basi affixae, oblongae, apice uniporosae, basi subcordatae, connectivo postice in calcar breve producto. Ovarium calyci adhaerens, subrotundum, apice excavatum, disco quadridentato crenato coronatum, quadriloculare; ovula numerosa, anatropa, placcntas oblongas breviter stipitatas tegentia; stYlus teres, medio incrassalus; 
stigma capitatum. Capsula basi cum calyce connata, apice libera supra calycem cxcreta, quadrilocularis, loculicide quadrivalvis, valvis ovatis truncatis septigeris; PLAGENTAE oblongo-ovoïdeae, foveolatae, stipitatae. Semira numerosa, tetraëdra; testa reticulata; tegnen membranaceum; hILvir micropylae approximatum; RAPHE simplex; CHALAzA subbasilaris. Nugleus ovö̈deus.

\section{Crescit in sylvis Melintang: Sumatra.}

Explicatio Tab. 68. Figura speciei. 1. Alabastrum. 2. Idem, corollâ et calycis parte abscissa. 3. Flos expansus. 4, 5. Stamina. 6. Calycis pars cum cavitatibus antheras includentibus. 7. Pistillum. 8. Sectio longitudinalis ovarii , placentầ unicâ denudata. 9. Ovarii vertex. 10. Sectio transversalis ovarii. 11. Capsula cum calyce persistente. 12. Capsula dehiscens, valvulâ unicâ reflexâ. 13. Semen, parte testae abscissâ. 14. Tegmen cum raphe. 15. Nucleus.

\section{DRIESSENIA. Krs.}

Calcras tubus brevis, tetragonus, limbo 4 dentato. Petala 4, faucem versus tubo calycis inserta, ovata. Stanirus 8, antheris basi affixis, connectivo basi tripartito. Ovariun calycis tubo adnatum, disco tubuloso apice setis 8 capitatis terminato coronatum; sTYLus basi incrassatus; sTIGMA eapitaturn. CA PSULA cum calyce connata, quadrilocularis, apice extrorsum valvis quatuor loculicide dehiscens. Senina ovoïdea; hilo micropylae approximato, chalazâ subbasilari.

Puatra herbacea, foliis longe petiolatis ellipticis, floribus minutis axillaribus.

Dit geslacht heb ik den ijverigen en gelukkigen beoefenaar der Natuurkundige wetenschappen, wijlen den Hoogleeraar Driessen, vroeger een sieraad der Groningsche Hoogeschool, toegewijd. Het wijkt; door zijn uiterlijk aanzien, geheel van de andere Indische geslachten af; doch komt, door zijne kenmerken, Sonerila, waar de kapsels echter van binnen naar buiten openspringen, terwijl zij tevens cene drieledige verdeeling heeft, zeer nabij.

\section{DRIESSENIA EXANTHA. KHS.}

1). foliis ellipticis, floribus axillaribus congregatis.

Planta herbacea, saepe 2 metrorum; Cavuis subteres, glabriusculus; rami tetragoni, sulcati, farinosi. Folia opposita, longe petiolata, elliptica, utroque acuminata, supra glabra, subtus farinosa, membranacea, quinquenervia, 0,2 longa, 0,07 lata. Flores axillares, congregati; pedurculd quadrigoni apicem versus incrassati. Calrras tubus ovoïdeus, limbo subconstricto quadridentato, glaber. Corolda in alabastro pyramidali obtuso aestivatione convoluta; Petala 4, oblonga, obtusa, glabra. Stanina 8, aestivatione inflexa; filamenta teretia; anTHerae oblongo-ovatae, apice uniporosae, connectivo introrsum bi- et extrorsum uni-calcarato inaequali. Ovariusi cum calyce connatum, vertice tubo membranaceo decemdentato, quadriloculare; ovuLA numerosa, placentas stipitatas oblongas tegentia; sTruvs teres, basi incrassatus; stigna punctiforme. CA Psula cum calyce connata, apice extrorsum valvis qua- 
tuor loculieide dehiscens. Placentae partitae; subpendulae... Senina ovöidea; testa fovcolata; irlum micropylae approximatum; crataza laterali-basilaris. Nucleus ovöideus.

\section{Crescit in monte Prarawin: Bonreo.}

Explicatio Tab. 53. Figura speciei. 1. Alabastrum. 2. Flos. 3. Petalum. 4. Flos, eorollâ ablatâ. 5, 7. Stamina antiee, 6, 8. postiee visa. 9. Flos, , eorollâ et staminibus ablatis, ealycis parte reflexâ, ut appareat membrana disci. 10. Dens membranae disei. 11. Sectio longitudinalis objeeti 9. 12. Calyx adultior. 13. Calyx fructiger. 14. Seetio longitudinalis 'ejusdem. 15, 16. Capsula matura." 17. Semen. 18. Embryo.

\section{PH YLL A G A T HIS. BLUME.}

\section{PHYLLAGATHIS ROTUNDIFOLIA. BL.}

P. foliis rotundatis, floribus bracteatis eongestis.

Planta hẻrbaeea; caulis obscure tetragonus; setosus. Folia pauca, opposita, abortu alterna, longe petiolata, petiolo trigono supra sulcato fusco-farinoso praesertim in aciebus setoso 0,1 longo, rotunda, breviter acuminata, basi obtusa vel truncata, supra glabra, subtus glabra saepe purpurea, septuplinervia, 0,3 longa, 0;2 lata. Flones terminales, involucrati bracteis subrotundis obtusis, in racemo abbreviato seeundi. CALXX obpyramidatus, octosulcatus, limbo quadripartito, partibus obtusis carinatis carinâ setigerâ. Corolla aestivatione convoluta; petala 4, ovata, acuta, carnosa. Sramina 8, aestivatione inflexa; FILAMENTA subteretia, glabra; ANTHERAE basi aflixae, oblongae, apice poro bilabiato labio altero abbreviato altero rotundato dehiscentes, basi cordatae, connectivo inappendieulato. Ovarium cum calycis tubo concretum, vertice diseo crenulato excavato, quadrilocularis; ovula numerosa, anatropa, plaeentas ovoïdeas in parte inferiore stipitis ope axi loeuli affixas tegentia; styuus teres; sTiGMa punctiforme. Capsula cum calyce connata obpyramidata, glabra, apice. loculicide dehiscens. Columelua angulața, placentas semiteretes apice acutas basi obtusas foveolatas stipitatas gerens. Semina numerosa, hilo et micropylae approximata.

\section{Crescit in sylvis juxta Paauw: Sumatra.}

Explicatio Tab. 57. Figura speciei. 1. Inflorescentiae pars. 2. Alabastrum. 3. Flos. 4. Floris pars, ut ovarium appareat. 5. Sectio ovarii longitudinalis. 6. Sectio transversalis ejusdem. 7. Ovullëm. 8. Capsula a latere, 9. ab apice visa. 10. Capsula dehiscens. 11. Columella eum placentis.

\section{PHYLLAGATHLS GYMNANTHA. Kus.}

P. caule brevi et petiolis hirsutis, foliis srotundatis cordatis supra sparsim subtus 'in!nervis thirisutis, floribus umbellatis nudis.

Crescit in monte Batoe: BoRve. 


\section{KIBESSIA. DE Gandolle.}

De eilanden Java, Borneo en Sumatra hebben ieder eene soort van Kibessia. Zij groeijen daar in de donkere schaduw der bosschen tot struiken of kleine boomen, ontwikkelen hare jonge bladen met een helder azuurblaauw, dat vervolgens in donkergroen overgaat, en bloeijen met weinige, doch door de blaauwe kleur het oog trekkende bloemen. Gezellig in hare verspreiding, nemen zij op enkele plaatsen belangrijke ruimten in, en vertoonen zij zich in gemeenschap met Memecylon en scharlakenkleurige bloemen dragende Pavetta. Kibessia azurea groeit op Java tot op ongeveer 2000 N. ellen hoogte; Kibessia cordata van 300 tot 1000 ellen op Sumatra, en Kibessia simplex is, langs de helling van den Sakoembang en Balaran, op Borneo verspreid. Zij hebben allen een gelijkvormig aanzien en maken derhalve een zeer natuurlijk geslacht uit. Van het verwante geslacht Ewyckia onderscheiden deze planten zich, op het eerste aanzien, door de grootte der bloemen en, bij een oppervlakkig onderzoek, door de openingswijzc des kelks.

\section{KIBESSIA CORDATA. Krs.}

K. foliis oblongo-ovatis cordatis.

Arbuscula 2-4 metrorum; rami teretes, cinerei, glabri; ramuli obscure tetragoni, fusco-cinerei, glabri. Fours opposita, oblongo-ovata, acuminata, basi cordata, utrinque glabra, coriacea, trinervia, 0,12 longa, 0,05 lata; PeTrou semi-teretes, 0,005 longi. Flores axillares, saepe solitares, rarius terni; bracteae oppositae, parvae, ovatae; pedunculus teres, glaber. Calfx tubo campanulato muricatus, limbo in calyptra circumscisso deciduo. Conolla in alabastro acute conico aestivatione convoluta; PETala 4, ovata, obtusa, carnosa. Stamina 8, aestivatione inflexa; ficanienta linearia, glabra; antherae basi affixae, locellis discretis, rimis longitudinalibus dehiscentes, connectivo postice breviter appendiculato. Ovariugr cum calycis tubo connatum, apice excavatum, quadriloculare; ovdrs numerosa, placentas lateraliter connatas hemisphaericas tegentia; strutus subtetragonus, glaber; sTigma quadrifidum. SEnira numerosa, ovata, testà daedaleo-reticulatâ, hilo micropylae approximato, chalazâ laterali-basilari.

\section{Crescit in sylvis Melintang: Sunatra.}

Explicatio Tab. 66. Figura speciei. 1, 2. Alabastrum. 3. Alabastrum cum calycis calyptra. 4. Flos. 5, 6. Stamina. 7. Anthera ab anteriore. 8. Flos longitudinaliter dissectus. 9. Ovarium transverse dissectum. 10. Ovarium longitudinaliter dissectum. 11. Semen immaturum. 12, Idem longitudinaliter dissectum. 13. Idem, parte testae ablatâ.

\section{KIBESSIA SIMPLEX. Kнs.}

K. foliis ovalibus basi acutis acumine obtuso, floribus axillaribus vel alaribus solitariis, calycis setis simplicibus, calyptrâ subnuda.

Crescit in sylvis Sakoembang: Borneo. 


\section{EW Y CK I A. Butme.}

Dit geslacht, door den Hoogleeraar Blume aan den grootmoedigen bevorderaar der natuurkundige wetenschappen, den Heer van Ewyck, gewijd, bevatte tot heden slechts ééne soort, welke de ijverige Zippelius op Amboina verzamelde. Door onze onderzoekingen is dit geslacht met drie andere soorten verrijkt: eene derzelve groeide in de moerassige streken nabij Indrapoera, langs de rivier Salaut: E. tuberculata; de andere, E. galeata, wies op drooge, een weinig verhevene plaatsen, aan de Karraurivier en in de vlakte nabij Martapoera; de derde, E. cordata, vond ik op het heuvelig gebergte Rantau op Borneo; terwijl een, naauwelijks van E. cyanea te onderscheiden vorm, op den berg Pamatton en de omliggende vlakte werd verzameld. Deze soorten vormen door haar voorkomen, drie verschillende groepen. Tot de eerste behooren E. cyanea en tuberculata, welke beiden het geslachtskenmerk volkomen hebben; de tweede vorm, E. galeata, bezit hetzelve niet volledig en wijkt, door het zamenstel van den kelk en door de verdere onregelmatige uitgroeijing van denzelven, af; en de derde vorm, E. cordata, verschilt door het aanzien, den puntigen stempel en het viertal vruchtbare helmdraden. Dit verschil zoude, wanneer men getrouw bleef aan de, bij familiën gebruikelijke wijze van geslachtsvorming, het invocren van drie geslachten vorderen. Ik heb dit verschil echter alleen aangetoond, om de toekomstige hervormers dezer familie op deze Indische planten opmerkzaam te maken, en tevens om aan te toonen, dat de Chariantheae even gelijke wijzigingen in de organen bezitten, als de Melastomeae. Daarenboven blijft het ter beslissing over, of de Indische geslachten Kibessia, Ewyckia en Astronia to: de Charantheae behooren, dan wel of zij eene eigene afdeeling moeten vormen, die, door de wijze van zaaddragen, van de Melastomeae en Memecyleae kan onderscheiden worden.

\section{EWYCKIA GALEATA. Krs.}

E. calyce quadripartito.

Arbor 8-10 metrorum; truncus subteres, cortice cinereo rimoso, ligno albida; rami teretes, cinerei, rimosi, glabri; Randur teretes, nodis incrassatis, cicatrisati, cavitatibus semicircularibus, cinereo-fusci, glabri. Four distantia, opposita, breviter petiolata, ovalia, acuminata, basi acuta, utrinque glabra, coriacea, trinervia, 0,10 longa, 0,05 lata. Fuores axillares vel alares, breviter pedunculati, aggregati; bracteae duae, cucullatae. Caryx aestivatione valvatâ; tubus campanulatus; uımbus quadripartitus; partibus aequalibus, triangularibus, demum inaequalibus excretione partium duarum in ligulas obtusas. Corolla aestivatione convoluta; petala 4, obovata, oblusa, carnosa. Stamiva 8, aestivatione inflexa; FILAMENTA geniculata glabra; ANTHERAE basi affixae, locellis duabus rimis dehiscentibus, connectivo postice in calcar obtusum producto. Ovariun cum calyce connatum, quadriloculare; ovira numerosa, placentas lateraliter affixas tegentia; struus tetragonus; stigma capitatum. Semira anatropa, obovata.

Crescit juxta Martapoera: Bonweo.

Explicatio Tab. 67. Figura speciei. 1. Alabastrum. 2. Alabastrum longitudinaliter dissectum. 3, 4. Alabastra. 6. Flos expansus. 5. Flos, corollâ ablatâ. 7. Stamen a posteriore, 8. ab anteriore. 9. Calyx cum ovario longitudinaliter dissectus. 10. Idem transverse dissectus. 11. Semina immatura. 
Ewyckia galeatá verzamelden wij in de lage streken om Martapoera en Poeloe-lampei, alsmede gedurende onzen togt op de Doeson-rivier, langs de oevers. Beide groeiplaatsen hebben aan de plant een eigenaardig voorkomen gegeven. Op de eerste is zij met lederachtige, dikke, en op de andere van vleeziger, dunne bladen voorzien.

\section{EWYCKIA TUBERGULATA. KHs.}

E. calyce quadridentato tuberculato, foliis obovalibus.

Crescit in paludosis juxta Indrapoera: Sumatra.

III. EWYGKIA CORDATA. KHs.

E. calyce quadridentato tuberculato, foliis subsessilibus ovatis basi cordatis quintuplinerviis.

Crescit in monticula Rantau: BoRneo. 


\title{
CLEISOCRATERA, BOSCIIIA EN MIRANTIIISS,
}

\author{
DOOR
}

P. W. K O R T H A L S.

GLEISOCR A TERA. KHS.

CALYcrs tubus obconicus, basi cum ovario connatus, limbo quadridentato. Corolla supera, tubo brevissimo, limbo quadripartito, partibus tubo longioribus patentibus, aestivatione valvata. SталIIrA 4, corollae tubo affixa, exserta; a ATHERae supra basin affixae. OVariua disco epigyno carnoso coronatum, biloculare; ovuld in loculis solitaria, basi affixa in axi; styuus teres; stigria bipartitum. B. BCCA sicca, dipyrena, pyrenis osseis intus planis extus gibbis sulcatis. Senrrva semi-ovata, intus plana, extus gibba; TESTA membranacea. EmbRYo in medio albuminis subcornei, longitudinem nuclei adaequans, rectus, cotyledonibus ovatis; radiculâ terete, basi clavatâ, cotyledones longitudine duplo superante.

Arbusculum gracile Borneanum, foliis oppositis, stipulis subulatis, inflorescentiâ subcymosâ longe pedunculatâ.

Deze gewassen zijn door hun voorkomen aan die van het geslacht Saprosma, en door hunne kenmerken aan Psychotria en Amaracarpus verwant. Met de beide eerste geslachten heeft Cleisocratera slechts eene verwijderde overeenkomst; van het laatste kan het onderscheiden worden door de verdeeling van den kelkzoom, de vasthechting der helmknopjes, de verhouding van de kiem tot de kern, zijnde de kiem van Amaracarpus zeer klein, en op het eerste gezigt, door het slanke voorkomen. De eenige soort verzamelden wij op Borneo, langs de boorden der zij-rivieren, van eenen moerassigen, in den regentijd overstroomden bodem. 


\section{CLEISOCRATERA ELEGANS. KHs.}

Arbuscula coronầ patente; RAMI abortu alterni, ultimi oppositi, teretes, cinereo-fusci; RAJuUli glabri, fusci. Foura sessilia, opposita, inaequalia, ovata, acuminata, basi subcordata, subserrulata, utrinque glabra; STIPULAe intrapetiolares, subulatae, scariosae, munitae, terminalis subcymosa. Irflorescentia subcymosa; pedunculo communi longo, filiformi, versus apicem applanato, glabro; pedunculi partiales breve, medianis brevissimis; BRAGTEAE oblongae, acuminatae, minutae. CALYGIS tubus obconicus, basi cum ovario connatus, limbo quadridentato, dentibus obtusis, sinubus obtusis, glaber. Conolca aestivatione valvata; тUвus brevis, intus hirsutus, extus glaber; Lmrous quadripartitus, partibus ovalibus obtusis patentibus apice apiculatis. Stamira 4, fauci corollae inter partes affixa; filamenta brevia, linearia, glabra; aITHeRaE dorso supra basin affixae, ovales, utrinque obtusae, emarginatae. Ovariuni ovoïdeum, disco carnoso coronatum, glabrum, biloculare; ovula in loculis solitaria, basi in fundo ovarii axi affixa, adscendentia; styuds teres, glaber; sтrama bifidum, laciniis obtusis intus planis extus gibbis. BAcGa sicca, calyce excreto urceolato cincta, ovoidea, acutiuscula, dipyrena, pyrenis intus planis extus gibbis longitudinaliter sulcatis monospermis. Sennira pyrenis replententia, semiovata, intus plana, extus rotundata; TesTa membranacea. Alburren subcorneum. Emrriro in medio albuminis, longitudinem nuclei aequans, radiculâ cylindricâ basi incrassatà, cotyledonibus brevibus ovalibus subcarnosis.

\section{Crescit juxta flumen Doeson, praesertim ad lacum Babay: Bonneo.}

Explicatio Tab. 62. Figura speciei. 1. Alabastrum. 2. Flos expansus. 3. Corolla scissa et expansa. 4. Flos, corollâ ablatâ. 5. Idem apcrtus. 6. Florum capitulum. 7. Fructus. 8. Idcm, dimidiâ parte calycis abscissâ. 9. Fructus, pyrenis sejunctis. 10, 11. Pyrenae nudae. 12. Pyrenae longitudinaliter dissectae cum seminibus.

\section{B O S C I I. Kнs.}

CALYX bracteâ integrâ caducâ involutus, pentasepalus, aestivatione valvatâ. Corouta pentapetala, hypogyna, aestivatione contortâ. Sтамгін numerosa, hypogyna, pluriserialia, interiora sterilia vel antherae loculum unicum, exteriora loculos plures gerentia, loculis apice poro dehiscentibus. Ovariur sessile, 4-5 loculare; ovvu 4, biserialia, in medio loculi axi affixa, superimposita, anatropa; struus teres; stigma capitatum. CA PsUla lignosa, muricato-tessellata, quinquelocularis, loculicide quinquevalvis, valvis septam crassissimam glabram gerentibus.

ARBOR excelsa, partibus junioribus lepidotis, foliis ovalibus subtus albidis, floribus solitariis axillaribus vel alaribus albis.

Het geslacht Boschia behoort tot de familie der Herculiaceae, waar het nabij Durio en Neesia kan worden gerangschikt. Bij hetzelve zijn inzonderheid de helmknopjes, door hunne vasthechting, gedaante en wijze van opening, opmerkenswaardig. Ieder helmknopje is tolvormig, in het dunste gedeelte vastgehecht, en springt aan den top, waarschijnlijk door het afvallen van een klepje, met een rond gaatje open. 
Dc gcwassen van dit geslacht behooren, zoowel door hunne grootte, als door hunne bladkroon en rijken bloementooi, tot de voortreffelijkste boomen der bosschen. Zij werden in de Indisehe wouden door mij toegewijd aan den werkzamen cn wijssgeerigen Staatsman, welke, het welzijn der aan zijne zorg toevertrouwde Indische bevolking, in verband met de welvaart van Nederland, willende bevorderen, tallooze bunders grond, het verblijf van wilde dieren, met nuttige gewassen heeft doen beplanten.

\section{BOSCHIA EXCELSA. KHS.}

Arbor 30 metrorum, truneo cylindrieo, eortiee cinereo-fuseo, ligno rubescente, coronâ hemisphaericâ; RAMI patentes, fusei, ligno albescente; RAMuLi alterni, subteretes, lepidoti, novelli angulati. Gemna axillares, semi-oblongae. Folia alterna, ovalia, obtuse acuminata, basi obtusa, supra nitida, subtus albida, coriacea, nervis pinnatis lepidotis; PETIOLI subteretes, lepidoti. Fuores axillares vel alares, solitarii; peduncul tetragoni, lepidoti. Bractea uniea, florem juniorem includens, demum bifida, laciniis subaequalibus, extus lepidota, intus tomentosa. CALxx pentasepalus, aestivatione valvatus, sepalis ovatis acutiusculis extus dense lepidotis intus tomentosis. Corolla hypogyna, aestivatione convolutâ, pentapetala; petalis spathulatis, obtusiusculis, intus glabris, extus sparsim lepidotis. Stamiva numerosa, hypogyna, pluriserialia; FILAMENTa filiformia, glabra; ANTHERAE terminales; locellis 4 vel pluribus, in seriebus exterioribus $1-2$, vel 1 in serie interiore, discretis, turbinatis, apiee poro dehiscentibus. Ovariun superum, ovoïdeum, setis apice stellatis vestitum, quadri- vel quinque-loeulare; ovola 4 in singulo loculo, in medio loculi axi affixa, 2 deseendentia, 2 adscendentia, anatropa; struus teres, glaber; stigma capitatum, vertice exeavatum. Capsula obovö̈dea, murieato-tessellata, lignosa, 4-5 locularis, loculicide dehiscens, valvis fere ad basin usque seeedentibus septas erassas aneipites glabras gerentibus. Semriva mihi desunt.

Crescit in sylvis Melintang: Sumatra, et Balaran: Borneo.

Explicatio Tab. 69. Figura speciei. 1. Alabastrum bracteâ inclusum. 2. Alabastrum, bracteâ bifidâ. 3. Flos, calyce ablato. 4. Flos expansus cum bractea bifida. 5. Flos, calyce et petalorum parte ablatis. 6. Petalum. 7. Ovarium, aliis partibus floris abscissis. 8. Idem secundum longitudinem sectum. 9, 10, 11, 12. Antherae. 13. Sectio longitudinalis antherae. 14. Sectio transversalis ovarï. 15. Capsula.

M A R A NTHES. BL.

De boomen, uit welke het geslacht Maranthes gevormd is, groeijen in de hoogere streken van Java, ongeveer 800 tot $900 \mathrm{~N}$. ellen boven de zee, en in de lagere oorden van Borneo. Zij zijn zeer rijk aan bloemen, doch slechts weinige vruchtbeginsels komen tot rijpe vruchten. De kleine, aan den voet der bladen gezeten kliertjes, zijn opmerkelijk. - Het geslacht Maranthes behoort, met nog twee andere geslachten van Sumatra (Lepidocarpa en Diemenia), tot de familie der Chrysobalaneae, welke buitendien nog een, aan Chrysobalanus verwant gewas op Borneo bezit. 
MARANTHES MULTIFLORA. KHs.

ARBor speciosa, coronâ patente subrotundâ; RAMI teretes, nigrescentes, fusco-punctati, glabri; Ramuli subteretes, pubescentes. Folia alterna, ovali-oblonga, acuminata, basi attenuata biglandulosa, glandulis sessilibus cupulatis, margine saepe undulata, supra glabra, subtus glabriuscula, in nervis venisque pube minuta adpressa vestita, coriacea, $4,5 \mathrm{~cm}$. lata, $11 \mathrm{~cm}$. longa, venis vix productis; PETIOLI $7 \mathrm{~mm}$. longi, glabri, subtus teretes, supra plani. Stipulae nullae. Inflorescentia terminalis axillarisve, paniculata, tomentosa; pedunguli bi- vel tri-fidi; pedicelli compressi; BRaGteas ovatae, acutiusculae, dorso carinatae, extus tomentosae, admodum deciduae, $2 \mathrm{~mm}$. longae. C CALYX extus dense tomentosus, tubo obconico, limbo quinquepartito, partibus subrotundis obtusis margine ciliatis $4 \mathrm{~mm}$. longis et latis, acstivatione quincunciali. Corolla pentapetala; petala perigyna, obovata, obtusa, subintegerrima, ciliata, intus glabra, extus pubescentia, subcarnosa, subaequalia, $6 \mathrm{~mm}$. longa , $4 \mathrm{~mm}$. lata, rosea, decidua. Stamin a perigyna 20 ad 30 , saepe in parte ab axi remotâ disposita, abortientia, atque tunc in annulum obtuse crenatum transientia, aestivatione erecta; FILAMIENTA filiformia, glabra; ANTHERAE ovatae, paulo supra basin dorso affixae, vacillantes; PolLEr sphaericum. Ovariun parte laterali cum tubo calycis connatum, subrotundum, saepe didymum, dense pilosum, biloculare; ovuLA in singulo loculo geminata vel solitaria, basi loculorum affixa; sTYLus lateralis, aestivatione circinatim inflexus, teres, glaber; STIGMA capitatum. Fructus nondum maturus siccus, obovoïdeus, pubescens, epicarpio subcarnoso, sarcocarpio fibroso, endocarpio subcorneo dense piloso, bilocularis. Semrns in loculis solitaria, erecta, oblonga, obtusa, compressa, glabra. Spermodermis membranacea, testâ fuscâ, tcgmine albo arcte cum albumine albo parco coöalito. Enbryo erectus, subcarnosus; radicula minuta, subcompressa; cotrledones ovati, acutiusculi, basi truncati, albi.

\section{Crescit juxta Martapoera: BonNeo.}

Explicatio Tab. 70. Figura speciei. 1, 3. Alabastra. 2. Flos, calyce ablato. 4, 6. Flores expansi. 5. Calyx lateraliter scissus et expansus cum ovario filamentorumque partibus. 7. Ovarium longitudinaliter dissectum cum ovulis et styli parte. 8 et 9. Fructus. 10. Fructus secus longitudinem dissectum cum semine. 10. Ejusdem transversalis sectio. 11. Semen cum funiculo. 12. Idcm longitudinaliter dissectum. 



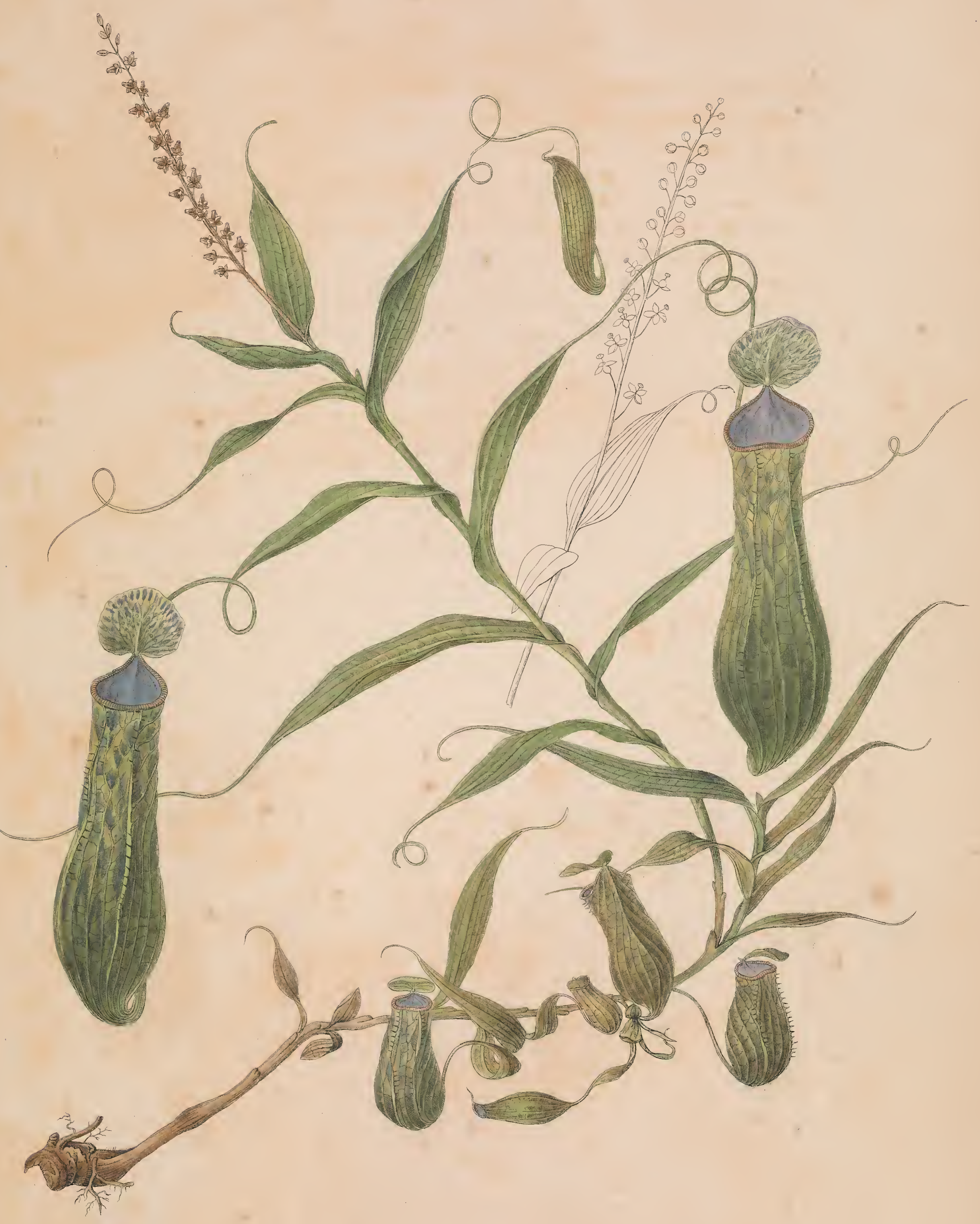





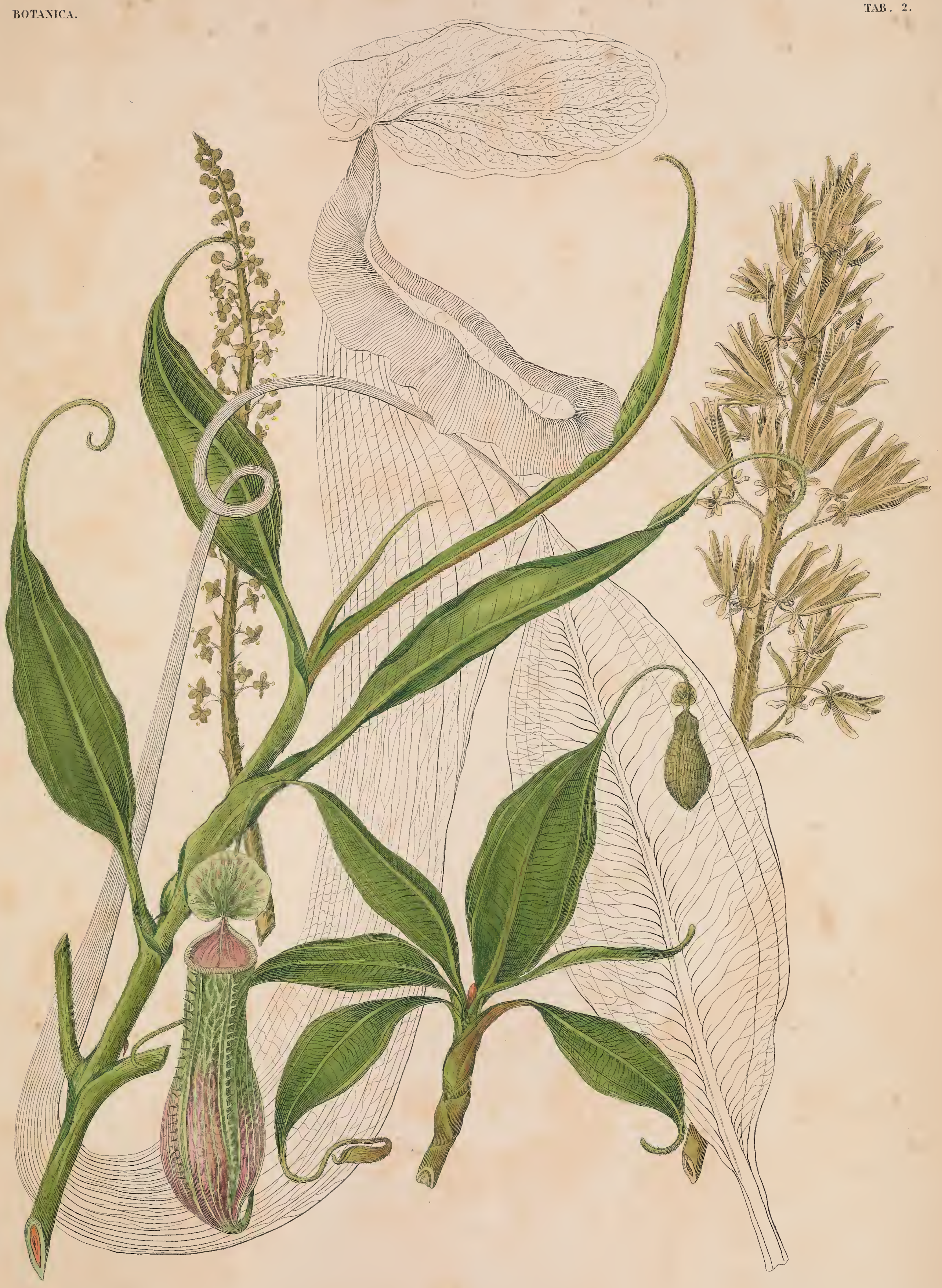

NEPENTHES BOSCHLANA. 
(6) 


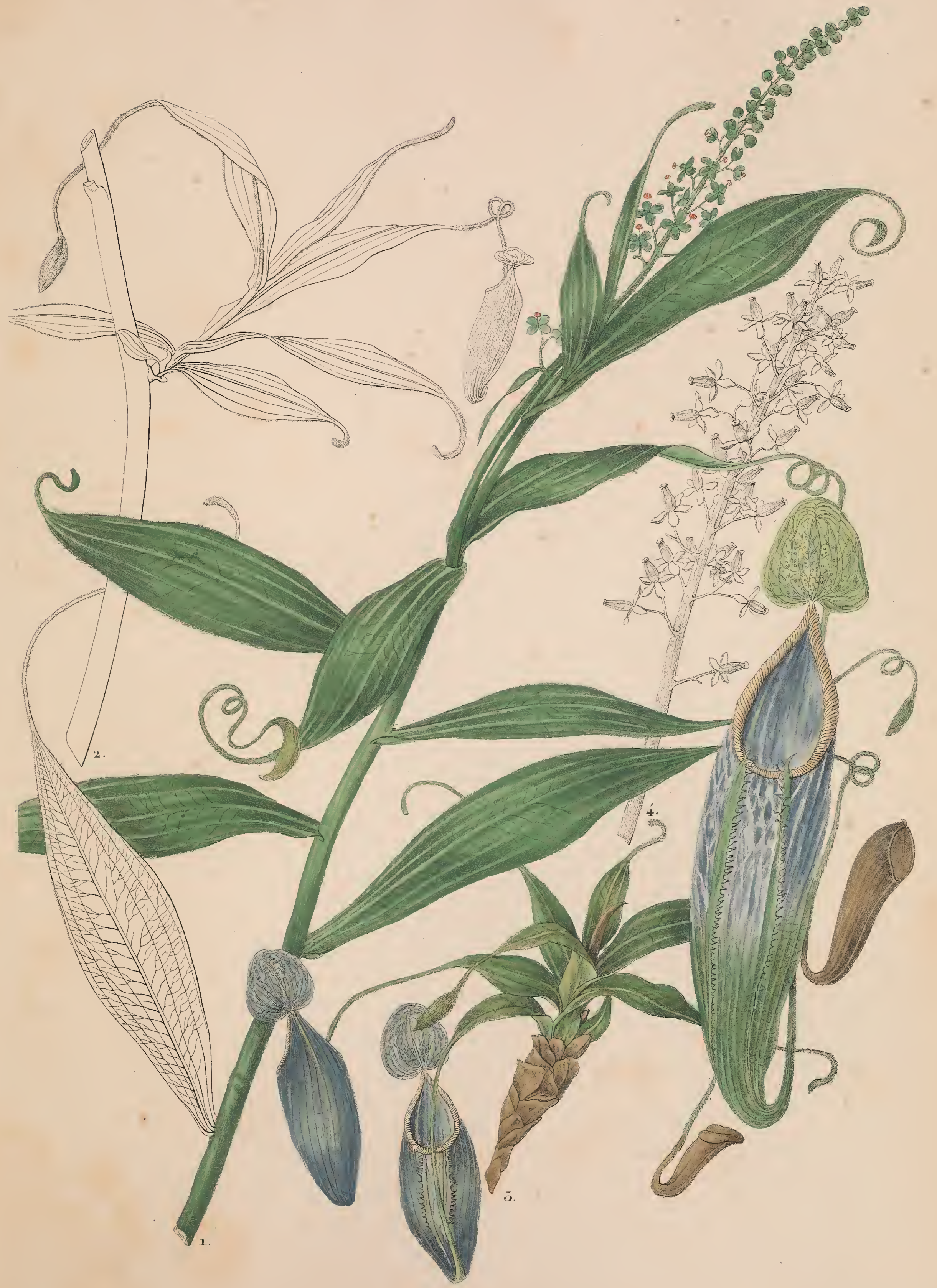


$\ominus$ 
BOTATRA.

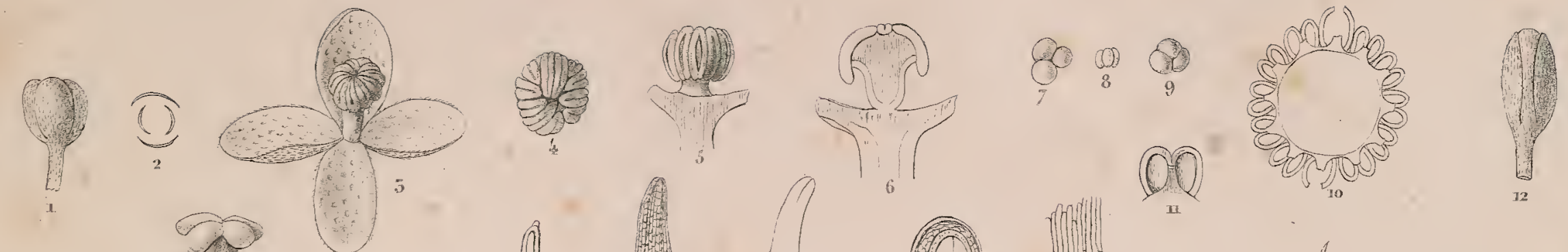

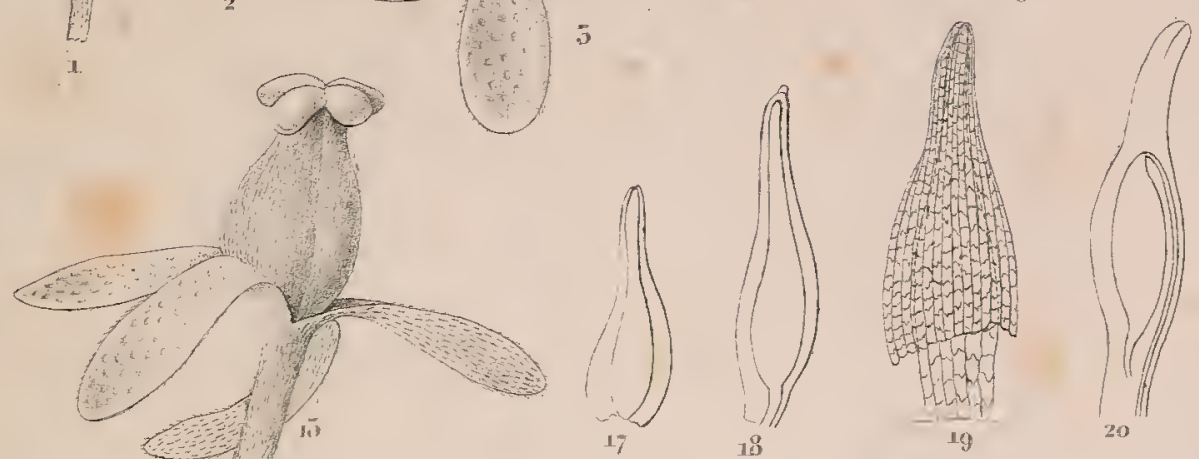

JWV
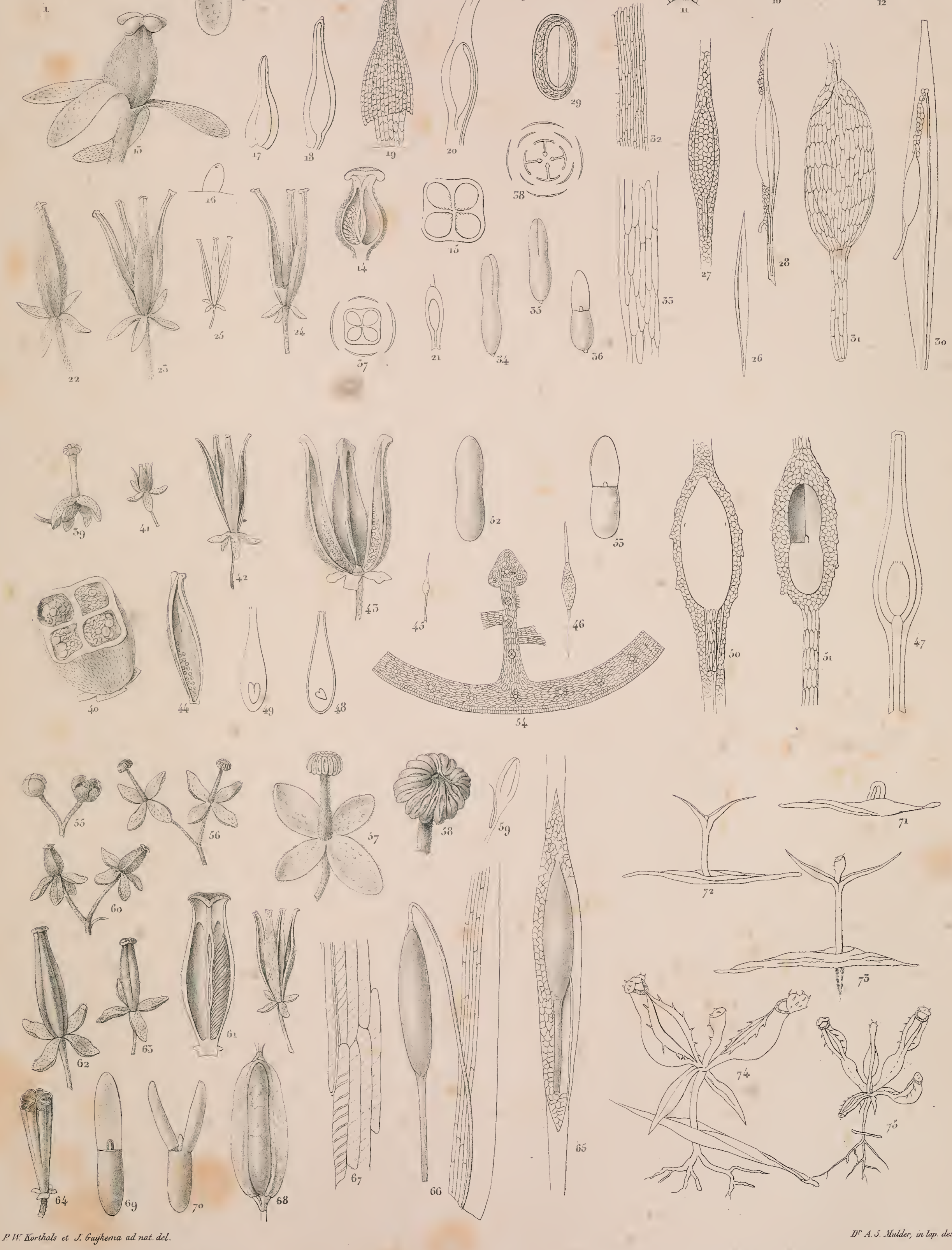

1-58. NEPENTHES GRACTIIS. 5 $g^{-54}$ N. BOSCHIANA. 55-70 N. GIMNAMPHORA. 71-75. N. PHYLLAMPHORA
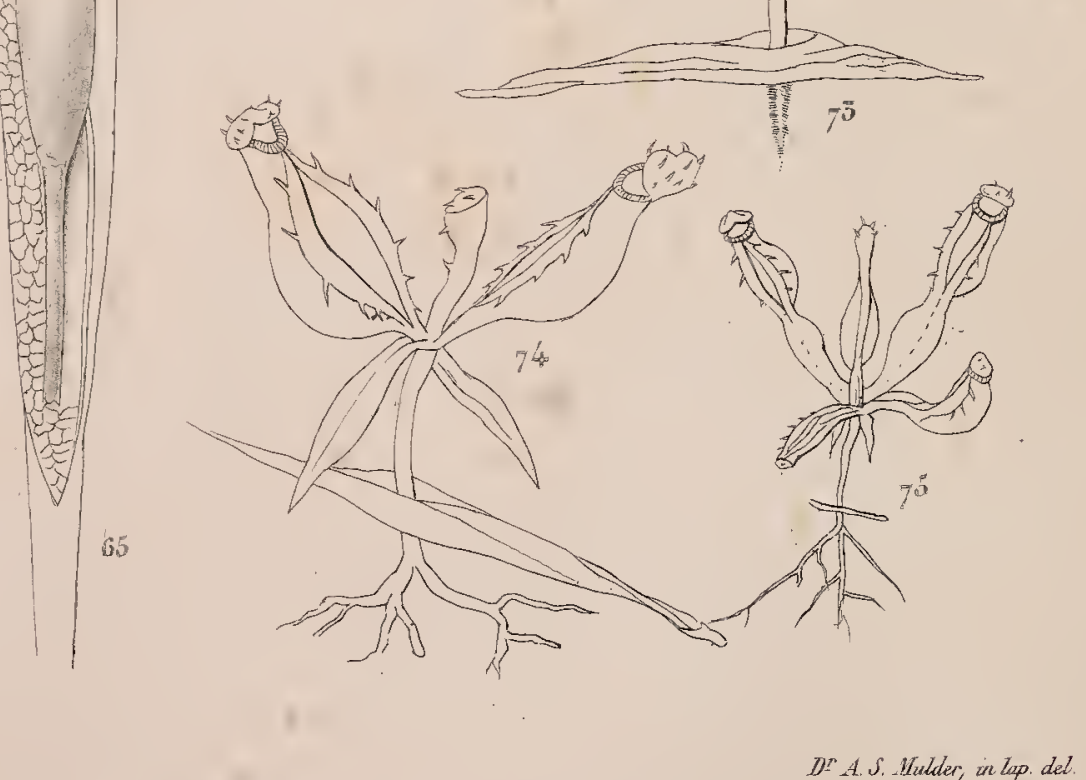

BOTAXICA.

TAB .

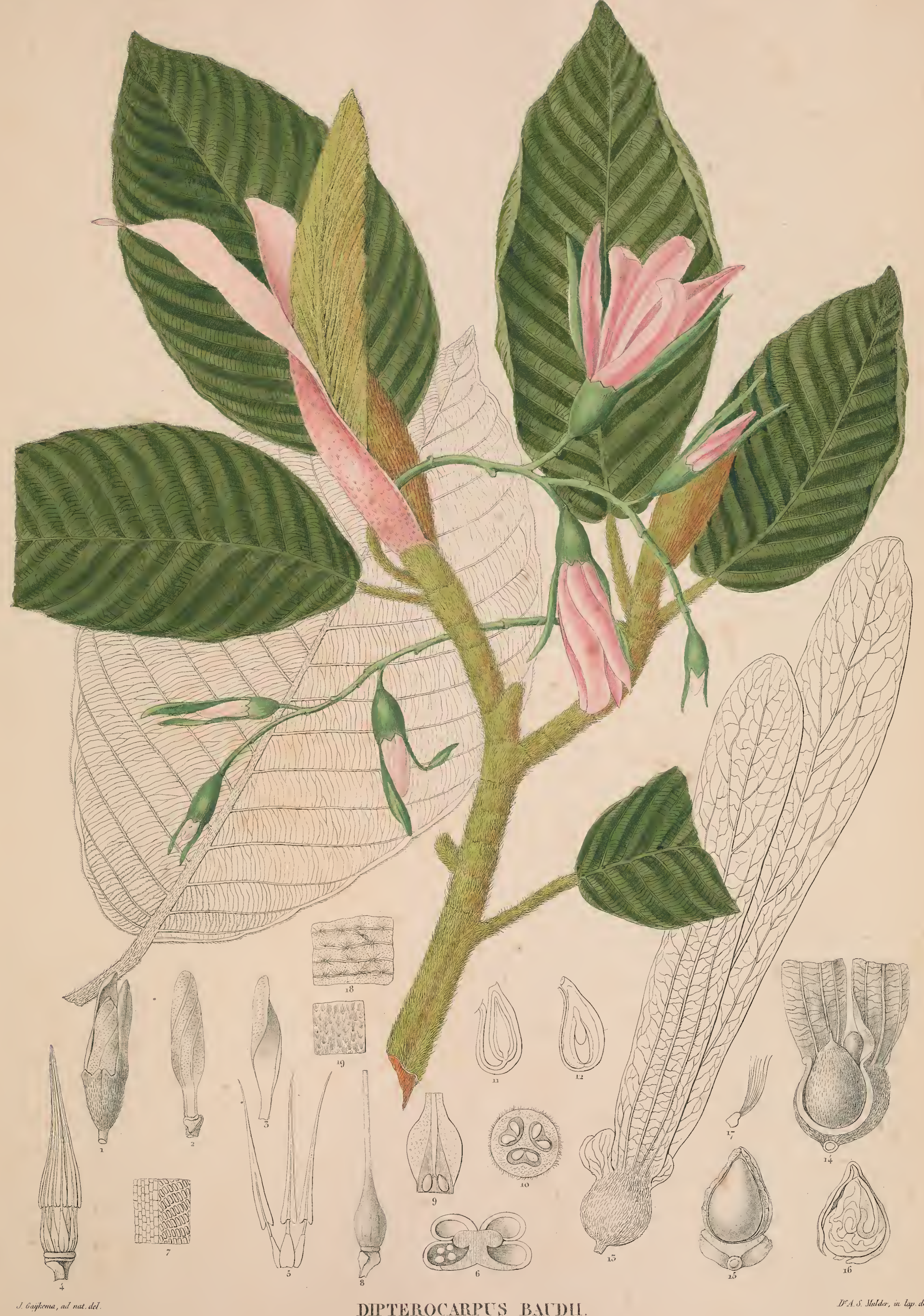



BOTANICA

TAB , (i.

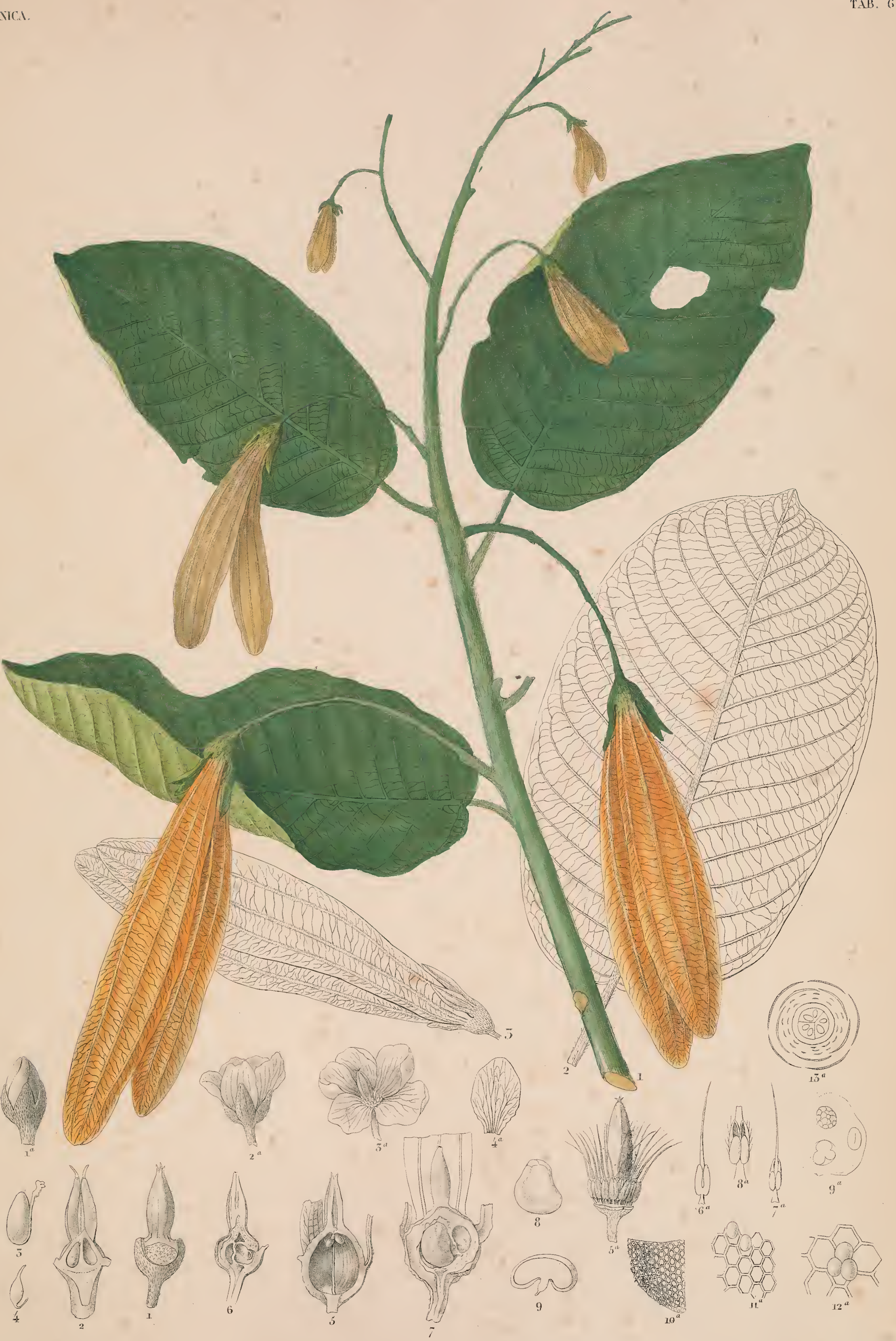

L-5. AYISOPTERA COSTATA 1-9. A. MARGIXITI $!^{n}-15^{a}$

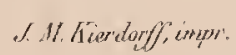



BOTAXICA.

TAB. 7.

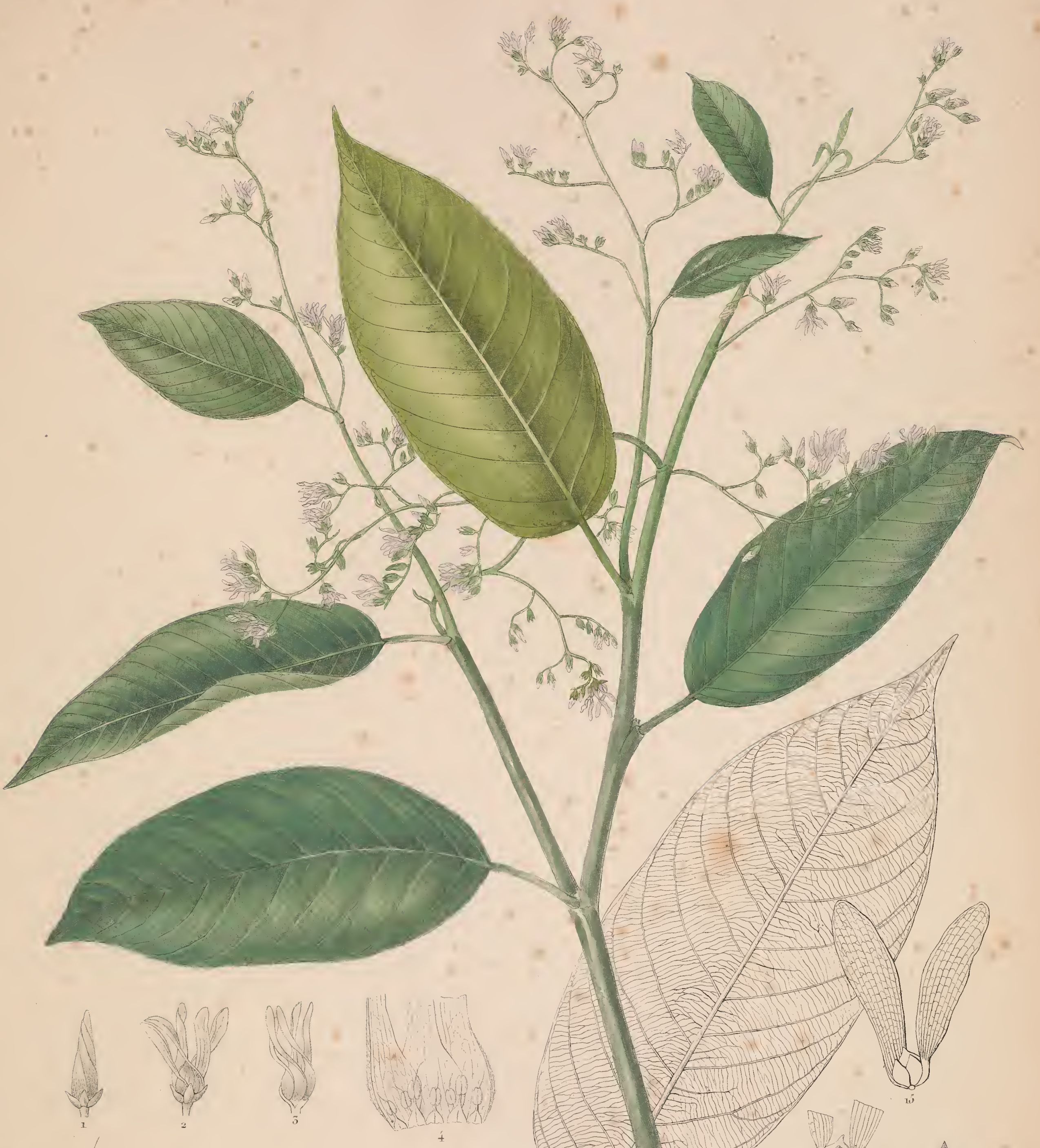

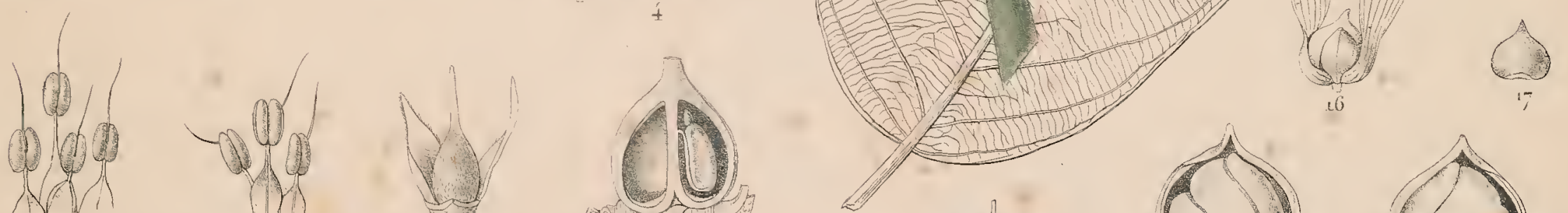

蚂

(3)
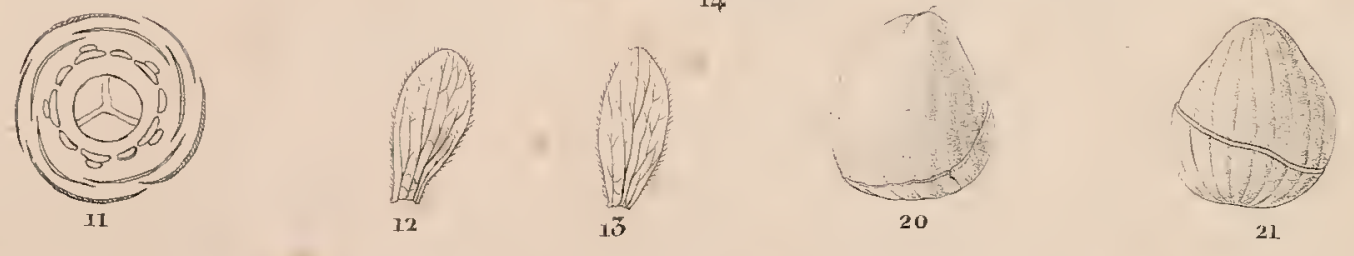

HOPEA BALANGERAN 1-14. H. ODORATA $15-21$. 



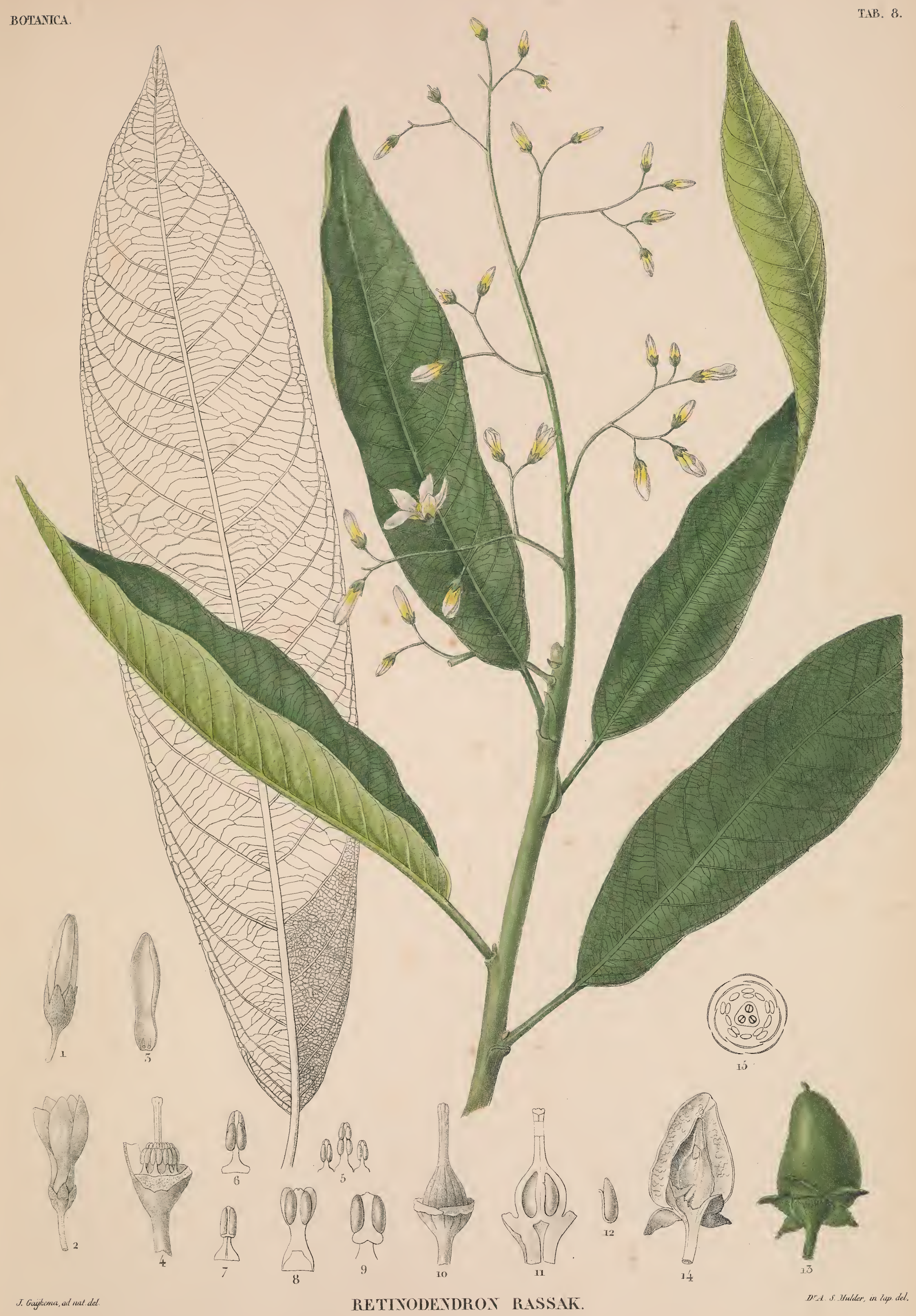





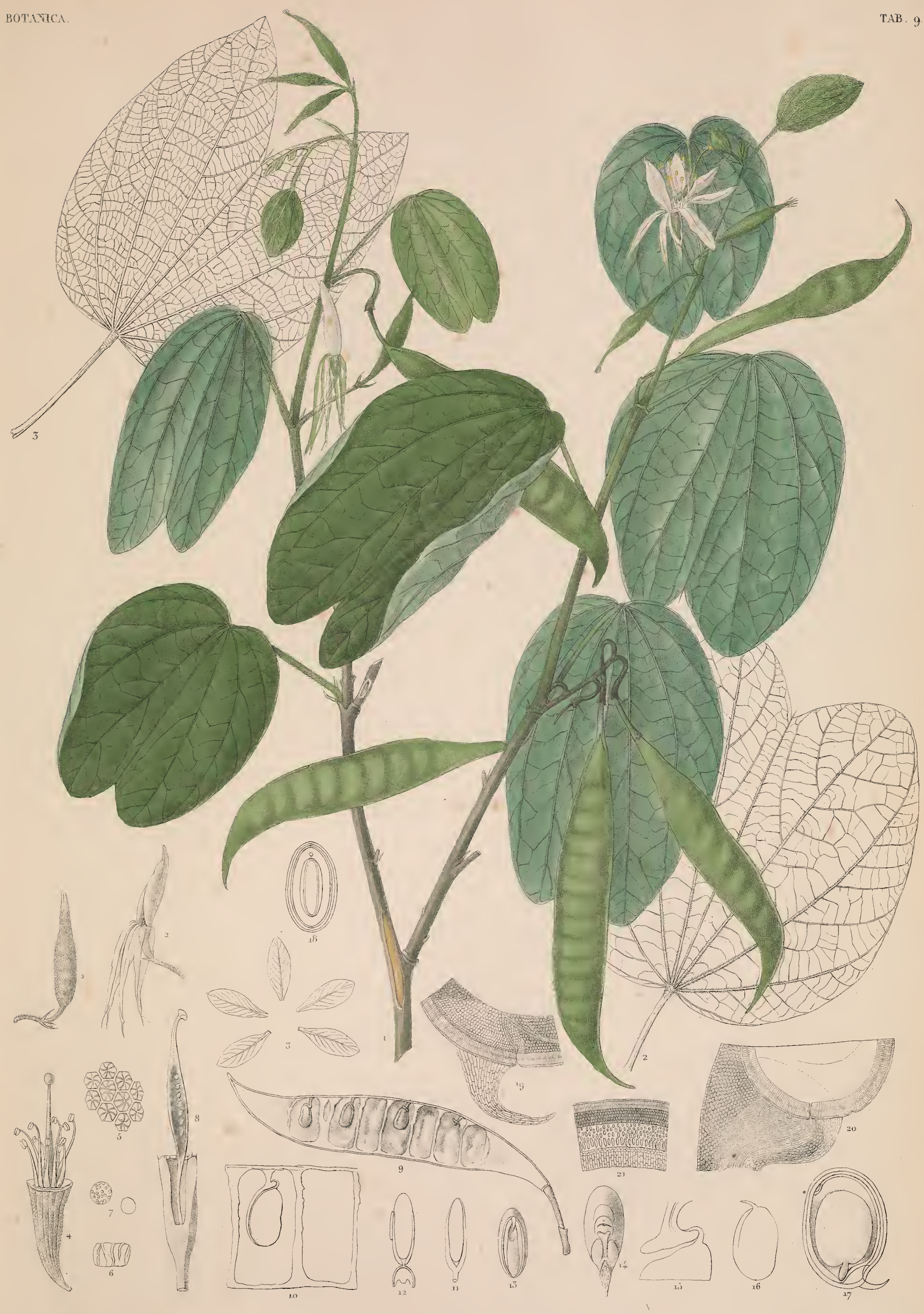

\footnotetext{
1-2. BACHINA IIRRSOTA 1-21. 3. B. ACTMUNATA.
} 
(2) 


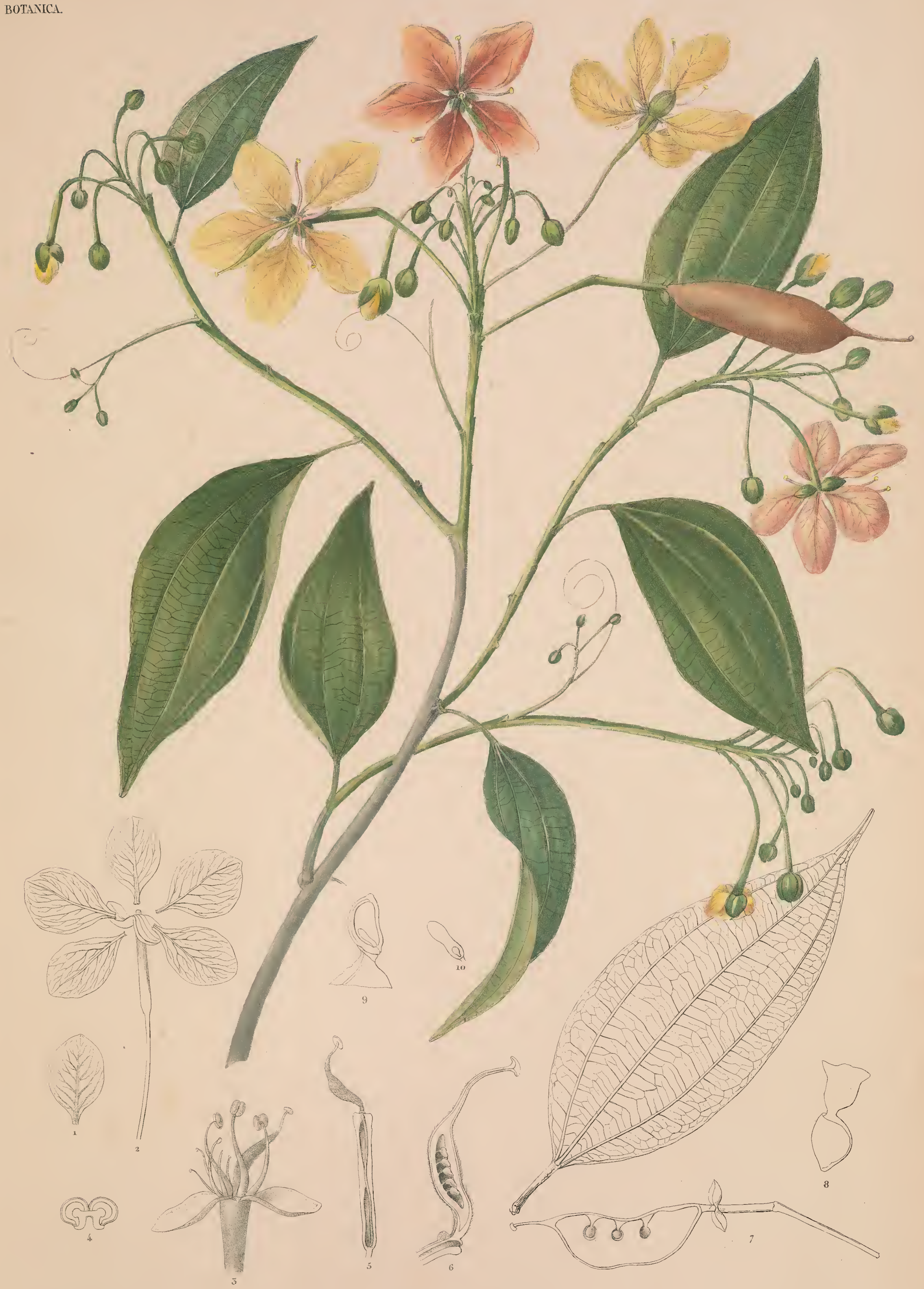

B.ALHINA KOCKLANA. 



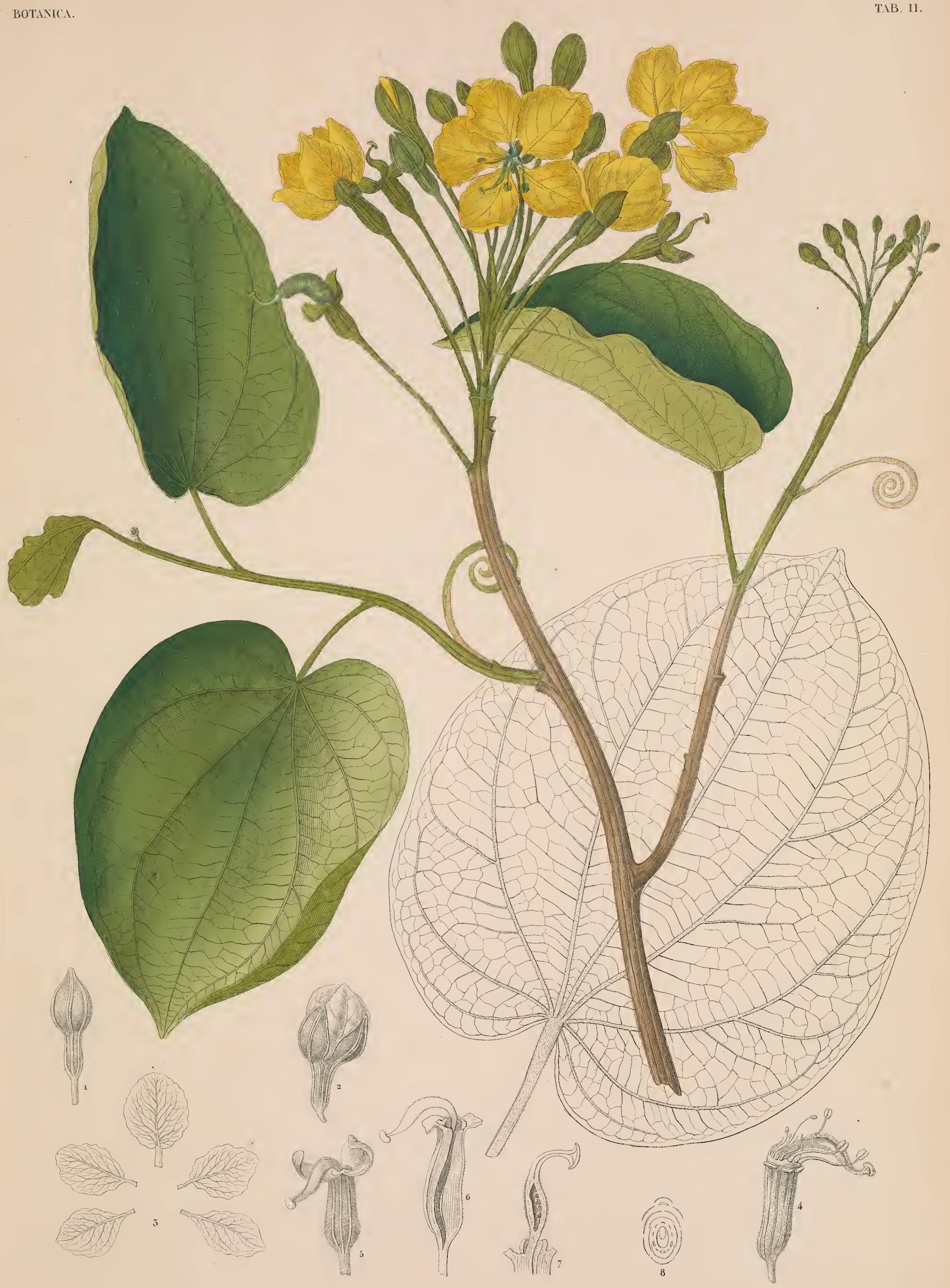

BAUHINLA PYRRANEURA. 
( 

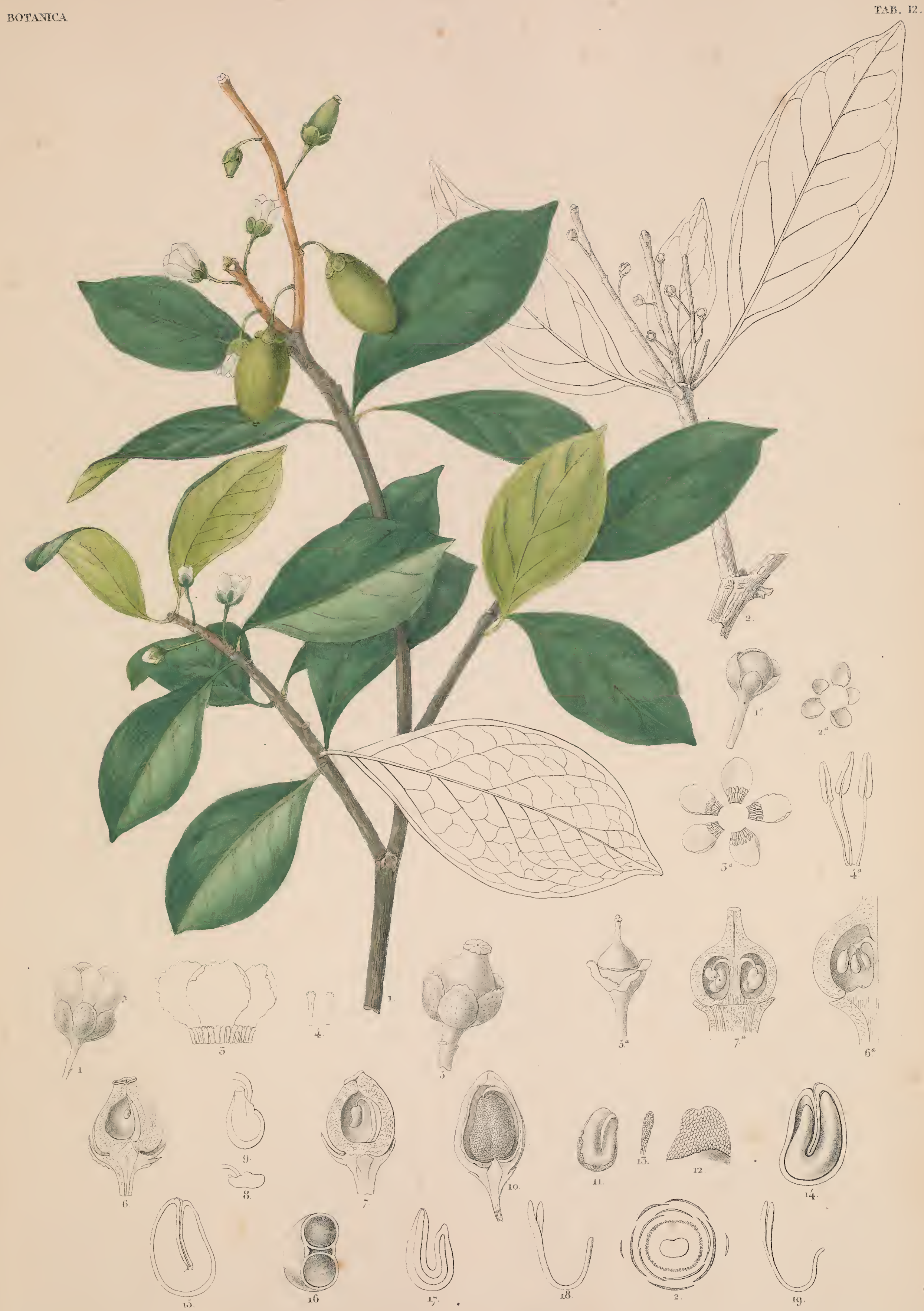

1. REINTARDTI PATENS 1.ng 2. R. ELONGATA $i^{n}-y^{a}$

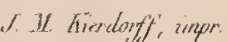





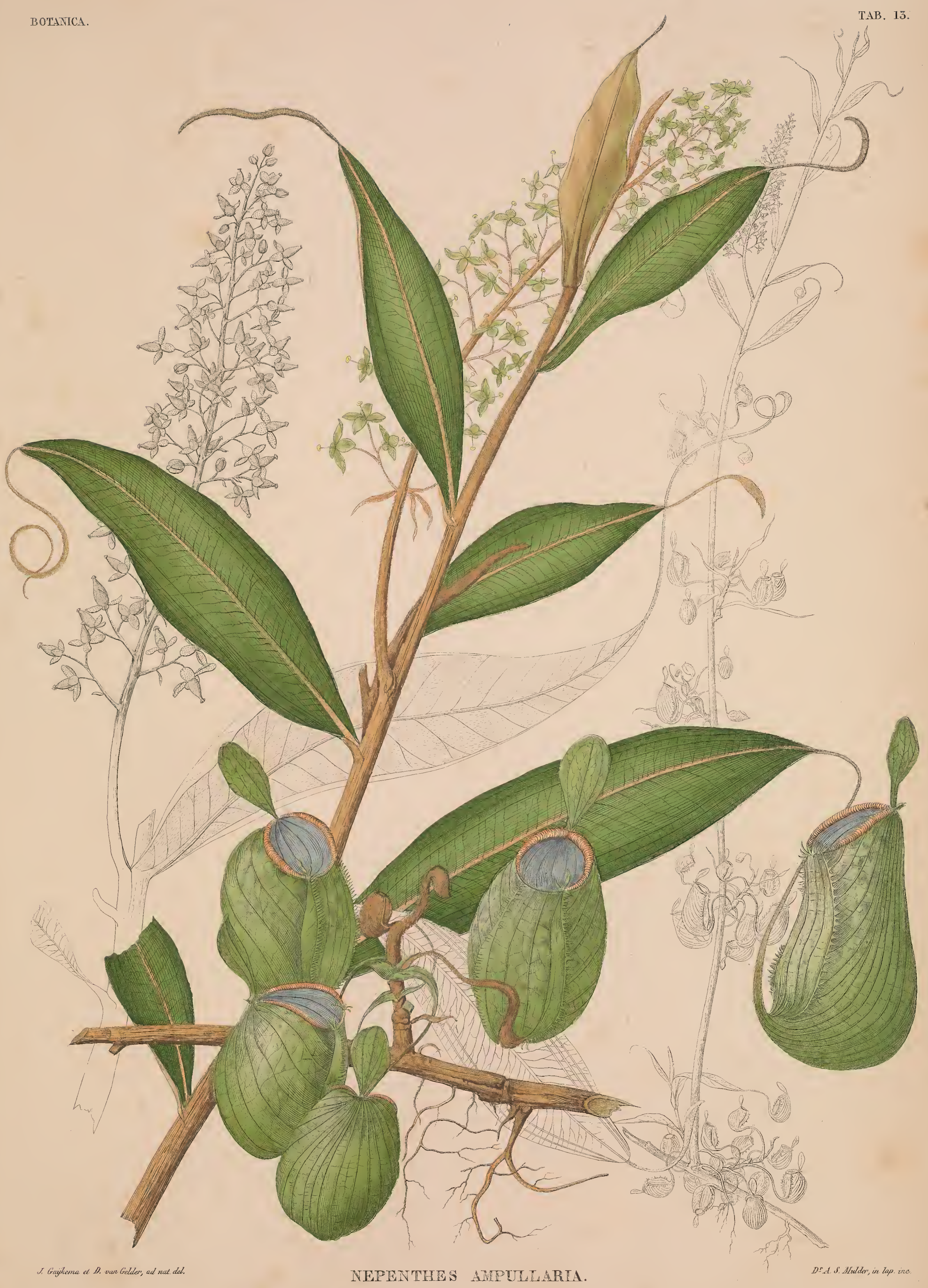





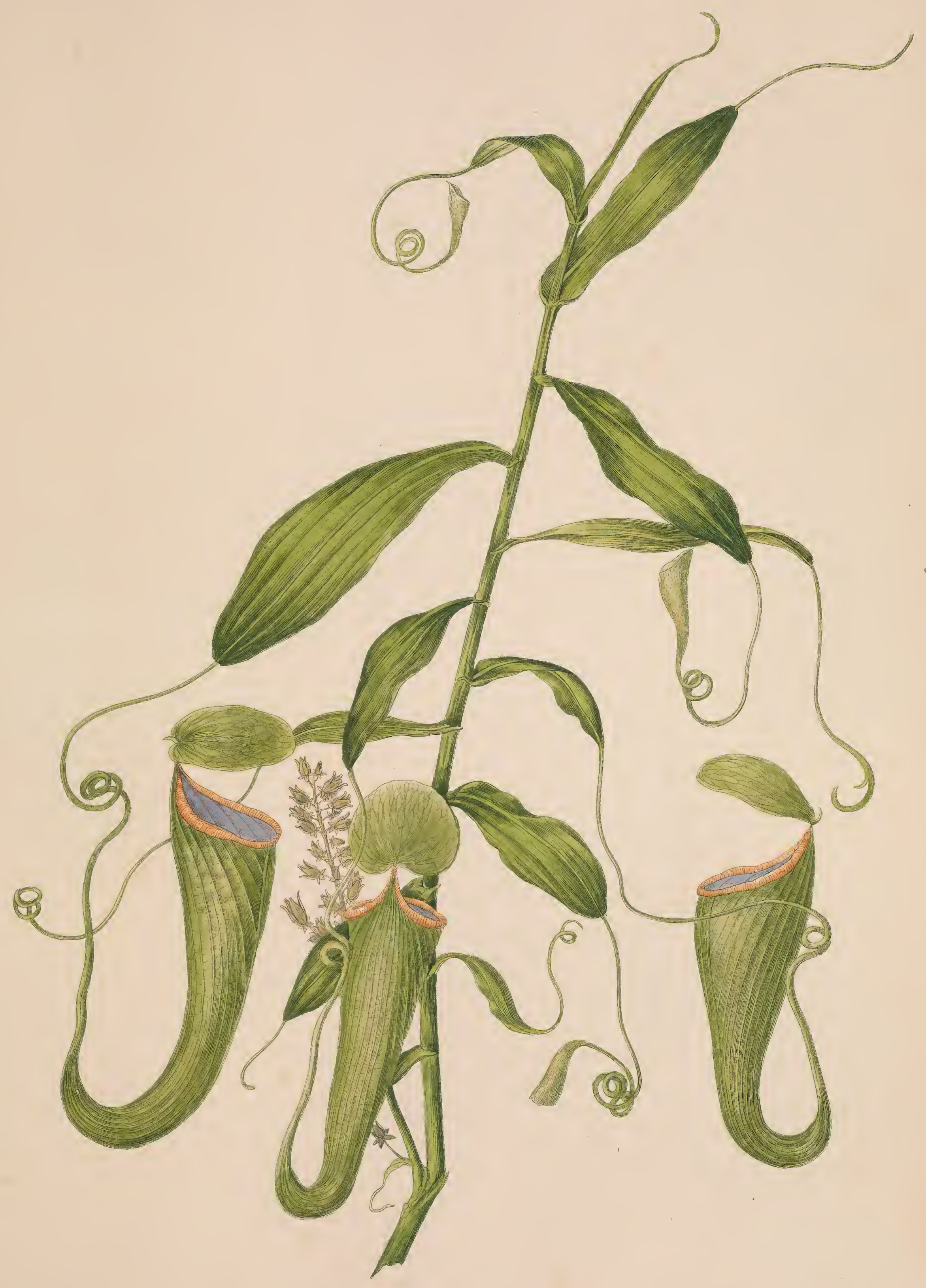


(-) 
() 


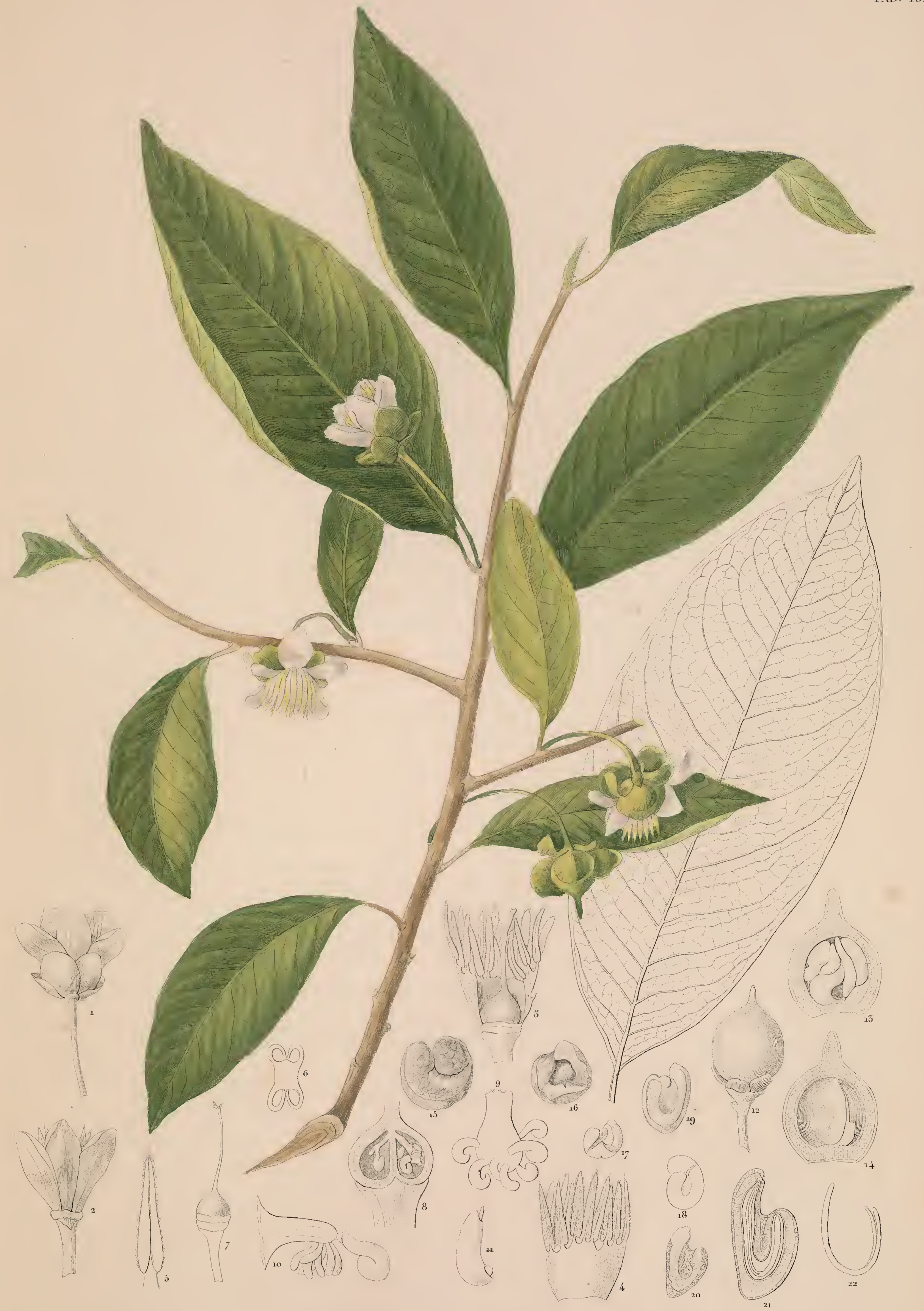





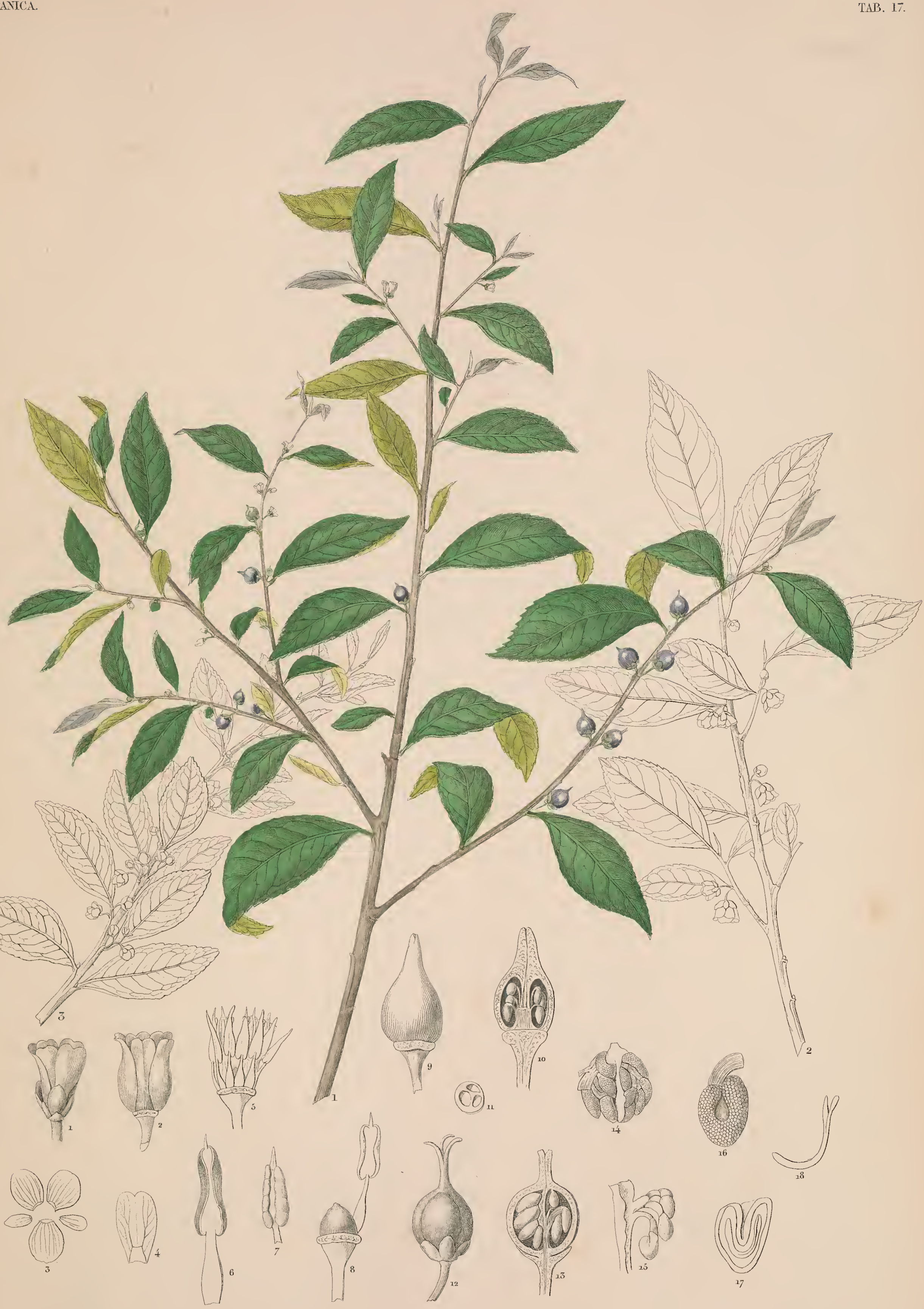

TAB. 17.

1-2. EURLA NITIDA. 3. E. RETTCULATA. 



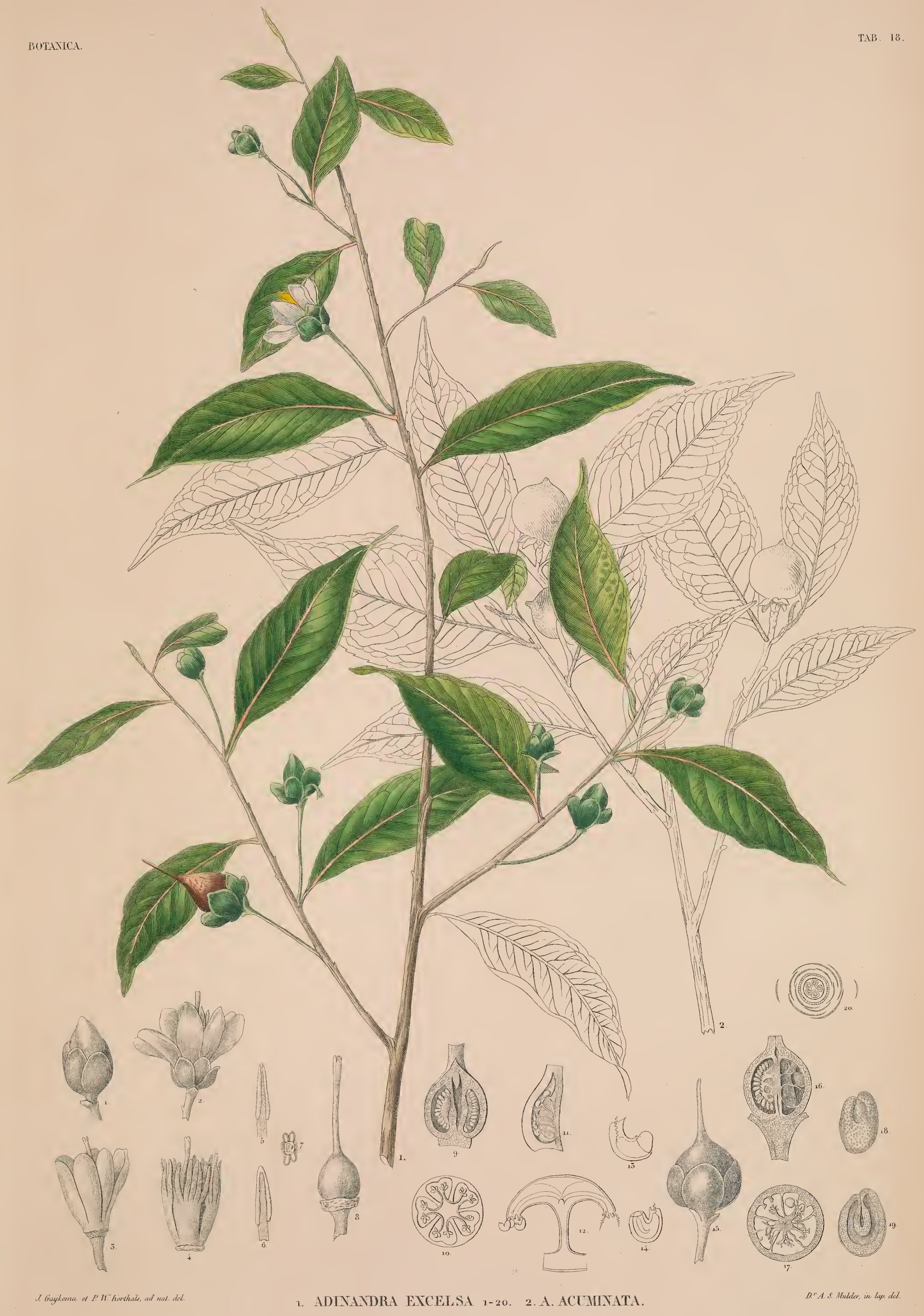





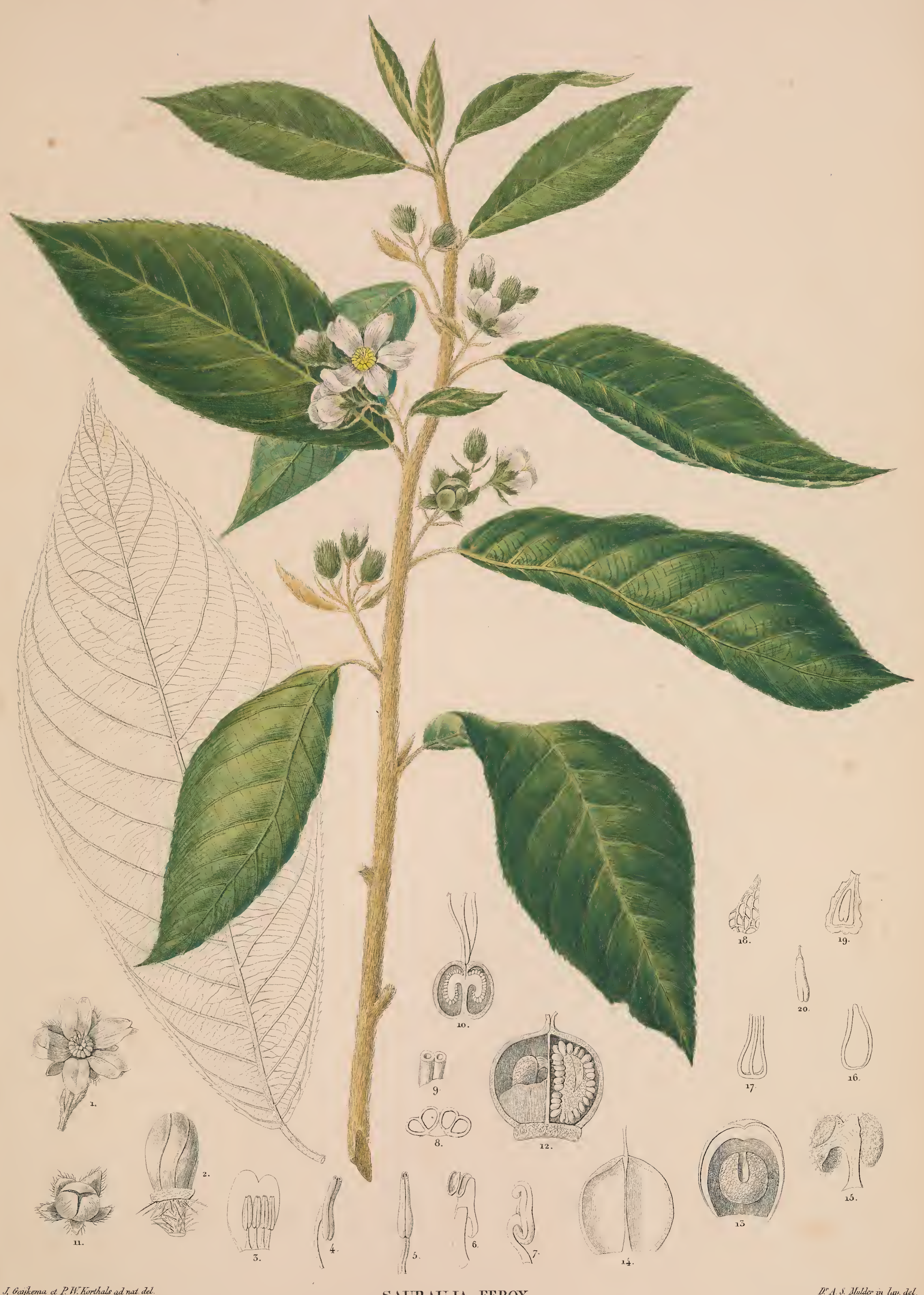



BOTAXTCA.
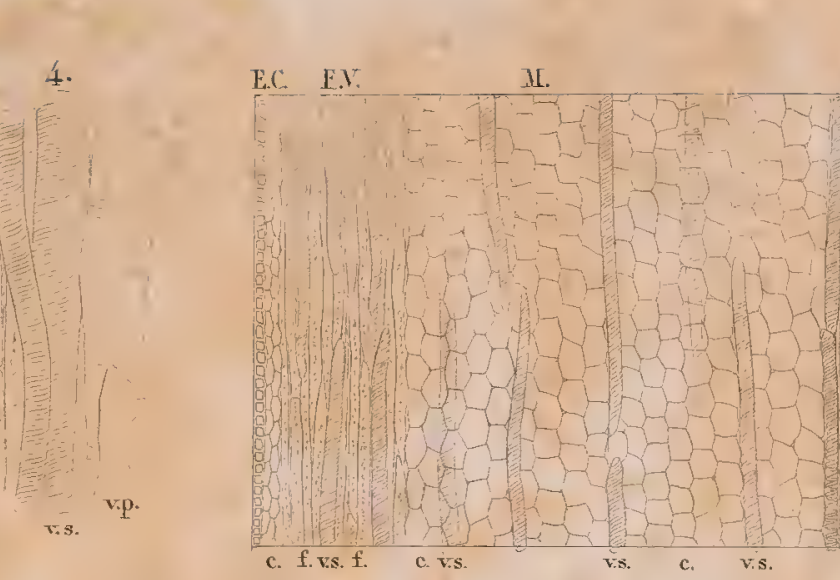

5.

T.IB. 20

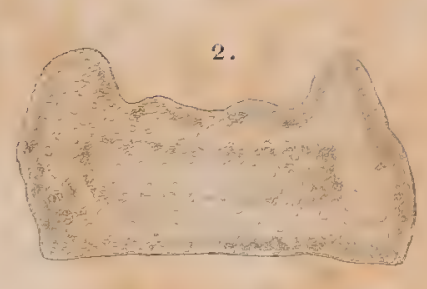

aro 0

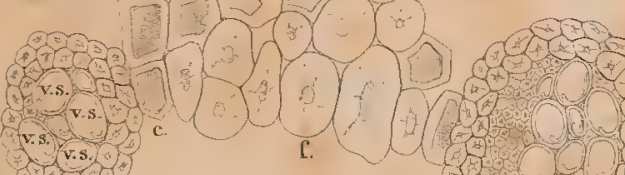
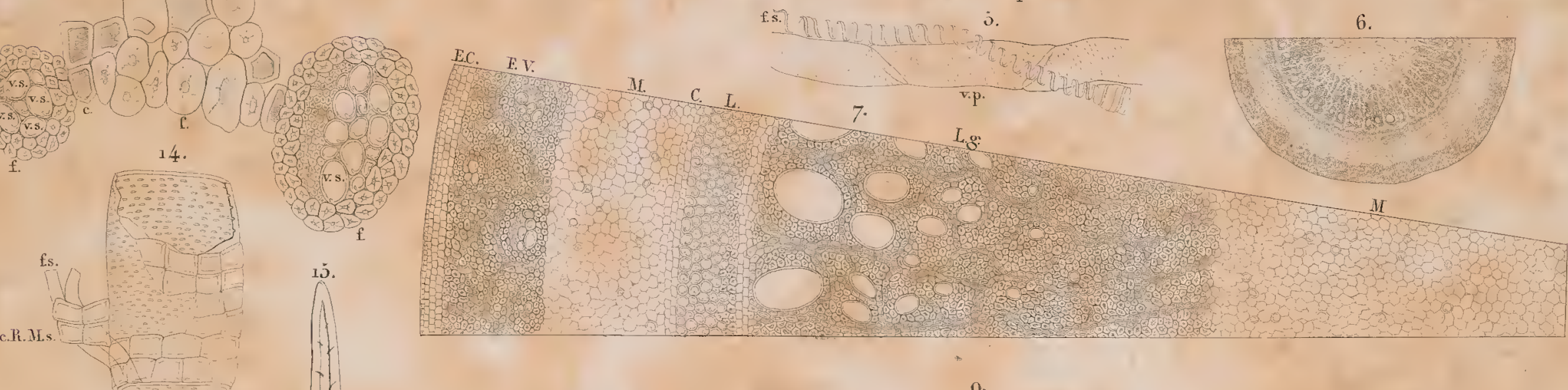

18. 17.
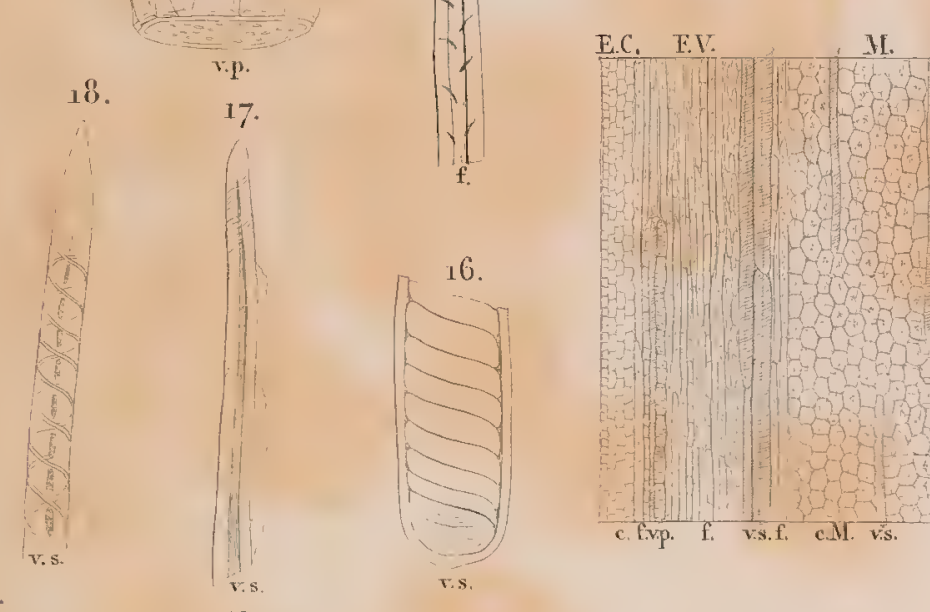

(1) 10.0 का
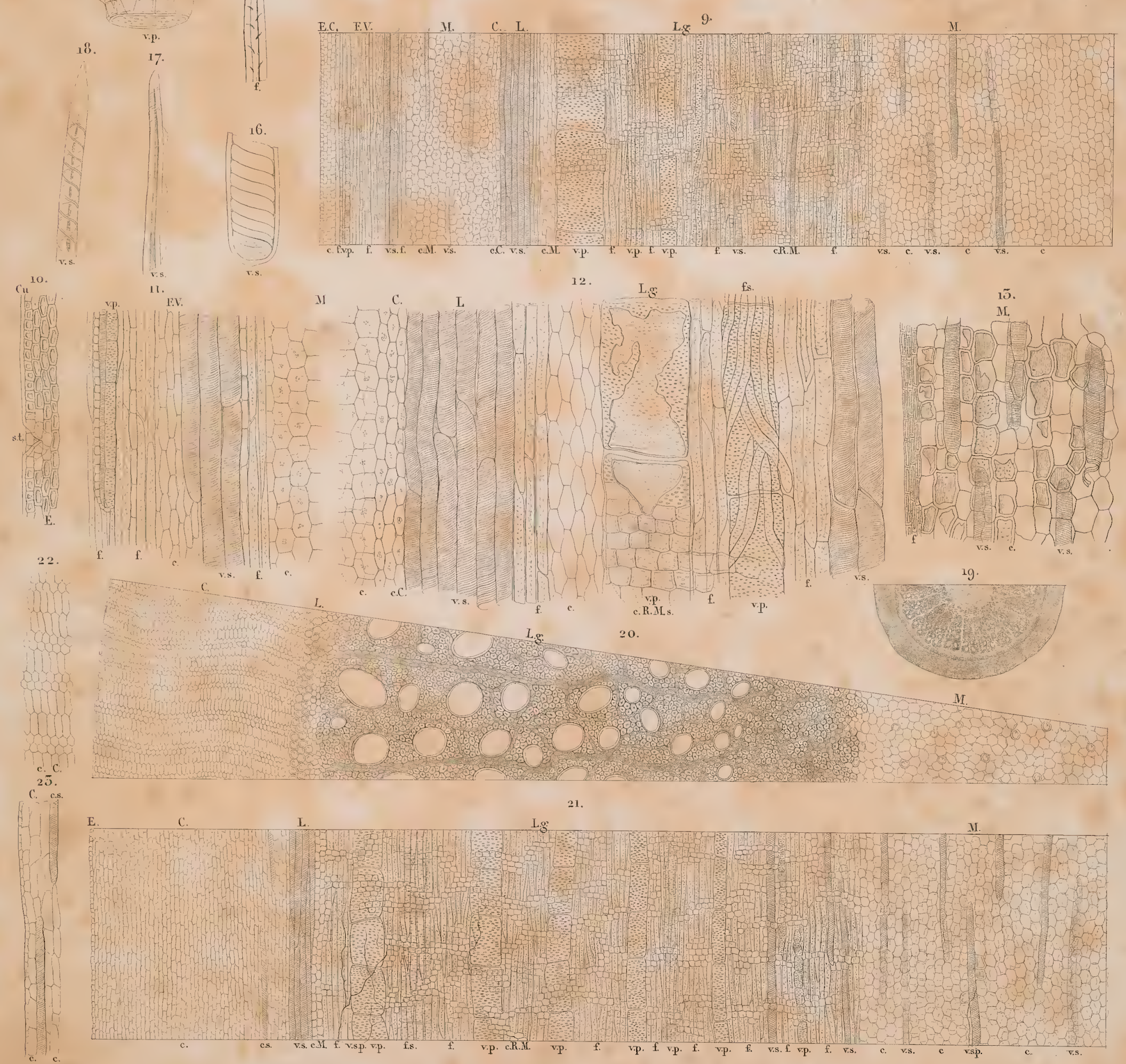



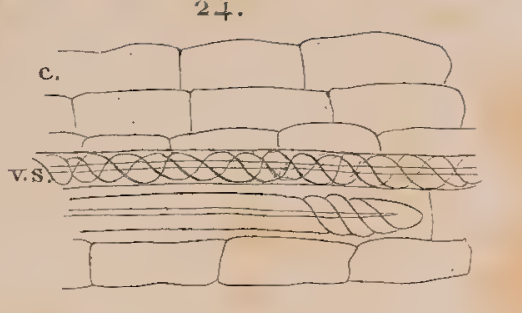

(IUt 32.

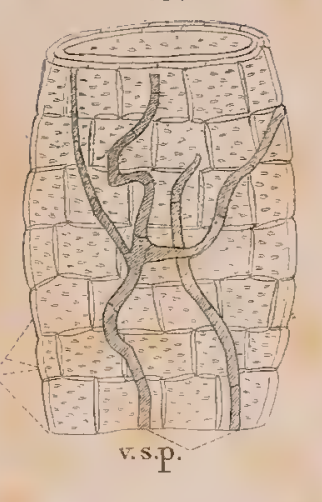

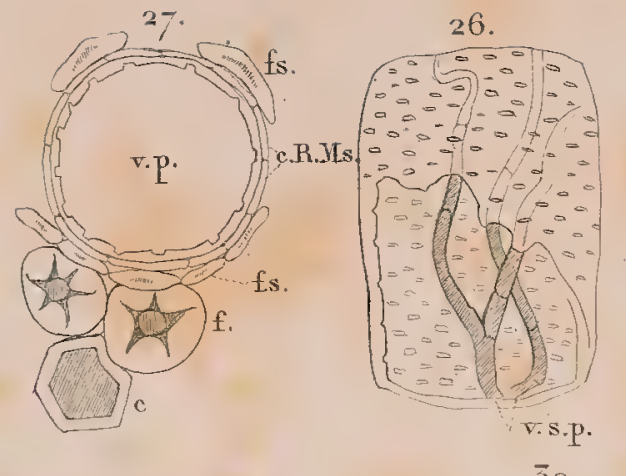
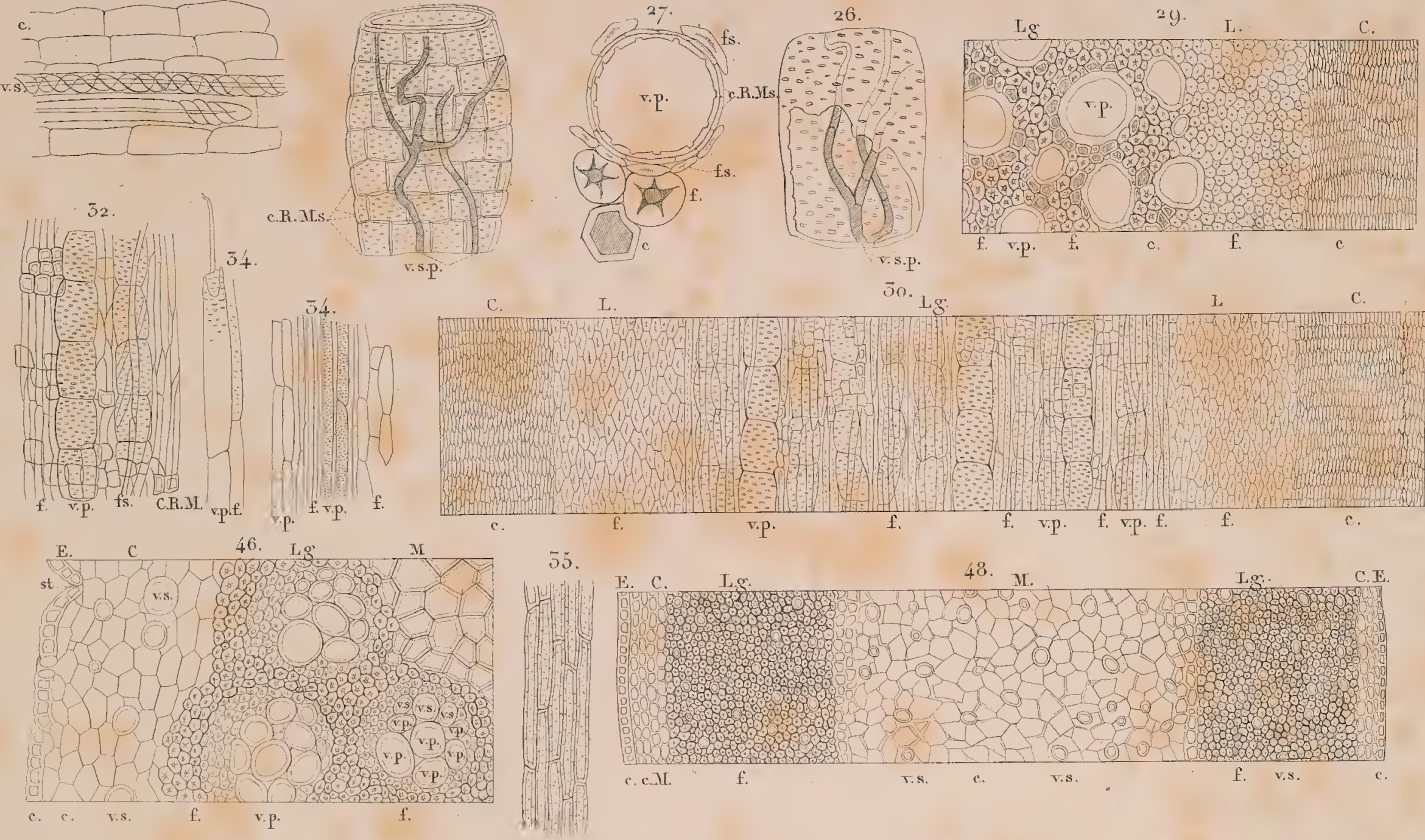

30.
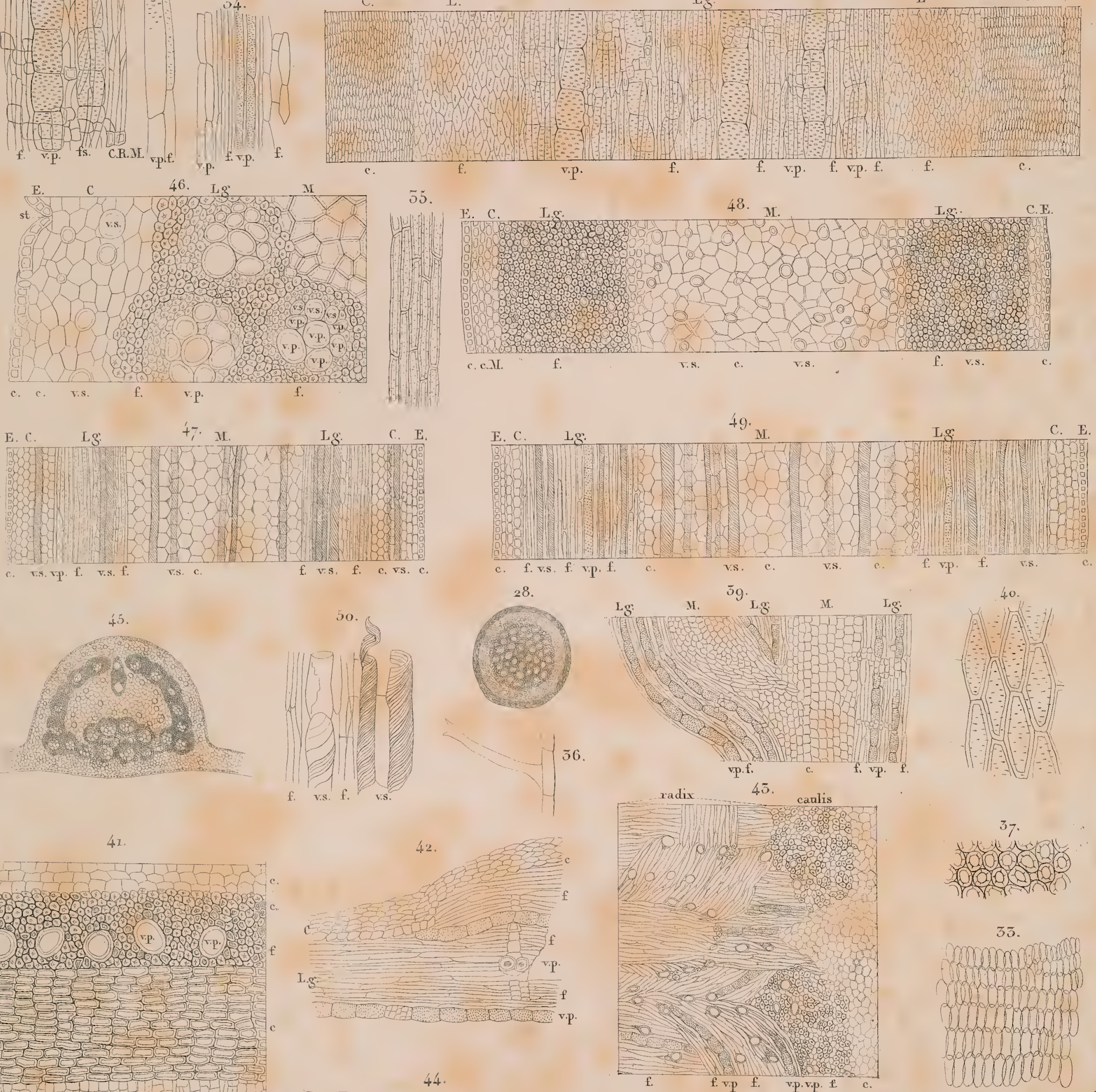

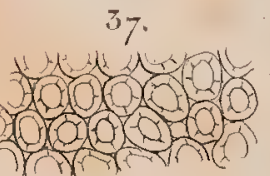
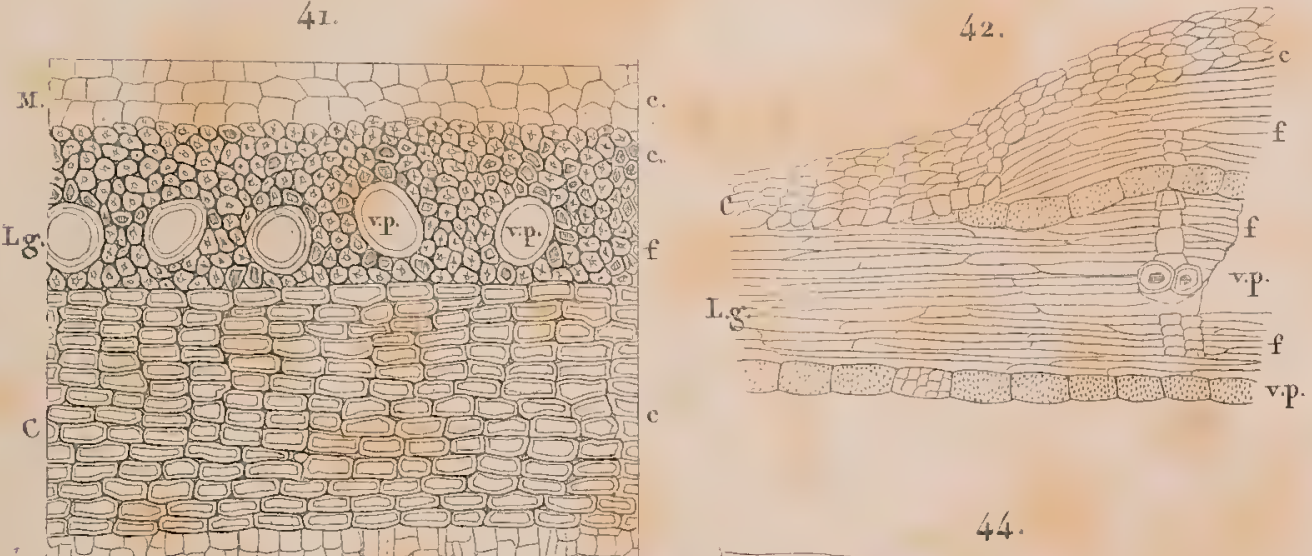

44.

$$
\text { s. }
$$
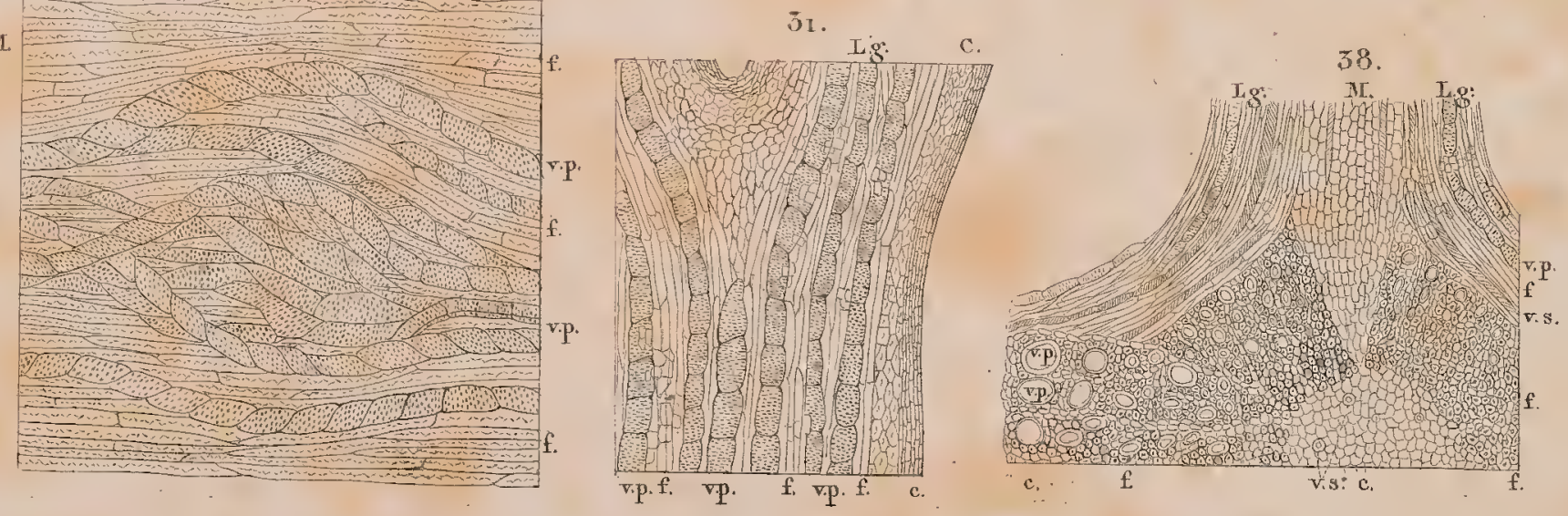

NEPENTHES.
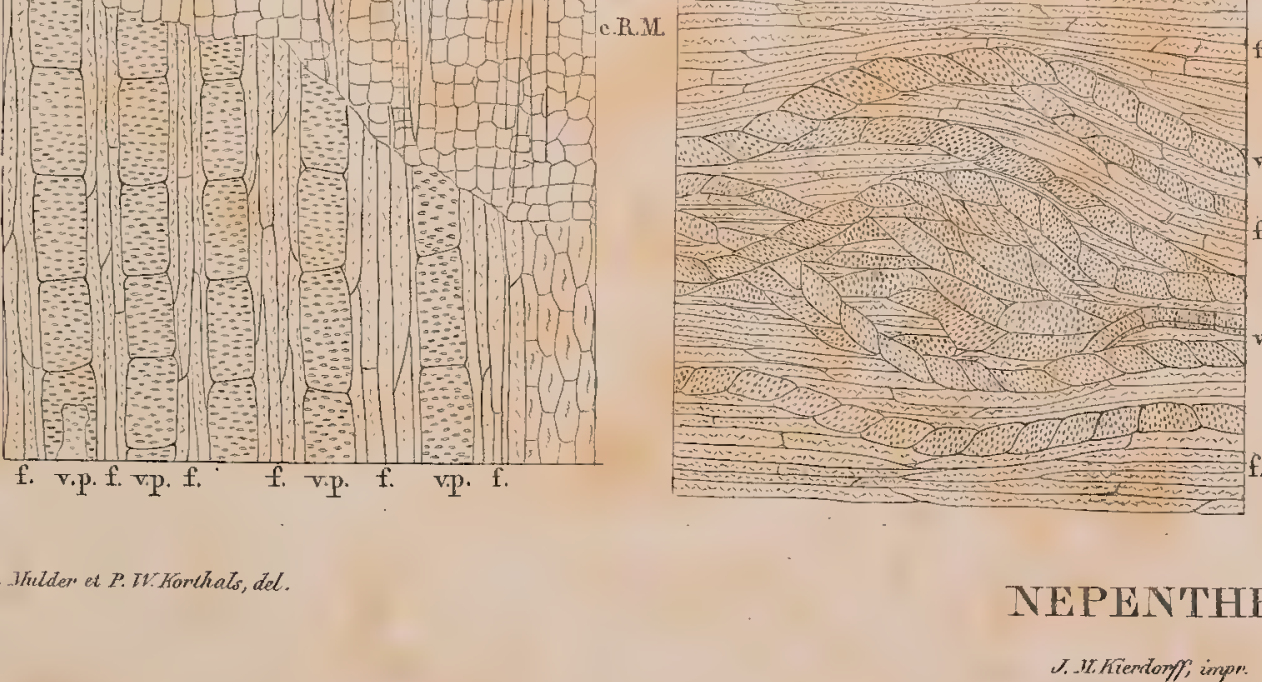


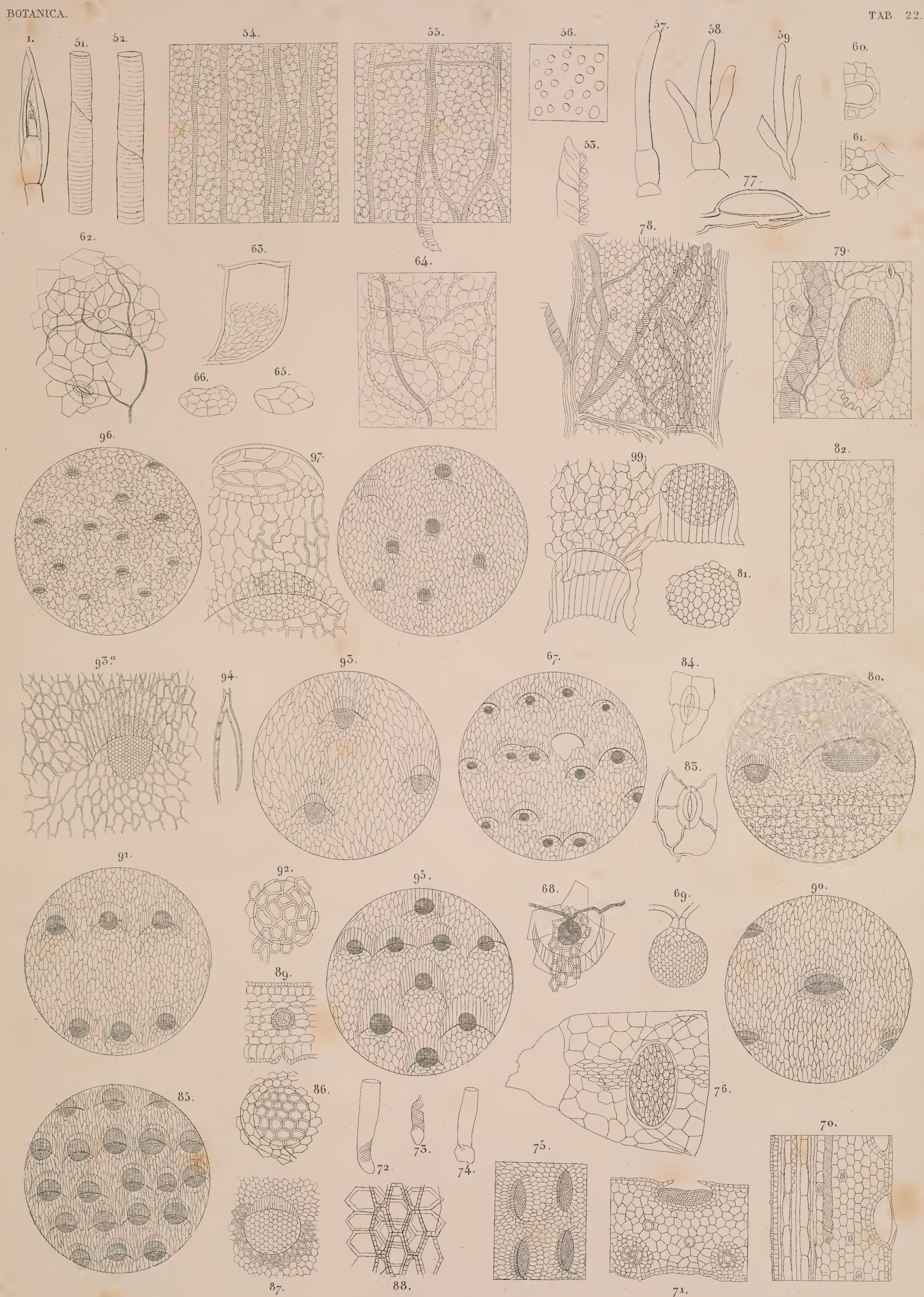

NEPENTHES. 



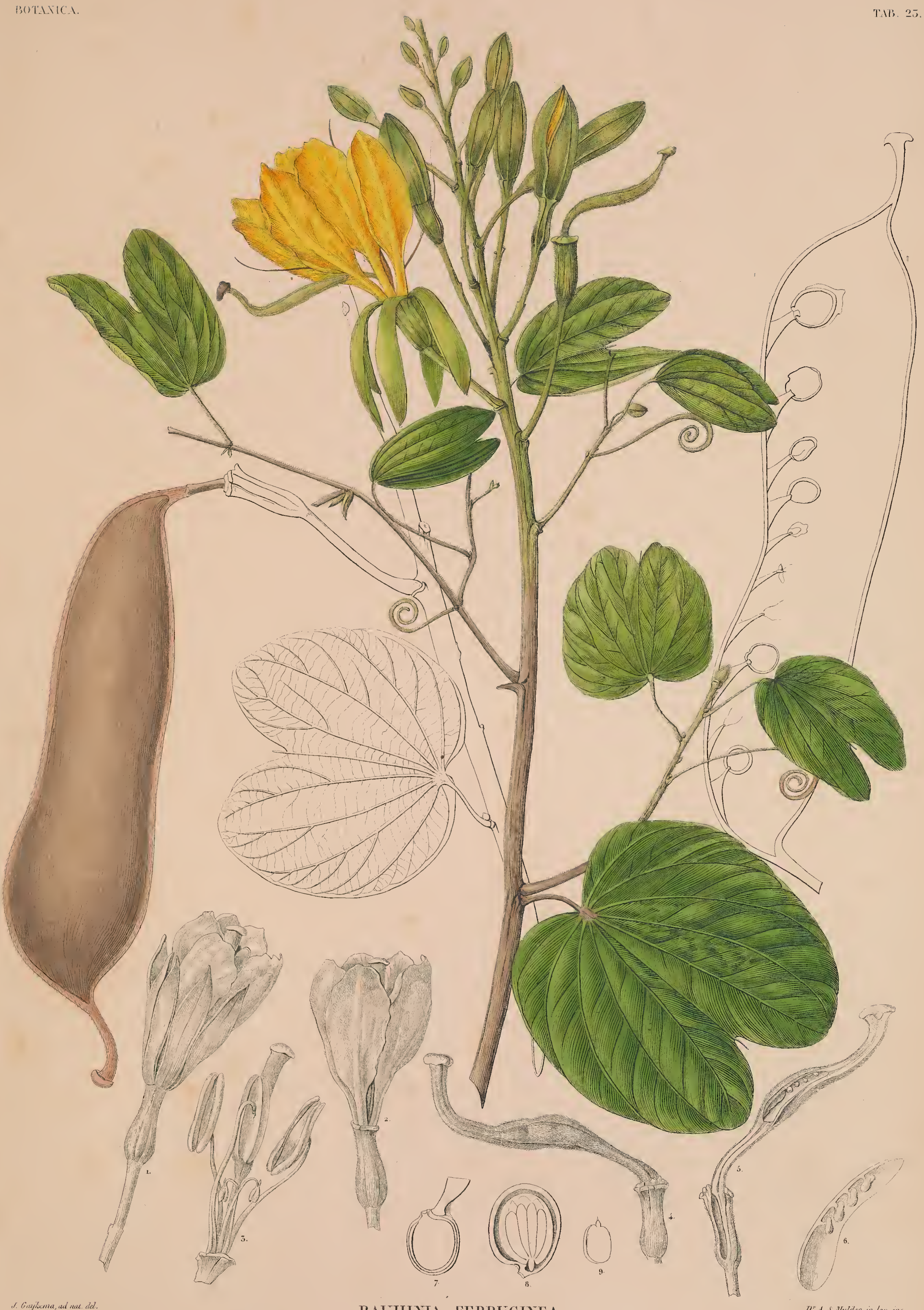

BALHINTA FERRCGLNEA. 



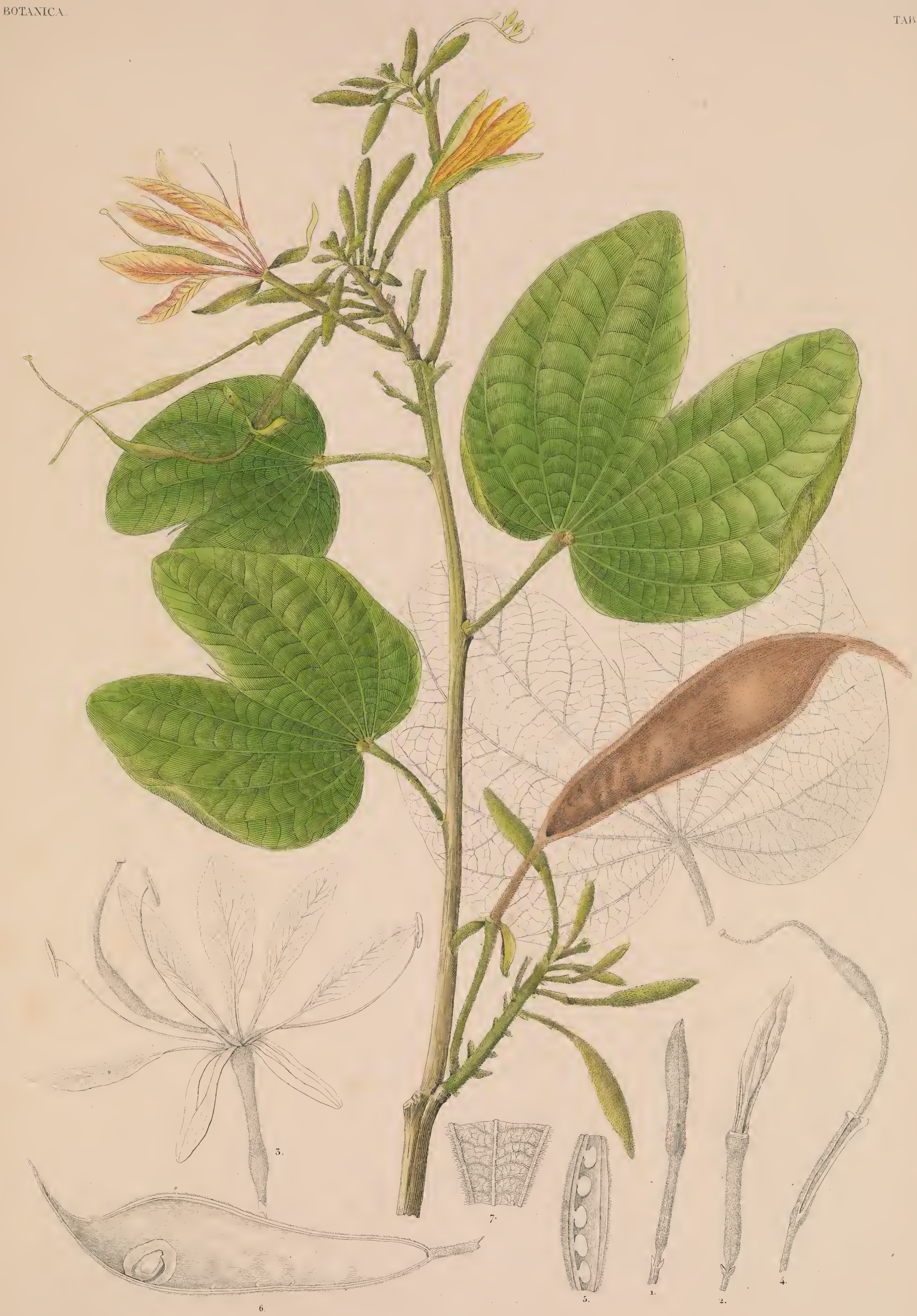

BAUHINLA ELONGATA. 
(.) 


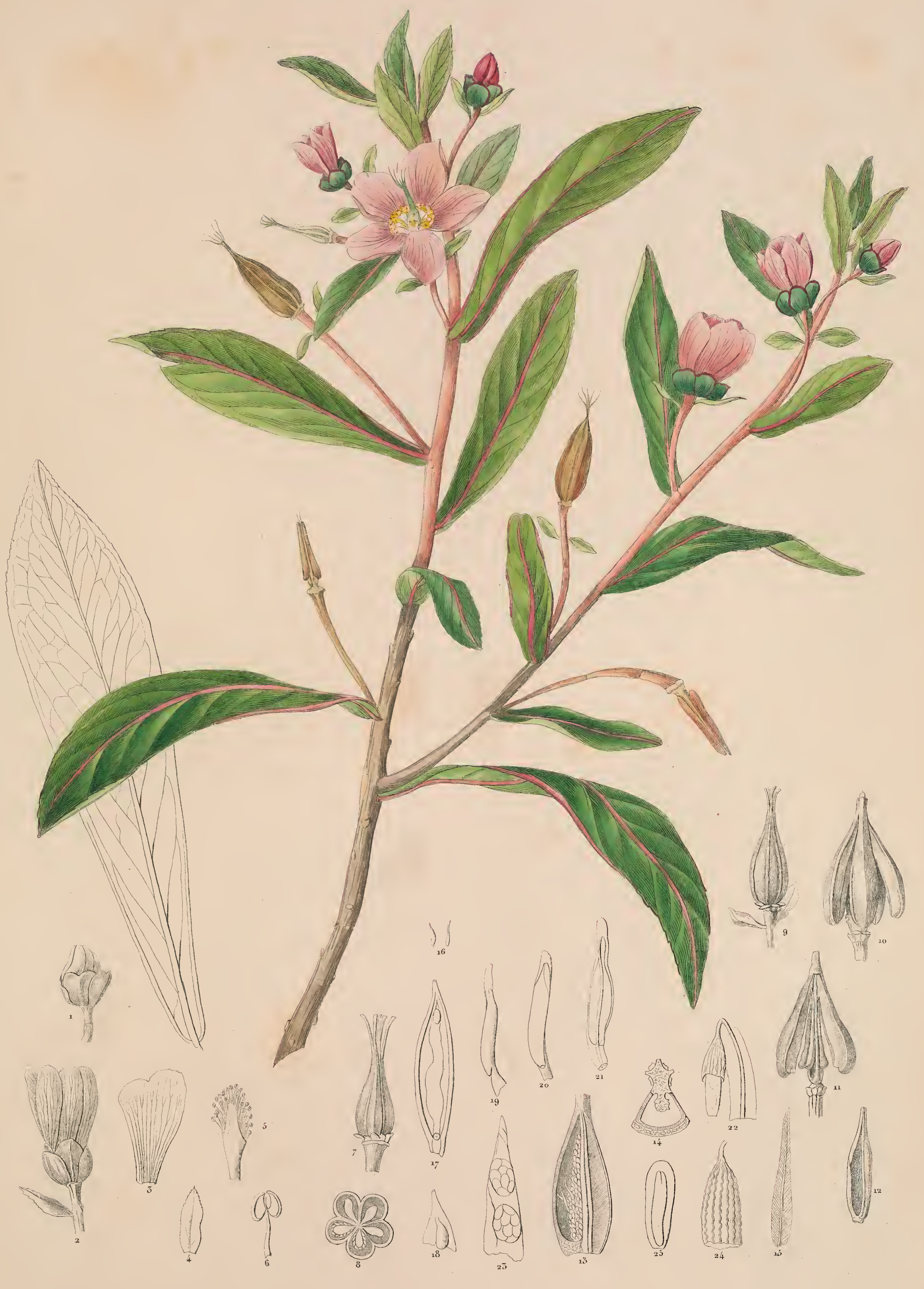

PLOLARIUM ELEGANS. 
. 


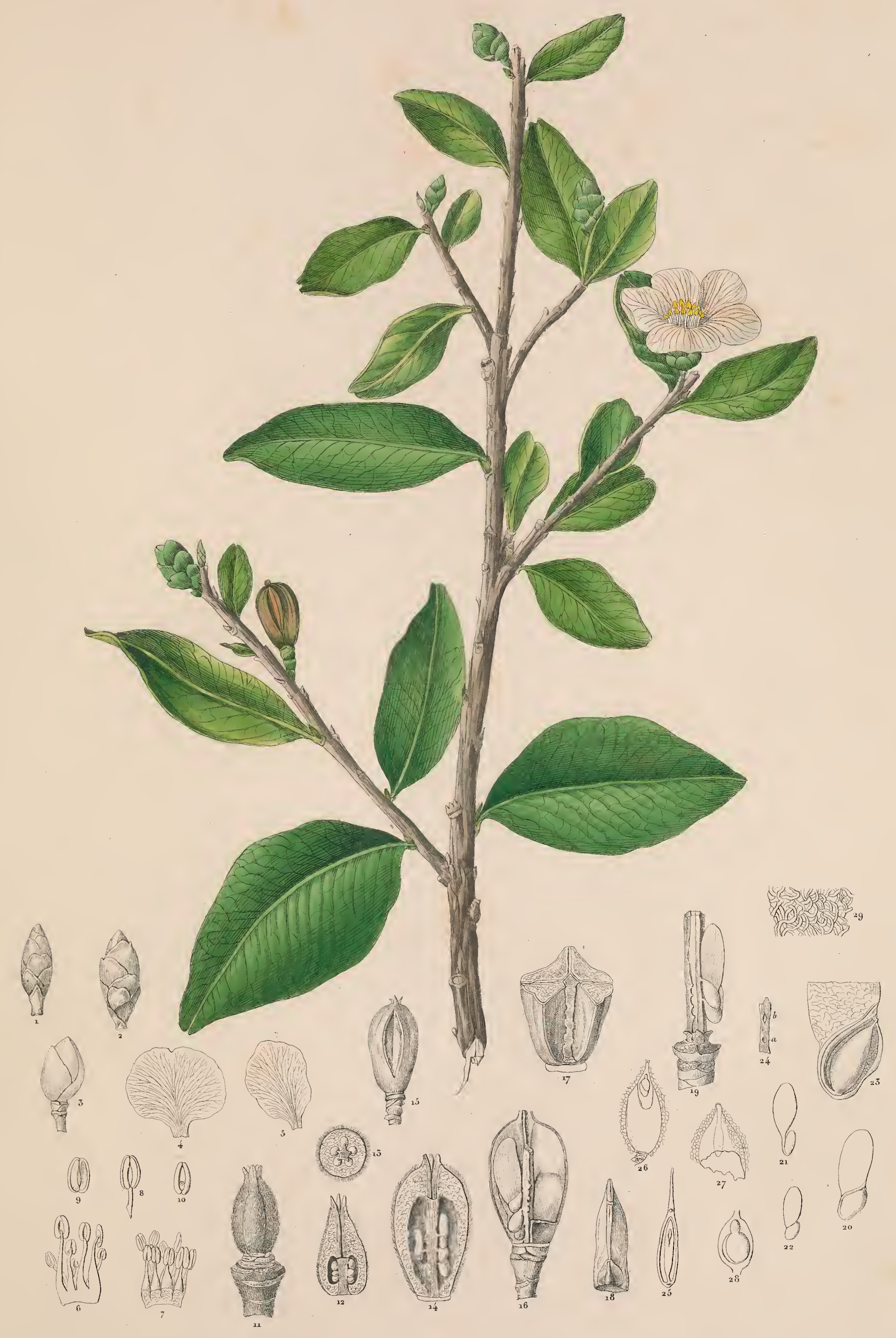

LAPLACEA VULCANICA. 
중 


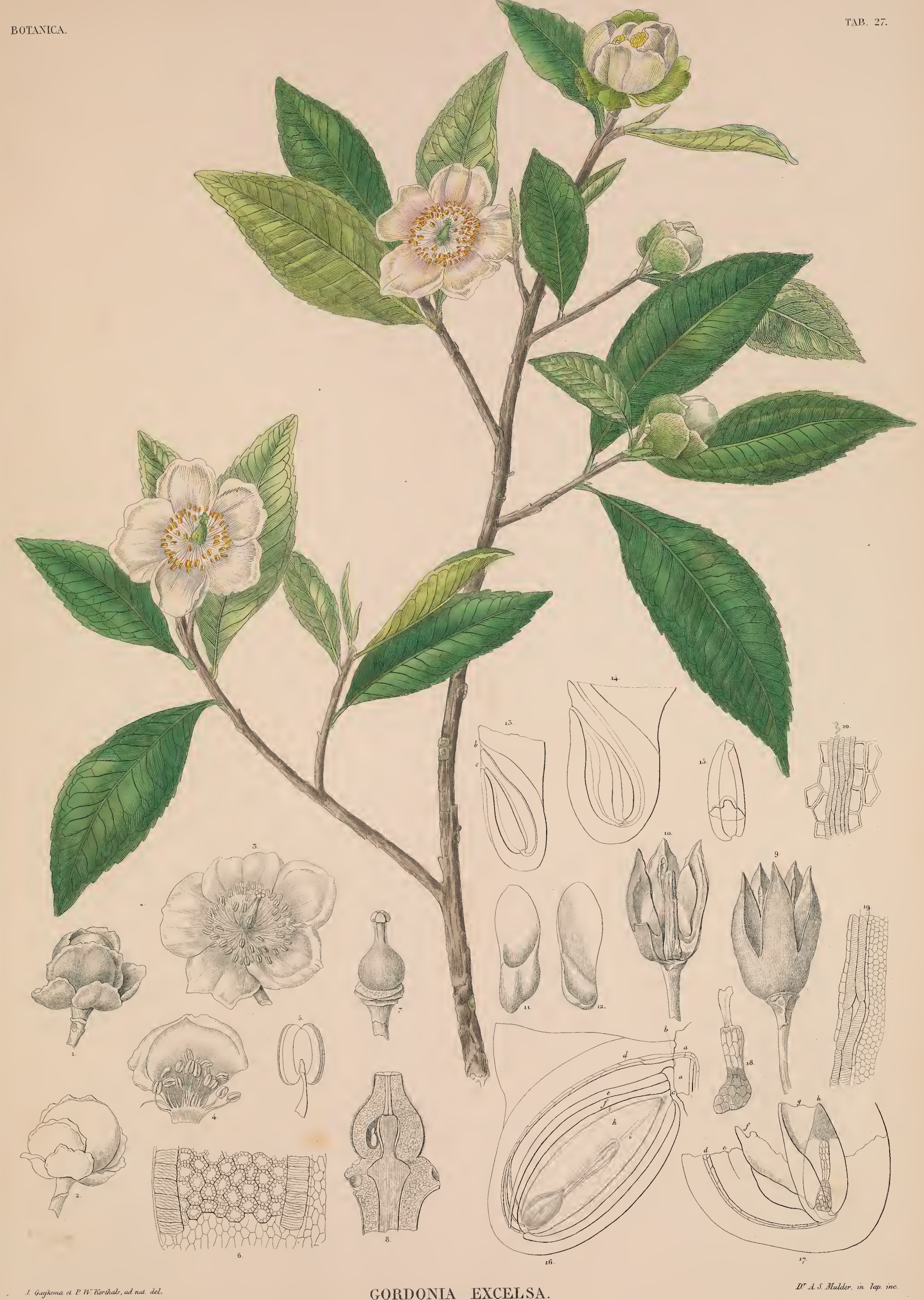


(ㄱ) 


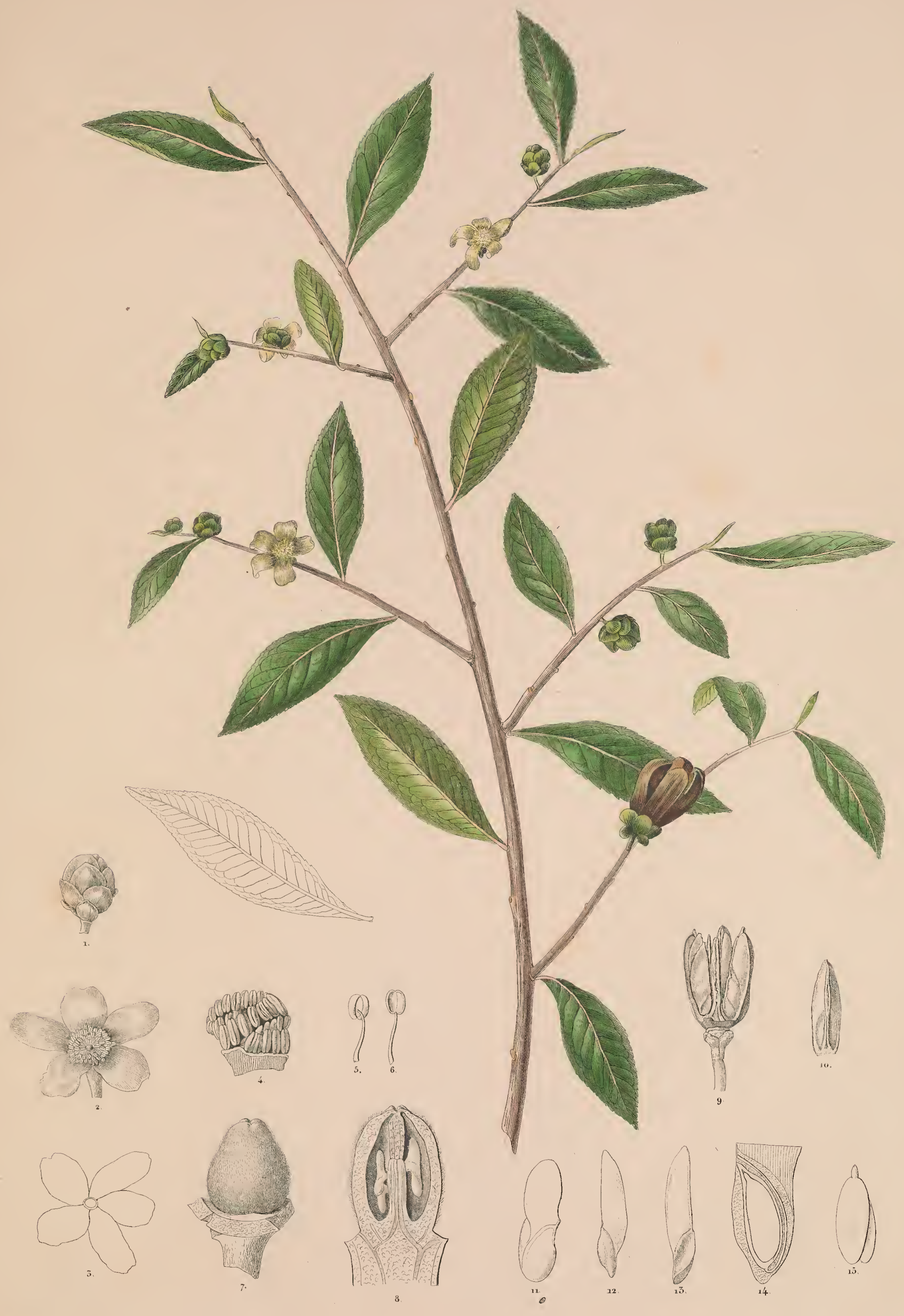


(-) 


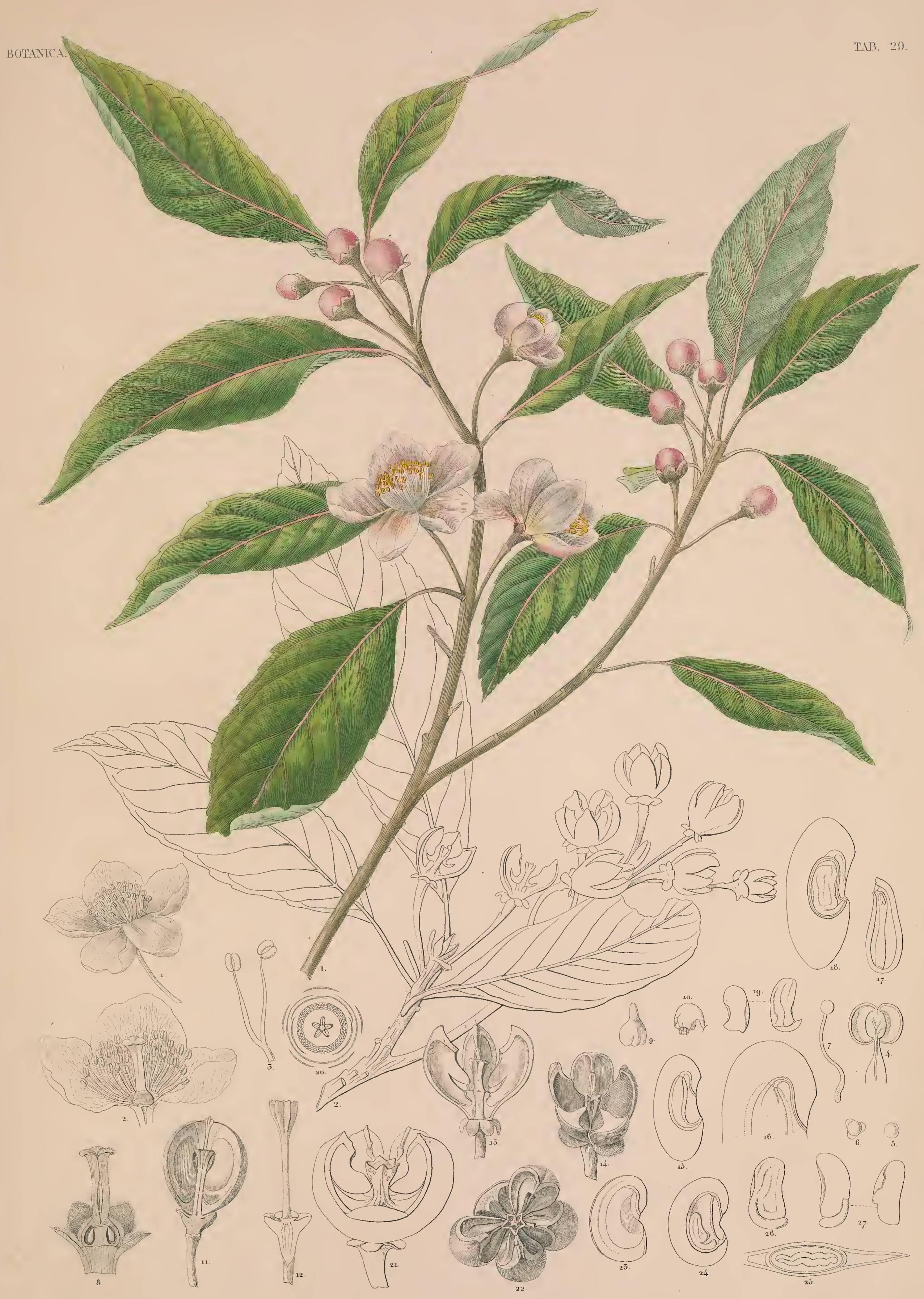

1-2. SCHLVA CRENATA 1-20,- S. NORONHAE 21-27. 
중 


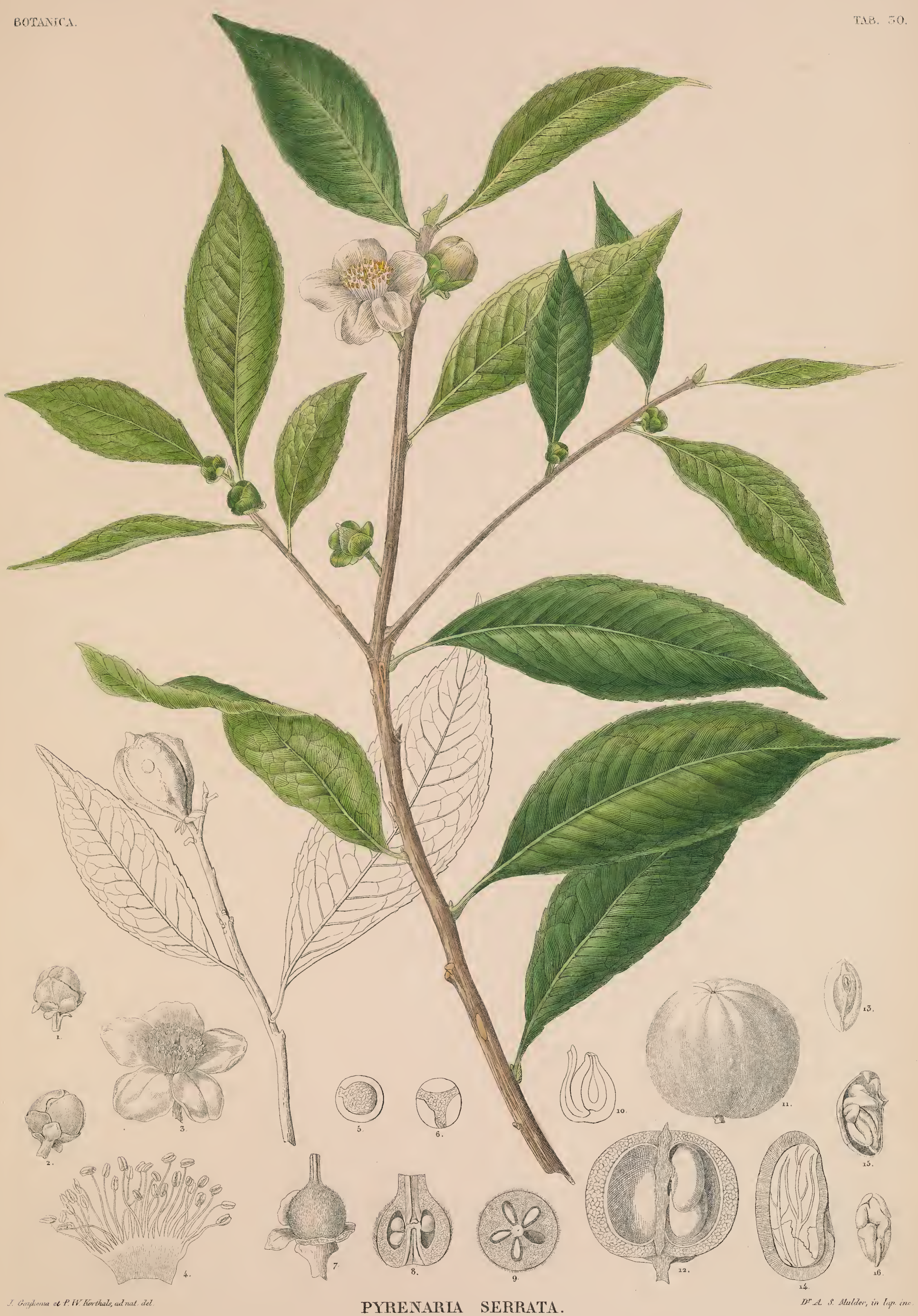


(-) 


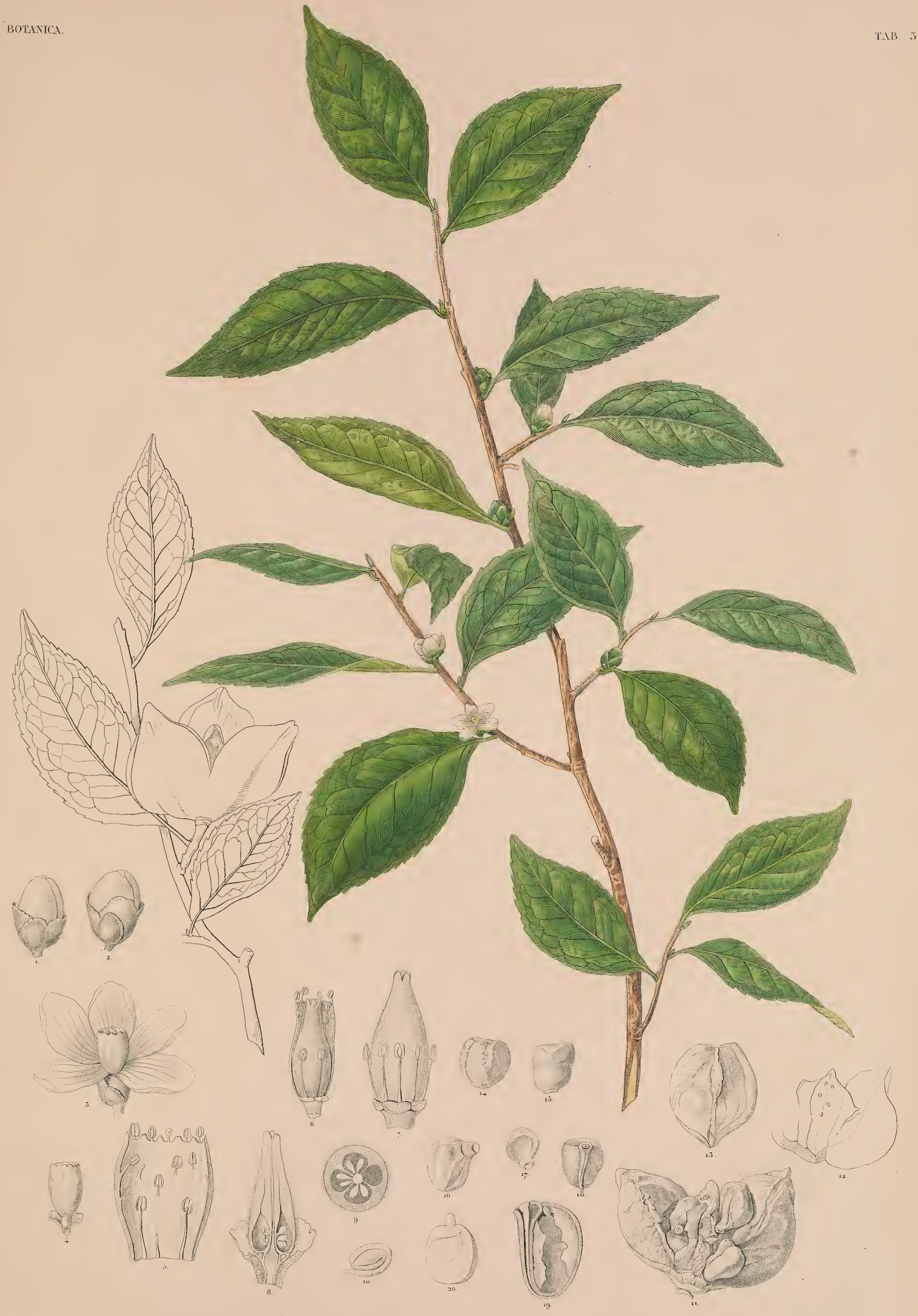





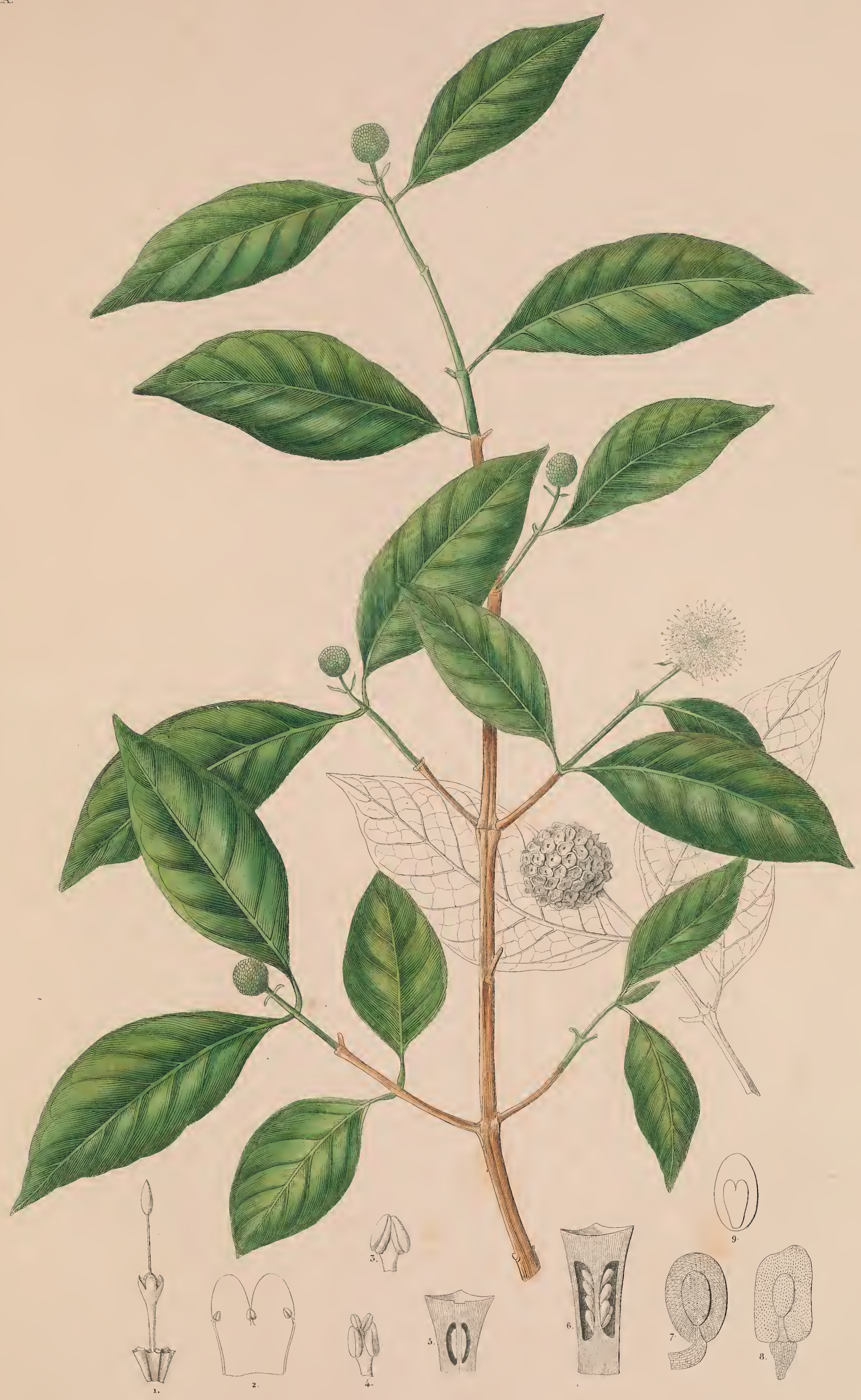

TAB. 32. 
장 
BOTANTCA.

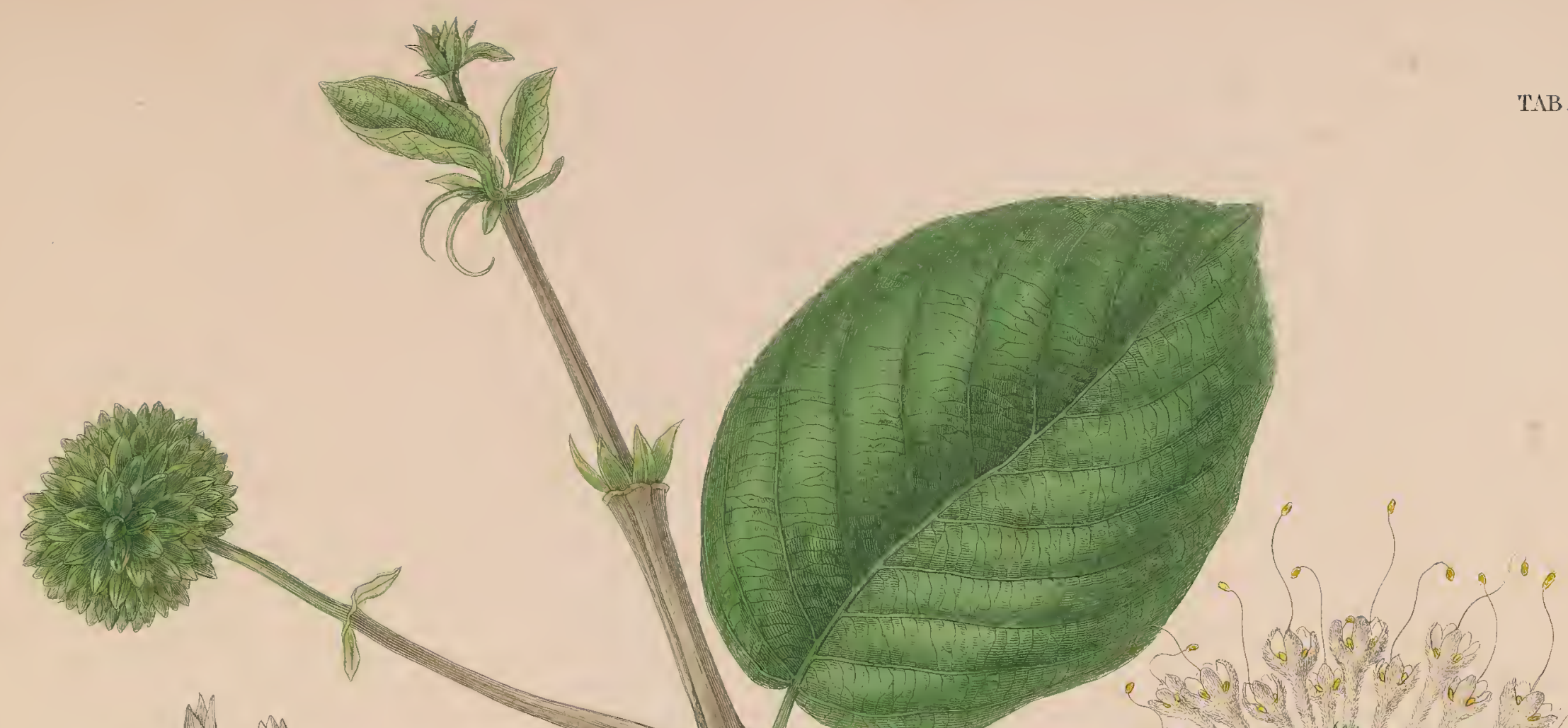

TAB. 33

M M M

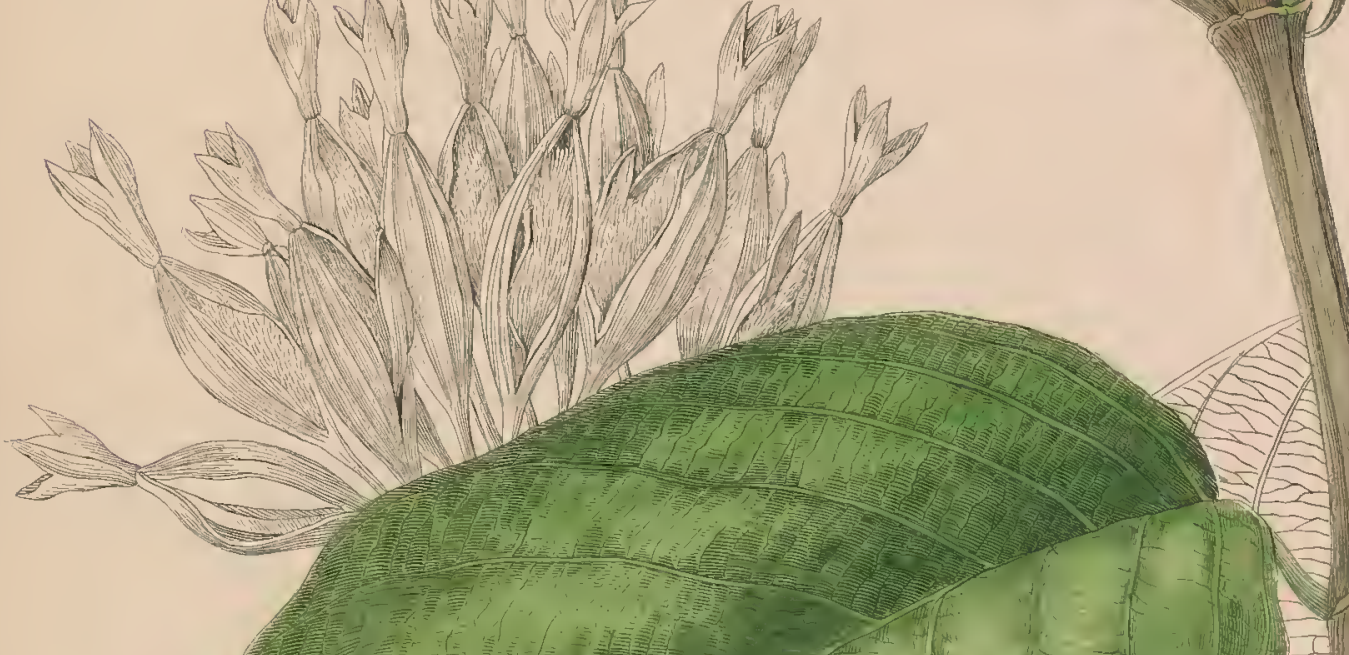

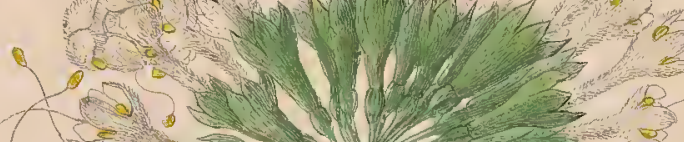

- $3 b^{2}$

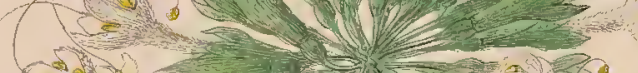

F

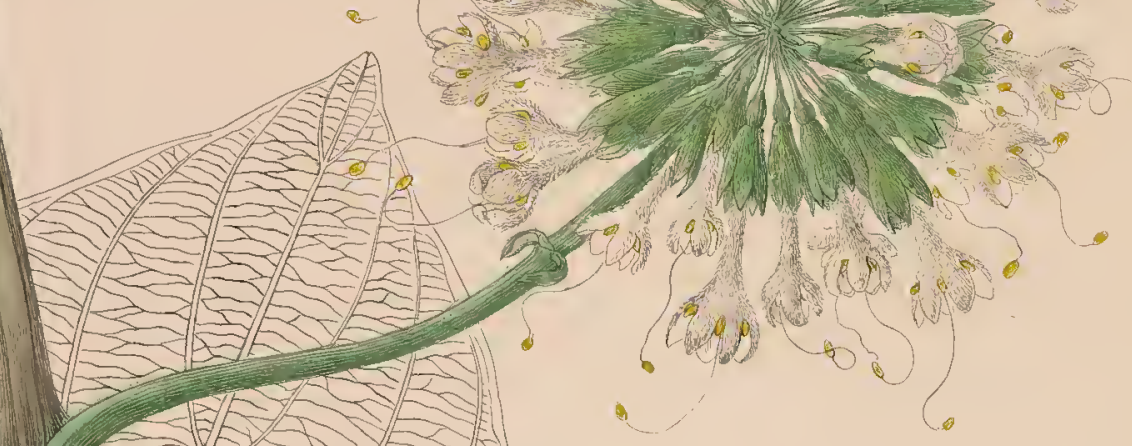

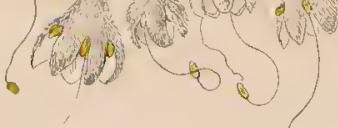

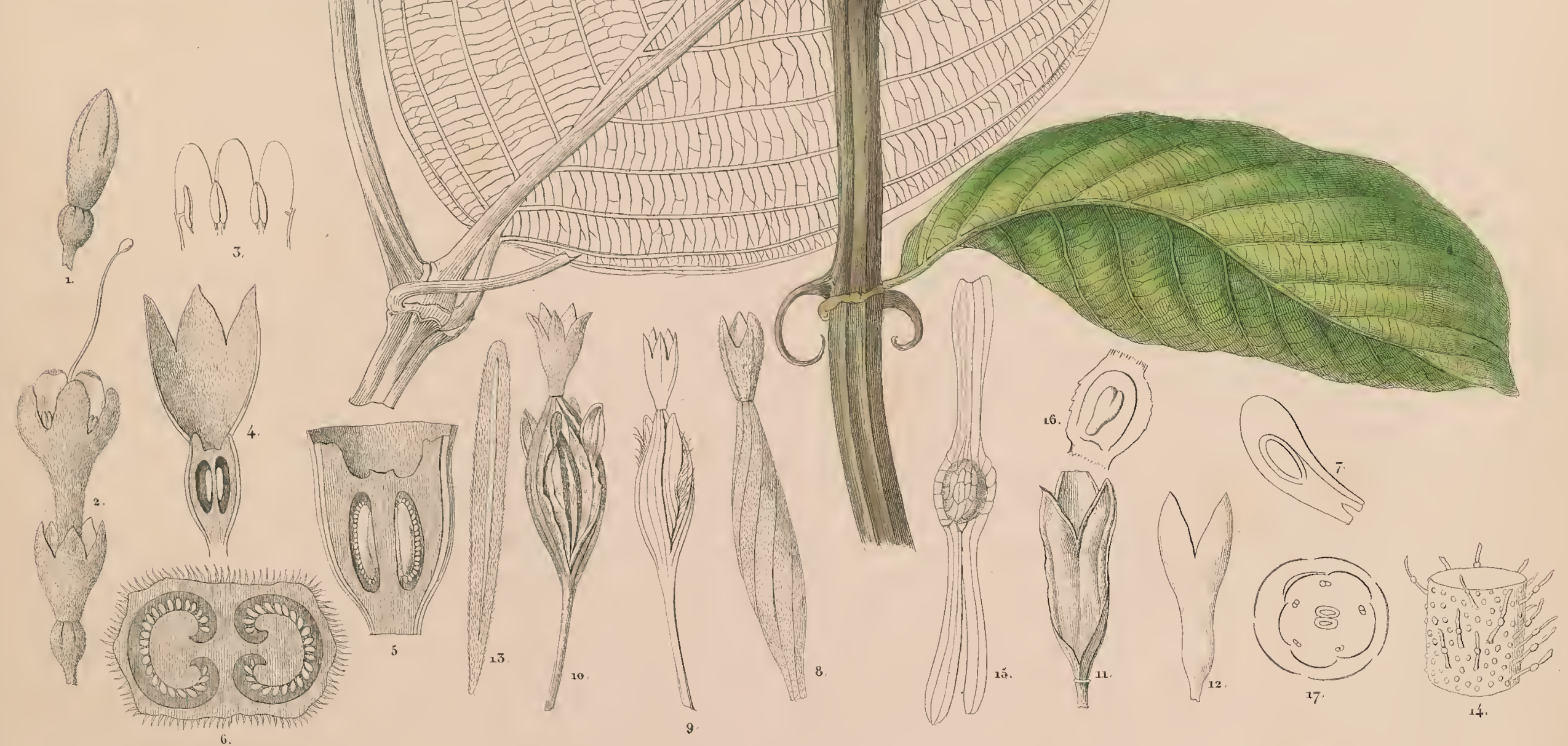


강 
BOTANICA.

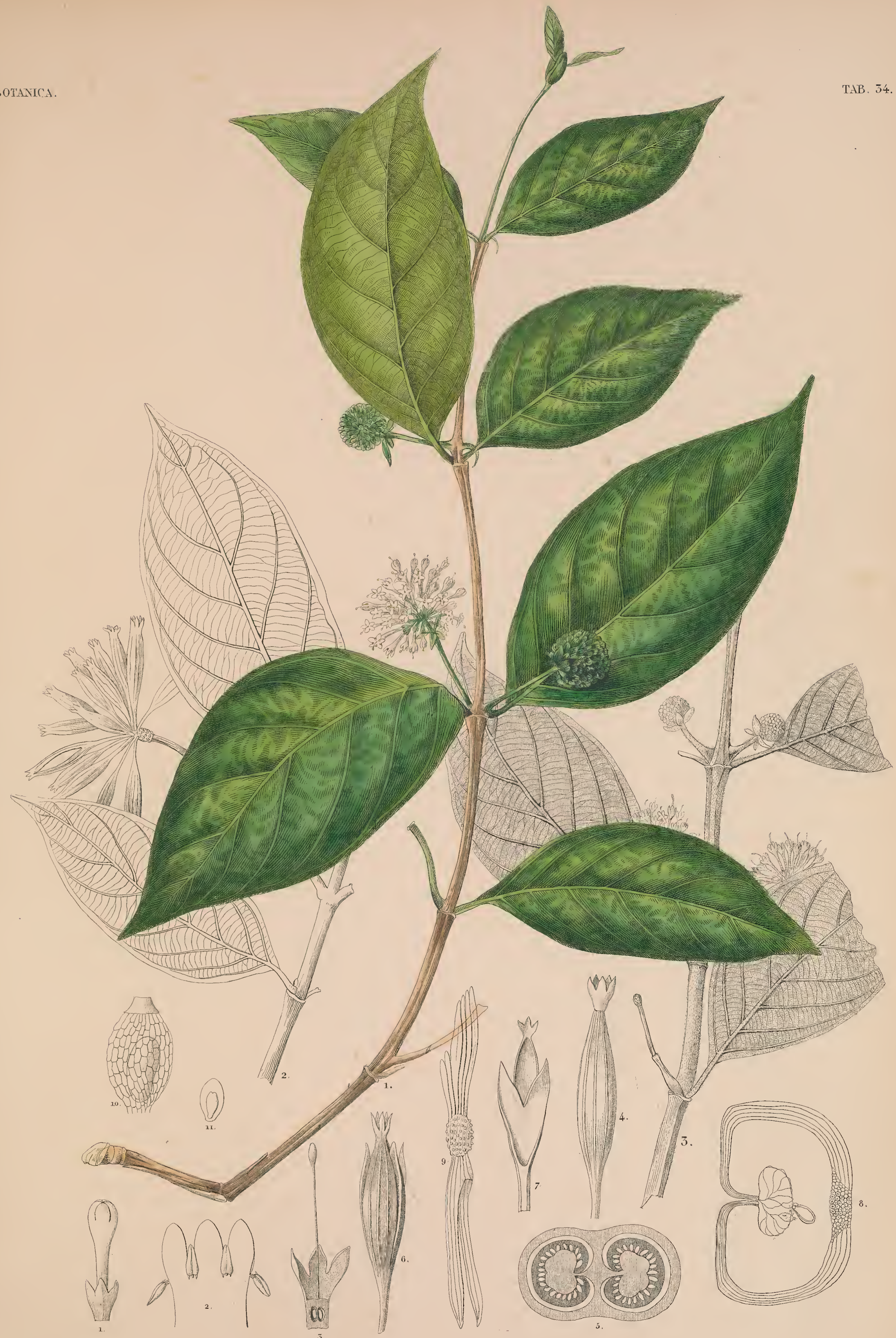

TAB. 34.

1, 2. UNCARTA GAMBIER, 1-10,- 3. U. ATTENUATA. 
e 
Botaxica.

TAB. 35

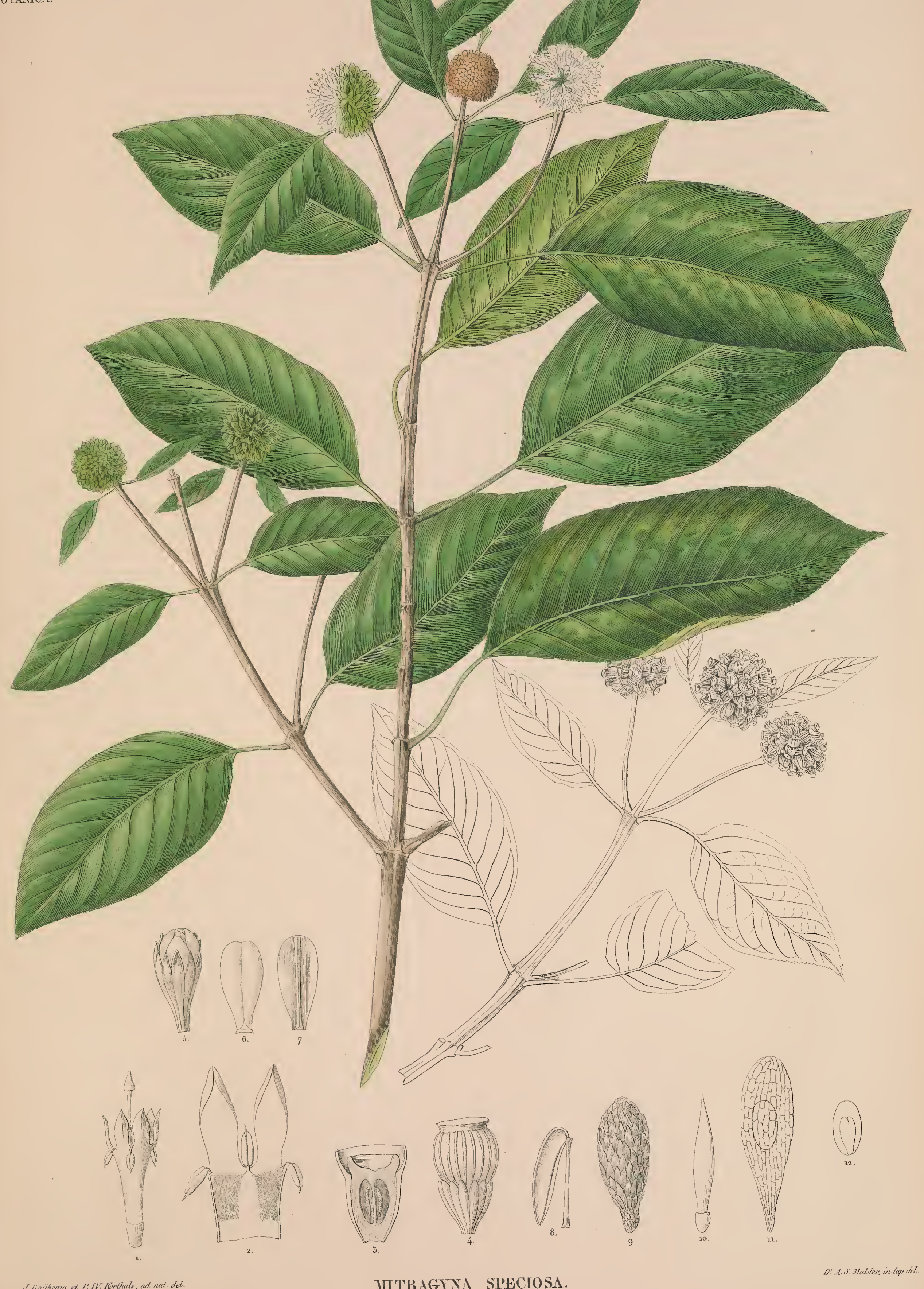




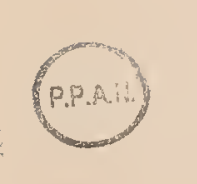




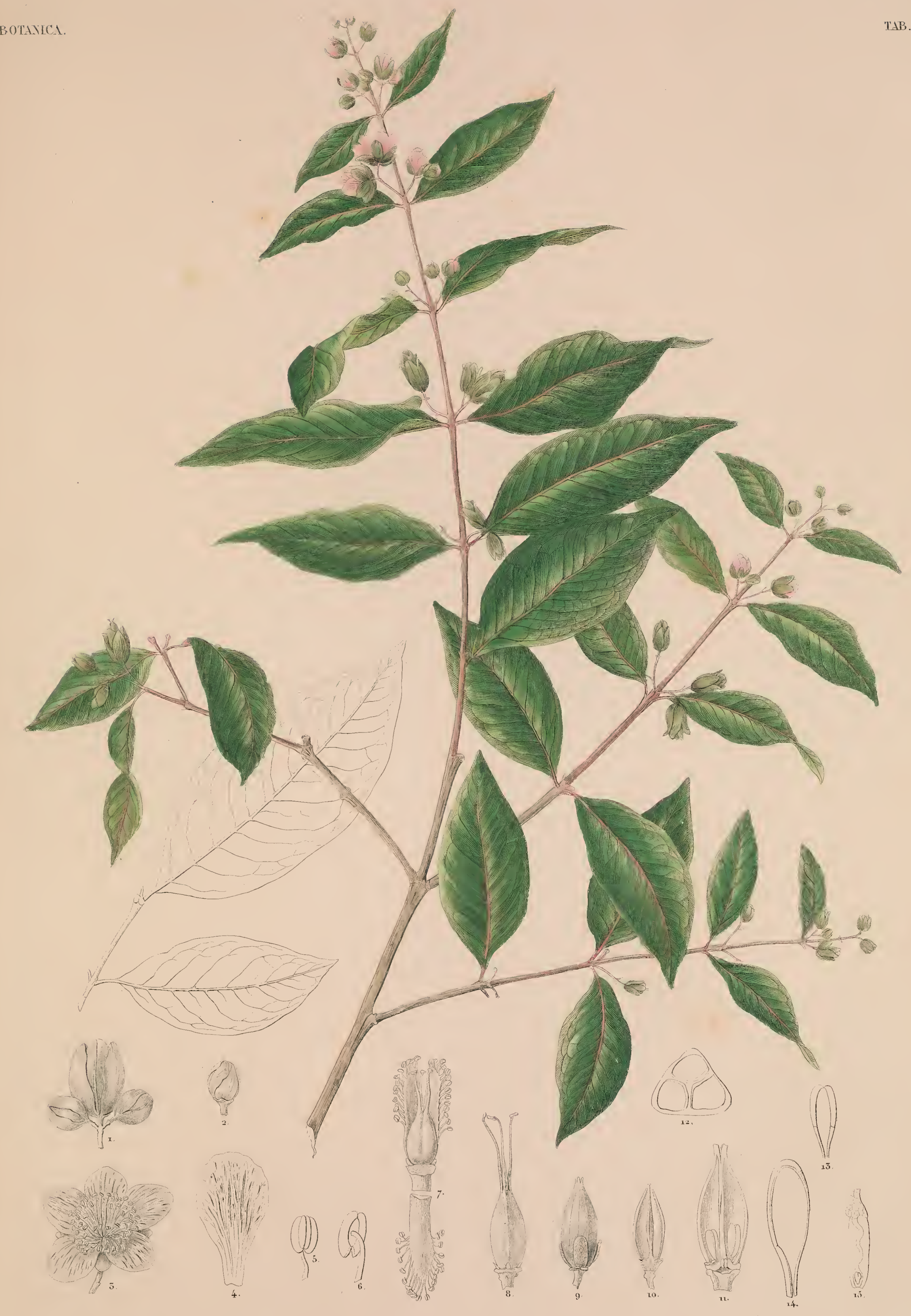


(2) 


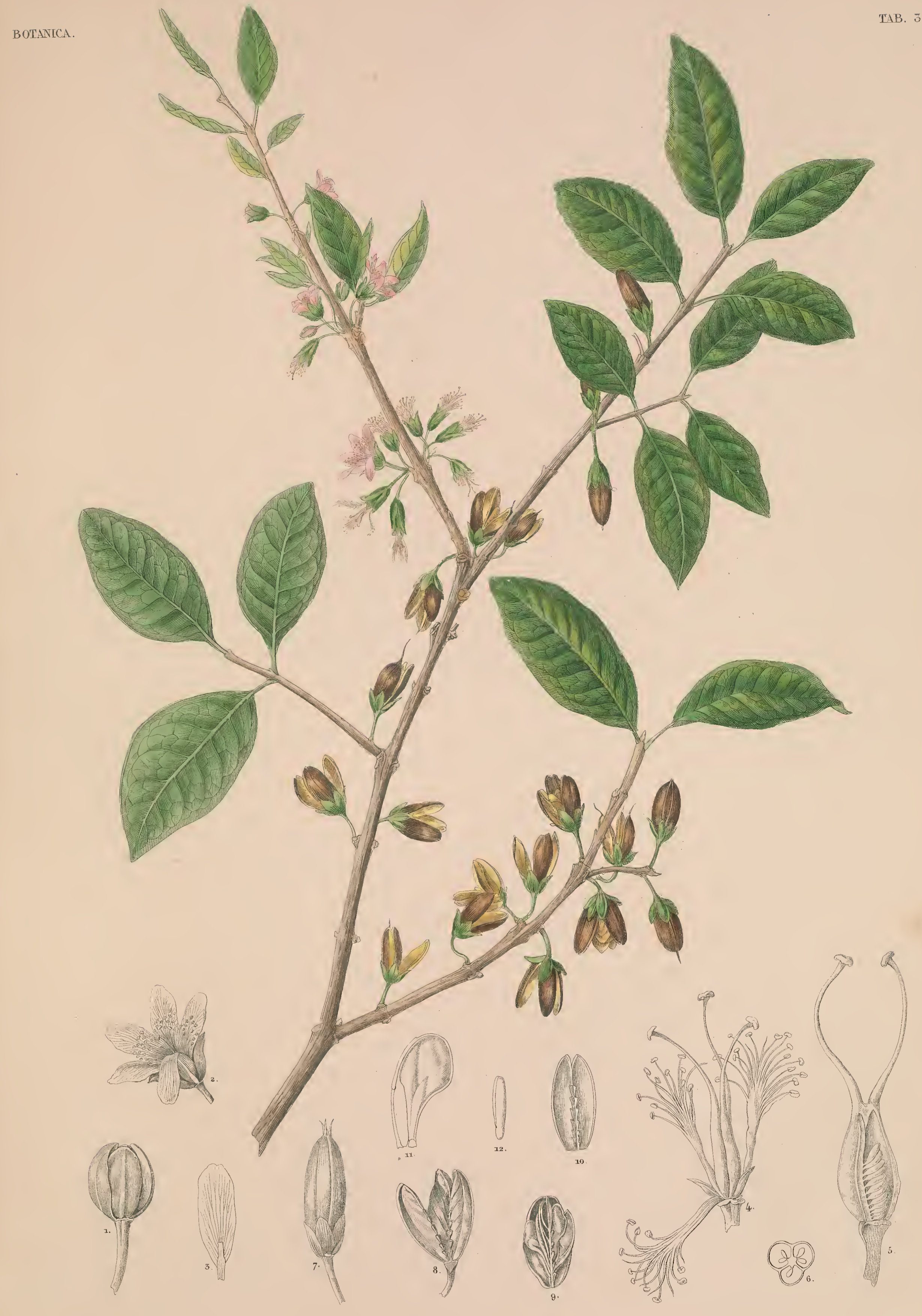

TRIDESMIS FORMOSA. 
$\odot$ 


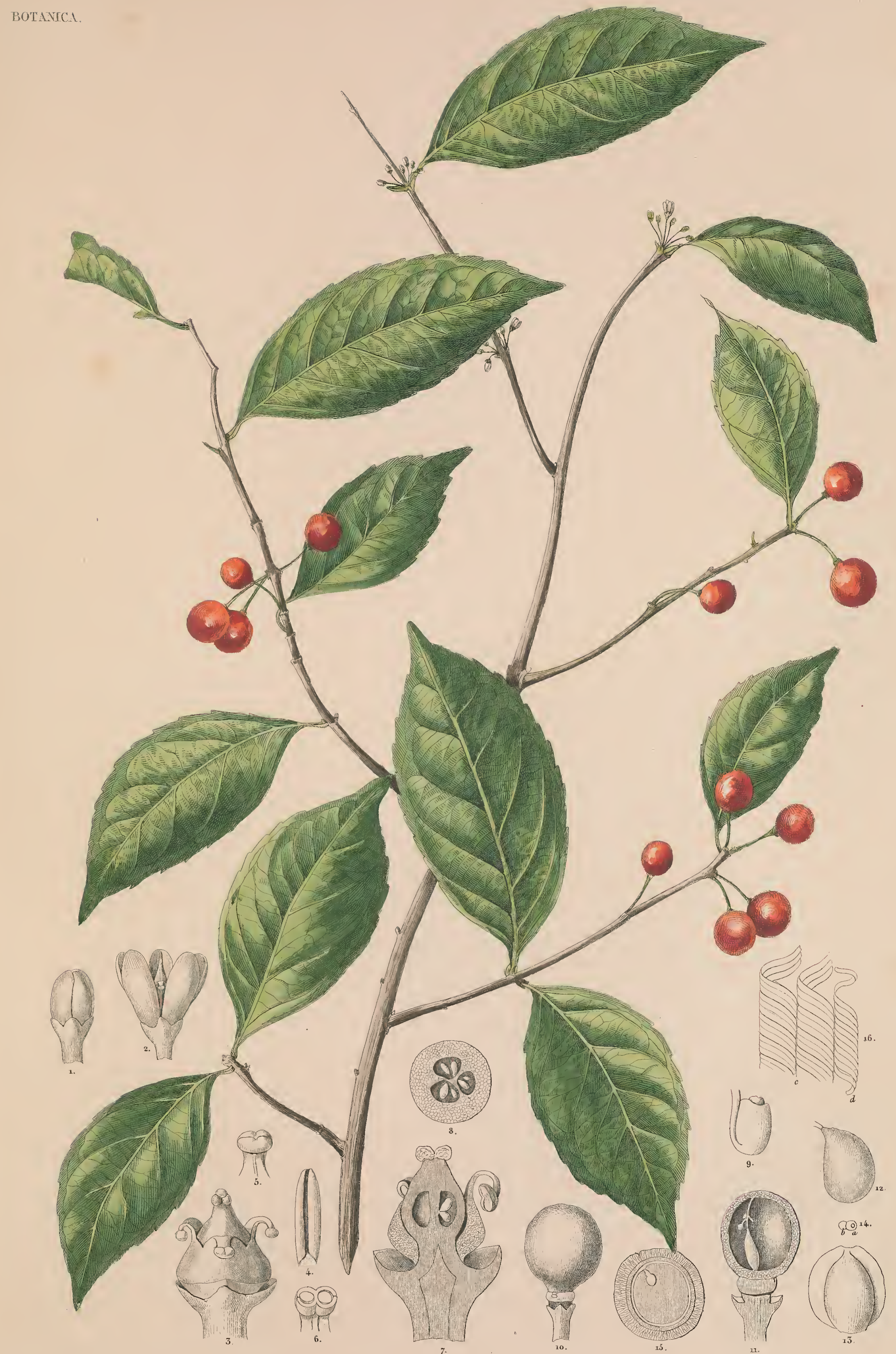

SALACIA KALAHIENSIS. 
(․․ 


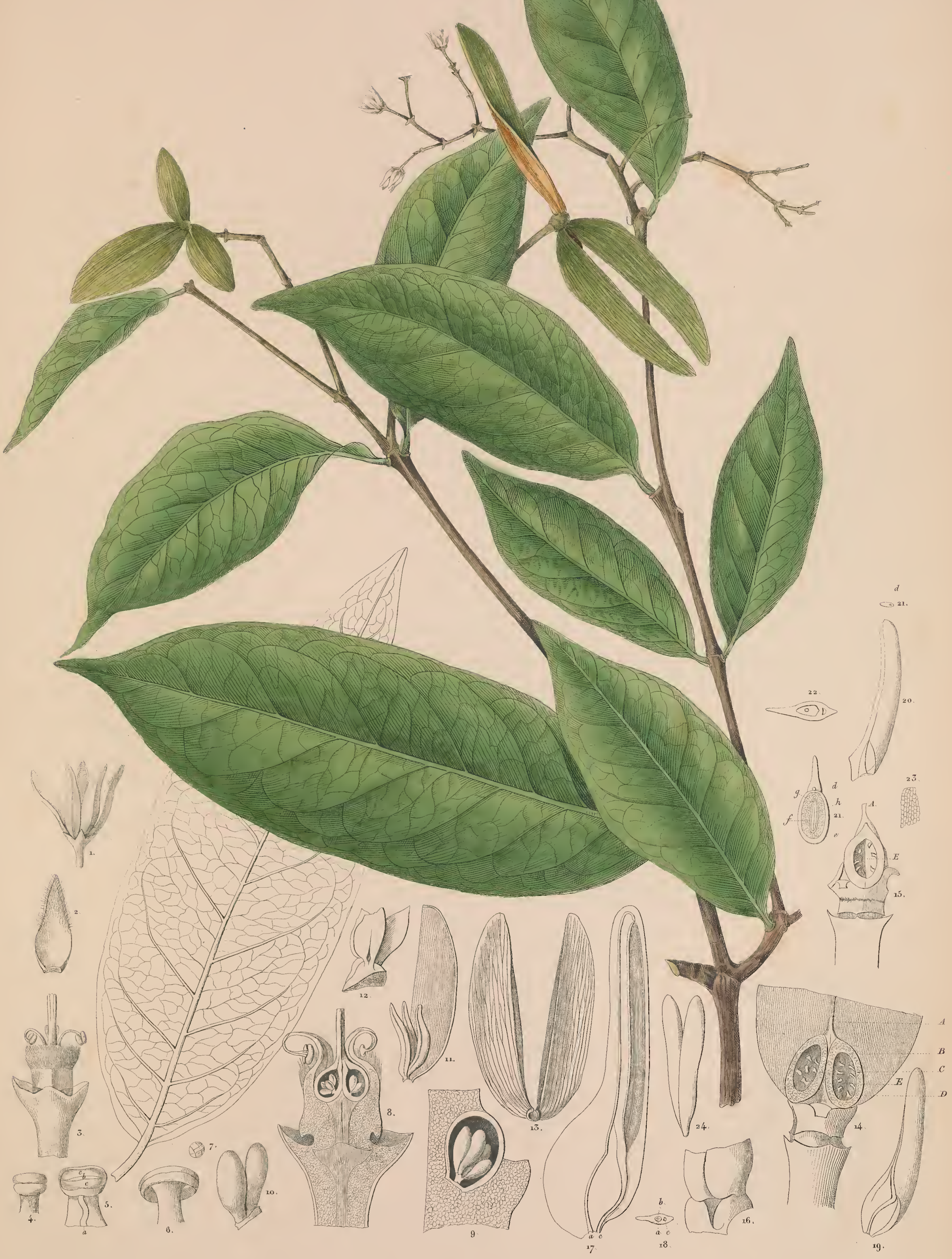

HIPPOCRATEA MACRANTHA. 
(2). 


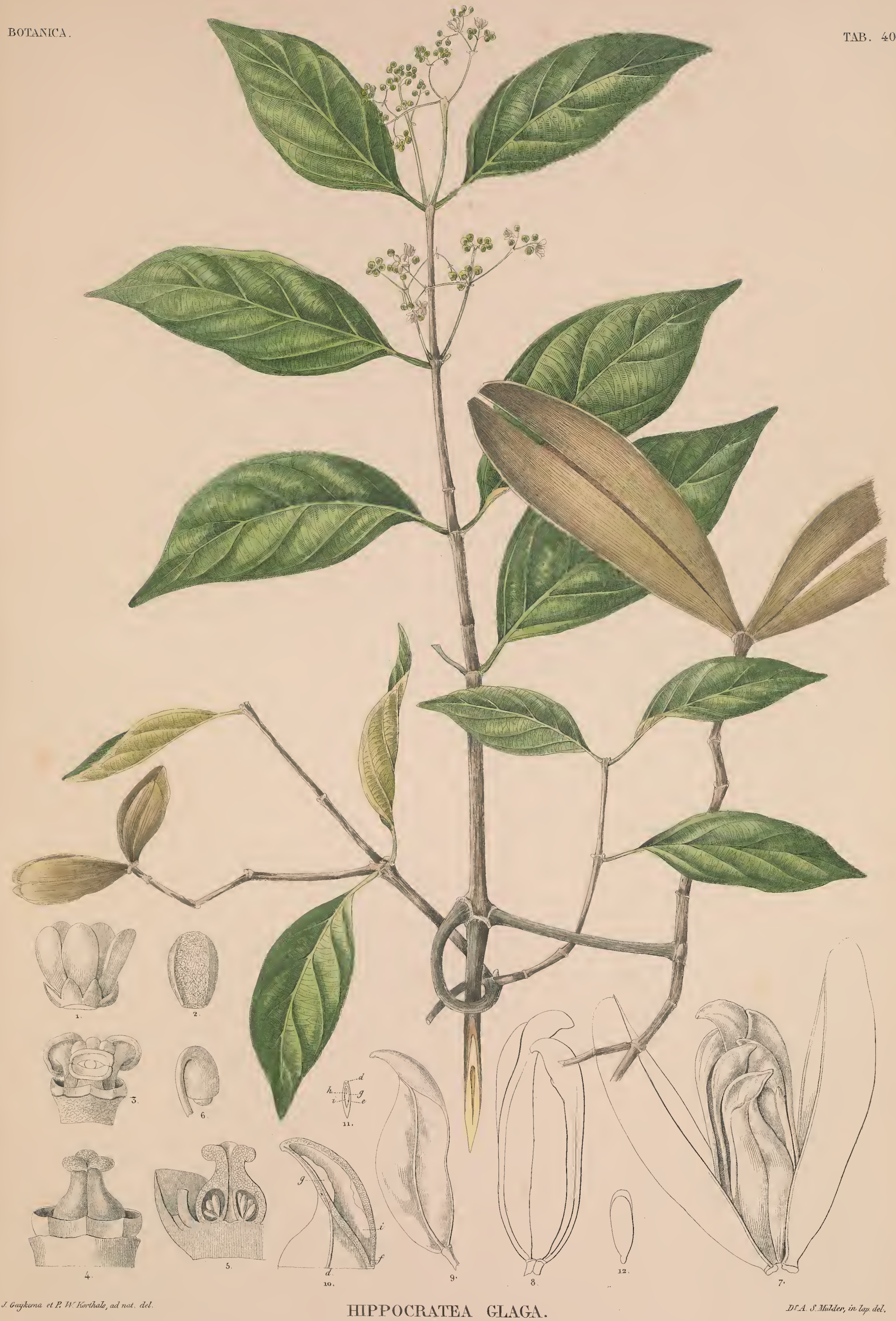


(.) 


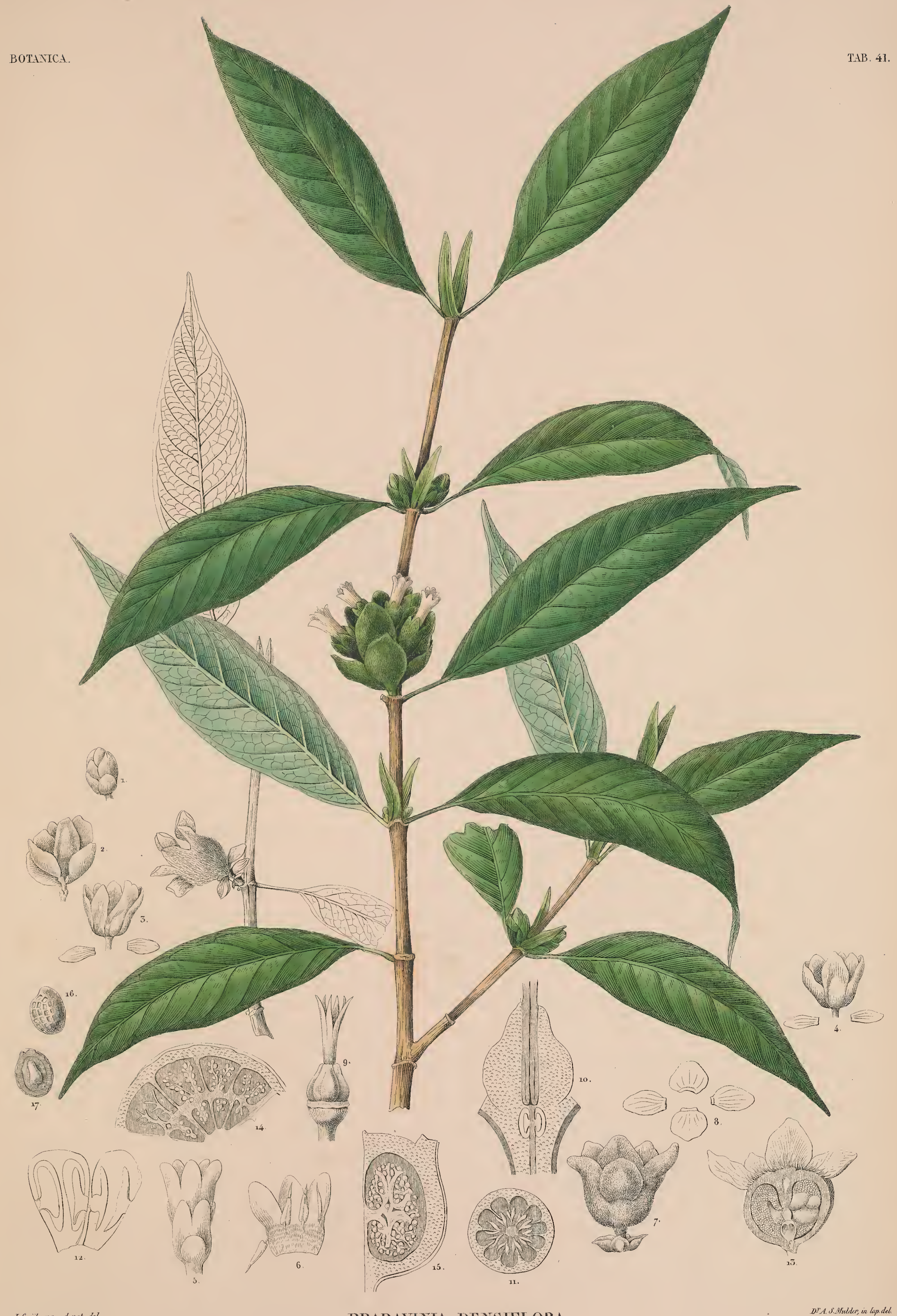

PRARIVINIA DENSIFLORA. 

BOTLNICA.

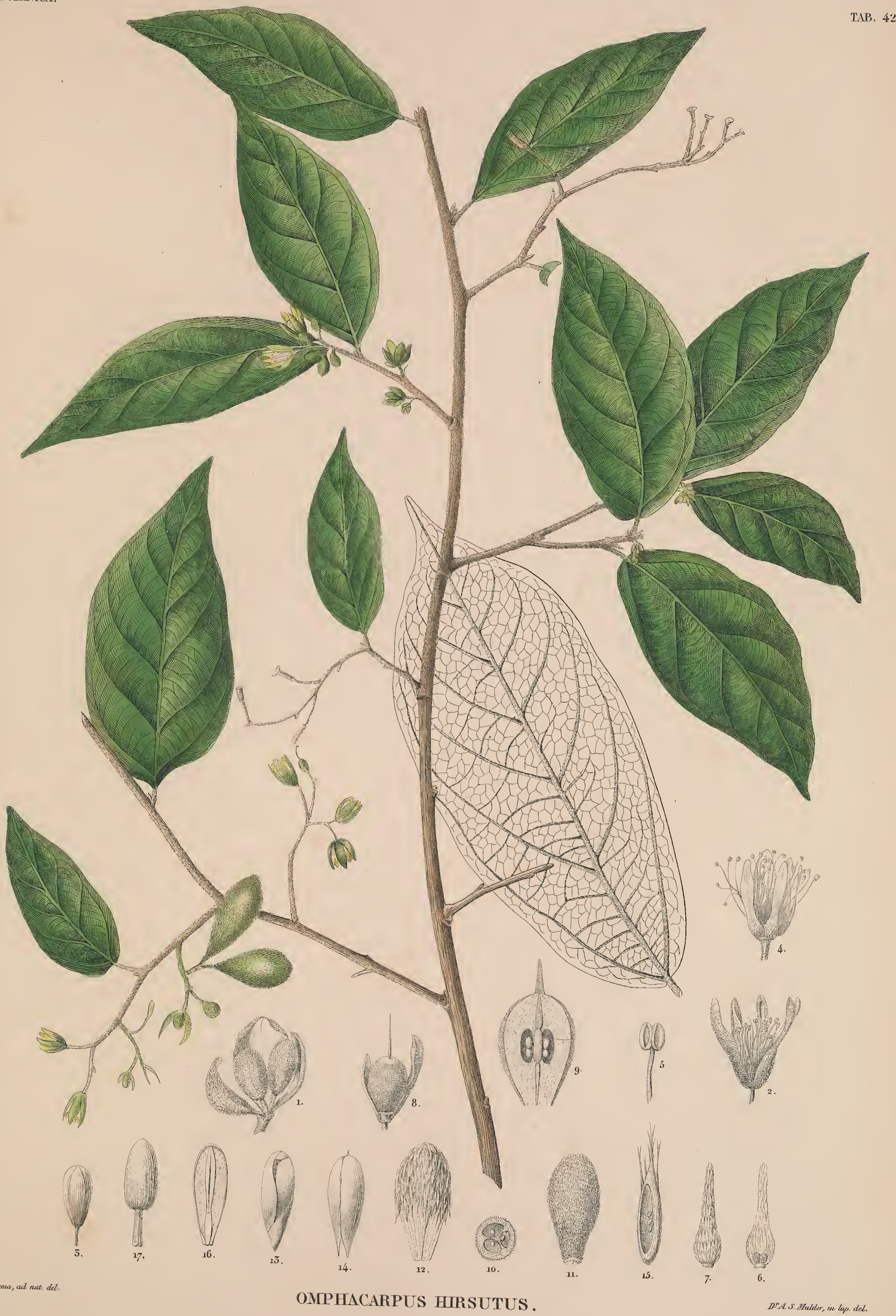




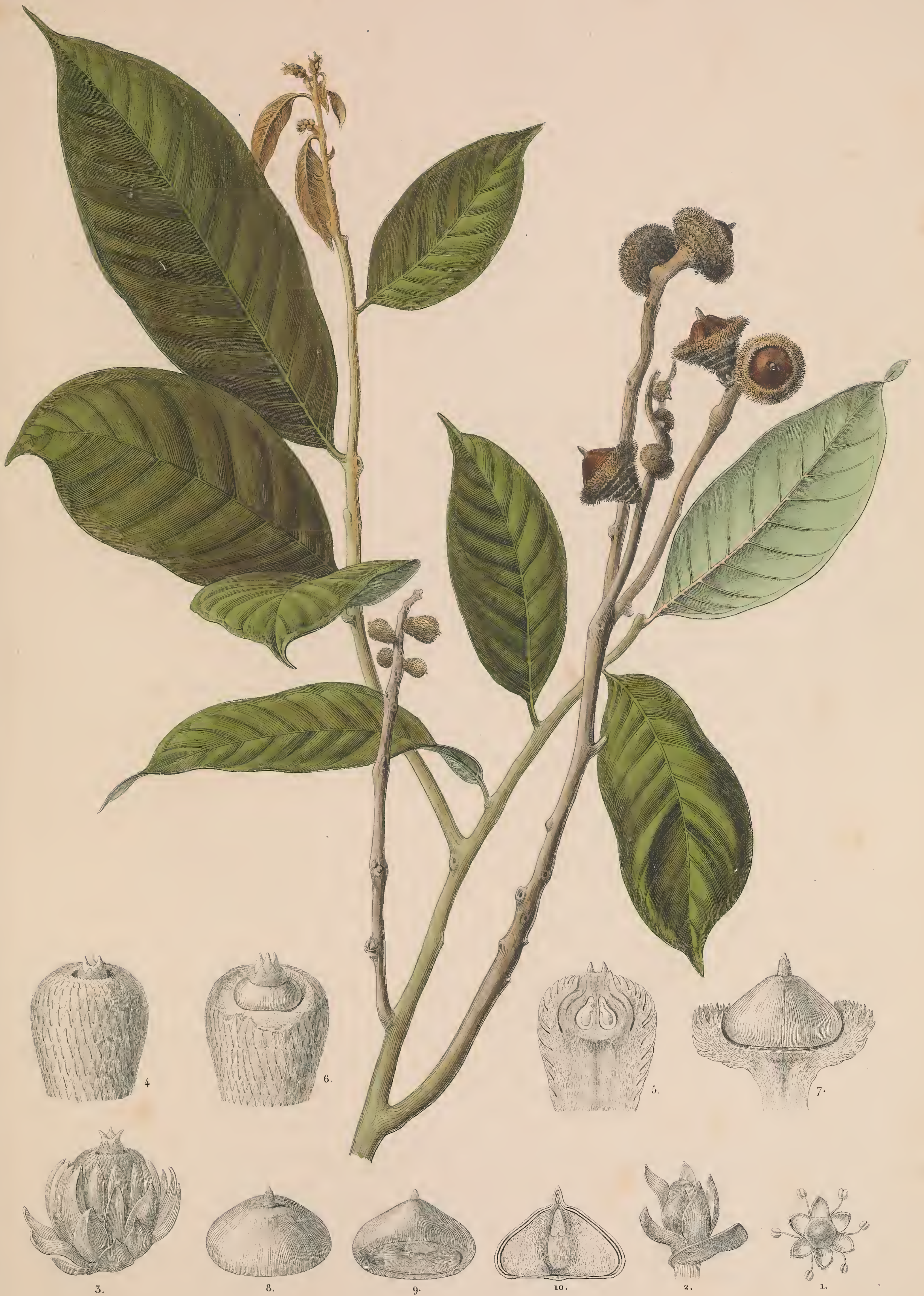

OUERCUS HYSTRIX. 


$$
\text { (-) }
$$


BOTANICA.

TAB 44 .
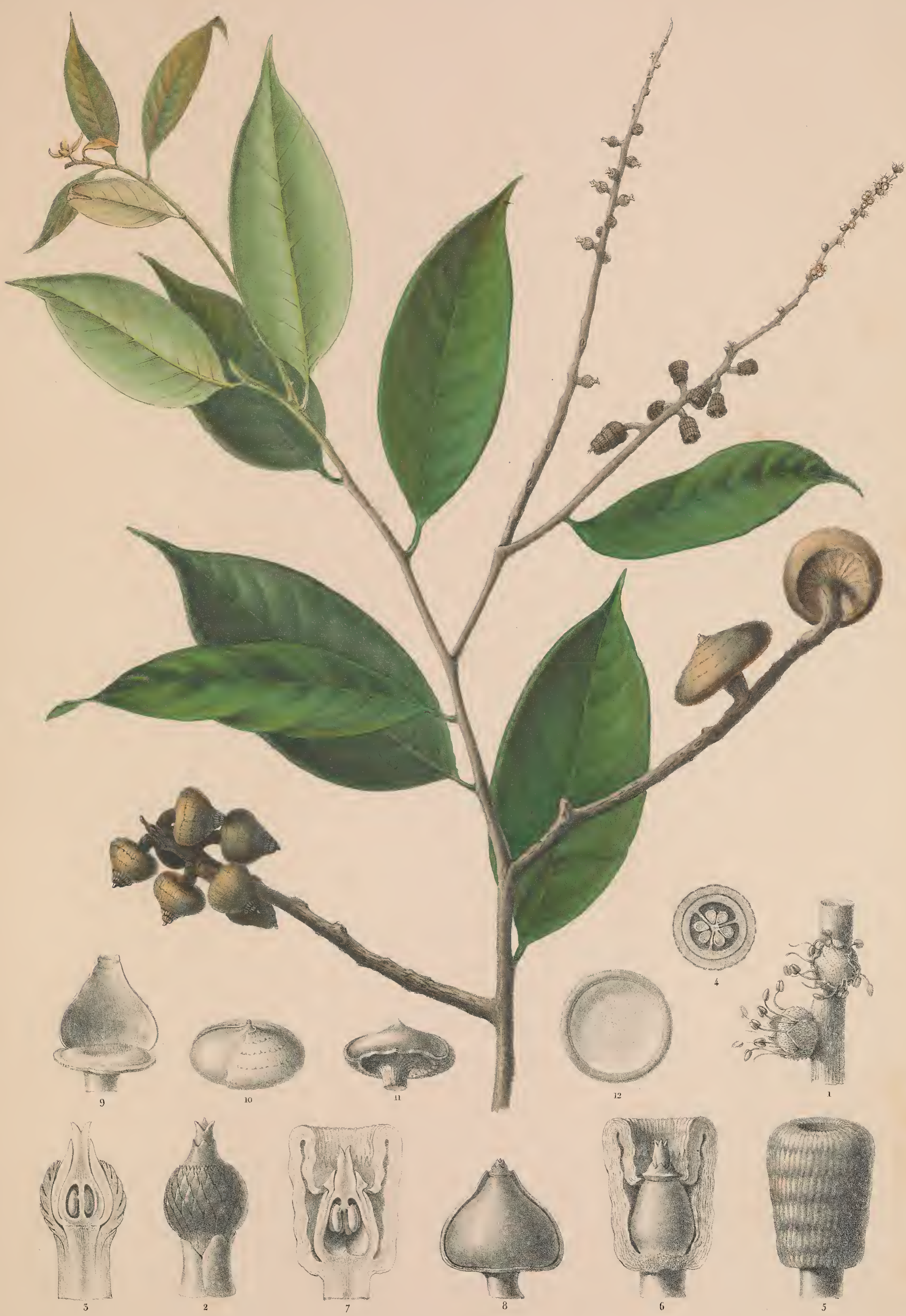

W. T. Gordon, in lop, del.
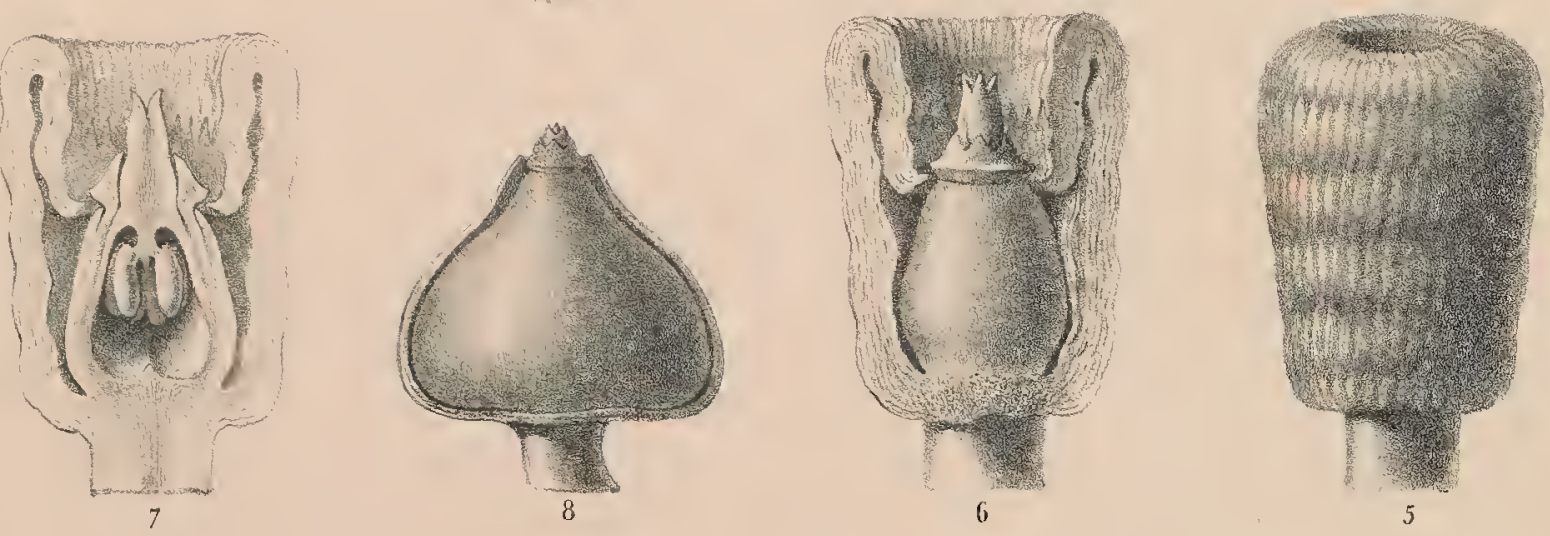

OLERCUS BLUMEANA. 
장 


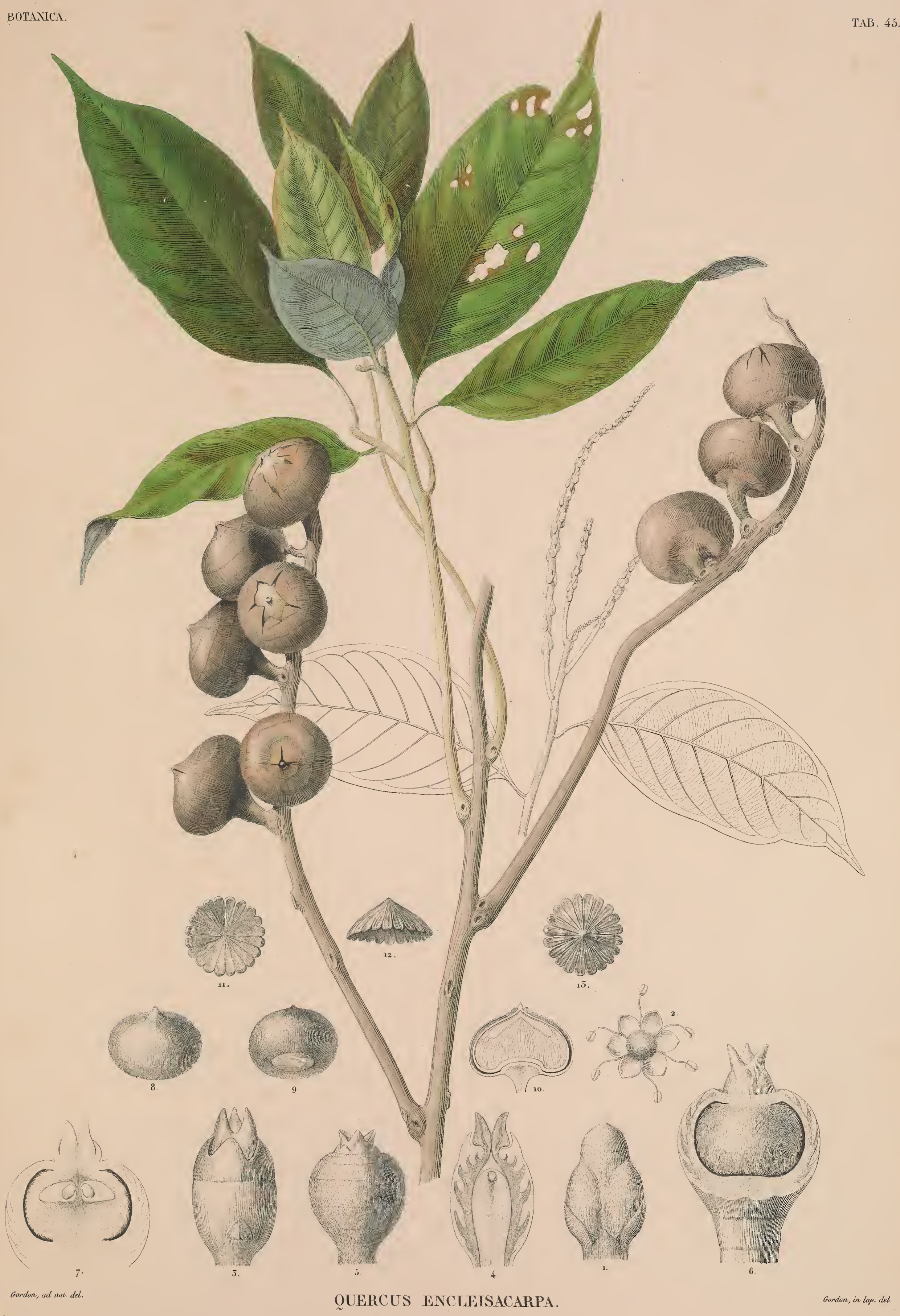


(2) 

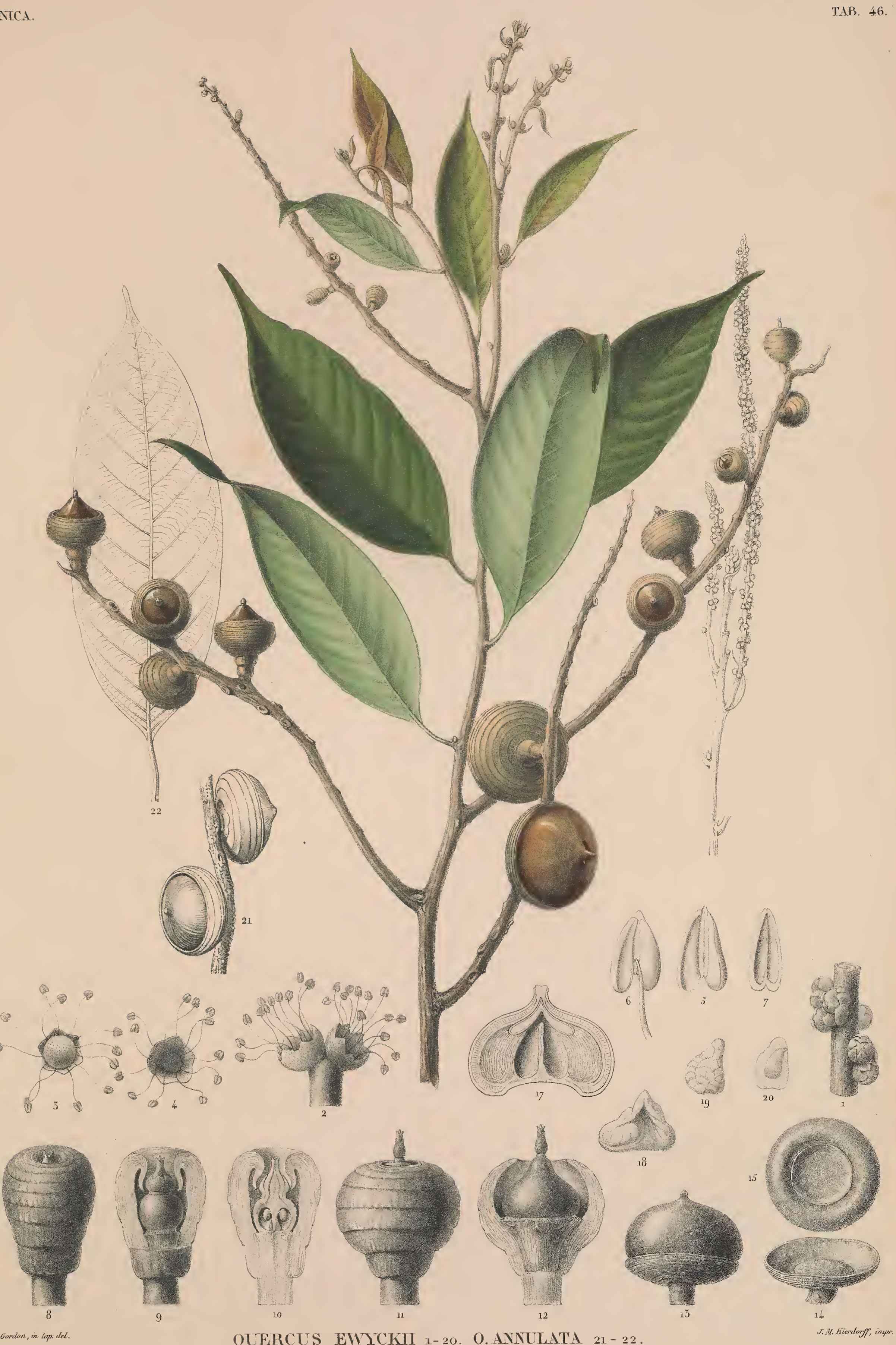



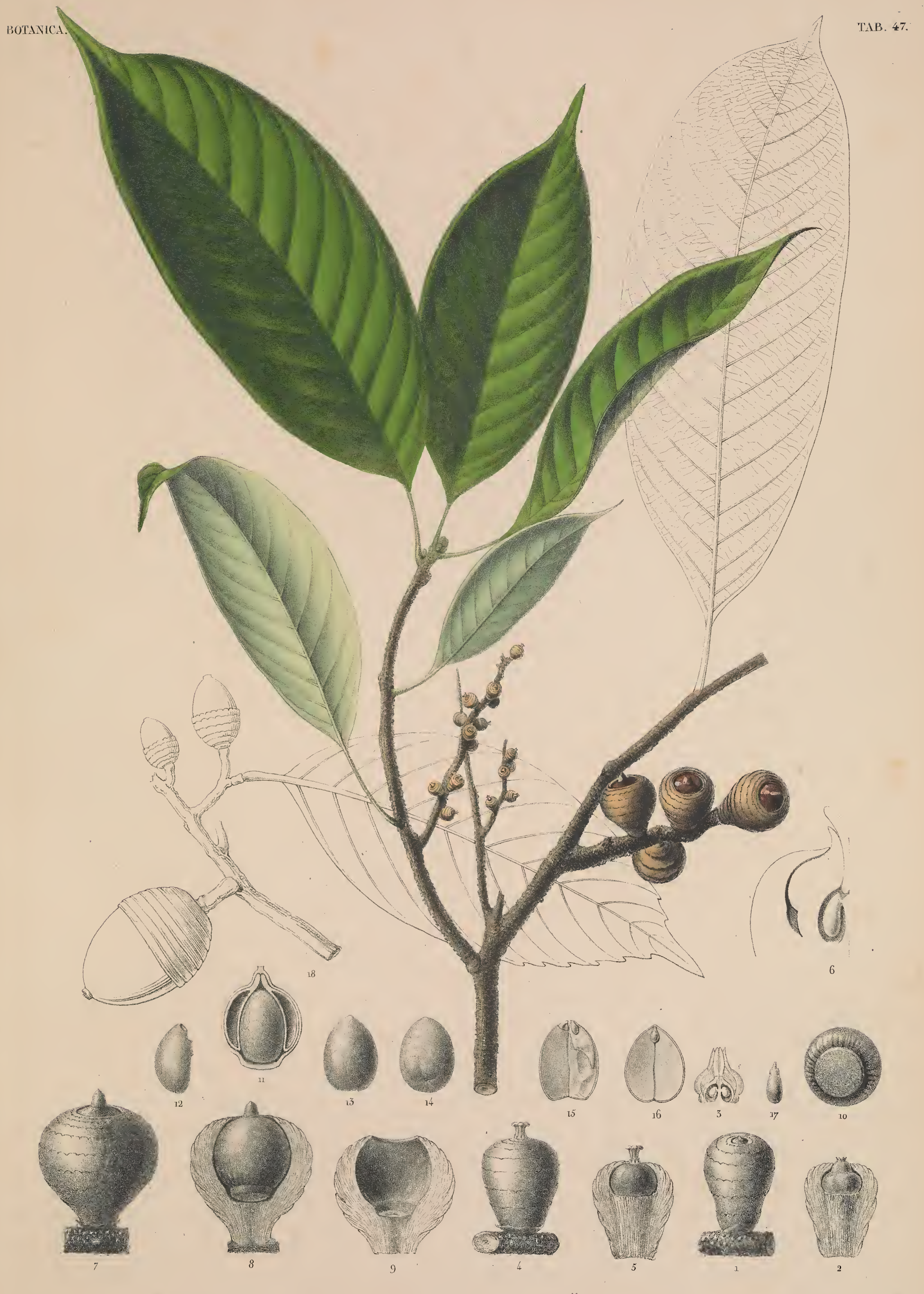

OUERCUS ARGENTATA 1-17,-0.0ÏDOCARPA 18. 
. 


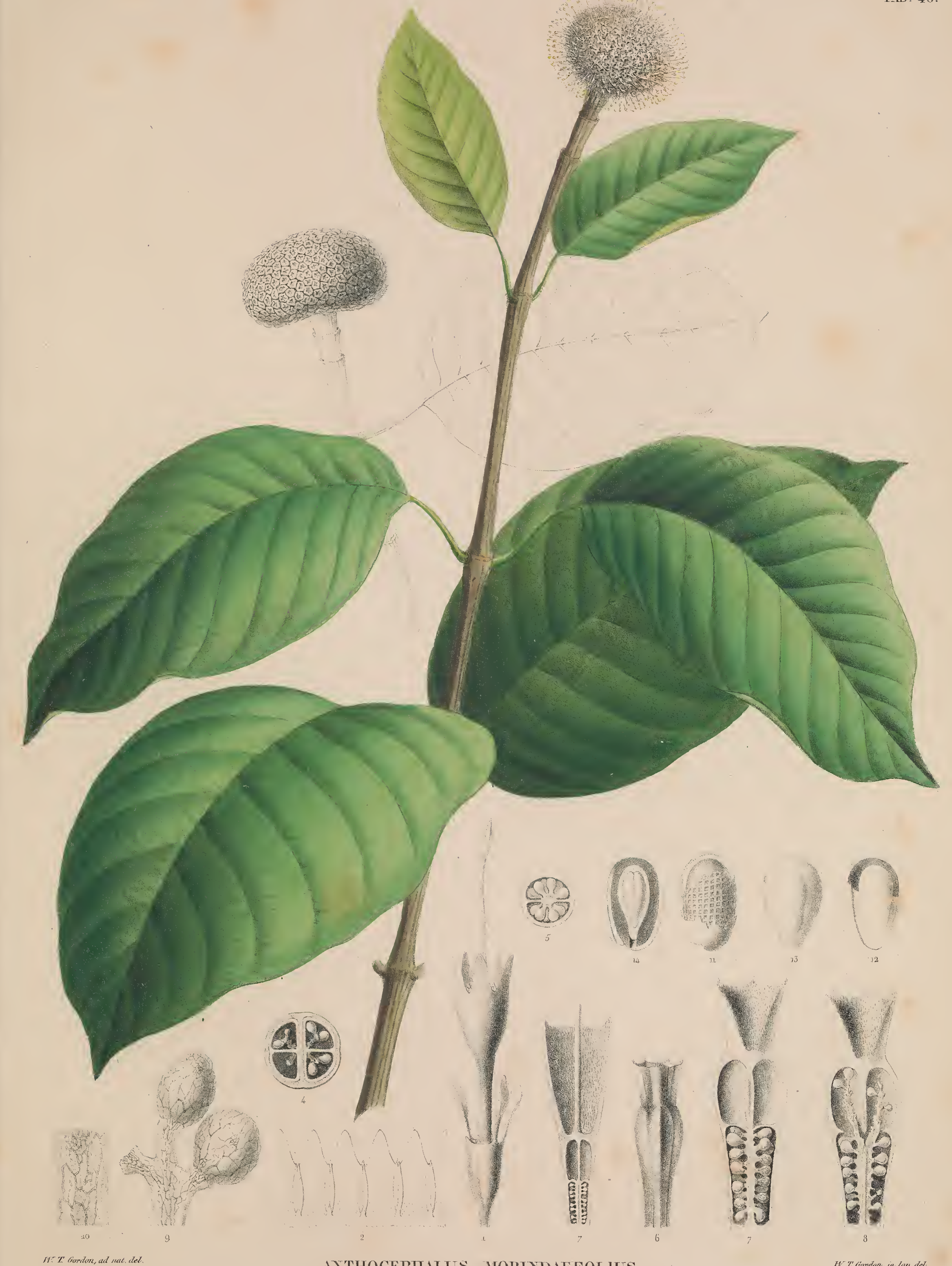


(.) 


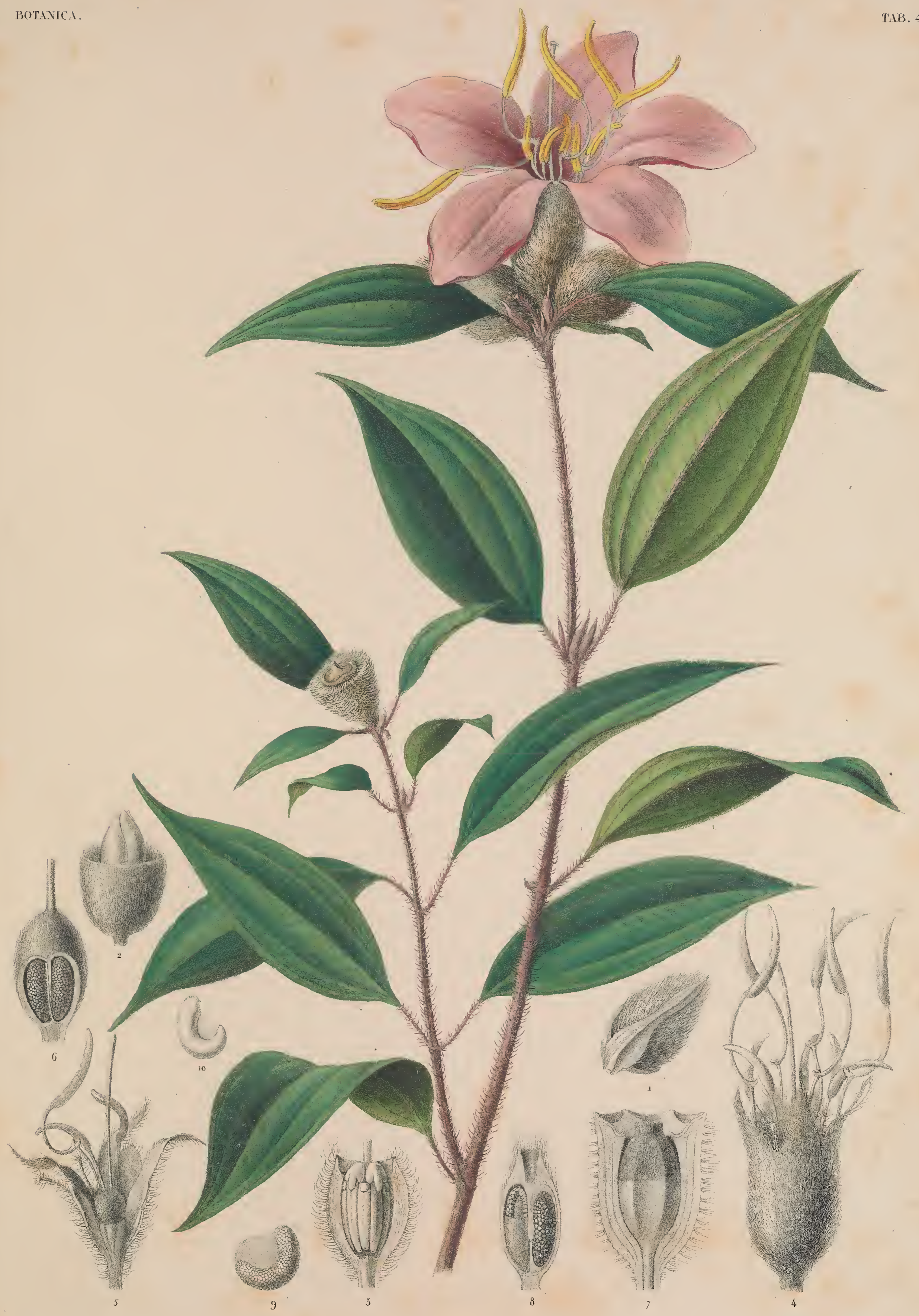

MELASTOMA PLLCHERRTUUM. 


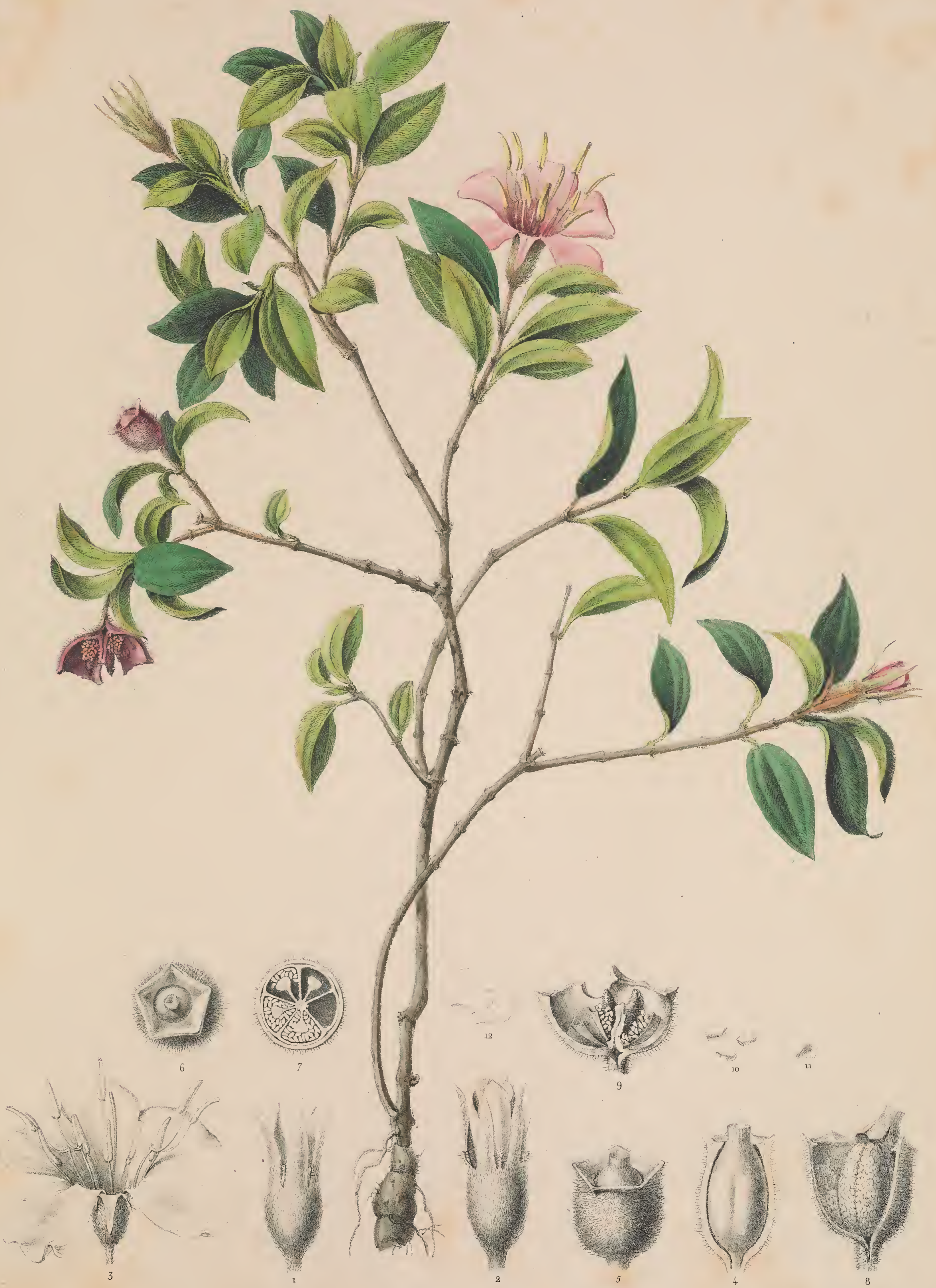

MELASTOMA BORUJANJM. 
(․ㅏㅇ 


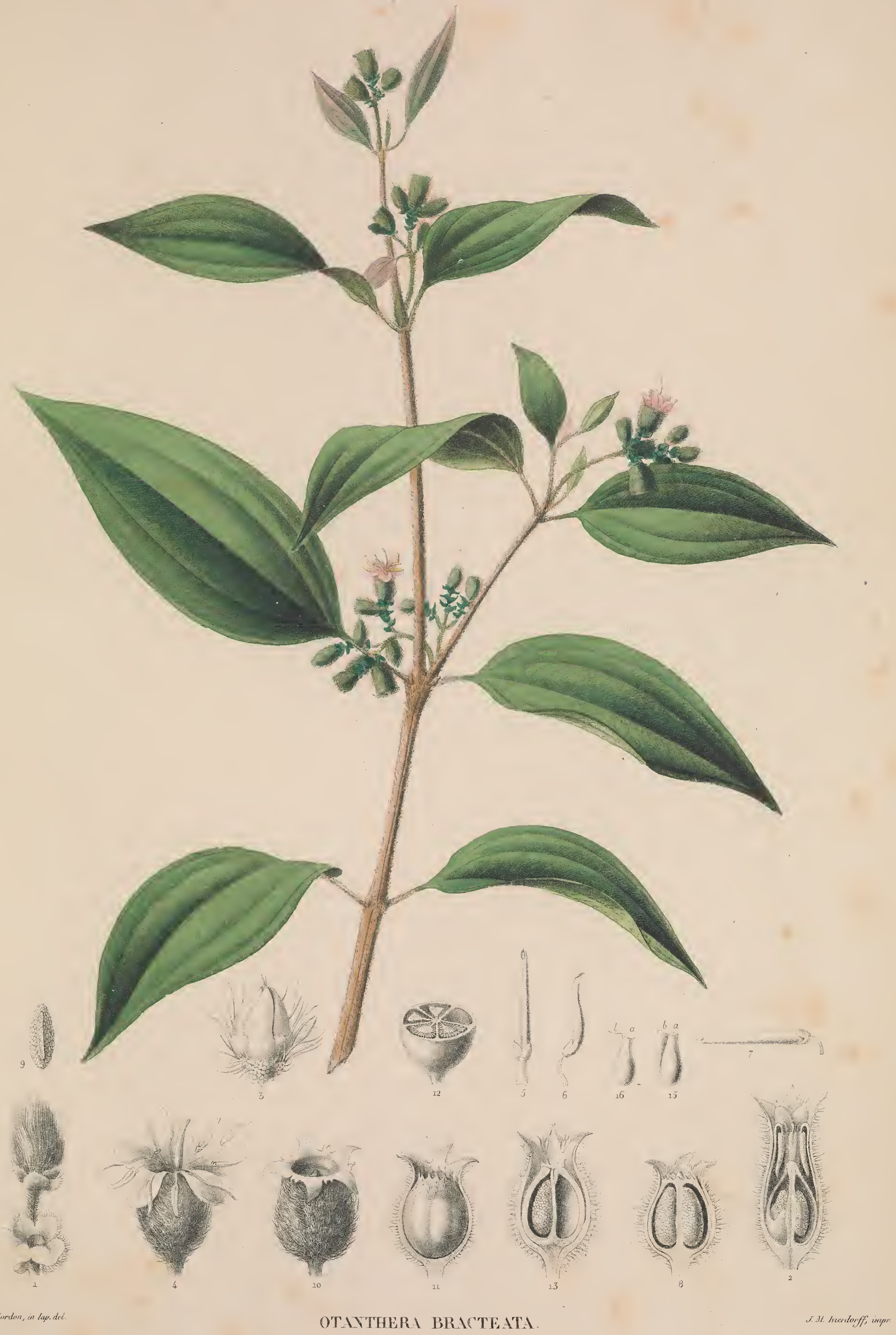





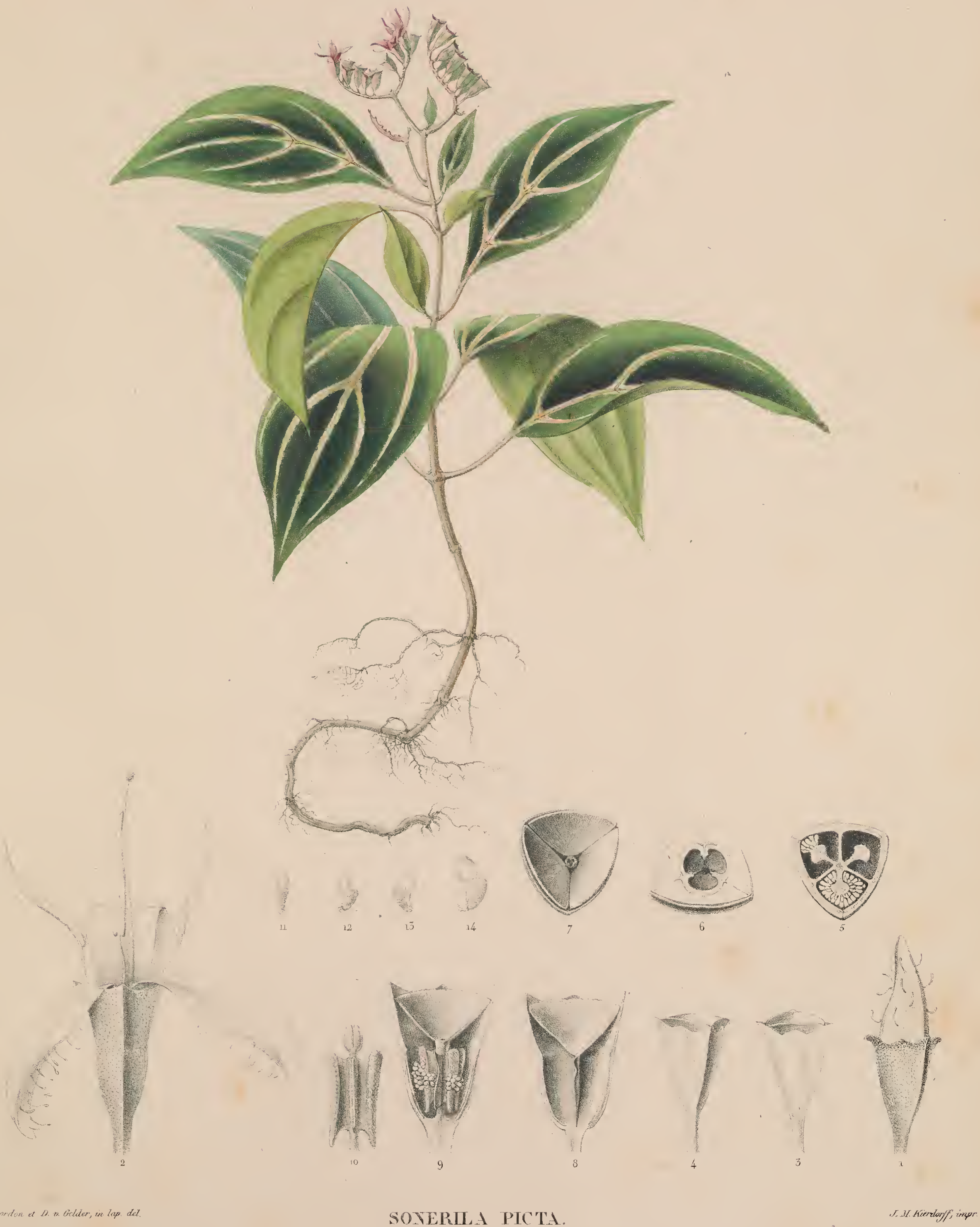


다 


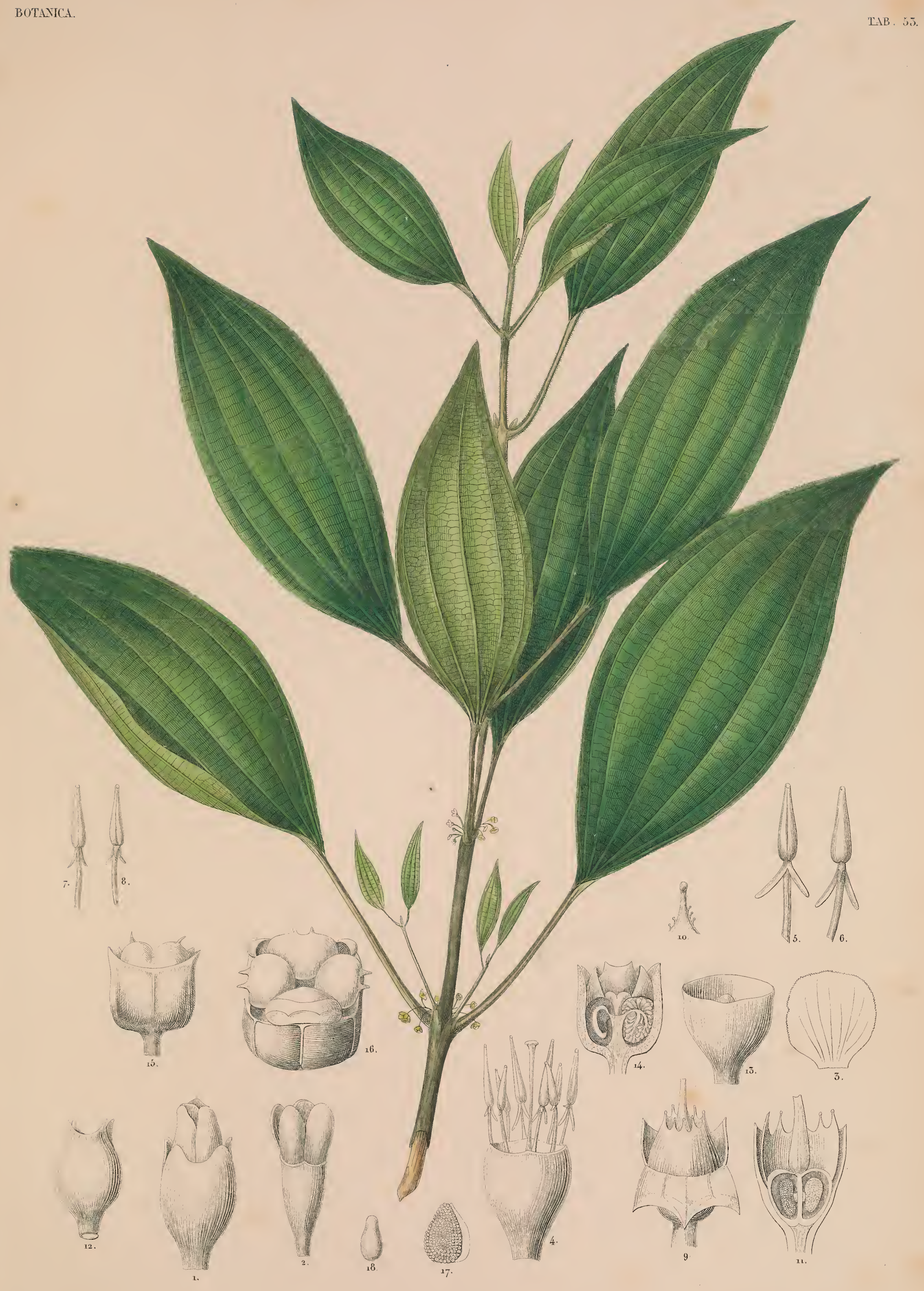

DRUESSENIA AXANTHA. 
… 


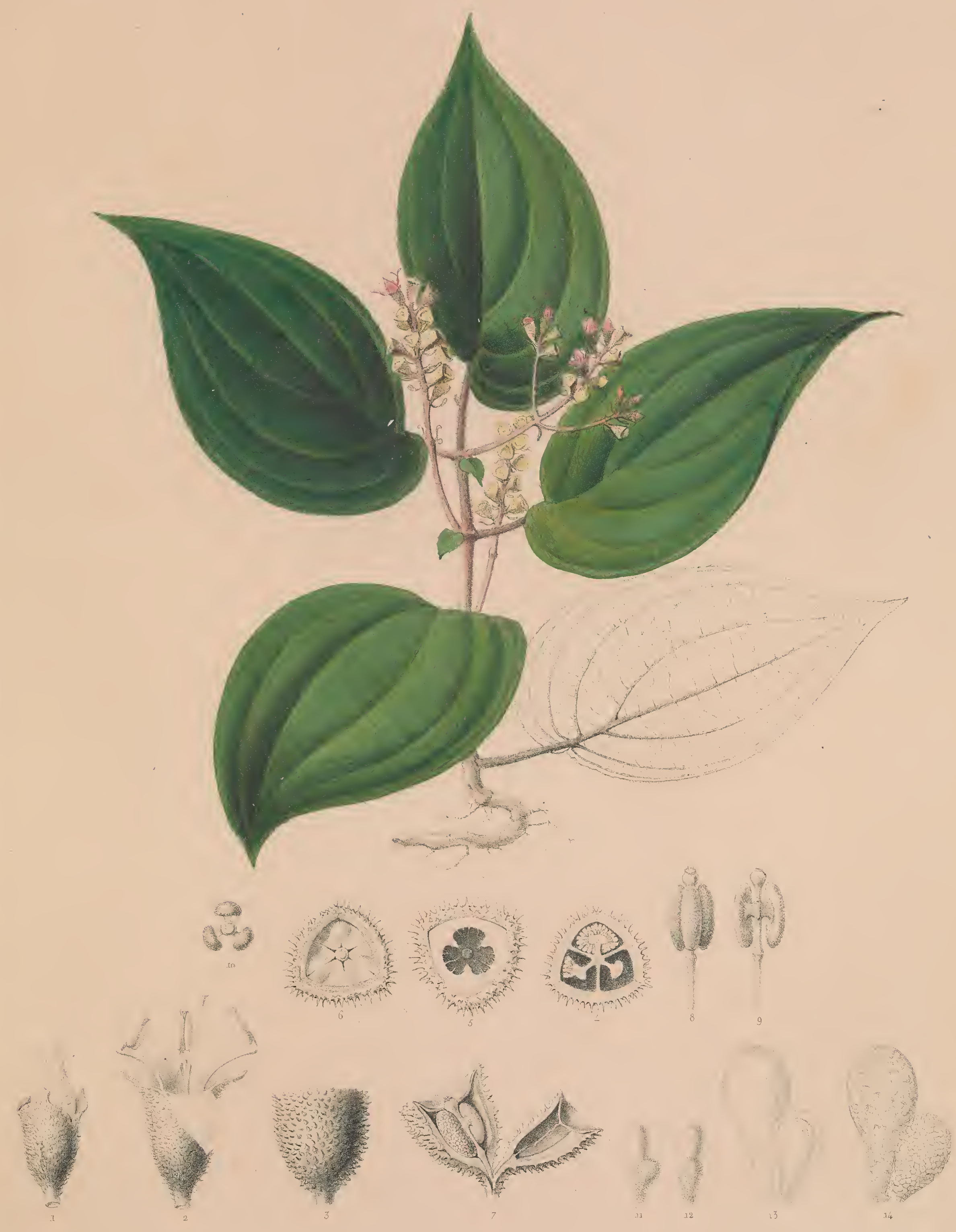


(ㄱ) 
BOTANCA.

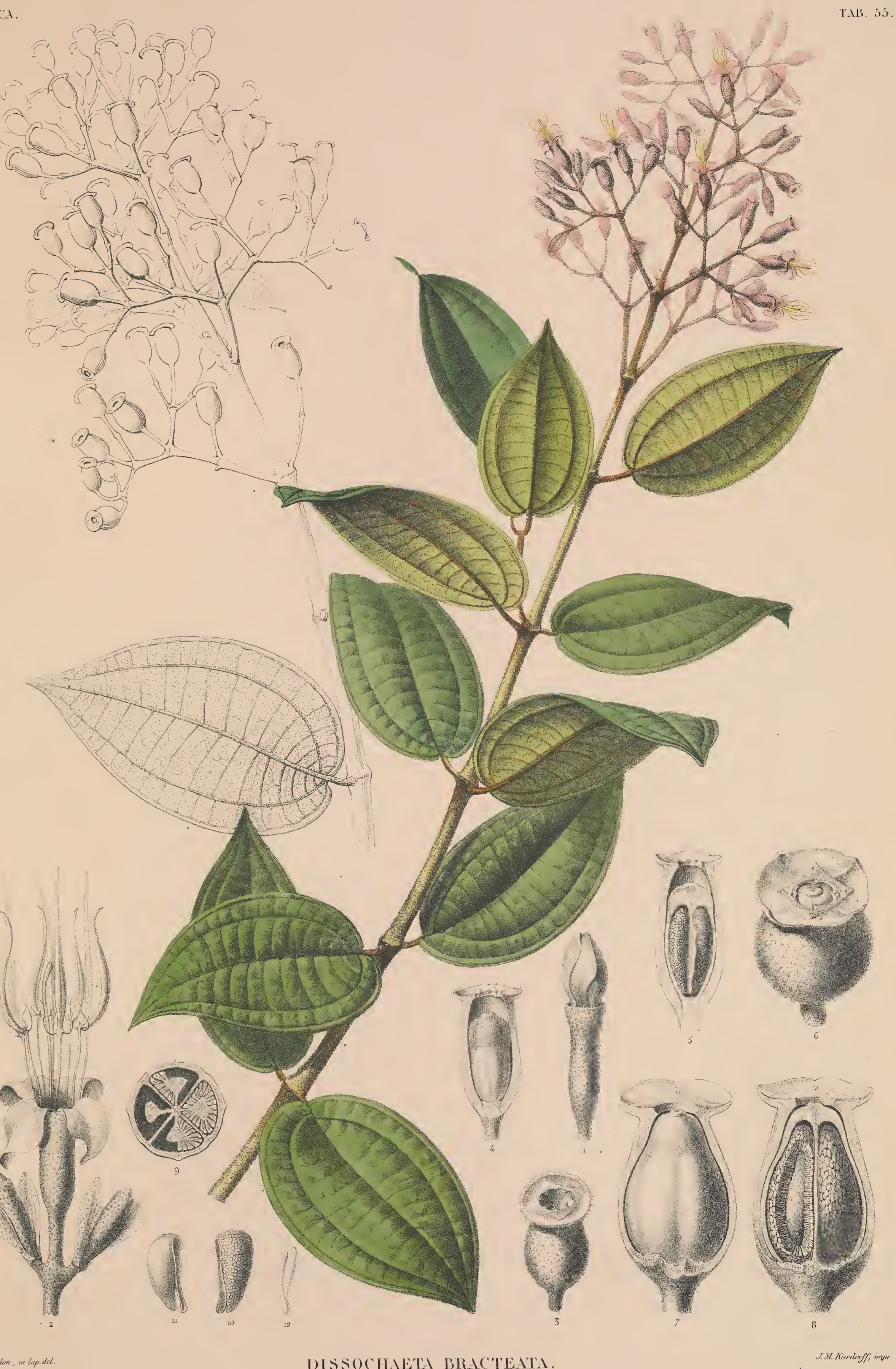


… 
Botarica.
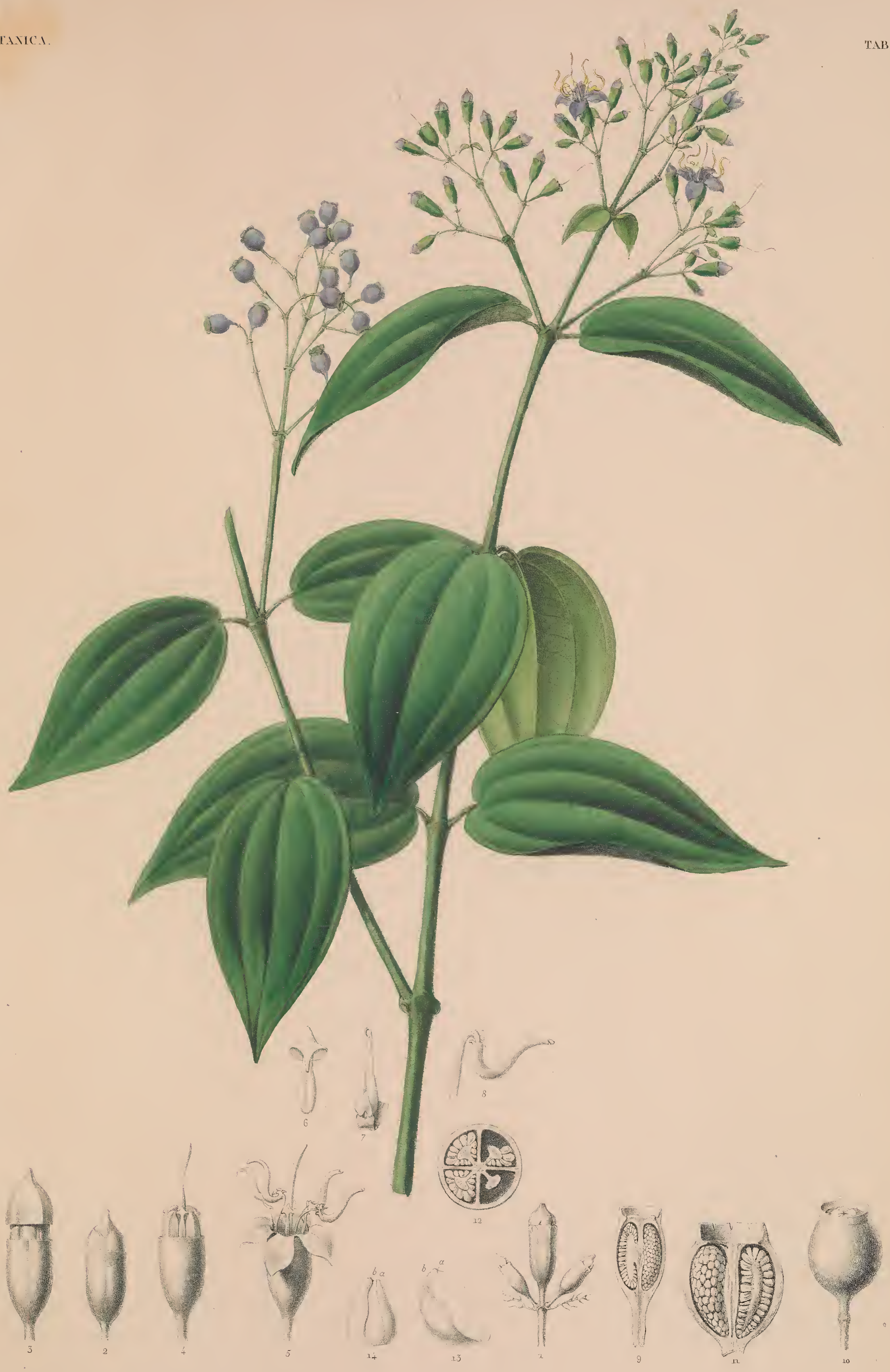

DISSOCHAETA CYAYOCARPA. 
ㅈ.. 


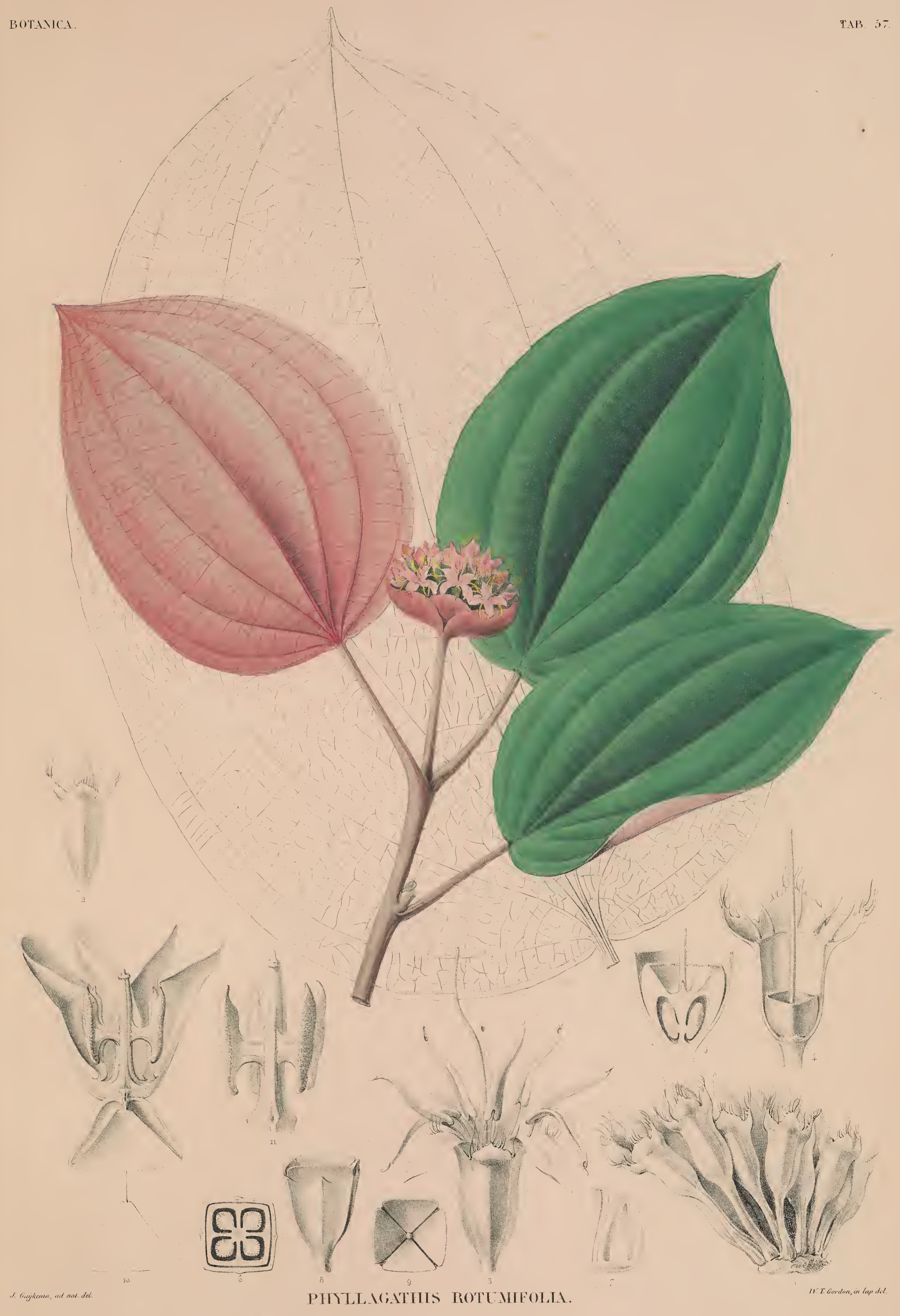


(2) 


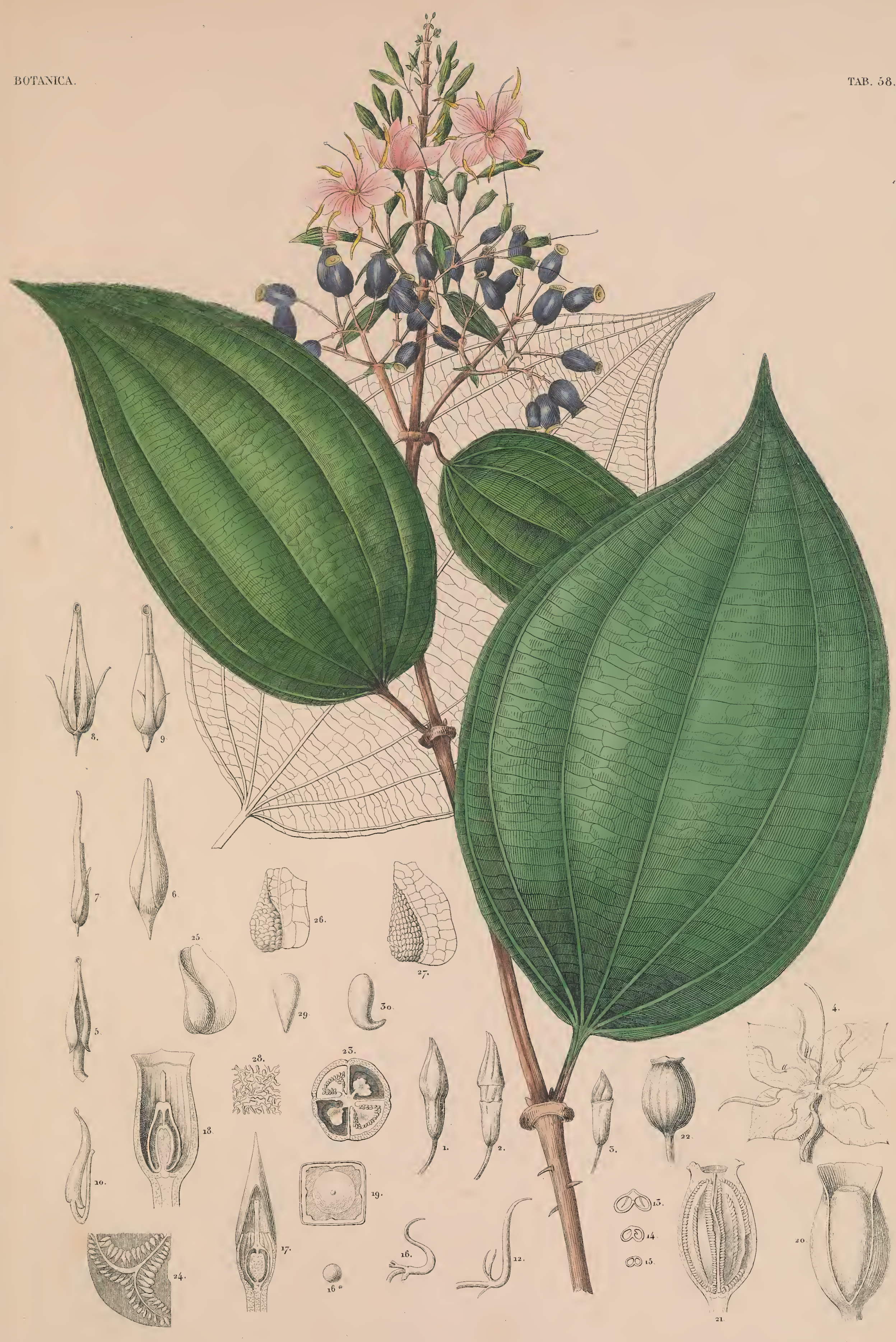


잉 

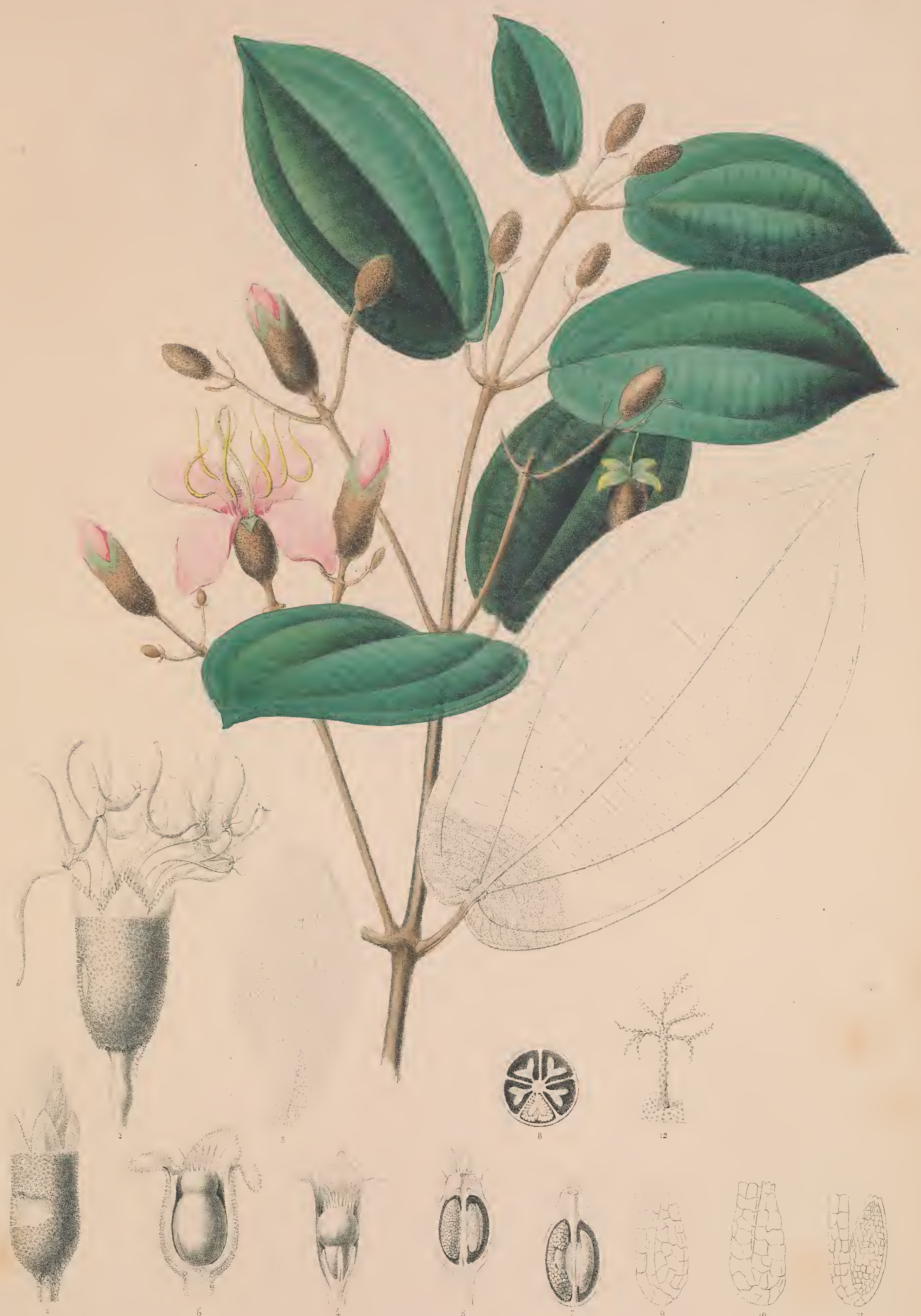

(1) 0

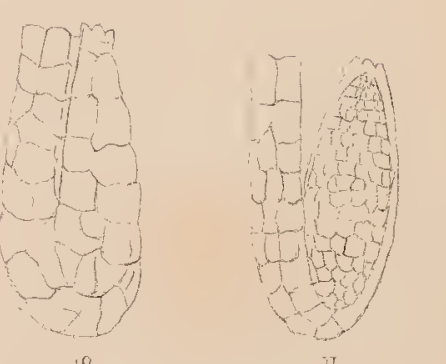

MARUMIA PACHYGYNA. 
(2) 


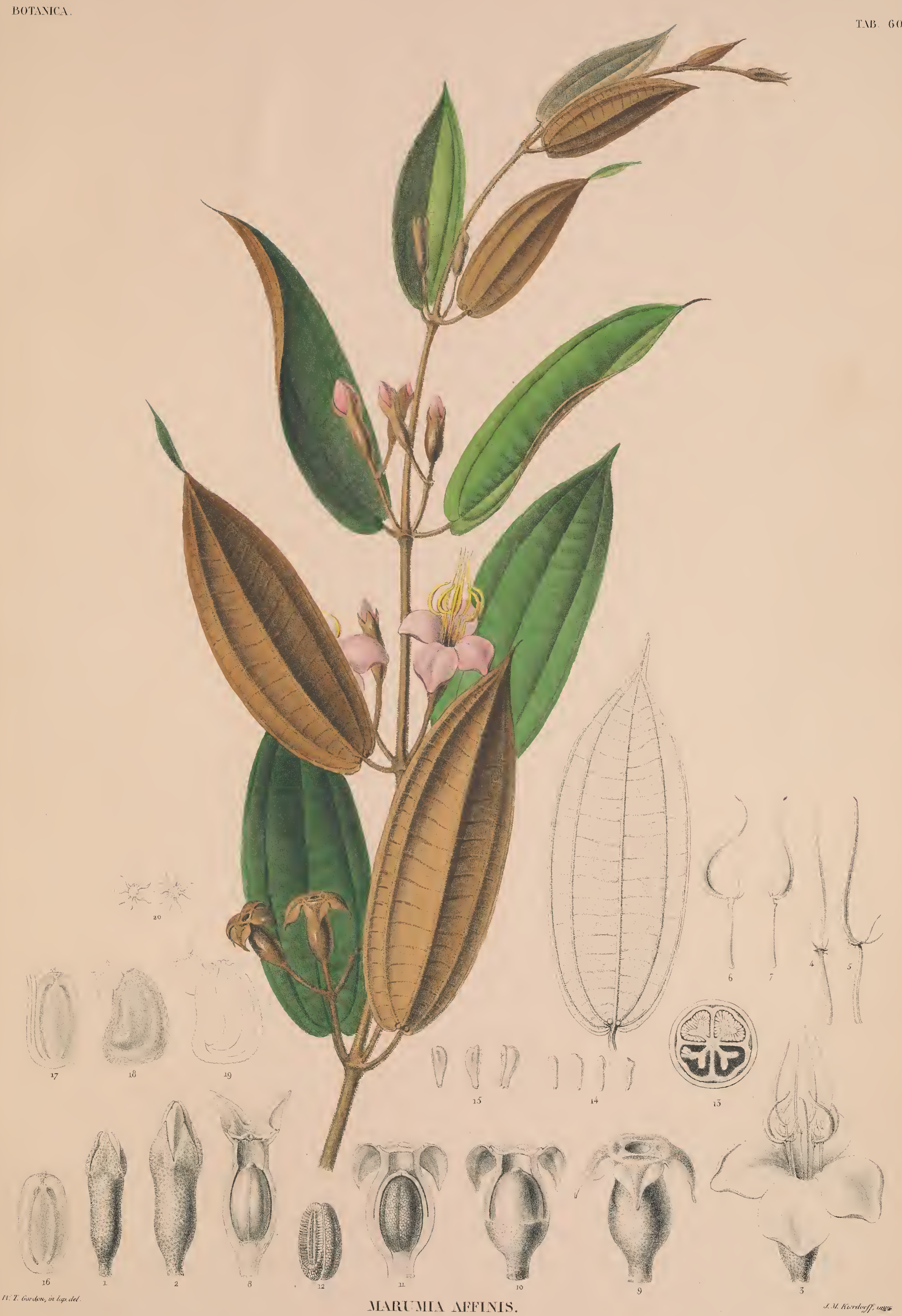


응 


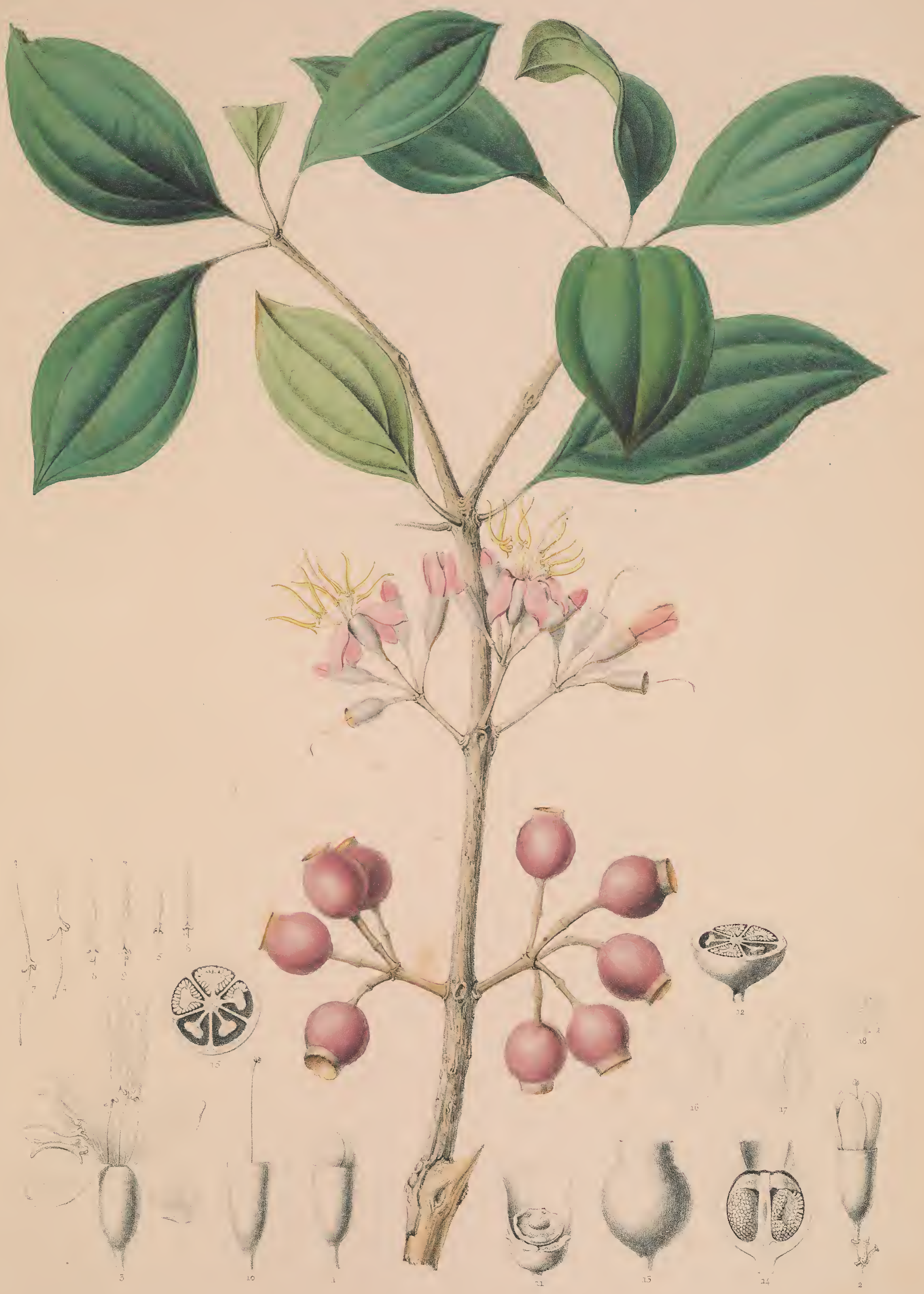


(-) 
BOTANICA.

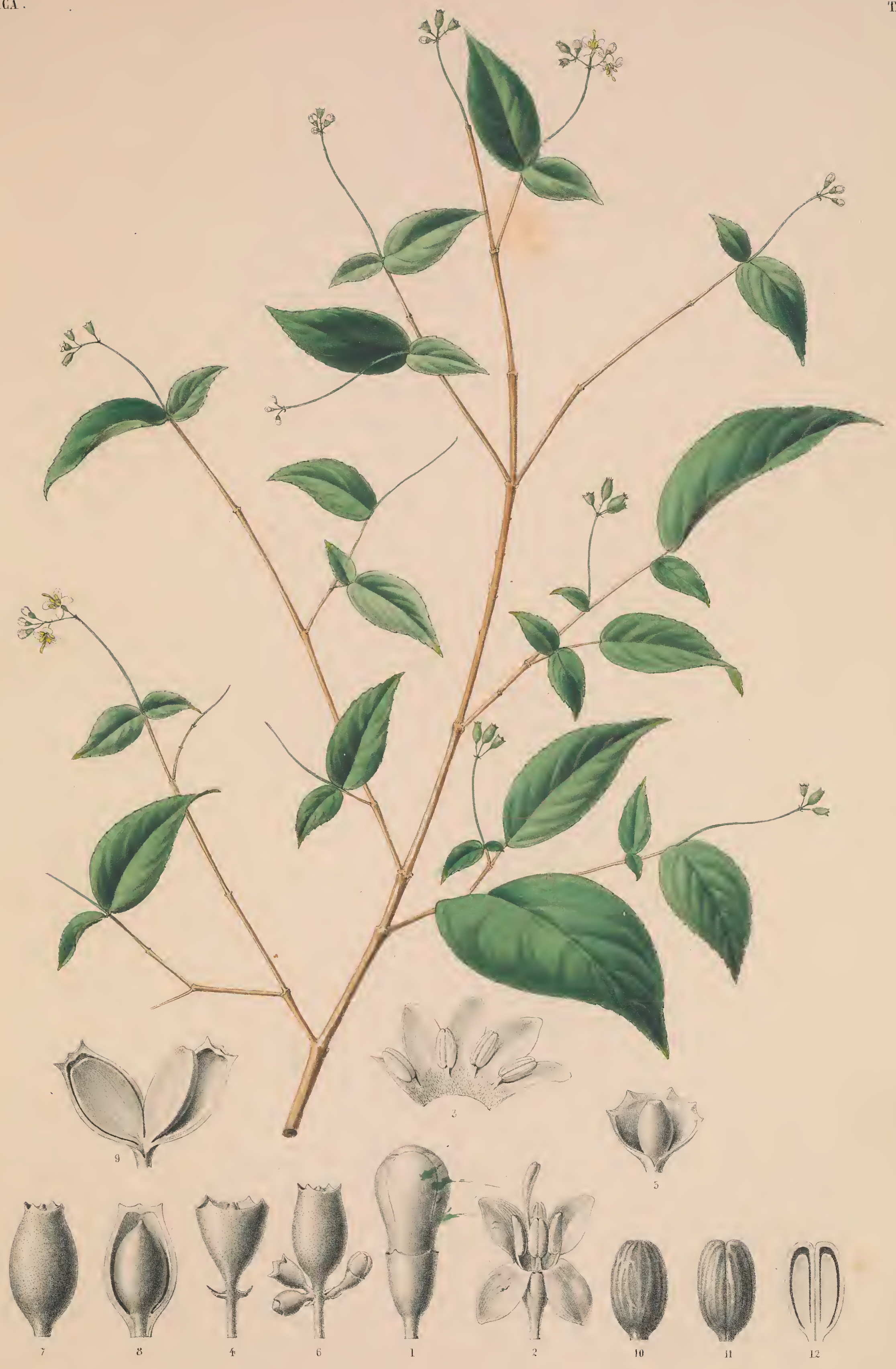

TAB. 6 . 
장 


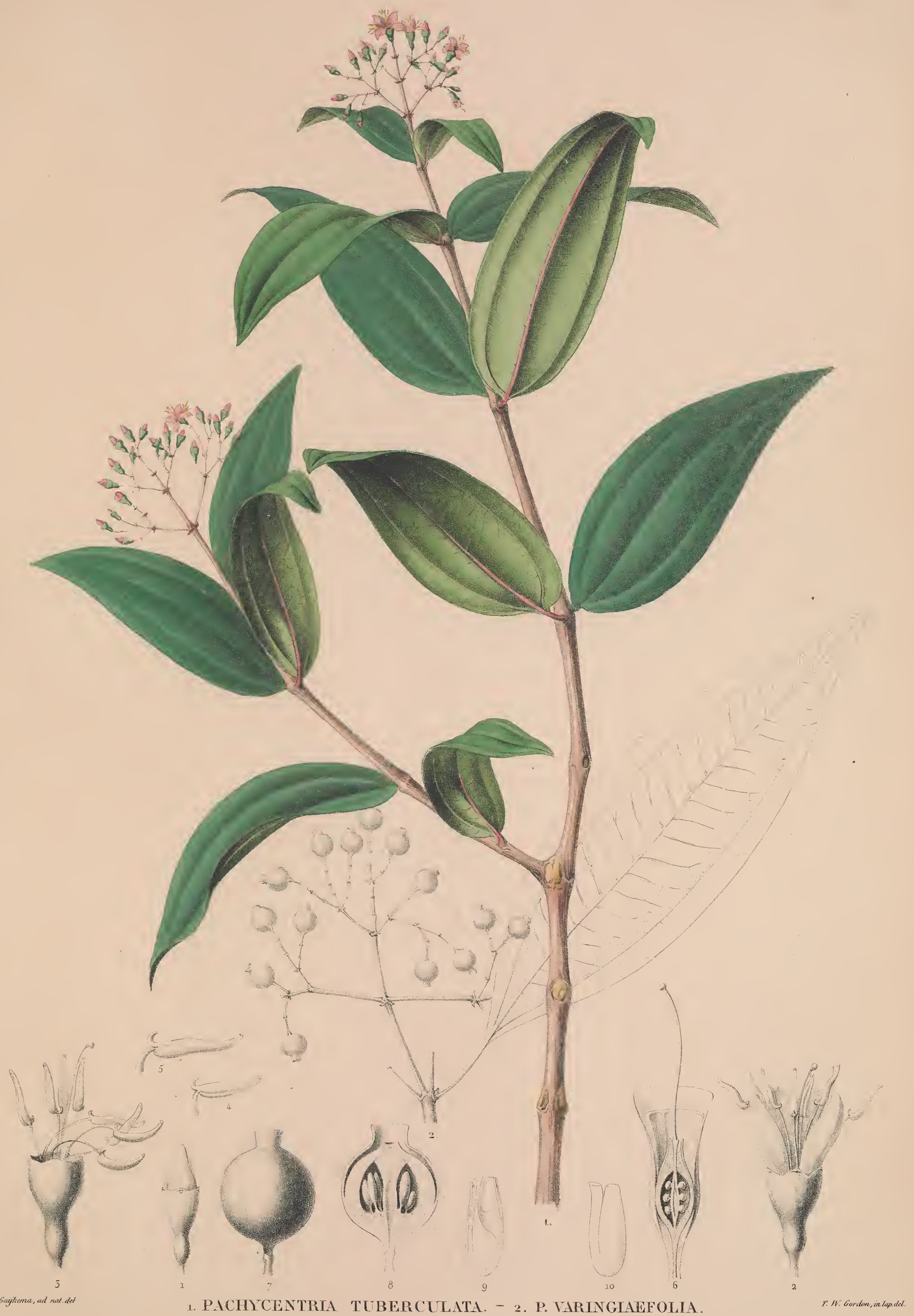


(-) 


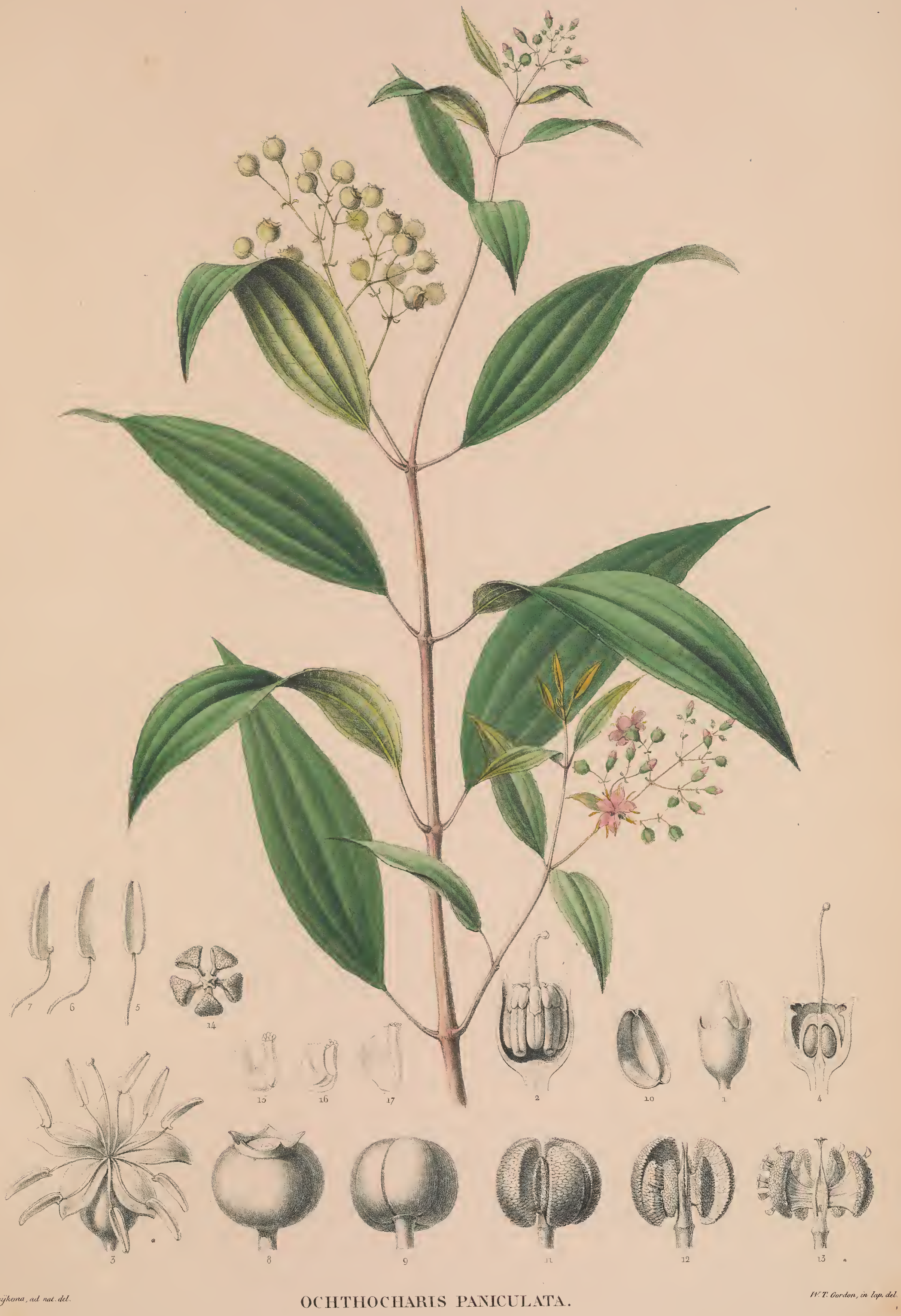


() 


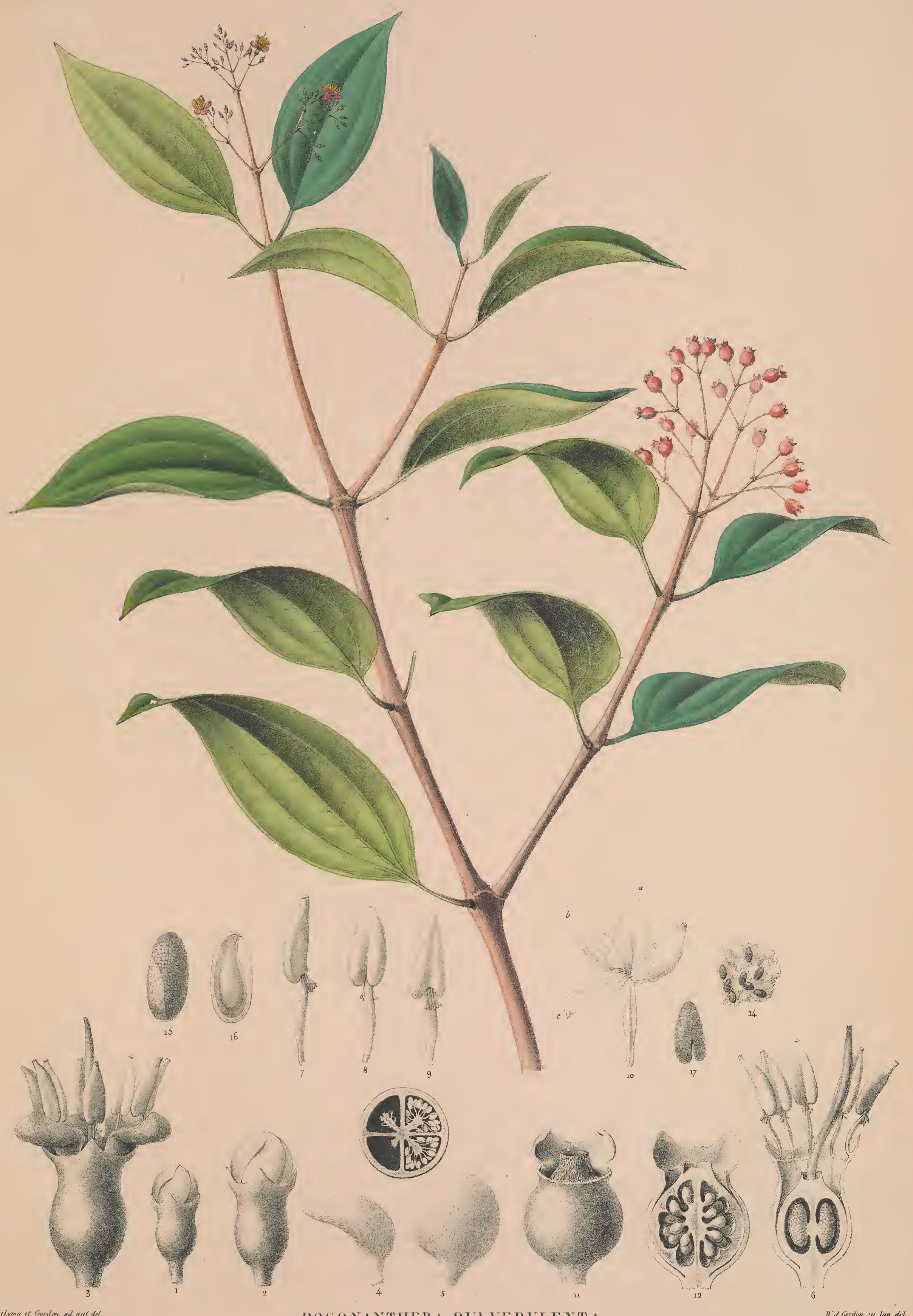

POGONANTHERA PULVERUTENTA. 
(2). 


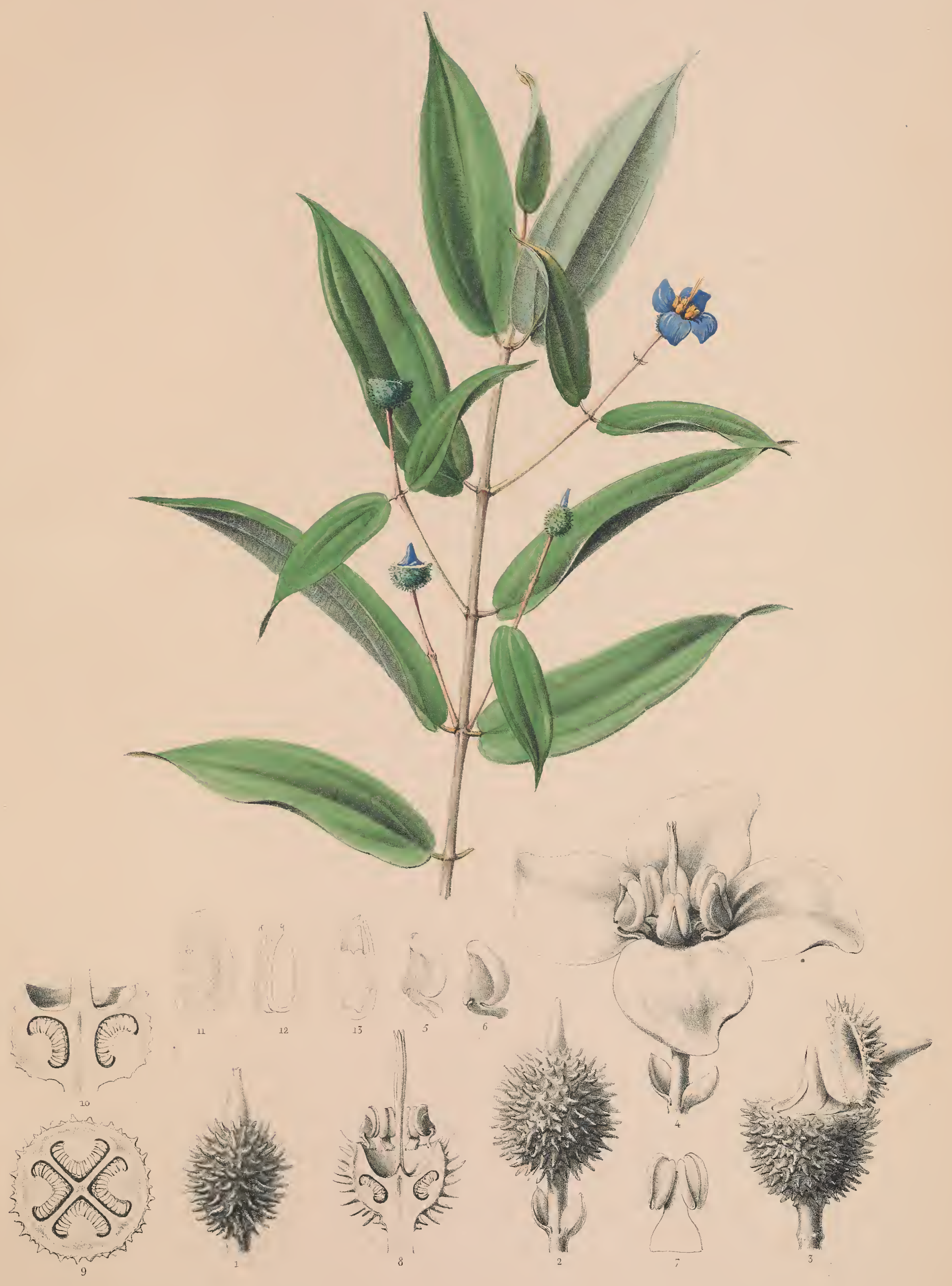


(-) 


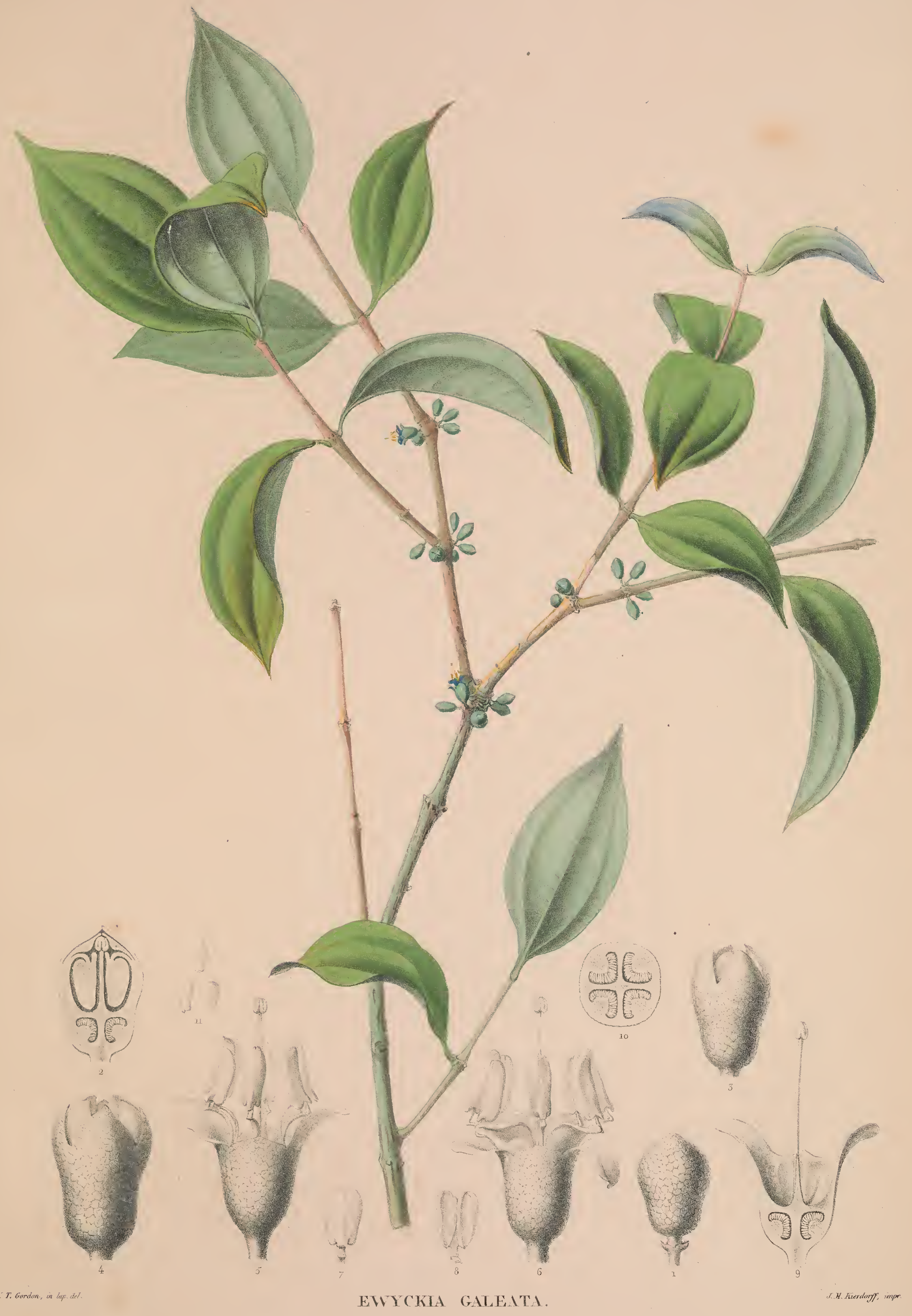


(-) 


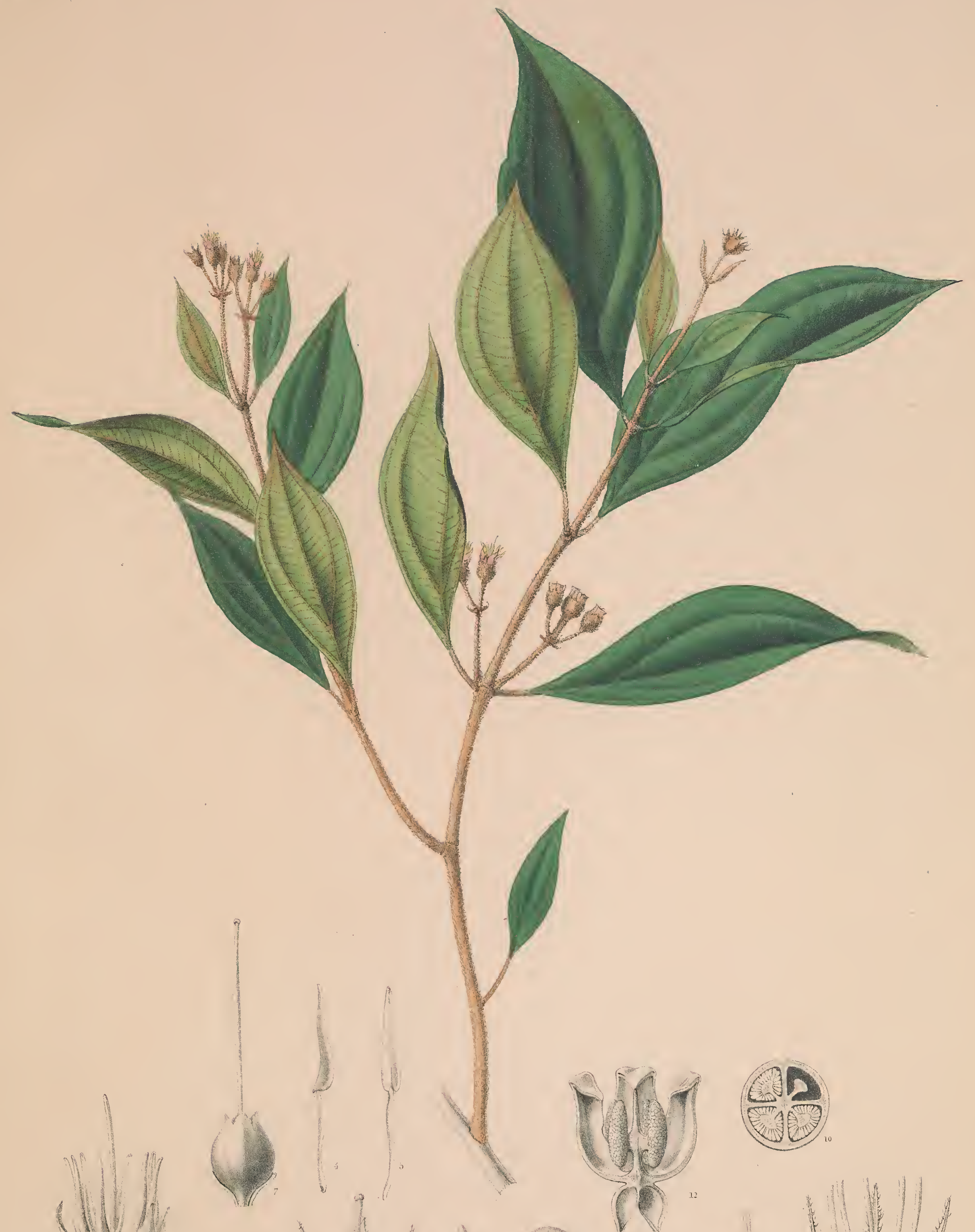


ㅈ. 


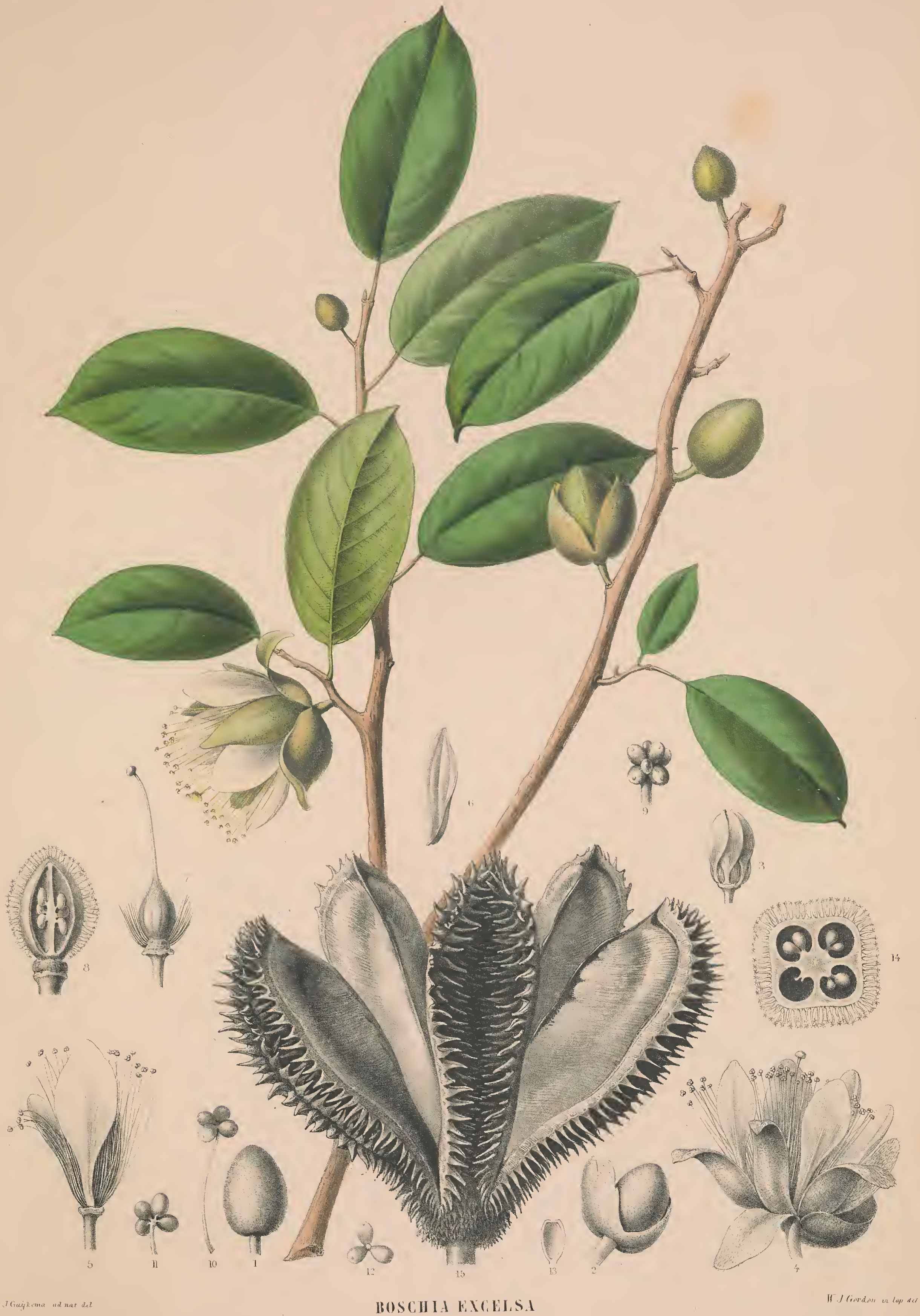


‥ 


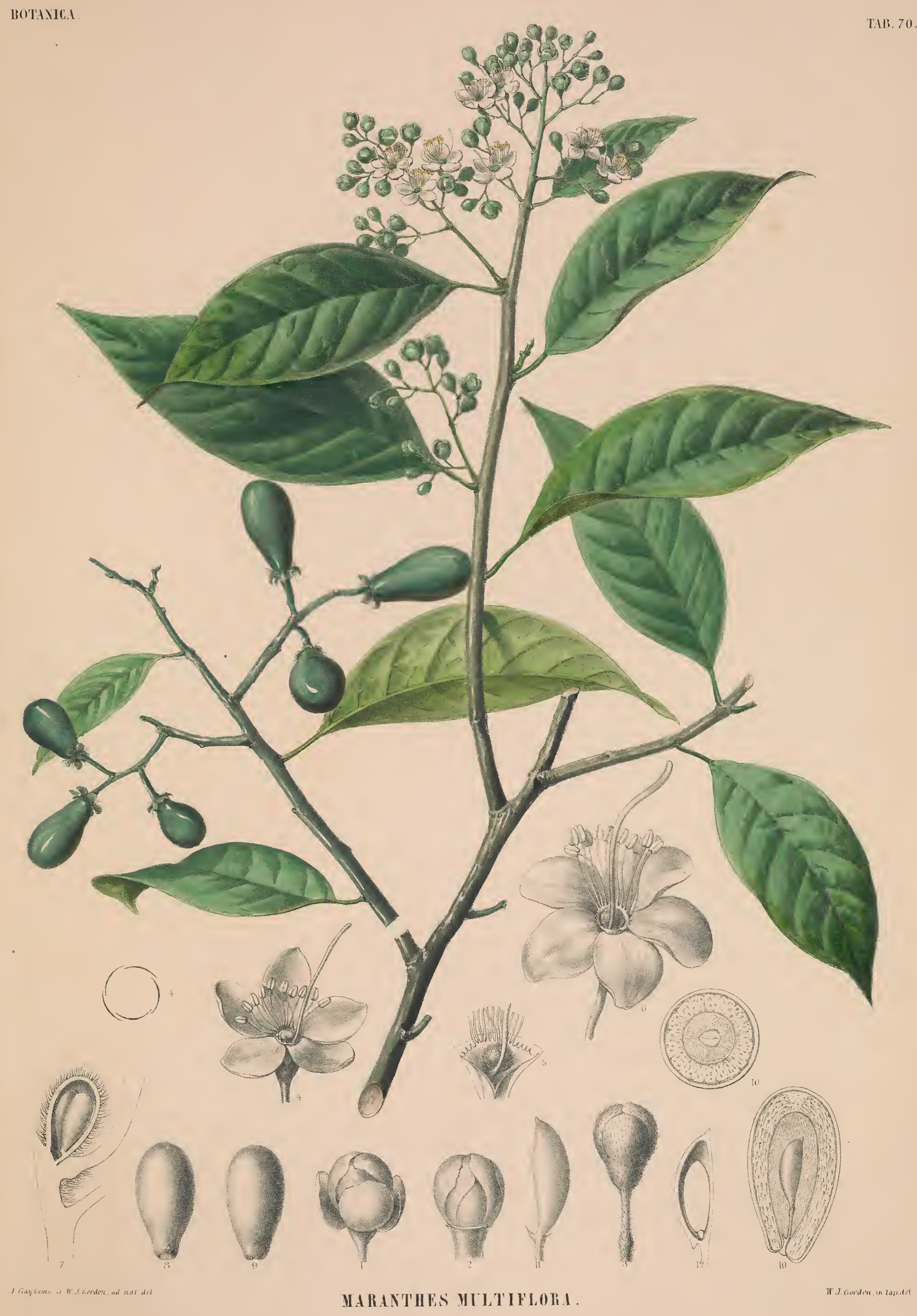


… 







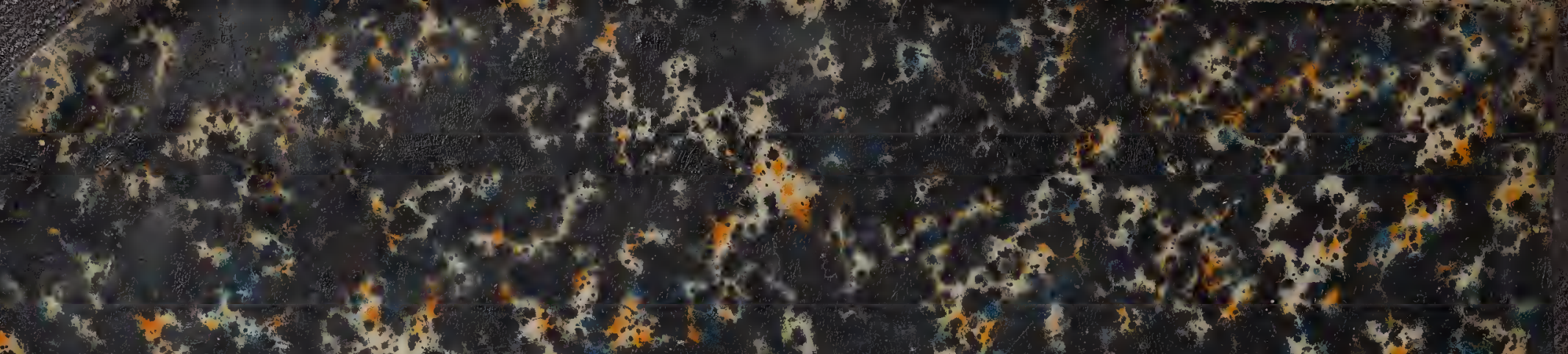

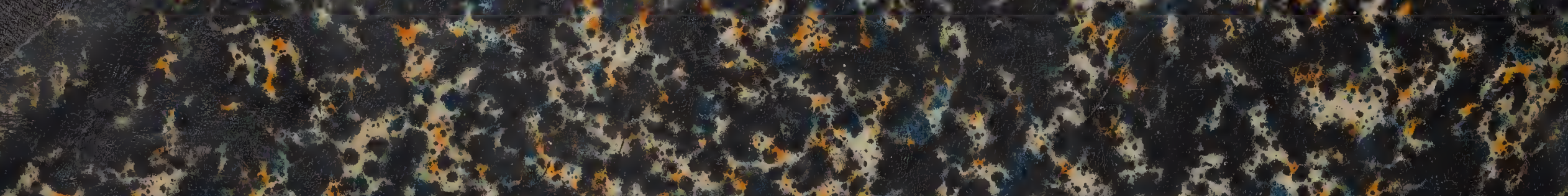

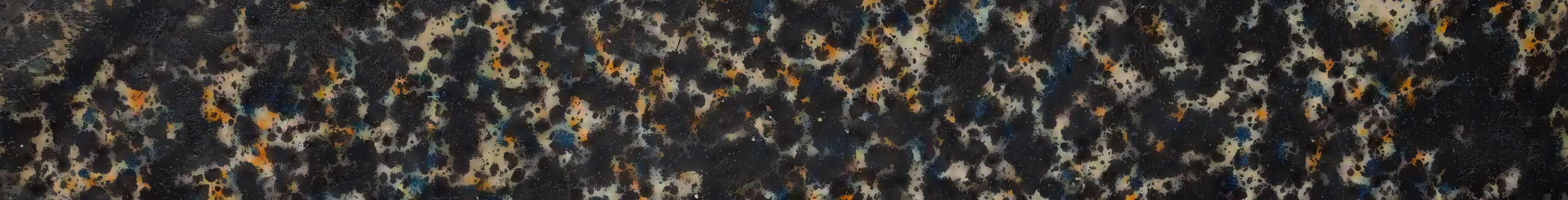

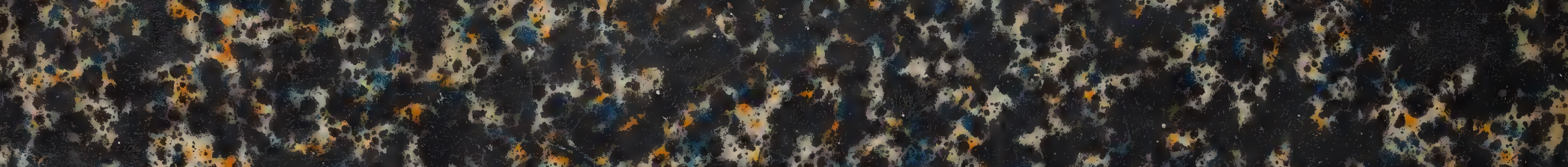

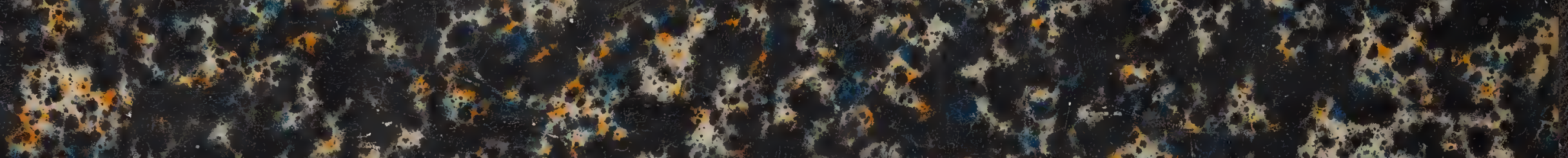
b. 30 ,

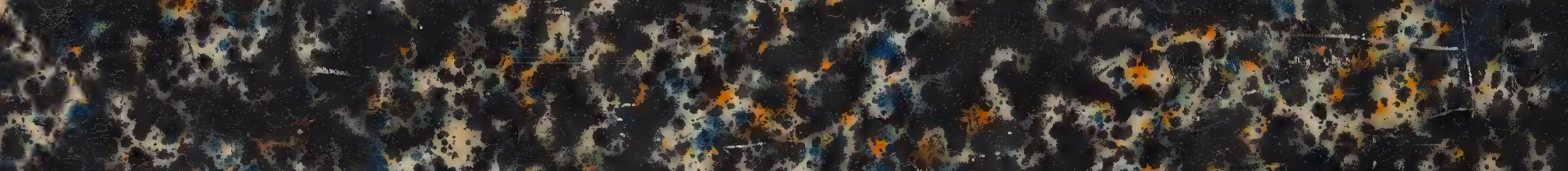

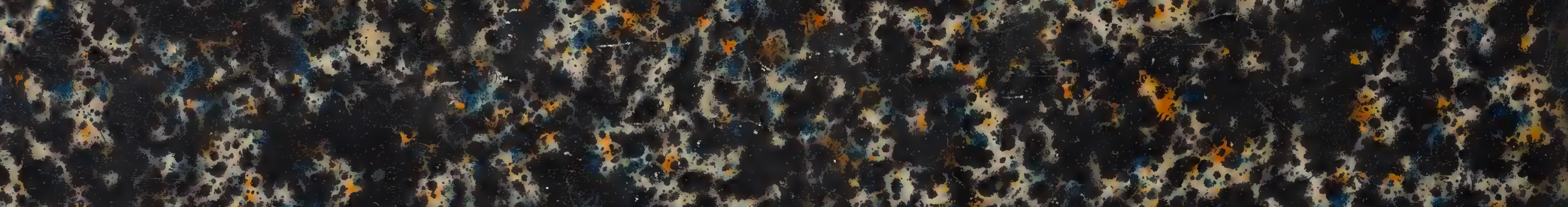

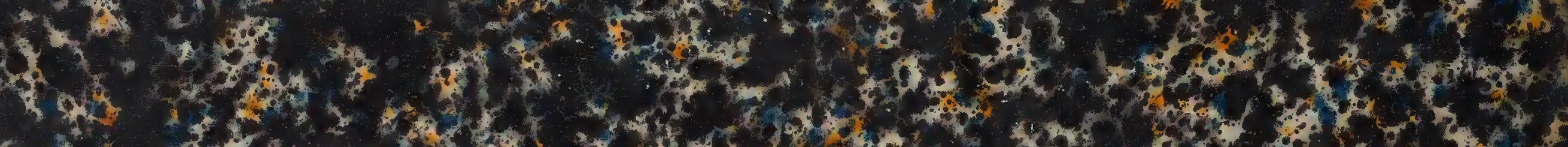
V. 2)

H.

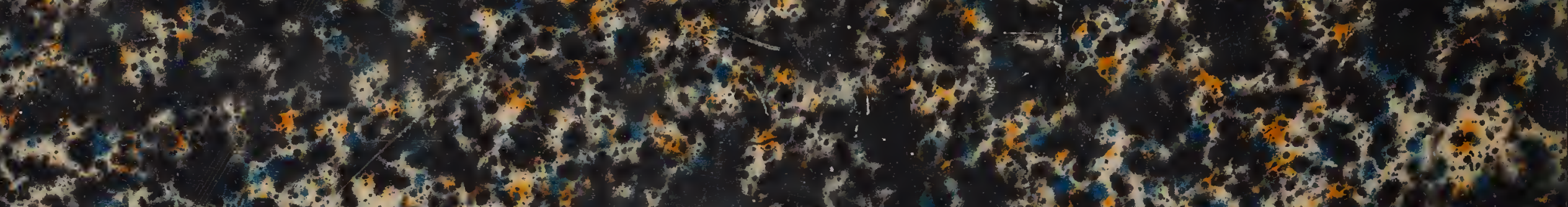

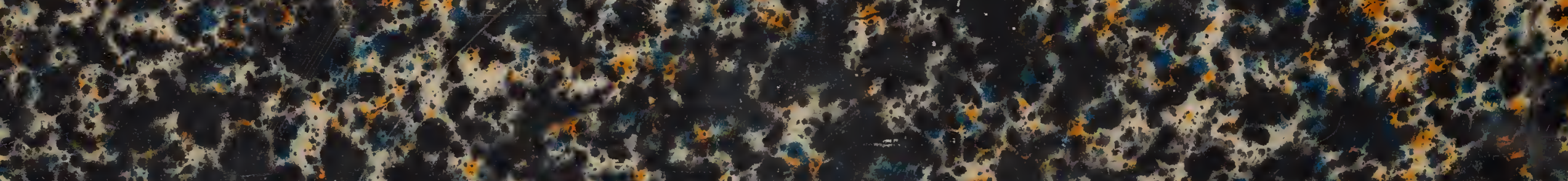

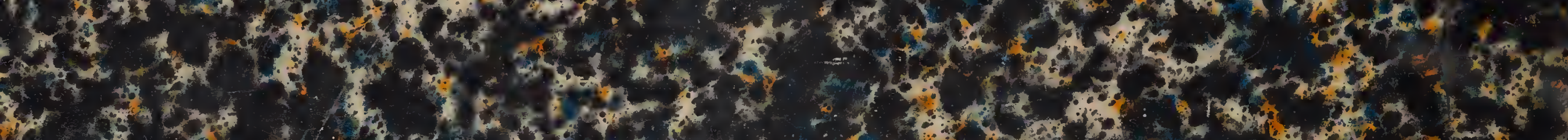

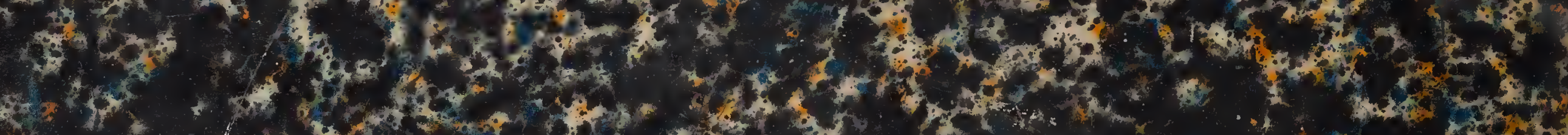

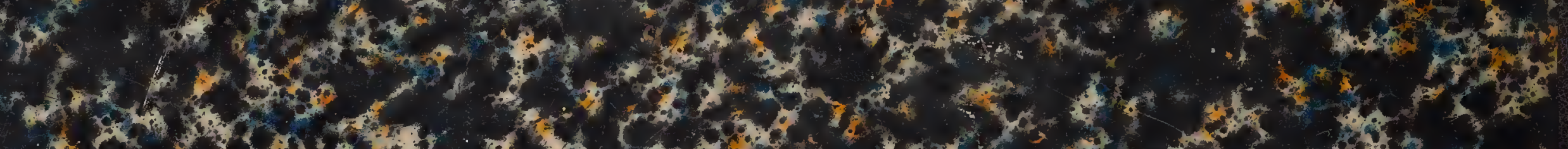
(5)

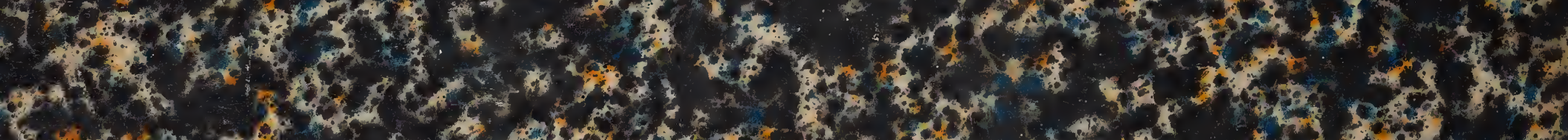

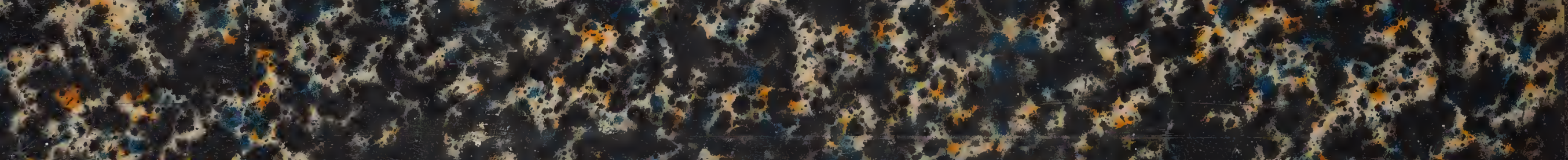

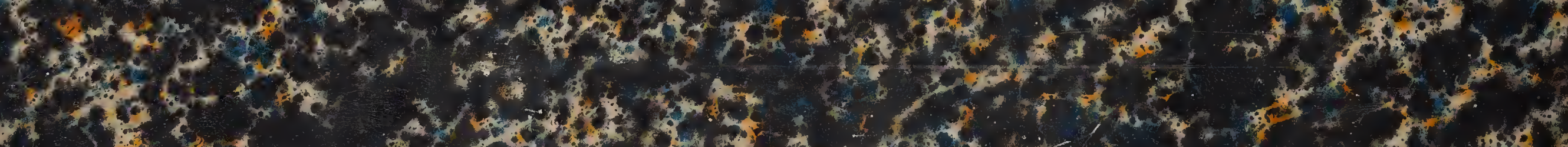
7 -

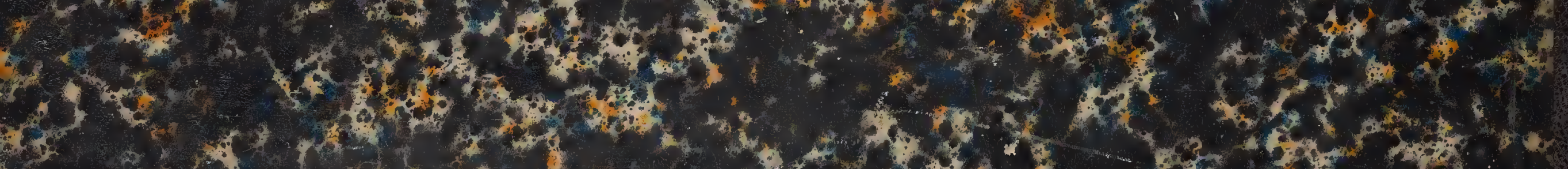

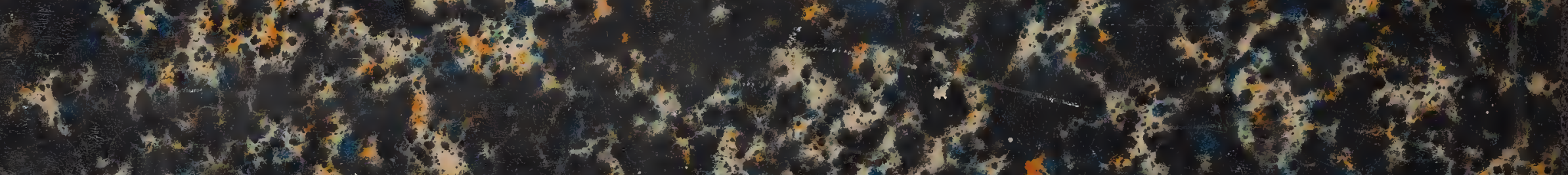
H.

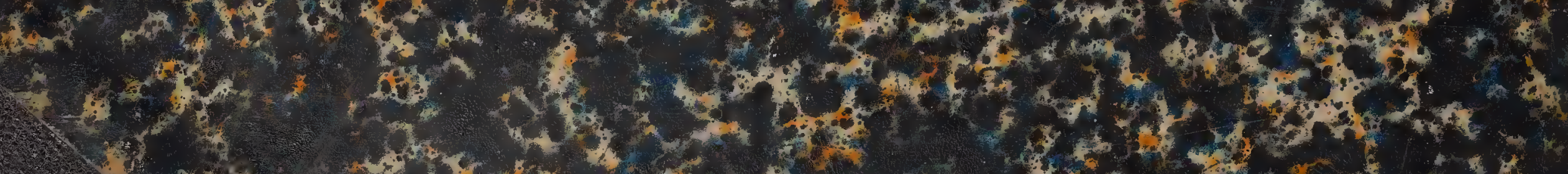

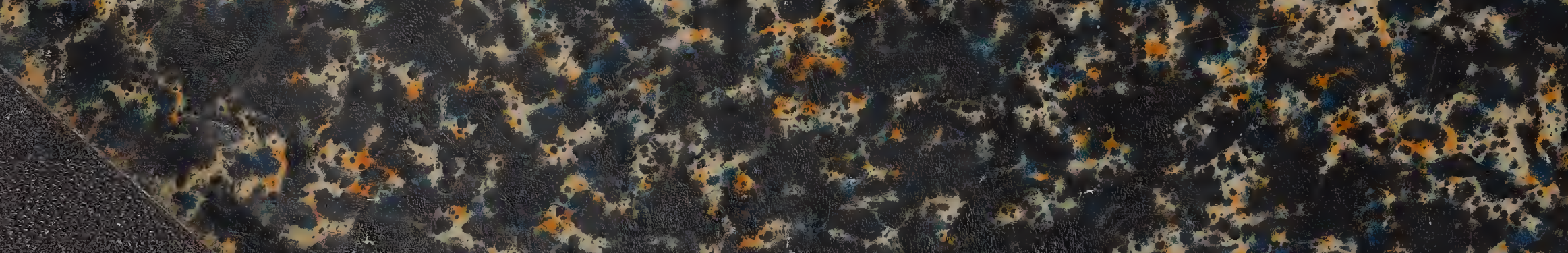

